\title{
THE RAT
}

\section{DATA AND REFERENCE TABLES}

HENRY H. DONALDSON 


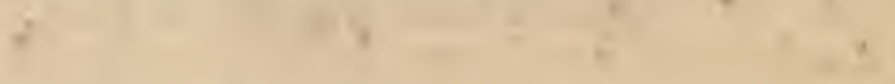

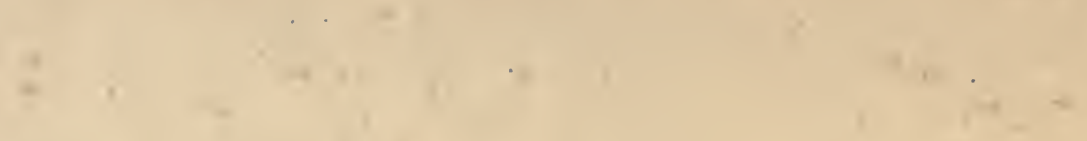

1

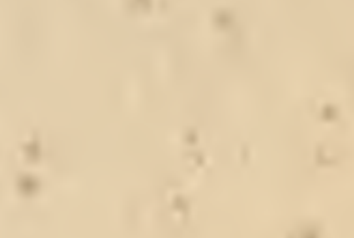

$+$

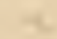

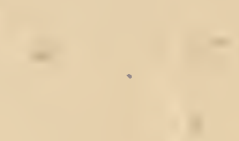

$+$

$+$

na

ta

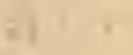

+1

n

.

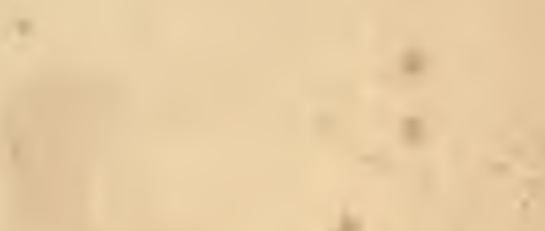

$+$

v<smiles>C1CCC2(CC1)CCCC2</smiles>

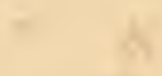

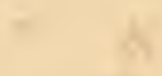

1

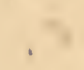

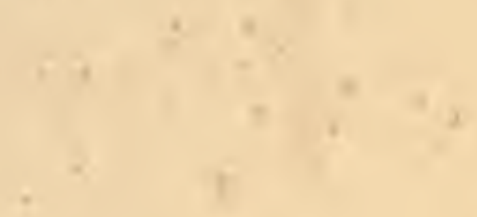

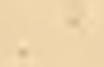

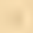

$*=$

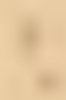

4

*

$+$

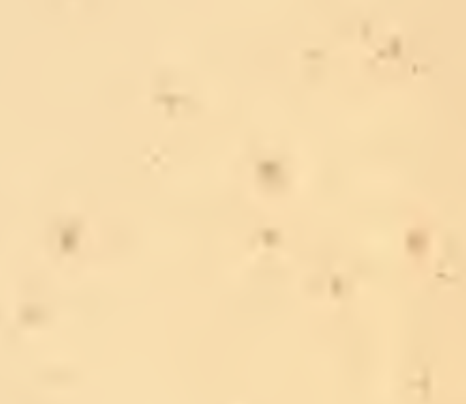

4<smiles>[CH2+]C</smiles><smiles>CCCCCCCCCCCCC</smiles>

$+2$

P
$+$ 

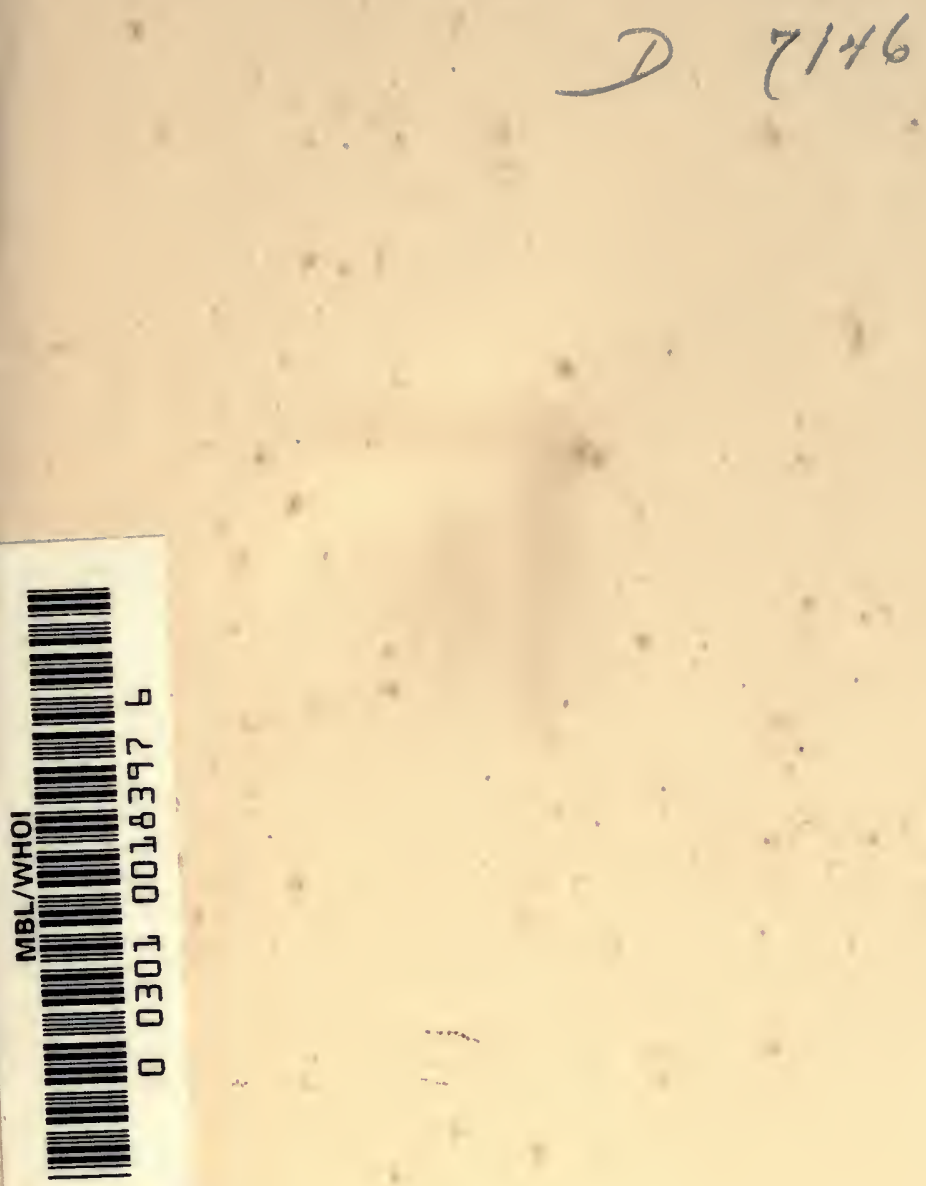


. 
MEMOIRS

THE WISTAR INSTITUTE OF ANATOMY AND BIOLOGY

No. 6

\section{THE RAT}

\section{REFERENCE TABLES AND DATA FOR}

THE ALBINO RAT

(MUS NORVEGICUS ALBINUS)

AND

THE NORWAY RAT (MUS NORVEGICUS)

COMPILED AND EDITED BY HENRY H. DONALDSON

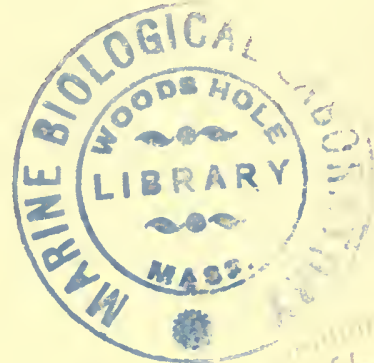

PHILADELPHIA 1915 
COPYRIGHT 1915

BY HENRY H. DONALDSON

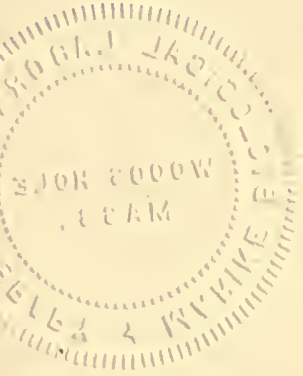




\section{PREFACE}

For a number of studies on the growth of the mammalian nervous system made by my colleagues and myself we have used the albino rat. In the course of the work we frequently felt the need of referring to other physical characters of the rat to which the nervous system might be related. This led us to collect such data as were already in the literature and also led us to make further investigations. The facts gathered in this way have proved useful to us and are here presented in the hope that they will be useful to others also.

The plan of the presentation is simple. An introduction treats of the rat as a laboratory animal, indicates the methods of gathering the data, and also gives examples of our use of the tables. This is followed by an outline of the classification of the common rats and by a brief statement of the history of the rat since it arrived in western Europe.

The rest of the book falls into two parts. The first part deals with the domesticated albino rat--concerning which we have the larger. amount of information.

The second part deals in a similar way with the wild Norway rat-the form from which the Albino has been derived. In connection with each part the several reference tables and the formulas employed for them and for the corresponding graphs are given, and at the end of the book a list of papers on the rat is added.

In the two parts which form the body of the book the purpose is to present for the rat under normal conditions the fundamental observations - giving data and conclusions only. It is hardly necessary to add that in most directions our information is fragmentary.

For all the formulas which apply to the data coming from the laboratories of The Wistar Institute, I take pleasure in thanking my colleague, Dr. S. Hatai. 
For aid in the preparation of these pages I am also much indebted to those unnamed assistants to whose lot has fallen the greater part of the computations for the tables and whose devotion to their work has added a human interest to a task otherwise monotonous.

To the many authors whose results are here briefly cited or quoted in extenso I take the opportunity to express my obligations-very sincere obligations-for experience shows that such results come only by hard labor.

Many of the illustrations have been taken from the journals in which they were originally published and my thanks are due to the editors and publishers of these journals for the privilege of reprinting the illustrations here.

During the preparation of this book my immediate colleagues have given me encouragement and aid, and I cherish the hope that, should the occasion arise, both of these will be again forthcoming to help mend the gaps and rectify the errors which a close scrutiny of these pages is certain to reveal. 


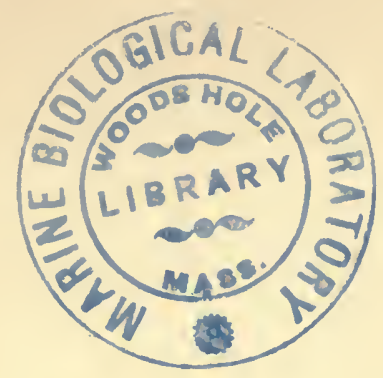

CONTENTS

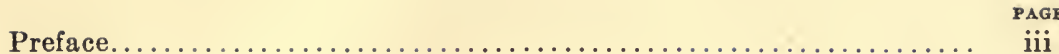

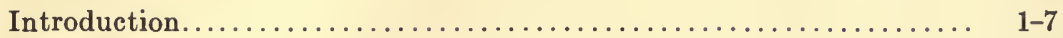

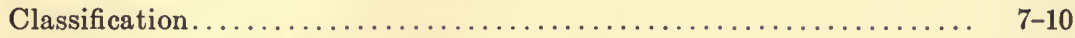

Early records and migrations of the common rats.............. 10-15

PART I

\section{ALBINO RAT-MUS NORVEGICUS ALBINUS}

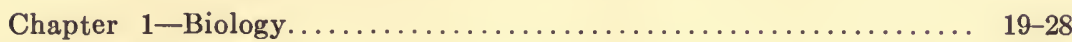

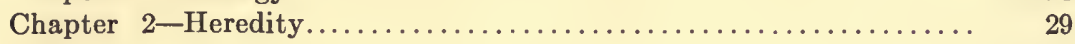

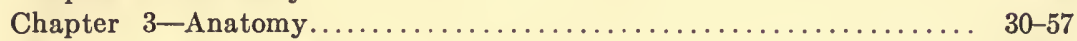

Chapter $4-$ Physiology................................... 58-62

Chapter $5-$ Growth in total body weight according to age......... 63-72

Chapter $6-$ Growth of parts or systems of the body in weight........ 73-85

Chapter 7-Growth of parts and organs in relation to body length and in relation to age................................. 86-175

Chapter $8-$ Growth in terms of water and solids.............. 176-179

Chapter 9-Growth of chemical constituents................ 180-184

Chapter 10-Pathology ................................. 185-186

\section{PART II}

\section{NORWAY RAT-MUS NORVEGICUS}

Chapter 11-Life history and distinguishing characters............ 189-194

Chapter 12-Growth in weight of parts and systems of the body..... 195-197

Chapter 13-Growth of organs in relation to body length.......... 198-210

Chapter 14-Growth in terms of water and solids............... 211-213

Chapter 15-References to the literature................... 214-267

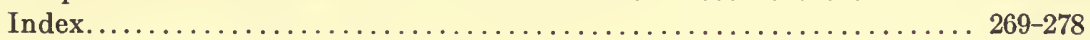

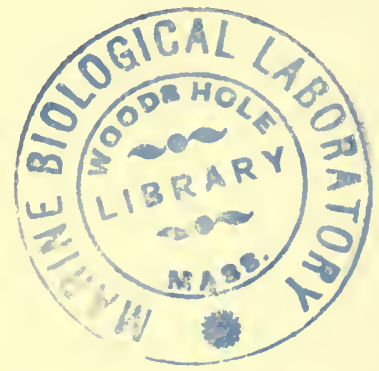





\section{THE RAT}

\section{INTRODUCTION}

The Norway rat, Mus norvegicus, is the one mammal now easily obtainable both wild and as a domesticated form. This latter is represented by either the Albino or the pied rats so common in our laboratories.

The Albinos are clean, gentle, easily kept and bred, and not expensive to maintain. They are omnivorous, thriving best on table scraps. The span of life is about three years and breeding begins at about three months. Furthermore the species is cosmopolitan. The litters are large and may be had at any season. The young are immature at birth. The domesticated Albino crosses readily with the wild Norway. The rat, both wild and domesticated, takes exercise voluntarily and is susceptible to training. It is also highly resistant to the usual woundinfecting organisms. For a number of lines of study therefore, the rat seems to be a peculiarly suitable animal.

Through the researches of several investigators at The Wistar Institute (since 1906) and through those of E. H. Dunn and of J. B. Watson at the University of Chicago, of Chalmers Watson and Sir Edward Schäfer at Edinburgh, of C. M. Jackson and L. G. Lowrey at the University of Missouri, of J. R. Slonaker at Leland Stanford University, of T. H. Osborne and L. B. Mendel at Yale University, of E. V. McCollum at the University of Wisconsin, as well as through those of several other investigators both in this country and abroad, there has been gathered a considerable body of data applying to the weight and size of the domesticated albino rat and its parts, as well as some similar data applying to the wild Norway rat, the parent species. It is the body of facts so gathered that it is our purpose to present, as far as possible in tabular form. 
Attention should be called to the fact that the observations presented in the tables have been made mainly on rats in the first year of life and but rarely on those which are older. It follows from this that the data apply to the rat in its most vigorous period and do not give information that can be used for the study of old age.

Since the quantitative data appearing in the tables are biological, they naturally exhibit more or less variability and reflect in each instance something of the conditions under which they have been obtained. It follows therefore that they must not be expected to possess the precision of physical or chemical determinations. Nevertheless, so long as the values here presented are not mistaken for absolute standards representing ideal or final determinations, they may be used with advantage.

Most of the matter presented is taken from researches already published in full, but in a few instances data from work in progress have been included also. In the latter instance the author's name is followed by (MS with date) when it is based on work conducted at The Wistar Institute-while in other instances the laboratory is also named.

In a few of the published tables-mainly from our own laboratory-it has been found necessary to make corrections-so that when the tables here printed do not agree with the originals, it is to be assumed that the changes are due to revision.

Owing to the absence of tables for the normal animal or to the failure of the authors to express their results in a quantitative form, much of the literature which is cited is unaccompanied by any text. Such papers however often contain valuable information on either the Albino or Norway rat and the citation of them serves to indicate the range of the studies in which this animal has been used.

Extensive reference tables have been computed for the various characters only as these appear under normal conditions, while the modifications which may be experimentally induced in these characters are merely mentioned in the text or presented very briefly. 
In a number of cases the results are represented by both graphs and tables. The purpose of the graphs is merely to furnish a general view of the form of change which occurs, while for the exact values, the tables must always be consulted. In those tables which are based on size, the body length of the rat, because it is least subject to incidental variations, is the measurement to which the others have been referred.

It is recognized however that some of the characters are functions of age and in that case it is of course necessary to know the age of the animal in order to obtain satisfactory results.

All of the longer tables are based on formulas. These formulas are those for the graphs which most closely fit the observed values-and their utility lies in giving precision to the values obtained and in making possible interpolations:- as a rule however they cannot be used for extrapolation. In this connection determinations of the normal variability are always wanted, yet although this need has been met in a measure, it is far from being satisfied.

Since heretofore tables of this nature have not been commonly available, a word as to their use is in order.

There exist now - and there will probably continue to appearstrains of the Albino having physical peculiarities related to the locality in which they are bred: e.g., a relatively short tail. The treatment of such an instance by the use of the tables is considered in the paragraph which follows.

As has been stated, the tabular values here given apply to the stock strain reared at The Wistar Institute and furnish data from which deviations found in other local strains can be measured. In all experimental work it is now generally agreed that the control and the test animals should be taken from the same litter, and the determinations of any modification made within the litter-the results for the several litters being given the same statistical weight in the subsequent computations. While this procedure might at first seem to render the reference tables superfluous, yet to compare the results from two laboratories working with different local strains, having according to the example chosen different normal tail lengths, a series of reference values 
such as the tables furnish, serves to reveal the relations in which the control animals from the respective laboratories stand to one another, and thus permits a more trustworthy comparison of the experimental results. ${ }^{1}$

Moreover in the course of routine work on the same colony one cannot be sure that the animals retain during successive years the same relations to the reference table values. For this reason we have been following the custom of referring all measurements to the reference tables and using the difference in deviation shown by the controls and by the test animals respectively as the measure of the modification experimentally produced,

By using such a procedure -in place of the assumption that the control animals from the same colony remain similar-the experimental results obtained from year to year are made fairly comparable with one another. ${ }^{2}$

But there is still another use of the tables which is perhaps the most important of any. In all experiments on the relative weights of parts or organs in which the size of the test animals differs from that of the controls, we readily obtain by weighing or measuring the differences for the entire animal. If however we wish to determine whether the relative size (weight or length) of the parts or organs of the test animals has been affected, we find that this cannot be done by comparing the test and control groups directly-for the relative values of parts and organs differ with the absolute size of the animal-but it can be done by reference to the tables in which the desired values are given ac-

${ }^{1}$ If a strain appears in which the length of the tail is on the average 4 per cent below the reference table value then if we compared directly with them the test animals which came from a strain normally in agreement with the reference tables-but which through experiment had had their tail length reduced by 3 per cent-it follows that the test animals, though modified by experiment, would still have relatively longer tails than the first strain.

Consequently to compare with each other the results obtained from the two strains, the deviations of both the controls and the test animals from the reference table values must be determined in both series and the differences within the series be used for the cross comparison.

2 The same principle and procedure as described in Note 1 applies to the treatment of different series taken, for example from our own colony, at different times. 
cording to body weight or body length or age, as the case may be. Thus by the use of the tables the determinations of the deviations shown by the test animals taken individually can be made and these values compared with the corresponding individual determinations for the control group. ${ }^{3}$

One further use of the tables when these are based on age, may be mentioned. The comparison of the experimental re-

${ }^{3}$ When the experimental conditions produce control and test animals different in size a determination of the relative size of any organ cannot be made directly or by the assumption that its normal size is in proportion to the body lengths or body weights of the contrasted groups-but only by comparison of the observed values with previously established normal values.

The following observed values are taken from Hatai ('15 a), Table 3. D. Normal females-1914 series. They read as follows:

\begin{tabular}{|c|c|c|c|c|}
\hline GROUP & RATION & BODY LENGTH & $\begin{array}{c}\text { BODY WEIGHT } \\
\text { FINAL }\end{array}$ & BRAIN WEIGHT \\
\hline \multirow{2}{*}{$\begin{array}{l}\text { Controls........ } \\
\text { Test animals... }\end{array}$} & Mixed & $\begin{array}{l}m m . \\
185\end{array}$ & $\begin{array}{c}g m s . \\
137\end{array}$ & $\begin{array}{c}g m s . \\
1.729\end{array}$ \\
\hline & $\begin{array}{l}\text { Lipoid free } \\
\text { and egg fat }\end{array}$ & & 100 & 1.569 \\
\hline
\end{tabular}

It is desired to determine in this case whether the relative brain weight of th test animals has been modified by the lipoid-free ration.

The absolute brain weight of the test animals is 0.160 grams less than that of the controls or 9.2 per cent of the larger number. If we assume that it should be in proportion to the observed body lengths it appears that the expected brain weight in the test animals would be 1.540 . Hence the observed value, 1.569 , is about 2 per cent high-by such a determination.

If we assume on the other hand that it should be in proportion to the observed body weights it appears that the expected brain weight in the test animals would be 1.262 . Hence the observed value is some 20 per cent too high by this determination. No one of these procedures is justifiable though examples of their use can be found in the literature. The only correct method is to compare the observed values with the reference table values for the brain weights of animals having the body lengths of the controls and test animals respectively-to determine in each case the percentage difference between the observed and the table value and finally to compare these percentages.

Using table 68 and reading the values for the females, we find that in this case the controls are 0.053 grams or 2.97 per cent below the table value while in the test animals the corresponding differences are 0.103 grams or 6.16 per cent.

The brain in the test animals is therefore smaller than that of the controls by $(6.16-2.97)=3.19$ per cent and this value may be taken as expressing the experimental modification of the brain in this series.

The foregoing represents the procedure to be generally used for determining modifications in the relative weight of any organ. 
sults obtained on animals with the corresponding results on man has heretofore been difficult because of the absence of a good basis for comparison. We have found reason to assume that in the case of the rat the postnatal span of life of three years is approximately equivalent to the span of ninety years in manor to put it another way, that the rat grows thirty times as fast as man. This ratio appears to hold for fractions of the span of life, as well as for the entire span. All of the data for the Albino, based on postnatal age, may therefore be compared fairly with the corresponding data for man, if the time intervals are taken as one for the rat to thirty for man. ${ }^{4}$

Finally it is desirable to explain here a seeming inconsistency in the arrangement of the material presented. In the Preface the statement is made that Part I deals with the albino $\mathrm{l}$ at, while Part II deals with the Norway. So far as all of the important tables and records are concerned this statement does not need revision.

4 As an example of the comparison of the rat with man in respect to certain changes which are related to age the observations on the percentage of water in the brain may be quoted-Donaldson ('10):

TABLE 1

Comparison of the percentage of water in the encephalon of man and the albino rat at corresponding ages

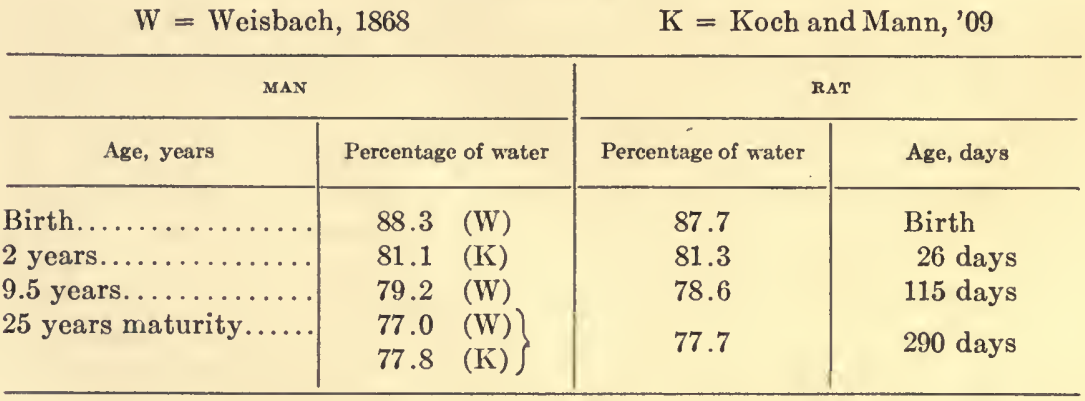

In table 1 the data for man, collected from various studies, are compared with data for the rat-on the assumption that the conditions in the rat brain at any age will be represented by those in the human brain at that age multiplied by thirty. 
It has been found however in arranging the literature that it would prove most useful to include in Part I all of the incidental and general observations on the wild Norway, on the ground that these applied to the entire species, and to reserve for Part II the more precise data which apply to the wild Norway, as contrasted with the domesticated Albino.

The reader therefore will find in the literature cited in Part I papers referring to M. decumanus, M. norvegicus and Epimys norvegicus as well as to the Albino (M. norvegicus albinus or var. Albino), sometimes designated the 'white' rat.

As will be pointed out in the section on The Early History of the rat, there is one more complication in this connection. Through an error, unfortunately perpetuated by some of the natural histories, the common Albino has been described as an Albino of the house rat-Mus rattus.

It thus happens that in some of the papers cited it is reported that the observations had been made on Mus rattus or ratus (sic), the word albino being sometimes added-sometimes omitted. In a few instances it is impossible to determine whether M. rattus is used for the Albino or whether the house rat was really studied.

In forming a judgment on these cases it must be kept in mind that for the last half century the house rat has been rare and hard to obtain both in western Europe and in the northern United States, so that unless the author gives good evidence for the name he has employed, it becomes highly probable that he was working with some form of the Norway. For these reasons it has been found most convenient to include also in Part I all the references to the house rat (Mus rattus).

\section{CLASSIFICATION AND NOMENCLATURE OF THE COMMON RATS}

Up to 1881 Mus (Linnaeus, 1758) was used as the generic designation for both the rats and mice. In 1881 Trouessart proposed the subgenus Epimys for the larger forms, the rats, reserving Mus for the smaller forms, the mice-Mus musculus being the type. In 1910 Miller established the use of Epimys for the rats and the change has been accepted. 
In the pages which follow however the designation Mus has been retained for the rat-as the older term is well understood, while the new term-Epimys-is at present generally unfamiliar.

The following condensed citations of the place of the original descriptions-with some of the associated references-serve to give a brief history of the nomenclature.

MUS, Linnaeus, 1758

EPIMYS, Trouessart, 1881-Miller, 1910.

-norvegicus, Erxleben (1777 descr. orig.)

-decumanus, Pallas (1778).

-aquaticus, Gessner, 1551.

Cosmopolita; ab Asia occident. in Europam navibus translat. et inde in omnes Orbis Regiones.

-rattus, Linnaeus (1758 descr. orig.)

Cosmopolita; ab Asia occident., in Europam a navibus translat., et inde in omnes orbis regiones.

-alexandrinus, Geoffroy, (1812 (or 1829 vide Sherborn, 1897) descr. orig.)

Asia minori, Arabia, Aegyptus, Algeria, etc.

Italia, Hispania, Gallia merid.-orient. et occid., et inde in omnes orbis regiones.

Since attention was called to Erxleben's description in 1777 (Rehn, 1900) his specific name, norvegicus, as the designation for the common brown or Norway rat, has been used in place of decumanus (Pallas, 1778). The designation norvegicus is now well established and will be used here.

There seems no question that Mus rattus and Mus r. alexandrinus are related to one another as color varieties of the same species (de l'Isle, 1865; Millais, '05) and they are so considered in the following pages. For convenience we shall use the term Norway or Norway rat for Mus norvegicus-and the term Rattus or house rat as a general designation for both Mus rattus rattus and M. rattus alexandrinus unless the occasion calls for the precise name.

Albinos of the house rat have without doubt existed in the west of Europe at one time or another ever since this form overran that region (Topsell, 1658) and one or more such skins, as well as pied skins, from animals taken within the past fifty years, are in several of our United States museums. 
At present Albinos of the house rat appear to be not uncommon in India (Lloyd, '12) where the house rat population is large. In western Europe and other regions in which the house rat population is waning, a careful search by several investigators during the last decade has failed to reveal a living albino specimen.

At the present time, therefore, the Albino of Mus norvegicus is the only albino variety generally found. In these pages this form is designated Mus norvegicus albinus-when the name is given in full, but where possible the single word Albino is used for it.

When the albino variety is mentioned here the strain as commonly reared is the one meant. As a rule this strain is far removed from its wild ancestor and moderately inbred. It may be conveniently designated as the common albino strain. In the colony at The Wistar Institute, we have in addition to this a closely inbred strain reared by Dr. King and also a strain of 'extracted' Albinos. These latter are the Albinos descended from the $\mathrm{F}_{2}$ generation of hybrids from the wild Norway and the domesticated Albino.

During the first few generations after their appearance, these extracted Albinos show clearly certain Norway characters, which distinguish them from the rats with a longer albino ancestry. With the peculiarities of either the inbred or of the extracted strain, we are however not specially concerned at the present time.

While all Albinos breed true as to color, the composition of the gametes is undoubtedly different among them in accordance with their remote ancestry. Mudge ('10) recognizes thirteen gametic types. The gametic dissimilarity of various Albinos in respect to hair color is shown by the fact that in breeding tests (Doncaster, '06 and Mudge, '10) Albinos extracted from ancestors with characteristic differences in pigmentation will reveal their origin by producing, when crossed with the pigmented strain, characteristically pigmented descendents, the markings of which can be predicted.

We are naturally concerned with the gametic composition of the general population of Albinos constituting our colonies today. As the several colonies stand, the Albinos forming them do not 
form a strictly homozygous population, even from the standpoint of color, since in subsequent crosses with pigmented forms they give offspring with different color markings according to their several latent characters. On the other hand it may be fairly said that as yet we have no evidence for any correlation of the somatic characters so far studied, with those slight differences in gametic composition of the common albino strain which we can recognize. It is to be noted moreover that the difficulty which thus appears in the case of the albino rat repeats itself for other mammals also, and therefore it does not constitute a peculiarity of this animal.

\section{CLASSIFICATION: REFERENCES}

Alston, 1879-1882. Blasius, 1857. Doncaster, '06. Erxleben, 1777. Geoffroy, 1812. Gesner, 1551. l'Isle, 1865. Linnaeus, 1758, 1766. Lloyd, '12. Millais, '05. Miller, '10. Mudge, '10. Pallas, 1778. Rehn, 1900. Topsell, 1658. Trouessart, 1881, 1897, '10. Tullberg, 1900.

\section{EARLY RECORDS AND MIGRATIONS OF THE COMMON RATS}

The common wild rats in the United States usally live in close association with man. There are two species of these, both of which have been introduced from Europe. These are Mus rattus (Linnaeus, 1758; $1766=$ Mus rattus rattus, Millais, '05) together with its gray form, Mus alexandrinus (Goeffroy, 1812; $=$ Mus rattus alexandrinus, Millais, '05) and Mus norvegicus (Erxleben, 1777 = Mus decumanus, Pallas, 1778). This last species is our common gray, brown or Norway rat. In addition to these, all of which are wild, there is a fourth form-the albino rat (Mus norvegicus albinus) a variety of Mus norvegicus (Hatai, '07) which is known at present only as a domesticated strain (Donaldson, '12 b).

Mus rattus - the house rat - the first species described in western Europe, is probably indigenous to India. ${ }^{1}$ As now found,

\footnotetext{
${ }^{1}$ Fossil remains of the rat (Mus rattus) are reported in the pliocene in Lombardy (Cornalia, 1858) and in the quaternary at Molina di Anosa near Pisa (Forsyth Major) and again from the pleistocene cave deposits of the island of Crete (Bate '12). This species appears in glacial times (Diluvialzeit) and in association with man in the remains of the Lake dwellers in western Germany and in Mecklenburg (Blasius, 1857). It is reported also from the diluvial deposits in Bohemia (Voldřich, 1880).
} 
the melanic form of Mus rattus (or Mus rattus rattus, Millais) the 'black' rat, is more frequent in the colder latitudes, and Mus rattus alexandrinus (Millais) the gray form (the 'roof' or 'snake' rat) in the warmer latitudes, but the two are not sharply segregated. At the same time both of these seem more dependent on warmth, or more resistant to it, than the Norway rat.

Although we shall have little to say in the following pages about Mus rattus, yet it is desirable to give its history in order to obtain the proper setting for Mus norvegicus, at present the dominant species. The geological evidence just given indicates the very early appearance of the house rat in Europe but our records of its migrations all fall within the present era.

The history of the early migrations is of necessity vague and incomplete, and even in the later times when dates are given it must be remembered that such animals might have been present for some time without appearing in numbers sufficient to cause comment.

There is no good evidence that the Greeks or Romans before the present era were familiar with the rat as a pest, and therefore, even if present, it was probably not abundant at that period on the shores of the Mediterranean.

The history of the house rat from the earliest times to the eleventh century makes an interesting archaeological study, but the conclusions which may be drawn from the scanty records and indefinite allusions are too uncertain to be of value for our present purpose and we therefore pass directly to the later authors.

Possibly as far back as the migration of the hordes (Völkerwanderung, 400-1100 A. D.) and later in consequence of the increasing use of trade routes with the East, the house rat entered western Europe in appreciable numbers (Hehn, '11). It is reported to have arrived there after the twelfth century (Keller, '09, citing Theodoros Prodromos). Giraldus Cambrensis, ${ }^{2}$ (1146?-1220) records several anecdotes concerning it.

${ }^{2}$ Albertus Magnus (d. 1280) is sometimes cited as having mentioned the black rat. This is not correct. A. de l'Isle (1865) has pointed out that the description in question applies to the dormouse-Myoxus quercinus. 
As the Norway rat did not reach western Europe until 17271730 it follows that the European rat of the middle ages, the rat of the legends of the Pied Piper $^{3}$ (1284), of the great plagues (before 1700) and of the early anathemas against vermin, was Mus rattus.

The species first brought to South America on the ships of the very early explorers was Mus rattus (Vega, 1609; de Ovalle, 1646). Pennant (1781) gives 1544 as the date of arrival in Peru. ${ }^{4}$ We have also a notable instance of a plague of these rats in the Bermudas in 1615 (Lefroy, 1882).

Of the two species in question, Mus rattus is alone recognized by Linnaeus in his Fauna suesica 1746, and in his Systema (1758 and 1766). It does not concern us here to follow the history of Mus rattus in the United States further than to say that this species only (represented by the two forms) was present up to the time of the arrival of the Norway rat in North America toward the end of the eighteenth century, and that Mus rattus rattus-the black rat-is still found in a number of scattered localities in the northern United States, while in the southern states, Mus rattus alexandrinus is much the more common. It does not appear that either of these forms has ever penetrated far into the interior of the country.

Turning to the cosmopolitan Mus norvegicus - the species at present established in China, Japan, India, western Europe and temperate North America-we find that the historical record of its movements, though by no means complete, has the virtue of being recent.

v. Gesner (Historia animalium, 1551) mentions a Mus aquaticus which appears to be the form now called Norvegicus, but apparently he himself had never seen it.

According to Pallas (1831) the Norway rat invaded Europe from the East early in the eighteenth century and was observed

${ }^{3}$ It may be noted in passing that the ancient inscriptions in Hameln relating to the Pied Piper do not mention the rat (Meinardus, 1882).

${ }^{4}$ Pennant (1781) says there were no rats in South America before the time of Blasco Minez. Minez is evidently a misprint for Núñez; Blasco Núñez being the first Viceroy of Peru, from 1544-1546. 
in large numbers crossing the Volga in the Russian province of Astrakhan. Pallas gives 1727 as the year of this migration. In view of other dates, this can hardly be the date of the first invasion. The Norway rat reached England-probably by ships -about 1728-1730 (Donndorff, 1792) and was soon designated the 'Hanover' rat by those who wished to connect the misfortunes of the country with the recently established house of Hanover.

There is however no reason to suppose that the Norway rat had yet reached Germany and the name has a political rather than a scientific interest.

In 1750 the Norway rats are reported (Donndorff, 1792) to have reached eastern Prussia and in 1753 they were noticed in Paris (Donndorff, 1792). Their early distribution to other localities in Europe need not be recounted, but there is evidence that they spread rapidly and soon displaced more or less completely the Mus rattus which had preceded them.

This historical sketch shows that the migration of Mus rattus into western Europe antedated that of Mus norvegicus certainly by some six hundred years, but the Norway rat being the more pugnacious and powerful species has become dominant wherever it has followed the earlier form.

This dominance is undoubtedly due in part to these characters of the Norway, but it seems probable that the progressive disuse of wood as a building material has been a factor also (Przibram, '12).

We find however that in many places, both in Europe and the United States, where the house rat was thought to have been exterminated, it still survives in small numbers.

The arrival of the Norway rat on the north Atlantic seaboard of the United States is usually given as 1775 (Harlan, 1825). The exact date, though of interest, is hardly important for our present purpose.

Mus rattus was already in possession, but in the course of the years, how rapidly we do not know, the Norway rat became the dominant form in the northern latitudes of this country-moving along the trade routes to all points which furnish a continuous food supply and a moderate summer temperature. 
In the present connection our interest in the Norway rat is due mainly to the fact that the common albino rat (M. n. a binus) kept as a pet or laboratory animal, and concerning which we desire all possible information, is a variety of the Norway rat. This relationship is shown not only by the usual methods of comparison, but also by the haemoglobin crystals (Reichert and Brown, '09) the shape of skull (Hatai, '07 c) and the fact that the two forms interbreed freely.

Concerning the place and time of origin of the albino strain there is little information at hand. Allusions to albino rats before the time when the Norway rat appeared in Europe clearly show that there must have been an albino strain of Mus rattus. What we know of the present distribution of Albinos of Mus rattus has been given on pages 8 and 9 in the preceding chapter.

By some curious slip however, many of the natural histories and books of reference speak of the common Albino as an Albino of Mus rattus. This of course is not correct, but owing to the confusion thus early introduced, it is difficult to trace the history of the present albino variety ${ }^{5}$ of the Norway.

We do not know whether the common albino variety had a single or multiple origin, or whether the colonies found in Europe (Rodwell, 1858) are directly related to those now existing here. Moss, 1836, mentions Albinos in or near Bristol, England about 1822. In their general physical characters the European and American Albinos are similar (Donaldson, '12 and '12 a). Judging from the way in which the Albinos of other species arise, we may safely assume that the present strain is derived from one or more albino mutants or sports (Hatai, '12). These must have been captured and the albino descendents segregated and kept

${ }^{5}$ Unfortunately there is one more complicating circumstance-namely, the existence of a melanic variety of Mus norvegicus. This melanic variety is often mistaken for Mus rattus rattus because of its color, and this leads to errors of statement concerning the distribution of Mus rattus and also concerning the ability of the two species-rattus and norvegicus-to interbreed. They are in fact mutually infertile (Morgan, '09). The number of incidental allusions to this melanic variety of norvegicus shows its occurrence to be widespread. See: Edwards, 1871, 1872. Hamy, '06. l'Isle, 1865. Lapicque and Legendre, '11. Schäff. 1891. Webster, 1892. 
as pets, as at present ${ }^{6}$ there is nowhere to be found an established colony of Albinos living in open competition with the common Norways or with forms of Mus rattus, but all of the colonies are maintained practically under conditions of domestication.

In the northern United States, except along the water front of the larger ports, where the house rat arrives from time to time on vessels, we have therefore to deal almost exclusively with the Norway rat. The Norway has been in this region probably not more than a hundred and fifty years. Though living wild, it is more or less dependent on the food conditions found where man is established. The familiar Albino-Mus norvegicus albinus-is a sport derived from the wild Norway, and is the form on which most of the investigations here presented have been made.

\section{EARLY RECORDS AND MIGRATIONS: REFERENCES}

Albertus Magnus, b. 1206-d. 1280. Barrett-Hamilton, 1892. Bate, '12 Baumgart, '04. Blasius, 1857. Borcherding, 1889. Campbell, 1892. Clarke. 1891. Cornalia, 1858-1871. Cornish, 1890. Donaldson, '12 '12 a. '12 b. Donndorff, 1792. Edwards, 1871, 1872. Fischer, 1869. Geisenheymer, 1892. Geoffroy, 1812. Gesner, 1551. Giraldus Cambrensis, b. 1146?-d. 1220. Godman, 1826-1828. Gourlay, '07. Hamy, '06. Harlan, 1825. Hatai, '07, '07 c, '12. Hehn, '11. Hossack, '07, '07 b. l'Isle, 1865. Keller, '09. Keller-Zschokke, 1892. Lantz, '09. Lapicque, '11. Lefroy, 1882. Liebe, 1891. Lindner, 1891. Linnaeus, 1746, 1758. Lloyd, '10. '12. Löns, '08. Major (see Baumgart, '04). Meinardus, 1882. Messer, 1889. Middendorff, 1875. Millais, '04. Mojsisovics, '97. Moss, 1836. Murray, 1866. Ovalle, 1646. Pallas, 1831. Pennant, 1781. Prodromus, Theodorus (see Keller, '09). Przibram, '12. Reichert and Brown, '09. Rodwell, 1858. Schäff, 1891. Vega, 1688. Ward, '06. Webster, 1892. Woldřich, 1880-1884.

Rattenkönig.

Ahrend, '03. Demaison, '06. Dollfus, '06. Koepert, '04.

${ }^{6}$ Rodwell, 1858, page 10, mentions what may have been a colony of Albinos living wild at the Ainsworth Colliery near Bury, England. 



\section{PART I}

ALBINO RAT-MUS NORVEGICUS ALBINUS 



\section{CHAPTER 1}

\section{BIOLOGY}

1. Life history. 2. Span of life. 3. Puberty-ovulation-menopause. 4. Period of gestation-lengthening of the gestation period. 5. Superfecundation -Superfetation. 6. Fecundity and weight at birth. 7. Recognition of sex. 8. Sex ratio. 9. Body weight according to sex. 10. Behavior. a) Under natural conditions. b) Under experimental conditions.

1. Life history. The albino rat is born blind, hairless, with a short tail, closed ears and undeveloped limbs. It responds to contacts and olfactory and taste stimuli, utters a squeaking sound and is capable of some locomotory movements which are a combination of wriggling and paddling. The head is always searching. The young can find their way back to the mother at about ten days of age (Watson, '03). The eyes open at from the 14 th to the 17 th days, most often on the 15 th or 16 th. King has also observed that in a given litter the eyes of the females usually open some hours before those of the males. For some seven days more, i.e., up to the time when the young rats are 21-22 days of age, they are dependent on the mother. After this they may be weaned, although if permitted, the young will depend partly on the mother for some days longer.

This adjustment of relations fits with the fact that the female may be impregnated one or two days after casting a litter (Kirkham, '10; Kirkham and Burr, '13) and since the gestation period is about 21.5-22.5 days, this would enable the female to free herself from the first litter before the second one was born. As will be pointed out later, the gestation period may be prolonged in nursing animals.

When the young rats become habituated to independence, i.e., at about 25 days, they enter on a period of activity, the phases of which have been followed by Slonaker ('07, '12). In the cases which he observed, it was found that increasing age was accom- 
panied by increasing activity up to the age period of $87-120$ days, after which the activity declined.

On the assumption that the span of life in man is thirty times that of the albino rat (Donaldson, '08) this age of greatest activity would correspond to the age of $7.5-10$ years in man.

As shown by the records of activity (Slonaker, '12) the albino rat is nocturnal. This habit can be modified more or less by feeding or by disturbance during the day time.

The measure of activity in the cases observed by Slonaker was the number of turns of the revolving cage in which the animal was kept, the cage being set in motion by the voluntary running or other movements of the animal, and the revolutions being automatically recorded. In the case of four rats kept in separate revolving cages from 30 days of age until natural death, the following record of activity was obtained (Slonaker, '12).

TABLE 2

Total number of miles run during life

\begin{tabular}{|c|c|c|c|c|}
\hline $\begin{array}{l}\text { AGE IN MONTHS } \\
\text { AT DEATH. }\end{array}$ & $\begin{array}{l}\text { RAT No. } 1 \\
\text { M. MILES }\end{array}$ & $\begin{array}{c}\text { No. } 4 \\
\text { M. MILES }\end{array}$ & $\begin{array}{l}\text { No. } 2 \\
\text { M. MILES }\end{array}$ & $\begin{array}{l}\text { No. } 3 \\
\text { F. MILEs }\end{array}$ \\
\hline $\begin{array}{l}25 \ldots \ldots \ldots \\
26 \ldots \ldots \ldots \\
32 \ldots \ldots \\
34 \ldots \ldots\end{array}$ & 1265 & 1391 & 2098 & 5447 \\
\hline
\end{tabular}

This table shows not only great variability in the total performances, but also for the one female a record of over five thousand miles in a little less than three years. On the average, threefourths of the total distance is run before the rat has reached middle life, and the last months of old age are always marked by greatly lessened activity.

2. Span of life. The assumption has been made (Donaldson, '08) that dating from birth, the span of life of the albino rat is three years. A rat three years old therefore may be regarded as corresponding to a man ninety years old. So far as this assumption has been tested, it appears to be a useful approximation. 
Slonaker ('12, '12 a) working at Leland Stanford University under the favorable climatic conditions of California, has made some direct tests.

Four albino rats living in revolving cages attained an average age of 29.5 months, while three control animals reared in stationary cages, but under conditions otherwise similar, attained an average age of 40.3 months. In all these cases, death was reported as due to 'old age.'

The average age of these seven individuals was about 34 months, while the greatest age, attained by one of the controls, was 45 months. The three controls all lived longer than any of the four in the revolving cages. It appears from this that living in the revolving cage shortened the span of life-an unexpected result.

3. Puberty-Ovulation and Menopause. Sexual maturity as indicated by the structure of the gonads usually occurs in both males and females at the age of about two months or less.

According to our observations, puberty in the female may occur at 60-70 days after birth--although the females usually begin to breed at 90-100 days. On the other hand there are occasional instances of remarkable precocity. In the breeding Albino it is found that impregnation most readily follows 1-4 days after a litter has been cast. This accords with the time of ovulation (Kirkham, '10; Sobotta and Burckhard, '10; Kirkham and Burr, '13). During the breeding season of the female ovulation occurs at intervals of about three weeks, but only from April to October do the females regularly ovulate 20-48 hours after parturition (Kirkham and Burr, '13). The menopause commonly appears at the age of 15-18 months, but King (MS., '15) reports a female 22 months old-crossed with a male of like age-giving birth to a litter of one.

4. Period of gestation. The gestation period of the non-lactating albino rat is usually stated to be about 21-22 days. In the cases where the gestation period has been exactly recorded in our colony the exact time of copulation and of birth having been observed, Stotsenburg (MS '14) has found it to be from 21 days and 15 hours to 22 days and 16 hours. 
Lengthening of gestation period. King ('13), makes the following statements which apply to lactating Albinos, maintained on a mixed diet.

The gestation period in lactating albino rats is of normal length if the female is suckling five or less young and is carrying five or less young.

The gestation period may be prolonged from one to six days if an albino female, suckling five or less young, is carrying six or more young.

The period of gestation is always prolonged when a female is'suckling six or more young. In these cases the number of young in the second litter seems to have less influence on the length of the gestation period than has the number of young suckled; but if both litters are very large the gestation period may be extended to 34 days.

5. Superfecundation and superfetation. Superfecundation occurs occasionally in the albino rat and causes an interval of two, three or more days between the birth of different members of the litter (King, '13).

In support of this statement the following instances are cited:

1) Litter born October 27, 1911; examined November 10, 1911, 12 individuals - 11 of these weighed about 14 grams each. The remaining one had very little hair, weighed 7.1 grams and appeared 4-5 days old.

2) Litter born December 20, 1911; examined January 2, 1912, 10 individuals -9 of like size weighed $16-17$ grams each. The remaining one small; hair just appearing; weighed 10.8 grams.

3) Litter born February 26, 1912; examined March 11, 1912, 10 individuals -3 had their eyes open and weighed 10.1-10.5 grams. The remaining seven were apparently but one or two days old and weighed 4.2 grams on the average.

In rare instances ovulation takes place in the albino rat during pregnancy and superfoetation occurs. In two cases of this kind litters have been produced at intervals of about twoweeks (King, '13, pp. 388 and 389).

6. Fecundity and weight at birth. At the beginning of ovulation in the albino rat Sobotta and Burckhard ('10) find on the average a total of thirteen ova in both fallopian tubes. The largest litter we have noted in the common Albino contained sixteen. One instance also of sixteen fetuses 18 days old has been observed Stotsenburg (MS '15). 
Kolazy ('71) reports litters consisting of 5-17 young. Crampe ('84) records for 2503 young represented by 394 litters, an average of 6.3 per litter. From 1911-1913, 275 litters (1928 individuals) in our colony gave an average of 7.0 individuals per litter, and in 1914, 814 litters (5691 individuals) gave an average of 6.99 individuals per litter. Litter size does not appear to be influenced by season (King and Stotsenburg, '15).

Under certain food conditions the size of the litters is much modified. When an exclusive diet of ox flesh is given to Albinos-2-4 months of age at the beginning of the experimentand these are compared with control rats fed on bread and milk, Chalmers Watson ('06 a) finds in the meat fed Albinos pregnancy less frequent, the weight of the mammae less, and the average number of young in a litter, as well as the average weight of the young, both smaller than in the controls. Such an exclusive meat diet is therefore unfavorable both for breeding and for early growth. On the other hand, Stotsenburg (MS '15) found that mothers fed on a table scrap diet produced a larger number of fetuses than those fed on bread and milk.

As to the size of the litters at different periods in the life of the female, there are a few observations. Lloyd ('09 a) in his studies on two strains of the house rat, published tables which he interpreted to mean that the number of individuals in a litter was independent of the body weight of the mother. Pearson ('10) however was able to show from Lloyd's data that in both groups the number in a litter increased with the body weight of the mother.

It seems probable however that the heavier rats were also older, as Pearson suggests, and that the proper interpretation of the increase in the size of the litter is to relate it with the age of the mother. In these groups none of the animals were beyond the prime of life and hence the explanation is very probably correct.

There is now available some detailed information on the relation between the weight and age of the mother and the characters of the young.

A study of 11 litters of common albino rats containing 91 young bred by King (MS '15) at The Wistar Institute, gives 
the average individual birth weight for the male as 4.72 grams and for the female 4.56 grams.

The data from these 11 stock litters used for tables $3,4,5,6$ have not been published elsewhere in a separate form. In the paper by King ('15), however these data are combined with corresponding data for the inbred Albinos to form similar tables. The results obtained from the stock data here given are quite in agreement with those from the combined data of King ('15). The birth weight may be modified by a series of conditions as shown in the following tables.

TABLE 3.

Influence of the age of the mother on birth weight

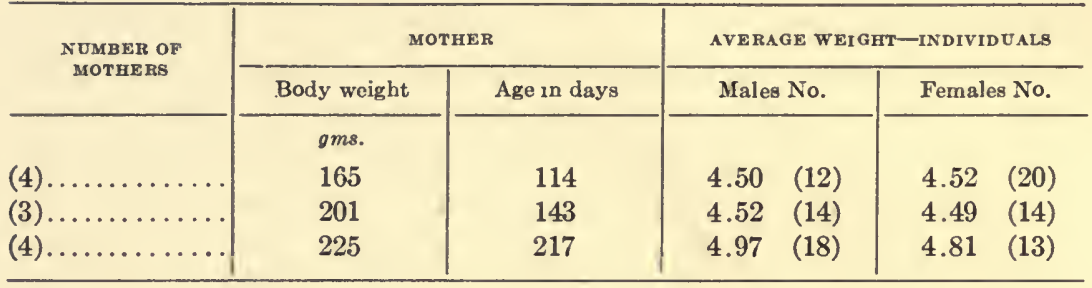

Table 3 shows that with increasing age up to 217 days the individual birth weight increases with the age of the mother. At the same time it is to be seen that the body weight of the mother also increases.

When the same data are arranged according to the bodyweight of the mother, we get the relations shown in table 4 .

TABLE 4

Influence of weight of mother on birth weight

\begin{tabular}{|c|c|c|c|c|c|c|}
\hline \multirow{2}{*}{$\begin{array}{l}\text { NUMBER OF } \\
\text { SOTEERS }\end{array}$} & \multicolumn{2}{|c|}{ MOTHER } & \multicolumn{4}{|c|}{ AVERAGE WEIGHT-INDIVIDEALS } \\
\hline & Body weight & Age in days & $\mathrm{Ma}$ & & Fen & \\
\hline (4). & 165 & 114 & 4.53 & (12) & 4.40 & (20) \\
\hline (3). & 200 & 150 & 4.65 & (14) & 4.55 & (16) \\
\hline$(4) \ldots \ldots$ & 226 & 211 & 4.88 & (18) & 4.76 & (11) \\
\hline
\end{tabular}

Here the birth weight increases with the increasing bodyweight, but the age is also increasing in the successive groups. The influence of the size of the litter on birth weight does not 
give regular results, but if we take the extreme records, we find that in the small litters of 6.5 the individual birth weight is higher than in the large litters of 10 or more (table 5).

The failure to get regular results is probaby due to the small number of cases here used.

TABLE 5

The influence of the size of the litter on the individual birth weight

\begin{tabular}{|c|c|c|c|c|c|c|c|}
\hline \multirow{2}{*}{$\begin{array}{l}\text { NUMBER OF } \\
\text { MOTHERS }\end{array}$} & \multicolumn{3}{|c|}{ МOTHER } & \multicolumn{4}{|c|}{$\begin{array}{l}\text { AVERAGE, WEIGHT- } \\
\text { INDIVIDUALS }\end{array}$} \\
\hline & Body weight & Age in days & No. in litter & & & & ales \\
\hline (4)... & 195 & 165 & 6.5 & 4.99 & (14) & 4.65 & (12) \\
\hline (3).. & 199 & 149 & 8.3 & 4.56 & (13) & 4.42 & (12) \\
\hline (4) $\ldots$ & 195 & 139 & 10.0 & 4.60 & (17) & 4.53 & (23) \\
\hline
\end{tabular}

Finally, if we take the individual birth weights as the criterion and compare the birth weights under 4.5 grams (for the male) with the birth weights of 5 grams or more (for the male) it appears that the heavier birth weights are associated with the heavier weight of the mother-as we should expect from table 4 . At the same time it is to be noted that the age at which the heavier birth weights are recorded is greater.

TABLE 6

The individual birth weight in relation to body weight of mother

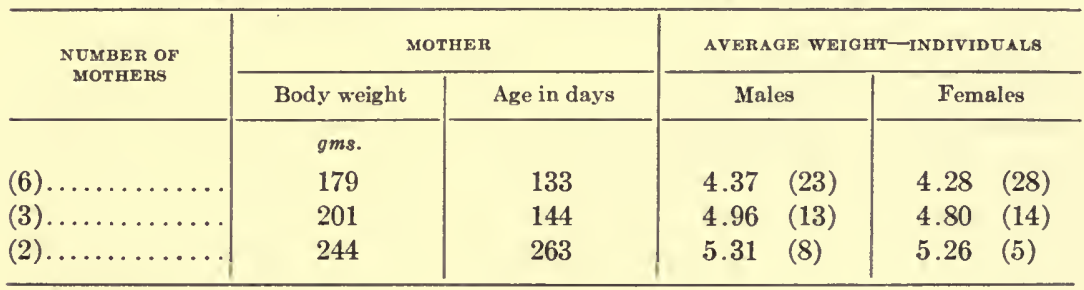

These relations exhibited by table 6 and based on this small number of stock Albinos agrees with those already determined by King on a much larger series which combines the data here used with a large series of litters from inbred Albinos.

This agreement shows that in these respects there is no significant difference between the stock Albinos and the inbred strain 
of King. The general conclusion which King reaches is that increasing weight or increasing age of the mother (the two being correlated) give a heavier birth weight, while the increase in the number in a litter tends to diminish the individual birth weight. There is to be observed also a diminution in birth weight in those litters born of mothers below the standard in size, or suffering from infectious disease. With the larger material just mentioned, it is also possible for King and Stotsenburg ('15) to show a modification of the birth weight in relation to the place of the litter in the series of litters born by a given female, see table 7 .

TABLE 7

Showing the sex ratios and average number of young in 75 litters of stock albino rats. Data arranged according to the position of the litters in the litter series

\begin{tabular}{|c|c|c|c|c|c|c|}
\hline LITTER SERIES & $\begin{array}{l}\text { NUMBER OF } \\
\text { LITTERS }\end{array}$ & $\begin{array}{l}\text { NUMBER OF } \\
\text { INDIVIDUALS }\end{array}$ & MALES & FEMALES & $\begin{array}{c}\text { NUMBER } \\
\text { MALES TO } \\
100 \\
\text { FEMALES }\end{array}$ & $\begin{array}{l}\text { AVERAGE } \\
\text { NO. YOUNG } \\
\text { PER } \\
\text { LITTER }\end{array}$ \\
\hline $1 \ldots$ & 21 & 131 & 72 & 59 & 122.0 & 6.2 \\
\hline $2 \ldots$ & 21 & 162 & 85 & 77 & 110.4 & 7.7 \\
\hline 3. & 18 & 127 & 64 & 63 & 101.6 & 7.0 \\
\hline \multirow[t]{2}{*}{$4 \ldots \ldots \ldots \ldots$} & 15 & 96 & 41 & 55 & 74.5 & 6.4 \\
\hline & 75 & 516 & 262 & 254 & 102.1 & 6.8 \\
\hline
\end{tabular}

The observations indicate that the number of individuals in the litter generally increases from the first to the second litter, and after that decreases. These results would quite accord with Crampe's conclusions. According to Crampe ('84) the second litter of albino rats is the best. The majority of albino females do not produce more than four or five litters.

7. Recognition of sex. The recognition of sex through external characters in the young rat has been studied by Jackson ('12). He finds in brief that the male, as contrasted with the female, may be recognized by (1) The larger size of the genital papilla; (2) the greater ano-genital distance (see table 8); (3) the absence of clearly marked nipples. (This test is applicable only up to the age of 16 days, i.e., before the development of hair on the ventral surface.) (4) Small extent of the bare area just ventral to the anus (test applicable only after the 16th day). 
As a rule the descent of the testes occurs about the fortieth day of age or somewhat earlier. The following is a condensed form of Jackson's table for the ano-genital distance.

TABLE 8

Ano-genital distance in young albino rats of various ages

\begin{tabular}{|c|c|c|c|c|c|c|}
\hline \multirow[t]{2}{*}{$A G E$} & \multicolumn{2}{|c|}{ NUMBER OF EACH SEX } & \multicolumn{2}{|c|}{$\begin{array}{c}\text { AVERAGE GROSS BODY } \\
\text { WEIOHT }\end{array}$} & \multicolumn{2}{|c|}{$\begin{array}{l}\text { AVERAOE ANO-GENITAL } \\
\text { DISTANCE }\end{array}$} \\
\hline & Male & Female & Male & Female & Male & Female \\
\hline & & & gms. & gms. & $g m s$. & $g m s$. \\
\hline New born. & 10 & 12 & 5.7 & 5.4 & 2.8 & 1.2 \\
\hline 7 days.... & 17 & 26 & 11.0 & 10.4 & 5.2 & 2.7 \\
\hline 14 days.. & 13 & 15 & 19.5 & 18.2 & 8.2 & 4.9 \\
\hline 20 days. . & 19 & 26 & 27.4 & 27.4 & 12.0 & 7.0 \\
\hline $42-50$ days & 19 & 13 & 73.3 & 71.0 & 21.0 & 13.0 \\
\hline
\end{tabular}

8. Sex ratio. On the basis of 30 litters comprising 255 individuals, Cuenot ('99) reports among albino rats-when the litters are examined shortly after birth-105.6 males to each 100 females.

King ('11 b) in 80 litters containing 452 individuals, found 107.3 males to 100 females, and in a later series of 120 litters (which includes the 80 litters just mentioned) containing 690 individuals, a sex ratio of 107.8 males to 100 females. Finally, in a group of 814 litters, comprising 5691 individuals, King and Stotsenburg ('15) found 108.1 males to 100 females.

In a thriving colony therefore a ratio of about 108 males it to be expected. This however is subject to a seasonal variation. At the two periods of greatest reproductive activity-in the spring (March-May) and again in the autumn (September-November) the proportion of males (the sex ratio) is low.

In the first litters of young females the sex ratio tends to be higher than in the later litters-but no relation of sex ratio to size of litter has been found (King and Stotsenburg, '15).

9. Body weight according to sex-at maturity. At maturity the body weight of the male Albino is much greater than that of the female. According to our records for the common strainages not known-the four largest males thus far examined weighed $320,327,343$ and 438 (fat) grams respectively, and the four largest females 280, 287, 319 and 359 (fat) grams. In Albi- 
nos of the common strain, the following maximum weights for each sex at known ages have been observed by King (MS '15).

TABLE 9

Body weight in grams

\begin{tabular}{|c|c|c|}
\hline AGE IN DAYS & MALES & FEMALES \\
\hline $\begin{array}{l}395 \ldots \ldots \ldots \ldots \\
425 \ldots \ldots \ldots \ldots \\
455 \ldots \ldots \ldots \ldots\end{array}$ & $\begin{array}{l}397 \\
409\end{array}$ & 284 \\
\hline $485 \ldots \ldots$ & 437 & $\left\{\begin{array}{l}265 \\
324\end{array}\right.$ \\
\hline
\end{tabular}

10. Behavior. a) The normal activities of the rat under natural conditions have been studied and described by a number of observers (see references).

b) As the albino rat is easily tamed and responds readily to training it has already been used for a number of studies in which behavior tests have been employed. Studies have been made for example on imitation, temperament, the influence of practice, retentiveness, the rôle of the several organs of sense and the relation of the learning rate to age and to the relative brain weight (see references).

\section{BIOLOGY: REFERENCES}

Life history. Donaldson, '08. King, '13. Kirkham, '10. Kirkham and Burr, '13. McCoy, '09. Slonaker, '07, '12. Stewart, 1898. Watson, '03.

Span of life. Donaldson, '08. Slonaker, '12, '12 a.

Puberty, Ovulation, Menopause. Hewer, '14. Kirkham and Burr, '13. Sobotta and Burckhard, '10.

Period of gestation. King, '13.

Superfecundation. King, '13.

Fecundity and weight at birth. Crampe, '84. King, '15. King and Stotsenburg. '15. Kolazy, 1871. Lloyd, '09 a. Pearson, '10. Sobotta and Burckhard, '10. Watson, '06 a.

Recognition of sex. Jackson, '12.

Sex ratio. Cuenot, 1899. King, '11 a, 11 b. King and Stotsenburg, '15.

Body weight according to sex. King and Stotsenburg, '15.

Behavior. a) Under natural conditions. Advisory Committee, '12. Bechstein, 1801. Bell, 1837-1874. Buckland, 1859. Buffon, 1749-1789. Dehne, 1855. Fisher, 1872. Hewett, '04. Kolazy, 1871. Lambert, '10. Lantz, '10. Manouvrier, '05. Mitchell, '11. b) Under experimental conditions. Adams, '13. Basset, '14. Berry, '06. Carr and Watson, '08. Cesana, '10. Hubbert, '14, '15. Hunter, '12, '13. Lashley, '12. Richardson, '09. Small, 1899, 1900, '01. Szymanski, '14. Ulrich, '13. Vincent, '12,'13,'15, '15 a, '15 b. Watson, J. B., '03, '07, '13, '14. 


\section{CHAPTER 2}

\section{HEREDITY}

\section{General.-2. Coat color}

Inbreeding brother and sister from the same litter of Albinos for twenty successive generations (King, 1911-1915, MS) has not been followed by any physical deterioration.

Studies on heredity in the Norway rat have been concerned mainly with the inheritance of coat color. The gray coat of the wild Norway is dominant in crosses between the wild gray and the Albino. The Albinos in the $\mathrm{F}_{2}$ generation appear in the proportion of one Albino to three pigmented. In the $\mathrm{F}_{2}$ and in the later generations pied animals may be had and the color pattern both fixed and modified by selection (Castle, '12, 12 a, and Castle and Phillips, '14). The inheritance of brain weight in the reciprocal crosses Norway $\times$ Albino has been studied by Hatai (MS '13).

The references to the literature are grouped into 1) those touching the general problem and 2) those especially applying to coat color.

\section{HEREDITY : REFERENCES}

1. General. Castle, '11, '12, '12 a. Castle and Phillips, '14. Crampe, 1883, 1884. Darwin, 1883. Hagedoorn, '11, '14. Hatai, '11 a, '12. Lloyd, '08, '09, '11. Pearson, '11. Przibram, '07, '10, '11. Ritzema-Bos, 1894. Yerkes, '13.

2. Coat color. Bateson, '03. Castle, '14 a, '14 b. Castle and Phillips, '14. Crampe, 1877. Doncaster, '06. Fischer, 1874. Frédéric, '07. Haacke, 1895. MacCurdy and Castle, '07. Morgan, '09. Mudge, '08, '08 a, '09. 


\section{CHAPTER 3}

\section{ANATOMY}

1. Anatomy, general. 2. Embryology. a) Spermatogenesis. b) Ovulation. c) Earlier stages. d) Later stages. 3. Bones, joints and connective tissues. a) Teeth. 4. Muscles. 5. Vessels and lymphatics. a) Blood. 6. Nervous system. a) Central 1) Brain. 2) Spinal cord. b) Peripheral. 1) Cerebral. 2) Spinal nerves and ganglia. 3) Autonomic. c) Technical methods. 7. Sense organs. 8. Integument. 9. Gastro-pulmonary system. a) Gastro-intestinal system. b) Pulmonary system. 10. Uro-genital system. 11. Endocrine system.

Since this book purposes to present mainly those results that can be systematically arranged and are in a quantitative form - there will appear several divisions of this chapter marked only by references to the literature.

Further, even in those divisions for which there are some available data it happens in many instances that the presentation of them can be better given in the chapters which treat of growth -and in such instances the reader is merely referred to the later place of presentation. These general statements apply to the subsequent chapters as well.

1. Anatomy, general. In only two instances has the rat been used as the basis for a general presentation of mammalian anatomy. These are in the books by Martin and Moale, 1884, and Goto, 1906. The remaining references are to studies which apply to portions or systems only" (see classified references-at the end of the chapter).

2. Embryology, a) Spermatogenesis. According to Hewer ('14):

In the newborn animal, active mitosis is occurring in the testis, and at $3 \frac{1}{2}$ weeks the spermatogonia can be distinguished from the spermatocytes. No lumen begins to appear in the tubules as a rule until 7 weeks. At 8 weeks spermatids are easily distinguishable: at $8 \frac{1}{2}$ weeks isolated spermatozoa may occasionally be seen. At 9 weeks typical ripe spermatozoa are plentiful, but the fully formed epididymis contains no free spermatozoa. At 10 weeks all the tubules show active 
spermatogenesis: the second crop of spermatozoa is appearing, while the first crop can be seen in the epididymis. Reduced number of chromosomes 19. Allen (MS '15).

b) Ovulation. According to the observations of Sobotta and Burckhard, '10, ovulation is simultaneous in both ovaries-as many as 13 egg cells have been found discharged. The ovumafter fixation with Zenker's solution containing somewhat less than the usual proportion of acetic acid-measured $60-65 \mu$ in diameter with a nucleus about $25 \mu$ in diameter. The reduced number of chromosomes is 16 . The full number of chromosomes 32. The authors.incorrectly assume that the common Albino is a variety of Mus rattus.

For the diameter of the living unsegmented egg Kirkham and Burr ('13) give $79 \mu$ as a mean value.

For the volume of the ovum see table 11 .

c) On the early stages of development we have the observations of Huber ('15 a). His description is as follows:

The material at hand permits the conclusion that in the albino rat the segmenting ova pass from the oviduct to the uterine horn at the end of the fourth day after the beginning of insemination, probably in the 12-cell to 16-cell stage. With the beginning of the fifth day, as will appear from further discussion, all of the ova are to be found in the uterine horn.

The following summary of the data gained by a study of the models of oviducts containing ova in stages from the pronuclear to 12 -cell to

TABLE 10

Showing the distance of the ova from the fimbria at various ages. Based on table 3, Huber ('15a)

\begin{tabular}{|c|c|c|c|c|c|c|c|}
\hline $\begin{array}{l}\text { RECORD NUM- } \\
\text { BER }\end{array}$ & $\begin{array}{c}\text { SIDE } \\
\text { RECON- } \\
\text { STRUCTED }\end{array}$ & AGE & $\begin{array}{l}\text { NUM- } \\
\text { BER OF } \\
\text { OVA }\end{array}$ & STAGE & 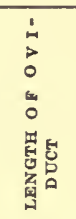 & 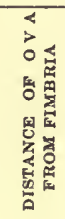 & 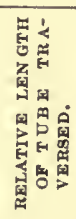 \\
\hline 106. & R. & 1 day & 8 & Pronuclear & $\begin{array}{c}\mathrm{cm} . \\
3.2\end{array}$ & $\begin{array}{l}\mathrm{cm} . \\
0.8\end{array}$ & 0.25 \\
\hline $59 \ldots$ & $\mathrm{R}$. & 2 days & 4 & 2 -cell & $2.29^{1}$ & 1.4 & 0.63 \\
\hline $62 \ldots$ & L. & 2 days 22 hrs. & 5 & 2-cell & $2.45^{1}$ & 2.0 & 0.84 \\
\hline $50 \ldots$ & $\mathrm{R}$. & 3 days 1 hour & 4 & 4-cell & 2.8 & 2.5 & 0.90 \\
\hline $51 \ldots$ & L. & 4 days & 5 & 12 to 16 cell & 2.86 & 2.86 & 1.00 \\
\hline
\end{tabular}

1 Not the entire length of oviduct was available for reconstruction. 
16-cell stages in which latter stage transit to the uterine horn occurs, is presented to indicate rate of transit within the oviduct. The regularity of the rate of transit as revealed in the summary may perhaps speak for the trustworthiness of the age data as concerns my material.

It will be observed that the ova approach the uterine end of the oviduct while in the 2-cell stage (see table 10); transit through the last portion of the oviduct, where the greater part of the segmentation occurs, being relatively slow. It is hoped that these data, for the accuracy of which I am dependent on reconstructions, may be of service to others who may desire to collect segmentation stages of the albino rat.

In order to obtain the volume changes of the ova during transit through the oviduct, beginning with the pronuclear and extending to the 8-cell to 11-cell stages, reconstructions were made at a magnification of 1000 diameters of ova presenting the stage in question. The respective volumes of these models were determined and the data reduced to the actual volumes.

TABLE 11

Volumes of ova and embryos. Based on table 4 Huber ('15 a)

\begin{tabular}{|c|c|c|c|c|c|}
\hline \multirow{2}{*}{$\begin{array}{c}\text { RECORD } \\
\text { NEMBER }\end{array}$} & \multicolumn{2}{|c|}{$A G E$} & \multirow{2}{*}{ STAGE } & \multirow{2}{*}{$\begin{array}{l}\text { ACTUAL YOL. OF } \\
\text { EGG MASS IN } \\
\text { C. MM. }\end{array}$} & \multirow{2}{*}{$\begin{array}{l}\text { AVERAGE VOL. PER } \\
\text { STAGE GIVEN IN } \\
\text { C. MM. }\end{array}$} \\
\hline & Days & Hours & & & \\
\hline $106 .$. & 1 & 0 & Pronuclear & 0.000151 & 0.000156 \\
\hline $106 \ldots$ & 1 & 0 & Pronuclear & 0.000143 & \\
\hline $106 \ldots$ & 1 & 0 & Pronuclear & 0.000158 & \\
\hline $106 . . \ldots \ldots$ & 1 & 0 & Pronuclear & 0.000171 & \\
\hline $59 \ldots \ldots$ & 2 & 0 & 2 cell & 0.000162 & 0.000173 \\
\hline $59 \ldots$ & 2 & 0 & 2 cell & 0.000183 & \\
\hline $50 \ldots$. & 3 & 1 & 4 cell & 0.000183 & 0.000162 \\
\hline $50 \ldots$. & 3 & 1 & 4 cell & 0.000155 & \\
\hline $57 \ldots \ldots$ & 3 & 17 & 8 cell & 0.000189 & 0.000184 \\
\hline $57 \ldots \ldots$ & 3 & 17 & 8 cell & 0.000160 & \\
\hline $57 \ldots .$. & 3 & 17 & 8 cell & 0.000187 & \\
\hline $57 \ldots$. & 3 & 17 & 8 cell & 0.000182 & \\
\hline $57 \ldots$ & 3 & 17 & 8 cell & 0.000200 & \\
\hline $57 \ldots \ldots$ & 3 & 17 & 11 cell & 0.000210 & 0.000210 \\
\hline
\end{tabular}

The uniformity of the figures giving the actual volume of the egg mass, as determined by the weight of the water displaced by the models of the respective ova reconstructed, leads me to feel that the errors committed in reconstruction were not serious. The last column of the table, giving averages, is of interest since it shows a very slight increase in the volume of the egg mass during segmentation and transit through the oviduct. Following the pronuclear stage, which, as has been seen, extends through a relatively long period and into the beginning of the second day, by which time the ova have migrated about one-fourth of 
the length of the oviduct, there occurs only three successive mitotic divisions, including the first segmentation division, namely mitoses resulting in 2-cell, 4-cell, and 8-cell stages while the ova are in transit in the oviduct. In making this statement it is assumed that in the successive segmentations, the several cells divide synchronously, which is not in conformity with the fact. These three mitotic divisions are spaced at intervals of about 18 hours.

In the next following division, the fourth, the ovum passes from the oviduct to the uterine horn. Since the normal gestation period of the non-lactating albino rat is only 21 to 23 days, this slow rate of increase in volume and multiplication of cells during the first four days of development is of especial interest and is very probably to be accounted for by the inadequacy of the food supply of the ovum during its transit through the oviduct.

d) Later stages. Observations have been made by Stotsenburg (MS '15) on the daily increase in the weight of the fetus from the 13 th to the 22nd day after insemination. The data and graph are given in chapter 5, pp. 64 and 65 .

3. Bones, joints and connective tissues. On the following page is an enumeration of the bones forming the skeleton of the rat.

For data on the growth of the entire skeleton see Chapter 6 . Skull measurements have been made by Hatai ('07 c). The following description is extracted from his paper.

For this study 53 male and 51 female skulls of mature Albinos (rats more than 150 days old) were measured. These skulls had been carefully cleaned and dried at room temperature. The following measurements were made with vernier calipers: 1 ) the length of the entire skull; 2) the fronto-occipital length; 3 ) the zygomatic width; 4) the length of the nasal bone; 5) the height of the skull; 6 ) the width of the cranium or the squamosal distance. In every case the maximum length alone was recorded in millimeters.

The horizontal straight line joining the tip of the nasal bone to the end of the occipital bone is called the length of the entire skull. This however is not exactly equal to the sum of the length of the nasal bone and that of the fronto-occipital.

The fronto-occipital length was determined in the following way: Since the length measured with the calipers from the tip of the nasal bone to the posterior end of the inter-parietal bone is usually less than the length measured from the same point to the end of the occipital bone, both measurements were taken (see fig. 1). The difference between these two measurements was added to the length from the tip of the frontal bone to the end of the inter-parietal bone, and the sum was called the fronto-occipital length.

The width of the cranium (squamosal distance) was determined by 


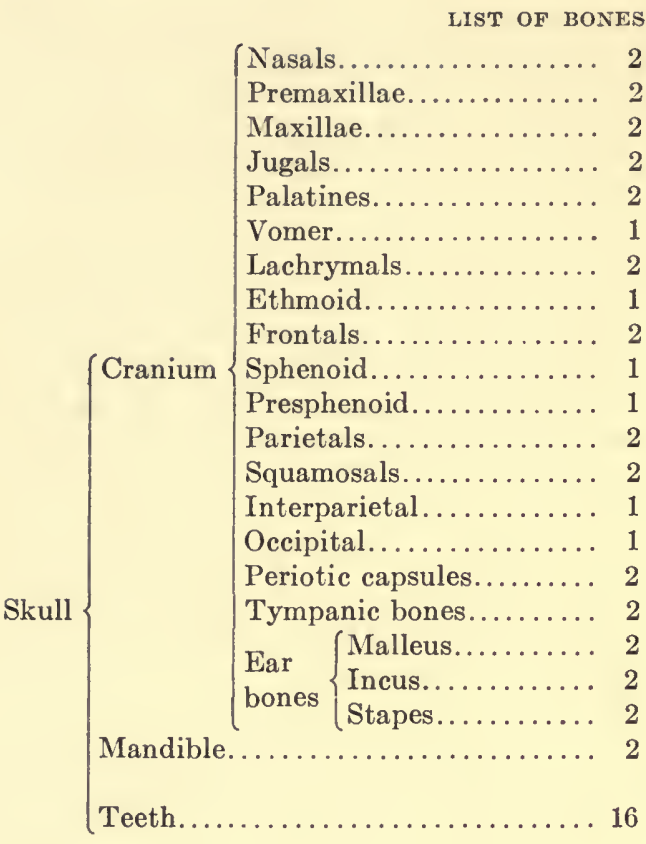

Hyoid

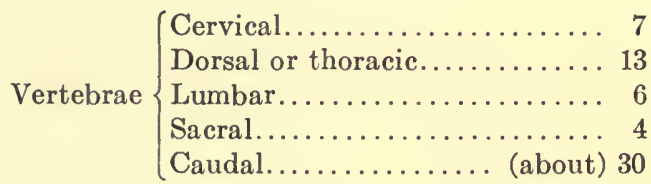

Sternum ...........

Shoulder $\{$ Scapula..... 2

girdle $\{$ Clavicle..... 2

Pelvic
girdle $\quad \begin{cases}\text { Ilium......... } & 2 \\ \text { Ischium...... } & 2 \\ \text { Os pubis..... } & 2\end{cases}$

Humerus............ 2

Ulna................ 2

Radius.............. 2

$\left\{\begin{array}{lll}\text { Carpus....... } 16 & 16\end{array}\right.$

Fore feet $\{$ Metacarpus.. 10 Phalanges.... 28

Femur.............. 2

Tibia.............. 2

Fibula.............. 2

Sesamoid $\left\{\begin{array}{c}\text { Patellae...... } \\ \text { bones }\end{array}\right.$

Hind feet $\begin{cases}\text { Tarsus........ } & 16 \\ \text { Metatarsus... } & 10 \\ \text { Phalanges.... } & 28\end{cases}$

281

Nails (20) omitted
6

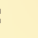

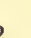

(n)

2




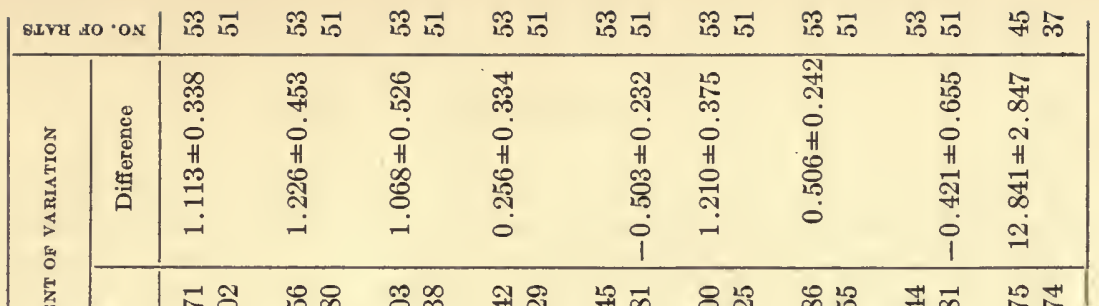

ปั้

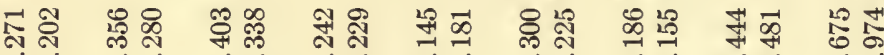

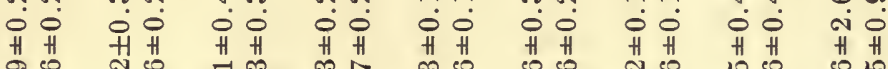

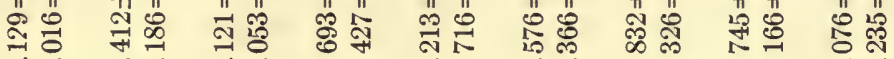
ฐ ฐँ

.ั้ ริ)

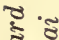

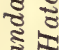
a

进范要要

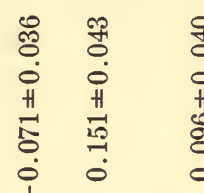

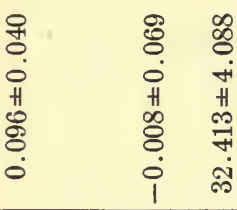

ริำ

: $:$

\begin{tabular}{|c|c|c|c|c|c|c|c|c|c|c|}
\hline & 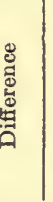 & 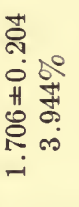 & 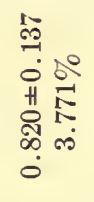 & 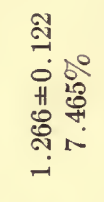 & 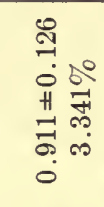 & 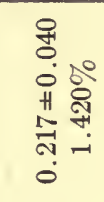 & 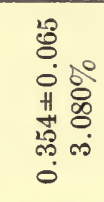 & 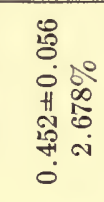 & $\stackrel{5}{0}$ & \\
\hline & & 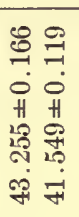 & 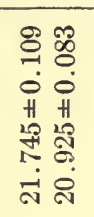 & 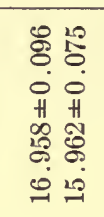 & 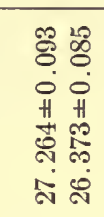 & 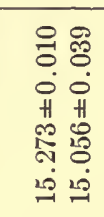 & 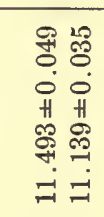 & 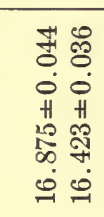 & 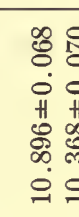 & \\
\hline & & $\mathrm{roO}_{0}$ & ro ot & ro ot & ro ot & ro ot & $5_{0} 0$ & $\mathrm{roO}_{0}$ & $r_{0}$ & \\
\hline
\end{tabular}

iों iो

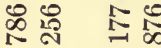

유묘

8

क्षे용

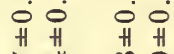

i 0

영 영

io

iᄋ

然

赑 -i - io

io 00

00

00 io 곰요

ฐั้

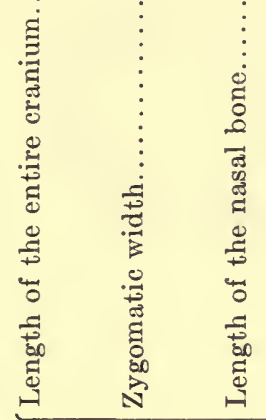

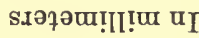

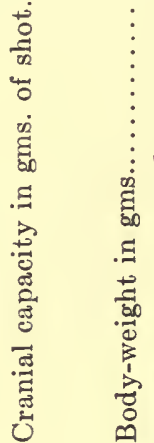


By practice Hatai has been able to reduce the difference between the first and second filling to less than one per cent. The cranial capacity thus determined in the terms of shot weight can be transformed into brain weight as follows: by dividing the weight of the shot in the case of the males by 5.980 and in the case of the females by 6.009 . The relations between the cranial capacity, in terms of shot weight, and the body weight are represented by the formulas (8) and (9).

TABLE 13

Showing the range of variates and rate of increase for various characters according to sex Hatai ('or c)

\begin{tabular}{|c|c|c|c|c|c|c|}
\hline & \multicolumn{3}{|c|}{ MALE } & \multicolumn{3}{|c|}{ FEMALE } \\
\hline & $\begin{array}{l}\text { Mini- } \\
\text { mum }\end{array}$ & Mean1 & $\begin{array}{l}\text { Maxi- } \\
\text { mum }\end{array}$ & $\begin{array}{l}\text { Maxi- } \\
\text { mum }\end{array}$ & Mean 1 & $\begin{array}{l}\text { Mini- } \\
\text { mum }\end{array}$ \\
\hline & $m m$. & $m m$. & $m m$. & $m m$. & $m m$. & $\mathrm{mm}$. \\
\hline Length of the entire cran- & & & & & & \\
\hline Rate & $\begin{array}{c}59.4 \\
100\end{array}$ & 100 & 100 & 100 & 100 & 100 \\
\hline Zygomatic width. & $\begin{array}{r}19.6 \\
49.8\end{array}$ & $\begin{array}{l}21.7 \\
50.2\end{array}$ & $\begin{array}{l}24.8 \\
52.3\end{array}$ & $\begin{array}{c}23.4 \\
52.5\end{array}$ & $\begin{array}{r}20.9 \\
50.3\end{array}$ & $\begin{array}{l}18.9 \\
48.5\end{array}$ \\
\hline $\begin{array}{r}\text { Length of the nasal bone. } \\
\text { Rate }\end{array}$ & $\begin{array}{c}14.7 \\
37.3\end{array}$ & $\begin{array}{l}17.0 \\
39.2\end{array}$ & $\begin{array}{c}18.7 \\
39.3\end{array}$ & $\begin{array}{c}17.8 \\
40.0\end{array}$ & $\begin{array}{r}15.7 \\
37.7\end{array}$ & $\begin{array}{c}14.4 \\
37.0\end{array}$ \\
\hline $\begin{array}{l}\text { Fronto-occipital length. } \\
\text { Rate }\end{array}$ & $\begin{array}{c}24.9 \\
63.2\end{array}$ & $\begin{array}{l}27.3 \\
63.0\end{array}$ & $\begin{array}{c}28.8 \\
60.7\end{array}$ & $\begin{array}{r}28.2 \\
63.3\end{array}$ & $\begin{array}{c}26.4 \\
63.5\end{array}$ & $\begin{array}{l}24.9 \\
64.0\end{array}$ \\
\hline $\begin{array}{l}\text { Squamosal distance. } \\
\text { Rate }\end{array}$ & $\begin{array}{c}14.6 \\
37.0\end{array}$ & $\begin{array}{r}15.3 \\
35.3\end{array}$ & $\begin{array}{r}16.2 \\
34.1\end{array}$ & $\begin{array}{c}16.2 \\
36.4\end{array}$ & $\begin{array}{l}15.1 \\
36.2\end{array}$ & $\begin{array}{l}14.4 \\
37.0\end{array}$ \\
\hline Height of cranium & $\begin{array}{r}10.4 \\
26.4\end{array}$ & $\begin{array}{l}11.5 \\
26.5\end{array}$ & $\begin{array}{c}13.0 \\
27.4\end{array}$ & $\begin{array}{c}12.2 \\
27.4\end{array}$ & $\begin{aligned} 11.1 & \\
26.8 & \end{aligned}$ & $\begin{array}{r}10.3 \\
26.4\end{array}$ \\
\hline
\end{tabular}

1 Taken from Table 12.

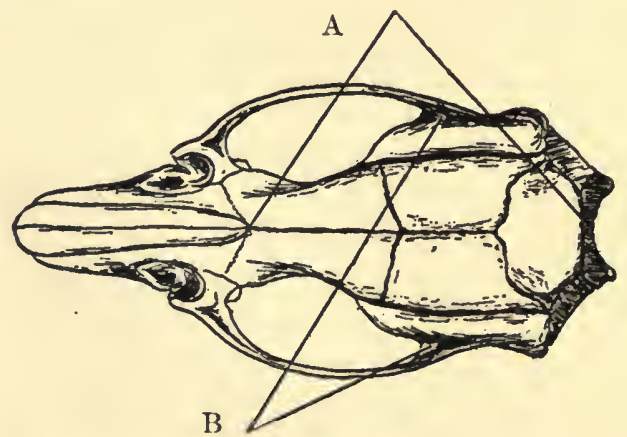

Fig 1. A. Fronto-occipital length. B. Squamosal distance. 
The greatest difference found between the measurements of the skulls for the two sexes is in the nasal bones, which are nearly 2 per cent longer in the male skull. The greater relative length of the nasal bones in the male may be regarded as a secondary sexual character (Hatai).

a) Teeth. Addison and Appleton ('15) report as follows on the size and growth of the incisor teeth in the Albino.

The dental formula of the albino rat is

$$
\mathrm{I} \frac{1}{1} \mathrm{C} \frac{0}{0} \mathrm{P} \frac{0}{0} \mathrm{M} \frac{3}{3}
$$

There is only one set of teeth, and hence the dentition is monophyodont. The time of eruption of the various teeth extends over a period of $3 \frac{1}{2}$ weeks. The incisors are the first to appear, viz., at 8 to 10 days after birth. The first and second molars erupt at about the 19th and 21st days respectively, and it is after this latter period that the young animals may be weaned and are able to maintain an independent existence, as far as food is concerned. The third molars are delayed until two weeks later and do not appear until about the 35th day.

The incisors are permanently-growing (or rootless) teeth, while the molars have a definite limited period of development and acquire roots. A wide diastema separates the incisors from the molars as may be seen by reference to figure 1 (loc. cit.) The incisors are strongly curved and Owen (1840-1845) has described the lower incisor as being the smaller segment of a larger circle, and the upper incisor as the larger segment of a smaller circle. In the case of lower incisor of the albino rat this statement needs a slight modification.

The times of the early stages of development of the incisors were as follows:

14 day fetus-slight thickening of oral epithelium.

15 day fetus-distinct thickening and growth inwards of oral epithelium.

16 day fetus-dental ledge and beginning of flask-shaped enamel organ.

17 day fetus-dental papilla with crescentic enamel organ capping it.

19 day fetus - both ameloblasts and odontoblasts differentiated.

New-born animal-enamel and dentine formation begun.

8 to 10 days-eruption of the tooth. 
The rate at which the teeth increase in length during their formative period and prior to attrition is given in the following table:

TABLE 14

\begin{tabular}{|c|c|c|}
\hline & \multicolumn{2}{|c|}{ LENGTH OF INCISORS } \\
\hline & Upper & Lower \\
\hline & $m m$. & $m m$. \\
\hline 1 day old. . & 2.3 & 3 \\
\hline 4 days old. & 3.6 & 5 \\
\hline 7 days old. & 5 & $7-8$ \\
\hline 10 days old. & 7 & 11 \\
\hline
\end{tabular}
day.

Average growth of upper incisor $0.52 \mathrm{~mm}$. and of lower incisor $0.88 \mathrm{~mm}$. per TABLE 15

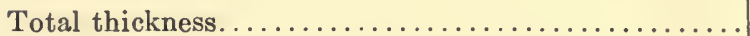

Outer fibrous layer.

Pigmented portion of outer fibrous layer.

Inner plexiform layer.

\begin{tabular}{|c|c}
\multicolumn{2}{|c}{ INCisors } \\
\hline Upper & Lower \\
\cline { 2 - 2 }$\mu$ & \\
$100-110$ & $140-150$ \\
$30-40$ & $20-30$ \\
$8-10-12$ & $6-8$ \\
70 & $120-125$ \\
\end{tabular}

TABLE 16

\begin{tabular}{|c|c|c|c|c|c|c|c|}
\hline & $\begin{array}{l}23 \\
\text { DAYS }\end{array}$ & $\begin{array}{c}41 \\
\text { DAYS }\end{array}$ & $\begin{array}{c}10 \\
\text { WEEKS }\end{array}$ & $\begin{array}{c}15 \\
\text { WEEKS }\end{array}$ & $\begin{array}{c}5 \\
\text { MONTHS }\end{array}$ & $\begin{array}{c}8 \\
\text { MONTHS }\end{array}$ & $\begin{array}{c}10 \\
\text { MONTHS }\end{array}$ \\
\hline & $m m$. & $m m$. & $m m$. & $m m$. & $m m$. & $m m$. & $m m$. \\
\hline Naso-occipital length.... & 29.7 & 32.5 & 39 & 40 & 43 & 44 & 46.5 \\
\hline Interzygomaticl $\ldots \ldots \ldots \ldots \ldots$ & 13.7 & 14 & 14.5 & 14.6 & 15.4 & 15.1 & 15.5 \\
\hline Upper diastema.............. & 7.4 & 9.5 & 10 & 11.4 & 12.3 & 12.5 & 13 \\
\hline Upper incisor-total length...... & 12.8 & 15 & 18.3 & 20.3 & 23.3 & 23.7 & 26.2 \\
\hline 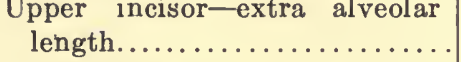 & 5.1 & 5.5 & 7 & 8.4 & 8.7 & 9 & 9.3 \\
\hline Lower diastema............... & 4.6 & 5 & 5.6 & 6 & 6.7 & 7 & 6.8 \\
\hline Lower incisor-total length..... & 18.1 & 21.7 & 25.5 & 26.4 & 29.4 & 29.9 & 31.3 \\
\hline 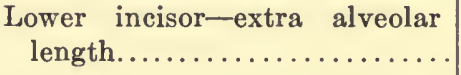 & 6.5 & 7 & 10.5 & 11.4 & 11.6 & 12 & 12.4 \\
\hline
\end{tabular}

1 Same as 'squamosal distance,' figure 1, p. 36. 
Throughout life growth continues, and in the adult animal is on the average $2.2 \mathrm{~mm}$. per week in the upper and $2.8 \mathrm{~mm}$. per week in the lower incisor.

In a five months animal the thickness of the enamel and its constituent layers measured in the mid-line of the teeth is given in table 15.

Measurements of the incisors and skulls of animals of different ages were made and are shown in table 16.

The lower incisor of a five months animal forms a segment of about four-fifths of a semicircle $\left(140-145^{\circ}\right)$.

4. Muscles. Morpurgo (1898) has furnished data on the Musc. radialis of the albino rat; giving the number of muscle fibers and of nuclei at different ages (table 17).

TABLE 17

\begin{tabular}{|c|c|c|c|}
\hline $\mathrm{AGE}$ & $\begin{array}{c}\text { NO. OF } \\
\text { MUSCLE FIBERS }\end{array}$ & $\begin{array}{l}\text { NO. OF NUCLEI } \\
\text { PER CUBIC MM. }\end{array}$ & $\begin{array}{l}\text { AREA OF CROSB } \\
\text { SECTION IN } \\
\text { MM. X } 37 \text { DIAM. }\end{array}$ \\
\hline 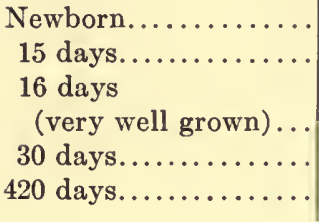 & $\begin{array}{l}5919 \\
7252 \\
\\
7587 \\
7625 \\
8014\end{array}$ & $\begin{array}{r}570645 \\
357764 \\
\\
347343 \\
139861 \\
37542\end{array}$ & $\begin{array}{r}552 \\
868 \\
\\
1010 \\
2766 \\
11817\end{array}$ \\
\hline
\end{tabular}

5. Vessels and lymphatics. a) Blood. Specific gravity 1.056 (Sherrington and Copeman, 1893). The diameter of the erythrocytes is as follows (White, '01):

\begin{tabular}{|c|c|}
\hline FOR M. DECUMANUS & $\begin{array}{c}\text { DIAMETERR } \\
\text { IN } \mu\end{array}$ \\
\hline Determination by (Treadwell). & 6.5 \\
\hline Determination by (Wormley, 1888).. & 7.0 \\
\hline Determination by (Gulliver, 1875$) \ldots \ldots \ldots \ldots \ldots$ & 6.5 \\
\hline
\end{tabular}

1) Percentage of water in the blood. Hatai (MS '15) has determined the percentage of water in the blood of a small series of Albinos. 
The Albinos were from The Wistar Institute stock strain, grown on the scrap diet and examined before the day's feeding. The rat was chloroformed, but before the heart ceased beating it was exposed in situ, the tip clipped away and the blood from it caught in a small glass weighing bottle. The fresh weight was immediately taken and after drying at $95^{\circ} \mathrm{C}$. for a week the weight of the residue was obtained.

The results are given in table 18.

TABLE 18

Percentage of water in the blood of the Albino, Hatai (MS. '15)

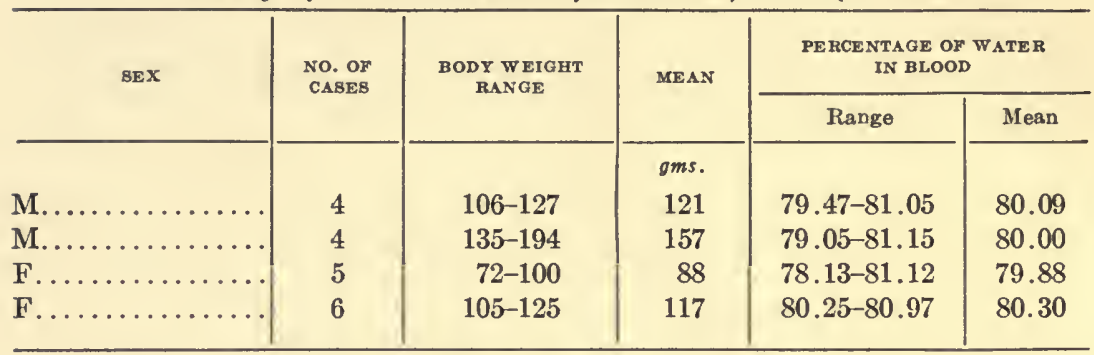

In 50 rats ( 27 males +23 females) between the weights of 50 and 150 grams the average number of erythrocytes was found by Chisolm ('11) to be 8.8 millions and the average hemoglobin content 87.8 per cent as measured on the human scale.

TABLE 19

Rivas (University of Pennsylvania MS. '14). Observations on the Albino rat blood-normal.

\begin{tabular}{|c|c|c|c|c|c|c|c|}
\hline \multirow{2}{*}{$\begin{array}{l}\text { PERCENTAGE } \\
\text { OF } \\
\text { HEMOGLOBIN }\end{array}$} & \multicolumn{2}{|c|}{ IN 1 CU. MM. } & \multicolumn{5}{|c|}{ PERcentages of } \\
\hline & $\begin{array}{l}\text { Erythro- } \\
\text { cytes in } \\
\text { millions }\end{array}$ & $\begin{array}{l}\text { Leuco- } \\
\text { cytes }\end{array}$ & $\begin{array}{c}\text { Poly- } \\
\text { morph. }\end{array}$ & $\begin{array}{c}\text { Small } \\
\text { lymph. }\end{array}$ & $\begin{array}{l}\text { Large } \\
\text { lymph. }\end{array}$ & Eosinoph. & Basoph. \\
\hline 85. & 8.6 & 8,800 & 68.5 & 24.9 & 6.2 & & \\
\hline $85 \ldots$ & 9.2 & 7,200 & 56.5 & 34.4 & 9.1 & 0.4 & $\mathbf{0}$ \\
\hline $88 \ldots$ & 8.2 & 8,400 & 47.5 & 44.9 & 5.9 & 3.0 & 0.85 \\
\hline $90 \ldots$ & 7.4 & 8,000 & 44.9 & 49.3 & 5.2 & 0.9 & 0 \\
\hline $90 \ldots$ & 8.0 & 8,000 & 69.9 & 25.4 & 4.2 & 0.7 & 0.70 \\
\hline $90 \ldots$ & 8.4 & 9,400 & 42.4 & 50.5 & 4.0 & 0.0 & 0 \\
\hline $93 \ldots$ & 8.4 & 16,000 & 43.6 & 51.9 & 4.3 & 0.5 & 0.26 \\
\hline $95 \ldots$ & 7.6 & 11,600 & 71.6 & 20.7 & 4.1 & 0.6 & 0 \\
\hline $97 \ldots$ & 7.6 & 8,800 & 56.4 & 37.6 & 4.5 & 1.5 & 0 \\
\hline $100 \ldots$ & 8.4 & 9,400 & 51.2 & 42.1 & 6.2 & 0.7 & 0 \\
\hline
\end{tabular}


In addition the observations of Rivas, University of Pennsylvania (MS '14) are given in table 19. The data are arranged according to the increasing haemoglobin content.

For the wandering cells we have tables 20 and 21 by Kanthack and Hardy, 1894.

TABLE 20

Showing the percentage and size of the various forms of the wandering cells of the blood in the rat

\begin{tabular}{|c|c|c|c|}
\hline TYPE OF CELL & GRANULATION & PERCENTAGE OF TYPE & DIAMETERS IN $\mu$ \\
\hline Oxyphile...... & $\left\{\begin{array}{l}\text { Coarse } \\
\text { Fine }\end{array}\right.$ & $\begin{array}{r}2 \\
45\end{array}$ & $\begin{array}{c}10 \\
7-8\end{array}$ \\
\hline $\begin{array}{l}\text { Basophile....... } \\
\text { Hyaline......... } \\
\text { Lymphocytes.... }\end{array}$ & (absent) & $\begin{array}{r}2 \\
50\end{array}$ & $\begin{array}{c}8-10 \\
6\end{array}$ \\
\hline
\end{tabular}

TABLE 21

(From the same authors)

Shows the percentage and size of various forms of the wandering cells in the peritoneal fluid of the rat

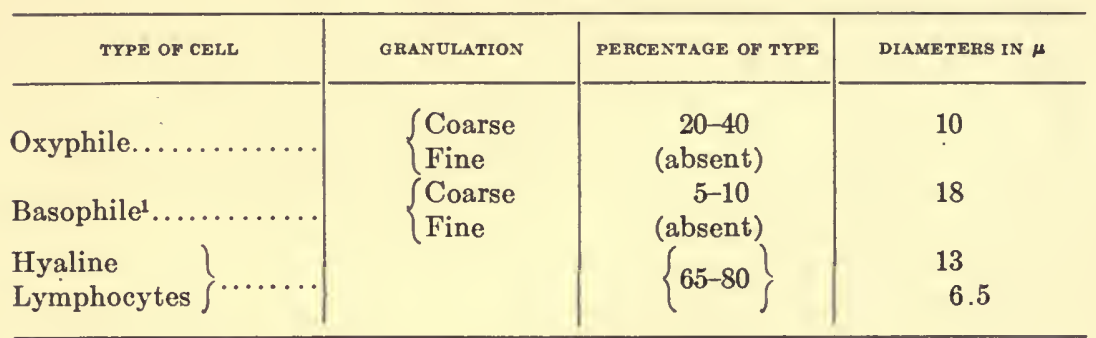

${ }^{1}$ Basophile cells in connective tissue $23 \mu$ in diameter.

6. Nervous system. a) Central. 1) Brain. Specific gravity 1.050-1.056, Reichardt ('06). For brain weight see Chapter 7, p. 90, and table 68. For the percentage of water see Chapter 8, p. 176 and table 74. For the chemical composition see Chapter 9, p. 181 and tables 80, 81. Cell division in the central nervous system continues after birth. The observations of Hamilton ('01) are given in table 22. 
TABLE 22

The number of mitoses in 13 consecutive sections, each section $6.75 \mu$ in thickness, from the brain and spinal cord of rats at different stages of development. The fetus weighed $0.78 \mathrm{gms}$. and had a crown-rump length of $17 \mathrm{~mm}$. It was probably at 17.5 days of gestation.

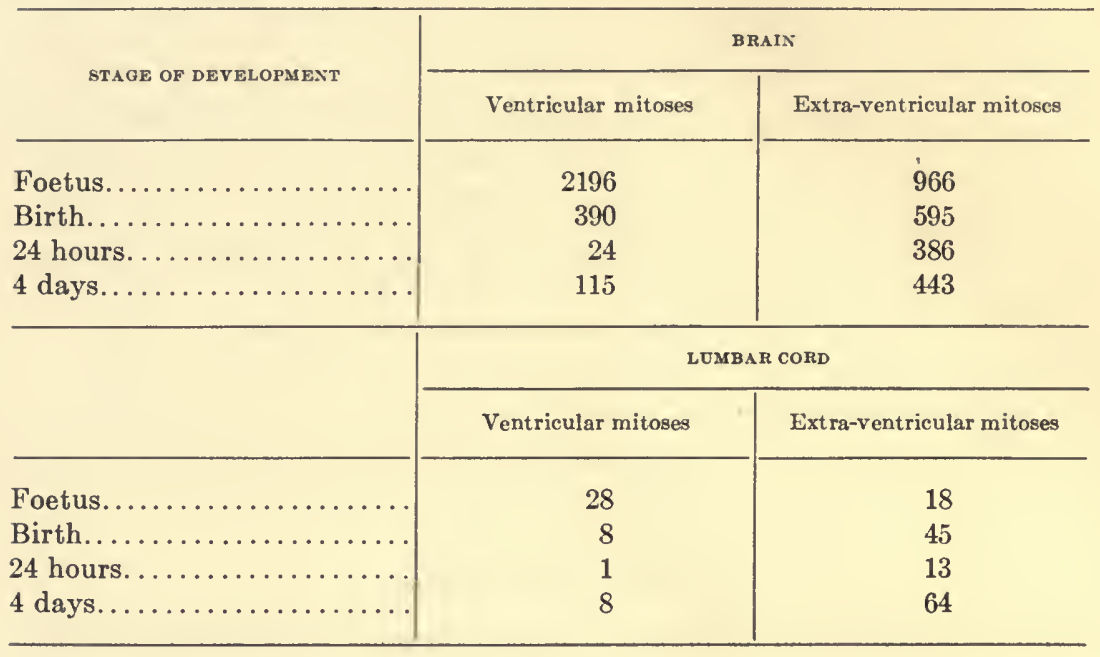

For the first 25 days after birth Allen ('12) has obtained the results given in table 23 .

\section{TABLE 23}

Showing the number of mitoses per cubic millimeter of nerve tissue in the central nervous system of the stock Albino at certain levels. The figures are taken from calculations of the volume of tissue and based on the number of mitoses in the consecutive sections at each level of the cord, five in the largest portion of the cerebellum and five in the cerebrum in the region of the optic chiasma. The letters (a) (b) and (c) refer to different rats of the same age

\begin{tabular}{|c|c|c|c|c|c|}
\hline \multirow{2}{*}{ AGE, DAYS } & \multicolumn{3}{|c|}{ CORD } & \multirow{2}{*}{ CEREBELLOM } & \multirow{2}{*}{ CEREBREM } \\
\hline & Cervical & Thoracic & Lumbar & & \\
\hline $1 \ldots \ldots \ldots$ & 208 & 115 & 259 & 1597 & 430 \\
\hline $4 \ldots \ldots$ & 437 & 176 & 351 & 2111 & 447 \\
\hline $6 \ldots \ldots$ & 446 & 236 & 320 & & 193 \\
\hline $7 \ldots$ & & & & 4848 & \\
\hline $12 \ldots$ & 46 & 75 & 14 & 839 & 37 \\
\hline $20 \ldots$ & 00 & 00 & 00 & (c) 520 & \\
\hline $20 \ldots \ldots \ldots$ & 00 & 00 & 00 & (b) & (b) 27 \\
\hline $20 \ldots \ldots \ldots$ & 00 & 00 & 00 & (a) & (a) 18 \\
\hline $25 \ldots \ldots$ & 00 & 00 & 00 & 00 & 27 \\
\hline
\end{tabular}


The diameters of the Purkinje cells have been studied by Addison, '11.

The Albinos were from the stock colony of The Wistar Institute, reared on the scrap diet. The cerebellum was fixed in Ohlmacher's solution (King, '10) imbedded in paraffin and stained with carbol-thionine and acid fuchsin. The values for the respective diameters given in table 24 are in each instance averages of ten measurements from the largest cells found in equivalent areas at the several ages. The measurements stop at 20 days of age. After this age there is but little change in the diameters of the largest cells.

TABLE 24

Diameters of Purkinje cells and their nuclei

\begin{tabular}{|c|c|c|}
\hline \multirow{2}{*}{ AGE IN DAYS } & \multicolumn{2}{|c|}{ DIAMETERS IN $\mu$} \\
\hline & Cell & Nucleus \\
\hline 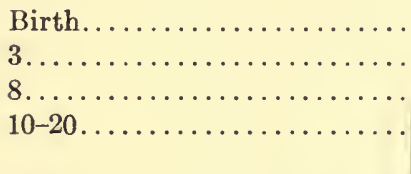 & $\begin{aligned} 12 \times 7 \\
14 \times 8 \\
18 \times 12 \\
21 \times 14 \\
\text { (largest) } 24 \times 19\end{aligned}$ & $\begin{array}{r}8 \times 6.3 \\
8.3 \times 7.4 \\
11 \times 8.5 \\
12 \times 9.0\end{array}$ \\
\hline
\end{tabular}

2) Spinal cord. For the weight of the spinal cord see Chapter 7 , p. 90, and table 68. For the percentage of water see Chapter 8 , p. 176, and table 74. For the chemical composition see Chapter 9, p. 180 and table 80 . Cell division in the spinal cord after birth has been studied by Hamilton, '01, see table 22 and Allen (12) see table 23.

b) Peripheral. 1) Cerebral nerves. Fortuyn ('14) counted 3000 myelinated fibers in the $n$. cochlearis of the Norway rat.

Boughton ('06) studied the increase with age (body weight) in the number of myelinated fibers in the oculomotor nerve in the albino rat and measured the areas of the entire fiber and the axis in osmic preparations. The results are given in table 25 .

2) Spinal nerves and ganglia. One of the larger spinal ganglia from a cervical nerve root of an Albino weighing 140 grams was fixed in a formalin-acetic sublimate mixture $(6$, loc. 


\section{TABLE 25}

Oculo motor nerve

\begin{tabular}{|c|c|c|c|c|c|c|}
\hline \multirow{2}{*}{$\begin{array}{l}\text { BODY WEIGHT IN } \\
\text { GRAMB AND SEX }\end{array}$} & \multicolumn{3}{|c|}{ NUMBER OF FIBERS } & \multicolumn{2}{|c|}{ AREAS IN $\mu^{2}$} & \multirow{2}{*}{$\begin{array}{l}\text { PERCENTAGE } \\
\text { OF AXIS }\end{array}$} \\
\hline & Large & Small & Total & Entire fiber & Axis & \\
\hline 11 M........ & 764 & & 764 & & & \\
\hline 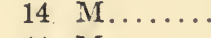 & 880 & 38 & 918 & 13.2 & 6.6 & 50 \\
\hline 44 M... & 885 & 220 & 1105 & & & \\
\hline $51 \quad \mathrm{~F} \ldots \ldots \ldots$ & 926 & 227 & 1153 & & & \\
\hline $80 \quad \mathrm{~F} \ldots \ldots \ldots$ & 887 & 290 & 1177 & 41.8 & 21.2 & 51 \\
\hline 109 F......... & 888 & 329 & 1217 & & & \\
\hline 172 M... & 882 & 465 & 1347 & & & \\
\hline 192 M... & 932 & 316 & 1248 & & & \\
\hline $213 \quad$ M........ & 925 & 383 & 1308 & & & \\
\hline $218 \mathrm{M} . \ldots \ldots$ & 926 & 471 & 1397 & & & \\
\hline 278 M........ & 901 & 566 & 1467 & & & \\
\hline $318 \quad$ M........ & 930 & 379 & 1309 & & & \\
\hline $414 \quad M . \ldots \ldots$ & 928 & 408 & 1336 & 56.7 & 27.3 & 48 \\
\hline
\end{tabular}

cit. p. 3) by Hatai ('01) and cut in paraffin sections 6-7 $\mu$ thick.

Selecting cells according to size from large to small the measurements of the cell body and the nucleus were made as in table 26.

TABLE 26

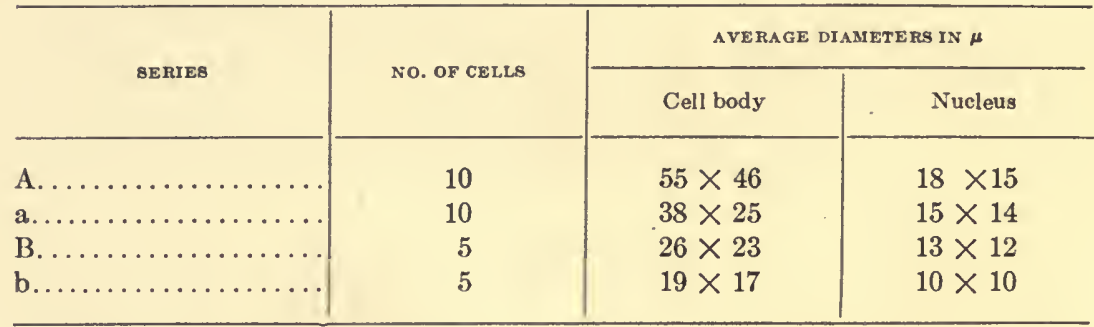

Further studies on the spinal roots and ganglia were made by Hatai ('02) and ('03 b).

From a series of male Albinos the spinal ganglia with accompanying dorsal root nerves were fixed in one per cent osmic acid and cut in paraffin. The measurements on this material Hatai ('02) are given in table 27. Incorporated in the same table 
are the enumerations for the myelinated fibers in the ventral roots (Hatai, '03 b).

It was found that the number of myelinated fibers in the ventral roots diminishes from sections near the spinal cord to those near the spinal ganglion. The amount of the diminution decreases with the age (body weight) of the rat. The increase in the number of cells in the spinal ganglia from the small to the large rats is certainly due in part to the fact that in the small animals some of the smallest ganglion cells escape enumeration.

The increase in the number of myelinated fibers in the spinal roots with advancing age is due mainly to progressive myelination. Both roots at maturity still contain functional fibers without myelin sheaths (Ranson, '06).

\section{TABLE 27}

Number of ganglion cells and number and size of myelinated root fibers in spinal nerves from three levels of the spinal cord at five ages (body weights)

Results from Tables II, VI and VIII combined. Hatai ('02) Also data on ventral root fibers from Hatai ('03 b)

\begin{tabular}{|c|c|c|c|c|c|c|c|}
\hline \multicolumn{2}{|c|}{$\begin{array}{l}\text { BODY WEIGHT } \\
\text { IN GMS. }\end{array}$} & \multirow{2}{*}{$\begin{array}{c}\text { TOTAL OF } \\
\text { MYELINATED } \\
\text { VENTRAL } \\
\text { ROOT } \\
\text { FIBERS } \\
558\end{array}$} & \multirow{2}{*}{$\begin{array}{c}\begin{array}{c}\text { TOTAL OF } \\
\text { GANGLION } \\
\text { CELLS }\end{array} \\
10996\end{array}$} & \multirow{2}{*}{$\begin{array}{c}\text { TOTAL OF } \\
\text { MYELINATED } \\
\text { DORSAL ROOT } \\
\text { FIBERS } \\
1998\end{array}$} & \multirow{2}{*}{$\begin{array}{c}\begin{array}{c}\text { TOTAL } \\
\text { COMPOBED } \\
\text { OF MATURE } \\
\text { FIBERS }\end{array} \\
1043\end{array}$} & \multirow{2}{*}{$\begin{array}{c}\begin{array}{c}\text { IMMATURE } \\
\text { FIBERS }\end{array} \\
955\end{array}$} & \multirow{2}{*}{$\begin{array}{c}\text { MEAN } \\
\text { DIAMETER } \\
\text { IN } \mu \text { OF } 20 \\
\text { largest DOR- } \\
\text { BAL ROOT } \\
\text { FIBERS } \\
\text { ENTIRE }\end{array}$} \\
\hline క్ & 10.3 & & & & & & \\
\hline 3 & 24.5 & 1007 & 9793 & 2569 & 2263 & 306 & 11.6 \\
\hline 包 & 68.5 & 1302 & 11772 & 3683 & 3569 & 114 & 13.3 \\
\hline & 167.0 & 1474 & 12200 & 4227 & 4173 & 54 & 13.9 \\
\hline 5 & 264.3 & 1522 & & 4028 & & & \\
\hline.$\frac{0}{0}$ & 10.3 & 286 & 7142 & 607 & 283 & 424 & 4.8 \\
\hline 趈 & 24.5 & 434 & 7068 & 683 & 497 & 366 & 7.1 \\
\hline 일 & 68.5 & 561 & 7611 & 1420 & 1259 & 161 & 8.9 \\
\hline F & 167.0 & 613 & 7406 & 1522 & 1460 & 82 & 11.6 \\
\hline 咅 & 264.3 & 772 & & 1650 & & & \\
\hline 4 & 10.3 & 333 & 8315 & 723 & 303 & 420 & 5.1 \\
\hline है & 24.5 & 698 & 8200 & 911 & 678 & 233 & 8.0 \\
\hline 고 & 68.5 & 704 & 9514 & 1317 & 1181 & 136 & 11.3 \\
\hline$n$ & 167.0 & 1028 & 9442 & 1644 & 1565 & 79 & 12.0 \\
\hline 困 & 264.3 & 965 & & 2102 & & & \\
\hline
\end{tabular}


For the numerical relations of cells and fibers in the second cervical nerve data have been furnished by Ranson ('06).

TABLE 28

Second cervical nerve

Observations on normal male rats (Albinos.) Osmic acid fixation-paraffin sections

\begin{tabular}{|c|c|c|c|c|}
\hline \multirow{2}{*}{ AGE IN DAYS } & \multirow{2}{*}{ BODY WEIGHT } & \multirow{2}{*}{$\begin{array}{l}\text { CELLS IN } \\
\text { GANGLION }\end{array}$} & \multicolumn{2}{|c|}{ NUMBER OF MYELINATED FIBERS } \\
\hline & & & Dorsal root & Ventral root \\
\hline $72 \ldots \ldots \ldots \ldots$ & 110 & 7721 & 2472 & 689 \\
\hline $72 \ldots$ & 110 & 8116 & 2394 & 660 \\
\hline $72 \ldots$ & 110 & & 1959 & 590 \\
\hline $72 \ldots$ & 110 & & 2217 & 591 \\
\hline $72 \ldots$ & 155 & 9343 & & \\
\hline & 161 & & 2090 & 672 \\
\hline 240 (left side)... & 188 & 8624 & 2689 & 703 \\
\hline 240 (right side) & 188 & & 2891 & 773 \\
\hline & 302 & & 2386 & 646 \\
\hline
\end{tabular}

When the number of myelinated fibers in the two rami on the distal side of the II cervical spinal ganglion is compared with the total number found in the two roots-a distal excess in the number of fibers is found. This is shown in table 29. The distal excess appears to be due to branching of the fibers in their course, Ranson ('06).

TABLE 29

\begin{tabular}{|c|c|c|c|c|c|c|c|c|}
\hline \multirow{2}{*}{$\begin{array}{l}\text { BODY } \\
\text { WEIGHT } \\
\text { GMS. }\end{array}$} & \multicolumn{3}{|c|}{ IN RoOTs } & \multicolumn{2}{|c|}{ DISTAL EXCESS } & \multicolumn{3}{|c|}{ IN RAMI } \\
\hline & Ventral & Dorsal & Sum & Absolute & $\begin{array}{l}\text { Percent- } \\
\text { age }\end{array}$ & Sum & $\begin{array}{l}\text { Ventral } \\
\text { Ramus }\end{array}$ & $\begin{array}{l}\text { Dorsal } \\
\text { Ramus }\end{array}$ \\
\hline 161. & 672 & 2090 & 2762 & 276 & 10 & 3098 & 708 & 2390 \\
\hline $302 \ldots$ & 646 & 2386 & 3032 & 257 & 8 & 3289 & 887 & 2402 \\
\hline
\end{tabular}

Enumerations of the myelinated fibers in the ventral roots of the II spinal nerve of the Albino have been made by Dunn ('12). Each record is the mean of two enumerations of rats of like age. Areas in $\mu^{2}$ of the entire fiber and of the axis-together with the percentage value of the axis. Each entry is based on the mean of the 20 largest fibers. In this series there is a change 
in the relative area of the axis with age, as well as a decrease in the total areas in the oldest group.

TABLE 20

Giving for Albinos of different ages the numbers of myelinated fibers in the ventral root of the second cervical nerve and the areas of the fibers. Dunn ('12)

\begin{tabular}{|c|c|c|c|c|c|}
\hline AGE, NUMBER, SEX & WEIGHT & $\begin{array}{l}\text { NUMBER } \\
\text { FIBERS }\end{array}$ & \begin{tabular}{|} 
AVERAGE AREA \\
TEN LARGEST \\
FIBERS
\end{tabular} & $\mid \begin{array}{c}\text { AVERAGE AREA } \\
\text { OF AXES } \\
\text { IN } \mu^{2}\end{array}$ & $\begin{array}{l}\text { PERCENTAGE } \\
\text { OF AXIS }\end{array}$ \\
\hline & grams & & & & \\
\hline 7 days & & & & & \\
\hline Two females.... & 8.59 & 368 & 17.2 & 10.6 & 61.6 \\
\hline Two males..... & 9.33 & 366 & 22.3 & 13.9 & 62.3 \\
\hline 14 days & & & • & & \\
\hline Two females... & 20.92 & 542 & 38.5 & 18.1 & 47.0 \\
\hline Two males..... & 21.33 & 565 & 32.9 & 15.2 & 46.2 \\
\hline 36 days & & & & & \\
\hline Two females... & 42.24 & 653 & 78.2 & 31.2 & 40.0 \\
\hline Two males..... & 41.93 & 613 & 80.6 & 31.7 & 39.3 \\
\hline 75 days & & & & & \\
\hline Two females... & 136.70 & 560 & 115.4 & 49.6 & 43.0 \\
\hline Two males..... & 169.55 & 668 & 116.9 & 52.8 & 45.1 \\
\hline 132 days & & & & & \\
\hline Two females... & 164.26 & 683 & 136.0 & 59.3 & 43.6 \\
\hline Two males..... & 267.00 & 625 & 141.0 & 63.2 & 44.8 \\
\hline 180 days & & & & & \\
\hline Two females... & 212.50 & 518 & 168.8 & 75.9 & 44.9 \\
\hline Two males..... & 264.80 & 609 & 201.3 & 98.2 & 48.7 \\
\hline 270 days & & & & & \\
\hline Two females... & 176.91 & 776 & 261.0 & 133.4 & 51.3 \\
\hline Two males..... & 340.05 & 617 & 216.8 & 107.1 & 49.4 \\
\hline 640 days & & & & & \\
\hline Three males... & 334.47 & 864 & 170.7 & 78.2 & 45.8 \\
\hline
\end{tabular}

From a study of the diameters of the cell bodies and their nuclei in the second cervical spinal ganglion of the adult Albino, values which apply to the mean of the entire cell 'population' of this ganglion have been obtained (Hatai, '07 b). The ganglion examined was from a mature male weighing 194 grams. The 
ganglion was fixed in osmic acid and imbedded in paraffin. The mean values are as follows:

TABLE 31

\begin{tabular}{|c|c|c|c|}
\hline & MEAN DIAMETER & STANDARD DEVIATION & $\begin{array}{l}\text { COEFFICIENT or } \\
\text { VARIATION }\end{array}$ \\
\hline Cell body. & $\begin{array}{c}\mu \\
28.6\end{array}$ & 14.9 & 18.4 \\
\hline Nucleus.............. & 13.1 & 1.8 & 13.7 \\
\hline
\end{tabular}

On the basis of these observations, formula (12) was devised for computing the diameter of the nucleus from the diameter of the cell body.

For comparison with the data in table 31 see data in table 26 obtained by a different method of fixation.

The number of myelinated fibers in the peroneal nerve of the normal Albino is given from Greenman's observations ('13) in table 32. Ages not known.

TABLE 32

\begin{tabular}{|c|c|c|c|c|}
\hline LEVEL OF SECTION COUNTED & $\begin{array}{c}\text { BODY WEIGHT } \\
104 \text { F. } \\
\text { RIGHT NERVE }\end{array}$ & $\begin{array}{l}\text { BODY WEIGHT } \\
117 \mathrm{~F} \text {. } \\
\text { RIGHT NERVE }\end{array}$ & $\begin{array}{l}\text { BODY WEIGHT } \\
182 \mathrm{M} \text {. } \\
\text { LEFT NERVE }\end{array}$ & AVERAGES \\
\hline 1. Proximal............. & 2240 & 2430 & 2192 & 2288 \\
\hline $\begin{array}{c}\text { Distance from } 1 \text { to } 2 \text { in } \\
m m \ldots \ldots \ldots \ldots\end{array}$ & 3.0 & 4.7 & 3.1 & \\
\hline 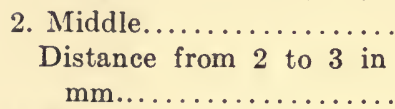 & 2118 & 2292 & 2418 & 2276 \\
\hline 3. Distal............... & 2392 & 2213 & 2364 & 2323 \\
\hline Averages......... & 2250 & 2312 & 2325 & 2296 \\
\hline
\end{tabular}

TABLE 33

Normal Albinos: Sectional area of ten largest in $\mu^{2} ;$ relation of axis to sheath

\begin{tabular}{c|r|r|r|r|r|r}
\hline \multicolumn{3}{c|}{ Proximal ENd } & \multicolumn{3}{|c}{ Distal Exd } \\
\cline { 1 - 2 } Body weight & Entire fiber & Axis & $\begin{array}{c}\text { Per cent of } \\
\text { axis }\end{array}$ & Entire fiber & Axis & $\begin{array}{c}\text { Per cent of } \\
\text { axis }\end{array}$ \\
\hline $104 \ldots \ldots \ldots \ldots$ & 109.8 & 55.6 & 50.6 & 85.0 & 42.3 & 49.7 \\
$117 \ldots \ldots \ldots \ldots$ & 137.7 & 75.2 & 54.6 & 85.8 & 42.6 & 49.6 \\
$182 \ldots \ldots \ldots \ldots$ & 150.3 & 82.9 & 55.1 & 113.0 & 56.7 & 50.1 \\
\hline Average & & & & & & \\
$135 \ldots \ldots \ldots \ldots$ & 132.6 & 71.2 & 53.7 & 94.6 & 47.2 & 49.9 \\
\hline
\end{tabular}


Greenman ('13) also found in osmic preparations the sectional areas of the 10 largest myelinated fibers and the areas of their axes. The length of nerve used was $10 \mathrm{~mm}$. The results are given in table 33 .

3) Autonomic. In the course of a study intended primarily to determine whether the small myelinated fibers in the spinal accessory could be regarded as representing the fibers of the rami communicantes, Roth ('05) in a series of cervical nerves, counted on one side the number of myelinated fibers $4 \mu$ or less in diameter, and in the corresponding ramus communicans he also counted the myelinated fibers of like size. His findings are given in table 34 .

TABLE 34

\begin{tabular}{|c|c|c|c|}
\hline \multirow{2}{*}{ NERVE } & \multicolumn{2}{|c|}{$\begin{array}{l}\text { MYELINATED FIBERS LESS THAN } 4 \mu \text { IN } \\
\text { DIAMETER IN VENTRAL ROOT }\end{array}$} & \multirow{2}{*}{$\begin{array}{l}\text { MYELINATED FIBERS } \\
\text { LESS THAN } 4 \mu \text { IN } \\
\text { RAMUS COMMUNICANS }\end{array}$} \\
\hline & Rat I & Rat II & \\
\hline 2nd cervical.. & 130 & 168 & None \\
\hline 3rd cervical... & 105 & 126 & None \\
\hline 4th cervical... & 380 & 363 & 195 \\
\hline 5th cervical... & 432 & 449 & 220 \\
\hline
\end{tabular}

c) Technical methods. To determine the effects of various fixatives on the brain of the rat, King ('10) carried through a series of weighings of mature rat brains which had been subjected to the action of various fixatives. A summary of the results is given in table 35 .

The solution of Ohlmacher ('97), the formula for which is as follows:

Absolute alcohol, 80 parts.

Chloroform, 15 parts.

Glacial acetic acid, 5 parts.

Corrosive sublimate to saturation (about 20 per cent) was found to give excellent results with the cells of the cerebral cortex. 
TABLE 35

Summary of Data Collected (King '10)

\begin{tabular}{|c|c|c|c|c|c|c|c|c|c|c|}
\hline $\begin{array}{l}\dot{0} \\
\dot{z} \\
\dot{\alpha}\end{array}$ & 葸 & 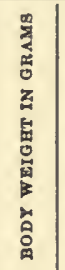 & 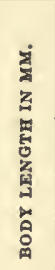 & 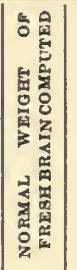 & $\begin{array}{l}\text { SOL.UTIONS UBED FOR } \\
\text { FIXATION }\end{array}$ & 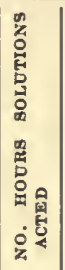 & 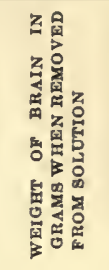 & 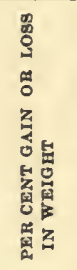 & 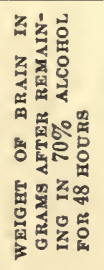 & 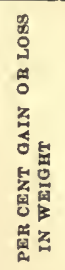 \\
\hline 1 & $\sigma^{7}$ & 277 & 219 & 1.94 & $4 \%$ Formaldehyde.. & 48 & 2.5750 & +33 & 1.5706 & -19 \\
\hline 2 & $a^{7}$ & 163 & 196 & 1.83 & $4 \%$ Formaldehyde.. & 48 & 2.8200 & +54 & 1.6463 & -10 \\
\hline 3 & \$ & 158 & 199 & 1.85 & Formol-Müller (cold) & 20 & 2.2437 & +21 & 1.5537 & -16 \\
\hline 4 & 이 & 129 & 183 & 1.78 & $4 \%$ Formaldehyde.. & 48 & 2.6778 & +50 & 1.6577 & -7 \\
\hline 5 & $q$ & 164 & 188 & 1.80 & $\begin{array}{l}\text { Formol-Müller } \\
\qquad(\text { warm }) \ldots \ldots \ldots\end{array}$ & 3 & 2.1880 & $\begin{array}{l}\dot{+} \\
+22\end{array}$ & 711 & +4 \\
\hline 6 & $\sigma^{7}$ & 187 & 198 & 1.85 & Ohlmacher... & 5 & 1.6100 & -12 & 1.4471 & -22 \\
\hline 7 & $q$ & 137 & 184 & 1.78 & Ohlmacher.... & 2 & 1.7389 & -2 & 1.4099 & -21 \\
\hline 8 & $\sigma^{7}$ & 160 & 190 & 1.81 & $\begin{array}{l}\text { Zenker... } \\
\text { Müller... }\end{array}$ & $\begin{array}{r}6 \\
48\end{array}$ & 1.8716 & +3 & 1.6666 & -8 \\
\hline 9 & \% & 170 & 197 & 84 & $\begin{array}{l}\text { Dahlgren... } \\
\text { Müller...... }\end{array}$ & $\begin{array}{r}4 \\
48\end{array}$ & 1.9000 & +3 & 1.7273 & -7 \\
\hline 10 & $a^{7}$ & 182 & 186 & 1.79 & Picro-formol... & 4 & 1.7881 & -0 & 1.4663 & -18 \\
\hline 11 & $\sigma^{7}$ & 275 & 228 & 1.98 & Ohlmacher. . & 6 & 1.8267 & -8 & 1.6248 & -18 \\
\hline 12 & $0^{7}$ & 206 & 207 & 1.88 & Ohlmacher. & 2 & 1.6924 & -10 & 1.5748 & -16 \\
\hline 13 & $\sigma^{7}$ & 228 & 210 & 1.90 & Ohlmacher... & 4 & 1.5787 & -17 & 1.4498 & -25 \\
\hline 14 & $0^{7}$ & 169 & 194 & 1.83 & Ohlmacher..... & 3 & 1.5458 & -16 & 1.4633 & -20 \\
\hline 15 & $0^{7}$ & 126 & 157 & 1.65 & Ohlmacher.. & 3 & 1.3978 & -16 & 1.3099 & -21 \\
\hline 16 & $\sigma^{7}$ & 158 & 181 & 1.77 & Ohlmacher. & 3 & 1.4590 & -18 & 1.4000 & -21 \\
\hline 17 & $\sigma^{7}$ & 232 & 199 & 1.85 & Ohlmacher. . & 3 & 1.6390 & -11 & 1.4875 & -20 \\
\hline 18 & $q$ & 111 & 154 & 1.63 & r-formol. & $1 \frac{1}{2}$ & 1.6040 & -2 & 1.3297 & -18 \\
\hline 19 & \% & 106 & 159 & 1.66 & Zenker (modified). & $1 \frac{1}{4}$ & 1.7451 & +5 & 1.3167 & -21 \\
\hline 20 & $0^{x}$ & 6 & & 0.30 & Ohlmacher.... & 1 & 0.2523 & -16 & 0.2074 & -31 \\
\hline 21 & १ & 6 & & 0.29 & Ohlmacher... & 2 & 0.2489 & -14 & 0.2011 & -30 \\
\hline 22 & $\sigma^{7}$ & 108 & 156 & 1.64 & $2 \frac{1}{2} \% \mathrm{~K}_{2} \mathrm{Cr}_{2} \mathrm{O}_{7}$. & 48 & 2.8445 & +73 & 2.1409 & +31 \\
\hline 23 & $\sigma^{7}$ & 88 & 163 & 1.68 & $2 \frac{1}{2} \% \mathrm{~K}_{2} \mathrm{Cr}_{2} \mathrm{O}_{7}$. & 48 & 2.5594 & +52 & 1.7518 & +4 \\
\hline 24 & $\sigma^{7}$ & 162 & 187 & 1.79 & Alcohol $\mathrm{K}_{2} \mathrm{Cr}_{2} \mathrm{O}_{7}$. & 48 & 2.5073 & +40 & 1.8885 & +6 \\
\hline 25 & $0^{x}$ & 190 & 207 & 1.88 & Alcohol $\mathrm{K}_{2} \mathrm{Cr}_{2} \mathrm{O}_{7}$. & 48 & 2.8169 & +50 & 2.1797 & +16 \\
\hline 26 & $\sigma^{2}$ & 174 & 184 & 1.78 & Weak alcohol... & 27 & 1.7753 & -00 & 1.6201 & -9 \\
\hline 27 & $\sigma^{2}$ & 168 & 191 & 1.81 & Alcohol-formol. & 24 & 1.6392 & -10 & 1.5147 & -16 \\
\hline 28 & $\sigma^{2}$ & 221 & 198 & 1.85 & $95 \%$ Alcohol... & 24 & 1.4418 & -22 & 1.4611 & -21 \\
\hline 29 & $\sigma^{x}$ & 151 & 184 & 1.78 & Sublimate-acetic. . & $1 \frac{1}{2}$ & 1.8604 & +5 & 1.4484 & -19 \\
\hline 30 & $\sigma^{x}$ & 213 & 202 & 1.86 & Carnoy's fluid.. & 3 & 1.8192 & +2 & 1.4077 & -24 \\
\hline 31 & $\sigma^{7}$ & 181 & 194 & 1.82 & Carnoy's fluid. & 4 & 1.7575 & -3 & 1.3042 & -23 \\
\hline 32 & 우 & 141 & 178 & 1.75 & Graf ( $5 \%$ formalin) & $2 \frac{1}{2}$ & 2.1520 & +23 & 1.7421 & -00 \\
\hline 33 & $\sigma^{2}$ & 165 & 191 & 1.81 & Graf ( $10 \%$ formalin) & $1 \frac{1}{2}$ & 1.9283 & +7 & 1.5994 & -12 \\
\hline 34 & \% & 149 & 184 & 1.77 & Carnoy's fluid...... & 19 & 1.7416 & -2 & 1.3110 & -28 \\
\hline
\end{tabular}


TABLE 35-Concluded.

\begin{tabular}{|c|c|c|c|c|c|c|c|c|c|c|}
\hline 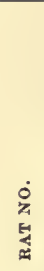 & 啚 & 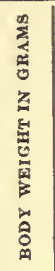 & 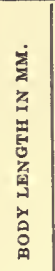 & 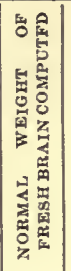 & $\begin{array}{l}\text { SOLUTIONS USED FOR } \\
\text { FIXATION }\end{array}$ & 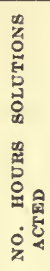 & 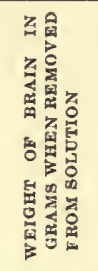 & 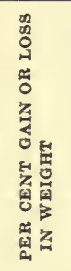 & 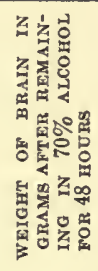 & 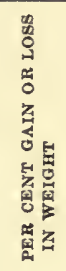 \\
\hline 35 & \& & 167 & 189 & 1.80 & Lang's fluid. . & 20 & 2.0670 & +15 & 1.6794 & -7 \\
\hline 36 & $\sigma^{7}$ & 208 & 203 & 1.86 & Lang's fluid. & 4 & 2.0429 & +10 & 1.7970 & -3 \\
\hline 37 & q & 173 & 194 & 1.82 & Marina's fluid. & 72 & 1.2219 & -33 & 1.2913 & -29 \\
\hline 38 & $0^{x}$ & 197 & 201 & 1.86 & Marina's fluid... & 96 & 1.2146 & -35 & 1.2546 & -33 \\
\hline 39 & $\sigma^{7}$ & 259 & 214 & 1.92 & Cor. sublimate.. & 4 & 2.0760 & +8 & 1.4695 & -23 \\
\hline 40 & $\sigma^{7}$ & 177 & 195 & 1.83 & Cor. sublimate... & 20 & 2.0229 & +11 & 1.4087 & -23 \\
\hline 41 & $0^{7}$ & 265 & 216 & 1.92 & Sublimate-formol.. & 4 & 2.3315 & +21 & 1.6565 & -14 \\
\hline 42 & $\sigma^{7}$ & 213 & 203 & 1.86 & $\mathrm{NaCl}+$ sublimate... & 4 & 1.9927 & +7 & 1.3947 & -25 \\
\hline 43 & q & 213 & 204 & 1.86 & Tellyesniczky... & 48 & 1.9643 & +6 & 1.6372 & -12 \\
\hline 44 & 우 & 137 & 177 & 1.74 & Tellyesniczky....... & 24 & 1.7981 & +3 & 1.4906 & -14 \\
\hline 45 & $\sigma^{7}$ & 196 & 200 & 1.85 & $\mathrm{NaCl}+$ sublimate... & 20 & 2.1549 & +16 & 1.5074 & -19 \\
\hline 46 & 우 & 135 & 179 & 1.75 & Sublimate-formol. & 20 & 2.0512 & +17 & 1.3687 & -22 \\
\hline 47 & $\sigma^{7}$ & 141 & 179 & 1.75 & Cox (osmic)...... & 48 & 1.9917 & +2 & 1.5483 & -12 \\
\hline 48 & $\sigma^{2}$ & 150 & 182 & 1.76 & Cox (osmic). . & 72 & 2.1555 & +22 & 1.8365 & +4 \\
\hline 49 & $0^{7}$ & 171 & 192 & 1.81 & Cox (formol-acetic). & 48 & 1.7687 & -2 & 1.5003 & -17 \\
\hline 50 & $\sigma^{7}$ & 137 & 178 & 1.75 & Cox (formol-acetic). & 72 & 1.8944 & +8 & 1.5221 & -13 \\
\hline
\end{tabular}

In a later study King ('13 a) followed in some detail the effects of formaldehyde on the brain of the Albino. The conclusions reached were as follows:

1. A 4 per cent solution of formaldehyde causes a pronounced swelling in the brains of rats of all ages.

2. A solution of formaldehyde undergoes some chemical change on standing, since a solution five months old causes less swelling in the brain of the rat than does a freshly made solution.

3. A 4 per cent solution of formaldehyde neutralized with $\mathrm{NaCO}_{3}$ produces a much greater amount of swelling in the brain of the rat than does a solution that has a faintly acid reaction.

4. A strong neutralized solution of formaldehyde causes a greater percentage weight increase in the rat's brain than does a weak neutralized solution. A reverse result is obtained when the solutions are not neutralized. 
5. If rats' brains are subjected to the action of a solution of formaldehyde that is kept at a constant temperature of $36^{\circ} \mathrm{C}$., they undergo a greater amount of swelling than is produced when the solution is kept at a temperature of 8 to $11^{\circ} \mathrm{C}$. The maximum weight increase in the brains is reached by the end of the first day in the former case, and not until the third day in the latter case.

6. When the conditions under which the solution acts are uniform, the maximum weight increase in rats' brains subjected to the action of a 4 per cent solution of formaldehyde is attained in all cases by the third day, and there is then a gradual decrease in weight. Brains of very young animals tend to reach the maximum earlier than do those of older animals.

7. The percentage weight increase in rats' brains as the result of the action of a 4 per cent formaldehyde solution tends to be greater in the brains of young animals than in those of adults.

8. In animals of the same age the larger brain does not show a greater percentage weight increase after treatment with a solution of formaldehyde than does the smaller one.

9. A 4 per cent solution of formaldehyde extracts solids from the brains of rats of all ages. This is shown by the fact that the percentage of solids in brains that have been subjected to the action of such a solution is always less than that found in the fresh brains of animals of the same age. Brains of very young rats lose much more of their solids than do brains of older animals.

10. Brains of animals infected with pneumonia show a slightly greater percentage weight increase when treated with a 4 per cent solution of formaldehyde than do the brains of healthy animals.

11. Even under the most favorable conditions an aqueous solution of formaldehyde is not a satisfactory fixative for the cell structures in brain tissues, as it causes a pronounced distention of the nuclei and gives a poor preservation of the nuclear contents.

The more important data are given in tables $36,37,38,39,40$. 
TABLE 36

Percentage weight increase in rats' brains, each kept for ten weeks on $40 \mathrm{cc}$. of a neutralized solution of 4 per cent formaldehyde made five months before the experiments began (averages for three brains at each age)

\begin{tabular}{|c|c|c|c|c|c|c|c|c|}
\hline \multirow{2}{*}{ TIME SOLUTION ACTED } & \multicolumn{8}{|c|}{ AGE OF RATS } \\
\hline & $\begin{array}{l}\text { New- } \\
\text { born }\end{array}$ & $\begin{array}{c}10 \\
\text { days }\end{array}$ & $\stackrel{20}{\text { days }}$ & $\begin{array}{c}40 \\
\text { days }\end{array}$ & $\begin{array}{c}50 \\
\text { days }\end{array}$ & $\begin{array}{c}70 \\
\text { days }\end{array}$ & $\begin{array}{c}100 \\
\text { days }\end{array}$ & $\begin{array}{l}200 \\
\text { days }\end{array}$ \\
\hline 1 day.............. & $29.7^{1}$ & 28.8 & 25.0 & 25.2 & $26.9^{1}$ & 24.5 & $28.3^{1}$ & 15.3 \\
\hline 3 days.... & 28.0 & $35.0^{1}$ & $28.3^{1}$ & $26.3^{1}$ & 26.8 & $27.3^{1}$ & 26.8 & $21.0^{1}$ \\
\hline 7 days.... & 27.3 & 33.0 & 27.3 & 25.0 & 25.1 & 25.1 & 25.7 & 18.6 \\
\hline 2 weeks.. & 23.9 & 31.9 & 27.3 & 24.5 & 25.1 & 25.3 & 26.3 & 18.9 \\
\hline 3 weeks... & 23.4 & 31.4 & 28.3 & 24.9 & 25.5 & 24.4 & 25.3 & 19.3 \\
\hline 4 weeks.... & 22.5 & 30.5 & 26.7 & 24.5 & 24.8 & 25.6 & 26.2 & 19.4 \\
\hline 10 weeks..... & 17.6 & 27.9 & 26.9 & 24.7 & 25.2 & 25.6 & 25.0 & 19.2 \\
\hline Average percentage gain & 24.6 & 31.2 & 27.1 & 25.0 & 25.6 & 25.4 & 26.2 & 18.8 \\
\hline
\end{tabular}

${ }^{1}$ Maximum weight increase.

TABLE 37

Percentage weight increase in rats' brains, each kept for ten weeks in $40 \mathrm{cc}$. of a neutralized solution of 4 per cent formaldehyde made at the time the experiments began (averages for three brains at each age)

\begin{tabular}{|c|c|c|c|c|c|c|c|c|}
\hline \multirow{2}{*}{ TIME SOLUTION ACTED } & \multicolumn{8}{|c|}{ AGE OF RATS } \\
\hline & $\begin{array}{l}\text { New- } \\
\text { born }\end{array}$ & $\begin{array}{c}10 \\
\text { days }\end{array}$ & $\stackrel{20}{\text { days }}$ & $\begin{array}{l}40 \\
\text { days }\end{array}$ & $\begin{array}{c}50 \\
\text { days }\end{array}$ & $\begin{array}{c}70 \\
\text { days }\end{array}$ & $\begin{array}{c}100 \\
\text { days }\end{array}$ & $\begin{array}{c}200 \\
\text { days }\end{array}$ \\
\hline 1 day.... & $44.4^{1}$ & 58.2 & 39.5 & $37.9^{1}$ & $39.3^{1}$ & 34.4 & $45.6^{1}$ & 32.4 \\
\hline 3 days... & 42.0 & $64.6^{1}$ & $41.5^{1}$ & 37.6 & 38.5 & $38.6^{1}$ & 43.1 & $34.7^{1}$ \\
\hline 7 days. & 41.5 & 62.1 & 40.1 & 36.4 & 35.6 & 34.1 & 41.1 & 30.9 \\
\hline 2 weeks. & 38.0 & 62.9 & 39.7 & 35.9 & 36.1 & 34.9 & 41.0 & 30.8 \\
\hline 3 weeks.. & 37.7 & 63.4 & 40.0 & 35.7 & 36.9 & 34.3 & 40.4 & 31.2 \\
\hline 4 weeks.. & 36.1 & 62.8 & 39.9 & 35.5 & 35.4 & 35.7 & 40.5 & 31.6 \\
\hline 10 weeks.... & 33.9 & 61.4 & 39.4 & 35.5 & 36.1 & 35.5 & 37.7 & 31.8 \\
\hline Average percentage gain & 39.1 & 62.2 & 40.0 & 36.4 & 36.7 & 35.4 & 41.3 & 31.9 \\
\hline
\end{tabular}

1 Maximum weight increase. 
TABLE 38

Percentage weight increase in rats' brains, each kept for four weeks in 40 cc. of a neutralized solution of 4 per cent formaldehyde made fresh for each lot of animals killed (averages for two brains at each age)

\begin{tabular}{|c|c|c|c|c|c|c|c|c|}
\hline \multirow{2}{*}{ TIME SOLUTION ACTED } & \multicolumn{8}{|c|}{ AGE OF RATS } \\
\hline & $\begin{array}{l}\text { New- } \\
\text { born }\end{array}$ & $\begin{array}{c}10 \\
\text { days }\end{array}$ & $d_{\text {days }}^{20}$ & $\begin{array}{c}40 \\
\text { days }\end{array}$ & $\stackrel{50}{\text { days }}$ & $\begin{array}{c}70 \\
\text { days }\end{array}$ & $\begin{array}{l}100 \\
\text { days }\end{array}$ & $\begin{array}{c}200 \\
\text { days }\end{array}$ \\
\hline 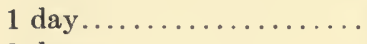 & 60.4 & 54.7 & 45.8 & $47.6^{1}$ & $50.4^{1}$ & 44.9 & $44.2^{1}$ & 36.1 \\
\hline 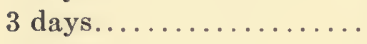 & $65.8^{1}$ & $58.5^{1}$ & $52.9^{1}$ & 47.4 & 47.7 & $48.8^{1}$ & 42.7 & $40.1^{1}$ \\
\hline 7 days...... & 65.4 & 58.5 & 48.3 & 45.6 & 45.1 & 44.2 & 38.3 & 36.2 \\
\hline 2 weeks.... & 65.1 & 58.4 & 48.9 & 45.3 & 44.8 & 43.2 & 38.6 & 33.0 \\
\hline 3 weeks... & 64.8 & 58.2 & 48.9 & 44.7 & 45.2 & 43.9 & 38.8 & 34.7 \\
\hline 4 weeks..... . & 61.7 & 57.8 & 50.4 & 45.1 & 45.4 & 44.9 & 39.3 & 34.9 \\
\hline Average percentage gain & 63.4 & 57.7 & 49.2 & 35.9 & 46.4 & 44.8 & 40.3 & 35.8 \\
\hline
\end{tabular}

1 Maximum weight increase.

TABLE 39

Percentage weight increase in rats' brains, each kept for four weeks in $40 \mathrm{cc}$. of non-neutralized solution of 4 per cent formaldehyde made fresh for each lot of animals killed (averages for two brains at each age)

\begin{tabular}{|c|c|c|c|c|c|c|c|c|}
\hline \multirow{2}{*}{ TIME SOLUTION ACTED } & \multicolumn{8}{|c|}{ AGE OF RATS } \\
\hline & $\begin{array}{l}\text { New- } \\
\text { born }\end{array}$ & $\begin{array}{c}10 \\
\text { days }\end{array}$ & $\begin{array}{c}20 \\
\text { days }\end{array}$ & $\begin{array}{c}40 \\
\text { days }\end{array}$ & $\begin{array}{c}50 \\
\text { days }\end{array}$ & $\begin{array}{c}70 \\
\text { days }\end{array}$ & $\begin{array}{c}100 \\
\text { days }\end{array}$ & $\begin{array}{c}200 \\
\text { days }\end{array}$ \\
\hline 1 day....... & $34.5^{1}$ & 37.3 & 36.7 & $39.7^{1}$ & $44.2^{1}$ & 39.5 & $41.1^{1}$ & 32.2 \\
\hline 3 days... & 18.6 & $45.1^{1}$ & $45.4^{1}$ & 39.1 & 42.8 & $42.3^{1}$ & 39.4 & $35.4^{1}$ \\
\hline 7 days... & 9.9 & 37.8 & 38.2 & 35.6 & 38.1 & 34.3 & 33.8 & 30.2 \\
\hline 2 weeks... & 3.5 & 30.4 & 34.6 & 31.5 & 32.6 & 31.5 & 29.0 & 26.7 \\
\hline 3 weeks.... & 0.4 & 25.9 & 30.7 & 28.3 & 30.6 & 29.5 & 27.4 & 24.5 \\
\hline 4 weeks..... & -1.5 & 23.5 & 27.9 & 26.6 & 27.8 & 27.3 & 24.3 & 24.5 \\
\hline Average percentage gain. & 13.1 & 33.3 & 35.6 & 33.5 & 36.0 & 34.1 & 32.5 & 28.9 \\
\hline
\end{tabular}

Maximum weight increase. 
TABLE 40

The percentage of solids in brains of rats of various. ages kept from four to eighteen weeks in solutions of 4 per cent formaldehyde (computations made from original brain weights)

\begin{tabular}{|c|c|c|c|c|c|c|c|c|}
\hline \multirow{2}{*}{ EXPERIMENTS } & \multicolumn{8}{|c|}{ AGE OF RATS } \\
\hline & $\begin{array}{l}\text { New- } \\
\text { born }\end{array}$ & $\begin{array}{c}10 \\
\text { days }\end{array}$ & $\begin{array}{c}20 \\
\text { days }\end{array}$ & $\begin{array}{c}40 \\
\text { days }\end{array}$ & $\begin{array}{c}50 \\
\text { days }\end{array}$ & $\begin{array}{c}70 \\
\text { days }\end{array}$ & $\begin{array}{c}100 \\
\text { days }\end{array}$ & $\begin{array}{l}200 \\
\text { days }\end{array}$ \\
\hline $\begin{array}{l}\text { Brains kept } 18 \text { wks. in neu- } \\
\text { tralized stock solutions }\end{array}$ & 8.1 & 10.3 & 14.7 & 18.4 & 19.4 & 19.5 & & 20.9 \\
\hline $\begin{array}{l}\text { Brains kept } 10 \text { wks. in sol. } \\
5 \text { mos. old .................. }\end{array}$ & 8.1 & 10.1 & 16.5 & 19.4 & 19.4 & 20.5 & 19.7 & 20.5 \\
\hline $\begin{array}{l}\text { Brains kept } 10 \text { wks. in } \\
\text { freshly made sol......... }\end{array}$ & 7.8 & 10.3 & 16.0 & 19.2 & 19.5 & 20.1 & 20.1 & 21.6 \\
\hline $\begin{array}{l}\text { Brains kept } 4 \text { wks. in } 40 \\
\text { cc. neutral sol......... }\end{array}$ & 8.2 & 10.1 & 16.4 & 19.3 & 19.6 & 19.6 & 20.9 & 21.8 \\
\hline $\begin{array}{l}\text { Brains kept } 4 \text { wks. in } 40 \\
\text { cc. acid sol............... }\end{array}$ & 9.6 & 10.9 & 16.7 & 19.3 & 19.1 & 20.7 & 20.1 & 21.1 \\
\hline $\begin{array}{l}\text { Brains kept } 4 \text { wks. in } 20 \\
\text { cc. neutral sol........... }\end{array}$ & 9.2 & 9.8 & 16.2 & 19.7 & 20.5 & 19.9 & 20.2 & 21.5 \\
\hline $\begin{array}{l}\text { Brains kept } 4 \text { wks. in } 20 \\
\text { cc. acid sol............. }\end{array}$ & 10.5 & 10.9 & 16.3 & 19.0 & 20.0 & 20.1 & 20.8 & 21.6 \\
\hline $\begin{array}{l}\text { Brains kept } 4 \text { wks. in neu- } \\
\text { tral sol. at temp. } 26^{\circ} \mathrm{C} .\end{array}$ & 9.7 & 9.8 & 15.1 & 18.7 & 19.4 & 19.8 & 20.1 & 20.1 \\
\hline $\begin{array}{l}\text { Brains kept } 4 \text { wks. in neu- } \\
\text { tral sol. at temp. } 8 \text { to } \\
11^{\circ} \mathrm{C} \ldots \ldots \ldots \ldots \ldots \ldots\end{array}$ & 8.3 & 10.6 & 16.3 & 19.2 & 19.0 & 20.1 & 20.1 & 21.7 \\
\hline Averages for above series & 8.6 & 10.6 & 16.3 & 19.2 & 19.6 & 20.1 & 20.3 & 21.2 \\
\hline $\begin{array}{l}\text { Normal percentage of sol- } \\
\text { ids in rats' brains (Don- } \\
\text { aldson)......................... }\end{array}$ & 12.2 & 14.6 & 17.5 & 19.5 & 20.9 & 21.1 & 21.3 & 21.6 \\
\hline $\begin{array}{l}\text { Percentage loss of solids } \\
\text { as result of action of } \\
\text { formaldehyde.......... }\end{array}$ & 29.5 & 29.4 & 7.4 & 1.5 & 6.2 & 4.7 & 4.7 & 1.8 \\
\hline
\end{tabular}

7. Sense organs. The cochlea makes $2 \frac{1}{4}$ turns (Fortuyn, '14, p. 348).

8. Integument (see references).

9. Gastro-pulmonary systems. For the weights of the various viscera see tables $68-72$.

a) Gastro-intestinal system. The volumes of the liver and pancreas cells-with those of their respective nuclei-have been de- 
termined by Morgulis ('11). The organs were fixed in Zenker's solution and imbedded in paraffine and were taken from one normal Albino-110 days old; body length $176 \mathrm{~mm}$.; body weight, 137.7 grams.

TABLE 41

Liver cells

\begin{tabular}{|c|c|c|c|c|}
\hline \multirow{2}{*}{$\begin{array}{c}\text { No. OF } \\
\text { MEASUREMENTS } \\
\text { OF CELIS }\end{array}$} & \multicolumn{2}{|c|}{ VOLUME IN $\mu^{3}$ OF } & \multirow{2}{*}{$\begin{array}{l}\text { NO. OF } \\
\text { MEASUREMENTS } \\
\text { OF NUCLEUS }\end{array}$} & \multirow{2}{*}{$\begin{array}{l}\text { DIAMETERS OF } \\
\text { NUCLETS IN } \mu\end{array}$} \\
\hline & Entire cell & Nucleus & & \\
\hline $100 \ldots$ & 5075 & 247.2 & 50 & $7.56 \times 8.25$ \\
\hline \multicolumn{5}{|c|}{ Pancreas cells } \\
\hline 100. & 1829 & 94.3 & 40 & $5.48 \times 6.00$ \\
\hline
\end{tabular}

b) Pulmonary system (see references), also table 70.

10. Uro-genital system (see references), also table 70.

11. Endocrine system (see references), also table $7 \%$.

\section{ANATOMY: REFERENCES}

1. Anatomy, general. Akamatsu, '05. Brisson, 1756. Duesberg, '07. Flower, 1872. Goto, '06. Hewer, '14. Krause, 1876. Leydig, 1854, 1857. Martin and Moale, 1884. Meyer, 1800. Morrell, 1872. Owen, 1868. Waller, 1693.

2. Embryology. a) Spermatogenesis. Benda, 1887. Brown, 1885. Duesberg, '08, '08 a, '09. Ebner, 1888. Hewer, '14. Jensen, 1887. Leeuwenhoeck, 1693. Lenhossék, 1898. Meves, 1898. Montane, 1889. Regaud, '04. Renson, 1882. Retzius, '09. Wiedersperg, 1885. b) Ovulation. Bellonci, 1885. Blanc, 1892. Coe, '08. Kirkham, '10. Kirkham and Burr, '13. Mark and Long, '12. Sobotta and Burckhard, '10. Tafani, 1889, 1889 a. c) Early stages. Cristiani, 1892. Fraser, 1883. Huber, '15, '15 a, '15 b. Klebs, 1891. Melissinos, '07. Robinson, 1892, '04. Ryder, 1888. Selenka, 1883, 1884. Solger, 1889. d) Later stages. Adloff, 1898. Askanazy ,'08. Braun, 1882. Brunn, 1887. Chievitz, 1885. Freund, 1892. Glas, '04. Gottschau, 1883. Henneberg, 1899, 1900. Lewis, '15. Meyerheim, 1898. Robinson, 1889, 1892, 1892a, 1896. Soulié,'03. Tandler,'02. Uskow, 1883. Weiss,'01. Widakowich,'09. Willach, 1888. Williams,'96. Zuckerkandl,'03.

3. Bones and joints and connective tissues. Bignotte, 1900. Donaldson, '12 a. Hansemann, '04. Hartley, '07. Hatai, '07 c. Hyrtl, 1845. Katzenstein, '03. Kohimeyer, '06. Renaut, '04. Retterer, '05. Weiss, 1900. a) Teeth. Addison and Appleton, '15. Beretta, '13. Brunn, 1880. MacGillavry, 1875, 1876. Owen, 1840-1845. Terra, '11. Wiedersheim, '03.

4. Muscles, Bell, '11. Gulliver, 1839, 1842. Kolster, '01. McMunn, 1884. Meek, '99. Mellanby, '08. Morpurgo, 1898, 1899, 1899 a. Rosenfeld, 1899. Schäfer, 1900a. Stirling, 1883. 
5. Vessels and blood. Chisholm, '11. Gamgee, '98. Gulliver, 1875. Halliburton, 1888. Höber, '11. Job, '15. Jolly and Stini, '05. Kanthack and Hardy, 1894. Minot, 1900. Preyer, 1866, 1871. Quinquaud, 1873. Reichert and Brown, '09. Schäfer, 1898. Sherrington and Copeman, 1893. Tandler, 1899; White, '01. Wormley, 1888.

6. Nervous system. a) Central. 1) Brain. Addison, '11. Allen, '12. Bechterew, 1890. Bradley, '03. Cajal, 1897, 1909-1911. Donaldson, '08, '09, '10, '11, '11 a, '11 b. Donaldson and Hatai, '11, '11 a. Fortuyn, '14. Gentes, '03. Goldstein, '04. Haller, '10. Hamilton, '01. Hatai, '03, '09, '09 a. King, J. L., '10. King, H. D., '11. Lapicque, '07. Lewis, 1881. Meek, '07. Reichardt, '06 Retzius, 1894. Watson, '03. Wagner, 1841. 2) Spinal cord. Allen, '12. Bardeleben, 1899. Hatai, '02 b. Lenhossek, 1889. Pontier and Gérard, 1900. Ranson, '13, '14 a. Retzius, 1893. Robinson, 1892 a. Spitzka, 1886. Sterzi, '04. Stieda, 1869. Van der Vloet, '06. b) Peripheral. 1, 2) Cerebrospinal. Beck, 1896. Benedicenti, 1892. Berkley, 1893, 1895. Bischoff, 1832. Boughton, '06. Cabibbe, '04. Cannieu, '94. Donaldson, 1900, '05. Dunn, '12. Fortuyn, '14. Greenman, '13. Hamilton, '01. Hatai, '01, '01 a, '02, '02 a, '03, '03 b, '03 c, '03 d, '04, '07 b. Krause, 1870. Ploschko, 1897. Ramström, '05. Ranson, '06. Stirling, 1883. 3) Autonomic. Apolant, 1896. Asp, 1873. Barteneff, 1891. Cajal, 1893. Carpenter and Conel, '14. Fusari and Panasci, 1891. Fusari, 1894. Korolkow, 1892. Martinotti, 1889. Roth, '05. c) Technical methods. Cajal, 1889, '03. King, '10, '13 a. Ohlmacher, 1897. Turner, '04.

7. Sense organs. Asai, '08. Bulle, 1887. Ebner, 1873. Fortuyn, '14. Gmelin, 1892. Hönigschmied, 1873. Koganei, 1885. Lauber, '01. Lovén, 1868, Mayer, 1843. Münch, 1896. Schäfer, 1900 a. Stahr, '03. Tello, '06. Tuckerman, 1892. Wyss, 1870.

8. Integument. Calef, 1900. Durham, '04. Peters, 1890. Romer, 1896.

9. Gastro-pulmonary systems. a) Gastro-intestinal. Asher, '08. Asher and Erdely, '03. Asp, 1873. Brümmer, 1876. Bujard, '05, '09. Custor, 1873. Cuvier, 1805. Demjanenko, '09. Edelmann, 1889. Ellenberger and Guenther, '08. Falcone, 1898. Frenkel, 1892. Garnier, 1897. Gillette, 1872. Heuser, '14. Home, 1807. Hoyer, 1890. Klein, 1871. Kupfer, 1876. Langley, 1882. Loewenthal, 1894, 1894 a, 1900, '08. Mayer, 1894. Mazzarelli, 1890. Morgulis, '11. Mouret, 1895. Müller, 1830. Nicolas, 1890. Podwisotzky, 1878. Podwyssotzki, 1882. Ranvier, 1883, 1884, 1885, 1886, 1886 a. Rapp, 1839. Retzius, 1841. Rubeli, 1890. Salter, 1859. Saviotti, 1869. Schmidt, 1863. Schwalbe, 1872. Severin, 1885. Toepfer and Fleischmann, 1891. Watney, 1874. Zillinberg-Paul, '09. Zumstein, 1891. b) Pulmonary system. Arnstein, 1877. Frankenhaeuser, 1879. Fuchs-Wolfring, 1898. Gegenbaur, 1892. Guieysse; 1898. Hansemann, 1895. Klein, 1875. Linser, 1900. Livini, 1896. Miller, 1893. Schulze, 1871. Zumstein, 1890.

10. Urogenital system. Beiling, '06. Belloy, 1899. Disselhorst, 1897, 1897 a, '04. Fischel, '14. Harz, 1883. Leydig, 1850. Lowenthal, 1897. Mueller, '02. Oudemans, 1892. Rauther, '03. Regaud, 1900, $1900 \mathrm{a}, 1900 \mathrm{~b}, 1900 \mathrm{c}$, '01, $01 \mathrm{a}$, '01 b, '01 c, '01 d, '02, '02 a, '03. Stutzmann, 1898. Watson and Campbell, '06.

11. Endocrine system (see also Endocrine system under Physiology). Dostoiewsky, 1886, 1886 a. Elliot and Tuckett, '06. Erdheim, '06. Gemelli, '03, '05, '06, '06 a. Hatai, '14, '14 a. Sandri, '08. Stendell, '13. Tilney, '11, '13. Vincent, '10. Watson, C., '07, '09. 


\section{CHAPTER 4}

\section{PHYSIOLOGY}

1. Muscle and nerve. 2. Nervous system. a) Central. b) Peripheral. b ${ }^{1}$ ) Degeneration. $b^{2}$ ) Regeneration. 3. Special senses. 4. Blood and lymph. 5. Circulation-blood and lymph. 6. Respiration. 7. Digestion and secretion (exclusive of ductless glands). 8. Nutrition. a) Body temperature. 9. Reproduction. 10. Endocrine system.

The quantitative data for the functions of the normal Albino are rather scanty. Those available are given in their topical order and the references at the end of the chapter are also arranged by topics - as usual.

Tabular records for the very important studies of Osborne and Mendel on the modifications of body growth by the use of various proteins are reluctantly omitted because of the general plan of presenting in these pages data for the normal rat only.

8. Nutrition. A study of the nitrogen excretion has been made by Hatai ('05). Chicago Colony, ration: Uneeda biscuit and water.

From observations on 89 male rats at different ages and weights the following results were obtained:

1. The total amount of urine increases with the weight up to 120 grams, then decreases very decidedly. From 180 grams it again increases up to 220 grams, beyond which weight it remains rather constant. A diminution of urine in animals between 120 and 180 grams, or approximately 70-125 days old, seems to be a normal phenomenon rather than mere statistical variation. Whether or not this is a phenomenon of adolescence needs further investigation. It must be noted, however, that puberty in the rat begins at about seventy days after birth. The smaller animals excrete a relatively greater quantity of urine than the larger animals.

2. The total amount of nitrogen is quite independent of the amount of urine, and increases constantly and continuously throughout life. The smaller rats, however, excrete a relatively greater quantity than the larger animals.

3 . The percentage value of urinary nitrogen is 91 per cent of the total in the case of smaller animals, and 89 per cent in the case of the larger. 
TABLE 42

Showing the amount of urine, feces, and nitrogen during three days. Male rats alone were used

\begin{tabular}{|c|c|c|c|c|c|c|c|c|c|c|c|c|c|}
\hline 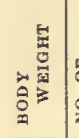 & 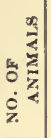 & $\frac{a}{3}$ & 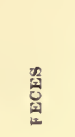 & 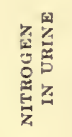 & 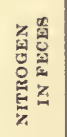 & 撹 & 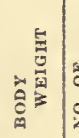 & 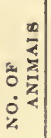 & 思 & $\begin{array}{l}\text { 盟 } \\
\text { 量 }\end{array}$ & 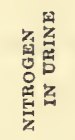 & 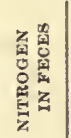 & 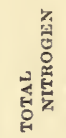 \\
\hline \multirow{3}{*}{$\begin{array}{r}g m . \\
38\end{array}$} & \multirow{3}{*}{8} & $\begin{array}{l}c c . \\
5.75\end{array}$ & $\begin{array}{c}m g m . \\
327\end{array}$ & $\begin{array}{r}m g m . \\
52\end{array}$ & $\underset{4}{m g m}$ & $\begin{array}{c}m g m . \\
56\end{array}$ & \multirow{3}{*}{$\begin{array}{c}g m . \\
162\end{array}$} & \multirow{3}{*}{4} & $\begin{array}{c}c c . \\
16.13\end{array}$ & $\underset{748}{m g m .}$ & $\underset{162}{m g m}$ & $\begin{array}{c}\text { mgm } \\
32\end{array}$ & $\begin{array}{c}\text { mgmi. } \\
194\end{array}$ \\
\hline & & 6.25 & 217 & 45 & 4 & 49 & & & 11.50 & 208 & 140 & 11 & 151 \\
\hline & & 5.00 & 105 & 42 & 1 & 43 & & & 12.00 & 227 & 141 & 16 & 157 \\
\hline \multicolumn{2}{|c|}{ Average } & 5.7 & 216 & 46 & 3 & 50 & \multicolumn{2}{|c|}{ Average } & 13.2 & 394 & 148 & 20 & 168 \\
\hline \multirow{3}{*}{53} & & 12.62 & 347 & 85 & 11 & 96 & \multirow{3}{*}{178} & \multirow{3}{*}{4} & 12.13 & 379 & 187 & 17 & 204 \\
\hline & 7 & 9.52 & 0 & 65 & 0 & 65 & & & 12.00 & 482 & 154 & 21 & 175 \\
\hline & & 9.17 & 57 & 54 & 3 & 57 & & & 13.38 & 374 & 162 & 15 & 177 \\
\hline \multicolumn{2}{|c|}{ Average } & 10.4 & 135 & 68 & 5 & 73 & \multicolumn{2}{|c|}{ Average } & 12.5 & 412 & 168 & 18 & 185 \\
\hline \multirow{3}{*}{70} & & 16.69 & 395 & 93 & 13 & 106 & \multirow{3}{*}{191} & & 16.00 & 177 & 194 & 9 & 203 \\
\hline & 8 & 10.87 & 205 & 103 & 7 & 110 & & 3 & 17.30 & 163 & 185 & 9 & 194 \\
\hline & & 10.41 & 68 & 92 & 3 & 95 & & & 11.30 & 348 & 164 & 17 & 181 \\
\hline \multicolumn{2}{|c|}{ Average } & 12.8 & 223 & 96 & 8 & 104 & \multicolumn{2}{|c|}{ Average } & 14.9 & 229 & 181 & 12 & 193 \\
\hline \multirow{3}{*}{85} & & 15.9 & 438 & 97 & 22 & 119 & \multirow{3}{*}{207} & & 19.30 & 776 & 158 & 29 & 187 \\
\hline & 5 & 12.4 & 219 & 102 & 4 & 106 & & 4 & 10.80 & 516 & 182 & 24 & 206 \\
\hline & & 9.5 & 330 & 83 & 13 & 96 & & & 19.00 & 195 & 181 & 7 & 188 \\
\hline \multicolumn{2}{|c|}{ Average } & 12.6 & 329 & 94 & 13 & 107 & \multicolumn{2}{|c|}{ Average } & 16.4 & 496 & 174 & 20 & 194 \\
\hline \multirow{3}{*}{99} & & 15.50 & 556 & 137 & 20 & 157 & \multirow{3}{*}{220} & \multirow{3}{*}{2} & 24.00 & 809 & 217 & 42 & 259 \\
\hline & 6 & 10.83 & 38 & 124 & 3 & 127 & & & 20.00 & 235 & 181 & 8 & 189 \\
\hline & & 8.98 & 199 & 100 & 5 & 105 & & & 19.00 & 382 & 148 & 29 & 177 \\
\hline Averag & & 11.8 & 264 & 120 & 9 & 130 & Avera & age & 21.00 & 475 & 182 & 26 & 208 \\
\hline & & 15.41 & 374 & 122 & 10 & 132 & & & 18.80 & 794 & 207 & 30 & 237 \\
\hline 106 & 6 & 17.67 & 294 & 119 & 5 & 124 & 239 & 4 & 17.80 & 502 & 175 & 15 & 190 \\
\hline & & 17.33 & 248 & 110 & 18 & 128 & & & 18.00 & 404 & 178 & 16 & 194 \\
\hline Averag & & 16.8 & 305 & 117 & 11 & 128 & Avera & age & 18.2 & 566 & 187 & 20 & 207 \\
\hline & & 22.3 & 776 & 143 & 26 & 169 & & & 20.38 & 333 & 204 & 21 & 225 \\
\hline 116 & 5 & 14.5 & 138 & 135 & 8 & 143 & 266 & 4 & 24.00 & 896 & 225 & 32 & 257 \\
\hline & & 18.0 & 39 & 123 & 0 & 123 & & & 22.00 & 690 & 259 & 28 & 287 \\
\hline Averag & & 18.3 & 318 & 134 & 11 & 145 & Avera & age & 22.1 & 639 & 229 & 27 & 256 \\
\hline & & 18.25 & 906 & 120 & 26 & 146 & & & 20.25 & 956 & 246 & 37 & 283 \\
\hline 127 & 4 & 13.00 & 346 & 115 & 17 & 132 & 298 & 5 & 18.00 & 638 & 272 & 26 & 298 \\
\hline & & 18.75 & 127 & 129 & 6 & 135 & & & 17.35 & 598 & 262 & 24 & 286 \\
\hline Averag & & 16.7 & 460 & 121 & 16 & 138 & Avera & age & 18.5 & 731 & 260 & 29 & 289 \\
\hline & & 17.58 & 359 & 153 & 15 & 168 & & & 16.88 & 1424 & 261 & 25 & 286 \\
\hline 144 & 5 & 16.25 & 360 & 166 & 10 & 176 & 333 & 3 & 26.50 & 475 & 280 & 20 & 300 \\
\hline & & 15.00 & 49 & 113 & 1 & 114 & & & 19.50 & 857 & 297 & 37 & 334 \\
\hline Averag & & 16.3 & 256 & 144 & 9 & 153 & Avera & & 20.9 & 919 & 279 & 27 & 306 \\
\hline & & 13.90 & 425 & 126 & 14 & 140 & & & 13.00 & 877 & 250 & 45 & 295 \\
\hline 156 & 5 & 13.90 & 638 & 151 & 16 & 167 & 370 & 3 & 12.80 & 817 & 289 & 32 & 321 \\
\hline & & 15.75 & 445 & 169 & 17 & 186 & & & 19.30 & 217 & .291 & 9 & 299 \\
\hline Averag & & 14.5 & 503 & 149 & 16 & 165 & Avera & & 15.00 & 637 & 277 & 29 & 306 \\
\hline
\end{tabular}


4. The total amount of nitrogen eliminated by the rat during twentyfour hours at different weights may be determined with a high degree of accuracy by the formula (33).

The normal protein metabolism of the rat has been studied by Folin'and Morris ('13). They find a distribution of nitrogen in the urine as shown in tables $43,44$.

TABLE 43

Female rat weighing 290 grams. Average of 5 days

\begin{tabular}{|c|c|c|}
\hline & MGM. & PER CENT \\
\hline Total N.. & 173.50 & 100.00 \\
\hline 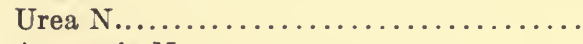 & 143.20 & 77.30 \\
\hline Ammonia $N \ldots . . . \ldots \ldots \ldots \ldots \ldots \ldots$ & 9.10 & 5.20 \\
\hline Uric Acid N............... & 0.69 & 0.40 \\
\hline Creatinine N............. & 4.50 & 2.65 \\
\hline Creatinine + Creatine N.... & 4.70 & 2.71 \\
\hline
\end{tabular}

TABLE 44

Male rat weighing 197 grams. Average of 6 days

\begin{tabular}{|c|c|c|}
\hline & MGM. & PER CENT \\
\hline Total N.. & 126.00 & 100.00 \\
\hline 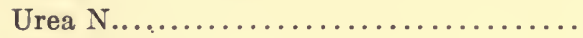 & 105.90 & 84.00 \\
\hline Ammonia N... & 6.70 & 5.30 \\
\hline Uric Acid N.... & 0.52 & 0.41 \\
\hline Creatinine N............... & 2.90 & 2.30 \\
\hline Creatinine + Creatine N...... & 3.00 & 2.38 \\
\hline
\end{tabular}

"It will be seen from examination of the average results that the percentage composition of rat urine differs but little from that of human urine."

a) Body temperature. Using the mercurial thermometer in the rectum, Pembrey ('95) reports a body temperature of $37.5^{\circ} \mathrm{C}$. in adult Albinos. Macleod ('07) by the same method finds a range of $37.5-38.5^{\circ} \mathrm{C}$. with a mean of $37.9^{\circ} \mathrm{C}$.; Congdon ('12) also by the same method a temperature of $37.9^{\circ} \mathrm{C}$. in the young; in the adult, when reared at $16^{\circ} \mathrm{C}$, a temperature of $36.2^{\circ} \mathrm{C}$. and when reared at $33^{\circ} \mathrm{C}$., of $37.2^{\circ} \mathrm{C}$. Graham and Hutchison 
('14) using the thermoelectric method of Philips and Demuthobtained the following:

TABLE 45

\begin{tabular}{|c|c|c|}
\hline \multirow{2}{*}{ EXTERNAL TEMPERATURE } & \multicolumn{2}{|c|}{ BODY TEMPERATURE (C.) } \\
\hline & High & Low \\
\hline 5 C....................... (a) & 36.1 & 21.1 \\
\hline Series (b) & 34.9 & 19.0 \\
\hline $21 \mathrm{C} \ldots \ldots \ldots \ldots \ldots \ldots \ldots \ldots \ldots \ldots \ldots \ldots$ & 38.7 & 32.4 \\
\hline 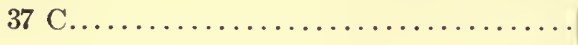 & 41.8 & 32.9 \\
\hline
\end{tabular}

\section{PHYSIOLOGY： REFERENCES} '08.

1. Muscle and nerve. Boinet, 1895. Engelmann, 1877. Lee,'10. Mellanby,

2. Nervous system. a) Central. Ferrier, 1886. Hatai, '03 a, '04 a, '07 a, '08, '15 a. Mills, 1897. Schäfer, 1900. Watson, '05. b) Peripheral. b $b^{1}$ ) Degeneration. $\left.b^{2}\right)$ Regeneration. Greenman, '13. Ranson, '03, '04, '06, '14. Tournade, '13.

3. Special Senses. Bogardus and Henke, '11. Hunter, '14. Vincent, '12, '13, '15, '15 a, '15 b.

4. Blood and Lymph. Erdély, '05. Robertson, 12. Rywosch,'07. Trommsdorf, '09.

5. Circulation. Rattone and Mondino, 1888, 1888 a, 1889, 1889 a.

6. Respiration. Bert, 1878. Boycott and Damant, '08 a. Boycott and Damant and Haldane, '08. Pembrey, 1895. Pembrey and Spriggs, '04.

7. Digestion and Secretion (exclusive of the ductless glands). Ackroyd, '14, '15. Astaschewsky, 1877. Basch, 1870. Basler, '09. Bohlen, 1894. Drasch, 1886. Eimer, 1869. Ellenberger, '06. Elliott and Barclay-Smith '04. Gruetzner, 1875, 1878, 1894, 1898, '05. Hohmeier,'01. Jolyet and Chaker, 1875. Langley and Sewall, 1879. Langley, 1879. Matthes and Marquardsen, 1898. Paneth, 1888, 1888 a. Ranvier, 1887, 1888, 1894. Schiff, 1859. Zawarykin, 1883.

8. Nutrition and body temperature. Aldrich, '12. Aron, '12, '13. Brüning, '14, '14 a. Chidester, '12. Congdon, '12. Cook, '13. Czermak, 1895. Falta and Noeggerath, '05. Folin and Morris, '13. Forbes and Keith, '14. Frank and Schittenhelm, '12. Gevaerts, '01. Graham and Hutchison, '14. Gregersen, '11. Gudernatsch, '15. Hart and McCollum, '13. Hatai, '05. Hewer, '14. Heymann, '04. Hill, '13. Hill and Macleod, '03. Hopkins, '12. Hopkins and Neville, '12. Hunt, '10. Hunter, Givens and Guion, '14. Jackson, '15 b. Jacob. '06. Knapp, '08. Kreidl and Neumann, '08. Lane-Claypon, '09. Langlois and Loir, '02. McCollum, '09. McCollum and Davis, '13, '13 a, '14. Macleod, '07. Mendel, '13. Morgulis, '11. Osborne, '13. Osborne and Mendel, '11, '11 a, '11 b, '12, '12 a, '12 b, '12 c, '12 d, '12 e, '12 f, '12 g, '13, '13 a, '13 b '14, '14 a, '14 b, '14 c, '14 d, '14 e, '15. Paul, '06. Pembrey. 1895. Pitts, 1898. Poljakoff, 1888. Rohdé and Jones, '09. Watson, B. P., '07. Watson, C., '06, 
'06 a, '06 b. '07 a, '07 b, '07 c, '07 d, 'i0 '12. Watson and Lyon, '06. Watson and Gibbs, '06.

9. Reproduction. Carmichael and Marshall, '07. Cuénot, 1899. Fischel, '14. Hewer, '14. Marshall and Jolly, '07, '08. Regaud, 1900 d, 1900 e, 1900 f. Steinach, '10, '11, '12, '13.

10. Endocrine System. Barnabo, '13. Biedl, '13. Boinet, 1895, 1895 a. Brown-Sequard, 1856. Cristiani, 1893, 1893 a, 1893 b, 1895, 1900. Cristiani and Cristiani, '02, '02 a, '02 b, '02 c, '02 d. Erdheim, '06 a, '07, '11, '11 a, '11 b. Gemelli, '06. Goetsch and Cushing, '13. Goldmann, '09, '12. Harley, 1857, 1858, 1858 a, 1858 b. Hohlbaum, '12. Hunt and Seidell '09. Iselin, '08. Leischner, '07. Leischner and Köhler, '11. Leopold and Reuss, '08. Olds, '10. Poll, 1898, 1899. Schäfer, '08. Schiff, 1884, 1884 a. Steinach, 1894. Strehl and Weiss, '01. Toyofuku, '11. Vincent, 1897, 1897 a. '12. Vincent and Jolly, '05, '06. Watson, C., '14. Wiesel, 1899, 1899 a. 


\section{CHAPTER 5}

\section{GROWTH IN TOTAL BODY WEIGHT ACCORDING TO AGE}

1. Introduction. 2. Growth before birth. 3. Growth between birth and maturity. 4. Modifications of growth in total body weight. 5. Weight-length ratios.

1. Introduction. Under the general caption of growth several series of data are grouped in this chapter and in the four chapters which follow it. The chapter heads explain the several groupings and show that some data are presented according to age and other data according to some bodily measurement.

The reasons for this procedure will be evident in each instance. The effort has been made to gather as much of the data as possible under the caption of growth as this seemed the best way to make the records available for reference.

The following tables present the size, weight and composition of the albino rat and some of its parts, under conditions which may be considered normal.

As regards absolute measurements, it must be borne in mind that the Albino is very responsive to external conditions as represented by food, housing, temperature, exercise, and incidental disturbances, especially light and noises.

No two colonies today are kept under more than approximately similar conditions and it follows that the average size of the animals from different colonies varies. The conditions just noted also appear to influence the relative weights of some of the viscera. For these reasons, each set of determinations will be accompanied by a statement, as complete as possible, concerning the special conditions surrounding the animals on which the observations were made.

2. Growth before birth. For the data on growth during the first few days of fetal life, see Chapter 3, Embryology, early stages, pp. 31-33 Huber ('15 a) and other references there given. 
At about the 13th day after insemination the fetus is large enough to be directly weighed and from this date to birth the growth has been followed.

In a series of 38 females, each of which had already born one litter, Stotsenburg (MS '15) has observed exactly the time of

Fetus of albino rat

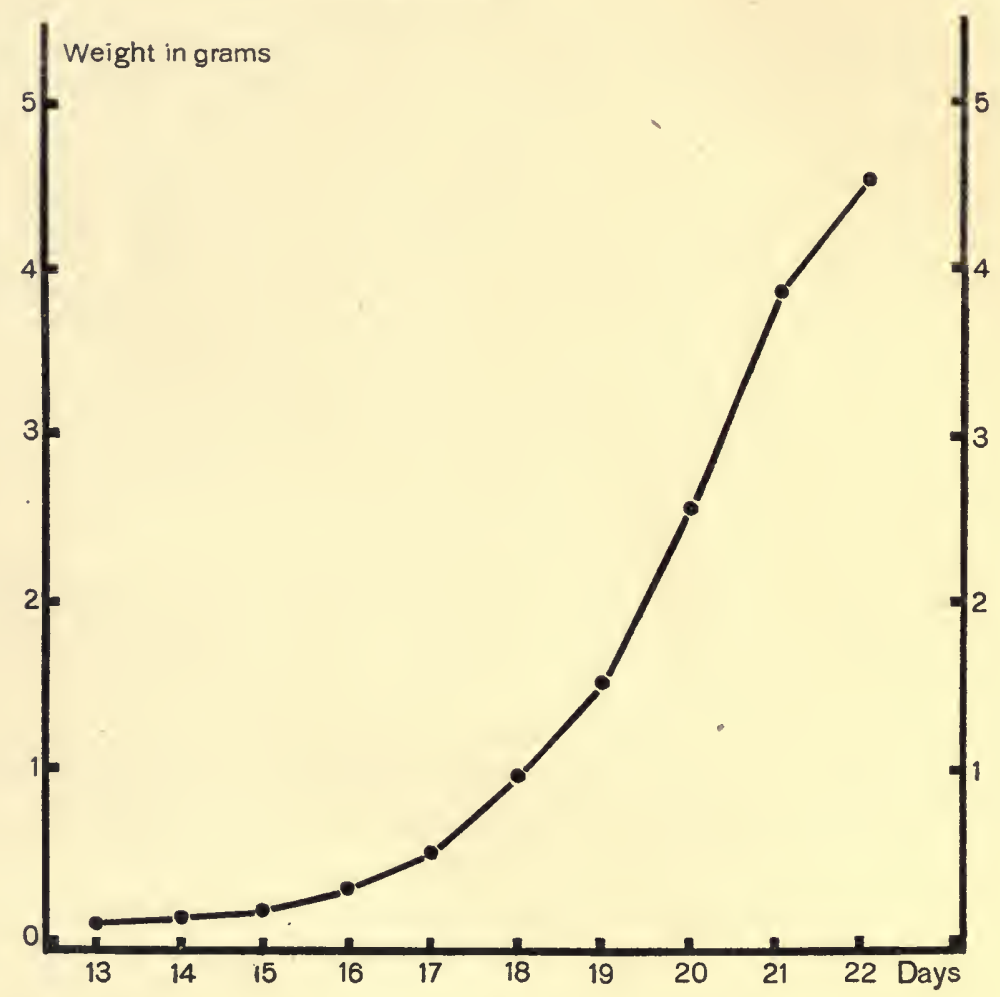

Chart 1 shows the course of fetal growth from the 13th to the 22nd day gestation. Stotsenburg (MS'15). The data are given in table 46.

insemination and then weighed the fetuses at the ages given in table 46. Before weighing the membranes were removed and in some instances the crown-rump length was measured (table 47). The graph representing the growth before birth from the 13 th day on is given in chart 1 , the interval used for one day being two-fifths of that used for one gram. 
3. Growth between birth and maturity. The first observations were made at the University of Chicago by Donaldson, Dunn and Watson ('06) on stock rats fed mainly on milk-soaked bread

TABLE 46

Showing the mean weights of the fetuses at ten ages during gestation

\begin{tabular}{|c|c|c|c|}
\hline AGE IN DAYS & NUMBER OF FETUSES & $\begin{array}{l}\text { PVERAGE WEIGHT OF } \\
\text { FETUS IN GRAMS }\end{array}$ & $\begin{array}{l}\text { RATE OF INCREASE } \\
\text { IN WEIGHT }\end{array}$ \\
\hline & & & per cent \\
\hline$\ldots \ldots \ldots$ & 34 & 0.040 & \\
\hline $14 \ldots \ldots \ldots \ldots$ & 44 & 0.112 & 179 \\
\hline $15 \ldots \ldots \ldots \ldots \ldots$ & 37 & 0.168 & 50 \\
\hline $16 \ldots \ldots \ldots \ldots \ldots \ldots$ & 44 & 0.310 & 83 \\
\hline $17 \ldots \ldots \ldots \ldots \ldots$ & 21 & 0.548 & 77 \\
\hline $18 \ldots \ldots \ldots \ldots \ldots \ldots$ & 43 & 1.000 & 83 \\
\hline $19 \ldots \ldots \ldots \ldots \ldots \ldots$ & 30 & 1.580 & 58 \\
\hline $20 \ldots \ldots \ldots \ldots \ldots \ldots$ & 25 & 2.630 & 65 \\
\hline $21 \ldots \ldots \ldots \ldots \ldots \ldots$ & 42 & 3.980 & 51 \\
\hline $22 \ldots \ldots \ldots \ldots \ldots \ldots \ldots$ & 10 & 4.630 & 16 \\
\hline
\end{tabular}

TABLE 47

Giving the crown-rump length of fetus in millimeters. Scrapdiet only. The fetuses here measured are part of those used for Table 46

\begin{tabular}{|c|c|c|c|c|c|}
\hline SERIAL NUMBER & $\begin{array}{c}\text { AGE IN } \\
\text { DAYS }\end{array}$ & $\begin{array}{l}\text { NUMBER } \\
\text { IN LITTER }\end{array}$ & $\begin{array}{l}\text { AVERAGE } \\
\text { WEIGHT OF } \\
\text { FETUS IN } \\
\text { GRAMS }\end{array}$ & $\begin{array}{l}\text { AVERAGE } \\
\text { CROWN- } \\
\text { RCMP } \\
\text { LENGTH } \\
\text { IN MM. }\end{array}$ & $\begin{array}{l}\text { RANGE OF } \\
\text { LENGTH } \\
\text { IN MM. }\end{array}$ \\
\hline 42. & 14 & 8 & 0.093 & 9.5 & $9.0-10.0$ \\
\hline $43 \ldots \ldots \ldots \ldots \ldots \ldots$ & 15 & 12 & 0.107 & 9.4 & $9.0-10.0$ \\
\hline $37 \ldots \ldots \ldots \ldots \ldots \ldots \ldots \ldots \ldots$ & 15 & 8 & 0.218 & 12.1 & $12.0-12.5$ \\
\hline $41 \ldots \ldots \ldots \ldots \ldots$ & 16 & 11 & 0.322 & 13.0 & $12.5-13.0$ \\
\hline $40 \ldots \ldots \ldots \ldots$ & 17 & 7 & 0.525 & 16.3 & $16.0-17.0$ \\
\hline $36 \ldots \ldots \ldots \ldots \ldots$ & 18 & 9 & 0.947 & 19.1 & $18.0-21.0$ \\
\hline $37 \ldots \ldots \ldots \ldots$ & 19 & 8 & 1.490 & 22.7 & $20.5-24.0$ \\
\hline $35 \ldots \ldots \ldots \ldots$ & 20 & 10 & 2.510 & 27.7 & $24.0-32.0$ \\
\hline $34 \ldots \ldots \ldots \ldots$ & 21 & 9 & 4.070 & 36.7 & $35.0-39.0$ \\
\hline $44 \ldots \ldots \ldots$ & 22 & 10 & 4.630 & 39.2 & $36.0-41.0$ \\
\hline
\end{tabular}

with corn as a staple. The values before fourteen days of age were obtained from weighing different litters, each litter being weighed only once. The original values at birth and for the first ten days were plainly too high and have been replaced by new 
data (Donaldson, MS '14). After the 14th day the weighing of 19 males and 17 females was made at frequent intervals, so long as the animals kept in good condition. Tables 63 and 64 give for males and females respectively not only the mean values but the range, and in the case of the females, after 90 days, the

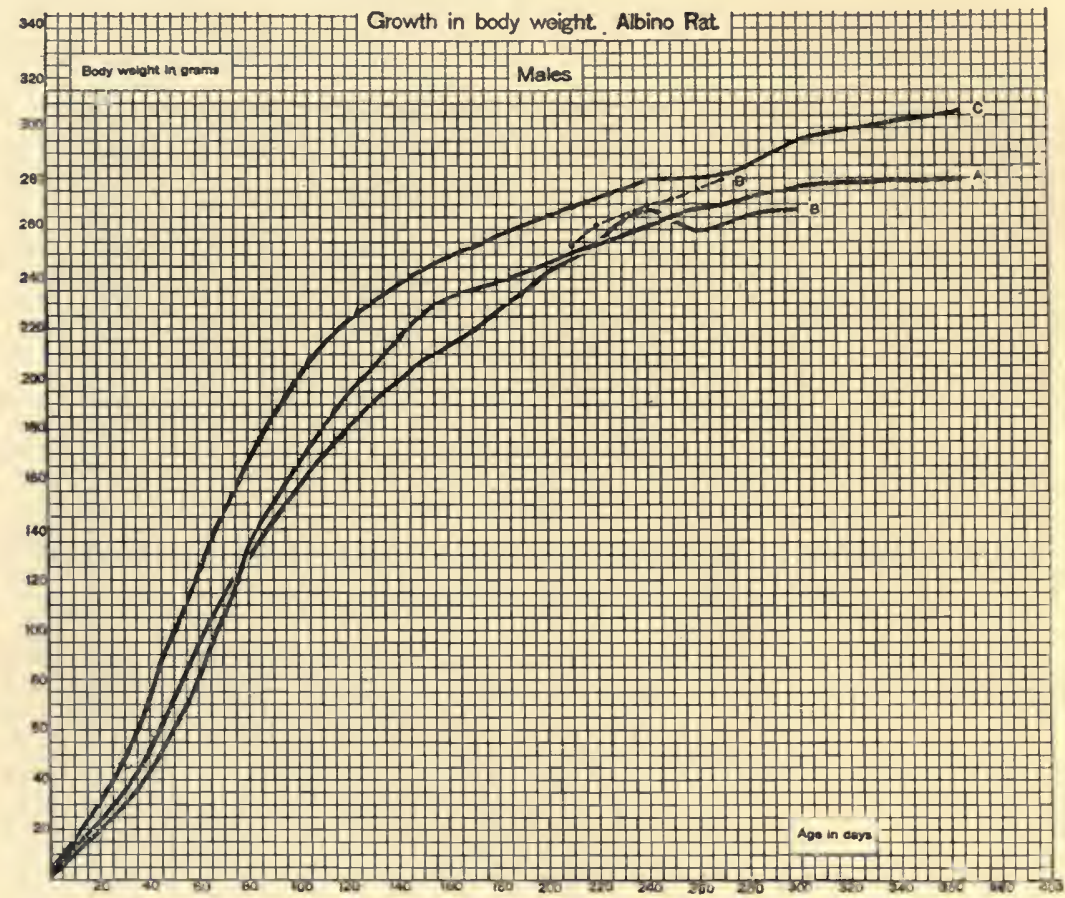

Chart 2 Growth in body weight on age. Male albino rat.

A. Observations of Donaldson, Dunn and Watson ('06). See table 63.

$B$. Observations of Ferry, '13. See table 65.

$B^{\prime}$. Observations of Ferry, '13. See column 2, table 65 .

C. Observations of King (MS '15). Data from two series combined. See table 67.

observed values for the unmated animals are accompanied by a second series of values computed for mated rats on the basis of Watson's ('05) observations which show that mated females gain in weight about 0.03 per cent per diem faster than the unmated. These data are used for graph A, chart 2, males, and graph A, chart 3, females. 
Using the mean values in table 63 for the males from 10 days of age on, and the corresponding values in table 64 for the females and taking the records for the mated females where given, Hatai has determined the graph for which formulas 34 and 35 give the values for the male, and formulas 36 and 37 the values for the female for this special series. By the use of these formulas the body weights have been computed for each day of age

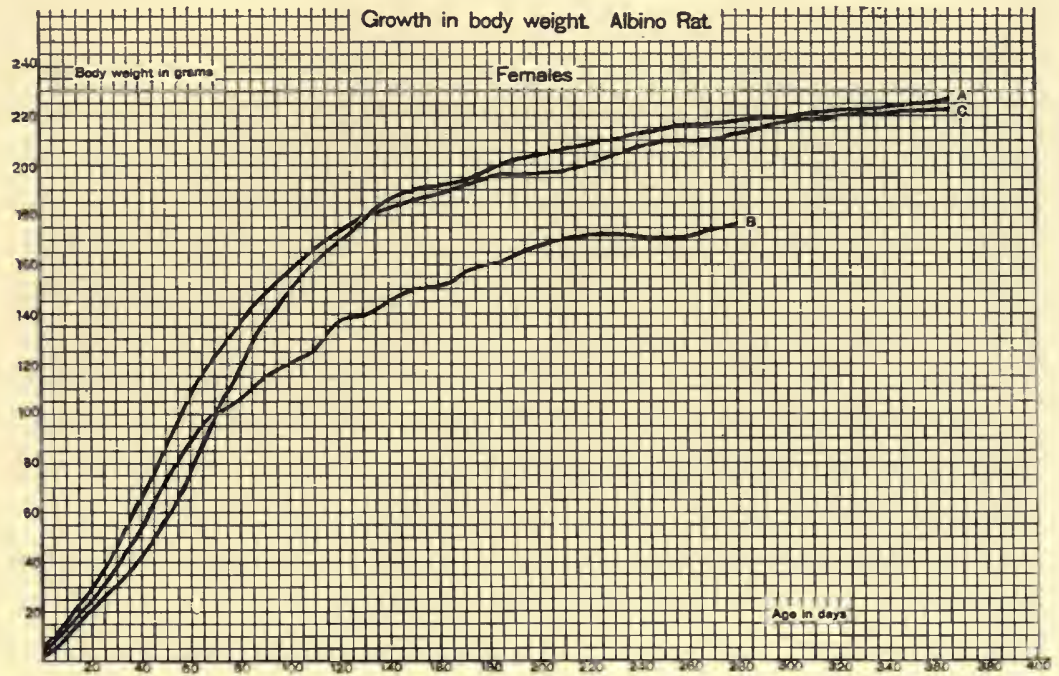

Chart 3 Growth in body weight on age. Female albino rat.

A. Observations of Donaldson, Dunn and Watson ('06). See table 64 .

B. Observations of Ferry, '13. See table 65.

C. Observations of King (MS '15). Data from two series combined. See table 67.

from 10-100 days and at intervals of five days from 100-365 days (see table 62).

The values given for the first ten days of age in table 62 have been obtained from a revised series of direct observations Donaldson (MS '14).

The weight at birth as here given, is for rats that have suckled.

A second series of data for body weight on age have been gathered by Miss Ferry. 
Using the rats from the colony maintained for the experiments of Osborne and Mendel at the Connecticut Agricultural Station in New Haven, Ferry ('13) has recorded the growth with age from the 10th to the 280th day of life.

The diet of the rats consisted of Austin's dog-biscuit, and sunflower seeds with fresh vegetables (chiefly carrots or corn and string beans) two or three times a week, and a small amount of cooked meat twice a week. A little salt was always kept in the cage. The cages were small.

Table 66 gives the numbers of rats weighed at the several ages and table 65 the mean values for each sex. The females were unmated. In chart 2 graph $\mathrm{B}$ shows the values for the males and in chart 3 graph $B$ shows the values for the females.

The broken line record marked $\mathrm{B}^{\prime}$ in chart 2 gives the values found in column 2 , table 65 , and probably gives the truer picture for the normal weight change.

Finally at The Wistar Institute King (MS '15) has conducted two series of observations (1912-1913) (1913-1915) on the increase in body weight with age in stock Albinos. There were 23 males and 23 females in the first series and 27 of each sex in the second. The records for the two series have been combined. The observations extend from 13-485 days and the weighings were made at the ages given in table 67 . These rats received a 'scrap' diet (i.e., a diet composed of table refuse from which materials known to be injurious had been removed).

In chart 2 the record for the males is given by graph $\mathrm{C}$ and in chart 3 the record for the females by graph C. In chart 4 the graphs for both sexes appear extended to 485 days.

In 1913 Jackson ('13) published a series of body weights for both sexes according to age, but as these animals did not grow well after about 70 days of age, the table has not been copied here.

On comparing the graphs for the males in the several series(see chart 2) it appears that the males reared by King grew best -while in the graphs for the females (chart 3) the record by Ferry shows the poorest growth for the females. It appears therefore that laboratory conditions including diet (assumed in each case to be wholesome) may modify the growth and that the two sexes are not necessarily affected to a like degree. 
4. Modifications of growth in total body weight. No change occurs in the growth of castrated males, Stotsenburg ('09).

A slight increase in growth was observed by Hatai ('03 a, p. 61) after lecithin feeding.

Increased growth occurs in spayed females, Stotsenburg ('13). This increase is in part due to the accumulation of fat and in part to general enlargement.

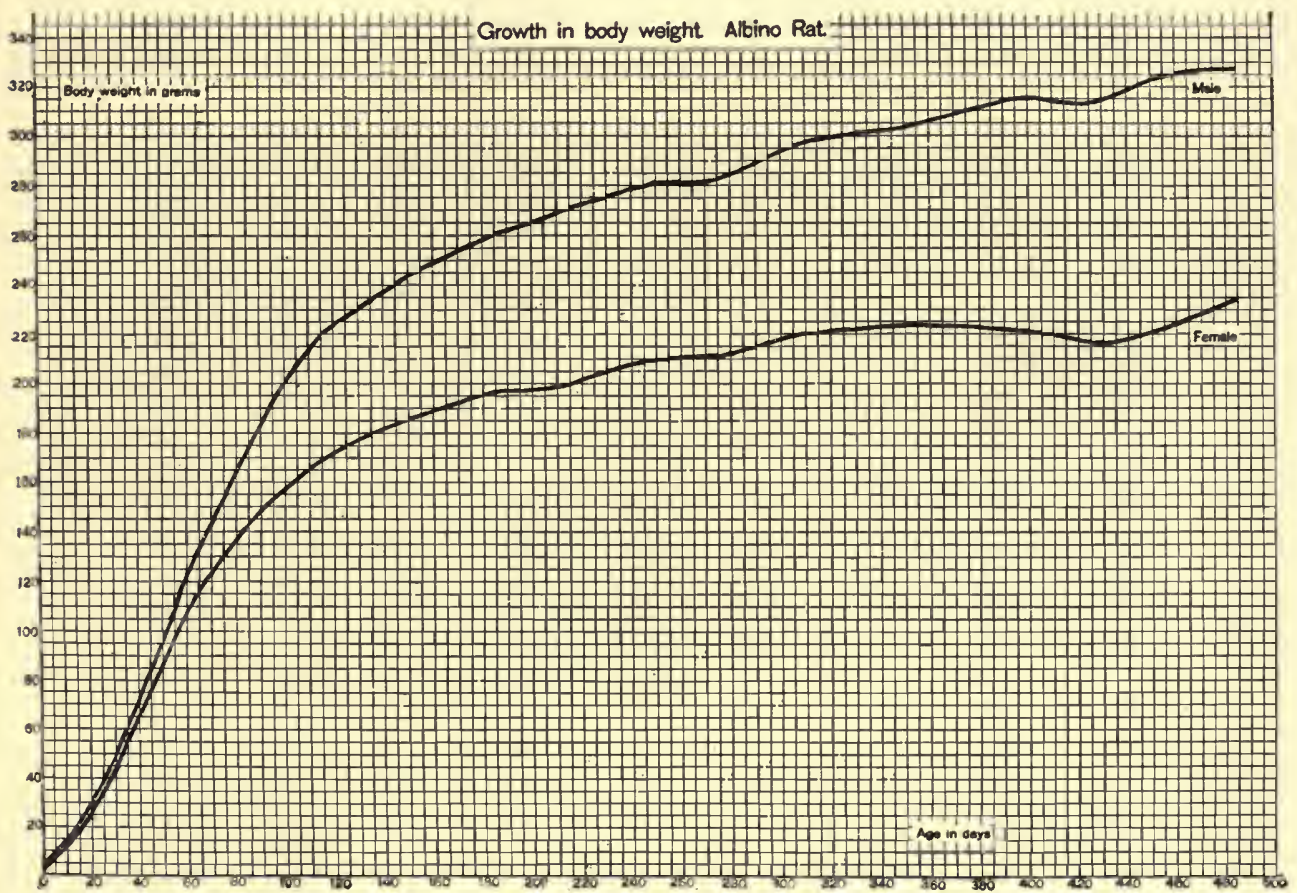

Chart 4 Growth in body weight on age for 485 days. Males and females. Observations by King (MS., '15). Data from two series combined. See table 67.

Bearing young also causes an increase in body weight in the females, J. B. Watson ('05).

A decrease follows all forms of underfeeding (Hatai, '04 a, '07 a, '08; Donaldson, '11 a) including feeding with certain vegetable proteins. See many references to Osborne and Mendel in chapter 4, Physiology: Nutrition, p. 61.

Decrease also follows an excessive meat diet when begun with young animals (Mus norvegicus) (C. Watson, '06, '06 a, '06 b). 
TABLE 48

Giving in grams the values obtained by dividing the body weight by body length in millimeters. Based on data in Table 68

\begin{tabular}{|c|c|c|c|c|c|c|c|c|}
\hline \multirow{2}{*}{$\begin{array}{l}\text { BODY } \\
\text { LENGTH }\end{array}$} & \multicolumn{2}{|c|}{ Ratio } & \multirow{2}{*}{$\begin{array}{c}\text { BODY } \\
\text { LENGTH }\end{array}$} & \multicolumn{2}{|c|}{ RATIO } & \multirow{2}{*}{$\begin{array}{c}\text { BODY } \\
\text { LENGTH }\end{array}$} & \multicolumn{2}{|c|}{ RATIo } \\
\hline & Male & Female & & Male & Female & & Male & Female \\
\hline 50 & 0.10 & 0.10 & 86 & 0.22 & 0.23 & 121 & 0.37 & 0.39 \\
\hline 51 & 0.10 & 0.10 & 87 & 0.23 & 0.24 & 122 & 0.37 & 0.39 \\
\hline 52 & 0.10 & 0.10 & 88 & 0.23 & 0.24 & 123 & 0.38 & 0.40 \\
\hline 53 & 0.10 & 0.11 & 89 & 0.23 & 0.24 & 124 & 0.38 & 0.40 \\
\hline 54 & 0.10 & 0.11 & 90 & 0.24 & 0.25 & 125 & 0.39 & 0.41 \\
\hline 55 & 0.11 & 0.11 & & & & 126 & 0.39 & 0.41 \\
\hline 56 & 0.11 & 0.12 & 91 & 0.24 & 0.25 & 127 & 0.40 & 0.42 \\
\hline 57 & 0.11 & 0.12 & 92 & 0.24 & 0.26 & 128 & 0.40 & 0.43 \\
\hline 58 & 0.12 & 0.12 & 93 & 0.25 & 0.26 & 129 & 0.41 & 0.43 \\
\hline 59 & 0.12 & 0.13 & 94 & 0.25 & 0.27 & 130 & 0.41 & 0.44 \\
\hline \multirow[t]{2}{*}{60} & 0.13 & 0.13 & 95 & 0.26 & 0.27 & & & \\
\hline & & & 96 & 0.26 & 0.27 & 131 & 0.42 & 0.44 \\
\hline 61 & 0.13 & 0.14 & 97 & 0.26 & 0.28 & 132 & 0.42 & 0.45 \\
\hline 62 & 0.13 & 0.14 & 98 & 0.27 & 0.28 & 133 & 0.43 & 0.45 \\
\hline 63 & 0.14 & 0.14 & 99 & 0.27 & 0.29 & 134 & 0.43 & 0.46 \\
\hline 64 & 0.14 & 0.15 & 100 & 0.28 & 0.29 & 135 & 0.44 & 0.47 \\
\hline 65 & 0.14 & 0.15 & & & & 136 & 0.44 & 0.47 \\
\hline 66 & 0.15 & 0.16 & 101 & 0.28 & 0.30 & 137 & 0.45 & 0.48 \\
\hline 67 & 0.15 & 0.16 & 102 & 0.28 & 0.30 & 138 & 0.46 & 0.48 \\
\hline 68 & 0.16 & 0.16 & 103 & 0.29 & 0.30 & 139 & 0.46 & 0.49 \\
\hline 69 & 0.16 & 0.17 & 104 & 0.29 & 0.31 & 140 & 0.47 & 0.50 \\
\hline \multirow[t]{2}{*}{70} & 0.16 & 0.17 & 105 & 0.30 & 0.31 & & & \\
\hline & & & 106 & 0.30 & 0.32 & 141 & 0.47 & 0.50 \\
\hline 71 & 0.17 & 0.18 & 107 & 0.30 & 0.32 & 142 & 0.48 & 0.51 \\
\hline 72 & 0.17 & 0.18 & 108 & 0.31 & 0.33 & 143 & 0.48 & 0.52 \\
\hline 73 & 0.17 & 0.18 & 109 & 0.31 & 0.33 & 144 & 0.49 & 0.52 \\
\hline 74 & 0.18 & 0.19 & 110 & 0.32 & 0.34 & 145 & 0.50 & 0.53 \\
\hline 75 & 0.18 & 0.19 & & & & 146 & 0.50 & 0.54 \\
\hline 76 & 0.18 & 0.19 & 111 & 0.32 & 0.34 & 147 & 0.51 & 0.54 \\
\hline 77 & 0.19 & 0.20 & 112 & 0.33 & 0.34 & 148 & 0.52 & 0.55 \\
\hline 78 & 0.19 & 0.20 & 113 & 0.33 & 0.35 & 149 & 0.52 & 0.56 \\
\hline 79 & 0.19 & 0.21 & 114 & 0.34 & 0.35 & 150 & 0.53 & 0.56 \\
\hline \multirow[t]{2}{*}{80} & 0.20 & 0.21 & 115 & 0.34 & 0.36 & & & \\
\hline & & & 116 & 0.34 & 0.36 & 151 & 0.54 & 0.57 \\
\hline 81 & 0.20 & 0.21 & 117 & 0.35 & 0.37 & 152 & 0.54 & 0.58 \\
\hline 82 & 0.21 & 0.22 & 118 & 0.35 & 0.37 & 153 & 0.55 & 0.58 \\
\hline 83 & 0.21 & 0.22 & 119 & 0.36 & 0.38 & 154 & 0.56 & 0.59 \\
\hline 84 & 0.21 & 0.23 & 120 & 0.36 & 0.38 & 155 & 0.56 & 0.60 \\
\hline 85 & 0.22 & 0.23 & & & & 156 & 0.57 & 0.61 \\
\hline
\end{tabular}


TABLE 48-Concluded

\begin{tabular}{|c|c|c|c|c|c|c|c|c|}
\hline \multirow{2}{*}{$\begin{array}{c}\text { BODY } \\
\text { LENGTI }\end{array}$} & \multicolumn{2}{|c|}{ RATIO } & \multirow{2}{*}{$\underset{\text { LENGTH }}{\text { BODY }}$} & \multicolumn{2}{|c|}{ RATIO } & \multirow{2}{*}{$\begin{array}{c}\text { BODY } \\
\text { LENGTH }\end{array}$} & \multicolumn{2}{|c|}{ ratio } \\
\hline & Male & Female & & Male & Female & & Male & Female \\
\hline 157 & 0.58 & 0.61 & 188 & 0.84 & 0.90 & 219 & 1.22 & 1.32 \\
\hline 158 & 0.58 & 0.62 & 189 & 0.85 & 0.91 & 220 & 1.24 & 1.34 \\
\hline 159 & 0.59 & 0.63 & 190 & 0.86 & 0.92 & & & \\
\hline \multirow[t]{2}{*}{160} & 0.60 & 0.64 & & & & 221 & 1.25 & 1.36 \\
\hline & & & 191 & 0.87 & 0.94 & 222 & 1.27 & 1.38 \\
\hline 161 & 0.60 & 0.65 & 192 & 0.88 & 0.95 & 223 & 1.28 & 1.40 \\
\hline 162 & 0.61 & 0.65 & 193 & (1.89 & 0.96 & 224 & 1.30 & 1.41 \\
\hline 163 & 0.62 & 0.66 & 194 & 0.90 & 0.97 & 225 & 1.32 & 1.43 \\
\hline 164 & 0.63 & 0.67 & 195 & 0.91 & 0.98 & 226 & 1.33 & 1.45 \\
\hline 165 & 0.63 & 0.68 & 196 & 0.92 & 1.00 & 227 & 1.35 & 1.47 \\
\hline 166 & 0.64 & 0.69 & 197 & 0.94 & 1.01 & 228 & 1.37 & 1.49 \\
\hline 167 & 0.65 & 0.70 & 198 & 0.95 & 1.02 & 229 & 1.38 & 1.51 \\
\hline 168 & 0.66 & 0.70 & 199 & 0.96 & 1.03 & 230 & 1.40 & 1.52 \\
\hline 169 & 0.67 & 0.71 & 200 & 0.97 & 1.05 & & & \\
\hline \multirow[t]{2}{*}{170} & 0.67 & 0.71 & & & & 231 & 1.42 & 1.54 \\
\hline & & & 201 & 0.98 & 1.06 & 232 & 1.44 & 1.56 \\
\hline 171 & 0.68 & 0.72 & 202 & 0.99 & 1.07 & 233 & 1.45 & 1.58 \\
\hline 172 & 0.69 & 0.73 & 203 & 1.01 & 1.09 & 234 & 1.47 & 1.60 \\
\hline 173 & 0.70 & 0.75 & 204 & 1.02 & 1.10 & 235 & 1.49 & 1.62 \\
\hline 174 & 0.71 & 0.76 & 205 & 1.03 & 1.11 & 236 & 1.51 & 1.64 \\
\hline 175 & 0.72 & 0.77 & 206 & 1.04 & 1.13 & 237 & 1.53 & 1.67 \\
\hline 176 & 0.73 & 0.78 & 207 & 1.06 & 1.14 & 238 & 1.55 & 1.69 \\
\hline 177 & 0.73 & 0.79 & 208 & 1.07 & 1.16 & 239 & 1.56 & 1.71 \\
\hline 178 & 0.74 & 0.80 & 209 & 1.08 & 1.17 & 240 & 1.58 & 1.73 \\
\hline 179 & 0.75 & 0.81 & 210 & 1.10 & 1.19 & & & \\
\hline \multirow[t]{2}{*}{180} & 0.76 & 0.82 & & & & 241 & 1.60 & 1.75 \\
\hline & & & 211 & 1.11 & 1.20 & 242 & 1.62 & 1.78 \\
\hline 181 & 0.77 & 0.83 & 212 & 1.12 & 1.22 & 243 & 1.64 & 1.80 \\
\hline 182 & 0.78 & 0.84 & 213 & 1.14 & 1.23 & 244 & 1.67 & 1.82 \\
\hline 183 & 0.79 & 0.85 & 214 & 1.15 & 1.25 & 245 & 1.69 & 1.84 \\
\hline 184 & 0.80 & 0.86 & 215 & 1.17 & 1.26 & 246 & 1.71 & 1.87 \\
\hline 185 & 0.81 & 0.87 & 216 & 1.18 & 1.28 & 247 & 1.73 & 1.89 \\
\hline 186 & 0.82 & 0.88 & 217 & 1.19 & 1.29 & 248 & 1.75 & 1.92 \\
\hline \multirow[t]{2}{*}{187} & 0.83 & 0.89 & 218 & 1.21 & 1.31 & 249 & 1.77 & 1.94 \\
\hline & & & & & & 250 & 1.79 & 1.97 \\
\hline
\end{tabular}

5. Weight-length ratios. Although it is not our purpose to introduce derived values among the tables, yet it seemed desirable in this connection to put in a table showing the ratio of body weight to body length. This gives the weight value of a running millimeter of the animal. By the use of this table it can be de- 
termined whether a given rat is emaciated or fat. The values for the weights and lengths as given in table 68 have been used for obtaining these ratios.

\section{GROWTH IN TOTAL WEIGHT: REFERENCES}

2. Growth before birth. Huber, '15 a. 3. Growth after birth. Chisolm, '11. Donaldson, '06, '12 c. Dunn, '08. Ferry, '13. Jackson, '13. King, '15. King and Stotsenburg, '15. Robertson, '08. 4. Modifications of growth. Donaldson, 11 a. Hatai, '03 a. '04 a, '07 a, '08, '13 a, '15. Jackson, '15, '15 a, '15 b. Osborne and Mendel (See Physiology: Nutrition). Schäfer, '12. Stotsenburg, '09, '13. Watson, C., '06, '06 a, '06 b. Watson, J. B., '05. 


\section{CHAPTER 6}

\section{GROWTH OF PARTS AND SYSTEMS OF THE BODY IN WEIGHT}

1. Larger divisions. 2. Systems. 3. Teeth. 4. Blood. 5. Fat.

1. Larger divisions. The relative growth of the component parts (head, trunk and limbs) and of the systems (integument ligamentous skeleton, musculature and viscera) has been studied by Jackson and Lowrey ('12).

The rats were reared at the University of Missouri and fed daily with wheat bread soaked in whole milk-a supply of chopped corn being kept constantly in the cages. In addition fresh beef was given once a week. The rats were well grown except at five months and one year, when both sexes were somewhat low in body weight - the deficiency being most marked in the females.

The report of the work by Jackson and Lowrey ('12) is given largely in their own words.

The method of dissection was as follows. The animal was taken in the morning before feeding and killed by chloroform. The gross body weight, and the lengths of body and tail were recorded. The head (with skin) was then removed (just posterior to the foramen magnum and anterior to the larynx) and weighed. In the meantime, the trunk was suspended and the blood (unmeasured) was allowed to escape. Then the viscera were carefully removed and weighed individually (including brain, spinal cord, eyeballs, thyroid, thymus, heart, lungs, liver, spleen, stomach and intestines, both with contents and empty, suprarenals, kidneys and gonads). Urine was estimated if present. The extremities were separated at the shoulder and hip joints and weighed with skin. The skin (including ears, claws and adherent subcutaneous tissue) was next removed and weighed. The trunk weight was estimated by substracting the weight of the head and extremities from the net body weight.

Then the musculature with skeleton was weighed, the few remaining additional structures( genitalia, large vessels, pharynx and oesophagus, larynx and trachea, and masses of fat connected with the musculature) having been carefully removed. Finally the musculature was care- 
fully dissected off and the skeleton, including bones, cartilages and ligaments, was weighed. This weight, subtracted from that of the skeleton and musculature together, gives the weight of the musculature, including the tendons. Evaporation was reduced to a minimum by keeping the various structures in a closed moist container, so far as possible. The net body weight, which is the gross body weight minus contents of stomach, intestines and urinary bladder, was used as the basis in calculating the percentage weights. The percentages therefore differ slightly from those calculated upon the gross body weight. The difference is not of material importance in the case of the albino rat, however, as the intestinal and other contents do not average more than 5 per cent of the body at the ages observed (excepting at 6 weeks, where the average was about 8 per cent.) The observations were grouped at sevell ages, chosen for the following reasons. At one week the weight at birth has about doubled. At three weeks it has about doubled again, and this moreover is the age at which the animal is usually weaned. At six weeks the body weight has again about doubled, and the animal is well established upon its permanent diet. Ten weeks represents the age of puberty, and the body weight of six weeks has again about doubled. At one year the body weight has again nearly doubled, and this represents nearly the adult weight. Five months was arbitrarily selected as the time when the body weight is approximately half way between those of ten weeks and one year. While therefore observations are not available for the various intermediate age periods, these are sufficiently close together so that no important change in the relative weights of the constituent parts is likely to be overlooked. Moreover, on account of the variations at the different ages in the body weights, these form a fairly continuous series; and the relative weights of the various constituent parts are apparently more closely correlated with the body weight than with the age.

The relative weights of the component parts examined are given in table 49 (modified from table 2, p. 455 , loc. cit.).

TABLE 49

Albino rat-Average percentage weight of head, trunk and extremities at various ages-sexes combined (Jackson and Lowrey, '12)

\begin{tabular}{|c|c|c|c|c|c|}
\hline AGE, DAYS & BODY WEIGHT & HEAD & FORE-LIMBS & HIND-LIMBS & TRUNK \\
\hline & gms. & per cent & per cent & per cent & per cent \\
\hline $0 .$. & 5.4 & 21.65 & 7.39 & 9.45 & 61.51 \\
\hline $7 \ldots$ & 11.6 & 23.70 & 8.92 & 11.97 & 55.41 \\
\hline $21 \ldots$ & 25.5 & 20.22 & 9.25 & 14.87 & 55.66 \\
\hline $42 \ldots \ldots \ldots$ & 79.2 & 11.80 & 6.72 & 14.94 & 66.54 \\
\hline $70 \ldots \ldots$ & 141.9 & 9.56 & 5.32 & 15.59 & 69.53 \\
\hline $150 \ldots$ & 190.7 & 9.42 & 5.87 & 15.64 & 69.07 \\
\hline $365 \ldots$ & 222.2 & 9.29 & 4.76 & 14.63 & 71.32 \\
\hline
\end{tabular}


The authors call attention to the relative increase in the weight of the head during the first week-as peculiar in the rat-and also point out that the maximum relative weight is shown by the head at one week-by the forelimbs at three weeks, by the hind limbs at five months and by the trunk at a year-the wave of most active growth thus passing from the head caudad with advancing age.

2. Systems. The relative growth of the various systems is also given for the integument, ligamentous skeleton, musculature and viscera. The method of preparing each system has been previously noted. The following table is based on table 4 (loc. cit., p. 460) to which has been added the average values of the net body weights.

It is to be noted that the percentages in tables 49 and 50 are based on the 'net body weight' of the rats. According to Jackson and Lowrey this is about 95 per cent of the gross weight, and this factor can be used therefore to transform net into gross weight.

TABLE 50

Average percentage weights of integument, ligamentous skeleton, musculature, viscera and remainder. Based on Jackson and Lowrey ('12), table 4. For the corresponding absolute weights see table 51

\begin{tabular}{|c|c|c|c|c|c|c|c|}
\hline \multirow[b]{2}{*}{ AGE IN DAYS } & \multirow[b]{2}{*}{$\begin{array}{l}\text { SEX AND } \\
\text { NUMBER }\end{array}$} & \multirow[b]{2}{*}{$\begin{array}{c}\text { BODY } \\
\text { WEIGHT }\end{array}$} & \multicolumn{5}{|c|}{ PERCENTAGE VALUES-SEXES COMBINED FOR } \\
\hline & & & Integument & $\begin{array}{c}\text { Liga- } \\
\text { mentous } \\
\text { skeleton }\end{array}$ & $\begin{array}{c}\text { Muscula- } \\
\text { ture }\end{array}$ & Viscera & Remainder \\
\hline & & gms. & & & & & \\
\hline $0 \ldots$ & $\begin{cases}\text { M. } & 9 \\
\text { F. } & 9\end{cases}$ & 4.7 & 19.8 & 17.3 & 24.4 & 18.1 & 20.4 \\
\hline $7 .$. & $\left\{\begin{array}{lr}\text { M. } & 8 \\
\text { F. } & 11\end{array}\right.$ & 10.1 & 25.9 & 18.5 & 22.8 & 19.2 & 13.6 \\
\hline 21. & $\begin{cases}\text { M. } & 7 \\
\text { F. } & 6\end{cases}$ & 24.8 & 22.4 & 16.6 & 26.9 & 21.3 & 12.8 \\
\hline $42 .$. & $\begin{cases}\text { M. } & 6 \\
\text { F. } & 8\end{cases}$ & 64.5 & 20.9 & 14.0 & 32.7 & 20.4 & 12.0 \\
\hline 70. & $\begin{cases}\mathrm{M} . & 5 \\
\mathrm{~F} . & 5\end{cases}$ & 130.5 & 18.7 & 11.7 & 41.1 & 16.0 & 12.5 \\
\hline $150 \ldots$ & $\begin{cases}\text { M. } & 6 \\
\text { F. } & 7\end{cases}$ & 184.3 & 18.1 & 11.5 & 42.6 & 14.8 & 13.0 \\
\hline $365 .$. & $\begin{cases}M . & 4 \\
\text { F. } & 2\end{cases}$ & 234.6 & 18.0 & 10.9 & 45.4 & 13.3 & 12.4 \\
\hline
\end{tabular}


TABLE 51 .

Shows for the series of body weights of the albino rat by Jackson and Lowrey ('12) the absolute weights of integument, ligamentous skeleton, musculature, viscera and remainder determined by the use of the percentage values given in the preceding table 50

\begin{tabular}{|c|c|c|c|c|c|c|c|}
\hline $\begin{array}{c}\text { AGE } \\
\text { IN } \\
\text { DAYS }\end{array}$ & $\begin{array}{l}\text { MEAN BODY } \\
\text { WEIGHTS }\end{array}$ & sEX No. & INTEGUMENT & $\begin{array}{l}\text { LIGAMEN- } \\
\text { TOUS } \\
\text { SKELETON }\end{array}$ & MUSCULATURE & VISCERA & REMAINDER \\
\hline 0 & $\begin{array}{l}\text { Average } \\
\begin{aligned} \text { M. }+ \text { F. } & \\
& 5.11 \\
& 4.27 \\
4.69 & \end{aligned}\end{array}$ & $\begin{array}{ll}\text { M. } & 9 \\
\text { F. } & 9\end{array}$ & $\begin{array}{lr} & 1.00 \\
& 0.85 \\
0.93 & \end{array}$ & $\begin{array}{ll} & 0.87 \\
& 0.75 \\
0.81 & \end{array}$ & 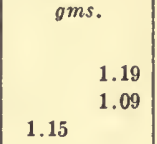 & $\begin{array}{r} \\
\quad 0.90 \\
0.79 \\
0.85 \quad\end{array}$ & $\begin{array}{r}1.15 \\
0.79 \\
0.97 \quad\end{array}$ \\
\hline 7 & $\begin{array}{r}10.47 \\
\quad 9.83 \\
10.10\end{array}$ & $\begin{array}{lr}\text { M. } & 8 \\
\text { F. } & 11\end{array}$ & $\begin{array}{rr} & 2.79 \\
& 2.33 \\
2.62 & \end{array}$ & $\begin{array}{r}1.93 \\
1.70 \\
1.87\end{array}$ & $\begin{array}{r}2.40 \\
2.24 \\
2.30 \quad\end{array}$ & $\begin{array}{l}2.00 \\
1.90\end{array}$ & $\begin{array}{l}1.36 \\
1.30\end{array}$ \\
\hline 21 & $\begin{array}{rr}26.91 \\
& 22.31 \\
24.78 & \end{array}$ & $\begin{array}{ll}\text { M. } & 7 \\
\text { F. } & 6\end{array}$ & $\begin{array}{r}6.35 \\
\\
5.55 \quad 4.69 \\
\end{array}$ & $\begin{array}{r}4.20 \\
3.97 \\
4.11 \quad\end{array}$ & $\begin{array}{r}7.45 \\
\quad 5.78 \\
6.67\end{array}$ & $\begin{array}{r}5.71 \\
4.77 \\
5.28\end{array}$ & $\begin{array}{l}3.23 \\
3.08\end{array}$ \\
\hline 42 & $\begin{array}{r}60.10 \\
67.80 \\
64.50\end{array}$ & $\begin{array}{ll}\text { M. } & 6 \\
\text { F. } & 8\end{array}$ & $\begin{array}{rr} & 12.14 \\
& 14.51 \\
13.48 & \end{array}$ & $\begin{array}{l}9.08 \\
8.95\end{array}$ & \begin{tabular}{rr|} 
& 19.41 \\
21.09 & \\
22.37
\end{tabular} & $\begin{array}{r}12.86 \\
13.36 \\
13.16\end{array}$ & $\begin{array}{l}6.67 \\
8.61\end{array}$ \\
\hline 70 & $\begin{array}{r}143.60 \\
117.50\end{array}$ & $\begin{array}{ll}\text { M. } & 5 \\
\text { F. } & 5\end{array}$ & $\begin{array}{rr}26.14 \\
& 22.56 \\
24.40 & \end{array}$ & $\begin{array}{rr}15.94 \\
14.34 \\
15.27\end{array}$ & $\begin{array}{r}57.15 \\
49.94 \\
53.64\end{array}$ & $\begin{array}{rr}23.26 \\
18.68 \\
20.88\end{array}$ & $\begin{array}{rr} & 21.11 \\
& 11.99 \\
16.31 & \end{array}$ \\
\hline 150 & $\begin{array}{r}218.70 \\
154.80\end{array}$ & $\begin{array}{ll}\text { M. } & 6 \\
\text { F. } & 7\end{array}$ & $\begin{array}{rr} & 41.99 \\
& 26.62 \\
33.36 & \end{array}$ & $\begin{array}{rr} & 22.84 \\
& 18.73 \\
21.38 & \end{array}$ & $\begin{array}{r}93.38 \\
\quad 65.94 \\
78.51\end{array}$ & $\begin{array}{rr}29.96 \\
24.30 \\
27.28\end{array}$ & $\begin{array}{rr} & 25.52 \\
& 19.20 \\
23.77 & \end{array}$ \\
\hline 365 & $\begin{array}{r}260.20 \\
183.50 \\
234.60\end{array}$ & $\begin{array}{ll}\text { M. } & 4 \\
\text { F. } & 2\end{array}$ & $\begin{array}{r}44.75 \\
35.78 \\
42.23\end{array}$ & $\begin{array}{r}25.50 \\
21.22 \\
25.57\end{array}$ & $\begin{array}{r}120.99 \\
79.46 \\
106.51\end{array}$ & $\begin{array}{r}33.83 \\
\quad 25.32 \\
31.20\end{array}$ & $\begin{array}{l}35.13 \\
18.72\end{array}$ \\
\hline
\end{tabular}

Ligamentous skeleton. Since the values for the skeleton as given in tables 50 and 51 were obtained by dissection of the soft parts from the bones, it is evident that these determinations for the skeleton, which here corresponds to the 'ligamentous skeleton' would be high as compared with those obtained after the soft parts had been completely removed by maceration - thus giving the 'cartilaginous skeleton' in the strict sense.

In view of this difference we have made recently a series of determinations of the relative weight of the cartilaginous skeleton after maceration, Conrow (MS '15). Using these determinations as a basis, table 52 has been formed which gives the values thus 
obtained. The differences between the values for the moist skeleton after maceration and those obtained after gross dissection may be designated as values for the 'periosteum, ligaments, etc.' and are so entered in table 52.

It is thus possible from these two tables to compare subsequent determinations of the skeleton after either dissection or maceration.

If rats normal in body weight for their age are compared, we find that the cartilaginous skeleton at birth represents 52.5 per

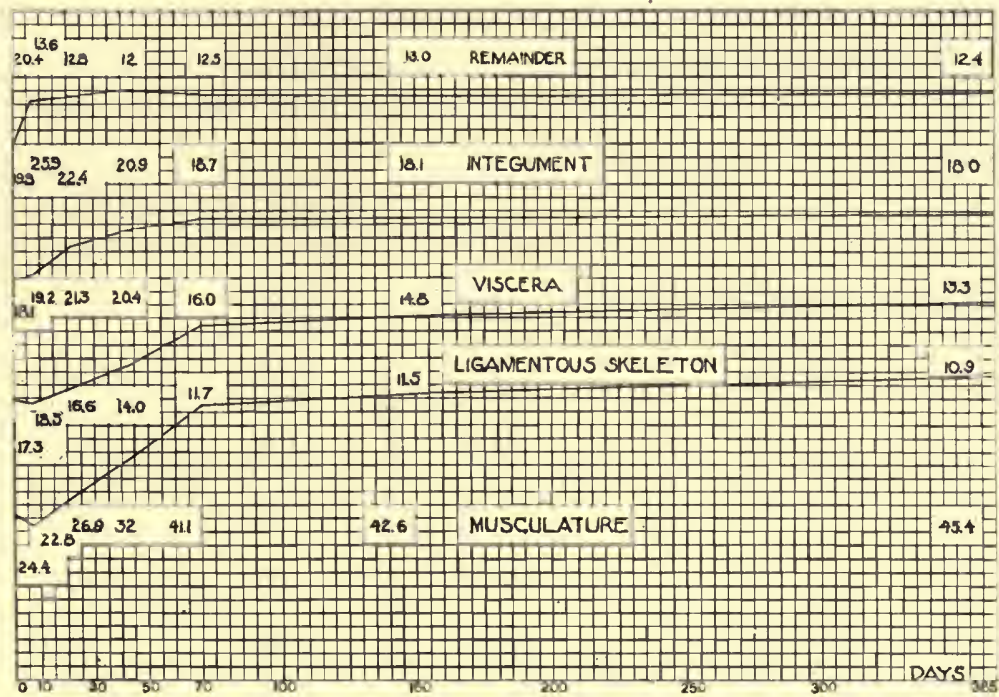

Chart 5 Giving for the sexes combined the percentage of the entire body weight represented by each of the several systems. Plotted on age in days. Table 50, Jackson and Lowrey ('12).

cent of the weight of the ligamentous skeleton, while at one year it represents 64.5 per cent. The ratio for the weight of the bony skeleton rises therefore one point for each 23 grams increase in body weight, or for each gram of increase in body weight the ratio rises about 0.044 of a point. Within the age limits heregiven, these factors may be used for transforming one set of values into the other. 
Jackson and Lowrey conclude (p. 472) that the data indicate no noteworthy differences between the sexes in the relative weights of the various parts and systems, and that the body of the albino rat has practically reached the adult proportions in its component parts and systems at the age of ten weeks.

Corresponding observations, though less extensive, made on the Norway rat are given in chapter 12.

TABLE 52

Giving the percentage values for the cartilaginous skeleton when this has been prepared by maceration (Conrow, MS.'15), also giving-by difference between these values and those in table 50-the percentage values for the "periosteum, ligaments, etc."

\begin{tabular}{|c|c|c|c|c|}
\hline \multirow[b]{2}{*}{ AGE IN DAYS } & \multirow[b]{2}{*}{ SEX AND NUMBER } & \multirow[b]{2}{*}{$\begin{array}{l}\text { BODY WEIGHT NET } \\
\text { BOTE SEXES }\end{array}$} & \multicolumn{2}{|c|}{ PERCENTAGE VALUE of MOIST } \\
\hline & & & $\begin{array}{l}\text { Cartilaginous } \\
\text { skeleton } \\
\text { (by maceration) } \\
\text { Conrow }\end{array}$ & $\begin{array}{c}\text { Periosteum } \\
\text { ligaments, etc. } \\
\text { Based on table } 50\end{array}$ \\
\hline $0 \ldots$ & $\left\{\begin{array}{ll}\text { M. } & 9 \\
\text { F. } & 9\end{array}\right\}$ & 4.7 & 8.95 & 8.35 \\
\hline $7 \ldots$ & $\left\{\begin{array}{cc}M . & 8 \\
F . & 11\end{array}\right\}$ & 10.1 & 9.36 & 9.14 \\
\hline 21. & $\left\{\begin{array}{ll}\text { M. } & 7 \\
\text { F. } & 6\end{array}\right\}$ & 24.8 & 9.61 & 6.99 \\
\hline $42 \ldots$ & $\left\{\begin{array}{ll}M . & 6 \\
\text { F. } & 8\end{array}\right\}$ & 64.5 & 7.46 & 6.54 \\
\hline $70 \ldots$ & $\left\{\begin{array}{ll}\mathrm{M} . & 5 \\
\mathrm{~F} . & 5\end{array}\right\}$ & 130.5 & 7.32 & 4.38 \\
\hline $150 \ldots$ & $\left\{\begin{array}{ll}\text { M. } & 6 \\
\text { F. } & 7\end{array}\right\}$ & 184.3 & 6.32 & 4.18 \\
\hline $365 \ldots$ & $\left\{\begin{array}{ll}\text { M. } & 4 \\
\text { F. } & 2\}\end{array}\right\}$ & 234.6 & 6.04 & 4.05 \\
\hline
\end{tabular}

Weight of entire cartilaginous skeleton. Using a 2 per cent solution of the commercial gold dust washing powder ('Gold dust washing powder' consists of about 45 per cent sodium carbonate, 30 per cent soap powder, and 25 per cent water), the skeletons of some 70 inbred Albinos (King) have been carefully prepared by Conrow (MS '15) at The Wistar Institute. The animals were reared on a scrap diet. A careful comparison with the stock Albinos has not yet been made, but at the same time there is no suggestion thus far that the values for the inbreds differ from 
those for the stock, when both age and body weight are taken into consideration. The weight of the skeleton is given in relation to the body weight. The value for the body used here is that normal to the body length (see table 68) when the observed body weight is less than that to be expected-but the observed body weight is used when that is above the normal for the body length. In the case of old rats undergoing senile loss of body weight the maximum body weight is the one used.

The weight of the teeth is included with that of the skeleton - but the weight of the nails is excluded. Under these conditions the following table gives the weight of the moist cartilaginous skeleton-immediately after complete cleaning, and also

\section{TABLE 53}

Giving data on the cartilaginous skeleton of the (inbred) Albino (Conrow MS '15).

The weights for the moist skeleton are given-but not for the room dried skeleton.

The percentage values for both on the body weight have been computed.

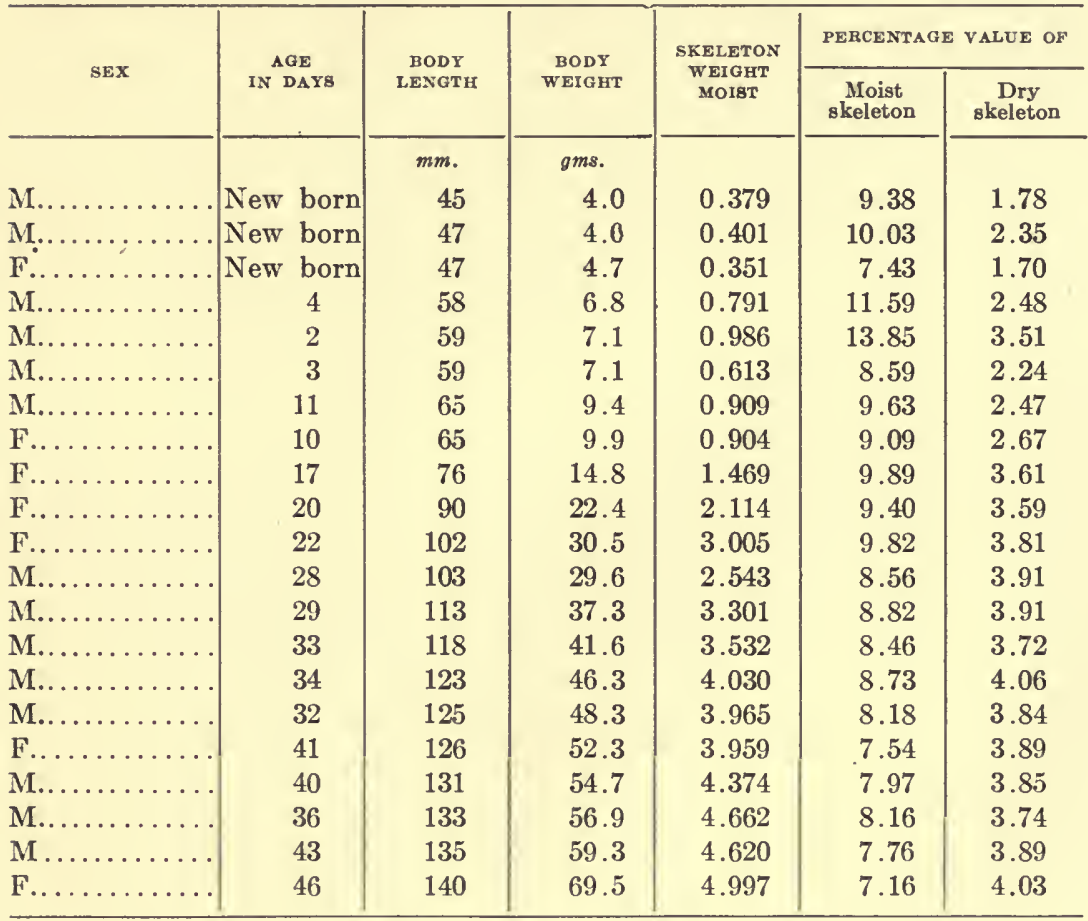


TABLE 53-Concluded

\begin{tabular}{|c|c|c|c|c|c|c|}
\hline \multirow{2}{*}{$\operatorname{sex}$} & \multirow{2}{*}{$\begin{array}{c}\text { AGE } \\
\text { IN DAYS }\end{array}$} & \multirow{2}{*}{$\begin{array}{l}\text { BODY } \\
\text { ENGTH }\end{array}$} & \multirow{2}{*}{$\begin{array}{c}\text { BODY } \\
\text { WEIGHT }\end{array}$} & \multirow{2}{*}{$\begin{array}{l}\text { SKELETON } \\
\text { WEIGHT } \\
\text { MOIST }\end{array}$} & \multicolumn{2}{|c|}{ PERCENTAGE VALUE of } \\
\hline & & & & & $\begin{array}{c}\text { Moist } \\
\text { skeleton }\end{array}$ & $\underset{\text { skeleton }}{\text { Dry }}$ \\
\hline & & $m m$. & gms. & & & \\
\hline$\ldots \ldots$ & 73 & 145 & 76.7 & 5.930 & 7.70 & 4.84 \\
\hline F... & 54 & 148 & 81.3 & 6.349 & 7.78 & 4.34 \\
\hline F... & 102 & 153 & 89.4 & 7.278 & 8.12 & 5.20 \\
\hline$\ldots \ldots$ & 84 & 164 & 109.9 & 8.114 & 7.36 & 4.79 \\
\hline F.......... & 117 & 164 & 109.9 & 7.424 & 6.74 & 4.58 \\
\hline F.......... & 106 & 171 & 125.0 & 8.876 & 7.08 & 4.72 \\
\hline$\ldots \ldots$ & 189 & 172 & 127.3 & 9.665 & 7.57 & 5.36 \\
\hline$\ldots \ldots \ldots$ & 119 & 181 & 149.7 & 10.209 & 6.80 & 4.77 \\
\hline F........... & 120 & 183 & 155.2 & 9.983 & 6.41 & 4.43 \\
\hline F.......... & 135 & $\cdot 185$ & 160.8 & 11.155 & 6.92 & 4.56 \\
\hline M.......... & 99 & 185 & 149.6 & 10.609 & 7.07 & 5.03 \\
\hline$\ldots \ldots$ & 105 & 186 & 152.3 & 10.539 & 6.90 & 4.74 \\
\hline$\ldots \ldots$ & 125 & 188 & 169.6 & 11.469 & 6.74 & 4.79 \\
\hline$\ldots \ldots$ & & 190 & 175.7 & 11.888 & 6.75 & 5.00 \\
\hline$\ldots \ldots \ldots$ & 320 & 196 & 223.0 & 13.386 & 5.98 & 4.00 \\
\hline M... & 173 & 197 & 184.3 & 11.283 & 6.10 & 4.00 \\
\hline F... & 281 & 199 & 205.8 & 13.132 & 6.36 & 4.64 \\
\hline M... & 253 & 199 & 190.8 & 12.557 & 6.56 & 4.82 \\
\hline M... & 196 & 200 & 194.1 & 12.409 & 6.38 & 4.53 \\
\hline$\ldots \ldots \ldots$ & 299 & 202 & 216.8 & 14.378 & 6.62 & 4.57 \\
\hline$\ldots \ldots$ & 302 & 203 & 220.7 & 13.974 & 6.32 & 4.69 \\
\hline F... & 392 & 203 & 220.7 & 12.911 & 5.84 & 3.56 \\
\hline M... & 121 & 207 & 218.7 & 13.594 & 6.22 & 4.37 \\
\hline$\ldots \ldots$ & 203 & 211 & 234.1 & 14.600 & 6.23 & 4.21 \\
\hline$M \ldots \ldots \ldots \ldots$ & 371 & 211 & 295.0 & 15.019 & 5.08 & 3.42 \\
\hline$\ldots \ldots$ & 169 & 214 & 246.3 & 15.543 & 6.30 & 4.52 \\
\hline M... & 205 & 215 & 250.5 & 15.688 & 6.25 & 4.58 \\
\hline M... & 304 & 216 & 307.0 & 16.810 & 5.47 & 3.76 \\
\hline M... & 367 & 219 & 318.0 & 19.321 & 6.07 & 4.26 \\
\hline$\ldots \ldots \ldots$ & 221 & 219 & 267.9 & 16.158 & 6.02 & 4.09 \\
\hline$\ldots \ldots$ & 314 & 221 & 344.0 & 20.078 & 5.83 & 4.05 \\
\hline$\ldots \ldots \ldots$ & 462 & 223 & 342.9 & 20.277 & 5.90 & 4.22 \\
\hline$M \ldots \ldots \ldots \ldots$ & 357 & 225 & 410.0 & 19.147 & 4.66 & 3.47 \\
\hline M.... & 518 & 226 & 343.0 & 20.433 & 5.95 & 4.29 \\
\hline M.......... & 332 & 226 & 419.0 & 22.257 & 5.30 & 3.93 \\
\hline M......... & 474 & 228 & 355.0 & 19.518 & 5.49 & 3.88 \\
\hline$M \ldots \ldots \ldots \ldots \ldots$ & 276 & 228 & 413.0 & 22.323 & 5.40 & 3.96 \\
\hline M....... & 726 & 230 & 446.0 & 21.720 & 4.86 & 3.55 \\
\hline M.......... & 255 & 238 & 420.0 & 25.390 & 6.04 & 4.49 \\
\hline$M \ldots \ldots \ldots \ldots$ & 253 & 240 & 440.0 & 23.698 & 5.38 & 4.01 \\
\hline M............ & 408 & 252 & 463.4 & 23.823 & 5.03 & 3.79 \\
\hline
\end{tabular}


the weight of the dry skeleton after drying in open, but dust free vessels, for thirty days or more at room temperature $\left(17^{\circ}-\right.$ $23^{\circ} \mathrm{C}$.).

In table 54 the same material has been used to show the lengths of the femur and tibia and the humerus and ulna together with some simple relations. In the case of the Albinos less than 30 days of age, drying in the air may cause so considerable a reduction in the lengths of these bones that no measurements are given in table 54 for dried long bones younger than 30 daysat which time the skeleton is fairly well calcified.

\section{TABLE 54}

From some of the same (inbred) Albinos as were used for table 53 the lengths of the femur, tibia, humerus and ulna have been determined and also the percentage lengths of the humerus and ulna on the femur and tibia, as well as the relation of both of these pairs to the body length (Conrow, MS '15)

\begin{tabular}{|c|c|c|c|c|c|c|c|c|c|}
\hline \multirow[b]{2}{*}{$\operatorname{sex}$} & \multirow{2}{*}{$\begin{array}{l}\text { AGE } \\
\text { DAYS }\end{array}$} & \multirow{2}{*}{$\begin{array}{c}\text { BODP } \\
\text { LENGTH }\end{array}$} & \multicolumn{4}{|c|}{ MEAN LENGTHS IN mm. OF } & \multicolumn{3}{|c|}{ PERCENTAGES OF } \\
\hline & & & Femu: & Tibia & Humerus & Ulna & $\frac{\mathrm{H} .+\mathrm{U} .}{\mathrm{F}+\mathrm{T} .}$ & $\frac{\text { F. T. }}{\text { Bd. L. }}$ & $\frac{\text { H. U. }}{\text { Bd. L. }}$ \\
\hline & & $m m$. & & & & & & & \\
\hline M.. & 32 & 125 & 18.7 & 23.0 & 15.9 & 18.8 & 83 & 33 & 27 \\
\hline F.. & 41 & 126 & 18.7 & 23.0 & 15.4 & 18.3 & 80 & 33 & 26 . \\
\hline M.. & 40 & 131 & 18.2 & 22.9 & 15.4 & 18.7 & 82 & 31 & 26 \\
\hline M... & 36 & 133 & 20.9 & 25.0 & 16.9 & 20.2 & 80 & 34 & 28 \\
\hline M... & 43 & 135 & 19.8 & 23.6 & 16.0 & 18.9 & 80 & 32 & 25 \\
\hline F... & 46 & 140 & 21.2 & 24.6 & 17.1 & 19.7 & 80 & 32 & 26 \\
\hline F... & 73 & 145 & 23.1 & 26.4 & 17.8 & 21.4 & 79 & 34 & 27 \\
\hline F..... & 54 & 148 & 23.5 & 27.4 & 18.4 & 22.0 & 79 & 34 & 27 \\
\hline F..... & 102 & 153 & 25.3 & 29.3 & 20.5 & 23.6 & 80 & 35 & 28 \\
\hline F. . & 84 & 164 & 26.1 & 29.8 & 20.7 & 24.6 & 81 & 34 & 27 \\
\hline F... & 117 & 164 & 27.3 & 31.5 & 21.3 & 25.7 & 79 & 35 & 28 \\
\hline F... & 106 & 171 & 27.8 & 31.5 & 22.1 & 25.8 & 80 & 34 & 28 \\
\hline F...... & 189 & 172 & 28.8 & 32.2 & 22.6 & 26.8 & 80 & 35 & 28 \\
\hline F..... & 119 & 181 & 30.3 & 33.0 & 23.6 & 27.1 & 80 & 34 & 27 \\
\hline F..... & 120 & 183 & 29.0 & 32.9 & 22.7 & 27.1 & 80 & 33 & 27 \\
\hline M.... & 119 & 183 & 30.7 & 33.6 & 23.9 & 26.6 & 78 & 35 & 27 \\
\hline F...... & 135 & 185 & 31.5 & 34.6 & 24.6 & 28.3 & 80 & 35 & 28 \\
\hline M.... & 99 & 185 & 30.6 & 34.0 & 23.9 & 27.1 & 78 & 34 & 27 \\
\hline M.... & 105 & 186 & 30.8 & 33.8 & 24.1 & 27.4 & 79 & 34 & 27 \\
\hline F...... & 125 & 188 & 30.6 & 33.8 & 23.6 & 28.1 & 80 & 34 & 27 \\
\hline F..... & & 190 & 30.7 & 34.6 & 24.4 & 28.6 & 81 & 34 & 27 \\
\hline F..... & 730 & 193 & 33.5 & 36.5 & 26.3 & 31.5 & 82 & 35 & 29 \\
\hline
\end{tabular}


TABLE 54-Concluded

\begin{tabular}{|c|c|c|c|c|c|c|c|c|c|}
\hline \multirow[b]{2}{*}{ SEX } & \multirow{2}{*}{$\begin{array}{l}\text { AGE } \\
\text { DAYS }\end{array}$} & \multirow{2}{*}{$\begin{array}{l}\text { BODY } \\
\text { LENGTH }\end{array}$} & \multicolumn{4}{|c|}{ MEAN LENGTHS IN $\mathrm{mm}$. OF } & \multicolumn{3}{|c|}{ PERCENTAGES OF } \\
\hline & & & Femur & Tibia & Humerus & Ulna & $\frac{\mathrm{H}_{0}+\mathrm{U}}{\mathrm{F} .+\mathrm{T}}$ & $\frac{\text { F. T. }}{\text { Bd. L. }}$ & $\frac{\mathrm{H} . \mathrm{U}}{\overline{\mathrm{Bd} . \mathrm{L}}}$ \\
\hline F.. & 320 & $\begin{array}{r}m m . \\
196\end{array}$ & 34.8 & 36.5 & 26.8 & 30.5 & 80 & 36 & 29 \\
\hline M.. & 173 & 197 & 32.8 & 35.6 & 25.5 & 28.9 & 79 & 34 & 27 \\
\hline M.. & 253 & 199 & 34.3 & 37.4 & 26.8 & 31.4 & 81 & 35 & 29 \\
\hline F... & 281 & 199 & 32.9 & 36.5 & 25.9 & 30.8 & 81 & 34 & 28 \\
\hline M.. & 196 & 200 & 33.9 & 36.9 & 26.3 & 30.3 & 79 & 35 & 28 \\
\hline F... & 392 & 203 & 32.1 & 35.1 & 25.0 & 29.3 & 80 & 33 & 26 \\
\hline F... & 302 & 203 & 34.5 & 37.8 & 26.6 & 31.9 & 80 & 35 & 28 \\
\hline M.. & 121 & 207 & 34.1 & 36.9 & 26.7 & 30.2 & 80 & 34 & 27 \\
\hline M.. & 203 & 211 & 34.6 & 38.6 & 26.9 & 31.6 & 79 & 34 & 27 \\
\hline M. . & 371 & 211 & 37.0 & 39.2 & 28.3 & 32.5 & 79 & 36 & 28 \\
\hline M.. & 169 & 214 & 35.0 & 37.3 & 27.3 & 30.7 & 80 & 33 & 27 \\
\hline M.. & 205 & 215 & 35.1 & 37.7 & 27.1 & 31.3 & 80 & 33 & 27 \\
\hline M.. & 304 & 216 & 37.9 & 41.7 & 29.8 & 34.6 & 81 & 36 & 29 \\
\hline M.. & 221 & 219 & 37.5 & 39.8 & 28.7 & 32.3 & 78 & 35 & 27 \\
\hline M... & 367 & 219 & 37.3 & 38.6 & 28.9 & 31.8 & 79 & 34 & 27 \\
\hline M.. & 314 & 221 & 38.6 & 40.4 & 29.9 & 34.1 & 81 & 35 & 28 \\
\hline M... & 462 & 223 & 37.3 & 39.2 & 29.4 & 32.1 & 80 & 34 & 27 \\
\hline M.. & 357 & 225 & 39.2 & 41.5 & 30.5 & 34.1 & 80 & 35 & 28 \\
\hline M.. & 518 & 226 & 37.7 & 39.2 & 29.6 & 32.4 & 80 & 34 & 27 \\
\hline M. . & 332 & 226 & 38.2 & 41.5 & 29.6 & 34.6 & 80 & 35 & 28 \\
\hline M... & 276 & 228 & 38.3 & 39.7 & 29.8 & 32.5 & 79 & 34 & 27 \\
\hline M.. & 474 & 228 & 40.0 & 41.3 & 30.9 & 34.2 & 80 & 35 & 28 \\
\hline M. & 726 & 230 & 39.2 & 40.9 & 30.5 & 33.1 & 79 & 34 & 27 \\
\hline M.. & 255 & 238 & 39.6 & 42.5 & 30.7 & 35.9 & 81 & 34 & 27 \\
\hline M.. & 253 & 240 & 40.7 & 43.8 & 32.0 & 36.0 & 80 & 35 & 28 \\
\hline M. . & 408 & 252 & 41.0 & 43.1 & 31.7 & 36.1 & 80 & 33 & 26 \\
\hline
\end{tabular}

Tests show that after 30 days of age, drying at room temperature causes less than one per cent of shrinkage in the absolute lengths of the bones. The values for the bone lengths given in the table are means for the right and left sides-the length for the two sides usually being very nearly the same. The body length in every case is taken on the rat immediately after chloroforming.

Weight of cranium. Determinations of the weight of the cranium dried at room temperature have been made, Donaldson ('12 a). By the cranium is meant the skull with upper 
teeth, minus the mandible with lower teeth and minus the ear bones. The mean weights are given in table 55 .

TABLE 55

The mean weight in grams of the crania in each body weight group of the four series of albino rats from Paris, London, Philadelphia, Vienna (based on table 4) Donaldson ('12 a). Each weight group is based on six cases, three males and three females

\begin{tabular}{|c|c|c|c|c|}
\hline \multirow{2}{*}{ BODY WEIGHT GROUP } & \multicolumn{4}{|c|}{ WEIGHT OF CRANIA IN GRAMS } \\
\hline & London & Paris & Philadelphia & Vienna \\
\hline grams & & & & \\
\hline $125 \ldots \ldots \ldots \ldots$ & 0.89 & 1.03 & 1.05 & 1.00 \\
\hline $175 \ldots \ldots$ & 1.23 & 1.27 & 1.41 & 1.40 \\
\hline $225 \ldots$ & 1.52 & 1.52 & 1.51 & 1.73 \\
\hline 275. & 1.79 & & 1.87 & 2.10 \\
\hline 325 . & & & 2.15 & \\
\hline
\end{tabular}

For the corresponding weights of the Norway crania see Table 84 .

3. Teeth. For the data on the growth of the incisor teeth (Addison and Appleton, '15), see chapter 3, p. 37-39.

4. Blood. By means of a formula (19) based on his observations Chisolm ('11) was able to compute approximately the volume of the blood in rats of different body weights. Hatai (MS '14) has added two formulas (19 a) (19 b) based on that of Chisolm and giving results somewhat closer to the observations when the determinations are made according to sex.

These three formulas have been transformed in turn from volume to weight by using as a factor 1.056 - the specific gravity of the blood-and three formulas for blood weight (20) (20 a) $(20 \mathrm{~b})$ have been thus obtained. These last have been used to compute the weight of the blood as given in table 70. Table 56 here given presents Chisolm's data on the other growth changes in the blood.

5. Fat. Boycott and Damant ('08, '08 a) have recorded the proportion of fat in rats of both sexes and of increasing body weights.

The total fat was determined in healthy animals living under ordinary laboratory conditions as to food. No details given. The fat was estimated by Leathes' modification of Liebermann's 
TABLE 56

Showing growth changes in the blood in rats of increasing age (body weight). Sexes combined-based on tables I and II, Chisolm ('11)

\begin{tabular}{|c|c|c|c|c|c|c|c|c|}
\hline \multirow{2}{*}{ 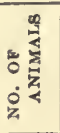 } & \multirow{2}{*}{$\begin{array}{c}\text { AGE IN } \\
\text { DAYS }\end{array}$} & \multirow{2}{*}{$\begin{array}{l}\text { BODY WT. } \\
\text { IN GMS. }\end{array}$} & \multirow{2}{*}{$\begin{array}{l}\text { LENGTH } \\
\text { OF BODY } \\
\text { IN MM. }\end{array}$} & \multirow{2}{*}{$\underset{\text { PER CENT }}{\mathrm{HB}_{\mathrm{B}}}$} & \multicolumn{2}{|c|}{$\mathrm{O}_{2}$ CAPACITY IN CC. } & \multicolumn{2}{|c|}{ BLOOD VOLUME IN CC. } \\
\hline & & & & & Total & $\begin{array}{l}\text { Per kilo } \\
\text { body wt. }\end{array}$ & Total & $\begin{array}{l}\text { Per kilo } \\
\text { body wt. }\end{array}$ \\
\hline 2 & 1 & 3.6 & & 89.0 & 0.0411 & 11.59 & 0.249 & 70.3 \\
\hline 5 & 2 & 4.8 & 47 & 72.0 & 0.0466 & 9.79 & 0.350 & 73.5 \\
\hline 3 & 8 & 10.0 & 59 & 50.3 & 0.0485 & 4.83 & 0.522 & 52.0 \\
\hline 9 & 16 & 12.8 & 72 & 63.0 & 0.0639 & 4.99 & 0.544 & 42.5 \\
\hline 3 & 21 & 14.2 & 82 & 49.0 & 0.0773 & 5.44 & 0.863 & 60.4 \\
\hline 3 & 28 & 14.3 & 84 & 44.7 & 0.0891 & 6.17 & 1.070 & 74.4 \\
\hline 9 & & 37.0 & 112 & 76.0 & 0.3730 & 10.00 & 2.620 & 70.0 \\
\hline 8 & & 57.0 & 134 & 84.6 & 0.5630 & 9.92 & 3.610 & 63.7 \\
\hline 8 & & 66.0 & 140 & 85.1 & 0.6490 & 9.88 & 4.120 & 62.7 \\
\hline 12 & & 75.0 & 144 & 79.9 & 0.7220 & 9.60 & 4.940 & 65.7 \\
\hline 15 & & 86.0 & 148 & 82.4 & 0.8600 & 10.02 & 5.670 & 66.0 \\
\hline 8 & & 95.0 & 155 & 84.0 & 0.9550 & 10.02 & 6.070 & 63.9 \\
\hline 8 & & 106.0 & 159 & 82.4 & 1.0270 & 9.74 & 6.810 & 64.5 \\
\hline 11 & & 115.0 & 166 & 92.5 & 1.2130 & 10.51 & 6.970 & 60.5 \\
\hline 9 & & 125.0 & 169 & 92.6 & 1.2410 & 9.89 & 7.260 & 57.9 \\
\hline 8 & & 146.0 & 178 & 89.1 & 1.4460 & 9.92 & 8.870 & 60.8 \\
\hline 8 & & 165.0 & 180 & 92.0 & 1.6630 & 10.10 & 9.890 & 59.3 \\
\hline 7 & & 194.0 & 189 & 92.4 & 1.9880 & 10.28 & 11.820 & 61.0 \\
\hline 10 & & 227.0 & 201 & 89.9 & 2.1860 & 9.68 & 13.180 & 58.2 \\
\hline 8 & & 268.0 & 206 & 85.4 & 2.2300 & 8.36 & 14.150 & 53.0 \\
\hline
\end{tabular}

methods (see Hartley, '07) which is easily applicable to the entire carcasses of animals. The figures, given as percentages of fatty acid on the crude weight of the animal, represent therefore masked as well as anatomical fat.

From the table 57 based on body weight it appears that the proportion of fat tends to be greater in the heavier animals, and from the tables based on the data grouped according to sex, it appears that the females have a somewhat larger percentage of fat than do the males. 
TABLE 57

Giving the proportion of fat (fatty acids) with increasing age (body weight.) Based on table A, Boycott and Damant ('08 a)

\begin{tabular}{|c|c|c|c|c|c|}
\hline \multicolumn{2}{|c|}{ NUMBER AND SEX } & \multirow{2}{*}{$\begin{array}{l}\text { BODY WEIGHT } \\
\text { IN GMS. }\end{array}$} & \multicolumn{3}{|c|}{ PERCENTAGE OF FATTY ACIDS } \\
\hline M. & F. & & Max. & Min. & Average \\
\hline 15 & 10 & $20-49$ & 9.2 & 0.85 & 4.1 \\
\hline 8 & 7 & $50-99$ & 6.1 & 1.00 & 4.0 \\
\hline 19 & 25 & 100-149 & 16.1 & 0.80 & 6.1 \\
\hline 11 & 17 & 150-199 & 14.6 & 1.30 & 7.6 \\
\hline 7 & 2 & $200-247$ & 9.7 & 1.30 & 5.8 \\
\hline
\end{tabular}

Eighty-three rats arranged according to sex

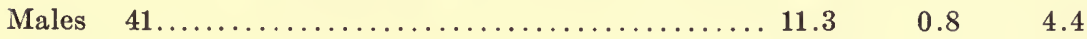

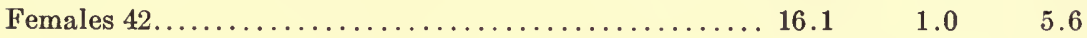

\section{GROWTH OF PARTS AND SYSTEMS: REFERENCES}

1. Larger divisions. Jackson and Lowrey, '12. 2. Systems. Donaldson, '11, '11 c, '12, '12 a. Donaldson and Hatai, '11, '11 a. Jackson and Lowrey, '12. 3. Teeth. Addison and Appleton, '15. MacGillavry, 1875. Meyerheim, 1898. 4. Blood and 5. Fat. Boycott and Damant, '08,'08 a. Chisolm,'11. Hartley, '07. 


\section{CHAPTER 7}

\section{GROWTH OF PARTS AND ORGANS IN RELATION TO BODY LENGTH AND IN RELATION TO AGE}

1. Introduction. 2. Methods of examination and graphs. 3. Body length on body weight. Body weight on body length. Tail length on body length. 4. Organs with an early rapid growth: Brain, spinal cord, eyeballs. 5. Organs with a nearly uniform growth: Heart, kidneys, liver, spleen, lungs, blood, alimentary tract, thyroid, hypophysis and suprarenals. 6. Organs with a rapid growth just preceding puberty. Ovaries, testes, thymus (on age). 7. Determinations of variation. 8. General tables. a) Tables, weight of entire body on age. Before birth; from birth on. b) Tables, increase in the length and weight of parts and organs on body length. 9. Table, weight of thymus on age. 10 . Table, weight of all viscera combined. 11. Tables, values for characters linked with age. 12. Formulas.

1. Introduction. The organs, the growth of which has been followed are tail (length), brain, spinal cord, eyeballs, heart, kidneys, liver, spleen, lungs (blood), alimentary tract, testes, ovaries, hypophysis, suprarenals, thyroid and thymus.

All the observations were made on stock Albinos from the colony at The Wistar Institute, except those for the total blood which are based on the records of Chisolm, ' 11 .

The mean values for the several organs were in each instance charted and with these as a guide a theoretical graph was found which could be expressed by a formula or a series of formulas. All the formulas were devised by Hatai.

To present the results in a convenient form the organs are grouped in the text according to the manner of their growth, each organ is accompanied by a chart showing the original data and the graph based on these data.

In each case reference is made to the formula or formulas on which the graph is based, but as a matter of convenience, the formulas utilized here for the graphs are grouped in the section entitled "Formulas" pp. 158-175. 
The charts serve to show the form of the graph of growth in each instance, but the precise weight values of the organs are to be read from the tables. For those who desire to find the weight of an organ in a rat of any body length or body weight a series of values-computed by the aid of the appropriate formulas-are given in tables 68-71 inclusive.

In making these tables the determinations for the corresponding body weights for each millimeter of length in each sex were first made by formulas (2a) and (2b) and the body weights so obtained were then used in computing the weights of the several organs.

In table 72 for the thymus however, it was found necessary to enter the weight values of the organ according to the age of the rat.

In table 73 the computed weight of the thymus on body weight is given on the assumption that the body weights are normal to age in conformity with the data in table 62 .

2. Methods of examination and graphs. Unless otherwise stated the following determinations were made on stock Albinos taken from the colony at The Wistar Institute. The animals were killed with chloroform twenty hours after the last feeding and were dissected according to a fixed procedure.

3. Body length on body weight. Technic: Immediately after killing the rat was laid on its back and gently extended-the tail being drawn out straight. With jointed calipers the distance from the tip of the nose to the tip of the tail was taken and its values in millimeters found by applying the points to a scale. Next the distance from the tip of the nose to the center of the anus was found and its value in millimeters determined in the same way. These measurements give first the total length, second, the body length and by the difference, the tail length.

Chart 6 gives the body length on the body weight. The data used are given in table 68 . The values were computed by formula (1). The graphs show that for a given body weight the male has the greater body length. Donaldson '09; Donaldson and Hatai ' 11 . 
Body weight on body length. The entire rat was next weighed to one-tenth of a gram. The weight thus obtained was not corrected for the contents of the alimentary canal-which according to Jackson and Lowrey ('12) amounts to about 5 per cent of the gross body weight. In gravid females a correction was made however by subtracting the weight of the uterus and fetuses from the observed value. The weight of the body on the body

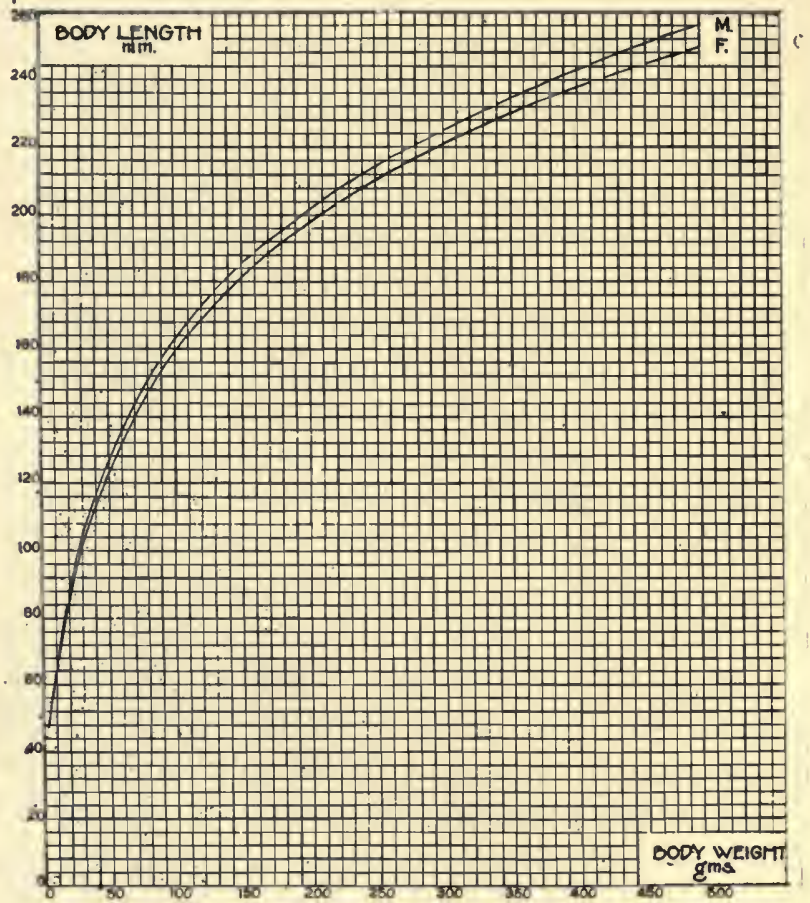

Chart 6 Giving for the males and females respectively the body length on the body weight. Formula (1), table 68 .

length is given in chart 7. The values for each millimeter of body length in each sex are given in table 68. The graphs were computed by formulas (2a) and (2b), and show that for a given body length the female has a greater body weight. Donaldson '09, Donaldson and Hatai, '11.

Tail length on body length. The method of obtaining the tail length has been given under body length. The values for 


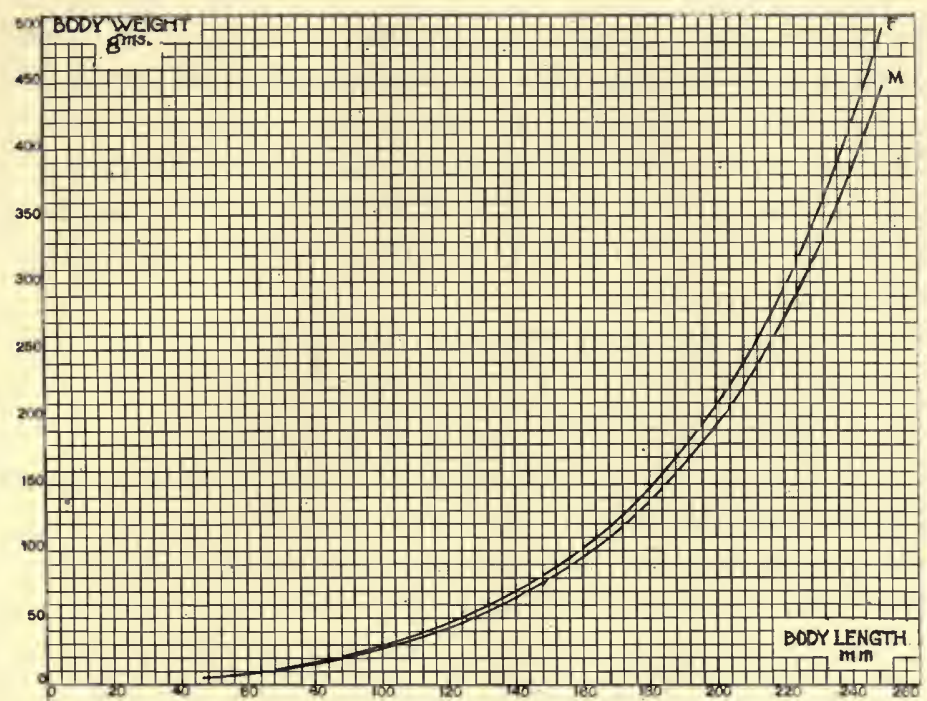

Chart 7 Giving for the males and females respectively the body weight on the body length. Formulas ( $2 \mathrm{a})$ and $(2 \mathrm{~b})$, table 68 .

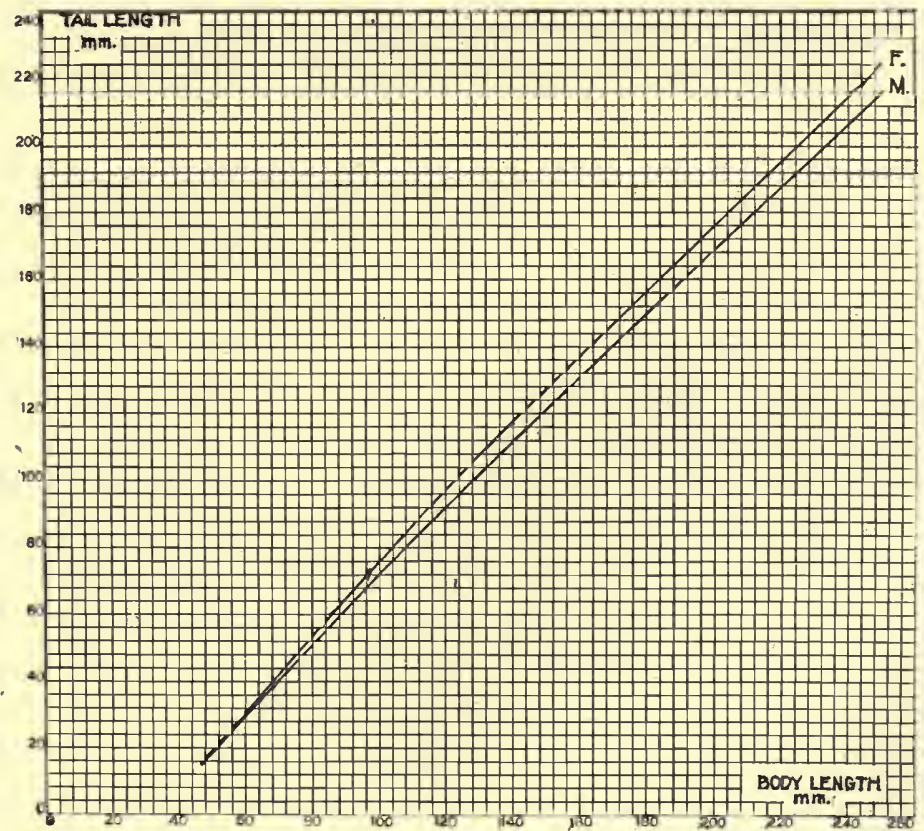

Chart 8 Giving the length of tail in millimeters on the body length, males, females. Formulas (4) and (5), table 68. 
the graphs in chart 8 and for the table 68 were determined by formulas 4 and 5 . The tail in the female is relatively longer than in the male. Hatai (MS '14).

4. Following the plan of grouping the organs according to the manner of their growth we shall first consider the weights of the brain, the spinal cord and both eyeballs. All of these organs have an early rapid growth.

Brain weight on body weight. Technic: The rat was first eviscerated - this leaves in the brain a minimal amount of blood. The bones of the skull were removed from above-the meninges being left intact. Care was taken to preserve the flocculi which lie in bony pockets. The brain was severed from the cord by a section at the level of the first cervical nerve-coinciding as a rule with the tip of the calamus as seen from the dorsal aspect. The brain was then raised from the floor of the cranium-the nerves being clipped close to the base. The hypophysis was not included. Care was taken to obtain the olfactory bulbs entire. Thus prepared the brain was dropped into a small glass stoppered weighing bottle in which it was weighed to the tenth of a milligram. In this instance, as in the case of all of the other organs, the dissection was made under a glass hood to protect the operator from all drafts which might dry the organ during its preparation. The values for the graph, males only, chart 9 and for table 68 were computed by formulas (6) and (7).

The graph for the male alone is given. As will be seen from table 68 , for the same body length the female has a slightly lighter brain and this difference increases to about 1.5 per cent when the female is of the same body weight.

Spinal cord weight on body weight. Spinal cord-Technic: Following the removal of the brain (vide ante) the spinal cord was exposed by removing the arches of the vertebrae from neck to sacrum. The filum terminale was found and the cord raisedso that the roots of the spinal nerves could be clipped close to the cord. The mass thus removed with meninges-was placed in a glass stoppered weighing bottle and weighed to the tenth of a milligram. The values for the graph, males only, in chart 9 and for table 68 were computed by formula (11). Donaldson ('08), ('09); Hatai, ('09a). 
For convenience the graph for the spinal cord is given on the same chart as that for the brain. The graph for the male only is entered. For the same body length as the male the spinal cord in the female is about 5 per cent heavier, and for the same body weight, about 2 per cent heavier. Donaldson ('08, '09); Hatai ('09a).

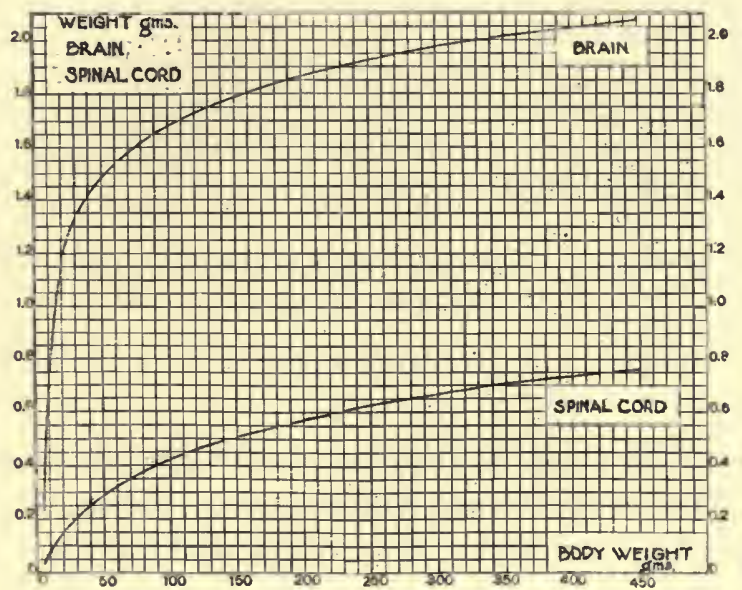

Chart 9 Giving the brain weight on the body weight. Males only. Formulas (6) and (7), table 68. Also spinal cord weight on the body weight. Males only. Formula (11), table 68 .

Weight of both eyeballs on body weight. Technic: Care being taken to remove the muscle attachments, both eyes were weighed in a closed weighing bottle. There is usually a close similarity in the weight of the right and left eyeballs. The graph is based on rats studied by Jackson ('13). His results have been corroborated by studies on the stock Albinos from the colony of the Wistar Institute, Hatai ('13). The values for the graph in chart 10 and those given in table 68 are based on formula (13). The graph for the male only is entered, but the values for the female are like those for the male of the same body weight. Under unfavorable nutritional conditions the weight of the eyeballs follows the age rather than the body weight. Hatai (MS '14). 


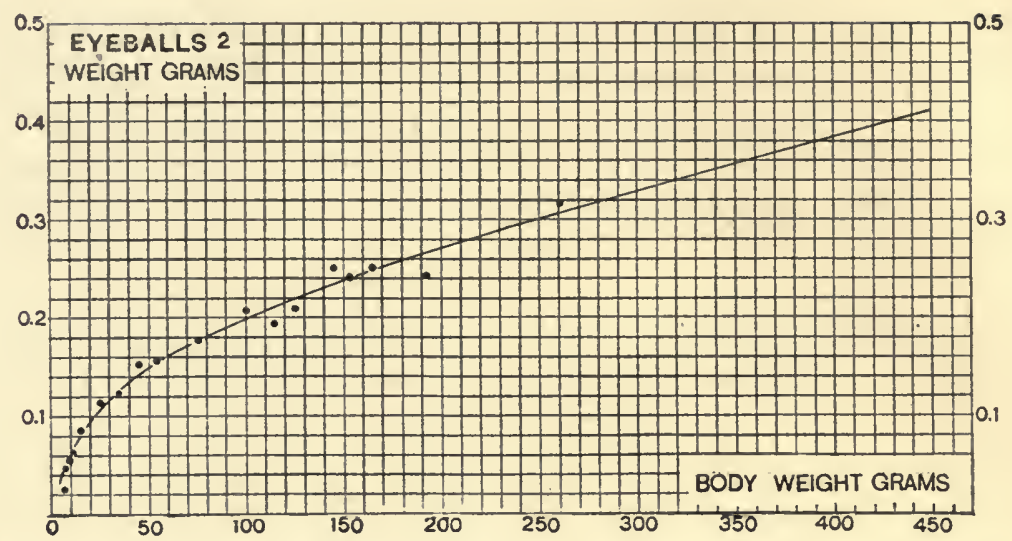

E" Chart 10 Showing the weight of eyeballs of the male albino rat according to body weight. The observed weights are represented by 149 male rats (Jackson). Table 68, formula (13).

- Observed weight. —Calculated weight.

5. Organs with a nearly uniform growth after the first very early phase of rapid growth-heart, kidneys, liver, spleen, lungs (blood), alimentary tract, hypophysis, suprarenals and thyroid.

In case of all of the organs to be described the preparation was carried on beneath a glass hood to prevent drying. The organ was weighed in a small glass stoppered bottle and the weight was taken to a tenth of a milligram.

The weight of the heart on body weight. Technic: The heart was removed after cutting all its vessels close to their proximal ends. It was then opened by longitudinal slits through its walls and the clots removed from the cavities thus exposed.

The graph given in chart 11 and the values in table 69 have been determined by formula (14).

The weight of the heart is closely correlated with that of the body and no difference according to sex has been noted. Hatai ('13); Jackson ('13).

Weight of both kidneys on body weight. Technic: All vessels were cut close to the hilum and any superficial fat removed.

The graph given in chart 12 and the values in table 69 were determined by formula (15) . 


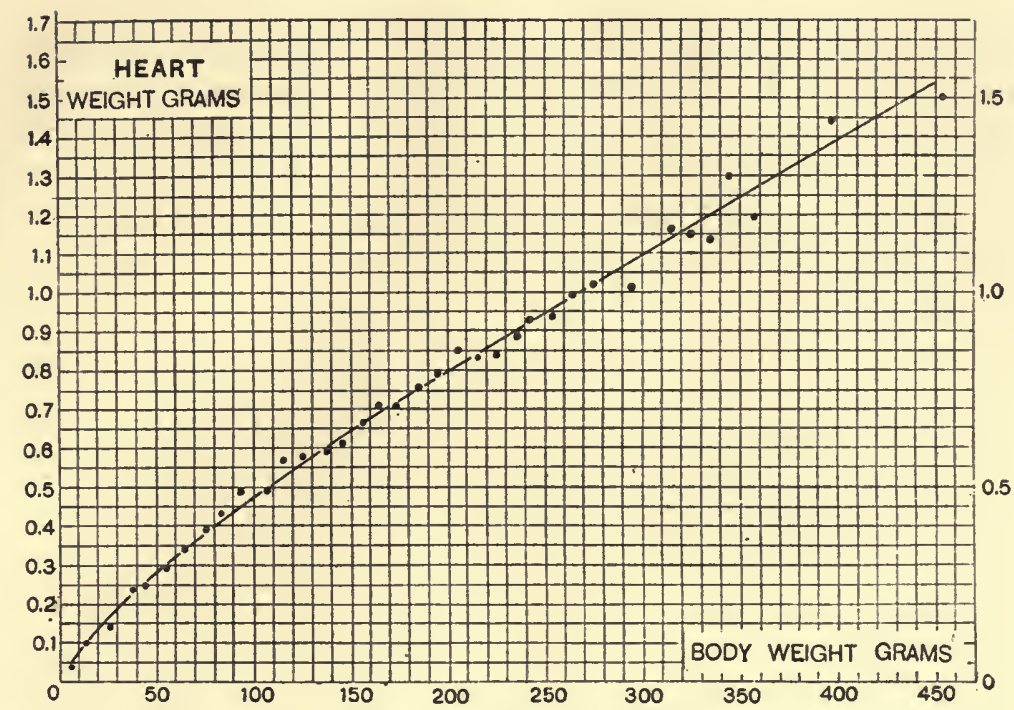

Chart 11 Showing the heart weight of the male albino rat according to body weight. The observed weights are represented by 134 male rats. Table 69 , formula (14).

- Observed weight. Calculated weight.

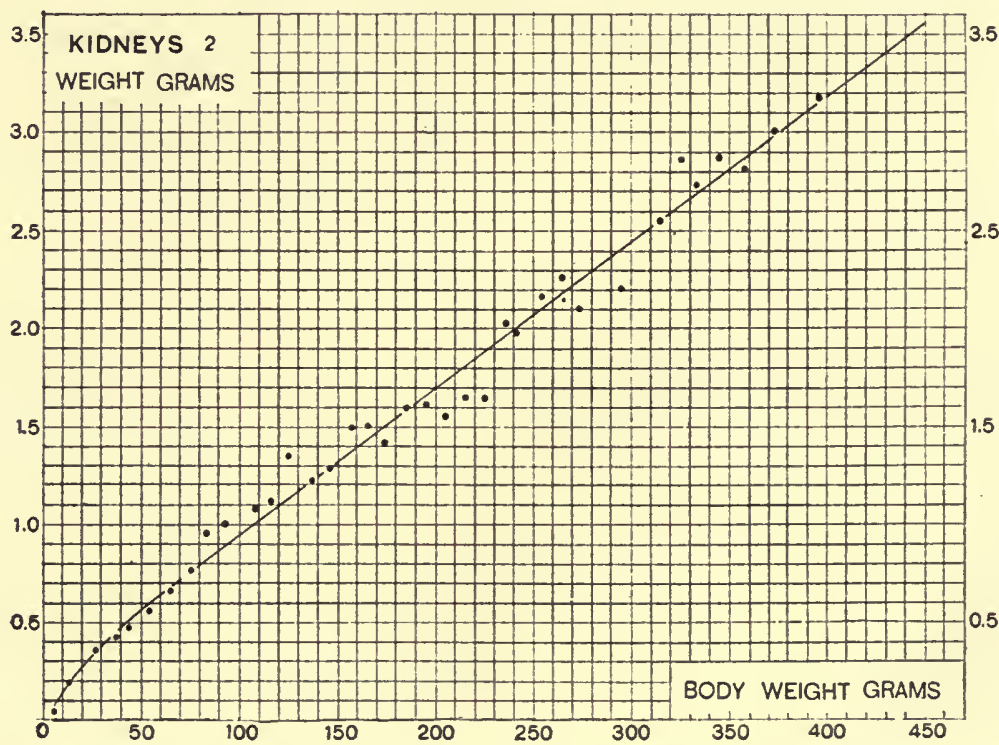

Chart 12 Showing the weight of kidneys of the male albino rat according to body weight. The observed weights are represented by 136 male rats. Table 69 , formula (15).

- Observed weight. —Calculated weight. 
No sex difference was observed but the graph represents the determinations for the male only. Hatai ('13); Jackson ('13).

Weight of the liver on the body weight. Technic: The vessels were cut close to their entrance into the liver and the blood in the larger vessels gently pressed out. The graph given in chart 13 and the values in table 69 were determined by formula (16).

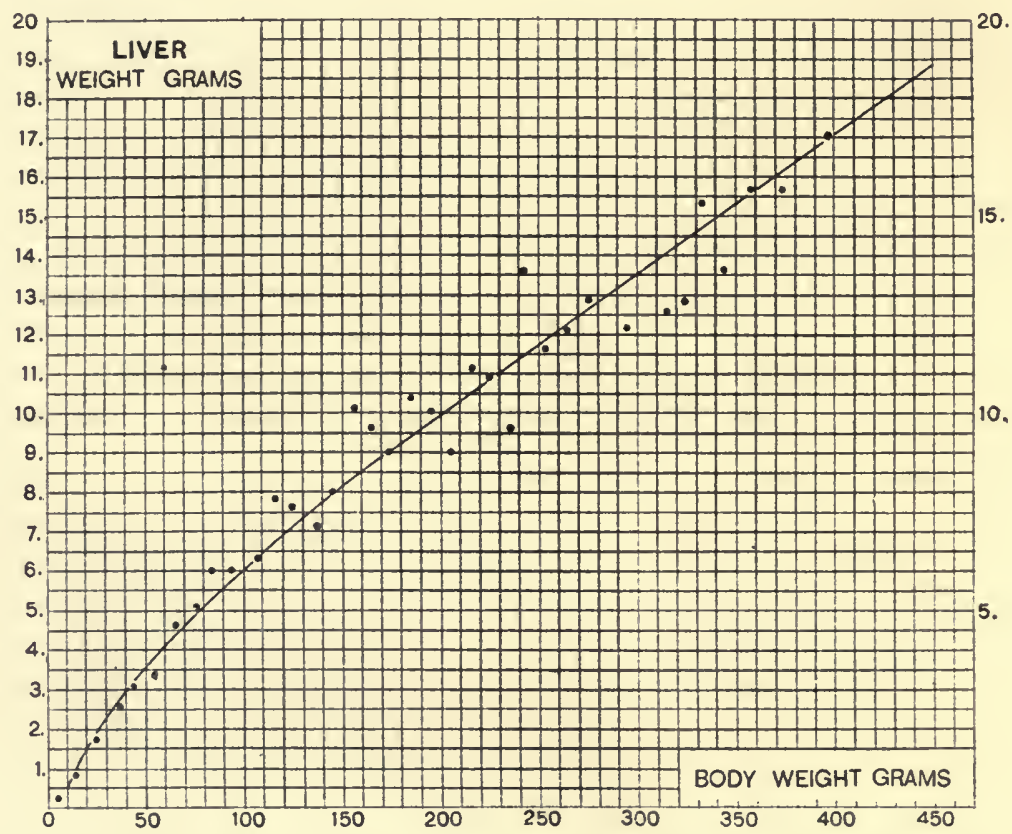

Chart 13 Showing the weight of liver of the male albino rat according to body weight. The observed weights are represented by 136 male rats. Table 69 , formula (16).

- Observed weight. —Calculated weight.

No sex difference in the weight of the liver has been notedbut the graph is given for the males only. Considerable variability is to be expected in the weight of an organ with such complex functions as those of the liver and this appears. A heavy liver usually accompanies a heavy spleen (Hatai). Hatai ('13); Jackson ('13). 
The weight of the spleen on the body weight. Technic: The vessels were cut close to the hilum. The determination of the weight of the spleen is complicated by the occurrence of "enlarged spleens" - so called. These differ from the normal by being often several times the normal weight, darker in color, soft to the touch and showing on the surface dark or grayish patches. Spleens with these characters plainly marked were not used. The graph in chart 14 and the values in table 69 were determined

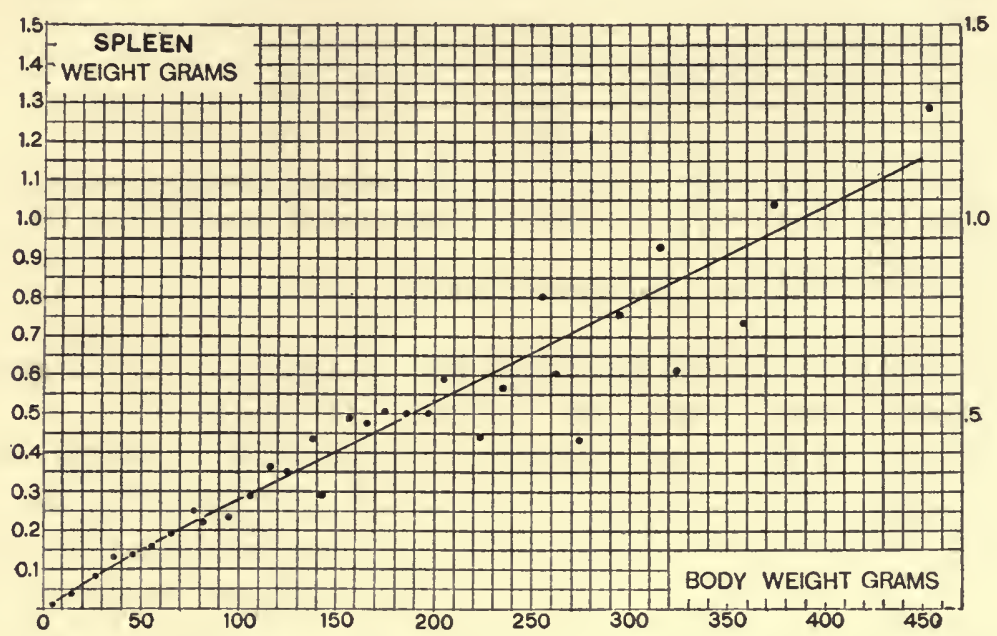

Chart 14 Showing the weight of spleen of the male albino rat according to body weight. The observed weights are represented by 87 male rats. Table 69 , formula (17).

- Observed weight. Calculated weight.

by formula (17). No sex difference was observed but the graph is based on male records only. Hatai ('13); Jackson ('13).

The weight of both lungs on the body weight. Technic: The lungs are severed from the trachea and the portion of the esophagus usually taken out with them is removed. After the first three months of life the lungs of the rat are often infected. Such infected lungs may be highly altered-but are always abnormally heavy. The endeavor has been made to exclude infected lungs from the series-but doubtless some have been used. The graph in chart 15 and the values in table 70 were determined by 


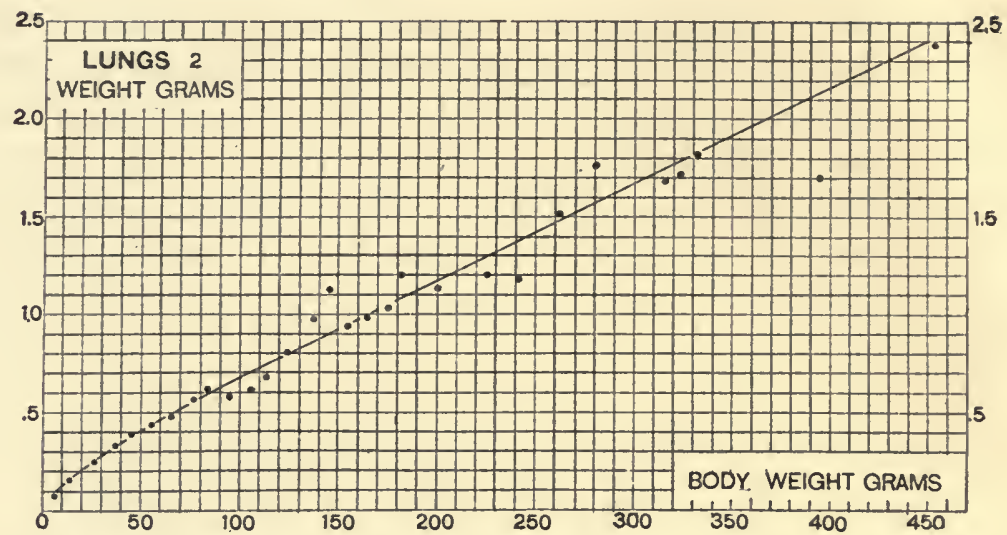

Chart 15 Showing the weight of lungs of the male albino rat according to body weight. The observed weights are represented by 90 male rats. Table 70 , formula (18).

- Observed weight. Calculated weight.

formula (18). No sex difference has been noted but the graph is based on male data alone. Hatai ('13); Jackson ('13).

Weight of the total blood on body weight. Technic: The observations on this relation were made by Chisolm '11 on Albinos and pied rats. His methods are given in the paper cited above (pp. 207-208) and depend on determinations of the oxygen capacity. Chisolm's formulas have been revised by Hatai (MS '14). The graph in chart 16 and the values in table 70 have

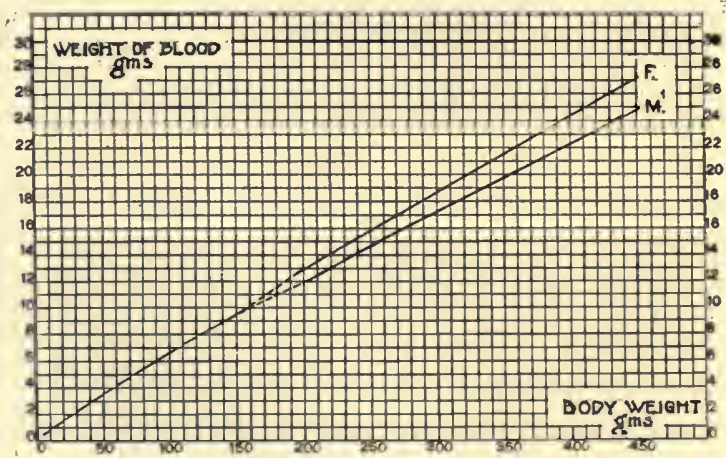

Chart 16 Giving weight of total blood on body weight. Males, females. Formulas (20), (20a), and (20 b), table 70 . 
been determined by formulas (20), (20 a), and (20 b). The data are for both sexes combined. Chisolm ('13); Jolly and Stini ('05).

The weight of the alimentary tract on body weight. Technic: The digestive tube from the level of the diaphragm to the anus was removed in its entirety - the pancreas, mesentery and small masses of fat being left adherent. The stomach and the large intestine were cut open and the contents removed while gentle

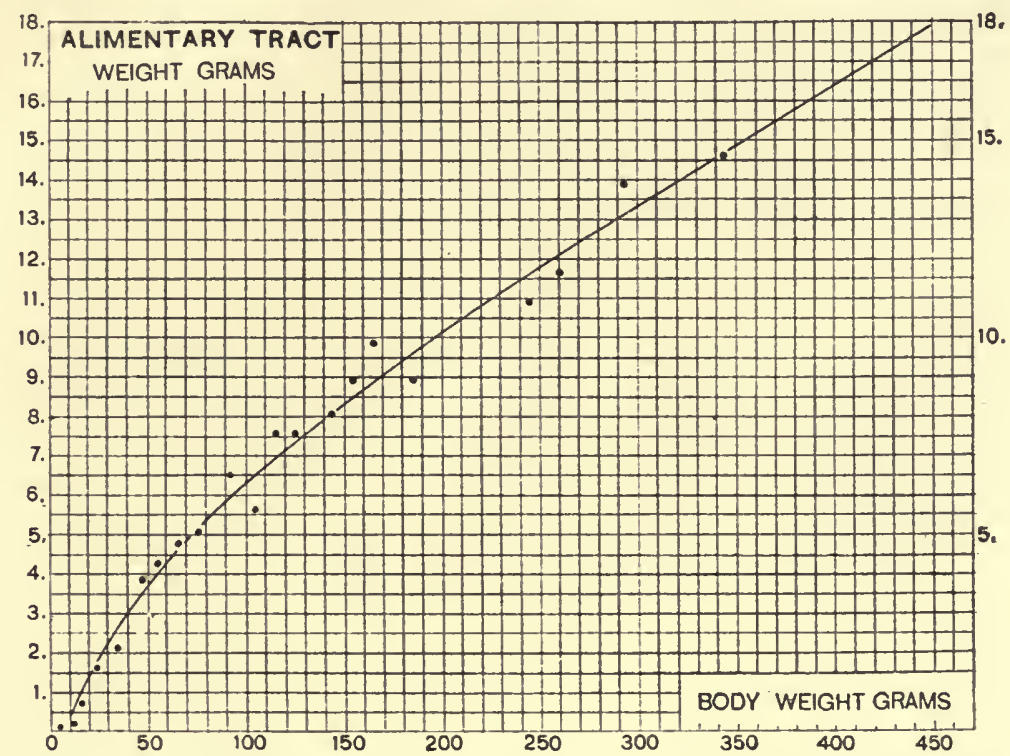

Chart 17 Showing the weight of alimentary tract of the male albino rat according to body weight. The observed weights are represented by 112 (Jackson) rats below 50 grams in body weight, and 82 (Wistar) rats above 50 grams in body weight. Table 70, formula (21).

- Observed weight. Calculated weight.

pressure on the small intestine-exerted from above downwards-served to expel what it contained. The records are based on one series examined by Jackson ('13) and another series from The Wistar Institute colony. All are males. The graph in chart 17 and the values in table 70 were determined by formula (21). Hatai ('13); and Jackson ('13).

Weight of the thyroid gland on body weight. Technic: Several minute muscles nearly the color of the gland must be re- 
moved before weighing. The data are from observations by Jackson ('13), as well as from those made at The Wistar Institute. A study of the data has not revealed any difference according to sex and the graph therefore is for both sexes combined. The graph in chart 18 and the values in table 71 have been determined by formula (32). Hatai ('13); Jackson ('13).

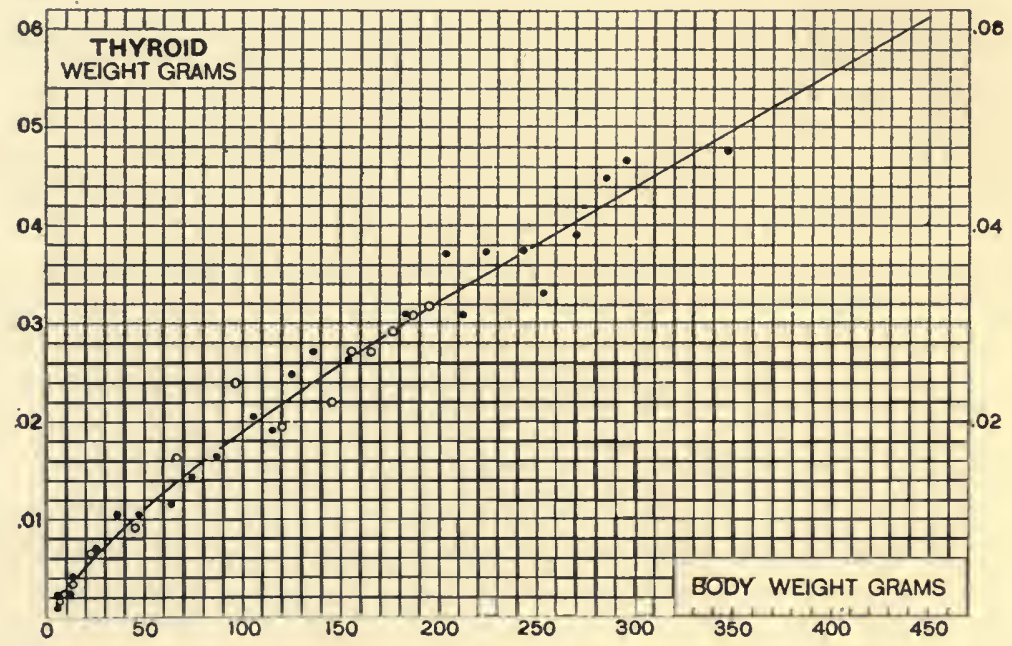

Chart 18 Showing the weight of thyroid gland of the albino rat according to body weight. The observed weights are represented by 42 (Jackson) female rats below 50 grams in body weight, and 49 (Wistar) male rats above 50 grams in body weight; and 36 (Jackson) female rats below 50 grams in body weight, and 27 (Wistar) female rats above 50 grams in body weight. Table 71, formula (32).

- Observed weight male. —Calculated weight for both sexes. o Observed weight, female:

The weight of the hypophysis on body weight. Technic: After the removal of the brain, the hypophysis is readily picked up from the floor of the skull with a small forceps. It is weighed as removed.

At about $40-50$ days of age there appears a difference in the weight of the hypophysis according to sex and with advancing age this difference tends to increase. The female has the heavier hypophysis. The graph for the male in chart 19 and the values for the male in table 71 have been determined by formula (28). 
The graph for the female and the corresponding tabular values

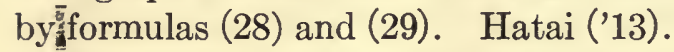

The weight of the suprarenals on body weight. Technic: The suprarenals are usually imbedded within some fat tissue-but with a little practice they may be dissected out cleanly. At about $40-50$ days of age there appears a difference in the weight

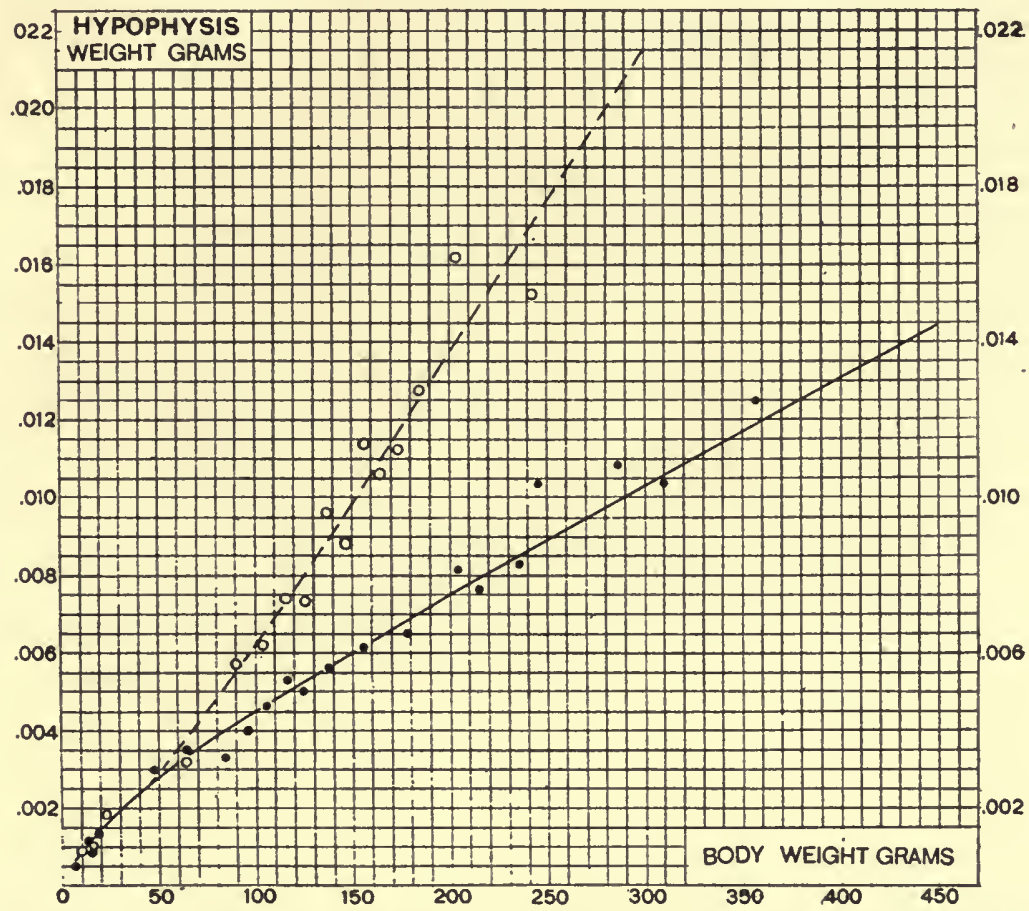

Chart 19 Showing the weight of hypophysis of the albino rat according to body weight. The observed weights are represented by 78 male and 80 female rats. Table 71, formulas (28) and (29).

- Observed weight, male.

Calculated weight, male. o Observed weight, female.

- - - Calculated weight, female.

of the suprarenals according to sex and with advancing age this difference tends to increase. The female has the heavier suprarenals. The graph for the male in chart 20 and the values for the male in table 71 have been determined by formula (30). The graph for the female and the corresponding tabular values, by formula (31). Hatai ('13); Jackson ('13). 
6. The third group of the organs here considered is formed by those the growth of which is represented by a sinuous graph in which the most marked rise appears shortly before puberty. These organs, so far as examined, are the ovaries, the testes and the thymus.

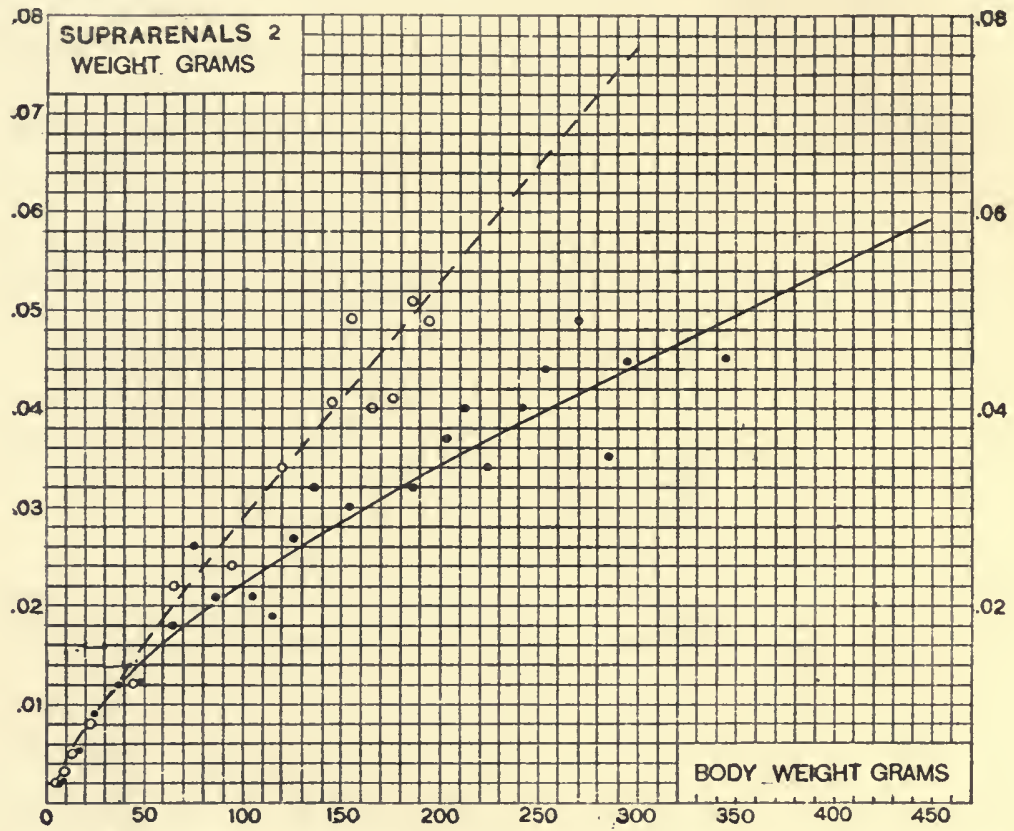

Chart 20 Showing the weight of suprarenals of the albino rat according to body weight. The observed weights are represented by 92 (Jackson) male rats below 50 grams in body weight, and 53 (Wistar) male rats above 50 grams in body weight; and 84 (Jackson) female rats below 50 grams in body weight, and 29 (Wistar) female rats above 50 grams in body weight. Table 71, formulas (30) and (31).

- Observed weight, male.

_C Calculated weight, male. o Observed weight, female.

- - - Calculated weight, female.

The weight of both ovaries on the body weight. Technic: The ovaries must be carefully dissected from their capsules and from the end of the fallopian tube. When the animal is small it is sometimes necessary to do this under a dissecting microscope. The data collected by Jackson ('13) are those used. The graph in chart 21 and the values in table 70 have been determined by formulas (25), (26), and (27). Hatai ('13, '14a); Jackson ('13). 


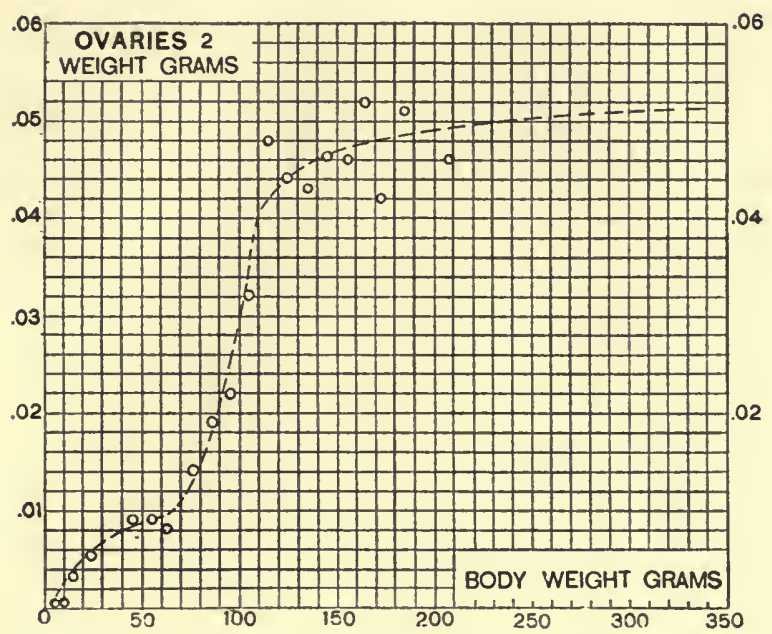

Chart 21 Showing the weight of ovaries of the female albino rat according to body weight. The observed weights are represented by 136 (Jackson) rats. Table 70, formulas (25), (26) and (27). $\circ$ Observed weight. -. - Calculated weight.

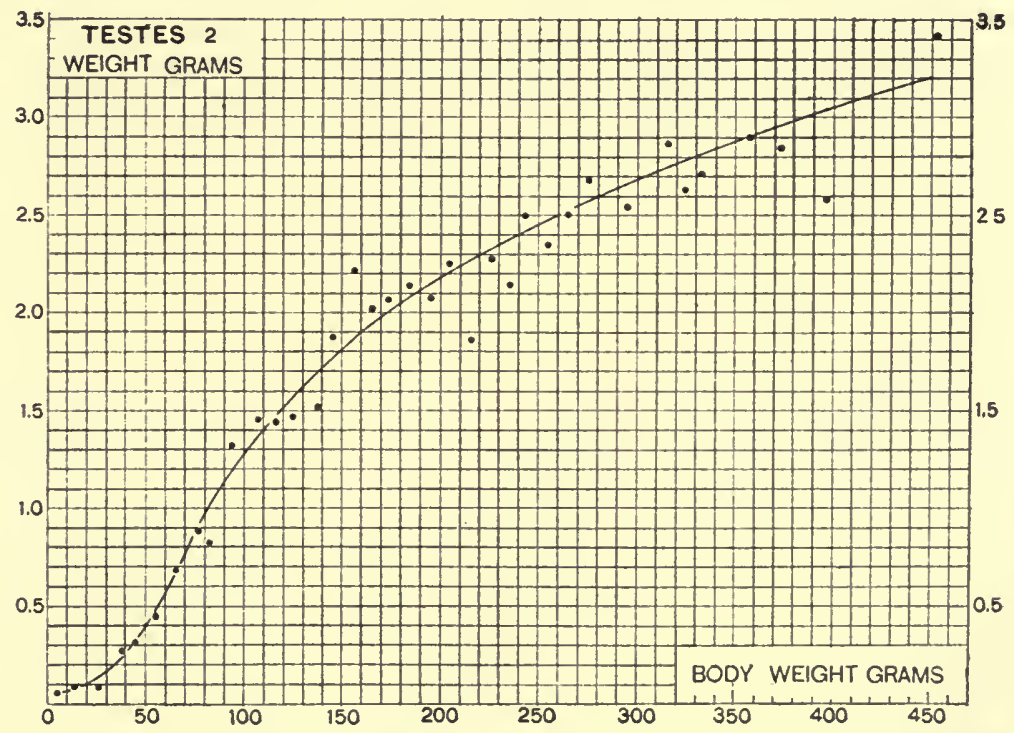

Chart 22 Showing the weight of testes of the male albino rat according to body weight. The observed weights are represented by 121 male rats. Table 70 , formulas (22), (23) and (24).

- Observed weight.

Calculated weight. 
The weight of both testes on body weight. Technic: The epididymis was removed before the testes were weighed. The graph in chart 22 and the values in table 70 were determined by formulas (22), (23) and (24). Hatai ('13); Jackson ('13).

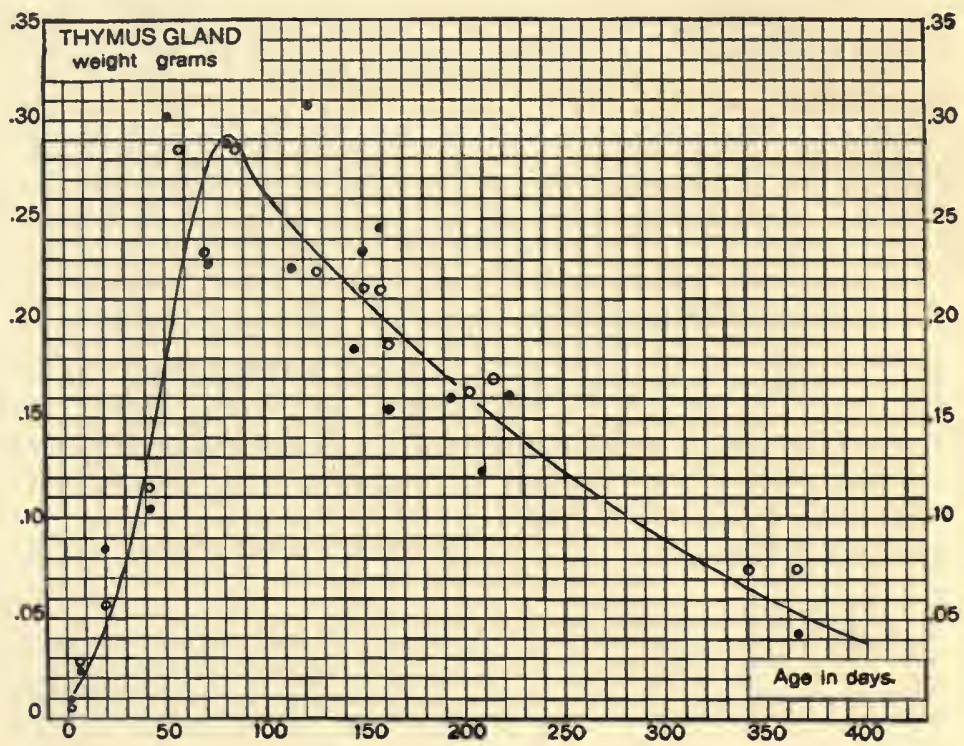

Chart 23. Showing the weight of the thymus of the albino rat according to age. The observed weights are represented by 229 males (164 Jackson and 64 Wistar) and 207 females (179 Jackson and 28 Wistar). Table 72, formulas (38) and (39).

Observed weight male, ofemale, computed weight.

Weight of thymus on age. In the case of the thymus the data are more useful when presented according to age than when presented according to body weight.

Technic: In preparing the thymus care must be taken to dissect away the large lymph glands as well as the fat lying about it. The records by Jackson ('13) have been combined with those from The Wistar Institute. The graph in chart 23 and the values in table 72 have been determined by the formulas (38) and (39). No weight difference according to sex has been noted. Hatai ('14); Jackson ('13). 
7. Determinations of variation. Variation in body weight and organ weight. In table 58 Jackson ('13) gives a series of determinations of the coefficient of variation for body weight on a litter basis and in age groups. The animals were selected by the method of 'random sampling.' These values are to be compared with those determined by King (MS '15). In King's series the. same groups of rats were examined at different ages (table 67).

For the same animals as were used in table 58 Jackson ('13) also gives for the several organs the coefficient of variation (table 59) and the coefficients of correlation with the body weight (table 60). The coefficients of variation for body weight on age are given by King (MS '15) in her growth series (table 67).

TABLE 58.

Coefficient of variation in body weight for total population by ordinary method, and on litter basis (fraternal variation) estimated by various methods (Jackson, '13).

\begin{tabular}{|c|c|c|c|c|c|c|c|}
\hline & 莮 & 焉 & $\stackrel{n}{i}$ & 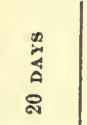 & 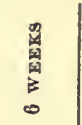 & 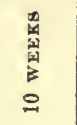 & 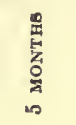 \\
\hline Total population. & Male & $13.6^{1}$ & $16.9^{1}$ & $24.4^{2}$ & $20.8^{2}$ & $18.8^{1}$ & $18.5^{3}$ \\
\hline (ordinary method) & Female & $9.9^{1}$ & $13.7^{1}$ & $29.4^{2}$ & $24.2^{2}$ & $16.8^{1}$ & $15.3^{1}$ \\
\hline Litter basis.. & Male & 7.0 & 6.1 & 5.7 & 6.6 & 5.8 & 7.4 \\
\hline $\begin{array}{l}\text { (average of litters calcu- } \\
\text { lated by ordinary me- } \\
\text { thod) }\end{array}$ & Female & 4.4 & 5.4 & 4.0 & 5.9 & 12.0 & 10.4 \\
\hline Litter basis.............. & Male & 6.8 & 7.6 & 6.8 & 7.1 & 6.1 & 8.1 \\
\hline $\begin{array}{l}\text { (calculated from Yule's } \\
\text { formula) }\end{array}$ & Female & 5.2 & 4.4 & 4.5 & 7.9 & 12.2 & 9.3 \\
\hline Litter basis... & Male & 7.3 & 8.4 & 6.0 & 7.2 & 6.7 & 8.5 \\
\hline $\begin{array}{l}\text { (from Kellogg's for- } \\
\text { mula) }\end{array}$ & Female & 5.2 & 4.5 & 4.1 & 8.5 & 12.0 & 9.0 \\
\hline
\end{tabular}

1 For net body weight.

${ }^{2}$ For gross body weight, larger series. 
TABLE 59

Coefficients of variation in organ weights, albino rat at different ages. Arranged according to mean values in the last column (Jackson, '12).

\begin{tabular}{|c|c|c|c|c|c|c|c|}
\hline & 0 DAYS & 7 DAYS & 21 DAYS & 42 DAYS & $70 \mathrm{DAYS}$ & $150 \mathrm{DAYS}$ & AVERAGE \\
\hline Brain........... & 12 & & 7 & 12 & & & 10 \\
\hline Eyeballs.......... & 16 & 15 & 13 & 8 & 11 & 9 & 12 \\
\hline Head..... & 10 & 11 & 15 & 10 & 14 & 13 & 12 \\
\hline Total body.... & 12 & 16 & 28 & 21 & 20 & 19 & 19 \\
\hline Lungs.............. & 23 & 17 & 24 & 19 & 21 & & 21 \\
\hline Kidneys........... & 24 & 22 & 34 & 15 & 17 & 19 & 22 \\
\hline Heart............. & 18 & 20 & 34 & 30 & 18 & 21 & 24 \\
\hline Liver............. & 22 & 19 & 41 & 19 & 33 & 25 & 26 \\
\hline Suprarenals....... & 24 & 20 & 33 & 22 & 21 & 39 & 26 \\
\hline Testes............. & 25 & 18 & 30 & 27 & 35 & 41 & 29 \\
\hline Thymus........... & 31 & 32 & 43 & 50 & 25 & 22 & 34 \\
\hline Spleen........... & 39 & 34 & 51 & 26 & 38 & 19 & 34 \\
\hline Intestinal canal & & & & & & & \\
\hline (plus contents) & 38 & 29 & 42 & 30 & & & 35 \\
\hline Ovaries............ & & & 42 & 47 & 51 & 33 & 43 \\
\hline Average of viscera & 23 & 22 & 31 & 24 & 26 & 24 & 25 \\
\hline
\end{tabular}

TABLE 60

Coefficients of correlation of organ weights with the body weight: albino rat at different ages. Arranged according to mean values in the lastcolumn (Jackson, '13).

\begin{tabular}{|c|c|c|c|c|c|c|c|}
\hline & ODAYS & 7 DAYS & 21 DAYS & 42 DAYS & 70 DAYS & 150 DAYs & AVERAG B \\
\hline Head.. & 0.76 & 0.89 & 0.93 & 0.95 & 0.75 & 0.85 & 0.86 \\
\hline Kidneys... & 0.70 & 0.79 & 0.96 & 0.92 & 0.90 & 0.91 & 0.86 \\
\hline Liver....... & 0.76 & 0.76 & 0.97 & 0.84 & 0.74 & 0.87 & 0.83 \\
\hline Lungs. .... . . & 0.74 & 0.80 & 0.87 & 0.94 & 0.62 & & 0.80 \\
\hline Brain..... & 0.69 & & 0.78 & 0.88 & & & 0.78 \\
\hline Heart.... & 0.58 & 0.50 & 0.91 & 0.97 & 0.86 & 0.84 & 0.78 \\
\hline Testes... & 0.67 & 0.75 & 0.95 & 0.75 & 0.48 & 0.88 & 0.75 \\
\hline Ovaries.............. & & & 0.73 & 0.64 & 0.82 & 0.81 & 0.75 \\
\hline $\begin{array}{l}\text { Intestinal canal } \\
\text { (plus contents).. }\end{array}$ & 0.29 & 0.59 & 0.84 & 0.76 & & & 0.62 \\
\hline Thymus........... & 0.67 & 0.74 & 0.89 & 0.90 & 0.51 & -0.09 & 0.60 \\
\hline Spleen....... & 0.54 & 0.44 & 0.97 & 0.50 & 0.41 & 0.46 & 0.55 \\
\hline Eyeballs.. & 0.67 & 0.52 & 0.67 & 0.31 & 0.22 & 0.32 & 0.45 \\
\hline Suprarcnals... & 0.51 & 0.13 & 0.58 & 0.41 & 0.41 & 0.35 & 0.40 \\
\hline Averag & 0.63 & 0.63 & 0.85 & 0.75 & 0.62 & 0.70 & 0.70 \\
\hline
\end{tabular}


8. General Tables. The tables which are not represented by charts in the text are usually short and have been introduced where they are mentioned, but as a matter of convenience all of those which are so represented are here grouped together as general tables under the following heads:

a). Tables for the increase in the weight of the entire body on age. Tables 61-67.

b). Tables for the increase in the length of the tail, in the weight of the entire body, and in the weight of several of the viscera according to body length. Tables 68-71 (72).

9. Table 72 for the weight of the thymus-based not on body length but on age.

10. Weight of all the viscera combined. Table 73.

11. Tables giving the values for characters other than body weight, linked with age. Table 74.

For the most part the tables are preceded by a slight descriptive heading only. Reference is made to the corresponding charts in connection with which all the details concerning them have been noted.

Tables showing the increase in the weight of the entire body with age.

Growth before birth, Stotsenburg (MS '15) (p. 64), table 61 . This table duplicates table 46 , but gives one additional entry.

TABLE 61

Showing the mean weights of the fetuses at ten ages during gestation and at birth. Stotsenburg (MS'15). Chart 1

\begin{tabular}{|c|c|c|c|}
\hline AGE IN DAYS & NUMBER OF FETUSES & $\begin{array}{c}\text { AVERAGE WEIGHT OF } \\
\text { FETUS }\end{array}$ & $\begin{array}{c}\text { RATE OF INCREASE IN } \\
\text { WEIGET }\end{array}$ \\
\hline & & grams & per cent \\
\hline $13 \ldots \ldots \ldots \ldots \ldots \ldots \ldots$ & 34 & 0.040 & \\
\hline $14 \ldots \ldots \ldots \ldots \ldots \ldots \ldots$ & 44 & 0.112 & 179 \\
\hline $15 \ldots \ldots \ldots \ldots \ldots \ldots \ldots$ & 37 & 0.168 & 50 \\
\hline $16 \ldots \ldots \ldots \ldots \ldots \ldots \ldots$ & 44 & 0.310 & 83 \\
\hline $17 \ldots \ldots \ldots \ldots \ldots \ldots \ldots$ & 21 & 0.548 & 77 \\
\hline $18 \ldots \ldots \ldots$ & 43 & 1.000 & 83 \\
\hline $19 \ldots \ldots \ldots \ldots \ldots \ldots \ldots$ & 30 & 1.580 & 58 \\
\hline $20 \ldots \ldots \ldots \ldots \ldots \ldots \ldots$ & 25 & 2.630 & 65 \\
\hline $21 \ldots \ldots \ldots \ldots \ldots \ldots \ldots$ & 42 & 3.980 & 51 \\
\hline $22 \ldots \ldots \ldots \ldots \ldots \ldots \ldots$ & 10 & 4.630 & 16 \\
\hline Strictly new born...... & 37 & 4.680 & \\
\hline
\end{tabular}


Growth after birth, tables 62-67.

\section{TABLE 62}

Body weight on age-both sexes. Based on records by Donaldson, Dunn and Watson ('06) and computed from 10-365 days, by formulas (34), (35) males; (36), (37) females. The values for the first ten days are from direct observation, Donaldson (MS'15). Not charted

\begin{tabular}{|c|c|c|c|c|c|c|c|c|c|c|c|}
\hline \multirow{2}{*}{$\begin{array}{l}\text { AGE } \\
\text { DAYS }\end{array}$} & \multicolumn{2}{|c|}{ BODY WEIGHT } & \multirow{2}{*}{$\begin{array}{l}\text { AGE } \\
\text { DAYY }\end{array}$} & \multicolumn{2}{|c|}{ BODY WEIGHT } & \multirow{2}{*}{$\begin{array}{l}\text { AGE } \\
\text { DAYS }\end{array}$} & \multicolumn{2}{|c|}{ BODY WEIGHT } & \multirow{2}{*}{$\begin{array}{l}\text { AGE } \\
\text { DAYYS }\end{array}$} & \multicolumn{2}{|c|}{ BODY WEIGHT } \\
\hline & Male & Female & & Male & Female & & Male & Female & & Male & Female \\
\hline B. & 4.8 & 4.7 & 33 & 32.8 & 34.4 & 66 & 94.5 & 89.4 & 99 & 164.3 & 145.1 \\
\hline 1 & 5.5 & 5.4 & 34 & 34.1 & 35.7 & 67 & 97.0 & 91.5 & 100 & 165.8 & 146.2 \\
\hline 2 & 5.9 & 5.8 & 35 & 35.4 & 37.0 & 68 & 99.5 & 93.6 & & & \\
\hline 3 & 6.4 & 6.3 & 36 & 36.8 & 38.3 & 69 & 102.1 & 95.8 & 105 & 172.7 & 151.4 \\
\hline 4 & 6.9 & 6.8 & 37 & 38.1 & 39.6 & 70 & 104.7 & 98.0 & 110 & 179.1 & 156.3 \\
\hline 5 & 7.6 & 7.5 & 38 & 39.6 & 40.9 & & & & 115 & 185.2 & 160.9 \\
\hline 6 & 8.5 & 8.4 & 39 & 41.0 & 42.3 & 71 & 107.3 & 100.2 & 120 & 190.9 & 165.2 \\
\hline 7 & 9.5 & 9.4 & 40 & 42.5 & 43.7 & 72 & 110.0 & 102.4 & 125 & 196.2 & 169.2 \\
\hline 8 & 10.5 & 10.4 & & & & 73 & 112.7 & 104.7 & 130 & 201.2 & 173.0 \\
\hline 9 & 11.8 & 11.6 & 41 & 44.1 & 45.1 & 74 & 115.5 & 107.0 & 135 & 206.0 & 176.5 \\
\hline \multirow[t]{2}{*}{10} & 13.5 & 13.0 & 42 & 45.7 & 46.6 & 75 & 118.3 & 109.3 & 140 & 210.5 & 179.9 \\
\hline & & & 43 & 47.3 & 48.1 & 76 & 121.1 & 111.6 & 145 & 214.7 & 183.1 \\
\hline 11 & 13.9 & 13.7 & 44 & 48.9 & 49.6 & 77 & 124.0 & 114.0 & 150 & 218.7 & 186.1 \\
\hline 12 & .14 .4 & 14.4 & 45 & 50.6 & 51.1 & 78 & 126.8 & 116.4 & & & \\
\hline 13 & 14.9 & 15.1 & 46 & 52.3 & 52.7 & 79 & 129.8 & 118.8 & 155 & 222.5 & 188.9 \\
\hline 14 & 15.5 & 15.8 & 47 & 54.1 & 54.3 & 80 & 132.8 & 121.3 & 160 & 226.0 & 191.6 \\
\hline 15 & 16.1 & 16.5 & 48 & 55.9 & 55.9 & & & & 165 & 229.4 & 194.2 \\
\hline 16 & 16.7 & 17.3 & 49 & 57.7 & 57.5 & 81 & 134.7 & 122.6 & 170 & 232.6 & 196.5 \\
\hline 17 & 17.3 & 18.1 & 50 & 59.6 & 59.2 & 82 & 136.5 & 124.0 & 175 & 235.7 & 198.8 \\
\hline 18 & 18.0 & 18.9 & & & & 83 & 138.4 & 125.4 & 180 & 238.6 & 201.0 \\
\hline 19 & 18.7 & 19.8 & 51 & 61.5 & 60.9 & 84 & 140.2 & 126.8 & .185 & 241.3 & 203.0 \\
\hline \multirow[t]{2}{*}{20} & 19.5 & 20.7 & 52 & 63.4 & 62.6 & 85 & 142.0 & 128.1 & 190 & 243.9 & 204.9 \\
\hline & & & 53 & 65.4 & 64.3 & 86 & 143.7 & 129.5 & 195 & 246.3 & 206.7 \\
\hline 21 & 20.3 & 21.6 & 54 & 67.4 & 66.1 & 87 & 145.5 & 130.8 & 200 & 248.6 & 208.4 \\
\hline 22 & 21.1 & 22.5 & 55 & 69.5 & 67.9 & 88 & 147.2 & 132.1 & & & \\
\hline 23 & 22.0 & 23.4 & 56 & 71.6 & 69.7 & 89 & 148.9 & 133.4 & 205 & 250.9 & 210.1 \\
\hline 24 & 22.9 & 24.4 & 57 & 73.7 & 71.6 & 90 & 150.5 & 134.6 & 210 & 253.1 & 211.6 \\
\hline 25 & 23.9 & 25.4 & 58 & 75.9 & 73.4 & & & & 215 & 254.9 & 213.1 \\
\hline 26 & 24.9 & 26.5 & 59 & 78.1 & 75.3 & 91 & 152.1 & 135.8 & 220 & 256.8 & 214.4 \\
\hline 27 & 25.9 & 27.5 & 60 & 80.3 & 77.3 & 92 & 153.7 & 137.1 & 225 & 258.6 & 216.8 \\
\hline 28 & 27.0 & 28.6 & & & & 93 & 155.3 & 138.3 & 230 & 260.2 & 217.0 \\
\hline 29 & 28.1 & 29.7 & 61 & 82.5 & 79.2 & 94. & 156.9 & 139.4 & 235 & 261.9 & 218.1 \\
\hline \multirow[t]{2}{*}{30} & 29.2 & 30.9 & 62 & 84.9 & 81.2 & 95 & 158.4 & 140.6 & 240 & 263.3 & 219.2 \\
\hline & & & 63 & 87.2 & 83.2 & 96 & 160.0 & 141.8 & 245 & 264.8 & 220.3 \\
\hline 31 & 30.4 & 32.0 & 64 & 89.6 & 85.2 & 97 & 161.4 & 142.9 & 250 & 266.1 & 221.2 \\
\hline 32 & 31.6 & 33.2 & 65 & 92.0 & 87.3 & 98 & 162.9 & 144.0 & & & \\
\hline
\end{tabular}


TABLE 62-Concluded

\begin{tabular}{|c|c|c|c|c|c|c|c|c|c|c|c|}
\hline \multirow{2}{*}{$\begin{array}{l}\text { AGE } \\
\text { DAYS }\end{array}$} & \multicolumn{2}{|c|}{ BODY WEIGHT } & \multirow{2}{*}{$\begin{array}{l}\text { AGE } \\
\text { DAYS }\end{array}$} & \multicolumn{2}{|c|}{ BODY WEIGHT } & \multirow{2}{*}{$\begin{array}{l}\text { AGE } \\
\text { DAYS }\end{array}$} & \multicolumn{2}{|c|}{ BODY WEIGHT } & \multirow{2}{*}{$\begin{array}{l}\text { AGE } \\
\text { DAYS }\end{array}$} & \multicolumn{2}{|c|}{ BODY WEIGHT } \\
\hline & Male & Female & & Male & Female & & Male & Female & & Male & Female \\
\hline 255 & 267.3 & 222.1 & 290 & 274.2 & 226.9 & 320 & 277.7 & 229.3 & 355 & 279.7 & 230.4 \\
\hline 260 & 268.5 & 223.0 & 295 & 274.9 & 227.4 & 325 & 278.1 & 229.5 & 360 & 279.8 & 230.4 \\
\hline 265 & 269.6 & 223.7 & 300 & 275.5 & 227.9 & 330 & 278.5 & 229.8 & 365 & 279.9 & 230.4 \\
\hline 270 & 270.7 & 224.5 & & & & 335 & 278.8 & 229.9 & & & \\
\hline 275 & 271.6 & 225.1 & 305 & 276.2 & 228.3 & 340 & 279.1 & 230.1 & & & \\
\hline 280 & 272.5 & 225.8 & 310 & 276.8 & 228.7 & 345 & 279.3 & 230.2 & & & \\
\hline 285 & 273.4 & 226.4 & 315 & 277.2 & 229.0 & 350 & 279.6 & 230.3 & & & \\
\hline
\end{tabular}


TABLE 63

Body weight on age. Male Albinos unmated. Chicago colony. Donaldson, Dunn and Watson, ('06). The records for the first ten days as given in the original table are here omitted. Those values may be obtained from table 62. In addition to the average values the highest and lowest are also given. See graph A in chart 2

\begin{tabular}{|c|c|c|c|c|}
\hline \multirow{2}{*}{ AGE IN DAYS } & \multicolumn{3}{|c|}{ BODY WEIGHT IN GRAMS } & \multirow{2}{*}{$\begin{array}{l}\text { NUMBER OP } \\
\text { ANIMALS }\end{array}$} \\
\hline & Average & Lowest & Highest & \\
\hline $11 \ldots \ldots \ldots \ldots$ & 13.3 & 13.0 & 13.6 & 4 \\
\hline $12 \ldots \ldots \ldots \ldots$ & 14.8 & 11.4 & 19.5 & 6 \\
\hline $13 \ldots \ldots \ldots \ldots$ & 15.3 & 14.1 & 16.0 & 5 \\
\hline $14 \ldots \ldots \ldots \ldots$ & 15.2 & 14.0 & 17.6 & 6 \\
\hline $15 \ldots \ldots \ldots \ldots$ & 16.5 & 12.5 & 22.4 & 19 \\
\hline $17 \ldots \ldots \ldots \ldots$ & 17.8 & 13.9 & 24.0 & 19 \\
\hline $19 \ldots \ldots \ldots \ldots$ & 19.5 & 15.2 & 26.0 & 19 \\
\hline $21 \ldots \ldots \ldots \ldots$ & 21.2 & 14.6 & 30.1 & 19 \\
\hline $23 \ldots \ldots \ldots \ldots$ & 22.9 & 17.9 & 32.5 & 19 \\
\hline $25 \ldots \ldots \ldots \ldots$ & 25.3 & 19.0 & 35.8 & 19 \\
\hline $27 \ldots \ldots \ldots \ldots$ & 27.4 & 19.8 & 38.3 & 19 \\
\hline $29 \ldots \ldots \ldots \ldots$ & 29.5 & 22.1 & 39.3 & 19 \\
\hline $31 \ldots \ldots \ldots \ldots$ & 31.8 & 25.9 & 41.2 & 19 \\
\hline $34 \ldots \ldots \ldots \ldots$ & 34.9 & 27.4 & 43.3 & 19 \\
\hline $37 \ldots \ldots \ldots \ldots$ & 37.8 & 28.5 & 48.0 & 19 \\
\hline $40 \ldots \ldots \ldots \ldots$ & 42.2 & 30.8 & 52.2 & 19 \\
\hline $43 \ldots \ldots \ldots \ldots$ & 46.3 & 33.7 & 62.4 & 19 \\
\hline $46 \ldots \ldots \ldots \ldots$ & 50.5 & 35.9 & 66.2 & 19 \\
\hline $49 \ldots \ldots \ldots \ldots$ & 56.7 & 38.9 & 73.9 & 19 \\
\hline $52 \ldots \ldots \ldots \ldots$ & 62.5 & 39.8 & 82.5 & 19 \\
\hline $55 \ldots \ldots \ldots \ldots$ & 68.5 & 40.6 & 87.5 & 19 \\
\hline $58 \ldots \ldots \ldots \ldots$ & 73.9 & 45.1 & 100.1 & 19 \\
\hline $61 \ldots \ldots \ldots \ldots$ & 81.7 & 49.0 & 116.6 & 19 \\
\hline $64 \ldots \ldots \ldots \ldots$ & 89.1 & $52.7^{\circ}$ & 129.6 & 19 \\
\hline $67 \ldots \ldots \ldots \ldots$ & 99.3 & 57.7 & 140.2 & 19 \\
\hline $70 \ldots \ldots \ldots \ldots$ & 106.6 & 71.2 & 148.5 & 19 \\
\hline $73 \ldots \ldots \ldots \ldots$ & 113.8 & 71.4 & 152.4 & 19 \\
\hline $76 \ldots \ldots \ldots \ldots$ & 121.3 & 89.8 & 157.5 & 19 \\
\hline $79 \ldots \ldots \ldots \ldots$ & 128.2 & 97.0 & 161.2 & 19 \\
\hline $82 \ldots \ldots \ldots \ldots$ & 135.0 & 105.1 & $165 . \tilde{5}$ & 19 \\
\hline $85 \ldots \ldots \ldots \ldots$ & 143.8 & 117.0 & 168.5 & 19 \\
\hline $88 \ldots \ldots \ldots \ldots$ & 148.4 & 124.5 & 174.0 & 19 \\
\hline $92 \ldots \ldots \ldots \ldots$ & 152.3 & 124.0 & 179.6 & 19 \\
\hline $97 \ldots \ldots \ldots \ldots$ & 160.0 & 124.0 & 180.7 & 19 \\
\hline $102 \ldots \ldots \ldots \ldots$ & 168.8 & 120.0 & 192.2 & 19 \\
\hline $107 \ldots \ldots \ldots \ldots$ & 177.6 & 120.0 & 206.0 & 19 \\
\hline $112 \ldots \ldots \ldots \ldots$ & 183.8 & 125.0 & 215.6 & 19 \\
\hline
\end{tabular}


TABLE 63-Concluded

\begin{tabular}{|c|c|c|c|c|}
\hline \multirow{2}{*}{ AGE IN DAYS } & \multicolumn{3}{|c|}{ BODY WEIGHT IN GRAMS } & \multirow{2}{*}{$\begin{array}{c}\text { NUMBER OF } \\
\text { ANIMALS }\end{array}$} \\
\hline & Averøge & Lowest & Highest & \\
\hline $117 \ldots \ldots \ldots$ & 191.4 & 130.0 & 223.0 & 19 \\
\hline $124 \ldots \ldots \ldots \ldots$ & 197.3 & 123.0 & 238.2 & 19 \\
\hline $131 \ldots \ldots \ldots$ & 202.5 & 132.4 & 249.2 & 19 \\
\hline $138 \ldots \ldots \ldots$ & 209.7 & 145.6 & 248.4 & 19 \\
\hline $143 \ldots \ldots \ldots \ldots$ & 218.3 & 155.5 & 259.4 & 19 \\
\hline $150 \ldots \ldots$ & 225.4 & 162.4 & 268.2 & 19 \\
\hline $157 \ldots \ldots \ldots$ & 227.0 & 162.4 & 271.4 & 19 \\
\hline $164 \ldots \ldots \ldots \ldots$ & 231.4 & 159.0 & 271.8 & 17 \\
\hline $171 \ldots \ldots \ldots$ & 235.8 & 165.2 & 289.0 & 17 \\
\hline $178 \ldots \ldots \ldots$ & 239.4 & 167.9 & 291.2 & 17 \\
\hline $185 \ldots \ldots$ & 239.8 & 176.0 & 294.0 & 15 \\
\hline $216 \ldots$ & 252.9 & 190.5 & 294.5 & 10 \\
\hline $256 \ldots$. & 265.4 & 190.5 & 310.0 & 10 \\
\hline $365 \ldots \ldots$ & 279.0 & 203.6 & 320.0 & 6 \\
\hline $730 \ldots \ldots$ & 308.5 & 285.0 & 375.6 & 6 \\
\hline
\end{tabular}


TABLE 64

Body weight on age. Female albinos unmated. Values for 'mated' computed (Watson '05) Chicago colony. Donaldson, Dunn and Watson, ('06). The records for the first ten days as given in the original table are here omitted. Those values may be obtained from table 62. In addition to the average values the highest and lowest are also given. See graph $A$, in chart 3 .

\begin{tabular}{|c|c|c|c|c|}
\hline \multirow{2}{*}{ AGE IN DAYS } & \multicolumn{3}{|c|}{ BODY WEIGHT IN GRAMS } & \multirow{2}{*}{$\begin{array}{c}\text { NUMBER of } \\
\text { ANIMALS }\end{array}$} \\
\hline & Average & Lowest & Highest & \\
\hline $11 \ldots \ldots \ldots$ & 12.8 & 12.1 & 13.6 & 2 \\
\hline $12 \ldots \ldots \ldots \ldots$ & 15.1 & 13.6 & 17.7 & 5 \\
\hline $13 \ldots \ldots \ldots \ldots$ & 15.1 & 14.7 & 16.0 & 5 \\
\hline $14 . \ldots \ldots \ldots \ldots$ & 15.6 & 13.5 & 18.1 & 5 \\
\hline $15 \ldots \ldots \ldots$ & 17.7 & 13.1 & 23.2 & 17 \\
\hline $17 \ldots \ldots \ldots$ & 19.2 & 15.1 & 24.5 & 17 \\
\hline $19 \ldots \ldots \ldots$ & 20.6 & 16.9 & 27.0 & 17 \\
\hline $21 \ldots \ldots \ldots \ldots$ & 22.6 & 16.1 & 30.1 & 17 \\
\hline $23 \ldots \ldots \ldots \ldots$ & 24.9 & 17.3 & 33.3 & 17 \\
\hline $25 \ldots \ldots \ldots \ldots$ & 27.4 & 20.8 & 36.0 & 17 \\
\hline $27 \ldots \ldots \ldots \ldots$ & 30.0 & 23.9 & 38.5 & 17 \\
\hline $29 \ldots \ldots \ldots \ldots$ & 31.4 & 24.0 & 39.0 & 17 \\
\hline $31 \ldots \ldots \ldots$ & 32.9 & 26.3 & 42.8 & 17 \\
\hline $34 \ldots \ldots \ldots \ldots$ & 35.7 & 26.4 & 44.1 & 17 \\
\hline $37 \ldots \ldots \ldots \ldots$ & 39.5 & $29.8^{\circ}$ & 47.4 & 17 \\
\hline $40 \ldots \ldots \ldots \ldots$ & 43.7 & 30.6 & 52.4 & 17 \\
\hline $43 \ldots \ldots \ldots$ & 47.9 & 35.0 & 60.7 & 17 \\
\hline $46 \ldots \ldots \ldots \ldots$ & 52.0 & 41.4 & 63.0 & 16 \\
\hline $49 \ldots \ldots \ldots \ldots$ & 57.7 & 42.0 & 69.2 & 16 \\
\hline $52 \ldots \ldots \ldots \ldots$ & 62.9 & 41.7 & 74.8 & 16 \\
\hline $55 \ldots \ldots \ldots \ldots$ & 68.4 & 49.8 & 80.7 & 13 \\
\hline $58 \ldots \ldots \ldots \ldots$ & 74.6 & 53.6 & 86.6 & 13 \\
\hline $61 \ldots \ldots \ldots$ & 78.4 & 56.2 & 96.7 & 13 \\
\hline $64 \ldots \ldots \ldots \ldots$ & 85.8 & 57.5 & 106.8 & 12 \\
\hline $67 \ldots \ldots \ldots \ldots$ & 96.0 & 71.2 & 114.1 & 12 \\
\hline $70 \ldots \ldots \ldots \ldots$ & 99.8 & 79.0 & 122.6 & 11 \\
\hline $73 \ldots \ldots \ldots \ldots$ & 105.6 & 80.2 & 126.5 & 11 \\
\hline $76 \ldots \ldots \ldots \ldots$ & 110.4 & 89.6 & 131.6 & 11 \\
\hline $79 \ldots \ldots \ldots \ldots$ & 118.8 & 97.7 & 136.0 & 11 \\
\hline $82 \ldots \ldots \ldots \ldots$ & 124.7 & 101.0 & 139.2 & 11 \\
\hline $85 \ldots \ldots \ldots \ldots$ & 131.5 mated & 105.0 mated & 143.2 mated & 11 \\
\hline $88 \ldots \ldots \ldots \ldots$ & 136.0 & 115.6 & 157.4 & 11 \\
\hline $92 \ldots \ldots \ldots \ldots$ & $139.6 \quad 139.8$ & $118.7 \quad 118.9$ & $161.4 \quad 161.6$ & 11 \\
\hline $97 \ldots \ldots \ldots \ldots$ & $145.9 \quad 146.3$ & $119.6 \quad 120.0$ & $174.5 \quad 175.0$ & 11 \\
\hline $102 \ldots \ldots \ldots \ldots$ & $152.4 \quad 153.1$ & $\begin{array}{ll}124.6 & 125.2\end{array}$ & $\begin{array}{ll}185.7 & 186.5\end{array}$ & 11 \\
\hline $107 \ldots \ldots \ldots \ldots$ & $154.9 \quad 155.8$ & $129.6 \quad 130.3$ & $191.4 \quad 192.5$ & 11 \\
\hline $112 \ldots \ldots \ldots \ldots$ & $160.2 \quad 161.4$ & $138.5 \quad 139.5$ & $193.6 \quad 195.0$ & 11 \\
\hline
\end{tabular}


BODY WEIGHT ON AGE

TABLE 04-Coneluded

\begin{tabular}{|c|c|c|c|c|c|c|c|}
\hline \multirow{2}{*}{ AGE IN DAYS } & \multicolumn{6}{|c|}{ BODY WEIGHT IN GRAMS } & \multirow{2}{*}{$\begin{array}{l}\text { NOMBER OF } \\
\text { ANIMALS }\end{array}$} \\
\hline & \multicolumn{2}{|c|}{ Average } & \multicolumn{2}{|c|}{ Lowest } & \multicolumn{2}{|c|}{ Highest } & \\
\hline $117 \ldots \ldots \ldots$ & 166.5 & 168.0 & 142.5 & 143.8 & 199.0 & 200.8 & 11 \\
\hline $124 \ldots$ & 170.7 & 172.6 & 146.4 & 148.0 & 206.7 & 209.0 & 11 \\
\hline $131 .$. & 178.6 & 181.0 & 151.2 & 153.0 & 214.7 & 217.5 & 11 \\
\hline $138 .$. & 182.2 & 185.0 & 151.0 & 153.3 & 210.2 & 213.4 & 11 \\
\hline $143 \ldots$ & 183.4 & 186.6 & 154.0 & 156.7 & 219.4 & 223.4 & 11 \\
\hline 150. & 184.6 & 188.2 & 153.7 & 156.7 & 220.7 & 225.0 & 11 \\
\hline $157 \ldots$ & 184.0 & 188.0 & 154.9 & 158.2 & 217.6 & 222.4 & 11 \\
\hline 164. & 185.1 & 189.5 & 154.0 & 157.6 & 215.0 & 220.1 & 11. \\
\hline $171 .$. & 187.4 & 192.2 & 154.0 & 158.0 & 210.0 & 215.4 & 11 \\
\hline 178. & 191.7 & 197.0 & 153.0 & 157.2 & 215.0 & 221.0 & 11 \\
\hline 185. & 194.2 & 200.0 & 152.0 & 156.6 & 215.0 & 221.4 & 11 \\
\hline $192 \ldots$ & 195.9 & 202.2 & 155.0 & 160.0 & 217.0 & 224.0 & 11 \\
\hline 365. & & 226.4 & & 171.4 & & 280.0 & 7 \\
\hline
\end{tabular}


TABLE 65

Increase in the body weight of the albino rat with age, based on a personal communication, Ferry ('13). New Haven Colony. See graphs $B$ and $B^{1}$ Chart 2, and $B$, Chart 3

\begin{tabular}{|c|c|c|c|}
\hline \multirow{2}{*}{ AGE IN DAYS } & \multicolumn{3}{|c|}{ BODY WEIGHT } \\
\hline & $\underset{\text { (1) }}{\text { Males }}$ & & $\underset{(3)}{\text { Females }}$ \\
\hline & grams & & grams \\
\hline $10 \ldots \ldots \ldots \ldots \ldots$ & 14.6 & & 13 \\
\hline $20 \ldots \ldots \ldots \ldots \ldots$ & 22.3 & & 25 \\
\hline $30 \ldots \ldots \ldots \ldots \ldots \ldots$ & 35.3 & & 38 \\
\hline $40 \ldots \ldots \ldots \ldots$ & 51.7 & & 54 \\
\hline $50 \ldots \ldots \ldots \ldots \ldots \ldots$ & 73.1 & & 73 \\
\hline $60 \ldots \ldots \ldots \ldots \ldots \ldots$ & 96.8 & & 89 \\
\hline $70 \ldots \ldots \ldots \ldots \ldots$ & 113.6 & & 100 \\
\hline $80 \ldots \ldots \ldots \ldots \ldots$ & 127.7 & & 105 \\
\hline $90 \ldots \ldots \ldots \ldots \ldots \ldots$ & 143.7 & & 115 \\
\hline $100 \ldots \ldots \ldots \ldots \ldots \ldots$ & 157.3 & & 120 \\
\hline $110 \ldots \ldots \ldots \ldots \ldots \ldots$ & 168.3 & & 125 \\
\hline $120 \ldots \ldots \ldots \ldots \ldots \ldots$ & 180.8 & & 133 \\
\hline $130 \ldots \ldots \ldots \ldots \ldots$ & 190.4 & & 137 \\
\hline $140 \ldots \ldots \ldots \ldots \ldots \ldots$ & 197.4 & & 146 \\
\hline $150 \ldots \ldots \ldots \ldots \ldots$ & 208.3 & & 150 \\
\hline $160 \ldots \ldots \ldots \ldots \ldots \ldots$ & 211.9 & Males. & 152 \\
\hline $170 \ldots \ldots \ldots \ldots \ldots$ & 218.3 & & 158 \\
\hline $180 \ldots \ldots \ldots \ldots \ldots \ldots$ & 225.7 & & 160 \\
\hline $190 \ldots \ldots \ldots \ldots \ldots \ldots$ & 233.5 & (2) & 164 \\
\hline $200 \ldots \ldots \ldots \ldots \ldots \ldots$ & 243.1 & & 168 \\
\hline $210 \ldots \ldots \ldots \ldots \ldots \ldots$ & & 254.0 & 169 \\
\hline $220 \ldots \ldots \ldots \ldots \ldots \ldots$ & 253.3 & 262.0 & 172 \\
\hline $230 \ldots \ldots \ldots \ldots \ldots \ldots$ & & 264.0 & 172 \\
\hline $240 \ldots \ldots \ldots \ldots \ldots \ldots$ & 268.2 & 270.0 & 172 \\
\hline $250 \ldots \ldots \ldots \ldots \ldots \ldots$ & & 272.0 & 170 \\
\hline $260 \ldots \ldots \ldots \ldots$ & 259.1 & 276.0 & 171 \\
\hline $270 \ldots \ldots \ldots \ldots$ & & 280.0 & 173 \\
\hline $280 \ldots \ldots \ldots \ldots \ldots \ldots$ & 265.2 & 287.0 & 176 \\
\hline $300 \ldots \ldots \ldots \ldots \ldots$ & 267.4 & & \\
\hline
\end{tabular}

Column 1, males, includes some rats declining in body weight after 200 days.

Column 2, males, contains values from the normal growth curve (New Haven series).

Column 3, females, contains values read directly from normal growth curve, New Haven. 
TABLE 66

Giving the number of animals used by Ferry, ('13) in computing her growth table 65, for the rats at the Connecticut Agricultural Experiment Station in New Haven. (Personal Communication).

In both groups the maximum number of observations was made at $\$ 0$ days of age

\begin{tabular}{c|c|c|c}
\hline \multicolumn{2}{c|}{ MaLes } & \multicolumn{2}{|c}{ FEMALEs } \\
\hline Age in days & Number of rats & Age in days & Number of rats \\
\cline { 3 - 4 } $20-80$ & $47-81$ & $20-90$ & $39-68$ \\
$90-170$ & $30-40$ & $100-160$ & $20-37$ \\
$180-210$ & $18-27$ & $170-190$ & $11-14$ \\
$220-280$ & $6-12$ & $200-280$ & $6-8$ \\
\hline
\end{tabular}

TABLE 67

Giving the increase in body weight with age-stock Albinos. Mean of two seriesKing (MS'15) and giving also the coefficients of variation with their probable errors. The Wistar Institute Colony. See graph C, Charts 2 and 3, and Chart 4.

\begin{tabular}{|c|c|c|c|c|c|c|}
\hline \multicolumn{4}{|c|}{ MALES } & \multicolumn{3}{|c|}{ FEMALES } \\
\hline $\begin{array}{l}\text { Age in } \\
\text { days }\end{array}$ & $\mid$\begin{tabular}{c|} 
No. \\
individuals
\end{tabular} & $\begin{array}{l}\text { Average } \\
\text { bd. wt. }\end{array}$ & $\begin{array}{l}\text { Coefficient of } \\
\text { variation }\end{array}$ & \begin{tabular}{|c|} 
No. \\
individuals
\end{tabular} & $\begin{array}{l}\text { Average } \\
\text { bd. wt. }\end{array}$ & $\begin{array}{l}\text { Coefficient of } \\
\text { variation }\end{array}$ \\
\hline & & grams & & & grams & \\
\hline 13 & 50 & 17.2 & $11.8 \pm 0.795$ & 50 & 15.7 & $11.4 \pm 0.768$ \\
\hline 30 & 50 & 48.5 & $10.2 \pm 0.687$ & 50 & 45.7 & $11.0 \pm 0.741$ \\
\hline 60 & 50 & 122.9 & $17.0 \pm 1.140$ & 50 & 107.1 & $15.7 \pm 1.050$ \\
\hline 90 & 50 & 184.8 & $14.8 \pm 0.998$ & 39 & 148.0 & $12.5 \pm 0.951$ \\
\hline 120 & 50 & 223.2 & $13.4 \pm 0.903$ & 42 & 173.4 & $10.3 \pm 0.755$ \\
\hline 151 & 50 & 244.8 & $13.3 \pm 0.896$ & 45 & 186.3 & $10.4 \pm 0.735$ \\
\hline 182 & 50 & 258.4 & $14.2 \pm 1.220$ & 42 & 196.5 & $12.3 \pm 0.903$ \\
\hline 212 & 48 & 268.0 & $14.0 \pm 0.964$ & 42 & 197.3 & $12.4 \pm 0.910$ \\
\hline 243 & 44 & 279.7 & $13.9 \pm 0.998$ & 43 & 209.6 & $12.6 \pm 0.910$ \\
\hline 273 & 41 & 280.9 & $13.4 \pm 0.997$ & 38 & 210.8 & $11.5 \pm 0.890$ \\
\hline 304 & 36 & 296.1 & $14.0 \pm 1.110$ & 38 & 219.1 & $10.3 \pm 0.795$ \\
\hline 334 & 33 & 300.8 & $13.7 \pm 1.130$ & 35 & 222.4 & $10.8 \pm 0.870$ \\
\hline 365 & 28 & 306.1 & $13.0 \pm 1.160$ & 31 & 223.1 & $10.7 \pm 0.910$ \\
\hline 395 & 24 & 314.1 & $12.6 \pm 1.220$ & 31 & 220.5 & $11.5 \pm 0.984$ \\
\hline 425 & 23 & 312.2 & $13.4 \pm 1.320$ & 30 & 215.8 & $10.9 \pm 0.944$ \\
\hline 455 & 15 & 323.9 & $13.6 \pm 1.670$ & 18 & 220.2 & $8.9 \pm 0.998$ \\
\hline 485 & 12 & 326.0 & $15.0 \pm 2.060$ & 13 & 234.7 & $13.4 \pm 1.770$ \\
\hline
\end{tabular}


The four tables $68,69,70$ and 71 which follow have been worked out on the basis of body length by the use of the appropriate formulas. The details touching the organs represented, as well as the corresponding graphs, are to be found in the earlier paragraphs of this chapter. The values for the body weights are repeated in each table.

Weights of viscera combined. Using the data in tables 6871 (72) the total weight of the viscera-brain, spinal cord, both eyeballs, heart, both kidneys, liver, spleen, both lungs, alimentary tract, both testes, both ovaries, hypophysis, both suprarenals, thyroid and thymus (given separately) - has been entered after the total body weight at each millimeter of body length and for each sex. For obvious reasons the weight of the total blood (see table 70) has not been included.

For the thymus, the weight of which is most closely correlated with age, the following procedure has been employed: Using table 62 for the values for the body weights at given ages, the relation between age, body weight and thymus weight has been directly tabulated, and using these data as a basis, the values of the thymus for the body weight-which is assumed to be normal to the age-have been determined as given in table 73 . Owing to the manner in which they have been obtained, it has seemed best to give the thymus values in a separate column.

The entries for the thymus cease after a body length of $221 \mathrm{~mm}$. for males and $198 \mathrm{~mm}$. for females, as these mark the limit of the data in table 62. But in animals of this size or larger, the value for the thymus has become very small both absolutely and relatively.

Tables giving characters which depend primarily on age.

Table 74 gives the percentage of water in the brain and in the spinal cord for each sex from birth to 365 days. These values have been computed by formulas (40), (41) and (42). The graphs corresponding to these data for the males are given in chart 26. 
TABLE 68

Giving for each sex the tail length and the weights of the brain, spinal cord and both eyeballs for each millimeter of body length. See Charts 6, 7, 8, 9, 10

\begin{tabular}{|c|c|c|c|c|c|c|c|c|c|c|}
\hline \multicolumn{6}{|c|}{ MALES } & \multicolumn{5}{|c|}{ Females } \\
\hline \multirow{2}{*}{$\begin{array}{c}\text { Body } \\
\text { length }\end{array}$} & \multirow{2}{*}{$\begin{array}{c}\text { Tail } \\
\text { length }\end{array}$} & \multirow{2}{*}{$\begin{array}{c}\text { Body } \\
\text { weight }\end{array}$} & \multicolumn{2}{|c|}{ Weight in gms. } & \multirow{2}{*}{$\begin{array}{l}\text { Both } \\
\text { eye- } \\
\text { balls }\end{array}$} & \multirow{2}{*}{$\begin{array}{c}\text { Tail } \\
\text { length }\end{array}$} & \multirow{2}{*}{$\underset{\text { weight }}{\text { Body }}$} & \multicolumn{2}{|c|}{ Weight in gms. } & \multirow{2}{*}{$\begin{array}{l}\text { Both } \\
\text { eye- } \\
\text { balls }\end{array}$} \\
\hline & & & Brain & $\begin{array}{c}\text { Spinal } \\
\text { cord }\end{array}$ & & & & Brain & $\begin{array}{c}\text { Spinal } \\
\text { cord }\end{array}$ & \\
\hline$m m$. & $m m$. & gms. & & & $g m s$. & $m m$. & $g m s$. & & & gms. \\
\hline 47 & 14.9 & 4.9 & 0.226 & 0.033 & 0.029 & 15.4 & 4.7 & 0.211 & 0.033 & 0.028 \\
\hline 48 & 15.8 & 4.9 & 0.226 & 0.033 & 0.029 & 16.6 & 4.7 & 0.214 & 0.033 & 0.028 \\
\hline 49 & 16.9 & 5.0 & 0.232 & 0.034 & 0.030 & 17.8 & 4.9 & 0.217 & 0.034 & 0.029 \\
\hline 50 & 18.0 & 5.1 & $0.23 \mathrm{~s}$ & 0.034 & 0.031 & 19.0 & 5.0 & 0.222 & 0.035 & 0.029 \\
\hline 51 & 19.2 & 5.2 & 0.252 & 0.035 & 0.031 & 20.2 & 5.1 & 0.227 & 0.035 & 0.030 \\
\hline 52 & 20.4 & 5.3 & 0.266 & 0.036 & 0.032 & 21.5 & 5.3 & 0.255 & 0.036 & 0.032 \\
\hline 53 & 21.6 & 5.4 & 0.280 & 0.037 & 0.033 & 22.7 & 5.5 & 0.283 & 0.038 & 0.034 \\
\hline 54 & 22.7 & 5.6 & 0.300 & 0.038 & 0.034 & 23.9 & 5.8 & 0.323 & 0.041 & 0.036 \\
\hline $5 \tilde{5}$ & 23.9 & 5.8 & 0.320 & 0.040 & 0.036 & 25.2 & 6.2 & 0.361 & 0.044 & 0.039 \\
\hline 56 & 25.0 & 6.1 & 0.358 & 0.043 & 0.039 & 26.4 & 6.5 & 0.398 & 0.048 & 0.041 \\
\hline 57 & 26.2 & 6.4 & 0.395 & 0.046 & 0.041 & 27.6 & 6.9 & 0.433 & 0.051 & 0.044 \\
\hline 58 & 27.3 & 6.8 & 0.431 & 0.049 & 0.044 & 28.8 & 7.2 & 0.468 & 0.054 & 0.046 \\
\hline 59 & 28.5 & 7.1 & 0.465 & 0.052 & 0.0 & 30.0 & 7.6 & 0.500 & 0.057 & 0.049 \\
\hline 60 & 29.6 & 7.5 & 0.498 & 0.055 & 0.048 & 31.2 & 8.0 & 0.532 & 0.061 & 0.051 \\
\hline 61 & 30.7 & 7.9 & 0.530 & 0.059 & 0.0 & 32 & 8.4 & 0.564 & 0.064 & 0.053 \\
\hline 62 & 31.9 & 8.2 & 0.561 & 0.062 & 0.052 & 33.5 & 8.7 & 0.594 & 0.068 & 0.055 \\
\hline 63 & 33.0 & 8.6 & 0.591 & 0.065 & 0.0 & 34. & 9.1 & 0.624 & 0.071 & 0.057 \\
\hline 64 & 34.1 & 9.0 & 0.621 & 0.068 & 0.056 & 35.9 & 9.5 & 0.652 & 0.074 & 0.059 \\
\hline 65 & 35.2 & 9.4 & 0.650 & 0.071 & 0.058 & 37.0 & 9.9 & 0.679 & 0.077 & 0.061 \\
\hline 66 & 36.3 & 9.8 & 0.678 & 0.075 & 0.060 & 38.2 & 10.3 & 0.703 & 0.081 & 0.063 \\
\hline 67 & 37.4 & 10.1 & 0.695 & 0.078 & 0.062 & 39.4 & 10.8 & 0.726 & 0.084 & 0.065 \\
\hline 68 & 38.5 & 10.6 & 0.711 & 0.081 & 0.064 & 40.5 & 11.2 & 0.772 & 0.088 & 0.067 \\
\hline 69 & 39.6 & 11.0 & 0.761 & 0.084 & 0.066 & 41.7 & 11.6 & 0.811 & 0.091 & 0.068 \\
\hline 70 & 40.7 & 11.4 & 0.803 & 0.088 & 0.068 & 42.8 & 12.0 & 0.846 & 0.095 & 0.070 \\
\hline 71 & 41.8 & 11.8 & 0.840 & 0.091 & 0.0 & 43 & 12.5 & & & 0.072 \\
\hline 72 & 42.9 & 12.2 & 0.872 & 0.094 & 0.071 & & 12.9 & 0.904 & 0.101 & 0.073 \\
\hline 73 & 44.0 & 12.7 & 0.901 & 0.098 & 0.073 & 46.2 & 13.4 & 0.929 & 0.105 & 0.075 \\
\hline 74 & 45.1 & 13.1 & 0.928 & 0.101 & 0.074 & 47.3 & 13.9 & 0.952 & 0.108 & 0.077 \\
\hline 75 & 46.2 & 13.6 & 0.952 & 0.104 & 0.076 & 48.5 & 14.3 & 0.974 & 0.112 & 0.078 \\
\hline 76 & 47.2 & 14.0 & 0.974 & 0.107 & 0.077 & 49.6 & 14.8 & 0.994 & 0.115 & 0.080 \\
\hline 77 & 48.3 & 14.5 & 0.995 & 0.111 & 0.079 & 50.7 & 15.3 & 1.013 & 0.119 & 0.082 \\
\hline 78 & 49.4 & 15.0 & 1.015 & 0.114 & 0.081 & 51.8 & 15.8 & 1.031 & 0.122 & 0.083 \\
\hline 79 & 50.4 & 15.4 & 1.033 & 0.117 & 0.082 & 52.9 & 16.3 & 1.047 & 0.126 & 0.085 \\
\hline 80 & 51.5 & 15.9 & 1.051 & 0.121 & 0.084 & 54.0 & 16.8 & 1.064 & 0.129 & 0.086 \\
\hline
\end{tabular}


TABLE 68-Continued

\begin{tabular}{|c|c|c|c|c|c|c|c|c|c|c|}
\hline \multicolumn{6}{|c|}{ MALES } & \multicolumn{5}{|c|}{ FEMALES } \\
\hline \multirow{2}{*}{$\begin{array}{l}\text { Body } \\
\text { length }\end{array}$} & \multirow{2}{*}{$\begin{array}{c}\text { Tail } \\
\text { length }\end{array}$} & \multirow{2}{*}{$\underset{\text { weight }}{\text { Body }}$} & \multicolumn{2}{|c|}{ Weight in gms. } & \multirow{2}{*}{$\begin{array}{l}\text { Both } \\
\text { eye- } \\
\text { balls }\end{array}$} & \multirow{2}{*}{$\begin{array}{c}\text { Tail } \\
\text { length }\end{array}$} & \multirow{2}{*}{$\begin{array}{c}\text { Body } \\
\text { weight }\end{array}$} & \multicolumn{2}{|c|}{ Weight in gms. } & \multirow{2}{*}{$\begin{array}{l}\text { Both } \\
\text { eye- } \\
\text { balls }\end{array}$} \\
\hline & & & Brain & \begin{tabular}{|} 
Spinal \\
cord
\end{tabular} & & & & Brain & & \\
\hline$m m$. & $m m$. & gms. & & & gms. & $m m$. & gms. & & & gms. \\
\hline 81 & 52.6 & 16.4 & 1.067 & 0.124 & 0.085 & 55.1 & 17.3 & 1.079 & 0.133 & 0.088 \\
\hline 82 & 53.6 & 16.9 & 1.083 & 0.128 & 0.087 & 56.3 & 17.9 & 1.093 & 0.136 & 0.089 \\
\hline 83 & 54.7 & 17.4 & 1.098 & 0.131 & 0.088 & 57.4 & 18.4 & 1.107 & 0.140 & 0.091 \\
\hline 84 & 55.7 & 18.0 & 1.112 & 0.134 & 0.090 & 58.5 & 19.0 & 1.121 & 0.143 & 0.093 \\
\hline 85 & 56.8 & 18.5 & 1.126 & 0.138 & 0.091 & 59.5 & 19.5 & 1.134 & 0.147 & 0.094 \\
\hline 86 & 57.8 & 19.0 & 1.139 & 0.141 & 0.093 & 60.6 & 20.1 & 1.146 & 0.150 & 0.095 \\
\hline 87 & 58.9 & 19.6 & 1.152 & 0.144 & 0.094 & 61.7 & 20.7 & 1.159 & 0.154 & 0.097 \\
\hline 88 & 59.9 & 20.1 & 1.165 & 0.148 & 0.095 & & 21.2 & 1.170 & 0.158 & 0.098 \\
\hline 89 & 61.0 & 20.7 & 1.177 & 0.151 & 0.097 & & 21.8 & 1.181 & 0.161 & 0.100 \\
\hline 90 & 62.0 & 21.3 & 1.188 & 0.155 & $0 .($ & & .4 & 1.193 & 0.165 & 0.101 \\
\hline 91 & 63.0 & 21.9 & 1.200 & 0. & 0 & & 23.1 & 1.203 & 168 & 03 \\
\hline 92 & 64.1 & 22.4 & 1.211 & 0.162 & 0.1 & .2 & 23.7 & 1.214 & 0.172 & 0.104 \\
\hline 93 & 65.1 & 23.0 & 1.221 & 0.165 & 0.102 & .2 & 24.3 & 1.224 & 0.176 & 0.105 \\
\hline 94 & 66.2 & 23.7 & 1.231 & 0.168 & 0.1 & 3 & 25.0 & 1.234 & 0.179 & 0.107 \\
\hline 95 & 67.2 & 24.3 & 1.242 & 0.172 & 0.1 & 70.4 & 25.6 & 1.244 & 0.183 & 0.108 \\
\hline 96 & 68.2 & 24.9 & 1.252 & 0.175 & 0.1 & 4 & 26.3 & 1.253 & 0.186 & 0.109 \\
\hline 97 & 69.2 & 25.6 & 1.261 & 0.179 & 0.108 & 5 & 27.0 & 1.262 & 0.190 & 0.111 \\
\hline 98 & 70.3 & 26.2 & 1.271 & 0.182 & 0.109 & 73.6 & 27.7 & 1.271 & 0.194 & 0.112 \\
\hline 99 & 71.3 & 26.9 & 1.280 & 0.186 & 0.1 & 74.6 & 28.4 & 1.280 & 0.197 & 0.114 \\
\hline 100 & 72.3 & 27.5 & 1.289 & 0.189 & 0.112 & 75.7 & 29.1 & 1.289 & 0.201 & 0.115 \\
\hline 101 & 73.3 & 28.2 & 1.298 & 0.193 & & & & & & 0.116 \\
\hline 102 & 74.3 & 28.9 & 1.307 & 0.197 & 0.1 & 7 & 30.5 & 1.306 & 0.209 & 0.118 \\
\hline 103 & 75.4 & 29.6 & 1.315 & 0.200 & 0.1 & 78.9 & 31.3 & 1.314 & 0.212 & 0.119 \\
\hline 104 & 76.4 & 30.3 & 1.323 & 0.204 & 0.117 & 79.9 & 32.0 & 1.322 & 0.216 & 0.120 \\
\hline 105 & 77.4 & 31.1 & 1.332 & 0.207 & 0.119 & 81.0 & 32.8 & 1.330 & 0.220 & 0.122 \\
\hline 106 & 78.4 & 31.8 & 1.340 & 0.211 & 0.120 & 82.0 & 33.6 & 1.338 & 0.223 & 0.123 \\
\hline 107 & 79.4 & 32.5 & 1.348 & 0.214 & 0.121 & 83.1 & 34.4 & 1.346 & 0.227 & 0.124 \\
\hline 108 & 80.4 & 33.3 & 1.356 & 0.218 & 0.123 & 84.1 & 35.2 & 1.354 & 0.231 & 0.126 \\
\hline 109 & 81.4 & 34.1 & 1.363 & 0.221 & 0.124 & 85.2 & 36.0 & 1.361 & 0.235 & 0.127 \\
\hline 110 & 82.4 & 34.9 & 1.371 & 0.225 & 0.125 & 86.2 & 36.9 & 1.368 & 0.238 & 0.128 \\
\hline 111 & 83.4 & 35.7 & 1.378 & 0.228 & 0.126 & $8 \gamma .5$ & 38.8 & 1.376 & 0.242 & 0.130 \\
\hline 112 & 84.4 & 36.5 & 1.3866 & 0.232 & 0.128 & 88.3 & 38.6 & 1.383 & 0.246 & 0.131 \\
\hline 113 & 85.4 & 37.3 & 1.393 & 0.236 & 0.129 & 89.4 & 39.5 & 1.390 & 0.250 & 0.132 \\
\hline 114 & 86.4 & 38.2 & 1.400 & 0.239 & 0.130 & 90.4 & 40.3 & 1.397 & 0.253 & 0.134 \\
\hline 115 & 87.4 & 39.0 & 1.407 & 0.243 & 0.132 & 91.4 & 41.3 & 1.404 & 0.257 & 0.135 \\
\hline 116 & 88.4 & 39.9 & 1.414 & 0.246 & 0.133 & 92.5 & 42.2 & 1.411 & 0.261 & 0.136 \\
\hline
\end{tabular}


TABLE 68-Continued

\begin{tabular}{|c|c|c|c|c|c|c|c|c|c|c|}
\hline \multicolumn{6}{|c|}{ MALES } & \multicolumn{5}{|c|}{ FeMales } \\
\hline \multirow{2}{*}{$\begin{array}{c}\text { Body } \\
\text { length }\end{array}$} & \multirow{2}{*}{$\begin{array}{c}\text { Tail } \\
\text { length }\end{array}$} & \multirow{2}{*}{$\underset{\text { weight }}{\text { Body }}$} & \multicolumn{2}{|c|}{ Weight in gms. } & \multirow{2}{*}{$\begin{array}{l}\text { Both } \\
\text { eye- } \\
\text { bylls }\end{array}$} & \multirow{2}{*}{$\begin{array}{c}\text { Tail } \\
\text { length }\end{array}$} & \multirow{2}{*}{$\underset{\text { weight }}{\text { Body }}$} & \multicolumn{2}{|c|}{ Weight in gms. } & \multirow{2}{*}{$\begin{array}{l}\text { Both } \\
\text { eye- } \\
\text { balls }\end{array}$} \\
\hline & & & Brain & $\begin{array}{c}\text { Spinal } \\
\text { cord }\end{array}$ & & & & Brain & & \\
\hline$m m$. & $m m$. & oms. & & & gms. & $m m$. & gms. & & & gms. \\
\hline 117 & 89.4 & 40.8 & 1.421 & 0.250 & 0.134 & 93.5 & 43.1 & 1.418 & .265 & 0.138 \\
\hline 118 & 90.4 & 41.6 & 1.428 & 0.254 & 0.136 & & 44.1 & 1.424 & 268 & 0.139 \\
\hline 119 & 91.4 & 42.6 & 1.435 & 0.257 & 0.137 & 95.6 & 45.0 & 1.431 & 0.272 & 0.140 \\
\hline 120 & 92.4 & 43.5 & 1.442 & 0.261 & 0.138 & 96.6 & 46.0 & 1.438 & 0.276 & 0.142 \\
\hline 121 & 93.4 & 44.4 & 1.448 & 0.265 & 0.1 & 3 & 47.0 & 1.444 & 280 & .143 \\
\hline 122 & 94.4 & 45.4 & 1.455 & 0.268 & 0.141 & 98.7 & 48.0 & 1.450 & 0.284 & 0.144 \\
\hline 123 & 95.4 & 46.3 & 1.461 & 0.272 & 0.142 & 99.7 & 49.1 & 1.457 & 0.287 & 0.146 \\
\hline 124 & 96.4 & 47.3 & 1.468 & 0.276 & 0.143 & 100.7 & 50.1 & 1.463 & 0.291 & 0.147 \\
\hline 125 & 97.4 & 48.3 & 1.474 & 0.279 & 0.145 & 101.7 & 51.2 & 1.469 & & 0.148 \\
\hline 126 & 98 & 49.3 & 1.480 & 0.283 & 0.146 & 8 & .3 & 76 & & \\
\hline 127 & 99.3 & 50.4 & 1.487 & 0.287 & 0.147 & .8 & 53.4 & 1.482 & 0.303 & 0.151 \\
\hline 128 & 100.3 & 51.4 & 1.493 & 0.290 & 0.1 & & 54.5 & 1.488 & 0.307 & 0.153 \\
\hline 129 & 101.3 & 52.5 & 1.499 & 0.294 & 0.150 & 105.8 & 55.6 & 1.494 & 0.310 & 0.154 \\
\hline 130 & 102.3 & 53.6 & $1.505^{\circ}$ & 0.297 & 0.151 & 106.8 & 56.8 & 1.500 & 0.314 & 0.155 \\
\hline 131 & 103. & 54.7 & 1.511 & & & & & & & \\
\hline 132 & 104.2 & 55.8 & 1.517 & 0.305 & 0.1 & 10 & 59.2 & 1.512 & 0.322 & 0.158 \\
\hline 133 & 105.2 & 56.9 & 1.523 & 0.309 & 0.155 & 109.9 & 60.4 & 1.518 & 26 & 0.159 \\
\hline 134 & 106.2 & 58.1 & 1.529 & 0.312 & 0.1 & 11 & 61.6 & 23 & 30 & 161 \\
\hline 135 & 107.2 & 59.3 & 1.535 & 0.316 & 0.1 & 1 & 62.9 & 1.529 & 0.334 & 0.162 \\
\hline 136 & 108.2 & 60.5 & 1.541 & 0.320 & 0.1 & & 64.2 & 35 & 38 & 0.164 \\
\hline 137 & 109.1 & 61.7 & 1.546 & 0.323 & 0.1 & 114.0 & 65.5 & 1.540 & 0.341 & 0.165 \\
\hline 138 & 110.1 & 62.9 & 1.552 & 0.327 & 0.162 & 115.0 & 66.8 & 1.546 & 0.345 & 0.166 \\
\hline 139 & 111.1 & 64.1 & 1.558 & 0.331 & 0.164 & 116.0 & 68.1 & 1.552 & 0.349 & 0.168 \\
\hline 140 & 112.1 & 65.4 & 1.563 & 0.335 & 0.165 & 117.0 & 69.5 & 1.557 & 0.353 & 0.169 \\
\hline 141 & & 66.7 & & & & & & & & \\
\hline 142 & 114.0 & 68.0 & 1.575 & 0.342 & 0.168 & 0 & 72.3 & 1.568 & 61 & 0.172 \\
\hline 143 & 115.0 & 69.3 & 1.580 & 0.346 & 0.169 & 120.0 & 73.7 & 1.574 & 0.365 & 0.174 \\
\hline 144 & 115.9 & 70.7 & 1.586 & 0.349 & 0.171 & 121.0 & 75.2 & 1.579 & 0.369 & 0.175 \\
\hline 145 & 116.9 & 72.1 & 1.591 & 0.353 & 0.172 & 122.0 & 76.7 & 1.585 & 0.373 & 0.177 \\
\hline 146 & 117.9 & 73.5 & 1.597 & 0.357 & 0.173 & 123.0 & 78.2 & 1.590 & 0.377 & 0.178 \\
\hline 147 & 118.8 & 74.9 & 1.602 & 0.361 & 0.175 & 124.0 & 79.7 & 1.595 & 0.380 & 0.180 \\
\hline 148 & 119.8 & 76.3 & 1.607 & 0.365 & 0.176 & 125.0 & 81.3 & 1.601 & 0.384 & 0.181 \\
\hline 149 & 120.8 & 77.8 & 1.613 & 0.368 & 0.178 & 126.0 & 82.8 & 1.606 & 0.388 & 0.182 \\
\hline 150 & 121.7 & 79.3 & 1.618 & 0.372 & 0.179 & 127.0 & 84.4 & 1.611 & 0.392 & 0.184 \\
\hline 151 & 122.7 & 80.8 & 1.623 & 0.376 & 0.181 & & 80.1 & 1.616 & 0.396 & 0.186 \\
\hline 152 & 123.7 & 82.4 & 1.629 & 0.380 & 0.182 & 129.0 & 87.7 & 1.622 & 0.400 & 0.187 \\
\hline
\end{tabular}


TABLE 68-Continued

\begin{tabular}{|c|c|c|c|c|c|c|c|c|c|c|}
\hline \multicolumn{6}{|c|}{ MALES } & \multicolumn{5}{|c|}{ FEMALES } \\
\hline \multirow{2}{*}{$\begin{array}{l}\text { Body } \\
\text { length }\end{array}$} & \multirow{2}{*}{$\begin{array}{c}\text { Tail } \\
\text { length }\end{array}$} & \multirow{2}{*}{$\begin{array}{c}\text { Body } \\
\text { weight }\end{array}$} & \multicolumn{2}{|c|}{ Weight in gms. } & \multirow{2}{*}{$\begin{array}{l}\text { Both } \\
\text { eye- } \\
\text { balls }\end{array}$} & \multirow{2}{*}{$\begin{array}{c}\text { Tail } \\
\text { length }\end{array}$} & \multirow{2}{*}{$\begin{array}{c}\text { Body } \\
\text { weight }\end{array}$} & \multicolumn{2}{|c|}{ Weight in gms. } & \multirow{2}{*}{$\begin{array}{l}\text { Both } \\
\text { eye- } \\
\text { balls }\end{array}$} \\
\hline & & & Brain & \begin{tabular}{|} 
Spinal \\
cord
\end{tabular} & & & & Brain & & \\
\hline$m m$. & $m m$. & gms. & & & gms. & $m m$. & gms. & & & gms. \\
\hline 153 & 124.6 & 83.9 & 1.634 & 0.383 & 0.183 & 130.0 & 89.4 & 1.627 & 0.404 & 0.189 \\
\hline 154 & 125 & 85.5 & 1.639 & 0. & 0.185 & 13 & 91.1 & 1.632 & 0.408 & 0.190 \\
\hline 155 & 126.5 & 87.1 & 1.644 & 0.391 & 0.186 & 132.0 & 92.9 & 1.637 & 0.412 & 0.192 \\
\hline 156 & 127.5 & 88.7 & 1.649 & 0.395 & 0.188 & 133.0 & 94.6 & & 0.416 & \\
\hline 157 & 128.5 & 90.4 & 1.654 & 0.398 & 0.189 & 134.0 & 96.4 & 1.647 & 420 & 0.195 \\
\hline 158 & 129.4 & 92.1 & 1.659 & 0.402 & 0.191 & 0 & 98.3 & 52 & 24 & 196 \\
\hline 159 & 130.4 & 93.8 & 1.664 & 0.406 & 0.192 & 136.0 & 100.1 & 1.657 & 428 & 0.198 \\
\hline 160 & 131.3 & 95.6 & 1.670 & 0.410 & 0.194 & 137.0 & 102.0 & 1.662 & 0.432 & 0.200 \\
\hline 16 & 1 & 97.3 & 75 & 0 . & 0.1 & & & & 36 & \\
\hline 162 & 13 & 99.2 & 1. & 0 . & 0.1 & 9 & 10 & & 40 & \\
\hline 163 & 134.2 & 101.0 & 1.6 & 0.421 & 0. & 9 & 107.9 & 77 & 144 & 204 \\
\hline 164 & & 102.8 & 1. & 0.425 & 0. & 14 & 109.9 & & 48 & 206 \\
\hline 165 & 136.1 & 104.7 & 1.695 & 0.429 & 0.202 & 141.9 & 111.9 & 1.687 & 0.452 & .208 \\
\hline 166 & 137.1 & 106.7 & 1.699 & 0.433 & 0.2 & .9 & 114.0 & 1.692 & .456 & .209 \\
\hline 167 & 13 & 108.6 & 1. & 0.436 & 0 & 9 & 11 & & 60 & 211 \\
\hline 168 & 13 & 110.6 & 1.709 & 0.440 & 0. & .9 & 118.3 & 1.702 & .0 .464 & 0.213 \\
\hline 169 & 13 & 112.6 & 1. & 0.444 & 0.208 & & .5 & 1.707 & 0.468 & 0.215 \\
\hline 170 & 140.9 & 114.8 & 1.719 & $\cdot 0.448$ & 0.210 & 146.8 & 122.7 & 1.711 & 0.472 & 0.216 \\
\hline 171 & 14 & 116.7 & 1 & & & & & 16 & & \\
\hline 172 & 142.8 & 118.9 & 1.729 & 0.456 & 0. & .8 & 127.3 & 1.721 & 0.480 & 0.220 \\
\hline 173 & 143.7 & 121.0 & 1.734 & 0.459 & 0.215 & .8 & 129.6 & 1.726 & 0.484 & 0.222 \\
\hline 174 & 144.7 & 123.2 & 1.738 & 0.463 & 0.217 & 150.8 & 132.0 & 1.731 & 0.488 & 0.223 \\
\hline 175 & 145.6 & 125.4 & 1.743 & 0.467 & 0.218 & 151.8 & 134.4 & 1.735 & 0.492 & 0.225 \\
\hline 176 & 146.6 & 127.7 & 1.748 & 0.471 & 0.220 & .7 & 136.8 & 40 & .496 & 0.227 \\
\hline 177 & 147.5 & 130.0 & 1.753 & 0.475 & 0.222 & 153.7 & 139.3 & 1.745 & 0.500 & 0.229 \\
\hline 178 & 148.5 & 132.3 & 1.757 & 0.479 & 0.224 & 154.7 & 141.9 & 1.750 & 0.504 & 0.231 \\
\hline 179 & 149.4 & 134.6 & 1.762 & 0.483 & 0.225 & 155.7 & 144.4 & 1.754 & 0.508 & 0.232 \\
\hline 180 & 150.4 & 137.0 & 1.767 & 0.486 & 0.227 & 156.7 & 147.1 & 1.759 & 0.512 & 0.234 \\
\hline 181 & 151.3 & 139.5 & 1.771 & 0.490 & & & & 1.764 & & 0.236 \\
\hline 182 & 152.3 & 142.0 & 1.776 & 0.494 & 0.231 & 158.6 & 152.4 & 1.768 & 0.520 & 0.238 \\
\hline 183 & 153.2 & 144.5 & 1.781 & 0.498 & 0.233 & 159.6 & 155.2 & 1.773 & 0.524 & 0.240 \\
\hline 184 & 154.1 & 147.0 & 1.785 & 0.502 & 0.234 & 160.6 & 158.0 & 1.778 & 0.528 & 0.242 \\
\hline 185 & 155.1 & 149.6 & 1.790 & 0.506 & 0.236 & 161.5 & 160.8 & 1.782 & 0.532 & 0.244 \\
\hline 186 & 156.0 & 152.3 & 1.795 & 0.510 & 0.238 & 162.5 & 163.7 & 1.787 & 0.536 & 0.246 \\
\hline 187 & 157.0 & 155.0 & 1.799 & 0.513 & 0.240 & 163.5 & 166.6 & 1.791 & 0.540 & 0.248 \\
\hline 188 & 157.9 & 157.7 & 1.804 & 0.517 & 0.242 & 164.5 & 169.6 & 1.796 & 0.544 & 0.250 \\
\hline
\end{tabular}


TABLE 68-Continued

\begin{tabular}{|c|c|c|c|c|c|c|c|c|c|c|}
\hline & & v & & & & & & $\Delta L$ & & \\
\hline & & & Weight & gms. & & & & Weight & in gms. & \\
\hline & & & Brain & $\begin{array}{l}\text { Spinal } \\
\text { cord }\end{array}$ & & & & Brain & $\begin{array}{c}\text { Spinal } \\
\text { cord }\end{array}$ & \\
\hline$m m$. & $\mathrm{mm}$. & gms. & & & $g m s$. & $\mathrm{mm}$. & gms. & & & $g m s$. \\
\hline 189 & 158.9 & 160.5 & 1.808 & 0.521 & 0.244 & 165.4 & 172.6 & 1.801 & 0.548 & 0.252 \\
\hline 190 & 159.8 & 163.3 & 1.813 & 0.525 & 0.246 & 166.4 & 175.7 & 1.805 & 0.552 & 0.254 \\
\hline 191 & 160.7 & 166.2 & 1.818 & 0.529 & 0.248 & 167.4 & 178.8 & 1.810 & 0.556 & 0.256 \\
\hline 192 & 161.7 & 169.1 & 1.822 & 0.533 & 0.250 & 168.4 & 182.0 & 1.814 & 0.560 & 0.258 \\
\hline 193 & 162.6 & 172.0 & 1.827 & 0.537 & 0.252 & 169.3 & 185.2 & 1.819 & 0.564 & 0.261 \\
\hline 194 & 163.6 & 175.0 & 1.831 & 0.541 & 0.2 & 170.3 & 188.5 & 1.823 & 0.569 & 0.263 \\
\hline 195 & 164.5 & 178.1 & 1.8 & 0 . & 0.2 & 17 & .9 & 28 & 73 & 0.265 \\
\hline 196 & 165.4 & 181.2 & 1.840 & 0.548 & 0.258 & 172.2 & 195.3 & 1. & 0.577 & 0.267 \\
\hline 197 & 166.4 & 184.3 & 1.845 & 0.552 & 0.260 & 173.2 & 198.7 & 1.837 & 0.581 & 0.269 \\
\hline 198 & 167.3 & 187.5 & 1.849 & 0.556 & 0.262 & 174.2 & 202.2 & 1.841 & 0.585 & 0.272 \\
\hline 199 & 168.3 & 190.8 & 1.854 & 0.560 & 0.2 & .1 & 205.8 & 46 & 89 & 0.274 \\
\hline 200 & 169.2 & 194.1 & 1.858 & 0.564 & 0.266 & 176.1 & 209.4 & 1.850 & 0.593 & 0.276 \\
\hline 201 & 170.1 & 197.4 & 1.863 & 0.568 & 0 & .1 & .1 & 1. & 0.597 & 0.278 \\
\hline 202 & 171.1 & 200.8 & 1.867 & 0.572 & 0.271 & 178.0 & 216.8 & 1.859 & 0.601 & 0.281 \\
\hline 203 & 172.0 & 204.3 & 1.872 & 0.576 & $0.2^{\prime}$ & 179.0 & 220.7 & 1.864 & 0.605 & 0.283 \\
\hline 204 & 172.9 & 207.8 & 1.876 & 0.579 & 0.2 & 0 & 4.5 & 88 & 09 & 286 \\
\hline 205 & 173.9 & 211.4 & 1.880 & 0 . & 0 . & .9 & .4 & 72 & 13 & 0.288 \\
\hline 206 & 174.8 & 215.0 & 1.885 & 0.587 & 0.280 & 181.9 & 232.4 & 1.877 & 0.617 & 0.290 \\
\hline 207 & 175.7 & 218.7 & 1.889 & 0.591 & 0.282 & 182.9 & 236.5 & 1.881 & 0.621 & 0.293 \\
\hline 208 & 176.7 & 222.5 & 1.894 & 0.595 & 0.2 & 183.8 & 240.6 & 1.886 & 0.625 & 0.295 \\
\hline 209 & 177.6 & 226.3 & 1.898 & 0.599 & 0.288 & 184.8 & 244.8 & 1.890 & 0.630 & 0.298 \\
\hline 210 & 178.5 & 230.2 & 1.903 & 0.603 & 0.289 & 185.8 & 249.1 & 1.894 & 0.634 & 0.301 \\
\hline 211 & 179.5 & 234.1 & 1.907 & 0.607 & 0. & & & & 38 & 0.303 \\
\hline 212 & 180.4 & 238.1 & 1.911 & 0.611 & 0.294 & 187.7 & 257.8 & 1.903 & 0.642 & 0.306 \\
\hline 213 & 181.3 & 242.2 & 1.916 & 0.615 & 0.296 & 188.7 & 262.3 & 1.908 & 0.646 & 0.308 \\
\hline 214 & 182.3 & 246.3 & 1.920 & 0.619 & 0.299 & 189.6 & 266.9 & 1.912 & 0.650 & 0.311 \\
\hline 215 & 183.2 & 250.5 & 1.924 & 0.623 & 0.301 & 190.6 & 271.5 & 1.916 & 0.654 & 0.314 \\
\hline 216 & 184.1 & 254.7 & 1.929 & 0.626 & 0.304 & 191.5 & 276.2 & 1.921 & 0.658 & 0.317 \\
\hline 217 & 185.0 & 259.1 & 1.933 & 0.630 & 0.306 & 192.5 & 281.0 & 1.925 & 0.662 & 0.319 \\
\hline 218 & 186.0 & 263.5 & 1.937 & 0.634 & 0.309 & 193.5 & 285.8 & 1.929 & 0.666 & 0.322 \\
\hline 219 & 186.9 & 267.9 & 1.942 & 0.638 & 0.312 & 194.4 & 290.8 & 1.934 & 0.670 & 0.325 \\
\hline 220 & 187.8 & 272.5 & 1.946 & 0.642 & 0.314 & 195.4 & 295.8 & 1.938 & 0.675 & 0.328 \\
\hline 221 & 188.8 & 277.1 & 1.950 & 0.646 & 0. & 196.3 & 300.9 & 1.942 & 0.679 & 0.331 \\
\hline 222 & 189.7 & 281.8 & 1.955 & 0.650 & 0.320 & 197.3 & 306.1 & 1.947 & 0.683 & 0.334 \\
\hline 223 & 190.6 & 286.5 & 1.959 & 0.654 & 0.322 & 198.3 & 311.3 & 1.951 & 0.687 & 0.337 \\
\hline
\end{tabular}


TABLE 68-Concluded

\begin{tabular}{|c|c|c|c|c|c|c|c|c|c|c|}
\hline \multicolumn{6}{|c|}{ MALES } & \multicolumn{5}{|c|}{ FEMALES } \\
\hline \multirow{2}{*}{$\begin{array}{c}\text { Body } \\
\text { length }\end{array}$} & \multirow{2}{*}{$\begin{array}{c}\text { Tail } \\
\text { length }\end{array}$} & \multirow{2}{*}{$\begin{array}{c}\text { Body } \\
\text { weight }\end{array}$} & \multicolumn{2}{|c|}{ Weight in gms. } & \multirow{2}{*}{$\begin{array}{l}\text { Both } \\
\text { eye } \\
\text { balls }\end{array}$} & \multirow{2}{*}{$\begin{array}{c}\text { Tail } \\
\text { length }\end{array}$} & \multirow{2}{*}{$\begin{array}{c}\text { Body } \\
\text { weight }\end{array}$} & \multicolumn{2}{|c|}{ Weight in gms. } & \multirow{2}{*}{$\begin{array}{l}\text { Both } \\
\text { eye- } \\
\text { balls }\end{array}$} \\
\hline & & & Brain & $\begin{array}{c}\text { Spinal } \\
\text { cord }\end{array}$ & & & & Brain & & \\
\hline$m m$. & $m m$. & gms. & & & gms. & $m m$. & gms. & & & ams. \\
\hline 224 & 191.5 & 291.4 & 1.963 & 0.658 & 0.325 & 199.2 & 316.7 & 1.955 & 0.691 & 0.340 \\
\hline 225 & 192.5 & 296.3 & 1.968 & 0.662 & 0.328 & 200.2 & 322.1 & & & 0.343 \\
\hline 226 & 193.4 & 301.3 & 1.972 & 0.666 & 0.331 & 201.1 & 327.7 & 1.964 & & 0.346 \\
\hline 227 & 194.3 & 306.4 & 1.976 & 0.670 & 0.3 & 202.1 & 333.3 & 1.968 & 03 & 349 \\
\hline 228 & 195.3 & 311.5 & 1.981 & 0.673 & 0.337 & 203.0 & 339.0 & 1.972 & 707 & 352 \\
\hline 229 & 196.2 & 316.8 & 1.985 & 0.677 & 0.340 & 204.0 & 344.8 & 1.977 & 0.712 & 0.355 \\
\hline 230 & 197.1 & 322.1 & 1.989 & 0.681 & 0.343 & 205.0 & 350.7 & 81 & 0.716 & 0.359 \\
\hline 23 & 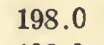 & 327.5 & 1.993 & 0.685 & 0. & & & & 20 & \\
\hline 232 & 198.9 & 333.0 & 1.998 & 0.689 & 0. & 9 & .8 & & 724 & 65 \\
\hline 233 & 199.9 & 338.6 & 2.002 & 0.693 & 0. & .8 & 369.0 & 94 & 0.728 & 369 \\
\hline 234 & 200.8 & 344.3 & 2.006 & 0.697 & 0. & & 375.3 & 98 & 732 & 0.372 \\
\hline 235 & 201.7 & 350.0 & 2.010 & 0.701 & 0.358 & 209.7 & 381.7 & 2.002 & 0.736 & 0.375 \\
\hline 236 & 202.6 & 355.9 & 2.014 & 0.705 & 0.3 & 210.7 & 388.2 & 2.006 & 0.740 & 0.379 \\
\hline 237 & 203.6 & 361.9 & 2.019 & 0.709 & 0. & 6 & 394.9 & 11 & 0.744 & 383 \\
\hline 238 & 204.5 & 367.9 & 2.023 & 0.713 & 0. & & 401.6 & 15 & 0.749 & 0.386 \\
\hline 239 & 205.4 & 374.1 & 2.027 & 0.717 & 0.3 & .5 & 408.4 & 2.019 & 0.753 & 0.390 \\
\hline 240 & 206.3 & 380.3 & 2.031 & 0.721 & 0.375 & 214.5 & 415.4 & 023 & 0.757 & 0.393 \\
\hline 241 & 207.3 & 38 & & 725 & & & .4 & & & \\
\hline 242 & 208.2 & 393.1 & 2.040 & 0.729 & 0.382 & 216.4 & 429.6 & 2.032 & 0.765 & 0.401 \\
\hline 243 & 209.1 & 399.6 & 2.044 & 0.733 & 0.385 & 217.3 & 436.9 & 2.036 & 0.769 & 0.405 \\
\hline 244 & 210.0 & 406.3 & 2.048 & 0.737 & 0.3 & 218.3 & 444.3 & 2.040 & 0.773 & 0.409 \\
\hline 245 & 210.9 & 413.1 & 2.052 & 0.741 & 0.392 & 219.2 & 451.9 & 2.044 & 0.777 & 0.413 \\
\hline 246 & 211.9 & 419.9 & 2.057 & 0.745 & 0.396 & 220.2 & 459.5 & 2.049 & 0.782 & 0.417 \\
\hline 247 & 212.8 & 426.9 & 2.061 & 0.748 & 0.400 & 221.1 & 467.3 & 2.053 & 0.786 & 0.421 \\
\hline 248 & 213.7 & 434.0 & 2.065 & 0.752 & 0.403 & 222.1 & 475.2 & 2.057 & 0.790 & 0.425 \\
\hline 249 & 214.6 & 441.2 & 2.069 & 0.756 & 0.407 & 223.1 & 483.3 & 2.061 & 0.794 & 0.429 \\
\hline 250 & 215.5 & 448.5 & 2.073 & 0.760 & 0.411 & 224.0 & 491.5 & 2.065 & 0.798 & 0.433 \\
\hline
\end{tabular}


TABLE 69

Giving for each sex the weights of body, heart, both kidneys, liver and spleen-for each millimeter of body length. See Charts 11,12,13 and 14

\begin{tabular}{|c|c|c|c|c|c|c|c|c|c|c|}
\hline \multicolumn{6}{|c|}{ MALES } & \multicolumn{5}{|c|}{ FEMALes } \\
\hline $\begin{array}{c}\text { Body } \\
\text { length }\end{array}$ & $\underset{\text { weight }}{\text { Body }}$ & Heart & $\begin{array}{c}\text { Both } \\
\text { kidneys }\end{array}$ & Liver & Spleen & $\begin{array}{l}\text { Body } \\
\text { weight }\end{array}$ & Heart & $\begin{array}{c}\text { Both } \\
\text { kidneys }\end{array}$ & Liver & Spleen \\
\hline$m m$. & gms. & $g m s$. & $g m s$. & $g m 8$. & gms. & gms. & gms. & $g m s$. & gms. & gms. \\
\hline 47 & 4.9 & 0.031 & 0.046 & 0.21 & 0.009 & 4.7 & 0.030 & 0.046 & 0.20 & 0.008 \\
\hline 48 & 4.9 & 0.031 & 0.047 & 0.21 & 0.009 & 4.7 & 0.030 & 0.046 & 0.20 & 0.008 \\
\hline 49 & 5.0 & 0.032 & 0.048 & 0.22 & 0.009 & 4.9 & 0.032 & 0.048 & 0.21 & 0.009 \\
\hline 50 & 5.1 & 0.033 & 0.049 & 0.22 & 0.009 & 5.0 & 0.033 & 0.050 & 0.22 & 0.009 \\
\hline 51 & 5.2 & 0.033 & 0.052 & 0.22 & 0.010 & 5.1 & 0.034 & 0.052 & 0.23 & 0.009 \\
\hline 52 & 5.3 & 0.034 & 0.055 & 0.23 & 0.010 & 5.3 & 0.035 & 0.055 & 0.23 & 0.009 \\
\hline 53 & 5.4 & 0.035 & 0.058 & 0.23 & 0.010 & 5.5 & 0.036 & 0.062 & 0.24 & 0.011 \\
\hline 54 & 5.6 & 0.036 & 0.064 & 0.24 & 0.011 & 5.8 & 0.038 & 0.070 & 0.25 & 0.012 \\
\hline 55 & 5.8 & 0.038 & 0.070 & 0.25 & 0.012 & 6.2 & 0.042 & 0.081 & 0.27 & 0.014 \\
\hline 56 & 6.1 & 0.041 & 0.078 & 0.26 & 0.014 & 6.5 & 0.044 & 0.088 & 0.28 & 0.015 \\
\hline 57 & 6.4 & 0.043 & 0.086 & 0.28 & 0.015 & 6.9 & 0.047 & 0.097 & 0.30 & 0.017 \\
\hline 58 & 6.8 & 0.046 & 0.095 & 0.29 & 0.017 & 7.2 & 0.049 & 0.103 & 0.32 & 0.018 \\
\hline 59 & 7.1 & 0.049 & 0.101 & 0.31 & 0.018 & 7.6 & 0.052 & 0.112 & 0.34 & 0.020 \\
\hline 60 & 7.5 & 0.052 & 0.110 & 0.33 & 0.020 & 8.0 & 0.056 & 0.119 & 0.36 & 0.022 \\
\hline 61 & 7.9 & 0.055 & 0.117 & 0.35 & 0.0 & 8.4 & 0 . & 0 . & 0.38 & 0.023 \\
\hline 62 & 8.2 & 0.057 & 0.123 & 0.37 & 0.023 & 8.7 & 0.061 & 0.132 & 0.40 & 0.025 \\
\hline 63 & 8.6 & 0.060 & 0.130 & 0.40 & 0.024 & 9.1 & 0.064 & 0.139 & 0.43 & 0.026 \\
\hline 64 & 9.0 & 0.063 & 0.137 & 0.42 & 0.026 & 9.5 & 0.067 & 0.145 & 0.45 & 0.028 \\
\hline 65 & 9.4 & 0.066 & 0.143 & 0.45 & 0.027 & 9.9 & 0.069 & 0.151 & 0.48 & 0.029 \\
\hline 66 & 9.8 & 0.069 & 0.150 & 0.48 & 0.029 & 10.3 & 0.072 & 0.157 & 0.52 & 0.031 \\
\hline 67 & 10.1 & 0.071 & 0.154 & 0.50 & 0.030 & 10.8 & 0.076 & 0.165 & 0.59 & 0.033 \\
\hline 68 & 10.6 & 0.074 & 0.162 & 0.56 & 0.032 & 11.2 & 0.079 & 0.171 & 0.63 & 0.034 \\
\hline 69 & 11.0 & 0.077 & 0.168 & 0.61 & 0.033 & 11.6 & 0.081 & 0.176 & 0.68 & 0.036 \\
\hline 70 & 11.4 & 0.080 & 0.173 & 0.66 & 0.035 & 12.0 & 0.084 & 0.182 & 0.73 & 0.037 \\
\hline 71 & 11.8 & 0.083 & 0.179 & 0.71 & 0.0 & 12.5 & 0. & 0. & 0.79 & 0.039 \\
\hline 72 & 12.2 & 0.085 & 0.184 & 0.75 & 0.038 & 12.9 & 0.090 & 0.194 & 0.83 & 0.040 \\
\hline 73 & 12.7 & 0.089 & 0.191 & 0.81 & 0.039 & 13.4 & 0.093 & 0.200 & 0.89 & 0.042 \\
\hline 74 & 13.1 & 0.091 & 0.194 & 0.85 & 0.041 & 13.9 & 0.097 & 0.206 & 0.94 & 0.044 \\
\hline 75 & 13.6 & 0.095 & 0.203 & 0.91 & 0.042 & 14.3 & 0.099 & 0.211 & 0.98 & 0.045 \\
\hline 76 & 14.0 & 0.097 & 0.207 & 0.95 & 0.044 & 14.8 & 0.102 & 0.217 & 1.03 & 0.047 \\
\hline 77 & 14.5 & 0.100 & 0.214 & 1.00 & 0.046 & 15.3 & 0.105 & 0.223 & 1.09 & 0.048 \\
\hline 78 & 15.0 & 0.104 & 0.220 & 1.06 & 0.047 & 15.8 & 0.109 & 0.229 & 1.14 & 0.050 \\
\hline 79 & 15.4 & 0.106 & 0.224 & 1.10 & 0.049 & 16.3 & 0.112 & 0.235 & 1.19 & 0.051 \\
\hline 80 & 15.9 & 0.109 & 0.230 & 1.15 & 0.050 & 16.8 & 0.115 & 0.241 & 1.24 & 0.053 \\
\hline
\end{tabular}


TABLE 69-Continued

\begin{tabular}{|c|c|c|c|c|c|c|c|c|c|c|}
\hline \multicolumn{6}{|c|}{ SALEES } & \multicolumn{5}{|c|}{ FEMALES } \\
\hline $\begin{array}{c}\text { Body } \\
\text { length }\end{array}$ & $\underset{\text { weight }}{\text { Body }}$ & Heart & $\begin{array}{c}\text { Both } \\
\text { kidneys }\end{array}$ & Liver & Spleen & $\begin{array}{l}\text { Body } \\
\text { weight }\end{array}$ & Heart & $\begin{array}{c}\text { Both } \\
\text { kidneys }\end{array}$ & Liver & Spleen \\
\hline$m m$. & gms. & gms. & gms. & $g m s$. & $g m s$. & gms. & $g m s$. & gms. & gms. & gms. \\
\hline 81 & 16.4 & 0.112 & 0.236 & 1.20 & 0.052 & 17.3 & 0.118 & 0.246 & 1.28 & 0.055 \\
\hline 82 & 16.9 & 0.115 & 0.242 & 1.24 & 0.053 & 17.9 & 0.121 & 0.253 & 1.34 & 0.057 \\
\hline 83 & 17.4 & 0.118 & 0.247 & 1.29 & 0.055 & & 0.124 & 0.258 & 1.39 & 0.058 \\
\hline 84 & 18.0 & 0.122 & 0.254 & 1.35 & 0.057 & 19.0 & 0.128 & 0.265 & 1.44 & 0.060 \\
\hline 85 & 18.5 & 0.125 & 0.259 & 1.40 & 0.059 & 19.5 & 0.131 & 0.270 & 1.49 & 0.062 \\
\hline 86 & 19.0 & 0.128 & 0.265 & 1.44 & 0.060 & 20.1 & 0.134 & 0.277 & 1.54 & 0.064 \\
\hline 87 & 19.6 & 0.131 & 0.271 & 1.50 & 0.062 & & 0.138 & 0.2 & & 0.065 \\
\hline 88 & 20.1 & 0.134 & 0.277 & 1.54 & 0.0 & 21.2 & 0.141 & 0.2 & 1.64 & 0.067 \\
\hline 89 & 20.7 & 0.138 & 0.283 & 1.59 & 0.0 & 21.8 & 0.144 & 0.294 & 1.69 & 0.069 \\
\hline 90 & 21.3 & 0.141 & 0.289 & 1.64 & 0.067 & 22.4 & 0.147 & 0.300 & 1.74 & 0.071 \\
\hline 91 & 21.9 & 0.14 & 3 & 1 & 0.06 & & & & & 73 \\
\hline 92 & 22.4 & 0.147 & 0.3 & 1.74 & 0.0 & & 0.155 & 0. & 1.84 & 0.075 \\
\hline 93 & 23.0 & 0.151 & 0.306 & 1.79 & 0.072 & 24.3 & 0.158 & 0. & & 0.076 \\
\hline 94 & 23.7 & 0.155 & 0.313 & 1.84 & 0.075 & 25.0 & 0.162 & 0.326 & 1.95 & 0.078 \\
\hline 95 & 24.3 & 0.158 & 0.319 & 1.89 & 0.0 & 25 & 0.165 & 0.3 & 1 & 0.080 \\
\hline 96 & 24.9 & 0.161 & 0.3 & 1.94 & 0.0 & 3 & 0.169 & 0. & & 0.082 \\
\hline 97 & 25.6 & 0.165 & 0.332 & 1.99 & 0. & .0 & 0.172 & 0. & 2.10 & 0.084 \\
\hline 98 & 26.2 & 0.168 & 0.338 & 2.05 & 0.0 & & 0.176 & 0. & & 0.086 \\
\hline 99 & 26.9 & 0.172 & 0.345 & 2.09 & 0.0 & 28.4 & 0.180 & 0.359 & 2.21 & 0.088 \\
\hline 100 & 27.5 & 0.175 & 0.350 & 2.14 & 0.086 & 29.1 & 0.183 & 0.365 & 2.26 & 0.090 \\
\hline 101 & 28.2 & 0.178 & 0.3 & 2.19 & 0 . & & & & & 0.092 \\
\hline 102 & 28.9 & 0.182 & 0.3 & 2.24 & 0.0 & & 0.190 & & 2.36 & 0.094 \\
\hline 103 & 29.6 & 0.186 & 0.370 & 2.29 & 0.0 & 31.3 & 0.194 & 0.3 & 2.41 & 0.097 \\
\hline 104 & 30.3 & 0.189 & 0.377 & 2.34 & 0.09 & 32.0 & 0.198 & 0.392 & 2.46 & 0.099 \\
\hline 105 & 31.1 & 0.193 & 0.384 & 2.40 & 0.096 & 32.8 & 0.202 & 0.400 & 2.52 & 0.101 \\
\hline 106 & 31.8 & 0.197 & 0.390 & 2.45 & 0.098 & 33.6 & 0.206 & 0.407 & 2.57 & 0.103 \\
\hline 107 & 32.5 & 0.200 & 0.397 & 2.50 & 0.100 & 34.4 & 0.209 & 0.414 & 2.63 & 0.106 \\
\hline 108 & 33.3 & 0.204 & 0.404 & 2.55 & 0.102 & 35.2 & 0.213 & 0.421 & 2.68 & 0.108 \\
\hline 109 & 34.1 & 0.208 & 0.411 & 2.61 & 0.105 & 36.0 & 0.217 & 0.428 & 2.73 & 0.110 \\
\hline 110 & 34.9 & 0.212 & 0.419 & 2.66 & 0.107 & 36.9 & 0.221 & 0.436 & 2.79 & 0.113 \\
\hline 111 & 35.7 & 0.216 & 0.426 & 2.71 & & & & & 2.84 & 0.115 \\
\hline 112 & 36.5 & 0.219 & 0.433 & 2.77 & 0.112 & 38.6 & 0.229 & 0.4 & 2.90 & 0.117 \\
\hline 113 & 37.3 & 0.223 & 0.440 & 2.82 & 0.114 & 39.5 & 0.234 & 0.459 & 2.96 & 0.120 \\
\hline 114 & 38.2 & 0.227 & 0.448 & 2.88 & 0.116 & 40.3 & 0.237 & 0.466 & 3.01 & 0.122 \\
\hline 115 & 39.0 & 0.231 & 0.455 & 2.93 & 0.118 & 41.3 & 0.242 & 0.475 & 3.07 & 0.125 \\
\hline 116 & 39.9 & 0.235 & 0.463 & 2.98 & 0.121 & 42.2 & 0.246 & 0.483 & 3.13 & 0.127 \\
\hline 117 & 40.8 & 0.239 & 0.471 & 3.04 & 0.123 & 43.1 & 0.250 & 0.491 & 3.18 & 0.130 \\
\hline
\end{tabular}


TABLE 69-Continued

\begin{tabular}{|c|c|c|c|c|c|c|c|c|c|c|}
\hline \multicolumn{6}{|c|}{ MALES } & \multicolumn{5}{|c|}{ FEMALES } \\
\hline $\begin{array}{r}\text { Body } \\
\text { length }\end{array}$ & $\begin{array}{l}\text { Body } \\
\text { weight }\end{array}$ & Heart & $\begin{array}{c}\text { Both } \\
\text { kidneys }\end{array}$ & Liver & Spleen & $\begin{array}{l}\text { Body } \\
\text { weight }\end{array}$ & Heart & $\begin{array}{c}\text { Both } \\
\text { kidneys }\end{array}$ & Liver & Spleen \\
\hline$m m$. & gms. & gms. & gms. & gms. & gms. & gms. & gms. & gms. & gms. & gms. \\
\hline 118 & 41.6 & 0.243 & 0.478 & 3.09 & 0.126 & 44.1 & 0.254 & 0.499 & 3.24 & 0.133 \\
\hline 119 & 42.6 & 0.248 & 0.486 & 3.15 & 0.128 & 45.0 & 0.258 & 0.507 & 3.29 & .135 \\
\hline 120 & 43.5 & 0.252 & 0.494 & 3.20 & 0.131 & 46.0 & 0.263 & 0.515 & 3.35 & 0.138 \\
\hline 121 & 44.4 & 0.256 & 0.502 & 3.26 & 0.133 & 47.0 & 0.267 & 0.524 & 3.41 & .141 \\
\hline 122 & 45.4 & 0.260 & 0.510 & 3.32 & 0.136 & 48.0 & 0.272 & 0.532 & 3.47 & 0.143 \\
\hline 123 & 46.3 & 0.264 & 0.518 & 3.37 & 0.139 & 49.1 & 0.276 & 0.542 & 3.53 & .146 \\
\hline 124 & 47.3 & 0.269 & 0.526 & 3.43 & 0.1 & 50.1 & 0.281 & 0 . & 3.59 & 149 \\
\hline 125 & 48.3 & 0.273 & 0.535 & 3.49 & 0.1 & 51.2 & 0.285 & 0. & 3.65 & 0.152 \\
\hline 126 & 49.3 & 0.277 & 0.543 & 3.54 & 0.147 & 52.3 & 0.290 & 0.568 & 3.71 & 0.155 \\
\hline 127 & 50.4 & 0.282 & 0.553 & 3.61 & 0.150 & 53.4 & 0.295 & 0.578 & 3.77 & 0.158 \\
\hline 128 & 51.4 & 0.286 & 0.561 & 3.66 & 0.152 & 54.5 & 0.299 & 0. & 3.83 & 0.161 \\
\hline 129 & 52.5 & 0.291 & 0.570 & 3.72 & 0. & .6 & 0.304 & 0 . & 39 & 164 \\
\hline 130 & 53.6 & 0.295 & 0.579 & 3.78 & 0.158 & 56.8 & 0.309 & 0.606 & 3.96 & 0.167 \\
\hline 131 & 54.7 & 0.300 & 0.588 & 3.84 & 0.1 & 58.0 & 0.314 & 0 . & 4.02 & 0.170 \\
\hline 132 & 55.8 & 0.305 & 0.598 & 3.90 & 0.164 & 59.2 & 0.319 & 0.626 & 4.09 & 0.173 \\
\hline 133 & 56.9 & 0.309 & 0.607 & 3.96 & 0.1 & 60.4 & 0.324 & 0. & 15 & 177 \\
\hline 134 & 58.1 & 0.314 & 0.617 & 4.03 & 0.1 & 6 & 0.328 & 0. & 4.21 & 0.180 \\
\hline 135 & 59.3 & 0.319 & 0.626 & 4.09 & 0.174 & 62.9 & 0.334 & 0.656 & 4.28 & 0.183 \\
\hline 136 & 60.5 & 0.324 & 0.636 & 4.15 & 0.177 & 64.2 & 0.339 & 0.666 & 4.35 & 0.187 \\
\hline 137 & 61.7 & 0.329 & 0.646 & 4.22 & 0.180 & 65.5 & 0.344 & 0.677 & 4.41 & 0.190 \\
\hline 138 & 62.9 & 0.334 & 0.656 & 4.28 & 0.1 & 66.8 & 0.349 & 0 . & 48 & 0.194 \\
\hline 139 & 64.1 & 0.338 & 0.666 & 4.34 & 0 . & 68.1 & 0.354 & 0 . & 4.54 & 0.197 \\
\hline 140 & 65.4 & 0.344 & 0.676 & 4.41 & 0.190 & 69.5 & 0.360 & 0.709 & 4.61 & 0.201 \\
\hline 141 & 66.7 & 0.349 & 0.6 & 4.47 & 0. & & & & & $0.20 x$ \\
\hline 142 & 68.0 & 0.354 & 0.697 & 4.54 & 0.197 & 72.3 & 0.370 & 0.732 & 4.75 & 0.208 \\
\hline 143 & 69.3 & 0.359 & 0.708 & 4.60 & 0.2 & 73.7 & 0.376 & 0.743 & 4.82 & 0.212 \\
\hline 144 & 70.7 & 0.364 & 0.719 & 4.67 & 0.204 & 75.2 & 0.382 & 0.755 & 4.89 & 0.216 \\
\hline 145 & 72.1 & 0.370 & 0.730 & 4.74 & 0.208 & 76.7 & 0.387 & 0.767 & 4.97 & 0.220 \\
\hline 146 & 73.5 & 0.375 & 0.741 & 4.81 & 0.211 & 78.2 & 0.393 & 0.779 & 5.04 & 0.224 \\
\hline 147 & 74.9 & 0.380 & 0.752 & 4.88 & 0.215 & 79.7 & 0.399 & 0.791 & 5.11 & 0.228 \\
\hline 148 & 76.3 & 0.386 & 0.764 & 4.95 & 0.219 & 81.3 & 0.405 & 0.803 & 5.19 & 0.232 \\
\hline 149 & 77.8 & 0.391 & 0.775 & 5.02 & 0.223 & 82.8 & 0.410 & 0.815 & 5.26 & 0.236 \\
\hline 150 & 79.3 & 0.397 & 0.787 & 5.09 & 0.227 & 84.4 & 0.416 & 0.828 & 5.33 & 0.240 \\
\hline 151 & 80.8 & 0.403 & 0.799 & 5.16 & 0.230 & 80.1 & 0.422 & & 5.41 & 0.244 \\
\hline 152 & 82.4 & 0.409 & 0.812 & 5.24 & 0.235 & 87.7 & 0.428 & 0.854 & 5.48 & 0.248 \\
\hline 153 & 83.9 & 0.414 & 0.824 & 5.31 & 0.239 & 89.4 & 0.435 & 0.867 & 5.56 & 0.253 \\
\hline
\end{tabular}


TABLE 69-Continued

\begin{tabular}{|c|c|c|c|c|c|c|c|c|c|c|}
\hline \multicolumn{6}{|c|}{ MALES } & \multicolumn{5}{|c|}{ FEMALES } \\
\hline $\begin{array}{c}\text { Body } \\
\text { length }\end{array}$ & $\underset{\text { weight }}{\text { Body }}$ & Heart & $\underset{\text { kidneys }}{\text { Both }}$ & Liver & Spleen & $\begin{array}{l}\text { Body } \\
\text { weight }\end{array}$ & Heart & $\underset{\text { kidneys }}{\text { Both }}$ & Liver & Spleen \\
\hline$m m$. & gms. & oms. & gms. & gms. & gms. & gms. & ms. & oms. & s. & ms. \\
\hline 154 & 85.5 & 0.420 & 0.836 & 5.38 & 0.243 & 91.1 & 0.441 & 0.880 & 5.64 & 0.257 \\
\hline 155 & 87.1 & 0.426 & 0.849 & 5.46 & 0.247 & 92.9 & 0.447 & 0.894 & 5.72 & 0.262 \\
\hline 156 & 88.7 & 0.432 & 0.862 & 5.53 & 0.251 & 94.6 & 0.453 & 0.908 & 5.80 & 0.266 \\
\hline 157 & 90.4 & 0.438 & 0.875 & 5.61 & 0.255 & 96.4 & 0.460 & 0.922 & & \\
\hline 158 & 92.1 & 0.444 & 0.888 & 5.68 & 0.260 & 98.3 & 0.467 & 0.937 & & \\
\hline 159 & 93.8 & 0.450 & 0.901 & 5.76 & 0.2 & 100.1 & 0.473 & 0 . & & \\
\hline 160 & 95.6 & 0.457 & 0.916 & 5.84 & 0.269 & 102.0 & 0.480 & 0.965 & 6.12 & 0.285 \\
\hline 16 & 97.3 & 0.463 & 0.929 & 5.92 & 0. & 1 & 0.486 & 0. & 21 & 0 \\
\hline 162 & 99.2 & 0.470 & 0.944 & 6.00 & 0.278 & .9 & 0.493 & 0 . & 29 & \\
\hline 163 & 101.0 & 0.476 & 0.9 & 6.08 & 0.2 & 9 & 00 & & & \\
\hline 164 & 102.8 & 0.483 & 0.9 & 6.16 & 0.2 & .9 & 0.507 & & 47 & \\
\hline 16 & 104.7 & 0.489 & 0.986 & 6.24 & 0.2 & .9 & 0.514 & & & 311 \\
\hline 166 & 106.7 & 0.496 & 1.002 & 6.33 & 0 & 114.0 & 0.522 & & 64 & 16 \\
\hline 167 & 108.6 & 0.502 & 1.016 & 6.41 & 0.3 & .1 & 0.529 & 4 & 73 & \\
\hline 168 & 11 & 0.510 & 1.032 & 6.50 & 0. & 3 & 0.536 & 1 & & \\
\hline 169 & 112.6 & 0.517 & 1. & 6 & 0 . & .5 & 0.544 & 1. & 6.92 & 333 \\
\hline 170 & 114.7 & 0.524 & 1.063 & 6. & 0.318 & .7 & 0.551 & 1.125 & 7.01 & 0.339 \\
\hline 17 & & & & & & & & & & \\
\hline 172 & 11 & 0.538 & 1.096 & 6.85 & 0. & .3 & 67 & 30 & .20 & \\
\hline 173 & 121.0 & 0.545 & 1. & 6.94 & 0 . & .6 & 0.575 & 78 & 7.29 & 356 \\
\hline 174 & 123.2 & 0.553 & 1.129 & 7.03 & 0. & & 0.583 & 1. & 7.39 & 362 \\
\hline 175 & 125.4 & 0.560 & 1.145 & 7.12 & 0.3 & 134.4 & 0.591 & 1.2 & 7.49 & 0.368 \\
\hline 176 & 127.7 & 0.568 & 1.163 & 7.22 & 0 . & 136.8 & 0.599 & 1. & 7.59 & 0.375 \\
\hline 177 & 130.0 & 0.576 & 1.1 & 7.31 & 0 . & 139.3 & 0.607 & 51 & 7.69 & 0.381 \\
\hline 178 & 132.3 & 0.584 & 1.198 & 7.40 & 0.3 & 141.9 & 0.615 & 1.271 & 7.79 & 0.387 \\
\hline 179 & 134.6 & 0.591 & 1.216 & 7.50 & 0.369 & 144.4 & 0.624 & 1.290 & 7.89 & 0.394 \\
\hline 180 & 137.0 & 0.599 & 1.234 & 7.60 & 0.375 & & 0.632 & 1.311 & 8.00 & 0.401 \\
\hline 181 & 139.5 & 0 & 1. & 7 & 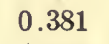 & & & & & \\
\hline 182 & 142.0 & 0.616 & 1.272 & 7.80 & 0.388 & 152.4 & 0.650 & 1.351 & 8.21 & 0.414 \\
\hline 183 & 144.5 & 0.622 & 1.291 & 7.90 & 0.394 & 155.2 & 0.659 & 1.372 & 8.32 & 0.421 \\
\hline 184 & 147.0 & 0.632 & 1.310 & 8.00 & 0.400 & 158.0 & 0.668 & 1.393 & 8.43 & 0.428 \\
\hline 185 & 149.6 & 0.641 & 1.330 & 8.10 & 0.407 & 160.8 & 0.677 & 1.414 & 8.54 & 0.435 \\
\hline 186 & 152.3 & 0.649 & 1.350 & 8.21 & 0.414 & 163.7 & 0.686 & 1.436 & 8.65 & 0.443 \\
\hline 187 & 155.0 & 0.658 & 1.370 & 8.31 & 0.421 & 166.6 & 0.696 & 1.458 & 8.77 & 0.450 \\
\hline 188 & 157.7 & 0.667 & 1.391 & 8.42 & 0.428 & 169.6 & 0.705 & 1.481 & 8.88 & 0.458 \\
\hline 189 & 160.5 & 0.676 & 1.412 & 8.53 & 0.435 & 172.6 & 0.715 & 1.503 & 9.00 & 0.465 \\
\hline 190 & 163.3 & 0.685 & 1.433 & 8.64 & 0.442 & 175.7 & 0.725 & 1.526 & 9.12 & 0.473 \\
\hline
\end{tabular}


TABLE $69-$ Continued

\begin{tabular}{|c|c|c|c|c|c|c|c|c|c|c|}
\hline \multicolumn{6}{|c|}{ MALES } & \multicolumn{5}{|c|}{ FEMALES } \\
\hline $\begin{array}{c}\text { Body } \\
\text { length }\end{array}$ & $\begin{array}{c}\text { Bodyy } \\
\text { weight }\end{array}$ & Heart & $\begin{array}{c}\text { Both } \\
\text { kidneys }\end{array}$ & Liver & Spleen & $\begin{array}{l}\text { Body } \\
\text { weight }\end{array}$ & Heart & $\underset{\text { kidneys }}{\text { Both }}$ & Liver & Spleen \\
\hline$m m$ & gms. & gms. & gms. & gms. & gms. & gms. & gms. & gms. & gms. & gms. \\
\hline 191 & 166.2 & 0.694 & 1.455 & 8.75 & 0.449 & 178.8 & 0.734 & 1.550 & 9.23 & 0.481 \\
\hline 192 & 169.1 & 0.704 & 1.477 & & 0.4 & 182.0 & 0.744 & & & 489 \\
\hline 193 & 172.0 & 0.713 & 1.499 & 8.98 & 0.464 & 185.2 & $0.755^{\circ}$ & 1.598 & 9.48 & 0.497 \\
\hline 194 & 175.0 & 0.722 & 1.521 & 9.09 & 0.471 & & 0.765 & 1.622 & 9.60 & 0.505 \\
\hline 195 & 178.1 & 0.732 & 1.544 & 9.21 & 0.479 & 191.9 & 0.776 & 1.6 & 9.73 & 0.514 \\
\hline 196 & 181.2 & 0.742 & 1.568 & 9.33 & 0.487 & 195.3 & 0.786 & 1.6 & & \\
\hline 197 & 184.3 & 0.752 & 1.5 & 9.45 & 0.4 & & 0.797 & 1. & & 531 \\
\hline 198 & 187.5 & 0.762 & 1.615 & 9.57 & 0.5 & 202.2 & 0.808 & 1.725 & 10.12 & 0.540 \\
\hline 199 & 190.8 & 0.772 & 1.640 & 9.69 & 0.5 & & 0.819 & 1.752 & & \\
\hline 20 & & 0.782 & 1.6 & & & & & & & \\
\hline 20. & 19 & & 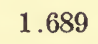 & & & & & & & \\
\hline 202 & 200.8 & 0.803 & 1.714 & 10 & 0 . & & & & & \\
\hline 203 & 204.3 & 0.814 & 1.740 & 10. & 0. & & 0. & & & \\
\hline 204 & 207.8 & 0.825 & 1.767 & 10 . & 0. & & 0. & & & 0.596 \\
\hline 205 & 211.4 & 0.836 & 1.793 & 10. & 0.5 & 4 & 0.8 & 0 & 9 & 06 \\
\hline 206 & 21 & 0.847 & 1.820 & 10. & 0.5 & & & & & \\
\hline 207 & 21 & 0.859 & 1.8 & 10 & 0 & & 13 & & & 26 \\
\hline 208 & 222 & 0.870 & 1.8 & 10. & & & & & & 0.636 \\
\hline 209 & & 0.882 & & & & & & & & \\
\hline 210 & 230.2 & 0.894 & 1.933 & 11.15 & 0.610 & & 0.951 & 2.074 & 11.84 & 0.657 \\
\hline 211 & & & & & & & & & & \\
\hline 212 & 23 & 0.9 & 1.9 & 11 & & & & & & 0.679 \\
\hline 213 & 242.2 & 0.930 & 2.023 & 11. & & & & & & 0.691 \\
\hline 214 & 246.3 & 0.942 & 2.053 & 11.74 & 0. & 9 & 1.004 & 2.2 & 12 & 0.702 \\
\hline 215 & 250.5 & 0.955 & 2.084 & 11.89 & 0.6 & 271.5 & 1.018 & 2.239 & 12.64 & 0.713 \\
\hline 216 & 254.7 & 0.968 & 2.115 & 12.04 & 0.6 & 276.2 & 1.032 & 2.274 & 12.80 & 0.725 \\
\hline 217 & 259.1 & 0.981 & 2.148 & 12.20 & 0.6 & 281.0 & 1.046 & 2.310 & 12.97 & 0.737 \\
\hline 218 & 263.5 & 0.994 & 2.180 & 12.35 & 0.694 & & 1.060 & 2.345 & 13.14 & 0.749 \\
\hline 219 & 267.9 & 1.007 & 2.213 & 12.50 & 0.704 & 290.8 & 1.075 & 2.382 & & 0.762 \\
\hline 220 & 272.5 & 1.021 & 2.247 & 12.67 & 0.716 & 295.8 & 1.090 & 2.419 & 13.50 & 0.774 \\
\hline 221 & 277.1 & 10 & 2.281 & & & & & & & \\
\hline 222 & 281.8 & 1.048 & 2.316 & 13.00 & 0.739 & 306.1 & 1.120 & 2.495 & 13.86 & 0.800 \\
\hline 223 & 286.5 & 1.062 & 2.350 & 13.17 & 0.751 & 311.3 & 1.135 & 2.533 & 14.04 & 0.813 \\
\hline 224 & 291.4 & 1.077 & 2.386 & 13.34 & 0.763 & 316.7 & 1.151 & 2.573 & 14.23 & 0.826 \\
\hline 225 & 296.3 & 1.091 & 2.423 & 13.51 & 0.775 & 322.1 & 1.167 & 2.613 & 14.41 & 0.840 \\
\hline 226 & 301.3 & 1.106 & 2.460 & 13.69 & 0.788 & 327.7 & 1.183 & 2.654 & 14.61 & 0.854 \\
\hline 227 & 306.4 & 1.121 & 2.497 & 13.87 & 0.801 & 333.3 & 1.200 & 2.695 & 14.80 & 0.868 \\
\hline
\end{tabular}


TABLE $69-$ Concluded

\begin{tabular}{|c|c|c|c|c|c|c|c|c|c|c|}
\hline \multicolumn{6}{|c|}{ MALES } & \multicolumn{5}{|c|}{ FEMALES } \\
\hline $\begin{array}{l}\text { Body } \\
\text { length }\end{array}$ & $\underset{\text { weight }}{\text { Body }}$ & Heart & $\begin{array}{c}\text { Both } \\
\text { kidneys }\end{array}$ & Liver & Spleen & $\underset{\text { weight }}{\text { Body }}$ & Heart & $\underset{\text { kidneys }}{\text { Both }}$ & Liver & Spleen \\
\hline$m m$. & gms. & gms. & gms. & gms. & $g m s$. & gms. & gms. & gms. & gms. & oms. \\
\hline 228 & 311.5 & 1.136 & 2.535 & 14.05 & 0.813 & 339.0 & 1.216 & 2.737 & 15.00 & 0.882 \\
\hline 229 & 316.8 & 1.152 & 2.574 & 14.23 & 6 & & 33 & & 20 & .896 \\
\hline 230 & 322.1 & 1.167 & 2.613 & 14.41 & 0.8 & 3 & 1.250 & 2.823 & 15.40 & 0.911 \\
\hline 231 & 327.5 & 1.183 & 2.652 & 14.60 & & 7 & 1.268 & 67 & 61 & 0. \\
\hline 232 & 333.0 & 1.199 & 2.693 & 14.79 & 0.867 & 362.8 & 1.285 & 2.912 & 15.82 & 0.941 \\
\hline 23 & 33 & 1.215 & 2.734 & 14.99 & 0 . & & 03 & & 3 & \\
\hline 234 & 344 & 1.232 & 2.776 & 15 & 0 . & .3 & 21 & & 24 & 972 \\
\hline 235 & 350.0 & 1.248 & 2.818 & 15.38 & 0.909 & .7 & 1.340 & 3. & 16.46 & 0.988 \\
\hline 236 & 355.9 & 1.265 & 2.861 & 15.58 & 0.9 & .2 & 1.358 & 3.098 & 16.68 & 1.004 \\
\hline 237 & 361.9 & 1.283 & 2.905 & 15.79 & 0.9 & 94.9 & 1.377 & 3.147 & 16.91 & 1.021 \\
\hline 238 & 367.9 & 1.300 & 2.949 & 15.99 & 0. & 6 & 1.397 & 3.196 & 17.14 & 37 \\
\hline 239 & 374.1 & 1.318 & 2.995 & 16.20 & 0. & .4 & 1.416 & 3.246 & 17.37 & .054 \\
\hline 240 & 380.3 & 1.336 & 3.040 & 16.42 & 0.98 & 415.4 & 1.436 & 3.297 & 17.61 & 1.072 \\
\hline 241 & & 1.354 & 3.086 & 16. & & & 1.456 & & & \\
\hline 242 & 393.1 & 1.372 & 3.134 & 16.85 & 1.016 & 429.6 & 1.477 & 3.401 & 18.08 & 1.107 \\
\hline 243 & 399.6 & 1.391 & 3.182 & 17.07 & 1. & .9 & 1.497 & 3.455 & 18.33 & 1.125 \\
\hline 244 & 406.3 & 1.410 & 3.231 & 17.30 & 1.049 & 444.3 & 1.518 & 3.509 & 18.58 & 1.143 \\
\hline 245 & 413.1 & 1.429 & 3.280 & 17.53 & 1.066 & 451.9 & 1.540 & 3.564 & 18.83 & 1.162 \\
\hline 246 & 419.9 & 1.449 & 3.330 & 17.76 & 1.083 & 459.5 & 1.561 & 3.620 & 19.09 & 1.181 \\
\hline 247 & 426.9 & 1.469 & 3.381 & 17.98 & 1.100 & 467.3 & 1.583 & 3.677 & 19.35 & 1.200 \\
\hline 248 & 434.0 & 1.489 & 3.433 & 18.23 & 1.118 & 475.2 & 1.606 & 3.734 & 19.61 & 1.220 \\
\hline 249 & 441.2 & 1.509 & 3.486 & 18.47 & 1.136 & 483.3 & 1.628 & 3.794 & 19.88 & 1.240 \\
\hline 250 & 448.5 & 1.530 & 3.539 & 18.72 & 1.154 & 491.5 & 1.652 & 3.853 & 20.15 & 1.260 \\
\hline
\end{tabular}


TABLE 70

Giving for each sex the weights of body, lungs, blood, alimentary tract and gonads (testes and ovaries) for each millimeter of body length. See Charts 15, 16, 17, 21 and 22.

\begin{tabular}{|c|c|c|c|c|c|c|c|c|c|c|}
\hline \multicolumn{6}{|c|}{ MALES } & \multicolumn{5}{|c|}{ FEMALES } \\
\hline $\begin{array}{c}\text { Body } \\
\text { length }\end{array}$ & $\underset{\text { weight }}{\text { Body }}$ & Lungs & Blood & $\underset{\text { tract }}{\text { Alimen }}$ & Testes & $\begin{array}{c}\text { Body } \\
\text { weight }\end{array}$ & Lungs & Blood & $\underset{\text { tract }}{\text { Alimen. }}$ & Ovaries \\
\hline$m m$. & gms. & gms. & gms. & gms. & $g m s$. & gms. & gms. & gms. & gms. & $g m 8$. \\
\hline 47 & 4.9 & 0.078 & 0.44 & 0.14 & 0.004 & 4.7 & 0.078 & 0.41 & 0.14 & 0.0006 \\
\hline 48 & 4.9 & 0.079 & 0.44 & 0.14 & 0.004 & 4.7 & 0.079 & .41 & .14 & .0006 \\
\hline 49 & 5.0 & 0.080 & 0.45 & 0.15 & 0.004 & 4.9 & 0.080 & 0.43 & 0.15 & 0.0008 \\
\hline 50 & 5.1 & 0.081 & 0.45 & .15 & 0.0 & 0 & 1 & 14 & .15 & 0.0009 \\
\hline 51 & 5.2 & 0.082 & 0.46 & 0.15 & 0.004 & 5.1 & 0.082 & 0.45 & 0.15 & 0.0009 \\
\hline 52 & 5.3 & 0.083 & 0.47 & 0.16 & 0.006 & 5.3 & 0.084 & 0.47 & 0.16 & 0.0010 \\
\hline 53 & 5.4 & 0.085 & 0.48 & 0.16 & 0.006 & 5.5 & 0.086 & 0.49 & 0.16 & 0.0011 \\
\hline 54 & 5.6 & 0.087 & 0.50 & 0.17 & 0.0 & 5.8 & 0.690 & 0 & 0.18 & 0.0013 \\
\hline 55 & 5.8 & 0.090 & 0.51 & 0.18 & 0.0 & 6.2 & 0.0 & 0 & .19 & 015 \\
\hline 56 & 6.1 & 0.093 & $0.53^{\circ}$ & 0.19 & 0.009 & 6.5 & 0.097 & 0.56 & 0.20 & 0.0016 \\
\hline 57 & 6.4 & 0.096 & 0.56 & 0.20 & 0.011 & 6.9 & 0.102 & 0.60 & 0.22 & 0.0019 \\
\hline 58 & 6.8 & 0.101 & 0.59 & 0.21 & 0.013 & 7.2 & 0.105 & 0.62 & 0.23 & 0.0020 \\
\hline 59 & 7.1 & 0.104 & 0.61 & 0.22 & 0.016 & 7.6 & 0.109 & 0.65 & 0.24 & 0.0022 \\
\hline 60 & 7.5 & 0.108 & 0.64 & 0.24 & 0.019 & 8.0 & 0.113 & 0.68 & 0.25 & 0.0024 \\
\hline 61 & 7.9 & 11 & 0 . & 0.25 & 0 . & 8.4 & 0 & & .27 & \\
\hline 62 & 8.2 & 0.115 & 0.69 & 0.26 & 0.0 & 8.7 & 0.120 & 0 & 0.27 & 0.0026 \\
\hline 63 & 8.6 & 0.119 & 0.73 & 0.27 & 0.031 & 9.1 & 0.124 & 0 & 0.28 & 0.0028 \\
\hline 64 & 9.0 & 0.123 & 0.76 & 0.28 & 0.036 & 9.5 & 0.128 & 0.79 & 0.30 & 0.0029 \\
\hline 65 & 9.4 & 0.127 & 0.79 & 0.29 & 0.041 & 9.9 & 0.131 & 0.82 & 0.31 & 0.0031 \\
\hline 66 & 9.8 & 0.130 & 0.82 & 0.30 & 0.047 & 10.3 & 0.135 & 0.85 & 0.34 & 0.0032 \\
\hline 67 & 10.1 & 0.133 & 0.84 & 0.31 & 0.050 & 10.8 & 0.139 & 0.89 & 0.41 & 0.0034 \\
\hline 68 & 10.6 & 0.138 & 0.88 & 0.39 & 0.051 & 11.2 & 0.143 & 0.92 & 0.47 & 0.0035 \\
\hline 69 & 11.0 & 0.141 & 0.91 & 0.44 & 0.052 & 11.6 & 0.146 & 0.95 & 0.52 & 0.0036 \\
\hline 70 & 11.4 & 0.145 & 0.93 & 0.50 & 0.053 & 12.0 & 0.150 & 0.98 & 0.58 & 0.0037 \\
\hline 71 & 11.8 & 0.14 & 0. & 0.55 & 0 & 12.5 & 0.1 & 2 & 34 & 039 \\
\hline 72 & 12.2 & 0.152 & 0.99 & 0.60 & 0.055 & 12.9 & 0.157 & 1.04 & 0.69 & 0.0040 \\
\hline 73 & 12.7 & 0.155 & 1.03 & 0.67 & 0.057 & 13.4 & 0.161 & 1.08 & 0.76 & 0.0041 \\
\hline 74 & 13.1 & 0.159 & 1.06 & 0.72 & 0.058 & 13.9 & 0.165 & 1.12 & 0.82 & 0.0042 \\
\hline 75 & 13.6 & 0.163 & 1.10 & 0.78 & 0.060 & 14.3 & 0.169 & 1.13 & 0.87 & 0.0043 \\
\hline 76 & 14.0 & 0.166 & 1.12 & 0.83 & 0.061 & 14.8 & 0.173 & 1.18 & 0.93 & 0.0044 \\
\hline 77 & 14.5 & 0.170 & 1.16 & 0.89 & 0.063 & 15.3 & 0.177 & 1.22 & 0.99 & 0.0046 \\
\hline 78 & 15.0 & 0.174 & 1.20 & 0.95 & 0.065 & 15.8 & 0.180 & 1.25 & 1.04 & 0.0047 \\
\hline 79 & 15.4 & 0.177 & 1.23 & 1.00 & 0.067 & 16.3 & 0.184 & 1.29 & 1.10 & 0.0048 \\
\hline 80 & 15.9 & 0.181 & 1.26 & 1.05 & 0.069 & 16.8 & 0.188 & 1.33 & 1.16 & 0.00 \\
\hline
\end{tabular}


TABLE 70-Continued

\begin{tabular}{|c|c|c|c|c|c|c|c|c|c|c|}
\hline \multicolumn{6}{|c|}{ MALES } & \multicolumn{5}{|c|}{ EEMALES } \\
\hline $\begin{array}{l}\text { Body } \\
\text { length }\end{array}$ & $\begin{array}{l}\text { Body } \\
\text { weight }\end{array}$ & Lungs & Blood & Alimen. & Testes & $\begin{array}{c}\text { Body } \\
\text { weight }\end{array}$ & Lungs & Blood & $\underset{\text { tract }}{\text { Alimen. }}$ & Ovaries \\
\hline$m m$. & $g m s$. & $g m 8$. & gms. & $g m s$. & gms. & gms. & gms. & gms. & gms. & gms. \\
\hline 81 & 16.4 & 0.185 & 1.30 & 1.11 & .07 & 17.3 & 0.192 & 1.36 & 1.21 & 0,0050 \\
\hline 82 & 16.9 & 0.189 & 1.33 & 1.17 & 0.0 & 17.9 & 0.196 & 0 & 1.28 & 0.0051 \\
\hline 83 & 17.4 & 0.193 & 1.37 & 1.22 & 0.076 & 18.4 & 0.200 & 1.44 & 1.33 & .0052 \\
\hline 84 & 18.0 & 0.197 & 1.41 & 1.29 & 0.078 & 19.0 & 0.204 & 1.48 & 1.39 & 0.0053 \\
\hline 85 & 18.5 & 0.201 & 1.45 & 1.34 & 0.081 & 19.5 & 0.208 & 1.52 & 1.44 & 0.0054 \\
\hline 86 & 19.0 & 0.204 & 1.48 & 1.39 & 0.084 & 20.1 & 0.212 & 1.56 & 1.50 & 0.0055 \\
\hline 87 & 19.6 & 0.209 & 1.52 & 5 & 0. & & 0. & 0 & 6 & 56 \\
\hline 88 & 20.1 & 0.212 & 1.56 & 1.50 & 0.0 & 21.2 & 0.220 & 1 & 1 & 57 \\
\hline 89 & 20.7 & 0.216 & 1.60 & 1.56 & $0.0 s$ & 21.8 & 0.224 & 1.68 & 1.67 & 0.0058 \\
\hline 90 & 21.3 & 0.221 & 1.64 & 1.62 & 0.09 & 22.4 & 0.228 & 1.72 & 1.73 & 0.0058 \\
\hline 91 & 21 & 5 & & & & & & & & \\
\hline 92 & 22.4 & 0.228 & 1.72 & 3 & 0.1 & & 0. & & & \\
\hline 93 & 23.0 & 0.232 & 1.76 & 1.78 & 0.107 & 3 & 0.241 & 1 & 1.90 & \\
\hline 94 & 23.7 & 0.237 & 1.81 & 1.85 & 0.1 & 5.0 & 0.2 & 1 & 6 & .0 \\
\hline 95 & 24.3 & 0.241 & 1.8 & 1. & 0.1 & .6 & 0. & & 2 & \\
\hline 96 & 24.9 & 0 & 1 & 5 & 0 & & & & & \\
\hline 97 & 25.6 & 0.250 & 1.94 & 2.02 & 0.1 & 0 & 0.2 & 2 & 2.14 & 0.0065 \\
\hline 98 & 26.2 & 0.254 & 1.98 & 2.07 & 0.1 & 7 & 0.2 & 2. & 2.20 & 0.0066 \\
\hline 99 & 26.9 & 0.258 & 2.02 & 2.13 & 0.1 & 4 & 0.2 & 2. & 2.25 & 0.0 \\
\hline 100 & 27.5 & 0.262 & 2.06 & 2.18 & 0.140 & 29.1 & 0.273 & 2.17 & 2.31 & 0.0067 \\
\hline 101 & 28 & 0.2 & & & & & & & & \\
\hline 102 & 28.9 & 0.271 & 2.16 & 0 & 0 . & 5 & 0 . & & 42 & 069 \\
\hline 103 & 29.6 & 0.276 & 2.21 & 2.35 & & & 0.2 & 2. & 2.49 & 0.0070 \\
\hline 104 & 30.3 & 0.280 & 2.2 & 2.41 & 0.1 & 32.0 & 0.2 & 2. & 2.54 & 0.0071 \\
\hline 105 & 31.1 & 0.285 & 2.31 & 2.47 & 0.17 & 32.8 & 0.296 & 2.42 & 2.60 & 0.0071 \\
\hline 106 & 31.8 & 0.290 & 2.35 & 2.53 & 0.177 & 33.6 & 0.301 & 2.47 & 2.66 & 0.0072 \\
\hline 107 & 32.5 & 0.294 & 2.40 & 2.58 & 0.1 & 34.4 & 0.306 & 2.53 & 2.72 & 0.0073 \\
\hline 108 & 33.3 & 0.299 & 2.45 & 2.64 & 0.192 & 35.2 & 0.311 & 2.58 & 2.78 & 0.0074 \\
\hline 109 & 34.1 & 0.304 & 2.5 & 270 & 0.2 & 36.0 & 0.316 & 2.63 & 2.84 & 0.0075 \\
\hline 110 & 34.9 & 0.309 & 2.56 & 2.76 & 0.208 & 36.9 & 0.321 & 2.69 & 2.90 & 0.0075 \\
\hline 111 & & & & & & & & & & \\
\hline 112 & 36.5 & 0.319 & 2.66 & 2.88 & 0.225 & 38.6 & & & 3.02 & 0.0077 \\
\hline 113 & 37.3 & 0.324 & 2.72 & 2.93 & 0.234 & 39.5 & 0.337 & 2.86 & 3.09 & 0.0078 \\
\hline 114 & 38.2 & 0.329 & 2.78 & 3.00 & 0.244 & 40.3 & 0.342 & 2.91 & 3.14 & 0.0078 \\
\hline 115 & 39.0 & 0.334 & 2.8 & 3.05 & 0.25 & 41.3 & 0.348 & 2.98 & 3.21 & 0.0079 \\
\hline 116 & 39.9 & 0.339 & 2.89 & 3.11 & 0.264 & 42.2 & 0.353 & 3.04 & 3.27 & 0.0080 \\
\hline 117 & 40.8 & 0.345 & 2.95 & 3.17 & 0.275 & 43.1 & 0.358 & 3.09 & 3.33 & 0.0081 \\
\hline
\end{tabular}


TABLE 70-Continued

\begin{tabular}{|c|c|c|c|c|c|c|c|c|c|c|}
\hline \multicolumn{6}{|c|}{ MALES } & \multicolumn{5}{|c|}{ FEMALES } \\
\hline $\begin{array}{l}\text { Body } \\
\text { length }\end{array}$ & $\underset{\text { weight }}{\text { Body }}$ & Lungs & Blood & Alimen. & Testes & $\begin{array}{c}\text { Body } \\
\text { weight }\end{array}$ & Lungs & Blood & $\begin{array}{c}\text { Alimen } \\
\text { tract }\end{array}$ & Ovaries \\
\hline $\mathrm{mm}$ & gms. & gms. & gms. & gms. & gms. & gms. & $g m s$. & $g m s$. & gms. & gms. \\
\hline 118 & 41.6 & 0.349 & 3.00 & 3.23 & 0.285 & 44.1 & 0.364 & 3.16 & 3.39 & 0.0081 \\
\hline 119 & 42.6 & 0.355 & 3.06 & 3.29 & 0.298 & 0 & 69 & 22 & 45 & .0082 \\
\hline 120 & 43.5 & 0.361 & 3.12 & 3.35 & 0.309 & 46.0 & 0.375 & 3.28 & 3.51 & 0.0083 \\
\hline 121 & 44.4 & 0.366 & 3.18 & 3.41 & 0.3 & 47.0 & 0.3 & 3 & .58 & \\
\hline 122 & 45.4 & 0.372 & 3.24 & 3.47 & 0.3 & 48.0 & 0.3 & & 64 & .0 \\
\hline 123 & 46.3 & 0.377 & 3.30 & 3.53 & 0. & 49.1 & 0 & & & 85 \\
\hline 124 & 47.3 & 0.383 & 3.36 & 3.59 & 0.3 & 50.1 & 0.3 & 3.54 & 77 & 0.0086 \\
\hline 125 & 48.3 & 0.389 & 3.43 & 3.66 & 0.377 & 51.2 & 0.405 & 3.61 & 3.83 & 0.0086 \\
\hline 126 & 49.3 & 0.394 & 3.49 & 3.72 & 0.392 & 52.3 & 0.411 & 3.68 & 3.90 & 0.0087 \\
\hline 127 & 50.4 & 0.401 & 3.56 & 3.78 & 0.4 & 53.4 & 0.418 & & 6 & 0. \\
\hline 128 & 51.4 & 0.406 & 3.63 & 3.84 & 0.4 & 5 & 0.4 & 2 & 3 & 89 \\
\hline 129 & 52.5 & 0.413 & 3.69 & 3.91 & 0.442 & 55.6 & 0.430 & 39 & 4.09 & 0.0089 \\
\hline 130 & 53.6 & 0.419 & 3.76 & 3.97 & 0.460 & 56.8 & 0.437 & 3.97 & 4.15 & 0.0090 \\
\hline 131 & 54.7 & 0.425 & 3. & 4.04 & & & & & 2 & \\
\hline 132 & 55.8 & 0.431 & 3.90 & 4.10 & 0. & 59.2 & 0. & 4 & 29 & \\
\hline 133 & 56.9 & 0.437 & 3.97 & 4.16 & 0.5 & 60.4 & 0.457 & 4.19 & 4.36 & 0.0092 \\
\hline 134 & 58.1 & 0.444 & 4.05 & 4.23 & 0.537 & 61.6 & 0.464 & 4.27 & 4.42 & 0.0093 \\
\hline 135 & 59.3 & 0.451 & 4.12 & 4.30 & 0.5 & 62.9 & 0.471 & 4.35 & 4.49 & 0.0093 \\
\hline 136 & 60.5 & 0.458 & 4.20 & 4.36 & 0.5 & 64.2 & 0.478 & 4.43 & 4.56 & 0.0094 \\
\hline 137 & 61.7 & 0.464 & 4.27 & 4.43 & 0.604 & 65.5 & 0.485 & 1 & 63 & 0.0095 \\
\hline 138 & 62.9 & 0.471 & 4.35 & 4.49 & 0.627 & 66.8 & 0.492 & 4.59 & 4.70 & 0.0099 \\
\hline 139 & 64.1 & 0.477 & 4.42 & 4.56 & 0.651 & 68.1 & 0.499 & 4.67 & 4.77 & 0.0102 \\
\hline 140 & 65.4 & 0.485 & 4.50 & 4.63 & 0.677 & 69.5 & 0.507 & 4.76 & 4.84 & 0.0106 \\
\hline 141 & 66. & 0.492 & 4.5 & 4.70 & & & & & & \\
\hline 142 & 68.0 & 0.499 & 4.66 & 4.76 & 0.731 & 72.3 & 0.5 & 4.93 & 4.98 & 0.0115 \\
\hline 143 & 69.3 & 0.506 & 4.74 & 4.83 & 0.759 & 73.7 & 0.530 & 5.01 & 5.05 & 0.0120 \\
\hline 144 & 70.7 & 0.514 & 4.83 & 4.90 & 0.790 & 75.2 & 0.538 & 5.11 & 5.13 & 0.0126 \\
\hline 145 & 72.1 & 0.521 & 4.92 & 4.97 & 0.821 & 76.7 & 0.546 & 5.20 & 5.20 & 0.0132 \\
\hline 146 & 73.5 & 0.529 & 5.00 & 5.04 & 0.8 & 78.2 & 0.554 & 5.29 & 5.27 & 0.0139 \\
\hline 147 & 74.9 & 0.536 & 5.09 & 5.11 & 0.885 & 79.7 & 0.562 & 5.38 & 5.35 & 0.0147 \\
\hline 148 & 76.3 & 0.544 & 5.17 & 5.18 & 0.918 & 81.3 & 0.571 & 5.48 & 5.42 & 0.0155 \\
\hline 149 & 77.8 & 0.552 & 5.27 & 5.26 & 0.955 & 82.8 & 0.579 & 5.57 & 5.50 & 0.0164 \\
\hline 150 & 79.3 & 0.560 & 5.36 & 5.34 & 0.991 & 84.4 & 0.587 & 5.67 & 5.57 & 0.0173 \\
\hline 151 & 80.8 & 0.568 & 5.45 & 5.40 & 1.0 & 86.1 & & 5.77 & 5.65 & 0 . \\
\hline 152 & 82.4 & 0.577 & 5.54 & 5.48 & 1.055 & 87.7 & 0.605 & 5.86 & 5.72 & 0.0195 \\
\hline 153 & 83.9 & 0.585 & 5.64 & 5.55 & 1.078 & 89.4 & 0.614 & 5.97 & 5.80 & 0.0207 \\
\hline
\end{tabular}


TABLE 70-Continued

\begin{tabular}{|c|c|c|c|c|c|c|c|c|c|c|}
\hline \multicolumn{6}{|c|}{ MALES } & \multicolumn{5}{|c|}{ FEMALES } \\
\hline$\underset{\substack{\text { Body } \\
\text { length }}}{ }$ & $\begin{array}{c}\text { Body } \\
\text { weight }\end{array}$ & Lungs & Blood & $\begin{array}{c}\text { Alimen } \\
\text { tract }\end{array}$ & Testes & $\underset{\text { weight }}{\text { Body }}$ & Lungs & Blood & $\underset{\text { tract }}{\text { Alimen. }}$ & Ovaries \\
\hline$m m$. & gms. & gms. & gms. & gms. & gms. & gms. & gms. & gms. & gms. & gms. \\
\hline 154 & 85.5 & 0.593 & 5.73 & 5.63 & 1.102 & 91.1 & 0.623 & 6.07 & 5.88 & 0.0219 \\
\hline 155 & 87.1 & 0.602 & 5.83 & 5.70 & 1.125 & 92.9 & 0.632 & 6.18 & & 0.0233 \\
\hline 156 & 88.7 & 0.610 & 5.92 & 5.77 & 1.148 & 94.6 & 0.641 & & & 0.0247 \\
\hline 157 & 90.4 & 0.619 & 6.03 & 5.85 & 1.173 & 96.4 & 0.651 & 6.39 & 6.12 & 0.0262 \\
\hline 158 & 92.1 & 0.628 & 6.13 & 5.93 & 1.196 & 98.3 & 0. & 6.50 & & 279 \\
\hline 159 & 93.8 & 0.637 & 6.23 & 6.00 & 1.219 & 100.1 & 0.670 & 6.61 & & 0.0296 \\
\hline 160 & 95.6 & 0.646 & 6.34 & 6.08 & 1.243 & 102.0 & 0.680 & 6.72 & & 0.0314 \\
\hline 161 & 9 & 0 & & & 1 & & & & & \\
\hline 162 & 99.2 & 0.665 & 6 & 24 & 1. & & 0 . & & & 344 \\
\hline 163 & 101.0 & 0.675 & 6.66 & 6.32 & 1.3 & & 0.711 & 7.07 & & 777 \\
\hline 164 & 102.8 & 0.684 & 6.77 & 6.40 & 1.3 & 10 & 0.721 & & & 400 \\
\hline 165 & 104.7 & 0.694 & 6.88 & 6.48 & 1.3 & 111 & 0.731 & 7 & & 11 \\
\hline 166 & 106.7 & 0.704 & 7.00 & 6.56 & 1.3 & & 0 . & & & \\
\hline 167 & 108.6 & 0.714 & 7.11 & 6.65 & 1. & & 0 . & 7 & & 25 \\
\hline 168 & 110.6 & 0.725 & 7.23 & 6.73 & 1.4 & & 0 . & 7. & & 0 \\
\hline 169 & 112.6 & 0.735 & 7.34 & 6.81 & 1.4 & 5 & 0 . & & & 35 \\
\hline 170 & 114.7 & 0.746 & 7.47 & 6.90 & 1.473 & 122.7 & 0.787 & 7.93 & 7.23 & 0.0439 \\
\hline 171 & & 0.756 & & & & & & & & \\
\hline 172 & 118.9 & 0.768 & 7.71 & 7.07 & 1. & 12 & 0. & 8 & & 46 \\
\hline 173 & 121.0 & 0.778 & 7.83 & 7.16 & 1. & 6 & 0 . & 8.33 & 60 & 449 \\
\hline 174 & 123.2 & 0.790 & 7.96 & 7.25 & 1.5 & & & 8.47 & & 452 \\
\hline 175 & 125.4 & 0.801 & 8.09 & 7.33 & 1.5 & & & & & \\
\hline 176 & 127.7 & 0.813 & 8.22 & 7.43 & 1.609 & & 0.8 & & & \\
\hline 177 & 130.0 & 0.824 & 8.36 & 7.52 & 1.632 & 139.3 & 0.8 & 8.89 & 7.88 & 0.0459 \\
\hline 178 & 132.3 & 0.836 & 8.49 & 7.61 & 1. & 9 & 0 . & 9.04 & & 0.0462 \\
\hline 179 & 134.6 & 0.848 & 8.62 & 7.70 & 1.675 & & & & & 0.0464 \\
\hline 180 & 137.0 & 0.860 & 8.76 & 7.79 & 1.698 & & 0.911 & 9.34 & 8.18 & 0.0466 \\
\hline 18 & & & & & & & & & & \\
\hline 182 & 142.0 & 0.886 & 9.05 & 7.98 & 1.7 & & & 10.22 & & 0.0469 \\
\hline 183 & 144.5 & 0.898 & 9.19 & 8.08 & 1.765 & 155.2 & 0.952 & 10.39 & 8.48 & 0.0471 \\
\hline 184 & 147.0 & 0.911 & 9.26 & 8.17 & 1.787 & 158.0 & 0.967 & 10.56 & 8.58 & 0.0473 \\
\hline 185 & 149.6 & 0.924 & 9.33 & 8.27 & 1.809 & 160.8 & 0.981 & 10.73 & 8.69 & 0.0474 \\
\hline 186 & 152.3 & 0.938 & 9.40 & 8.37 & 1.832 & 163.7 & 0.995 & 10.90 & 8.79 & 0.0476 \\
\hline 187 & 155.0 & 0.951 & 9.50 & 8.47 & 1.854 & 166.6 & 1.010 & 11.07 & 8.90 & 0.0477 \\
\hline 188 & 157.7 & 0.965 & 9.64 & 8.57 & 1.876 & 169.6 & 1.025 & 11.25 & 9.01 & 0.0479 \\
\hline 189 & 160.5 & 0.979 & 9.80 & 8.68 & 1.898 & 172.6 & 1.040 & 11.43 & 9.12 & 0.0480 \\
\hline 190 & 163.3 & 0.993 & 9.95 & 8.78 & 1.920 & 175.7 & 1.055 & 11.62 & 9.23 & 0.0482 \\
\hline
\end{tabular}


TABLE 70-Continued

\begin{tabular}{|c|c|c|c|c|c|c|c|c|c|c|}
\hline \multicolumn{6}{|c|}{ MALES } & \multicolumn{5}{|c|}{ FEMALES } \\
\hline $\begin{array}{l}\text { Body } \\
\text { length }\end{array}$ & $\underset{\text { weight }}{\text { Body }}$ & Lungs & Blood & Alimen. & Testes & $\begin{array}{c}\text { Body } \\
\text { weight }\end{array}$ & Lungs & Blood & $\underset{\text { tract }}{\text { Alimen }}$ & es \\
\hline $\mathrm{mm}$. & gms. & gms. & gms. & gms. & gms. & gms. & gms. & gms. & gms. & gms. \\
\hline 191 & 166.2 & 1.008 & 10.11 & 8.88 & 1.942 & 178.8 & 1.071 & 11.80 & 9.34 & .0483 \\
\hline 192 & 169.1 & 1.022 & 10.27 & 8.99 & 1.964 & 0 & 1.087 & 11.99 & 9.45 & .0484 \\
\hline 193 & 172.0 & 1.037 & 10.43 & 9.09 & 1.9 & 2 & 1.103 & 12.18 & 9.56 & 0.0485 \\
\hline 194 & 175.0 & 1.052 & 10.59 & 9.20 & 2.007 & 188.5 & 1.119 & 12.38 & 9.68 & 0.0487 \\
\hline 195 & 178.1 & 1.067 & 10.76 & 9.31 . & 2.030 & 191.9 & 1.136 & 12.58 & 9.80 & 0.0488 \\
\hline 196 & 181.2 & 1.083 & 10.93 & 9.42 & 2.051 & 195.3 & 1.153 & 12.78 & 9.92 & 0.0489 \\
\hline 197 & 184.3 & 1.098 & 11.10 & 9.53 & 2.073 & 1 & 1.170 & 12.98 & 10.03 & 0.0490 \\
\hline 198 & 187.5 & 1.114 & 11.27 & 9.64 & 2.0 & 2 & 1.188 & 13 & 5 & 91 \\
\hline 199 & 190.8 & 1.131 & 11.45 & 9.76 & 2.1 & 20 & 1.206 & 13 & 10.28 & 92 \\
\hline 200 & 194.1 & 1.147 & 11.63 & 9.87 & 2.138 & 209.4 & 1.223 & 13.61 & 10.40 & 0.0493 \\
\hline 201 & 197.4 & 1.164 & 11. & & 2 & & 1.2 & & & \\
\hline 202 & 200.8 & 1.181 & 11.99 & 1 & 2.1 & 8 & 0 & 14 & & \\
\hline 203 & 204.3 & 1.198 & 12.18 & 10. & 2.2 & 22 & 1.279 & 14 & & \\
\hline 204 & 207.8 & 1.215 & 12.36 & 10.35 & 2.224 & 224.5 & 1.298 & 14.48 & 10 & 97 \\
\hline 205 & 211.4 & 1.233 & 12.56 & 10.47 & 2.246 & 228.4 & 1.317 & 14.71 & 11.04 & 0.0498 \\
\hline 206 & 215.0 & 1.251 & 12.75 & 10.59 & 2.267 & 23 & 1.337 & 14 & 1.17 & 0.0 \\
\hline 207 & 218.7 & 1.269 & 12.95 & 10.71 & 2.2 & 2 & 57 & 8 & 1 & 00 \\
\hline 208 & 22 & 1.288 & 13.15 & 10. & 2. & .6 & 1. & 15 & 4 & 01 \\
\hline 209 & 226.3 & 1.307 & 13.35 & 10.97 & 2.3 & 24 & 1.398 & 15 & 11.58 & 0.0502 \\
\hline 210 & 230.2 & 1.326 & 13.46 & 11.10 & 2.354 & 24 & 1.419 & 15.90 & 11.72 & 0.0503 \\
\hline 211 & 234.1 & 1.3 & 13. & & & & & & & \\
\hline 212 & 238.1 & 1.365 & 13.98 & 11.36 & 2.397 & 257.8 & 1.462 & 16.41 & 2.00 & 505 \\
\hline 213 & 242.2 & 1.386 & 14.19 & 11.49 & 2.418 & 26 & 1.484 & 16 & 12.14 & 506 \\
\hline 214 & 246.3 & 1.406 & 14.41 & 11.63 & 2.4 & 26 & 1.507 & 16.92 & 29 & 507 \\
\hline 215 & 250.5 & 1.426 & 14.63 & 11.76 & 2.461 & 271.5 & 1.530 & 17.19 & 12.44 & 0.0508 \\
\hline 216 & 254.7 & 1.447 & 14.85 & 11.90 & 2.482 & 276.2 & 1.553 & 17.45 & 12.59 & 0.0508 \\
\hline 217 & 259.1 & 1.469 & 15.08 & 12.04 & 2.503 & 281.0 & 1.576 & 17.73 & 12.74 & 0.0509 \\
\hline 218 & 263.5 & 1.490 & 15.31 & 12.18 & 2.525 & 285.8 & 1.600 & 18.00 & 12.89 & 0.0510 \\
\hline 219 & 267.9 & 1.512 & 15.54 & 12.32 & 2.546 & 290.8 & 1.624 & 18.28 & 13.05 & 0.0511 \\
\hline 220 & 272.5 & 1.534 & 15.78 & 12.47 & 2.567 & 295.8 & 1.648 & 18.57 & 13.21 & 0.0512 \\
\hline 221 & 277.1 & 1.557 & 16. & 12. & & & & & & \\
\hline 222 & 281.8 & 1.580 & 16.26 & 12.77 & 2.609 & 306.1 & 1.705 & 19.15 & 13.53 & 0.0513 \\
\hline 223 & 286.5 & 1.603 & 16.55 & 12.91 & 2.630 & 311.3 & 1.724 & 19.44 & 13.69 & 0.0514 \\
\hline 224 & 291.4 & 1.627 & 16.76 & 13.07 & 2.652 & 3167 & 1.751 & 19.74 & 13.85 & 0.0515 \\
\hline 225 & 296.3 & 1.651 & 17.02 & 13.22 & 2.673 & 322.1 & 1.777 & 20.05 & 14.02 & 0.0516 \\
\hline 226 & 301.3 & 1.675 & 17.27 & 13.38 & 2.694 & 327.7 & 1.804 & 20.36 & 14.19 & 0.0516 \\
\hline 227 & 306.4 & 1.700 & 17.54 & 13.54 & 2.715 & 333.3 & 1.831 & 20.67 & 14.36 & 0.0517 \\
\hline
\end{tabular}


TABLE 70-Concluded

\begin{tabular}{|c|c|c|c|c|c|c|c|c|c|c|}
\hline \multicolumn{6}{|c|}{ MALES } & \multicolumn{5}{|c|}{ FEMALES } \\
\hline$\underset{\substack{\text { Bength } \\
\text { lenth }}}{ }$ & $\underset{\text { weight }}{\text { Body }}$ & Lungs & Blood & Alimen. & Testes & $\underset{\text { weight }}{\text { Body }}$ & Lungs & Blood & $\underset{\text { tract }}{\text { Alimen. }}$ & Ovaries \\
\hline$m m$ & gms. & gms. & gms. & gms. & gms. & gms. & gms. & gms. & oms. & gms. \\
\hline 228 & 311.5 & 1.725 & 17.80 & 13.74 & 2.736 & 339.0 & 1.859 & 20.99 & 14.54 & 0.0518 \\
\hline 229 & 316.8 & 1.751 & 18.07 & 13.86 & 2.757 & 344.8 & 1.887 & 21.31 & 14.71 & 0.0519 \\
\hline 230 & 322.1 & 1.777 & 18.34 & 14.02 & 2.778 & 350.7 & 1.916 & 21.64 & 14.89 & 0.0519 \\
\hline 231 & 327.5 & 1.803 & 18.62 & 14.19 & 2.799 & 356.7 & 1.945 & 21.97 & 15.07 & 0.0520 \\
\hline 232 & 333.0 & 1.830 & 18.90 & 14.35 & 2.820 & 362.8 & 1.975 & 22.31 & 15.26 & 0.0521 \\
\hline 233 & 338.6 & 1.857 & 19.19 & 14.52 & 2.841 & 369.0 & 2.005 & 22.65 & 15.44 & 0.0522 \\
\hline 234 & 344.3 & 1.885 & 19.47 & 14.68 & 2.862 & 375.3 & 2.035 & 23.00 & 15.63 & 0.0522 \\
\hline 235 & 350.0 & 1.913 & 19.77 & 14.87 & 2.883 & 381.7 & 2.067 & 23.35 & 15.82 & 0.0523 \\
\hline 236 & 355.9 & 1.941 & 20.07 & 15.05 & 2.904 & 388.2 & 2.098 & 23.71 & 16.01 & 0.0524 \\
\hline 237 & 361.9 & 1.970 & 20.37 & 15.23 & 2.926 & 394.9 & 2.130 & 24.08 & 16.21 & 0.0524 \\
\hline 238 & 367.9 & 2.000 & 20.68 & 15.41 & 2.946 & 401.6 & 2.163 & 24.45 & 16.41 & 0.0525 \\
\hline 239 & 374.1 & 2.030 & 20.99 & 15.59 & 2.967 & 408.4 & 2.196 & 24.82 & 16.61 & 0.0526 \\
\hline 240 & 380.3 & 2.060 & 21.30 & 15.78 & 2.988 & 415.4 & 2.230 & 25.20 & 16.82 & 0.0526 \\
\hline 241 & 000.0 & 2.090 & 21.62 & 15.97 & & & 2.264 & & & 0.0527 \\
\hline 242 & 393.1 & 2.122 & 21.95 & 16.16 & 3.030 & 429.6 & 2.298 & 25.98 & 17.23 & 0.0528 \\
\hline 243 & 399.6 & 2.153 & 22.27 & 16.35 & 3.051 & 436.9 & 2.334 & 26.37 & 17.45 & 0.0529 \\
\hline 244 & 406.3 & 2.186 & 22.61 & 16.55 & 3.072 & 444.3 & 2.369 & 26.77 & 17.66 & 0.0529 \\
\hline 245 & 413.1 & 2.219 & 22.95 & 16.75 & 3.093 & 451.9 & 2.406 & 27.18 & 17.88 & 0.0530 \\
\hline 246 & 419.9 & 2.251 & 23.28 & 16.95 & 3.113 & 459.5 & 2.443 & 27.60 & 18.10 & 0.0531 \\
\hline 247 & 426.9 & 2.285 & 23.64 & 17.15 & 3.134 & 467.3 & 2.480 & 28.02 & 18.33 & 0.0531 \\
\hline 248 & 434.0 & 2.320 & 23.99 & 17.36 & 3.155 & 475.2 & 2.518 & 28.45 & 18.55 & 0.0532 \\
\hline 249 & 441.2 & 2.354 & 24.35 & 17.57 & 3.176 & 483.3 & 2.557 & 28.89 & 18.79 & 0.0532 \\
\hline 250 & 448.5 & 2.390 & 24.71 & 17.78 & 3.197 & 491.5 & 2.597 & 29.32 & 19.02 & 0.0533 \\
\hline
\end{tabular}


TABLE 71

Giving for each sex the weights of body, hypophysis, suprarenals and thyroid for each millimeter of body length. See charts 18, 19, and 20.

\begin{tabular}{|c|c|c|c|c|c|c|c|c|}
\hline \multicolumn{5}{|c|}{ MALES } & \multicolumn{4}{|c|}{ FEMALES } \\
\hline 营 & $\begin{array}{l}\text { Body } \\
\text { weight }\end{array}$ & $\begin{array}{l}\text { Hypo- } \\
\text { physis }\end{array}$ & $\begin{array}{l}\text { Supra- } \\
\text { renals }\end{array}$ & Thyroid & Body weight & $\begin{array}{l}\text { Hypo- } \\
\text { physis }\end{array}$ & $\begin{array}{c}\text { Supra- } \\
\text { renals }\end{array}$ & Thyroid \\
\hline$m m$. & gms. & gms. & gms. & gms. & oms. & gms. & gms. & gms. \\
\hline 50 & 5.1 & 0.0005 & 0.0017 & 0.0015 & 5.0 & 0.0005 & 0.0017 & 0.0014 \\
\hline 51 & 5.2 & 0.0005 & 0.0017 & 0.0015 & 5.1 & 0.0005 & 0.0017 & 0.0015 \\
\hline 52 & 5.3 & 0.0005 & 0.0017 & 0.0015 & 5.3 & 0.0005 & 0.0018 & 0.0015 \\
\hline 53 & 5.4 & 0.0005 & 0.0018 & 0.0016 & 5.5 & 0.0006 & 0.0019 & 0.0016 \\
\hline 54 & 5.6 & 0.0005 & 0.0019 & 0.0016 & 5.8 & 0.0006 & 0.0021 & 0.0017 \\
\hline 55 & 5.8 & 0.0006 & 0.0021 & 0.0017 & 6.2 & 0.0006 & 0.0024 & 0.0018 \\
\hline 56 & 6.1 & 0.0006 & 0.0023 & 0.0018 & 6.5 & 0.0006 & 0.0026 & 0.0019 \\
\hline 57 & 6.4 & 0.0006 & 0.0025 & 0.0018 & 6.9 & 0.0007 & 0.0028 & 0.0020 \\
\hline 58 & 6.8 & 0.0007 & 0.0027 & 0.0019 & 7.2 & 0.0007 & 0.0030 & 0.0021 \\
\hline 59 & 7.1 & 0.0007 & 0.0029 & 0.0020 & 7.6 & 0.0007 & 0.0032 & 0.0022 \\
\hline 60 & 7.5 & 0.0007 & 0.0031 & 0.0021 & 8.0 & 0.0008 & 0.0034 & 0.0023 \\
\hline 61 & 7.9 & 0.0008 & 0.0034 & 0.0022 & 8.4 & 0.0008 & 0.0036 & 0.0024 \\
\hline 62 & 8.2 & 0.0008 & 0.0035 & 0.0023 & 8.7 & 0.0008 & 0.0038 & 0.0025 \\
\hline 63 & 8.6 & 0.0008 & 0.0037 & 0.0024 & 9.1 & 0.0009 & 0.0040 & 0.0026 \\
\hline 64 & 9.0 & 0.0009 & 0.0039 & 0.0025 & 9.5 & 0.0009 & 0.0042 & 0.0027 \\
\hline 65 & 9.4 & 0.0009 & 0.0041 & 0.0026 & 9.9 & 0.0009 & 0.0044 & 0.0028 \\
\hline 66 & 9.8 & 0.0009 & 0.0043 & 0.0027 & 10.3 & 0.0009 & 0.0045 & 0.0029 \\
\hline 67 & 10.1 & 0.0009 & 0.0045 & 0.0028 & 10.8 & 0.0010 & 0.0048 & 0.0030 \\
\hline 68 & 10.6 & 0.0010 & 0.0047 & 0.0030 & 11.2 & 0.0010 & 0.0049 & 0.0031 \\
\hline 69 & 11.0 & 0.0010 & 0.0049 & 0.0031 & 11.6 & 0.0010 & 0.0051 & 0.0032 \\
\hline 70 & 11.4 & 0.0010 & 0.0050 & 0.0032 & 12.0 & 0.0011 & 0.0053 & 0.0033 \\
\hline 71 & 11.8 & 0.0011 & 0.0052 & 0.0033 & 12.5 & 0.0011 & 0.0055 & 0.0034 \\
\hline 72 & 12.2 & 0.0011 & 0.0054 & 0.0034 & 12.9 & 0.0011 & 0.0056 & 0.0035 \\
\hline 73 & 12.7 & 0.0011 & 0.0056 & 0.0035 & 13.4 & 0.0012 & 0.0058 & 0.0037 \\
\hline 74 & 13.1 & 0.0011 & 0.0057 & 0.0036 & 13.9 & 0.0012 & 0.0060 & 0.0038 \\
\hline 75 & 13.6 & 0.0012 & 0.0059 & 0.0037 & 14.3 & 0.0012 & 0.0062 & 0.0039 \\
\hline 76 & 14.0 & 0.0012 & 0.0061 & 0.0038 & 14.8 & 0.0012 & 0.0064 & 0.0040 \\
\hline 77 & 14.5 & 0.0012 & 0.0063 & 0.0039 & 15.3 & 0.0013 & 0.0065 & 0.0041 \\
\hline 78 & 15.0 & 0.0013 & 0.0064 & 0.0041 & 15.8 & 0.0013 & 0.0067 & 0.0042 \\
\hline 79 & 15.4 & 0.0013 & 0.0066 & 0.0042 & 16.3 & 0.0013 & 0.0069 & 0.0044 \\
\hline 80 . & 15.9 & 0.0013 & 0.0067 & 0.0043 & 16.8 & 0.0014 & 0.0070 & 0.0045 \\
\hline 81 & 16.4 & 0.0013 & 0.0069 & 0.0044 & 17.3 & 0.0014 & 0.0072 & 0.0046 \\
\hline 82 & 16.9 & 0.0014 & 0.0071 & 0.0045 & 17.9 & 0.0014 & 0.0074 & 0.0047 \\
\hline 83 & 17.4 & 0.0014 & 0.0072 & 0.0046 & 18.4 & 0.0014 & 0.0076 & 0.0049 \\
\hline
\end{tabular}


TABLE 71-Continued

\begin{tabular}{|c|c|c|c|c|c|c|c|c|}
\hline \multicolumn{5}{|c|}{ MALES } & \multicolumn{4}{|c|}{ FEMALES } \\
\hline 总 & $\begin{array}{l}\text { Body } \\
\text { weight }\end{array}$ & $\begin{array}{l}\text { Hypo- } \\
\text { physis }\end{array}$ & $\begin{array}{l}\text { Supra- } \\
\text { renals }\end{array}$ & Thyroid & Body weight & $\begin{array}{l}\text { Hypo- } \\
\text { physis }\end{array}$ & $\begin{array}{l}\text { Supra- } \\
\text { renals }\end{array}$ & Thyroid \\
\hline$m m$. & gms. & gms. & gms. & $g m s$. & gms. & gms. & gms. & $g m s$ \\
\hline 84 & 18.0 & 0.0014 & 0.0074 & 0.0048 & 19.0 & 0.0015 & 0.0078 & 0.0050 \\
\hline 85 & 18.5 & 0.0015 & 0.0076 & 0.0049 & 19.5 & 0.0015 & 0.0079 & 0.0051 \\
\hline 86 & 19.0 & 0.0015 & 0.0078 & 0.0050 & 20.1 & 0.0015 & 0.0081 & 0.0052 \\
\hline 87 & 19.6 . & 0.0015 & 0.0079 & 0.0051 & 20.7 & 0.0016 & 0.0083 & 0.0054 \\
\hline 88 & 20.1 & 0.0015 & 0.0081 & 0.0052 & 21.2 & 0.0016 & 0.0084 & 0.0055 \\
\hline 89 & 20.7 & 0.0016 & 0.0083 & 0.0054 & 21.8 & 0.0016 & 0.0086 & 0.0056 \\
\hline 90 & 21.3 & 0.0016 & 0.0084 & 0.0055 & 22.4 & 0.0017 & 0.0087 & 0.0058 \\
\hline 91 & 21.9 & 0.0016 & 0.0086 & 0.0056 & 23.1 & 0.0017 & 0.0089 & 0.0059 \\
\hline 92 & 22.4 & 0.0017 & 0.0087 & 0.0058 & 23.7 & 0.0017 & 0.0091 & 0.0060 \\
\hline 93 & 23.0 & 0.0017 & 0.0089 & 0.0059 & 24.3 & 0.0017 & .0093 & 0.0062 \\
\hline 94 & 23.7 & 0.0017 & 0.0091 & 0.0060 & 25.0 & 0.0018 & 0.0094 & 0.0063 \\
\hline 95 & 24.3 & 0.0017 & 0.0093 & 0.0062 & 25.6 & 0.0018 & 0.0096 & 0.0064 \\
\hline 96 & 24.9 & 0.0018 & 0.0094 & 0.0063 & 26.3 & 0.0018 & 0.0098 & 0.0066 \\
\hline 97 & 25.6 & 0.0018 & 0.0096 & 0.0064 & 27.0 & 0.0019 & 0.0100 & 0.0067 \\
\hline 98 & 26.2 & 0.0018 & 0.0098 & 0.0066 & 27.7 & 0.0019 & 0.0101 & 0.0069 \\
\hline 99 & 26.9 & 0.0019 & 0.0099 & 0.0067 & 28.4 & 0.0019 & 0.0103 & 0.0070 \\
\hline 100 & 27.5 & 0.0019 & 0.0101 & 0.0068 & 29.1 & 0.0020 & 0.0105 & 0.0072 \\
\hline 101 & 28.2 & & 0.01 & & 8 & & & 073 \\
\hline 102 & 28.9 & 0.0020 & 0.0104 & 0.0071 & 30.5 & 0.0020 & 0.0108 & 0.0075 \\
\hline 103 & 29.6 & 0.0020 & 0.0106 & 0.0073 & 31.3 & 0.0021 & 0.0110 & 0.0076 \\
\hline 104 & 30.3 & 0.0020 & 0.0108 & 0.0074 & 32.0 & 0.0021 & 0.0112 & 0.0078 \\
\hline 105 & 31.1 & 0.0021 & 0.0109 & 0.0076 & 32.8 & 0.0021 & 0.0114 & 0.0079 \\
\hline 106 & 31.8 & 0.0021 & 0.0111 & 0.0077 & 33.6 & 0.0022 & 0.0117 & 0.0081 \\
\hline 107 & 32.5 & 0.0021 & 0.0113 & 0.0079 & 34.4 & 0.0022 & 0.0119 & 0.0082 \\
\hline 108 & 33.3 & 0.0021 & 0.0114 & 0.0080 & 35.2 & 0.0022 & 0.0121 & 0.0084 \\
\hline 109 & 34.1 & 0.0022 & 0.0116 & 0.0082 & 36.0 & 0.0023 & 0.0123 & 0.0085 \\
\hline 110 & 34.9 & 0.0022 & 0.0118 & 0.0083 & 36.9 & 0.0023 & 0.0126 & 0.0087 \\
\hline 111 & 35.7 & 0.0 & 0.0120 & 0.0 & 37.7 & & & 0.0089 \\
\hline 112 & 36.5 & 0.0023 & 0.0121 & 0.0086 & 38.6 & 0.0024 & 0.0130 & 0.0090 \\
\hline 113 & 37.3 & 0.0023 & 0.0123 & 0.0088 & 39.5 & 0.0024 & 0.0133 & 0.0092 \\
\hline 114 & 38.2 & 0.0024 & 0.0125 & 0.0090 & 40.3 & 0.0024 & 0.0135 & 0.0094 \\
\hline 115 & 39.0 & 0.0024 & 0.0126 & 0.0091 & 41.3 & 0.0025 & 0.0138 & 0.0096 \\
\hline 116 & 39.9 & 0.0024 & 0.0128 & 0.0093 & 42.2 & 0.0025 & 0.0140 & 0.0097 \\
\hline 117 & 40.8 & 0.0025 & 0.0130 & 0.0095 & 43.1 & 0.0025 & 0.0143 & 0.0099 \\
\hline 118 & 41.6 & 0.0025 & 0.0132 & 0.0096 & 44.1 & 0.0026 & 0.0145 & 0.0101 \\
\hline 119 & 42.6 & 0.0025 & 0.0134 & 0.0098 & 45.0 & 0.0026 & 0.0148 & 0.0102 \\
\hline 120 & 43.5 & 0.0026 & 0.0135 & 0.0100 & 46.0 & 0.0027 & 0.0150 & 0.0104 \\
\hline
\end{tabular}


TABLE 71-Continued

\begin{tabular}{|c|c|c|c|c|c|c|c|c|}
\hline \multicolumn{5}{|c|}{ MALES } & \multicolumn{4}{|c|}{ FEMALES } \\
\hline 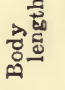 & $\begin{array}{l}\text { Body } \\
\text { weight }\end{array}$ & $\begin{array}{l}\text { Hypo- } \\
\text { physis }\end{array}$ & $\begin{array}{l}\text { Supra- } \\
\text { renals }\end{array}$ & Thyroid & Body weight & $\underset{\text { physis }}{\text { Hypo- }}$ & $\begin{array}{l}\text { Supra- } \\
\text { renals }\end{array}$ & Thyroid \\
\hline$m m$ & oms. & gms. & gms. & oms. & oms. & gms. & gms. & oms. \\
\hline 121 & 44.4 & 0.0026 & 0.0137 & 0.0101 & 47.0 & 0.0027 & 0.0153 & 0.0106 \\
\hline 122 & 45.4 & 0.0026 & 0.0139 & 0.0103 & 48.0 & 0.0027 & 0.0156 & 0.0108 \\
\hline 123 & 46.3 & 0.0027 & 0.0141 & 0.0105 & 49.1 & 0.0028 & 0.0159 & 0.0110 \\
\hline 124 & 47.3 & 0.0027 & 0.0142 & 0.0106 & 50.1 & 0.0028 & 0.0161 & 0.0111 \\
\hline 125 & 48.3 & 0.0027 & 0.0144 & 0.0108 & 51.2 & 0.0029 & 0.0164 & 0.0113 \\
\hline 126 & 49.3 & 0.0028 & 0.0146 & 0.0110 & 52.3 & 0.0029 & 0.0167 & 0.0115 \\
\hline 127 & 50.4 & 0.0028 & 0.0148 & 0.0112 & 53.4 & 0.0030 & 0.0170 & 0.0117 \\
\hline 128 & 51.4 & 0.0029 & 0.0150 & 0.0114 & 54.5 & 0.0031 & 0.0173 & 0.0119 \\
\hline 129 & 52.5 & 0.0029 & 0.0152 & 0.0116 & 55.6 & 0.0031 & 0.0176 & 0.0121 \\
\hline 130 & 53.6 & 0.0029 & 0.0154 & 0.0117 & 56.8 & 0.0032 & 0.0179 & 0.0123 \\
\hline 131 & 54.7 & 0.0030 & 0.0155 & 0.0119 & 58.0 & 0.0033 & 0.0182 & 0.0125 \\
\hline 132 & 55.8 & 0.0030 & 0.0157 & 0.0121 & 59.2 & 0.0034 & 0.0185 & 0.0127 \\
\hline 133 & 56.9 & 0.0031 & 0.0159 & 0.0123 & 60.4 & 0.0035 & 0.0188 & 0.0129 \\
\hline 134 & 58.1 & 0.0031 & 0.0161 & 0.0125 & 61.6 & 0.0035 & 0.0191 & 0.0131 \\
\hline 135 & 59.3 & 0.0031 & 0.0163 & 0.0127 & 62.9 & 0.0036 & 0.0195 & 0.0133 \\
\hline 136 & 60.5 & 0.0032 & 0.0165 & 0.0129 & 64.2 & 0.0037 & 0.0198 & 0.0135 \\
\hline 137 & 61.7 & 0.0032 & 0.0167 & 0.0131 & 65.5 & 0.0038 & 0.0201 & 0.0137 \\
\hline 138 & 62.9 & 0.0033 & 0.0169 & 0.0133 & 66.8 & 0.0039 & 0.0204 & 0.0139 \\
\hline 139 & 64.1 & 0.0033 & 0.0171 & 0.0135 & 68.1 & 0.0040 & 0.0208 & 0.0142 \\
\hline 140 & 65.4 & 0.0034 & 0.0173 & 0.0137 & 69.5 & 0.0041 & 0.0211 & 0.0144 \\
\hline 141 & 66.7 & 0.0034 & 0.0175 & 0.0139 & 70.9 & 0.0042 & 0.0 & 0.0146 \\
\hline 142 & 68.0 & 0.0034 & 0.0177 & 0.0141 & 72.3 & 0.0043 & 0.0218 & 0.0148 \\
\hline 143 & 69.3 & 0.0035 & 0.0179 & 0.0143 & 73.7 & 0.0044 & 0.0222 & 0.0150 \\
\hline 144 & 70.7 & 0.0035 & 0.0181 & 0.0146 & 75.2 & 0.0045 & 0.0226 & 0.0153 \\
\hline 145 & 72.1 & 0.0036 & 0.0183 & 0.0148 & 76.7 & 0.0046 & 0.0230 & 0.0155 \\
\hline 146 & 73.5 & 0.0036 & 0.0185 & 0.0150 & 78.2 & 0.0047 & 0.0233 & 0.0158 \\
\hline 147 & 74.9 & 0.0037 & 0.0187 & 0.0152 & 79.7 & 0.0048 & 0.0237 & 0.0160 \\
\hline 148 & 76.3 & 0.0037 & 0.0189 & 0.0155 & 81.3 & 0.0049 & 0.0241 & 0.0162 \\
\hline 149 & 77.8 & 0.0038 & 0.0192 & 0.0157 & 82.8 & 0.0050 & 0.0245 & 0.0164 \\
\hline 150 & 79.3 & 0.0038 & 0.0194 & 0.0159 & 84.4 & 0.0051 & 0.0249 & 0.0167 \\
\hline 151 & 80.8 & 0.0039 & 0.0196 & 0.0161 & 86.1 & 0.0052 & 0.0253 & 0.0169 \\
\hline 152 & 82.4 & 0.0039 & 0.0198 & 0.0164 & 87.7 & 0.0053 & 0.0257 & 0.0172 \\
\hline 153 & 83.9 & 0.0040 & 0.0200 & 0.0166 & 89.4 & 0.0055 & 0.0261 & 0.0175 \\
\hline 154 & 85.5 & 0.0040 & 0.0203 & 0.0169 & 91.1 & 0.0056 & 0.0266 & 0.0177 \\
\hline 155 & 87.1 & 0.0041 & 0.0205 & 0.0171 & 92.9 & 0.0057 & 0.0270 & 0.0180 \\
\hline 156 & 88.7 & 0.0041 & 0.0207 & 0.0173 & 94.6 & 0.0058 & 0.0274 & 0.0182 \\
\hline 157 & 90.4 & 0.0042 & 0.0210 & 0.0176 & 96.4 & 0.0060 & 0.0279 & 0.0185 \\
\hline
\end{tabular}


TABLE 71-Continued

\begin{tabular}{|c|c|c|c|c|c|c|c|c|}
\hline \multicolumn{5}{|c|}{ MALES } & \multicolumn{4}{|c|}{ FEMALIS } \\
\hline 总 & $\begin{array}{l}\text { Body } \\
\text { weight }\end{array}$ & $\begin{array}{l}\text { Hypo- } \\
\text { physis }\end{array}$ & $\begin{array}{l}\text { Supra- } \\
\text { renals }\end{array}$ & Thyroid & Body weight & $\begin{array}{l}\text { Hypo- } \\
\text { physis }\end{array}$ & $\underset{\text { Supra- }}{\text { renals }}$ & Thyroid \\
\hline$m m$. & gms. & gms. & $g m s$. & gins. & gms. & $g m s$. & gms. & gms. \\
\hline 158 & 92.1 & 0.0042 & 0.0212 & 0.0179 & 98.3 & 0.0061 & 0.0283 & 0.0188 \\
\hline 159 & 93.8 & 0.0043 & 0.0214 & 0.0181 & 100.1 & 0.0062 & .0288 & 0.0190 \\
\hline 160 & 95.6 & 0.0044 & 0.0217 & 0.0184 & 102.0 & 0.0064 & 0.0293 & 0.0193 \\
\hline 161 & 97.3 & 0.0044 & 0.0219 & 0.0186 & 103.9 & 0.0065 & 0.0297 & 0.0196 \\
\hline 162 & 99.2 & 0.0045 & 0.0222 & 0.0189 & 105.9 & 0.0067 & 0.0302 & 0.0199 \\
\hline 163 & 101.0 & 0.0045 & 0.0224 & 0.0191 & 107.9 & 0.0068 & 0.0307 & 0.0201 \\
\hline 164 & 102.8 & 0.0046 & 0.0226 & 0.0194 & 109.9 & 0.0070 & 0.0312 & 0.0204 \\
\hline 165 & 104.7 & 0.0046 & 0.0229 & 0.0197 & 111.9 & 0.0071 & 0.0317 & 0.0207 \\
\hline 166 & 106.7 & 0.0047 & 0.0 & 0.02 & 114 & 0.0073 & 22 & 210 \\
\hline 167 & 108.6 & 0.0048 & 0.0234 & 0.0202 & 116.1 & 0.0074 & 0.0327 & 0.0213 \\
\hline 168 & 110.6 & 0.0048 & 0.0236 & 0.0205 & 118.3 & 0.0076 & 0.0333 & 0.0216 \\
\hline 169 & 112.6 & 0.0049 & 0.0239 & 0.0208 & 120.5 & 0.0077 & 0.0338 & 0.0219 \\
\hline 170 & 114.7 & 0.0050 & 0.0242 & 0.0211 & 122.7 & 0.0079 & 0.0343 & 0.0222 \\
\hline 171 & 116.7 & 0.0050 & 0.0 & 0.0 & 12 & 0.0081 & 0.0 & 0.0225 \\
\hline 172 & 118.9 & 0.0051 & 0.0247 & 0.0217 & 127.3 & 0.0082 & 0. & 0.0228 \\
\hline 173 & 121.0 & 0.0052 & 0.0250 & 0.0220 & 129.6 & 0.0084 & 0.0360 & 0.0232 \\
\hline 174 & 123.2 & 0.0052 & 0.0252 & 0.0223 & 132.0 & 0.0086 & 0.0366 & 0.0235 \\
\hline 175 & 125.4 & 0.0053 & 0.0 & 0.0226 & 13 & 0.0088 & 372 & 0.0238 \\
\hline 176 & 127.7 & 0.0054 & 0.0258 & 0.0 & 13 & 0.0089 & 0.0378 & 0.0241 \\
\hline 177 & 130.0 & 0.0054 & 0.0261 & 0.0232 & 139.3 & 0.0091 & 0.0384 & 0.0245 \\
\hline 178 & 132.3 & 0.0055 & 0.0264 & 0.0235 & 141.9 & 0.0093 & 0.0390 & 0.0248 \\
\hline 179 & 134.6 & 0.0056 & 0.0266 & 0.0238 & 144.4 & 0.0095 & 0.0396 & 0.0251 \\
\hline 180 & 137.0 & 0.0056 & 0.0269 & 0.0242 & 147.1 & 0.0097 & 0.0402 & 0.0255 \\
\hline 181 & 139.5 & 0.0057 & 0.0272 & 0.0 & & 0.0099 & 0. & 0.0258 \\
\hline 182 & 142.0 & 0.0058 & 0.0275 & 0.0248 & 152.4 & 0.0101 & 0.0415 & 0.0262 \\
\hline 183 & 144.5 & 0.0059 & 0.0278 & 0. & .2 & 0.0103 & 0.0422 & 0.0266 \\
\hline 184 & 147.0 & 0.0059 & 0.0281 & 0.0255 & 158.0 & 0.0105 & 0.0429 & 0.0269 \\
\hline 185 & 149.6 & 0.0060 & 0.0284 & 0.0258 & 160.8 & 0.0108 & 0.0435 & 0.0273 \\
\hline 186 & 152.3 & 0.0061 & 0.0287 & 0.0262 & 163.7 & 0.0110 & 0.0442 & 0.0277 \\
\hline 187 & 155.0 & 0.0062 & 0.0291 & 0.0265 & 166.6 & 0.0112 & 0.0449 & 0.0280 \\
\hline 188 & 157.7 & 0.0063 & 0.0294 & 0.0269 & 169.6 & 0.0114 & 0.0457 & 0.0284 \\
\hline 189 & 160.5 & 0.0063 & 0.0297 & 0.0272 & 172.6 & 0.0117 & 0.0464 & 0.0288 \\
\hline 190 & 163.3 & 0.0064 & 0.0300 & 0.0276 & 175.7 & 0.0119 & 0.0471 & 0.0292 \\
\hline 191 & 166.2 & 0.0065 & 0.0304 & & 178.8 & 0.0121 & 0.0479 & 0.0296 \\
\hline 192 & 169.1 & 0.0066 & 0.0307 & 0.0284 & 182.0 & 0.0124 & 0.0486 & 0.0300 \\
\hline 193 & 172.0 & 0.0067 & 0.0310 & 0.0287 & 185.2 & 0.0126 & 0.0494 & 0.0304 \\
\hline
\end{tabular}


TABLE 71-Continued

\begin{tabular}{|c|c|c|c|c|c|c|c|c|}
\hline \multicolumn{5}{|c|}{ MALES } & \multicolumn{4}{|c|}{ FEMALES } \\
\hline 点 & $\underset{\text { weight }}{\text { Body }}$ & $\begin{array}{l}\text { Hypo- } \\
\text { physis }\end{array}$ & $\begin{array}{l}\text { Supra- } \\
\text { renals }\end{array}$ & Thyroid & Body weight & $\begin{array}{l}\text { Hypo- } \\
\text { physis }\end{array}$ & $\begin{array}{l}\text { Supra- } \\
\text { renals }\end{array}$ & Thyroid \\
\hline$m m$. & gms. & gms. & gms. & gms. & gms. & gms. & gms. & gms. \\
\hline 194 & 175.0 & 0.0068 & 0.0314 & 0.0291 & 188.5 & 0.0129 & 0.0502 & 0.0308 \\
\hline 195 & 178.1 & 0.0068 & 0.0317 & 0.0295 & 191.9 & 0.0131 & 0.0510 & 0.0312 \\
\hline 196 & 181.2 & 0.0069 & 0.0321 & 0.0299 & 195.3 & 0.0134 & 0.0518 & 0.0317 \\
\hline 197 & 184.3 & 0.0070 & 0.0324 & 0.0303 & 198.7 & 0.0136 & 0.0526 & 0.0321 \\
\hline 198 & 187.5 & 0.0071 & 0.0328 & 0.0307 & 202.2 & 0.0139 & 0.0535 & \\
\hline 199 & 190.8 & 0.0072 & 0.0331 & 0.0311 & .8 & 0.0142 & .0543 & 330 \\
\hline 200 & 194.1 & 0.0073 & 0.0335 & 0.0315 & 209.4 & 0.0145 & 0.0552 & 0.0334 \\
\hline 201 & 197.4 & 0.0074 & 0.0338 & 0.0 & 2 & 0.0 & 0 & \\
\hline 202 & 200.8 & 0.0075 & 0.0342 & 0.0 & 216.8 & 0.0 & .0569 & \\
\hline 203 & 204.3 & 0.0076 & 0.0346 & 0.0 & 220.7 & 0.0 & 9 & \\
\hline 204 & 207.8 & 0.0077 & 0.0350 & 0.0 & 5 & 0.0155 & 8 & 0. \\
\hline 205 & 211.4 & 0.0078 & 0.0354 & 0.0 & 228.4 & 0.0159 & 0.0597 & 0.0357 \\
\hline 206 & 215.0 & 0.0079 & 0.0358 & 0.0341 & 232.4 & 0.0162 & $0 . C 606$ & 0.0362 \\
\hline 207 & 218.7 & 0.0080 & 0.0362 & 0.0345 & 236.5 & 0.0166 & 0.0616 & 0.0367 \\
\hline 208 & 222.5 & 0.0081 & 0.0366 & 0.0 & 240.6 & 0.0 & 326 & 372 \\
\hline 209 & 226.3 & 0.0082 & 0.0370 & 0 & 8 & 0.0172 & .0636 & 0.0377 \\
\hline 210 & 230.2 & 0.0083 & 0.0374 & 0.0 & 249.1 & 0.0175 & 0.0646 & 0.0382 \\
\hline 211 & 23 & 0 . & & & & & & \\
\hline 212 & 238.1 & 0.0086 & 0.0 & 0 . & 8 & 0. & & 0.0392 \\
\hline 213 & 242.2 & 0.0087 & 0.0387 & 0.0 & 3 & 86 & & 0.0398 \\
\hline 214 & 246.3 & 0.0088 & 0.0391 & 0.0379 & 266.9 & 0.0189 & 0.0688 & 0.0403 \\
\hline 215 & 250.5 & 0.0089 & 0.0395 & 0.0384 & 271.5 & 0.0193 & 0.0699 & 0.0408 \\
\hline 216 & 254.7 & 0.0090 & 0.0400 & 0.0389 & 276.2 & 0.0196 & 0.0710 & 0.0414 \\
\hline 217 & 259.1 & 0.0092 & 0.0404 & 0.0 & 28 & 0.0 & 0.0 & 0.0420 \\
\hline 218 & 263.5 & 0.0093 & 0.0409 & 0.0399 & & 0.0204 & 0.0733 & 0.0425 \\
\hline 219 & 267.9 & 0.0094 & 0.0414 & 0.0404 & 290.8 & 0.0208 & 0.0744 & 0.0431 \\
\hline 220 & 272.5 & 0.0095 & 0.0418 & 0.0410 & 295.8 & 0.0212 & 0.0756 & 0.0437 \\
\hline 221 & 277.1 & 0.0 & 0. & & & & & \\
\hline 222 & 281.8 & 0.0098 & 0.0428 & 0.0421 & 306.1 & 0.0220 & 0.0781 & 0.0449 \\
\hline 223 & 286.5 & 0.0099 & 0.0433 & 0.0426 & 311.3 & 0.0224 & 0.0793 & 0.0455 \\
\hline 224 & 291.4 & 0.0101 & 0.0438 & 0.0432 & 316.7 & 0.0228 & 0.0805 & 0.0461 \\
\hline 225 & 296.3 & 0.0102 & 0.0443 & 0.0437 & 322.1 & 0.0232 & 0.0818 & 0.0467 \\
\hline 226 & 301.3 & 0.0103 & 0.0448 & 0.0443 & 327.7 & 0.0237 & 0.0831 & 0.0474 \\
\hline 227 & 306.4 & 0.0105 & 0.0453 & 0.0449 & 333.3 & 0.0242 & 0.0845 & 0.0480 \\
\hline 228 & 311.5 & 0.0106 & 0.0458 & 0.0455 & 339.0 & 0.0246 & 0.0858 & 0.0486 \\
\hline 229 & 316.8 & 0.0108 & 0.0464 & 0.0461 & 344.8 & 0.0250 & 0.0872 & 0.0493 \\
\hline 230 & 322.1 & 0.0109 & 0.0469 & 0.0467 & 350.7 & 0.0255 & 0.0885 & 0.0500 \\
\hline
\end{tabular}


TABLE 71-Concluded

\begin{tabular}{|c|c|c|c|c|c|c|c|c|}
\hline \multicolumn{5}{|c|}{ MALES } & \multicolumn{4}{|c|}{ FEMALES } \\
\hline 营苟 & $\begin{array}{l}\text { Body } \\
\text { weight }\end{array}$ & $\begin{array}{l}\text { Hypo- } \\
\text { physis }\end{array}$ & $\begin{array}{c}\text { Supra- } \\
\text { renals }\end{array}$ & Thyroid & Body weight & $\begin{array}{l}\text { Hypo- } \\
\text { physis }\end{array}$ & $\begin{array}{l}\text { Supra- } \\
\text { renals }\end{array}$ & Thyroid \\
\hline$m m$. & oms. & oms. & ams. & gms. & gms. & gms. & oms. & gms. \\
\hline 231 & 327.5 & 0.0111 & 0.0474 & 0.0473 & 356.7 & 0.0259 & 0.0899 & 0.0507 \\
\hline 232 & 333.0 & 0.0112 & 0.0480 & 0.0480 & 362.8 & 0.0264 & 0.0914 & 0.0513 \\
\hline 233 & 338.6 & 0.0114 & 0.0485 & 0.0486 & 369.0 & 0.0269 & 0.0928 & 0.0520 \\
\hline 234 & 344.3 & 0.0115 & 0.0491 & 0.0493 & 375.3 & 0.0274 & 0.0943 & 0.0527 \\
\hline 235 & 350.0 & 0.0117 & 0.0497 & 0.0499 & 381.7 & 0.0279 & 0.0958 & 0.0535 \\
\hline 236 & 355.9 & 0.0118 & 0.0503 & 0.0506 & 388.2 & 0.0284 & 0.0973 & 0.0542 \\
\hline 237 & 361.9 & 0.0120 & 0.0509 & 0.0512 & 394.9 & 0.0290 & 0.0989 & 0.0549 \\
\hline 238 & 367.9 & 0.0122 & 0.0514 & 0.0519 & 401.6 & 0.0295 & 0.1005 & 0.0557 \\
\hline 239 & 374.1 & 0.0123 & 0.0521 & 0.0526 & 408.4 & 0.0300 & 0.1021 & 0.0564 \\
\hline 240 & 380.3 & 0.0125 & 0.0527 & 0.0533 & 415.4 & 0.0306 & 0.1037 & 0.0572 \\
\hline 241 & 386.6 & 0.0127 & 0.0533 & 0.0540 & 422.4 & 0.0311 & 0.1053 & 0.0580 \\
\hline 242 & 393.1 & 0.0129 & 0.0539 & 0.0548 & 429.6 & 0.0317 & 0.1070 & 0.0588 \\
\hline 243 & 399.6 & 0.0130 & 0.0546 & 0.0555 & 436.9 & 0.0323 & 0.1087 & 0.0596 \\
\hline 244 & 406.3 & 0.0132 & 0.0552 & 0.0562 & 444.3 & 0.0329 & 0.1105 & 0.0604 \\
\hline 245 & 413.1 & 0.0134 & 0.0559 & 0.0570 & 451.9 & 0.0335 & 0.1122 & 0.0613 \\
\hline 246 & 419.9 & 0.0136 & 0.0565 & 0.0577 & 459.5 & 0.0341 & 0.1140 & 0.0621 \\
\hline 247 & $426.9^{\circ}$ & 0.0138 & 0.0572 & 0.0585 & 467.3 & 0.0347 & 0.1158 & 0.0630 \\
\hline 248 & 434.0 & 0.0140 & 0.0579 & 0.0593 & 475.2 & 0.0353 & 0.1177 & 0.0638 \\
\hline 249 & 441.2 & 0.0142 & 0.0586 & 0.0601 & 483.3 & 0.0359 & 0.1196 & 0.0647 \\
\hline 250 & 448.5 & 0.0144 & 0.0593 & 0.0609 & 491.5 & 0.0366 & 0.1251 & 0.0656 \\
\hline
\end{tabular}


TABLE 72

Giving the weight of the thymus in grams - sexes combined-for the first 400 days of life. See Chart 28

\begin{tabular}{|c|c|c|c|c|c|c|c|}
\hline $\begin{array}{l}\text { AGE IN } \\
\text { DAYS }\end{array}$ & $\begin{array}{l}\text { WEIGHT OF } \\
\text { THYMUS }\end{array}$ & $\begin{array}{l}\text { AGE IN } \\
\text { DAYS }\end{array}$ & $\begin{array}{c}\text { WEIGHT OF } \\
\text { THYMUS }\end{array}$ & $\begin{array}{c}\text { AGE IN } \\
\text { DAYS }\end{array}$ & $\begin{array}{l}\text { WEIGHT OF } \\
\text { THYMUS }\end{array}$ & $\begin{array}{c}\text { AGE IN } \\
\text { DAYS }\end{array}$ & $\begin{array}{l}\text { WEIGHT OF } \\
\text { THYMUS }\end{array}$ \\
\hline B. & 0.008 & 38 & 0.114 & 75 & 0.283 & 113 & 0.250 \\
\hline 1 & 0.008 & 39 & 0.118 & 76 & 0.285 & 114 & 0.249 \\
\hline 2 & 0.010 & 40 & 0.123 & 77 & 0.286 & 115 & 0.247 \\
\hline 3 & 0.012 & & & 78 & 0.288 & 116 & 0.246 \\
\hline 4 & 0.015 & 41 & 0.128 & 79 & 0.289 & 117 & 0.245 \\
\hline 5 & 0.017 & 42 & 0.133 & 80 & 0.290 & 118 & 0.244 \\
\hline 6 & 0.018 & 43 & 0.139 & & & 119 & 0.243 \\
\hline 7 & 0.020 & 44 & 0.144 & 81 & 0.290 & 120 & 0.242 \\
\hline 8 & 0.021 & 45 & 0.149 & 82 & 0.291 & & \\
\hline 9 & 0.022 & 46 & 0.154 & 83 & 0.291 & 121 & 0.241 \\
\hline \multirow[t]{2}{*}{10} & 0.024 & 47 & 0.160 & 84 & 0.290 & 122 & 0.240 \\
\hline & & 48 & 0.165 & 85 & 0.290 & 123 & 0.239 \\
\hline 11 & 0.026 & 49 & 0.171 & 86 & 0.289 & 124 & 0.238 \\
\hline 12 & 0.028 & 50 & 0.176 & 87 & 0.288 & 125 & 0.237 \\
\hline 13 & 0.029 & & & 88 & 0.287 & 126 & 0.236 \\
\hline 14 & 0.031 & 51 & 0.181 & 89 & 0.285 & 127 & 0.234 \\
\hline 15 & 0.034 & 52 & 0.187 & 90 & 0.283 & 128 & 0.233 \\
\hline 16 & 0.036 & 53 & 0.192 & & & 129 & 0.232 \\
\hline 17 & 0.038 & 54 & 0.198 & 91 & 0.281 & 130 & 0.231 \\
\hline 18 & 0.040 & 55 & 0.203 & 92 & 0.278 & & \\
\hline 19 & 0.043 & 56 & 0.208 & 93 & 0.276 & 131 & 0.230 \\
\hline \multirow[t]{2}{*}{20} & 0.046 & 57 & 0.213 & 94 & 0.273 & 132 & 0.229 \\
\hline & & 58 & 0.218 & 95 & 0.270 & 133 & 0.228 \\
\hline 21 & 0.048 & 59 & 0.224 & 96 & 0.269 & 134 & 0.227 \\
\hline 22 & 0.051 & 60 & 0.229 & 97 & 0.268 & 135 & 0.226 \\
\hline 23 & 0.054 & & & 98 & 0.266 & 136 & 0.225 \\
\hline 24 & 0.057 & 61 & 0.233 & 99 & 0.265 & 137 & 0.224 \\
\hline 25 & 0.061 & 62 & 0.238 & 100 & 0.264 & 138 & 0.223 \\
\hline 26 & 0.064 & 63 & 0.243 & 101 & 0.263 & 139 & 0.222 \\
\hline 27 & 0.067 & 64 & 0.247 & 102 & 0.262 & 140 & 0.221 \\
\hline 28 & 0.071 & 65 & 0.251 & 103 & 0.261 & & \\
\hline 29 & 0.075 & 66 & 0.255 & 104 & 0.260 & 141 & 0.220 \\
\hline \multirow[t]{2}{*}{30} & 0.079 & 67 & 0.259 & 105 & 0.259 & 142 & 0.219 \\
\hline & & 68 & 0.263 & 106 & 0.257 & 143 & 0.218 \\
\hline 31 & 0.083 & 69 & 0.267 & 107 & 0.256 & 144 & 0.217 \\
\hline 32 & 0.087 & 70 & 0.270 & -108 & 0.255 & 145 & 0.216 \\
\hline 33 & 0.091 & & & 109 & 0.254 & 146 & 0.215 \\
\hline 34 & 0.095 & 71 & 0.273 & 110 & 0.253 & 147 & 0.214 \\
\hline 35 & 0.100 & 72 & 0.276 & & & 148 & 0.213 \\
\hline 36 & 0.104 & 73 & 0.278 & 111 & 0.252 & 149 & 0.212 \\
\hline 37 & 0.109 & 74 & 0.281 & 112 & 0.251 & 150 & 0.211 \\
\hline
\end{tabular}


TABLE 72-Continued

\begin{tabular}{|c|c|c|c|c|c|c|c|}
\hline $\begin{array}{c}\text { AGE IN } \\
\text { DAYS }\end{array}$ & $\underset{\text { THYMUTS }}{\text { WEIGHT OF }}$ & $\underset{\text { DAYS }}{\text { AGE IN }}$ & $\begin{array}{c}\text { WEIGHT OF } \\
\text { THYMUS }\end{array}$ & $\begin{array}{l}\text { AGE IN } \\
\text { DAYS }\end{array}$ & $\begin{array}{c}\text { WEIGHT OF } \\
\text { THYMUS }\end{array}$ & $\begin{array}{c}\text { AGE IN } \\
\text { DAYB }\end{array}$ & $\begin{array}{c}\text { WEIGHT IN } \\
\text { THYMUS }\end{array}$ \\
\hline 151 & 0.210 & 191 & 0.172 & 231 & 0.138 & 271 & 0.108 \\
\hline 152 & 0.209 & 192 & 0.171 & 232 & 0.137 & 272 & 0.107 \\
\hline 153 & 0.208 & 193 & 0.170 & 233 & 0.136 & 273 & 0.106 \\
\hline 154 & 0.207 & 194 & 0.169 & 234 & 0.135 & 274 & 0.106 \\
\hline 155 & 0.206 & 195 & 0.168 & 235 & 0.134 & 275 & 0.105 \\
\hline 156 & 0.205 & 196 & 0.167 & 236 & 0.134 & 276 & 0.104 \\
\hline 157 & 0.204 & 197 & 0.166 & 237 & 0.133 & 277 & 0.104 \\
\hline 158 & 0.203 & 198 & 0.165 & 238 & 0.132 & 278 & 0.103 \\
\hline 159 & 0.202 & 199 & 0.164 & 239 & 0.131 & 279 & 0.102 \\
\hline 160 & 0.201 & 200 & 0.164 & 240 & 0.130 & 280 & 0.102 \\
\hline 161 & 0.200 & 201 & 0.163 & 241 & 0.130 & 281 & 0.101 \\
\hline 162 & 0.199 & 202 & 0.162 & 242 & 0.129 & 282 & 0.100 \\
\hline 163 & 0.198 & 203 & 0.161 & 243 & 0.128 & 283 & 0.099 \\
\hline 164 & 0.197 & 204 & 0.160 & 244 & 0.127 & 284 & 0.099 \\
\hline 165 & 0.196 & 205 & 0.159 & 245 & 0.127 & 285 & 0.098 \\
\hline 166 & 0.195 & 206 & 0.158 & 246 & 0.126 & 286 & 0.098 \\
\hline 167 & 0.194 & 207 & 0.157 & 247 & 0.125 & 287 & 0.097 \\
\hline 168 & 0.193 & 208 & 0.157 & 248 & 0.124 & 288 & 0.096 \\
\hline 169 & 0.192 & 209 & 0.156 & 249 & 0.124 & 289 & 0.096 \\
\hline 170 & 0.191 & 210 & 0.155 & 250 & 0.123 & 290 & 0.095 \\
\hline 171 & 0.190 & 211 & 0.154 & 251 & 0.122 & 291 & 0.094 \\
\hline 172 & 0.189 & 212 & 0.153 & 252 & 0.121 & 292 & 0.094 \\
\hline 173 & 0.188 & 213 & 0.152 & 253 & 0.121 & 293 & 0.093 \\
\hline 174 & 0.187 & 214 & 0.152 & 254 & 0.120 & 294 & 0.092 \\
\hline 175 & 0.186 & 215 & 0.151 & 255 & 0.119 & 295 & 0.092 \\
\hline 176 & 0.185 & 216 & 0.150 & 256 & 0.118 & 296 & 0.091 \\
\hline 177 & 0.184 & 217 & 0.149 & 257 & 0.118 & 297 & 0.090 \\
\hline 178 & 0.183 & 218 & 0.148 & 258 & 0.117 & 298 & 0.090 \\
\hline 179 & 0.183 & 219 & 0.147 & 259 & 0.116 & 299 & 0.089 \\
\hline 180 & 0.182 & 220 & 0.147 & 260 & 0.115 & 300 & 0.089 \\
\hline 181 & 0.181 & 221 & 0.146 & 261 & 0.115 & 301 & 0.088 \\
\hline 182 & 0.180 & 222 & 0.145 & 262 & 0.114 & 302 & 0.087 \\
\hline 183 & 0.179 & 223 & 0.144 & 263 & 0.113 & 303 & 0.087 \\
\hline 184 & 0.178 & 224 & 0.143 & 264 & 0.113 & 304 & 0.086 \\
\hline 185 & 0.177 & 225 & 0.142 & 265 & 0.112 & 305 & 0.085 \\
\hline 186 & 0.176 & 226 & 0.142 & 266 & 0.111 & 306 & 0.085 \\
\hline 187 & 0.175 & 227 & 0.141 & 267 & 0.110 & 307 & 0.084 \\
\hline 188 & 0.174 & 228 & 0.140 & 268 & 0.110 & 308 & 0.084 \\
\hline 189 & 0.173 & 229 & 0.139 & 269 & 0.109 & 309 & 0.083 \\
\hline 190 & 0.172 & 230 & 0.138 & 270 & 0.108 & 310 & 0.082 \\
\hline
\end{tabular}


WEIGHT OF THYMUS ON AGE

TABLE 72-Concluded

\begin{tabular}{|c|c|c|c|c|c|c|c|}
\hline $\begin{array}{l}\text { AGE IN } \\
\text { DAYS }\end{array}$ & $\begin{array}{c}\text { WEIGHT OF } \\
\text { THYMUS }\end{array}$ & $\begin{array}{c}\text { AGE IN } \\
\text { DAYS }\end{array}$ & $\begin{array}{c}\text { WEIGHT OF } \\
\text { THYMUS }\end{array}$ & $\begin{array}{l}\text { AGE IN } \\
\text { DAYS }\end{array}$ & $\begin{array}{l}\text { WEIGHT OF } \\
\text { THYMUS }\end{array}$ & $\begin{array}{l}\text { AGEIN } \\
\text { DAYS }\end{array}$ & $\begin{array}{l}\text { WEIGHT OF } \\
\text { THYMUS }\end{array}$ \\
\hline 311 & 0.082 & 334 & 0.069 & 357 & 0.057 & 379 & 0.047 \\
\hline 312 & 0.081 & 335 & 0.068 & 358 & 0.057 & 380 & 0.047 \\
\hline 313 & 0.081 & 336 & 0.068 & 359 & 0.056 & & \\
\hline 314 & 0.080 & 337 & 0.067 & 360 & 0.056 & 381 & 0.047 \\
\hline 315 & 0.080 & 338 & 0.067 & & & 382 & 0.046 \\
\hline 316 & 0.079 & 339 & 0.066 & 361 & 0.055 & 383 & 0.046 \\
\hline 317 & 0.078 & 340 & 0.066 & 362 & 0.055 & 384 & 0.045 \\
\hline 318 & 0.078 & & & 363 & 0.054 & 385 & 0.045 \\
\hline 319 & 0.077 & 341 & 0.065 & 364 & 0.054 & 386 & 0.045 \\
\hline \multirow[t]{2}{*}{320} & 0.077 & 342 & 0.065 & 365 & 0.054 & 387 & 0.044 \\
\hline & & 343 & 0.064 & 366 & 0.053 & 388 & 0.044 \\
\hline 321 & 0.076 & 344 & 0.064 & 367 & 0.053 & 389 & 0.043 \\
\hline 322 & 0.075 & 345 & 0.063 & 368 & 0.052 & 390 & 0.043 \\
\hline 323 & 0.075 & 346 & 0.063 & 369 & 0.052 & & \\
\hline 324 & 0.074 & 347 & 0.062 & 370 & 0.051 & 391 & 0.043 \\
\hline 325 & 0.074 & 348 & 0.062 & & & 392 & 0.042 \\
\hline 326 & 0.073 & 349 & 0.061 & 371 & 0.051 & 393 & 0.042 \\
\hline 327 & 0.073 & 350 & 0.061 & 372 & 0.050 & 394 & 0.041 \\
\hline 328 & 0.072 & & & 373 & 0.050 & 395 & 0.041 \\
\hline 329 & 0.072 & 351 & 0.060 & 374 & 0.050 & 396 & 0.041 \\
\hline \multirow[t]{2}{*}{330} & 0.071 & 352 & 0.060 & 375 & 0.049 & 397 & 0.040 \\
\hline & & 353 & 0.059 & 376 & 0.049 & 398 & 0.040 \\
\hline 331 & 0.071 & 354 & 0.059 & 377 & 0.048 & 399 & 0.040 \\
\hline 332 & 0.070 & 355 & 0.058 & 378 & 0.048 & 400 & 0.039 \\
\hline 333 & 0.069 & 356 & 0.058 & & & & \\
\hline
\end{tabular}


TABLE 73

Weights of viscera combined plus that of thymus for each sex and at each millimeter of body length. Not charted. The percentage of the body weight represented by the weight of the viscera is however given under 'viscera' in table 50, and chart 5.

\begin{tabular}{|c|c|c|c|c|c|c|}
\hline \multicolumn{4}{|c|}{ MALES } & \multicolumn{3}{|c|}{ FEMALE: } \\
\hline $\begin{array}{c}\text { Body } \\
\text { length }\end{array}$ & $\begin{array}{l}\text { Body } \\
\text { weight }\end{array}$ & $\begin{array}{l}\text { Weight } \\
\text { of viscera }\end{array}$ & $\begin{array}{l}\text { Weight } \\
\text { of thymus }\end{array}$ & $\begin{array}{c}\text { Body } \\
\text { weight }\end{array}$ & $\begin{array}{l}\text { Weight } \\
\text { of viscera }\end{array}$ & $\begin{array}{l}\text { Weight } \\
\text { of thymus }\end{array}$ \\
\hline $\mathrm{mm}$. & gms. & gms. & gms. & oms. & oms. & gms. \\
\hline 47 & 4.9 & 0.806 & 0.007 & 4.7 & 0.775 & 0.007 \\
\hline 48 & 4.9 & 0.808 & 0.007 & 4.7 & 0.779 & 0.007 \\
\hline 49 & 5.0 & 0.839 & 0.007 & 4.9 & 0.810 & 0.007 \\
\hline 50 & 5.1 & 0.853 & 0.007 & 5.0 & 0.834 & 0.008 \\
\hline 51 & 5.2 & 0.873 & 0.008 & 5.1 & 0.854 & 0.008 \\
\hline 52 & 5.3 & 0.916 & 0.008 & 5.3 & 0.901 & 0.008 \\
\hline 53 & 5.4 & 0.938 & 0.008 & 5.5 & 0.955 & 0.008 \\
\hline 54 & 5.6 & 0.991 & 0.008 & 5.8 & 1.046 & 0.010 \\
\hline 55 & 5.8 & 1.047 & 0.010 & 6.2 & 1.141 & 0.012 \\
\hline 56 & 6.1 & 1.130 & 0.011 & 6.5 & 1.218 & 0.015 \\
\hline 57 & 6.4 & 1.218 & 0.012 & 6.9 & 1.318 & 0.015 \\
\hline 58 & 6.8 & 1.301 & 0.015 & 7.2 & 1.401 & 0.016 \\
\hline 59 & 7.1 & 1.387 & 0.015 & 7.6 & 1.487 & 0.017 \\
\hline 60 & 7.5 & 1.486 & 0.016 & 8.0 & 1.573 & 0.017 \\
\hline 61 & 7.9 & 1.573 & 0.016 & 8.4 & 1.665 & 0.018 \\
\hline 62 & 8.2 & 1.656 & 0.017 & 8.7 & 1.735 & 0.020 \\
\hline 63 & 8.6 & 1.751 & 0.017 & 9.1 & 1.825 & 0.020 \\
\hline 64 & 9.0 & 1.837 & 0.018 & 9.5 & 1.914 & 0.020 \\
\hline 65 & 9.4 & 1.931 & 0.020 & 9.9 & 1.998 & 0.021 \\
\hline 66 & 9.8 & 2.026 & 0.020 & 10.3 & 2.114 & 0.021 \\
\hline 67 & 10.1 & 2.091 & 0.021 & 10.8 & 2.300 & 0.021 \\
\hline 68 & 10.6 & 2.272 & 0.021 & 11.2 & 2.467 & 0.022 \\
\hline 69 & 11.0 & 2.441 & 0.022 & 11.6 & 2.622 & 0.023 \\
\hline 70 & 11.4 & 2.614 & 0.022 & 12.0 & 2.787 & 0.024 \\
\hline 71 & 11.8 & 2.770 & 0.023 & 12.5 & 2.958 & 0.025 \\
\hline 72 & 12.2 & 2.911 & 0.024 & 12.9 & 3.093 & 0.026 \\
\hline 73 & 12.7 & 3.093 & 0.025 & 13.4 & 3.270 & 0.026 \\
\hline 74 & 13.1 & 3.226 & 0.026 & 13.9 & 3.424 & 0.027 \\
\hline 75 & 13.6 & 3.396 & 0.027 & 14.3 & 3.554 & 0.027 \\
\hline 76 & 14.0 & 3.524 & 0.028 & 14.8 & 3.704 & 0.028 \\
\hline 77 & 14.5 & 3.679 & 0.028 & 15.3 & 3.864 & 0.028 \\
\hline 78 & 15.0 & 3.842 & 0.029 & 15.8 & 4.001 & 0.031 \\
\hline 79 & 15.4 & 3.967 & 0.031 & 16.3 & 4.147 & 0.032 \\
\hline 80 & 15.9 & 4.107 & 0.032 & 16.8 & 4.294 & 0.033 \\
\hline
\end{tabular}


TABLE 73-Continued

\begin{tabular}{|c|c|c|c|c|c|c|}
\hline \multicolumn{4}{|c|}{ MALES } & \multicolumn{3}{|c|}{ FEMALES } \\
\hline $\begin{array}{c}\text { Body } \\
\text { length }\end{array}$ & $\underset{\text { weight }}{\text { Body }}$ & $\begin{array}{l}\text { Weight } \\
\text { of viscera }\end{array}$ & $\begin{array}{l}\text { Weight } \\
\text { of thymus }\end{array}$ & $\begin{array}{c}\text { Body } \\
\text { weight }\end{array}$ & $\begin{array}{c}\text { Weight } \\
\text { of viscera }\end{array}$ & $\begin{array}{c}\text { Weight } \\
\text { of thymus }\end{array}$ \\
\hline$m m$. & $g m s$. & gms. & gms. & gms. & gms. & gms. \\
\hline 81 & 16.4 & 4.255 & 0.034 & 17.3 & 4.419 & 0.034 \\
\hline 82 & 16.9 & 4.393 & 0.036 & 17.9 & 4.584 & 0.034 \\
\hline 83 & 17.4 & 4.529 & 0.038 & 18.4 & 4.717 & 0.035 \\
\hline 84 & 18.0 & 4.698 & 0.037 & 19.0 & 4.864 & 0.037 \\
\hline 85 & 18.5 & 4.834 & 0.040 & 19.5 & 4.996 & 0.038 \\
\hline 86 & 19.0 & 4.958 & 0.041 & 20.1 & 5.138 & 0.040 \\
\hline 87 & 19.6 & 5.115 & $0.043^{-}$ & 20.7 & 5.283 & 0.043 \\
\hline 88 & 20.1 & 5.239 & 0.044 & 21.2 & 5.413 & 0.044 \\
\hline 89 & 20.7 & 5.385 & 0.016 & 21.8 & 5.555 & 0.046 \\
\hline 90 & 21.3 & 5.531 & 0.048 & 22.4 & 5.697 & 0.048 \\
\hline 91 & 21.9 & 5.679 & 0.050 & 23.1 & 5.840 & 0.050 \\
\hline 92 & 22.4 & 5.809 & 0.052 & 23.7 & 5.983 & 0.052 \\
\hline 93 & 23.0 & 5.943 & 0.054 & 24.3 & 6.112 & 0.054 \\
\hline 94 & 23.7 & 6.102 & 0.056 & 25.0 & 6.266 & 0.055 \\
\hline 95 & 24.3 & 6.236 & 0.057 & 25.6 & 6.396 & 0.057 \\
\hline 96 & 24.9 & 6.381 & 0.059 & 26.3 & 6.547 & 0.059 \\
\hline 97 & 25.6 & 6.528 & 0.061 & 27.0 & 6.687 & 0.060 \\
\hline 98 & 26.2 & 6.672 & 0.063 & 27.7 & 6.831 & 0.061 \\
\hline 99 & 26.9 & 6.810 & 0.065 & 28.4 & 6.972 & 0.063 \\
\hline 100 & 27.5 & 6.942 & 0.067 & 29.1 & 7.112 & 0.065 \\
\hline 101 & 28.2 & 7.088 & 0.070 & 29.8 & 7.254 & 0.067 \\
\hline 102 & 28.9 & 7.237 & 0.073 & 30.5 & 7.384 & 0.067 \\
\hline 103 & 29.6 & 7.372 & 0.075 & 31.3 & 7.537 & 0.075 \\
\hline 104 & 30.3 & 7.517 & 0.078 & 32.0 & 7.666 & 0.079 \\
\hline 105 & 31.1 & 7.678 & 0.081 & 32.8 & 7.820 & 0.083 \\
\hline 106 & 31.8 & 7.824 & 0.083 & 33.6 & 7.960 & 0.087 \\
\hline 107 & 32.5 & 7.959 & 0.086 & 34.4 & 8.112 & 0.091 \\
\hline 108 & 33.3 & 8.110 & 0.089 & 35.2 & 8.254 & 0.095 \\
\hline 109 & 34.1 & 8.268 & 0.092 & 36.0 & 8.395 & 0.097 \\
\hline 110 & 34.9 & 8.418 & 0.095 & 36.9 & 8.546 & 0.099 \\
\hline 111 & 35.7 & 8.566 & 0.099 & 37.7 & 8.690 & 0.101 \\
\hline 112 & 36.5 & 8.727 & 0.104 & 38.6 & 8.841 & 0.105 \\
\hline 113 & 37.3 & 8.866 & 0.109 & 39.5 & 9.005 & 0.109 \\
\hline 114 & 38.2 & 9.037 & 0.111 & 40.3 & 9.134 & 0.113 \\
\hline 115 & 39.0 & 9.177 & 0.113 & 41.3 & 9.300 & 0.117 \\
\hline 116 & 39.9 & 9.330 & 0.116 & 42.2 & 9.451 & 0.120 \\
\hline 117 & 40.8 & 9.493 & 0.118 & 43.1 & 9.595 & 0.123 \\
\hline
\end{tabular}


TABLE 73-Continued

\begin{tabular}{|c|c|c|c|c|c|c|}
\hline \multicolumn{4}{|c|}{ MALES } & \multicolumn{3}{|c|}{ FEMales } \\
\hline $\begin{array}{c}\text { Body } \\
\text { length }\end{array}$ & $\begin{array}{c}\text { Body } \\
\text { weight }\end{array}$ & $\begin{array}{l}\text { Weight } \\
\text { of viscera }\end{array}$ & $\begin{array}{l}\text { Weight } \\
\text { of thymus }\end{array}$ & $\begin{array}{c}\text { Body } \\
\text { weight }\end{array}$ & $\begin{array}{c}\text { Weight } \\
\text { of viscera }\end{array}$ & $\begin{array}{l}\text { Weight } \\
\text { of thymus }\end{array}$ \\
\hline$m m$. & gms. & gms. & gms. & gms. & gms. & $g m s$. \\
\hline 118 & 41.6 & 9.644 & 0.120 & 44.1 & 9.746 & 0.126 \\
\hline 119 & 42.6 & 9.810 & 0.123 & 45.0 & 9.888 & 0.130 \\
\hline 120 & 43.5 & 9.964 & 0.127 & 46.0 & 10.043 & 0.133 \\
\hline 121 & 44.4 & 10.127 & 0.131 & 47.0 & 10.207 & 0.136 \\
\hline 122 & 45.4 & 10.294 & 0.135 & 48.0 & 10.360 & 0.139 \\
\hline 123 & 46.3 & 10.448 & 0.139 & 49.1 & 10.525 & 0.144 \\
\hline 124 & 47.3 & 10.616 & 0.140 & 50.1 & 10.679 & 0.147 \\
\hline 125 & 48.3 & 10.794 & 0.141 & 51.2 & 10.832 & 0.151 \\
\hline 126 & 49.3 & 10.950 & 0.142 & 52.3 & 10.999 & 0.154 \\
\hline 127 & 50.4 & 11.134 & 0.144 & 53.4 & 11.156 & 0.159 \\
\hline 128 & 51.4 & 11.290 & 0.149 & 54.5 & 11.320 & 0.164 \\
\hline 129 & 52.5 & $\cdot 11.474$ & 0.154 & 55.6 & 11.474 & 0.167 \\
\hline 130 & 53.6 & 11.644 & 0.159 & 56.8 & 11.640 & 0.171 \\
\hline 131 & 54.7 & 11.827 & 0.164 & 58.0 & 11.808 & 0.174 \\
\hline 132 & 55.8 & 12.002 & 0.167 & 59.2 & 11.984 & 0.178 \\
\hline 133 & 56.9 & 12.174 & 0.171 & 60.4 & 12.150 & 0.181 \\
\hline 134 & 58.1 & 12.373 & 0.175 & 61.6 & 12.306 & 0.184 \\
\hline 135 & 59.3 & 12.560 & 0.178 & 62.9 & 12.485 & 0.187 \\
\hline 136 & 60.5 & 12.740 & 0.181 & 64.2 & 12.663 & 0.190 \\
\hline 137 & 61.7 & 12.936 & 0.184 & 65.5 & 12.829 & 0.193 \\
\hline 138 & 62.9 & 13.116 & 0.187 & 66.8 & 13.007 & 0.196 \\
\hline 139 & 64.1 & 13.305 & 0.192 & 68.1 & 13.176 & 0.199 \\
\hline 140 & 65.4 & 13.509 & 0.196 & 69.5 & 13.356 & 0.203 \\
\hline 141 & 66.7 & 13.703 & 0.200 & 70.9 & 13.536 & 0.206 \\
\hline 142 & 68.0 & 13.898 & 0.203 & 72.3 & 13.715 & 0.210 \\
\hline 143 & 69.3 & 14.093 & 0.208 & 73.7 & 13.898 & 0.214 \\
\hline 144 & 70.7 & 14.303 & 0.211 & 75.2 & 14.089 & 0.218 \\
\hline 145 & 72.1 & 14.513 & 0.214 & 76.7 & 14.281 & 0.225 \\
\hline 146 & 73.5 & 14.723 & 0.218 & 78.2 & 14.464 & 0.233 \\
\hline 147 & 74.9 & 14.934 & 0.220 & 79.7 & 14.654 & 0.236 \\
\hline 148 & 76.3 & 15.147 & 0.223 & 81.3 & 14.848 & 0.239 \\
\hline 149 & 77.8 & 15.374 & 0.226 & 82.8 & 15.038 & 0.243 \\
\hline 150 & 79.3 & 15.600 & 0.229 & 84.4 & 15.222 & 0.247 \\
\hline 151 & 80.8 & 15.811 & 0.231 & 86.1 & 15.427 & 0.249 \\
\hline 152 & 82.4 & 16.039 & 0.233 & 87.7 & 15.612 & 0.251 \\
\hline 153 & 83.9 & 16.241 & 0.236 & 89.4 & 15.819 & 0.252 \\
\hline
\end{tabular}


TABLE 73-Continued

\begin{tabular}{|c|c|c|c|c|c|c|}
\hline \multicolumn{4}{|c|}{ MALES } & \multicolumn{3}{|c|}{ FEMALES } \\
\hline $\begin{array}{l}\text { Body } \\
\text { length }\end{array}$ & $\begin{array}{c}\text { Body } \\
\text { weight }\end{array}$ & $\begin{array}{l}\text { Weight } \\
\text { of viscera }\end{array}$ & $\begin{array}{l}\text { Weight } \\
\text { of thymus }\end{array}$ & $\underset{\text { weight }}{\text { Body }}$ & $\begin{array}{l}\text { Weight } \\
\text { of viscera }\end{array}$ & $\begin{array}{l}\text { Weight } \\
\text { of thymus }\end{array}$ \\
\hline$m m$. & gms. & gms. & gms. & gms. & gms. & gms. \\
\hline 154 & 85.5 & 16.456 & 0.239 & 91.1 & 16.023 & 0.253 \\
\hline 155 & 87.1 & 16.672 & 0.241 & 92.9 & 16.230 & 0.254 \\
\hline 156 & 88.7 & 16.877 & 0.244 & 94.6 & 16.435 & 0.256 \\
\hline 157 & 90.4 & 17.104 & 0.247 & 96.4 & 16.645 & 0.262 \\
\hline 158 & 92.1 & 17.321 & 0.249 & 98.3 & 16.854 & 0.269 \\
\hline 159 & 93.8 & 17.537 & 0.251 & 100.1 & 17.062 & 0.270 \\
\hline 160 & 95.6 & 17.770 & 0.253 & 102.0 & 17.270 & 0.273 \\
\hline 161 & 97.3 & 17.995 & 0.256 & 103.9 & 17.489 & 0.276 \\
\hline 162 & 99.2 & 18.227 & 0.259 & 105.9 & 17.710 & 0.278 \\
\hline 163 & 101.0 & 18.456 & 0.262 & 107.9 & 17.943 & 0.280 \\
\hline 164 & 102.8 & 18.682 & 0.264 & 109.9 & 18.165 & 0.283 \\
\hline 165 & 104.7 & 18.912 & 0.267 & 111.9 & 18.376 & 0.285 \\
\hline 166 & 106.7 & 19.155 & 0.270 & 114.0 & 18.607 & 0.286 \\
\hline 167 & 108.6 & 19.391 & 0.272 & 116.1 & 18.840 & 0.288 \\
\hline 168 & 110.6 & 19.638 & 0.274 & 118.3 & 19.073 & 0.289 \\
\hline 169 & 112.6 & 19.868 & 0.276 & 120.5 & 19.318 & 0.290 \\
\hline 170 & 114.7 & 20.121 & 0.278 & 122.7 & 19.549 & 0.291 \\
\hline 171 & 116.7 & 20.363 & 0.280 & 125.0 & 19.784 & 0.290 \\
\hline 172 & 118.9 & 20.620 & 0.282 & 127.3 & 20.030 & 0.289 \\
\hline 173 & 121.0 & 20.870 & 0.285 & 129.6 & 20.266 & 0.288 \\
\hline 174 & 123.2 & 21.127 & 0.286 & 132.0 & 20.522 & 0.288 \\
\hline 175 & 125.4 & 21.368 & 0.288 & 134.4 & 20.767 & 0.287 \\
\hline 176 & 127.7 & 21.647 & 0.289 & 136.8 & 21.015 & 0.284 \\
\hline 177 & 130.0 & 21.905 & 0.290 & 139.3 & 21.273 & 0.278 \\
\hline 178 & 132.3 & 22.160 & 0.291 & 141.9 & 21.532 & 0.273 \\
\hline 179 & 134.6 & 22.425 & 0.291 & 144.4 & 21.781 & 0.268 \\
\hline 180 & 137.0 & 22.693 & 0.291 & 147.1 & 22.062 & 0.266 \\
\hline 181 & 139.5 & 22.972 & 0.290 & 149.7 & 22.322 & 0.264 \\
\hline 182 & 142.0 & 23.244 & 0.290 & 152.4 & 22.594 & 0.262 \\
\hline 183 & 144.5 & 23.521 & 0.290 & 155.2 & 22.867 & 0.256 \\
\hline 184 & 147.0 & 23.791 & 0.287 & 158.0 & 23.142 & 0.251 \\
\hline 185 & 149.6 & 24.073 & 0.285 & 160.8 & 23.424 & 0.248 \\
\hline 186 & 152.3 & 24.367 & 0.278 & 163.7 & 23.700 & 0.247 \\
\hline 187 & 155.0 & 24.648 & 0.274 & 166.6 & 23.995 & 0.245 \\
\hline 188 & 157.7 & 24.943 & 0.271 & 169.6 & 24.282 & 0.238 \\
\hline 189 & 160.5 & 25.246 & 0.268 & 172.6 & 24.579 & 0.235 \\
\hline 190 & 163.3 & 25.541 & 0.266 & 175.7 & 24.876 & 0.232 \\
\hline
\end{tabular}


TABLE 73-Continued

\begin{tabular}{|c|c|c|c|c|c|c|}
\hline \multicolumn{4}{|c|}{ MaLes. } & \multicolumn{3}{|c|}{ FEMALES } \\
\hline$\underset{\text { length }}{\text { Body }}$ & $\underset{\text { weight }}{\text { Body }}$ & $\begin{array}{c}\text { Weight } \\
\text { of viscera }\end{array}$ & $\begin{array}{l}\text { Weight } \\
\text { of thymus }\end{array}$ & $\underset{\text { weight }}{\text { Body }}$ & $\begin{array}{c}\text { Weight } \\
\text { of viscera }\end{array}$ & $\begin{array}{l}\text { Weight } \\
\text { of thymus }\end{array}$ \\
\hline$m m$. & $g m s$. & gms. & $g m s$. & $g m 8$. & gms. & gms. \\
\hline 191 & 166.2 & 25.838 & 0.264 & 178.8 & 25.166 & 0.230 \\
\hline 192 & 169.1 & 26.144 & 0.262 & 182.0 & 25.475 & 0.223 \\
\hline 193 & 172.0 & 26.450 & 0.259 & 185.2 & 25.778 & 0.211 \\
\hline 194 & 175.0 & 26.756 & 0.256 & 188.5 & 26.089 & 0.190 \\
\hline 195 & 178.1 & 27.077 & 0.253 & 191.9 & 26.414 & 0.183 \\
\hline 196 & 181.2 & 27.396 & 0.251 & 195.3 & 26.736 & 0.171 \\
\hline 197 & 184.3 & 27.716 & 0.249 & 198.7 & 27.051 & \\
\hline 198 & 187.5 & 28.036 & 0.247 & 202.2 & 27.378 & \\
\hline 199 & 190.8 & 28.370 & 0.245 & 205.8 & 27.716 & \\
\hline $200^{\circ}$ & 194.1 & 28.692 & 0.241 & 209.4 & 28.051 & \\
\hline 201 & 197.4 & 29.035 & 0.238 & 213.1 & 28.380 & \\
\hline 202 & 200.8 & 29.379 & 0.230 & 216.8 & 28.731 & \\
\hline 203 & 204.3 & 29.726 & 0.226 & 220.7 & 29.083 & \\
\hline 204 & 207.8 & 30.071 & 0.224 & 224.5 & 29.433 & \\
\hline 205 & 211.4 & 30.418 & 0.222 & 228.4 & 29.795 & \\
\hline 206 & 215.0 & 30.767 & 0.220 & 232.4 & 30.150 & \\
\hline 207 & 218.7 & 31.127 & 0.218 & 236.5 & 30.526 & \\
\hline 208 & 222.5 & 31.499 & 0.210 & 240.6 & 30.893 & \\
\hline 209 & 226.3 & 31.871 & 0.205 & 244.8 & 31.272 & \\
\hline 210 & 230.2 & 32.244 & 0.197 & 249.1 & 31.661 & \\
\hline 211 & 234.1 & 32.616 & 0.190 & 253.4 & 32.042 & \\
\hline 212 & 238.1 & 33.002 & 0.183 & 257.8 & 32.432 & \\
\hline 213 & 242.2 & 33.389 & 0.177 & 262.3 & 32.825 & \\
\hline 214 & 246.3 & 33.784 & 0.169 & 266.9 & 33.230 & \\
\hline 215 & 250.5 & 34.172 & 0.150 & 271.5 & 33.645 & \\
\hline 216 & 254.7 & 34.570 & 0.140 & 276.2 & 34.053 & \\
\hline 217 & 259.1 & 34.982 & 0.130 & 281.0 & 34.470 & \\
\hline 218 & 263.5 & 35.384 & 0.124 & 285.8 & 34.888 & \\
\hline 219 & 267.9 & 35.785 & 0.118 & 290.8 & 35.331 & \\
\hline 220 & 272.5 & 36.219 & & 295.8 & 35.774 & \\
\hline 221 & 277.1 & 36.654 & & 300.9 & 36.198 & \\
\hline 222 & 281.8 & 37.082 & & 306.1 & 36.670 & \\
\hline 223 & 286.5 & 37.507 & & 311.3 & 37.109 & \\
\hline 224 & 291.4 & 37.958 & & 316.7 & 37.568 & \\
\hline 225 & 296.3 & 38.339 & & 322.1 & 38.028 & \\
\hline 226 & 301.3 & 38.861 & & 327.7 & 38.510 & \\
\hline 227 & 306.4 & 39.325 & & 333.3 & 38.982 & \\
\hline
\end{tabular}


TABLE 73-Concluded

\begin{tabular}{|c|c|c|c|c|c|c|}
\hline \multicolumn{4}{|c|}{ MALES } & \multicolumn{3}{|c|}{ FEMALES } \\
\hline $\begin{array}{l}\text { Body } \\
\text { length }\end{array}$ & $\begin{array}{c}\text { Body } \\
\text { weight }\end{array}$ & $\begin{array}{c}\text { Weight } \\
\text { of viscera }\end{array}$ & $\begin{array}{l}\text { Weight } \\
\text { of thymus }\end{array}$ & $\begin{array}{c}\text { Body } \\
\text { weight }\end{array}$ & $\begin{array}{c}\text { Weight } \\
\text { of viscera }\end{array}$ & $\begin{array}{l}\text { Weight } \\
\text { of thymus }\end{array}$ \\
\hline$m m$. & gms. & gms. & gms. & gms. & gms. & gms. \\
\hline 228 & 311.5 & 39.828 & & 339.0 & 39.476 & \\
\hline 229 & 316.8 & 40.255 & & 344.8 & 39.963 & \\
\hline 230 & 322.1 & 40.723 & & 350.7 & 40.462 & \\
\hline 231 & 327.5 & 41.210 & & 356.7 & 40.972 & \\
\hline 232 & 333.0 & 41.692 & & 362.8 & 41.492 & \\
\hline 233 & 338.6 & 42.194 & & 369.0 & 42.006 & \\
\hline 234 & 344.3 & 42.678 & & 375.3 & 42.531 & \\
\hline 235 & 350.0 & 43.201 & & 381.7 & 43.068 & \\
\hline 236 & 355.9 & 43.718 & & 388.2 & 43.605 & \\
\hline 237 & 361.9 & 44.250 & & 394.9 & 44.168 & \\
\hline 238 & 367.9 & 44.769 & & 401.6 & 44.731 & \\
\hline 239 & 374.1 & 45.301 & & 408.4 & 45.295 & \\
\hline 240 & 380.3 & 45.854 & & 415.4 & 45.882 & \\
\hline 241 & 386.6 & 46.398 & & 422.4 & 46.451 & \\
\hline 242 & 393.1 & 46.957 & & 429.6 & 47.041 & \\
\hline 243 & 399.6 & 47.514 & & 436.9 & 47.655 & \\
\hline 244 & 406.3 & 48.097 & & 444.3 & 48.258 & \\
\hline 245 & 413.1 & 48.678 & & 451.9 & 48.876 & \\
\hline 246 & 419.9 & 49.262 & & 459.5 & 49.506 & \\
\hline 247 & 426.9 & 49.838 & & 467.3 & 50.147 & \\
\hline 248 & 434.0 & 50.456 & & 475.2 & 50.780 & \\
\hline 249 & 441.2 & $51.066^{-}$ & & 483.3 & 51.446 & \\
\hline 250 & 448.5 & 51.689 & & 491.5 & 52.105 & \\
\hline
\end{tabular}

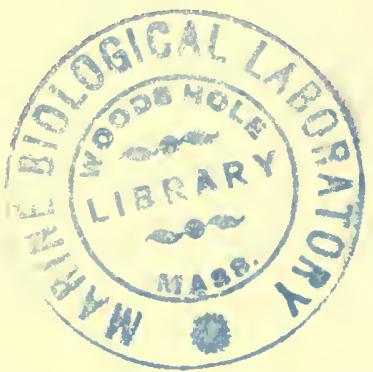


TABLE 74

Giving the percentage of water in the brain and in the spinal cord for each sex, on age: See Chart 26.

\begin{tabular}{|c|c|c|c|c|c|c|c|c|c|c|}
\hline \multirow[b]{2}{*}{$\begin{array}{l}\text { AGE } \\
\text { IN } \\
\text { DAYS }\end{array}$} & \multicolumn{5}{|c|}{ Males } & \multicolumn{5}{|c|}{ TEMALES } \\
\hline & $\begin{array}{c}\text { Body } \\
\text { weight } \\
\text { gms. }\end{array}$ & $\begin{array}{c}\text { Brain } \\
\text { weight } \\
\text { ams. }\end{array}$ & $\begin{array}{c}\text { Per cent } \\
\text { of water } \\
\text { brain }\end{array}$ & $\begin{array}{c}\text { Cord } \\
\text { weight } \\
\text { oms. }\end{array}$ & $\begin{array}{c}\text { Per cent } \\
\text { of water } \\
\text { cord }\end{array}$ & $\begin{array}{c}\text { Body } \\
\text { weight } \\
\text { gms. }\end{array}$ & $\begin{array}{c}\text { Brain } \\
\text { weight } \\
\text { gms. }\end{array}$ & $\begin{array}{c}\text { Per cent } \\
\text { of water } \\
\text { brain }\end{array}$ & $\begin{array}{c}\text { Cord } \\
\text { weight } \\
\text { gms. }\end{array}$ & $\begin{array}{c}\text { Per } \\
\text { cent of } \\
\text { water } \\
\text { cord }\end{array}$ \\
\hline B & 4.7 & 0.217 & 88.00 & 0.033 & 86.75 & 4.6 & 0.213 & 88.00 & 0.033 & 86.75 \\
\hline 1 & 5.5 & 0.290 & 87.95 & 0.038 & 86.42 & 5.4 & 0.269 & 87.95 & 0.037 & 86.42 \\
\hline 2 & 5.9 & 0.333 & 87.90 & 0.041 & 86.08 & 5.8 & 0.323 & 87.90 & 0.041 & 86.08 \\
\hline 3 & 6.4 & 0.395 & 87.85 & 0.046 & 85.74 & 6.3 & 0.373 & 87.85 & 0.045 & 85.74 \\
\hline 4 & 6.9 & 0.442 & 87.83 & 0.050 & 85. & 6.8 & 0.421 & 87.83 & 0.050 & 85.41 \\
\hline 5 & 7.6 & 0.509 & 87.79 & 0.056 & 85. & 7.5 & 0.492 & 87.79 & 0.056 & 85.07 \\
\hline 6 & 8.5 & 0.581 & 87.70 & 0.064 & 84.73 & 8.4 & 0.564 & 87.70 & 0.064 & 84.73 \\
\hline 7 & 9.5 & 0.657 & 87.50 & 0.072 & 84.40 & 9.4 & 0.645 & 87.50 & 0.073 & 84 \\
\hline 8 & 10.5 & 0.708 & 87.30 & 0.081 & 84 & 10.4 & 0 . & 8 & 82 & 0 \\
\hline 9 & 11.8 & 0.840 & 87.05 & 0.091 & 83.73 & 11.6 & 0.811 & 87.05 & 0.091 & 83.73 \\
\hline 10 & 13.5 & 0.947 & 86 & 0.104 & 83 & 0 & 0 & 8 & 02 & \\
\hline 11 & 13.9 & 0.969 & 86.26 & 0.106 & 82. & 13.7 & 0.940 & 86.26 & 07 & 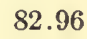 \\
\hline 12 & 14.4 & 0.991 & 85. & 0.110 & 82 & & 79 & & 12 & \\
\hline 13 & 14.9 & 1.011 & 85 & 0.1 & 82 & 1 & 1. & & 17 & \\
\hline 14 & 15.5 & 1.037 & 84.97 & 0.118 & 81 & 15.8 & 1.031 & & & 81.68 \\
\hline 15 & 16.1 & 1.057 & 84.58 & 0.122 & 81. & 16.5 & 1.048 & 84.59 & 0.127 & 81.28 \\
\hline 16 & 16.7 & 1.077 & 84.19 & 0.126 & 81. & 17.3 & 1.079 & 84 & 0 . & 80 \\
\hline 17 & 17.3 & 1.095 & 83.82 & 0.1 & 80 & 1 & 1 & 2 & 38 & 0 \\
\hline 18 & 18.0 & 1.112 & 83 & 0.135 & 80 & 9 & 1.118 & & 42 & 80.11 \\
\hline 19 & 18.7 & 1.131 & 83.12 & 0.139 & 79 & 19.8 & 1.140 & & & 79 \\
\hline 20 & 19.5 & 1.150 & 82.80 & 0.144 & 79.5 & 2 & 1.159 & 82.82 & 0.154 & 79.47 \\
\hline 21 & 2 & 9 & 9 & 9 & & & 77 & & & \\
\hline 22 & 21.1 & 1.184 & 82.19 & 0.154 & 78 & 22.5 & 1.195 & 82 & 0.165 & 78.67 \\
\hline 23 & 22.0 & 1.202 & 81.91 & 0.159 & 78.54 & 23.4 & 1.208 & 81.93 & 0.170 & 78.33 \\
\hline 24 & 22.9 & 1.219 & 81.64 & 0.165 & 78.22 & 24.4 & 1.226 & 81.66 & 0.176 & 78.00 \\
\hline 25 & 23.9 & 1.237 & 81.39 & 0.169 & 77.90 & 25.4 & 1.241 & 81.41 & 0.182 & 77.67 \\
\hline 26 & 24.9 & 1.252 & 81.15 & 0.175 & 77 & 26.5 & 1.251 & 81.17 & 0.187 & 77.36 \\
\hline 27 & 25.9 & 1.266 & 80.93 & 0.179 & 77.29 & 27.5 & 1.269 & 80.95 & 0.193 & 77.06 \\
\hline 28 & 27.0 & 1.282 & 80.72 & 0.186 & 77.00 & 28.6 & 1.282 & 80.74 & 0.198 & 76.76 \\
\hline 29 & 28.1 & 1.297 & 80.53 & 0.193 & 76.71 & 29.7 & 1.297 & 80.55 & 0.204 & 76.47 \\
\hline 30 & 29.2 & 1.311 & 80.35 & 0.198 & 76.43 & 30.9 & 1.310 & 80.37 & 0.210 & 76.19 \\
\hline 31 & 30.4 & 1.324 & 80.19 & 0.204 & 76 & .0 & & & & \\
\hline 32 & 31.6 & 1.338 & 80.04 & 0.210 & 75.90 & 33.2 & 1.334 & 80.07 & 0.221 & 75.66 \\
\hline 33 & 32.8 & 1.351 & 79.91 & 0.215 & 75.64 & 34.4 & 1.346 & 79.94 & 0.227 & 75.40 \\
\hline 34 & 34.1 & 1.363 & 79.79 & 0.221 & 75.39 & 35.7 & 1.358 & 79.82 & 0.233 & 75.16 \\
\hline 35 & 35.4 & 1.375 & 79.69 & 0.227 & 75.15 & 37.0 & 1.369 & 79.72 & 0.239 & 74.92 \\
\hline 36 & 36.8 & 1.389 & 79.60 & 0.233 & 74.91 & 38.3 & 1.380 & 79.63 & 0.245 & 74.69 \\
\hline
\end{tabular}


TABLE 74-Continued

\begin{tabular}{|c|c|c|c|c|c|c|c|c|c|c|}
\hline \multirow{2}{*}{$\begin{array}{c}\text { AGE } \\
\text { IN } \\
\text { DAYS }\end{array}$} & \multicolumn{5}{|c|}{ MALES } & \multicolumn{5}{|c|}{ FEMALES } \\
\hline & $\begin{array}{c}\text { Body } \\
\text { weight } \\
\text { oms. }\end{array}$ & $\begin{array}{l}\text { Brain } \\
\text { weight } \\
\text { gms. }\end{array}$ & $\begin{array}{c}\text { Per cent } \\
\text { of water } \\
\text { brain }\end{array}$ & $\begin{array}{c}\text { Cord } \\
\text { weight } \\
\text { gms. }\end{array}$ & $\begin{array}{l}\text { Per cent } \\
\text { of water } \\
\text { cord }\end{array}$ & $\begin{array}{c}\text { Body } \\
\text { weight } \\
\text { gms. }\end{array}$ & $\begin{array}{c}\text { Brain } \\
\text { weight } \\
\text { gms. }\end{array}$ & $\mid \begin{array}{c}\text { Per cent } \\
\text { of water } \\
\text { Brain }\end{array}$ & $\begin{array}{c}\text { Cord } \\
\text { weignt } \\
\text { gms. }\end{array}$ & $\begin{array}{c}\text { Per } \\
\text { cent of } \\
\text { water } \\
\text { cord }\end{array}$ \\
\hline 37 & 38.1 & 1.399 & 79.52 & 0.239 & 74.68 & 39.6 & 1.391 & 79.55 & 0.250 & 74.47 \\
\hline 38 & 39.6 & 1.411 & 79.46 & 0.245 & 74.46 & 40.9 & 1.400 & 79.49 & 0.255 & 74.26 \\
\hline 39 & 41.0 & 1.423 & 79.42 & 0.251 & 74.25 & 42.3 & 1.411 & 79.45 & 0.261 & 74.06 \\
\hline 40 & 42.5 & 1.434 & 79.39 & 0.257 & 74.04 & 43.7 & 1.422 & 79.42 & 0.267 & 73.86 \\
\hline 41 & 44.1 & 1.446 & 79.36 & 0.264 & 73 & 45.1 & 1.432 & 79.39 & 0.272 & 73.78 \\
\hline 42 & 45.7 & 1.457 & 79.34 & 0.269 & 73.87 & 46.6 & 1.441 & 79.37 & 0.278 & 73.72 \\
\hline 43 & 47.3 & 1.468 & 79.32 & 0.276 & 73.74 & 48.1 & 1.451 & 79.35 & 0.284 & 73.60 \\
\hline 44 & 48.9 & 1.478 & 79.30 & 0.281 & 7 & 6 & 1.460 & 7 & 0.289 & 73.50 \\
\hline 45 & 50.6 & 1.488 & 79.28 & 0.288 & 73. & 1 & 1.468 & 7 & 0.294 & 73.39 \\
\hline 46 & 52.3 & 1.498 & 79.26 & 0.293 & 73 & 52.7 & 1.478 & 79 & 0.300 & 73.30 \\
\hline 47 & 54.1 & 1.507 & 79.24 & 0.299 & 73. & 54.3 & 1.487 & 79.27 & 0.306 & 73.21 \\
\hline 48 & 55.9 & 1.518 & 79.22 & 0.305 & 73.17 & 55.9 & 1.495 & 79.25 & 0.311 & 73.12 \\
\hline 49 & 57.7 & 1.527 & 79.21 & 0.311 & 73. & 57.5 & 1.503 & 79.24 & 0.316 & 72.05 \\
\hline 50 & 59.6 & 1.537 & 79.19 & 0.317 & 72.97 & 59.2 & 1.512 & 79.23 & 0.322 & 72.97 \\
\hline 51 & 61 & 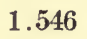 & 7 & 0 & & 6 & 1 & & & \\
\hline 52 & 63.4 & 1.555 & 7 & 0. & 72 & 6 & 1. & 79 & & 72 \\
\hline 53 & 65.4 & 1.563 & 79 . & 0.334 & 72 & 64.3 & 1.535 & 79 & 0 . & 72.69 \\
\hline 54 & 67.4 & 1.572 & 79.12 & 0.340 & 72.60 & 66.1 & 1.543 & 79.16 & 0.343 & 72.60 \\
\hline 55 & 69.5 & 1.581 & 79.10 & 0.346 & 72. & 9 & 1.551 & 79.14 & 0.348 & 72.51 \\
\hline 56 & 71.6 & 1.589 & 79.08 & 0.352 & 72 . & 69.7 & 1.558 & 79.12 & 0.353 & 72.43 \\
\hline 57 & 73.7 & 1.597 & 79.07 & 0.3 & 72 & 71.6 & 1.565 & 79 & 0 . & 72 \\
\hline 58 & 75.9 & 1.606 & 5 & 0.363 & 72 & 73.4 & 1.573 & 79 & 0.364 & 72.27 \\
\hline 59 & 78.1 & 1.614 & 79.04 & 0.369 & 72. & 75.3 & 1.580 & 79 & 0.370 & 72.19 \\
\hline 60 & 80.3 & 1.622 & 79.02 & 0.375 & 72.11 & 77.3 & 1.587 & 79.06 & 0.375 & 72.11 \\
\hline 61 & & 1.0 & & & & & & & & 72 \\
\hline 62 & 84.9 & 1.637 & 78 . & 0.3 & 71. & 81.2 & 1.601 & 70 & 0. & 71.97 \\
\hline 63 & 87.2 & 1.644 & & 0.391 & 71.91 & 83.2 & 1.607 & 79.01 & 0.389 & 71.91 \\
\hline 64 & 89.6 & 1.652 & 78.96 & 0.397 & 71.84 & 85.2 & 1.614 & 78.99 & 0.394 & 71.84 \\
\hline 65 & 92.0 & 1.659 & 78.94 & 0.402 & 71.77 & 87.3 & 1.621 & 78.98 & 0.399 & 71.77 \\
\hline 66 & 94.5 & 1.666 & 78.93 & 0.407 & 71.71 & 89.4 & 1.627 & 78.97 & 0.404 & 71.72 \\
\hline 67 & 97.0 & 1.673 & 78.92 & 0.413 & 71.65 & 91.5 & 1.633 & 78.96 & 0.409 & 71.66 \\
\hline 68 & 99.5 & 1.681 & 78.90 & 0.418 & 71.60 & 93.6 & 1.639 & 78.94 & 0.414 & 71.61 \\
\hline 69 & 102.1 & 1.688 & 78.89 & 0.424 & 71.54 & 95.8 & 1.645 & 78.93 & 0.419 & 71.54 \\
\hline 70 & 104.7 & 1.695 & 78.88 & 0.429 & 71.48 & 98.0 & 1.651 & 78.92 & 0.424 & 71.50 \\
\hline 71 & 107.3 & 1.8 & & 0.4 & & & 1.657 & & & 71.45 \\
\hline 72 & 110.0 & 1.709 & 78.85 & 0.439 & 71.38 & 102.4 & 1.663 & 78.89 & 0.433 & 71.41 \\
\hline 73 & 112.7 & 1.715 & 78.84 & 0.445 & 71.32 & 104.7 & 1.669 & 78.88 & 0.438 & 71.36 \\
\hline 74 & 115.5 & 1.722 & 78.82 & 0.450 & 71.27 & 107.0 & 1.675 & 78.86 & 0.442 & 71.32 \\
\hline
\end{tabular}


TABLE 74-Continued

\begin{tabular}{|c|c|c|c|c|c|c|c|c|c|c|}
\hline \multirow[b]{2}{*}{$\begin{array}{c}\Delta G E \\
\text { IN } \\
D A Y S\end{array}$} & \multicolumn{5}{|c|}{ MALES } & \multicolumn{5}{|c|}{ FEMALES } \\
\hline & $\begin{array}{c}\text { Body } \\
\text { weight } \\
\text { gms. }\end{array}$ & $\begin{array}{l}\text { Brain } \\
\text { weight } \\
\text { gms. }\end{array}$ & $\left|\begin{array}{c}\text { Per cent } \\
\text { of water } \\
\text { brain }\end{array}\right|$ & $\begin{array}{c}\text { Cord } \\
\text { weight } \\
\text { gms. }\end{array}$ & $\begin{array}{c}\text { Per cent } \\
\text { of water } \\
\text { cord }\end{array} \mid$ & $\begin{array}{c}\text { Body } \\
\text { weight } \\
\text { gmsr }\end{array}$ & $\begin{array}{c}\text { Brain } \\
\text { weight } \\
\text { oms. }\end{array}$ & $\begin{array}{c}\text { Per cent } \\
\text { of water } \\
\text { Brain }\end{array}$ & $\begin{array}{c}\text { Cord } \\
\text { weight } \\
\text { oms. }\end{array}$ & \begin{tabular}{|c} 
Per \\
cent of \\
water \\
cord
\end{tabular} \\
\hline 75 & 118.3 & 729 & 78.81 & 0.455 & 71.22 & 109.3 & 1.681 & 78.85 & 0.447 & 71.27 \\
\hline 76 & 121.1 & 1.735 & 78.80 & 0.460 & & 111.6 & 1.687 & 78.84 & 0.451 & \\
\hline 77 & 124.0 & 1.741 & 78.79 & 0.465 & 7 & 1 & 1.692 & & & \\
\hline 78 & 126.8 & 1.746 & 78.77 & 0.470 & 71. & 116.4 & 1.698 & 78 & 0.460 & \\
\hline 79 & 129.8 & 1.752 & 78.76 & 0.475 & & 118.8 & 1.703 & & 0.465 & 1.11 \\
\hline 80 & 132.8 & 1.758 & 78.75 & 0.480 & 71.00 & 121.3 & 1.709 & 78.80 & 0.469 & 71.07 \\
\hline 81 & 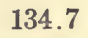 & 1.762 & 78.74 & 3 & & & 2 & & 1 & \\
\hline 82 & 136.5 & 1.765 & 78. & 0.4 & & & 1.715 & & & 71.00 \\
\hline 83 & 138.4 & 1.769 & 78. & 0.488 & & & 1.717 & & & \\
\hline 84 & 140.2 & 1.772 & 78. & 0.491 & 70 & 1 & 1.720 & 6 & 0.479 & 70.93 \\
\hline 85 & 142.0 & 1.776 & 78 & 0.4 & & & 1.723 & & & \\
\hline 86 & 143.7 & 1.779 & 78. & 0. & & & $1: 726$ & & & \\
\hline 87 & 145.5 & 1.782 & 78. & 0.499 & & & & & & \\
\hline 88 & 147 & 1.785 & 78 . & 0.502 & & & & & & 70.80 \\
\hline 89 & 14 & 1.7 & 78 & 0.504 & & & 33 & & 0 & 77 \\
\hline 90 . & 150.5 & 1.791 & 78. & 0.507 & & 6 & 1.736 & & 0.492 & 74 \\
\hline 91 & & & & & & & & & & \\
\hline 92 & 15 & 1.797 & & 0.5 & & & 1.740 & & & \\
\hline 93 & 155.3 & 1.7 & 78 & 0.5 & & & 1.743 & & & \\
\hline 94 & & 1.8 & & 0. & & & 45 & & & 70.64 \\
\hline 95 & 158.4 & 1.80 & & 0.518 & & & 1.747 & & & 70.62 \\
\hline 96 & 160.0 & 1.807 & 78 . & 0.5 & & & 1.749 & & & 70.60 \\
\hline 97 & 161.4 & 1.810 & & 0.5 & & & 1.751 & & & \\
\hline 98 & 162.9 & 1.812 & 78 . & 0.525 & & & 1.752 & 2 & 06 & 70.55 \\
\hline 99 & & & & & & & & & & 70.53 \\
\hline 100 & 165.8 & 1.817 & 78.55 & 0.529 & 70 & 146.2 & 1.756 & 78.60 & 0.510 & 70.51 \\
\hline 101 & & & & & & & & & & \\
\hline 102 & 168.6 & 1.821 & 78 . & 0. & 70 & 3 & 1.760 & 8 & 14 & 70.47 \\
\hline 103 & 170.0 & 1.824 & 78.53 & 0.534 & & & 1.762 & 78.58 & 0.515 & 70.46 \\
\hline 104 & 171.3 & 1.826 & 78.52 & 0.536 & 70 & & 1.764 & & & 70.44 \\
\hline 105 & 172.7 & 1.828 & 78. & 0.538 & 70 . & & & & & \\
\hline $106^{\circ}$ & 174.0 & 1.830 & 78.50 & 0.540 & 70 & 152.4 & 1.768 & & & 60.41 \\
\hline 107 & 175.3 & 1.832 & 78.49 & 0.541 & 70.25 & 153.4 & 1.770 & 78.54 & 0.522 & 70.40 \\
\hline 108 & 176.6 & 1.833 & 78.48 & 0.543 & 70.23 & 154.4 & 1.772 & 78.53 & 0.523 & 70.38 \\
\hline 109 & 177.9 & 1.835 & 78.47 & 0.544 & 70.22 & & 1.774 & 78.52 & 0.525 & 70.37 \\
\hline 110 & 179.1 & 1.837 & 78.46 & 0.546 & 70.20 & 156.3 & 1.775 & 78.51 & 0.526 & 70.36 \\
\hline 111 & & & & & & & & & & 10.03 \\
\hline 112 & 181.6 & 1.841 & 78.44 & 0.549 & 70.17 & 158.2 & 1.778 & 78.49 & 0.528 & 70.34 \\
\hline
\end{tabular}


TABLE 74-Continued

\begin{tabular}{|c|c|c|c|c|c|c|c|c|c|c|}
\hline \multirow[b]{2}{*}{$\begin{array}{l}\text { AGE } \\
\text { IN } \\
\text { DAYS }\end{array}$} & \multicolumn{5}{|c|}{ MALES } & \multicolumn{5}{|c|}{ FEMALES } \\
\hline & $\begin{array}{c}\text { Body } \\
\text { weight } \\
\text { gms. }\end{array}$ & $\begin{array}{l}\text { Brain } \\
\text { weight } \\
\text { gms. }\end{array}$ & $\begin{array}{c}\text { Per cent } \\
\text { of water } \\
\text { braln }\end{array}$ & $\begin{array}{c}\text { Cord } \\
\text { weight } \\
g m s .\end{array}$ & $\begin{array}{l}\text { Per cent } \\
\text { of water } \\
\text { cord }\end{array}$ & $\begin{array}{c}\text { Body } \\
\text { weight } \\
\text { gms. }\end{array}$ & $\begin{array}{c}\text { Brain } \\
\text { weight } \\
g m s .\end{array}$ & $\begin{array}{c}\text { Per cent } \\
\text { of water } \\
\text { Brain }\end{array}$ & $\begin{array}{c}\text { Cord } \\
\text { weight } \\
g m s .\end{array}$ & $\mid \begin{array}{c}\text { Per } \\
\text { cent of } \\
\text { water } \\
\text { cord }\end{array}$ \\
\hline 113 & $182: 8$ & 1.842 & 78.44 & 0.550 & 70.15 & 159.1 & 1.779 & 78.49 & 0.530 & 70.32 \\
\hline 114 & 184.0 & 1.844 & 78.43 & 0.552 & 70.14 & 160.0 & 1.781 & 78.48 & 0.531 & 70.31 \\
\hline 115 & 185.2 & 1.846 & 78.42 & 0.553 & 70.13 & 160.9 & 1.782 & 78.47 & 0.532 & 70.30 \\
\hline 116 & 186.4 & 1.848 & 78.41 & 0.555 & 70.12 & 161.8 & 1.783 & 78.46 & 0.533 & 70.29 \\
\hline 117 & 187.5 & 1.849 & 78.40 & 0.556 & 70 . & 162.6 & 1.785 & 78.46 & 0.535 & 70.28 \\
\hline 118 & 188.7 & 1.851 & 78.40 & 0.558 & 70.09 & 163.5 & 1.786 & 78.45 & 0.536 & 70.27 \\
\hline 119 & 189.7 & 1.852 & 78.39 & 0.559 & 70.08 & 164.3 & 1.788 & & 0.538 & 70.26 \\
\hline 120 & 190.9 & 1.854 & & 0.561 & & & & & 0.539 & 70.25 \\
\hline 121 & 192.0 & 855 & 7 & 0.562 & 70 & 16 & 1.790 & 43 & 0.540 & 7 \\
\hline 122 & 193.1 & 1.857 & 78 & 0.563 & 70. & 16 & 1.791 & & 0.541 & 70.24 \\
\hline 123 & 194.1 & 1.858 & 78.36 & 0.564 & 70 . & & 1.793 & & 0.542 & 70.24 \\
\hline 124 & 195.2 & 1.860 & 78.36 & 0.565 & 70.05 & 168.4 & 1.794 & 78.42 & 0.543 & 70.23 \\
\hline 125 & 196.2 & 1.861 & 78.35 & 0.566 & 70. & 169.2 & 1.795 & 78.41 & 0.544 & 70.23 \\
\hline 126 & 197.3 & 1.862 & 78 & 0.567 & 70 & 17 & 1.796 & 0 & 0.545 & 70.23 \\
\hline 127 & 198.3 & 1.863 & 78. & 0.569 & 70. & 17 & 1.798 & & 0.546 & 70.23 \\
\hline 128 & 199.3 & 1.865 & 78.33 & 0.570 & 70 . & & 1.799 & & 0.546 & 70.22 \\
\hline 129 & 200.3 & 1.866 & 78.32 & 0.572 & 70 & 172.3 & 1.801 & 78.38 & 0.547 & 70.22 \\
\hline 130 & 201.2 & 1.867 & 78.31 & 0.573 & 70.01 & 173.0 & 1.802 & 78.37 & 0.548 & 70.22 \\
\hline 131 & .2 & 1.868 & & 0.574 & & & 3 & & & 70.22 \\
\hline 132 & 203.2 & 1.870 & 78 & 0.575 & & & 1. & & & 70.22 \\
\hline 133 & 204.1 & 1.871 & 78.29 & 0.576 & 70. & 175.2 & 1.804 & 78 & 0.551 & 70.22 \\
\hline 134 & 205.1 & 1.873 & 78.29 & 0.577 & 70. & 175.9 & 1.805 & 78 & 0. & 70.22 \\
\hline 135 & 206.0 & 1.874 & 78 & 0.578 & 70 & 2 & 1.806 & 78.34 & 53 & 70.22 \\
\hline 136 & 206.9 & 1.875 & 78.27 & 0.579 & 70. & 17 & 1.807 & 78 & 0.554 & 70.22 \\
\hline 137 & 207.8 & 1.876 & 78.26 & 0.580 & 70. & 176.9 & 1.808 & 78.32 & 0.555 & 70.22 \\
\hline 138 & 208.7 & 1.877 & 78.26 & 0.580 & 70. & 177.6 & 1.809 & 78.32 & 0.555 & 70.22 \\
\hline 139 & 209.6 & 1.878 & 78.25 & 0.581 & 70. & 178.3 & 1.810 & 78.31 & 0.556 & 70.22 \\
\hline 140 & 210.5 & 1.879 & 78.24 & 0.582 & 70.00 & 179.9 & 1.811 & 78.30 & 0.557 & 70.22 \\
\hline 141 & 211.3 & 1.0 & & & & & & & & 70.22 \\
\hline 142 & 212.2 & 1.881 & 78.23 & 0.584 & 70. & 181.2 & 1.813 & 78.29 & 0.559 & 70.22 \\
\hline 143 & 213.0 & 1.882 & 78.23 & 0.584 & 70.00 & 181.8 & 1.813 & 78.29 & 0.559 & 70.22 \\
\hline 144 & 213.9 & 1.883 & 78.22 & 0.585 & 70.00 & 182.5 & 1.814 & 78.28 & 0.560 & 70.22 \\
\hline 145 & 214.7 & 1.884 & 78.22 & 0.586 & 70.00 & 183.1 & 1.815 & 78.28 & 0.561 & 70.22 \\
\hline 146 & 215.5 & 1.885 & 78.21 & 0.587 & 70.00 & 183.7 & 1.816 & 78.27 & 0.562 & 70.22 \\
\hline 147 & 216.3 & 1.886 & 78.21 & 0.588 & 70.00 & 184.3 & 1.817 & 78.27 & 0.562 & 70.22 \\
\hline 148 & 217.1 & 1.887 & 78.20 & 0.588 & 70.00 & 184.9 & 1.817 & 78.26 & 0.563 & 70.22 \\
\hline 149 & 217.9 & 1.887 & 78.20 & 0.589 & 70.00 & 185.5 & 1.818 & 78.26 & 0.564 & 70.22 \\
\hline 150 & 218.7 & 1.888 & 78.19 & 0.590 & 70.00 & 186.1 & 1.819 & 78.25 & 0.565 & 70.22 \\
\hline
\end{tabular}


TABLE $74-$ Continued

\begin{tabular}{|c|c|c|c|c|c|c|c|c|c|c|}
\hline \multirow[b]{2}{*}{$\begin{array}{l}\text { AGE } \\
\text { IN } \\
\text { DAYS }\end{array}$} & \multicolumn{5}{|c|}{ MALES } & \multicolumn{5}{|c|}{ FEMALES } \\
\hline & $\begin{array}{c}\text { Body } \\
\text { weight } \\
\text { gms. }\end{array}$ & $\begin{array}{l}\text { Brain } \\
\text { weight } \\
\text { gms. }\end{array}$ & $\begin{array}{c}\text { Per cent } \\
\text { of water } \\
\text { brain }\end{array}$ & \begin{tabular}{|c} 
Cord \\
welght \\
gms.
\end{tabular} & $\left|\begin{array}{c}\text { Per cent } \\
\text { of water } \\
\text { cord }\end{array}\right|$ & $\begin{array}{c}\text { Body } \\
\text { weight } \\
\text { gms. }\end{array}$ & $\begin{array}{c}\text { Brain } \\
\text { weight } \\
g m s .\end{array}$ & $\begin{array}{c}\text { Per cent } \\
\text { of water } \\
\text { Brain }\end{array}$ & $\begin{array}{c}\text { Cord } \\
\text { weight } \\
g m s .\end{array}$ & \begin{tabular}{|c|} 
Per \\
cent of \\
water \\
cord
\end{tabular} \\
\hline 151 & 219.5 & 1.889 & 78.19 & 0.591 & 70.00 & 186.7 & 1.820 & 78.25 & 0.565 & 70.22 \\
\hline 152 & 220.2 & 1.890 & 78.18 & 0.592 & 70.00 & 187.2 & 1.821 & 78.24 & 0.566 & 70.22 \\
\hline 153 & 221.0 & 1.891 & 78.18 & 0.592 & 70.00 & 187.8 & 1.821 & 78.24 & 0.567 & 70.22 \\
\hline 154 & 221.7 & 1.892 & 78.17 & 0.593 & 70.00 & 188.4 & 1.822 & 78.23 & 0.568 & 70.22 \\
\hline 155 & 222.5 & 1.893 & 78.17 & 0.594 & 70.00 & 188.9 & 1.823 & 78.23 & 0.568 & 70.22 \\
\hline 156 & 223.2 & 1.894 & 78.16 & 0.595 & 70.70 & .5 & 1.824 & 78.22 & 0.569 & \\
\hline 157 & 223.9 & 1.895 & 78.16 & 0.586 & 70.00 & 190.0 & 1.825 & 78.22 & 0.570 & 70.22 \\
\hline 158 & 224.7 & 1.896 & 78.15 & 0.596 & 70.00 & 6 & 1.825 & 1 & 0.571 & .22 \\
\hline 159 & 225.3 & 1.897 & 78 & 0.597 & 70 & 19 & 1.826 & 78 & 0.571 & 70.22 \\
\hline 160 & 226.0 & 1.898 & 78.14 & 0.598 & 70 & 19 & 1.827 & & 0.572 & 70.22 \\
\hline 161 & 226 . & 1 & 7 & & & & 28 & & & \\
\hline 162 & 227.4 & 1.900 & 78 & 0.600 & 70 & 6 & 1.829 & 9 & 74 & 70.22 \\
\hline 163 & 228.1 & 1.901 & 78.13 & 0.600 & 70 & & 1.829 & & 74 & 70.22 \\
\hline 164 & 228.8 & 1.902 & 78.12 & 0.601 & 70 . & 19 & 1.830 & 78 & 0.575 & 70.22 \\
\hline 165 & 229.4 & 1.902 & 78.12 & 0.602 & 70. & .2 & 1.831 & 78.18 & 0.576 & 70.22 \\
\hline 166 & 230.1 & 1.903 & 78.12 & 0.603 & 70 & .6 & 1.832 & 18 & 0.576 & 70.22 \\
\hline 167 & 230.7 & 1.903 & 78 & 0.603 & 70 & 1 & 1.832 & 78 & 77 & 70.22 \\
\hline 168 & 231.4 & 1.904 & 78 & 0.6 & 70 & & 33 & & & 70.22 \\
\hline 169 & 232.0 & 1.904 & 78.12 & 0.604 & 70 & 19 & 1.833 & 78 & 0.578 & 70.22 \\
\hline 170 & 232.6 & 1.905 & 78.12 & 0.605 & 70.00 & 196.5 & 1.834 & 78.18 & 0.578 & 70.22 \\
\hline 171 & & & & & & & 1.834 & & & \\
\hline 172 & 233.9 & 1.906 & 78.12 & 0.606 & & & 1.835 & & & 70.22 \\
\hline 173 & 234.5 & 1.907 & 78.12 & 0.606 & 70 & & 1.835 & 78 & 0.580 & 70.22 \\
\hline 174 & .1 & 1.907 & 78 & 0.607 & 70 & 4 & 1.836 & 8 & 0.580 & 70.22 \\
\hline 175 & 235.7 & 1.908 & 78.12 & 0.608 & 70 & 8 & 1.837 & 78 & 0.581 & 70.22 \\
\hline 176 & 236.3 & 1.909 & 78.12 & 0.608 & 70. & & 1.837 & 78. & 0.581 & 70.22 \\
\hline 177 & 236.9 & 1.909 & 78.12 & 0.609 & 70. & & 1.838 & 78. & 0.582 & 70.22 \\
\hline 178 & 237.4 & 1.910 & 78.11 & 0.609 & 69 & 20 & 1.838 & 78 & & 70.22 \\
\hline 179 & 238.0 & 1.910 & 78.11 & 0.610 & 69. & 20 & 1.839 & 78 & 0.583 & 70.22 \\
\hline 180 & 238.6 & 1.911 & 78.11 & 0.610 & 69.99 & 201.0 & 1.839 & 78.17 & 0.583 & 70.22 \\
\hline 181 & & 1.012 & & & & & & & & \\
\hline 182 & 239.7 & 1.912 & 78.11 & 0.612 & 69. & 201.8 & 1.841 & 78.17 & 0.584 & 70.22 \\
\hline 183 & 240.2 & 1.913 & 78.11 & 0.612 & 69.99 & 202.2 & 1.841 & 78.17 & 0.585 & 70.22 \\
\hline 184 & 240.8 & 1.913 & 78.11 & 0.613 & 69.99 & 202.6 & 1.842 & 78.17 & 0.585 & 70.22 \\
\hline 185 & 241.3 & 1.914 & 78.11 & 0.613 & 69.99 & 203.0 & 1.842 & 78.17 & 0.586 & 70.22 \\
\hline 186 & 241.8 & 1.915 & 78.11 & 0.814 & 69.99 & 203.4 & 1.843 & 78.17 & 0.586 & 70.22 \\
\hline 187 & 242.3 & 1.915 & 78.11 & 0.614 & 69.99 & 203.8 & 1.843 & 78.17 & 0.587 & 70.22 \\
\hline 188 & 242.9 & 1.916 & 78.11 & 0.615 & 69.99 & 204.2 & 1.844 & 78.17 & 0.587 & 70.22 \\
\hline
\end{tabular}


TABLE 74-Continued

\begin{tabular}{|c|c|c|c|c|c|c|c|c|c|c|}
\hline \multirow[b]{2}{*}{$\begin{array}{c}A G E \\
\text { IN } \\
\text { DAYS }\end{array}$} & \multicolumn{5}{|c|}{ MALES } & \multicolumn{5}{|c|}{ FEMALES } \\
\hline & $\begin{array}{c}\text { Body } \\
\text { weight } \\
\text { gms. }\end{array}$ & $\begin{array}{l}\text { Brain } \\
\text { weight } \\
\text { gms. }\end{array}$ & $\left|\begin{array}{c}\text { Per cent } \\
\text { of water } \\
\text { brain }\end{array}\right|$ & $\begin{array}{c}\text { Cord } \\
\text { weight } \\
\text { gms. }\end{array}$ & $\begin{array}{c}\text { Per cent } \\
\text { of water } \\
\text { cord }\end{array}$ & $\begin{array}{c}\text { Body } \\
\text { weight } \\
\text { gms. }\end{array}$ & $\begin{array}{c}\text { Brain } \\
\text { weight } \\
\text { gms. }\end{array}$ & $\left|\begin{array}{c}\text { Per cent } \\
\text { of water } \\
\text { Brain }\end{array}\right|$ & $\begin{array}{c}\text { Cord } \\
\text { weight } \\
\text { gms. }\end{array}$ & $\begin{array}{c}\text { Per } \\
\text { cent of } \\
\text { water } \\
\text { cord }\end{array}$ \\
\hline 189 & 243.4 & 1.916 & 78.11 & 0.615 & 69.99 & 204.6 & 1.844 & 78.17 & 0.588 & 70.22 \\
\hline 190 & 243.9 & 1.917 & 78.11 & 0.616 & 69.99 & 204.9 & 1.845 & 78.17 & 0.588 & 70.22 \\
\hline 191 & 244.4 & 1.917 & .11 & 0.616 & 69.99 & 5.3 & 1.845 & .17 & 0.588 & 70.22 \\
\hline 192 & 244.9 & 1.918 & 78.11 & 0.617 & 69. & 205.7 & 1.846 & 78.17 & 0.589 & 70.22 \\
\hline 193 & 245.4 & 1.918 & 78.11 & 0.617 & 69.98 & 206.0 & 1.846 & 78.17 & 0.589 & 70.22 \\
\hline 194 & 245.9 & 1.919 & 78.11 & 0.618 & 69.98 & 206.4 & 1.847 & 78.17 & 0.589 & 70.22 \\
\hline 195 & 246.3 & 1.919 & 78.11 & 0.618 & 69 & 7 & 1.847 & 17 & 0.590 & 70.21 \\
\hline 196 & 246.8 & 1.920 & 78.11 & 0.618 & 69 & 1 & 1.847 & 17 & 0.590 & 70.21 \\
\hline 197 & 247.3 & 1.920 & 78.10 & 0.619 & 69 & 207.4 & 1.848 & 78.17 & 0.591 & 70.21 \\
\hline 198 & 247.8 & 1.921 & 78.10 & 0.619 & 69.97 & 207.8 & 1.848 & 78.17 & 0.591 & 70.21 \\
\hline 199 & 248.2 & 1.921 & 78.10 & 0.620 & 69.97 & 208.1 & 1.849 & 78.17 & 0.591 & 70.21 \\
\hline 200 & 248.6 & 1.922 & 78 & 0.620 & 69 & .4 & 1.849 & 78.17 & 0.592 & 70.20 \\
\hline 201 & 1 & 1.922 & 78.10 & 0 & 6 & & 49 & 17 & 0 & 70.20 \\
\hline 202 & 249.6 & 1.923 & 78.10 & 0.621 & 69 & 9.1 & 1.850 & 78 & 92 & 70.20 \\
\hline 203 & 250.0 & 1.923 & 78. & 0.621 & 69 & 4 & 0 & 6 & 93 & 20 \\
\hline 204 & 250.4 & 1.924 & 7 & 0.622 & 6 & 8 & 51 & 16 & 0. & 70.20 \\
\hline 205 & 250.9 & 1.924 & 78.10 & 0.622 & 69 & .1 & 1.851 & 78 & 0 . & 70.20 \\
\hline 206 & 251.3 & 1.925 & 78.10 & 0.622 & 69. & 210.4 & 1.851 & 78.16 & 0.594 & 70.19 \\
\hline 207 & 251.7 & 1.925 & 78.10 & 0.623 & 69. & 210.7 & 1.852 & 78.16 & 0.594 & 70.19 \\
\hline 208 & 252.1 & 1.926 & 78.10 & 0.623 & 69 & .0 & 52 & 16 & 94 & 0.19 \\
\hline 209 & 25 & 26 & 9 & 324 & 6 & & 1.853 & 16 & 0.595 & 70.19 \\
\hline 210 & 252.9 & 1.927 & 78.09 & 0.624 & 69.9 & 211.6 & 1.853 & 78.16 & 0.595 & 70.19 \\
\hline 211 & & & & & & & & & & \\
\hline 212 & 253.7 & 1.928 & 78.09 & 0.625 & 69. & .2 & 1.854 & 78.16 & 0 . & 70.18 \\
\hline 213 & 254.2 & 1.928 & 78.09 & 0.625 & 69 & 5 & 54 & 78.16 & 0.596 & 70.18 \\
\hline 214 & 254.5 & 1.929 & 78.09 & 0.626 & 69 & & 1.855 & 78.16 & 0.597 & 70.18 \\
\hline 215 & 254.9 & 1.929 & 78.09 & 0.626 & 69.9 & 213.1 & 1.855 & 78.16 & 0.597 & 70.18 \\
\hline 216 & 255.3 & 1.929 & 78.09 & 0.626 & 69.93 & 213.4 & 1.855 & 78.16 & 0.597 & 70.18 \\
\hline 217 & 255.7 & 1.930 & 78.09 & 0.627 & 69.92 & 213.7 & 1.856 & 78.16 & 0.597 & 70.17 \\
\hline 218 & 256.1 & 1.930 & 78.08 & 0.627 & 69. & 213.9 & 1.856 & 78.15 & 0.598 & 70.17 \\
\hline 219 & 256.4 & 1.930 & 78.08 & 0.627 & 69.92 & 214.2 & 1.856 & 78.15 & 0.598 & 70.17 \\
\hline 220 & 256.8 & 1.931 & 78.08 & 0.628 & 69.91 & 214.4 & 1.857 & 78.15 & 0.598 & 70.16 \\
\hline 221 & 2 & & & & & & & & & 10 \\
\hline 222 & 257.5 & 1.931 & 78.08 & 0.628 & 69.90 & 215.0 & 1.857 & 78.15 & 0.599 & 70.16 \\
\hline 223 & 257.9 & 1.932 & 78.07 & 0.629 & 69.90 & 215.2 & 1.858 & 78.14 & 0.599 & 70.15 \\
\hline 224 & 258.2 & 1.932 & 78.07 & 0.629 & 69.90 & 215.5 & 1.858 & 78.14 & 0.599 & 70.15 \\
\hline 225 & 258.6 & 1.932 & 78.07 & 0.629 & 69.89 & 215.8 & 1.858 & 78.14 & 0.599 & 70.15 \\
\hline 226 & 258.9 & 1.933 & 78.07 & 0.630 & 69.89 & 216.0 & 1.859 & 78.14 & 0.600 & 70.14 \\
\hline
\end{tabular}


TABLE 74-Continued

\begin{tabular}{|c|c|c|c|c|c|c|c|c|c|c|}
\hline \multirow[b]{2}{*}{$\begin{array}{l}A G E \\
\text { IN } \\
\text { DAYS }\end{array}$} & \multicolumn{5}{|c|}{ MALES } & \multicolumn{5}{|c|}{ FEMALES } \\
\hline & $\begin{array}{c}\text { Body } \\
\text { weight } \\
g m s .\end{array}$ & $\begin{array}{c}\text { Brain } \\
\text { weight } \\
\text { gms. }\end{array}$ & $\begin{array}{c}\text { Per cent } \\
\text { of water } \\
\text { brain }\end{array}$ & $\begin{array}{c}\text { Cord } \\
\text { weight } \\
\text { gms. }\end{array}$ & $\left|\begin{array}{c}\text { Per cent } \\
\text { of water } \\
\text { cord }\end{array}\right|$ & $\begin{array}{c}\text { Body } \\
\text { weight } \\
g m s .\end{array}$ & $\begin{array}{c}\text { Brain } \\
\text { weight } \\
\text { gms. }\end{array}$ & $\begin{array}{c}\text { Per cent } \\
\text { of water } \\
\text { Brain }\end{array}$ & $\begin{array}{c}\text { Cord } \\
\text { weight } \\
g m s .\end{array}$ & $\mid \begin{array}{c}\text { Per } \\
\text { cent of } \\
\text { water } \\
\text { cord }\end{array}$ \\
\hline 227 & 259.2 & 1.933 & 78.07 & 0.630 & 69.89 & 216.2 & 1.859 & 78.14 & 0.600 & 70.14 \\
\hline 228 & 259.6 & 1.933 & 78.06 & 0.630 & & 216 & 1.859 & & 0.600 & \\
\hline 229 & 259.9 & 1.933 & 78.06 & 0.630 & 69.88 & 216.7 & 1.859 & 78.13 & 0.600 & 70.14 \\
\hline 230 & 260.2 & 1.934 & 78.06 & 0.631 & 69.88 & 217.0 & 1.860 & 78.13 & 0.601 & 70.13 \\
\hline 231 & 260.6 & .934 & 6 & 0.631 & 6 & 21 & 1.860 & 7 & 0.601 & 70 \\
\hline 232 & 260 . & 1.934 & 8.06 & 0.631 & 69 & & 1.860 & & & \\
\hline 233 & 261.2 & 1.935 & 78.05 & 0.632 & 69 & 7 & 1.861 & & 01 & \\
\hline 234 & 261.5 & 1.935 & 78.05 & 0.632 & 69 & & 1.861 & & 0.602 & \\
\hline 235 & 261. & 1.935 & 78.05 & 0.632 & 69 & & 1.861 & & 0.602 & \\
\hline 236 & 1.1 & 1.936 & 78.05 & 0.633 & 69 & 3 & 1.862 & 7 & 0.602 & 70 \\
\hline 237 & 262 . & 1.936 & & 0.6 & 69 & & 1.862 & & 02 & \\
\hline 238 & 262 & 1.936 & 4 & 0.6 & 6 & 8 & 1.862 & & 03 & \\
\hline 239 & & 1.937 & & 0.634 & 69 & 0 & 1.863 & & 0.603 & \\
\hline 240 & & & & 0.634 & 69 & & 1.863 & & 0.603 & \\
\hline 241 & & & & & & & & & & \\
\hline 242 & 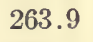 & 1.9 & & & & & & & & \\
\hline 243 & 4.2 & 1.938 & 78. & 0.635 & 69 & & 1.863 & & 0. & \\
\hline 244 & 264 . & 1.938 & & 5 & 69 & 0 & 1.864 & & & \\
\hline 245 & 26 & 8 & & 5 & 6 & & 54 & & & \\
\hline 246 & & 1.5 & & 0. & & & 1.864 & & 04 & 70 \\
\hline 247 & 2 & 1.939 & 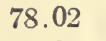 & 0.6 & & & 34 & & 04 & 70 \\
\hline 248 & 2 & 1.939 & 78.62 & 0.636 & 69. & 220.8 & 1.864 & 78 & 0. & 70 \\
\hline 249 & 2 & 1.940 & 78.01 & 0.636 & 69. & & 1.864 & 8 & 05 & \\
\hline 250 & 26 & 1.940 & 78 & 0.636 & 69 & 2 & 55 & $7 S$ & 05 & 70 \\
\hline 25 & & & & & & & & & & \\
\hline 252 & 6.6 & 1.940 & 78. & 0.637 & & & & & & \\
\hline 253 & 2 & 1.941 & 78. & 0.637 & & 7 & 1. & 78 & & \\
\hline 254 & 267.1 & 1.941 & & 0.6 & & .9 & & 7 & 0.606 & 3 \\
\hline 255 & 267. & 1.941 & & 0.638 & 69. & & 1.865 & 78.07 & 0.606 & 70.03 \\
\hline 256 & 267.6 & 1.941 & 78.00 & 0.638 & 69. & 222.3 & 1.866 & 78.07 & 0.606 & 70.02 \\
\hline 257 & 267.8 & 1.942 & 77.99 & & & & & & 0. & 70 \\
\hline 258 & & 1.942 & 77.99 & 0.638 & 69. & 222.6 & 1.866 & & 0.607 & 70.01 \\
\hline 259 & 268.3 & 1.942 & 77.99 & 0.639 & & & & & & 70.01 \\
\hline 260 & 268.5 & 1.943 & 77.98 & 0.639 & 69.74 & 223.0 & 1.866 & 78.05 & 0.607 & 70.00 \\
\hline 261 & & & & & & & & & & \\
\hline 262 & 269.0 & 1.943 & 77.98 & 0.639 & 69. & 223.3 & 1.867 & 78.05 & 0.607 & 69.99 \\
\hline 26 & 269.2 & 1.943 & & 0.640 & 69.73 & 223.4 & 1.867 & 78.05 & 0.608 & 69.99 \\
\hline 264 & 269.4 & 1.944 & 77.97 & 0.640 & 69.72 & 223.6 & 1.867 & 78.04 & 0.608 & 69.98 \\
\hline
\end{tabular}


TABLE 74-Continued

\begin{tabular}{|c|c|c|c|c|c|c|c|c|c|c|}
\hline \multirow{2}{*}{$\begin{array}{c}\text { AGE } \\
\text { IN } \\
\text { DAYS }\end{array}$} & \multicolumn{5}{|c|}{ MALES } & \multicolumn{5}{|c|}{ FEMALES } \\
\hline & $\begin{array}{c}\text { Body } \\
\text { weight } \\
\text { gms. }\end{array}$ & $\begin{array}{l}\text { Brain } \\
\text { weight } \\
\text { gms. }\end{array}$ & $\begin{array}{c}\text { Per cent } \\
\text { of water } \\
\text { brain }\end{array}$ & $\begin{array}{c}\text { Cord } \\
\text { weight } \\
g m s .\end{array}$ & $\begin{array}{c}\text { Per cent } \\
\text { of water } \\
\text { cord }\end{array}$ & $\begin{array}{c}\text { Body } \\
\text { weight } \\
\text { gms. }\end{array}$ & $\begin{array}{c}\text { Brain } \\
\text { weight } \\
g m s .\end{array}$ & $\left|\begin{array}{c}\text { Per cent } \\
\text { of water } \\
\text { Brain }\end{array}\right|$ & $\begin{array}{c}\text { Cord } \\
\text { weight } \\
\text { gms. }\end{array}$ & $\begin{array}{c}\text { Per } \\
\text { cent of } \\
\text { water } \\
\text { cord }\end{array}$ \\
\hline 265 & 269.6 & 1.944 & 77.97 & 0.640 & 69.72 & 223.7 & 1.867 & 78.04 & 0.608 & 69.98 \\
\hline 266 & 269.8 & 1.944 & 77.97 & 0.640 & & 223.9 & 1.867 & & $0.608^{\circ}$ & . 69.98 \\
\hline 267 & 270.0 & 1.944 & 77.96 & 0.640 & 6 & 2 & 1.867 & & 8 & \\
\hline 268 & 270.2 & 1.944 & 77.96 & 0.640 & 69. & 24.2 & 1.867 & 03 & .608 & \\
\hline 269 & 270.5 & 1.945 & 77.96 & 0.640 & & & 1.867 & & .608 & \\
\hline 270 & 270.7 & 1.945 & 77.95 & 0.641 & 69.7 & 224.5 & 1.868 & 78.02 & 0.609 & 69.96 \\
\hline 271 & 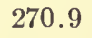 & 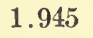 & 7 & & & & & & & \\
\hline 272 & 271.1 & 1.945 & 77. & 0.641 & & & 68 & & 09 & 69.95 \\
\hline 273 & 271.3 & 1.945 & 77.94 & 0.641 & & & 1.868 & & & 69.94 \\
\hline 274 & 271.5 & 1.945 & 77. & 0.641 & 69 & & 1.868 & & & 94 \\
\hline 275 & 271.6 & 1.946 & 77. & 0.641 & 69 & 1 & 38 & & 09 & \\
\hline 276 & 27 & & & 0. & & & & & & \\
\hline 277 & 27 & 1.8 & 77 & 0.641 & & & & & 09 & \\
\hline 278 & 272.2 & 1.946 & 77. & 0.642 & & & & & & 69.92 \\
\hline 279 & 272.3 & 1.946 & 77.92 & 0.642 & & & & & & \\
\hline 280 & & & & & & & & & & \\
\hline 28 & & & & & & & & & & \\
\hline 282 & 272.8 & 1.947 & 77.91 & 0.642 & 69 & & 1. & & 10 & \\
\hline 283 & 3.0 & 1.947 & 77.91 & 0.642 & & & 69 & & 10 & \\
\hline 284 & 27 & 1.9 & 77 & 0.6 & 69 & & 69 & & 10 & 90 \\
\hline 285 & & 1.947 & 72 & 0.642 & & & & & & \\
\hline 286 & & & & 0.643 & & & & & 0.611 & \\
\hline 287 & 273.7 & 1.948 & $77 . \varepsilon$ & 0.643 & & & 1.870 & & 0.611 & 0 \\
\hline 288 & 273.9 & 1.9 & 77. & 0.643 & & & 1.870 & & 0.611 & 69 \\
\hline 289 & 27 & 1. & 77. & 0.643 & 69 & & 70 & 6 & 611 & 69.87 \\
\hline 290 & 274.2 & 1.948 & 77.88 & 0.643 & 60 & & 1.870 & & 0.611 & 69.87 \\
\hline 291 & & & & & & & & & & \\
\hline 292 & 274.5 & 1.948 & 77. & 0.613 & & & 1.870 & & 11 & 69.86 \\
\hline 293 & 274.6 & 1.948 & 77.87 & 0.643 & & & 1.870 & & 0.611 & \\
\hline 294 & 274.7 & 1.948 & 77.86 & 0.643 & & & 1.870 & & 0.611 & 69.8 \\
\hline 295 & 274.9 & 1.948 & 77.86 & 0.644 & 69. & 22 & 1.870 & 77 & 0.611 & 69. \\
\hline 296 & 275.0 & 1.948 & 77.86 & 0.644 & 69.56 & 227.5 & 1.870 & 77.94 & 0.611 & 69.84 \\
\hline 297 & 275.2 & 1.949 & 77.85 & 0.644 & 69.56 & 227.6 & 1.871 & 77.93 & 0.612 & 69.83 \\
\hline 298 & 275.3 & 1.949 & 77.8 & 0.644 & .69 . & 227.7 & 1.871 & 77.93 & 0.612 & 69.8 \\
\hline 299 & 275.4 & 1.949 & & 0.644 & & & 1.871 & & 0.612 & 09.82 \\
\hline 300 & 275.5 & 1.949 & 77.84 & 0.644 & 69.54 & 227.9 & 1.871 & 77.92 & 0.612 & 69.82 \\
\hline & & & & & & & & & & \\
\hline 302 & 275.8 & 1.949 & 77.83 & 0.644 & 69.53 & 228.0 & 1.871 & 77.91 & 0.612 & 68.81 \\
\hline
\end{tabular}


TABLE 74-Continued

\begin{tabular}{|c|c|c|c|c|c|c|c|c|c|c|}
\hline \multirow[b]{2}{*}{$\begin{array}{c}\text { AGE } \\
\text { IN } \\
\text { DAYS }\end{array}$} & \multicolumn{5}{|c|}{ Males } & \multicolumn{5}{|c|}{ FEMALES } \\
\hline & $\begin{array}{c}\text { Body } \\
\text { weight } \\
\text { gms. }\end{array}$ & $\begin{array}{l}\text { Brain } \\
\text { weight } \\
\text { gms. }\end{array}$ & $\begin{array}{c}\text { Per cent } \\
\text { of water } \\
\text { brain }\end{array}$ & $\begin{array}{c}\text { Cord } \\
\text { weight } \\
\text { gms. }\end{array}$ & $\begin{array}{c}\text { Per cent } \\
\text { of water } \\
\text { cord }\end{array}$ & $\begin{array}{c}\text { Body } \\
\text { weight } \\
\text { gms. }\end{array}$ & $\begin{array}{c}\text { Brain } \\
\text { weight } \\
\text { gms. }\end{array}$ & $\left|\begin{array}{c}\text { Per cent } \\
\text { of water } \\
\text { Brain }\end{array}\right|$ & $\begin{array}{c}\text { Cord } \\
\text { weight } \\
\text { oms. }\end{array}$ & $\begin{array}{c}\text { Per } \\
\text { cent of } \\
\text { water } \\
\text { cord }\end{array}$ \\
\hline 303 & 275.9 & 1.949 & 77.83 & 0.645 & 69.52 & 228.1 & 1.871 & 77.91 & 0.612 & 69.80 \\
\hline 304 & 276.1 & 1.949 & 77.82 & 0.645 & 69. & 228.2 & 1.871 & & 0.612 & 69.80 \\
\hline 305 & 276.2 & 1.949 & 77.82 & 0.645 & 69 & 3 & 1.871 & 7 & 2 & 69.79 \\
\hline 306 & 276.3 & 1.949 & 77.82 & 0.645 & 69.50 & 228.3 & 1.871 & 77.90 & 0.612 & -7 \\
\hline 307 & 276.4 & 1.949 & 77.81 & 0.645 & 69. & & 1.871 & & 12 & \\
\hline 308 & 276.5 & 1.949 & 77.81 & 0.645 & 69 & & 1.871 & & 0.612 & 69.78 \\
\hline 309 & 276.6 & 1.950 & 77.80 & 0.645 & 69. & 28.6 & 1.872 & 77.88 & 0.613 & 69.77 \\
\hline 310 & 276.7 & 1.950 & 77.80 & 0.645 & 69.48 & 28.7 & 1.872 & 77.88 & 0.613 & 6077 \\
\hline 311 & $2 ?$ & ) & & 6 & & & 2 & & 3 & 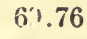 \\
\hline 312 & 277 . & 1.950 & 7 & 0.646 & & & & & & 69.7 \\
\hline 313 & 277.0 & 1.950 & 77.79 & 0.646 & 69 & 8 & 1.872 & 77 & 0. & 69.75 \\
\hline 314 & 277.1 & 1.950 & 8 & 0.646 & 69. & 28.9 & 1.872 & 77 & 0 . & 69 \\
\hline 315 & $27^{\prime}$ & 1.950 & & 0.6 & & & 1 & & & \\
\hline 316 & $27 \%$ & 1.9 & 77 & 0 . & & & & & & \\
\hline 317 & 277.5 & 1.950 & 77. & 0.6 & & & & & & 69.73 \\
\hline 318 & 277.5 & 1.950 & 77.76 & 0.646 & 69 & & 1.8 & 77.84 & 0. & 69 \\
\hline 319 & 277.6 & 1.950 & 6 & 0.646 & 6 & & 1 & & & 69 \\
\hline 320 & 277.7 & 1.950 & 77. & 0.646 & 69 & .3 & 1.872 & 77 & 0 . & 69.71 \\
\hline 321 & 27 & & & & & & & & & \\
\hline 322 & 277.9 & 1.951 & 77.74 & 0.647 & 69 & & 1.8 & 77 & 0 & 69 \\
\hline 323 & 278.0 & 1.951 & 77.74 & 0.647 & 69 & 4 & 1.8 & & 0 & 69 \\
\hline 324 & 278.0 & 1.951 & 77. & 0.6 & 69 & & 3 & 77 & 14 & .69 \\
\hline 325 & 278.1 & 1.951 & & 0.6 & & & & & & 69.68 \\
\hline 326 & 278.2 & 1.951 & 77.72 & 0.647 & 69 & & 1.8 & 77.80 & 0.614 & 69.68 \\
\hline 327 & 278.3 & 1.951 & 77.72 & 0.647 & 69 & .6 & 1.873 & 77 & 0 . & 69. \\
\hline 328 & 278.4 & 1.951 & 77. & 0.647 & & 7 & 1.8 & 77 & 0 . & $c 0$ \\
\hline 329 & 27 & 1.951 & & & & & & & 0.614 & 69.66 \\
\hline 330 & 278.5 & 1.951 & 77.70 & 0.647 & 69.36 & 229.8 & 1.873 & 77.78 & 0.614 & 69.66 \\
\hline 331 & & & & & & & & & & \\
\hline 332 & & 1.951 & 77.69 & 0.6 & & & 1.8 & 7 & 14 & \\
\hline 333 & 278.7 & 1.951 & 77.69 & 0.647 & 69. & 29.9 & 1.873 & 77.77 & 0.614 & 69.64 \\
\hline 334 & 278.7 & 1.952 & 77.68 & 0.648 & 69. & 229.9 & 1.874 & 77.76 & 0.615 & 69.63 \\
\hline 335 & 278.8 & 1.952 & 77.68 & 0.648 & & .9 & 1.874 & 77.76 & & 69.63 \\
\hline 336 & 278.9 & 1.952 & 77.67 & 0.648 & 69 & 230.0 & 1.874 & 77.75 & 0.615 & 69.62 \\
\hline 337 & 278.9 & 1.952 & 77.67 & 0.648 & & & 1.874 & 77.75 & 0.615 & 69.62 \\
\hline 338 & 279.0 & 1.952 & 77.66 & 0.648 & 69.31 & 230.0 & 1.874 & 77.74 & 0.615 & 69.61 \\
\hline 339 & 279.0 & 1.952 & 77.66 & 0.648 & 69. & 230.1 & 1.874 & 77.74 & 0.615 & 69.61 \\
\hline 340 & 279.1 & 1.952 & 77.65 & 0.648 & 69.30 & 230.1 & 1.874 & 77.73 & 0.615 & 69.60 \\
\hline
\end{tabular}


TABLE 74-Concluded

\begin{tabular}{|c|c|c|c|c|c|c|c|c|c|c|}
\hline \multirow[b]{2}{*}{$\begin{array}{l}\text { AGE } \\
\text { IN } \\
\text { DAYS }\end{array}$} & \multicolumn{5}{|c|}{ MALES } & \multicolumn{5}{|c|}{ FEMALES } \\
\hline & $\begin{array}{c}\text { Body } \\
\text { weight } \\
\text { gms. }\end{array}$ & \begin{tabular}{|c} 
Brain \\
weight \\
gms.
\end{tabular} & $\begin{array}{c}\text { Per cent } \\
\text { of water } \\
\text { brain }\end{array}$ & \begin{tabular}{|c} 
Cord \\
weight \\
gms.
\end{tabular} & $\begin{array}{c}\text { Per cent } \\
\text { of water } \\
\text { cord }\end{array}$ & $\begin{array}{c}\text { Body } \\
\text { weight } \\
\text { gms. }\end{array}$ & $\begin{array}{c}\text { Brain } \\
\text { weight } \\
\text { gms. }\end{array}$ & $\begin{array}{c}\text { Per cent } \\
\text { of water } \\
\text { brain }\end{array}$ & $\begin{array}{c}\text { Cord } \\
\text { weight } \\
\text { gms. }\end{array}$ & \begin{tabular}{|c|} 
Per \\
cent of \\
water \\
cord
\end{tabular} \\
\hline 341 & 279.2 & 1.952 & 77.64 & 0.648 & 69.29 & 230.1 & 1.874 & 77.72 & 0.615 & 69.59 \\
\hline 342 & 279.2 & 1.952 & 77.64 & 0.648 & 69.29 & 230.1 & 1.874 & 77.72 & 0.615 & 69.59 \\
\hline 343 & 279.3 & 1.952 & 77.63 & 0.648 & 69.28 & 230.2 & 1.874 & 77.71 & 0.615 & 69.58 \\
\hline 344 & 279.3 & 1.952 & 77.63 & 0.648 & 69.27 & 230.2 & 1.874 & 77.71 & 0.615 & 69.57 \\
\hline 345 & 279.3 & 1.952 & 77.62 & 0.648 & 69.2 & 230.2 & 1.874 & 77.70 & 0.615 & 69.57 \\
\hline 346 & 279.4 & 1.952 & 77.61 & 0.648 & 69.26 & 230.3 & 1.874 & 77.69 & 0.615 & 69.56 \\
\hline 347 & 279.4 & 1.953 & 77.61 & 0.648 & 69. & 2 & 1.874 & 7.69 & 0.615 & 69 \\
\hline 348 & 279.5 & 1.953 & 77.60 & 0.648 & 69. & 2 & 1.874 & & 0.615 & \\
\hline 349 & 279.5 & 1.953 & 77.60 & 0.648 & 69 . & 2 & 1.874 & 77 & 0.615 & 69.54 \\
\hline 350 & 279.6 & 1.953 & 77.59 & 0.648 & 69.23 & 230.3 & 1.874 & 77.67 & 0.615 & 69.54 \\
\hline 351 & 279.6 & 1.9 & & 8 & 69 & & & & & \\
\hline 352 & 279.6 & 1.953 & 77.58 & 0.648 & 69. & 2 & 1.874 & 77.66 & 0.615 & \\
\hline 353 & 279.7 & 1.953 & 77.57 & 0.649 & 69. & 23 & 1.875 & 77.65 & 0.616 & 69.52 \\
\hline 354 & 279.7 & 1.953 & 77.57 & 0.649 & 69 & & 1.875 & 77.65 & 0.616 & \\
\hline 355 & 279.7 & 1.953 & 77.56 & 0.649 & 69. & 230.4 & 1.875 & 77.64 & 0.616 & \\
\hline 356 & 279.8 & 1.953 & 77.55 & 0.649 & 69. & 230.4 & 1.875 & 77.63 & 0.616 & 69 \\
\hline 357 & 279.8 & 1.953 & 77.55 & 0.649 & 69. & 230.4 & 1.875 & 77.63 & 0.616 & 69.49 \\
\hline 358 & 279.8 & 1.953 & 77.54 & 0.649 & 69.18 & 230.4 & 1.875 & 77.62 & 0.616 & 69.48 \\
\hline 359 & 279.8 & 1.954 & 77.54 & 0.649 & 69.17 & 230.4 & 1.875 & 77.62 & 0.616 & 69.48 \\
\hline 360 & 279.8 & 1.954 & 77.53 & 0.649 & 69.16 & 230.4 & 1.875 & 77.61 & 0.616 & 69.47 \\
\hline 361 & 279.8 & & & & & & & & & \\
\hline 362 & 279.9 & 1.954 & 77.52 & 0.649 & 69.15 & 230.4 & 1.875 & 77.60 & 0.616 & 69.46 \\
\hline 363 & 279.9 & 1.954 & 77.51 & 0.649 & 69.14 & 230.4 & 1.875 & 77.59 & 0.616 & 69.45 \\
\hline 364 & 279.9 & 1.954 & 77.51 & 0.649 & 69.14 & 230.4 & 1.875 & 77.59 & 0.616 & 69.45 \\
\hline 365 & 279.9 & 1.954 & 77.50 & 0.649 & 69.13 & 230.4 & 1.875 & 77.58 & 0.616 & 69.44 \\
\hline
\end{tabular}


12. Formulas. Formulas for computing the length or weight of the body and of its several parts, systems or organs, also for expressing the values of other characters.

The formulas for the Albino-Group I- are given first, then those for the Norway-Group II. In Group I there are two divisions. The first division comprises the formulas based on size (body length and body weight). The second division comprises the formulas based on age. These formulas have been kept simple in order to facilitate their use. This condition has made it sometimes necessary to have different formulas for the different parts of the same series of data, but this was deemed more desirable than a reduction in the number of the formulas at the price of greater complexity.

After the formula there follows in parenthesis the number by which it is designated in the text, and every formula, whether it be general or subsidiary, is thus numbered, each subsidiary formula carrying the number of the general formula to which it is related, followed by a distinguishing letter. A catalog of the formulas, given in detail later, is here presented.

\section{CATALOG OF FORMULAS}

GROUP I. ALBINOS

First division: Formulas based on size

Body length on body weight (1).

Body weight on body length (2), (2 a), (2 b).

Body weight on brain weight (3).

Tail length on body length (4), (5).

Brain weight on body weight (6), (7).

Cranial capacity on body weight (8), (9), (10).

Spinal cord weight on body weight (11).

Diameters of ganglion cell and nucleus (12), (12 a).

Weight of both eyeballs on body weight (13).

Weight of heart on body weight (14).

Weight of both kidneys on body weight (15).

Weight of liver on body weight (16).

Weight of spleen on body weight (17).

Weight of both lungs on body weight (18).

Volume of blood on body weight (19), (19 a), (19 b).

Weight of blood on body weight (20), (20 a), (20 b).

Weight of alimentary tract on body weight (21). 
Weight of both testes on body weight (22), (23), (24).

Weight of both ovaries on body weight (25), (26), (27).

Weight of hypophysis on body weight (28), (29).

Weight of both suprarenals on body weight (30), (31).

Weight of thyroid on body weight (32).

Weight of nitrogen on body weight (33).

Second division: Formulas based on age in days

Body weight on age (34), (35), (36), (37).

Weight of thymus on age (38), (39).

Percentage of water in brain-on age (40), (41), (42), (42 a).

Percentage of water in spinal cord-on age (43), (44), (45), (45 a), (45 b), (45 c), $(45 \mathrm{~d})$.

GROUP II. NORWAYS

First division: Formulas based on size

Body length on body weight (46).

Body weight on body length (47), (48).

Body weight Norway on body weight Albino (49).

Tail length on body length (50), (51).

Brain weight on body weight (52).

Cranial capacity on body weight (53).

Spinal cord weight on body weight (54).

Spinal cord weight on brain weight (55).

\section{GROUP I. ALBINOS}

FIRST DIVISION: FORMULAS BASED ON SIZE

Body Length on Body Weight, (Donaldson, '09)

Body length (sexes combined) $=143 \log (B d . w t .+15)-134$ (1)

A study of tables 1 and 2 in the investigations by Donaldson '09 shows that for a given body weight the body length of the male is about 2.2 per cent greater than that of the female. If then the value found by this formula for any body weight is increased by 1.1 per cent of itself the sum obtained represents the body length for the male. If on the contrary, the value found is decreased by 1.1 per cent of itself, the difference obtained represents the body length for the corresponding female. 
By transposing formula (1) we obtain

$$
\text { Body weight (sexes combined })=10^{\frac{B d \cdot l+l+134}{143}}-15
$$

As the body length for a given body weight is for the male 1.1 per cent above the value in (2) and for the female 1.1 per cent below the value in (2), two new formulas have been made for the male and female respectively - thus

$$
\text { Body weight: }- \text { male }=10^{\frac{(100 \text { Bd.l. }-1.1 \text { Bd.l. })+13400}{14300}}-15
$$

$$
\text { Body weight: }- \text { female }=10 \frac{(100 \text { Bd.l. }+1.1 \text { Bd.l. })+13400}{14300}-15
$$

By use of formulas (2a) and (2b) the body weights corresponding to body lengths from $50-250 \mathrm{~mm}$ have been computed for each sex and the values obtained are those entered in the accompanying tables.

To illustrate the procedure with a formula of this sort the following example is given.

To compute the body weight for a body length of $150 \mathrm{~mm}$. (male) by the following formula (2a). 


$$
\text { Body weight }(\text { male })=10^{\frac{(100 \text { Bd.l. }-1.1 \text { Bd.l. })+13400}{14300}}-15
$$

Transpose 15 from right hand side to the left and take the logarithm of both sides. We have

$$
\begin{aligned}
\log (B d . w t .+15)=\log 10 & \times \frac{(100 \times 150-1.1 \times 150)+13400}{14300}: \\
& 1 \times \frac{15000-165+13400}{14300}=1.9745
\end{aligned}
$$

Thus 1.9745 is equivalent to the logarithm of body weight plus 15. Therefore body weight $+15=94.3$ (anti-logarithm of 1.9745). Finally, body weight $=94.3-15=79.3$ grams.

The above procedure is that to be followed with other formulas of the same type.

Body Weight on Brajn Weight (Donaldson, '08)

Body weight $($ sexes combined $)=8.7+10 \frac{B r \cdot w t .-0.554}{0.569}$

Tall Length on Body Length. (Hatai, MS '14.)

Tail length: male $=0.852$ Bd.l. $+38.8(\log B d . l)-$.

Tail length:-female $=0.874$ Bd.l. $+43.2(\log B d . l)-98.1$

Formulas (4) and (5) were used for table 68. 
Brain Weight on Body Weight. (Hatai, '09, p. 172)

For the brain weight of sexes combined, the following formulas have been obtained:-

Brain weight (sexes combined) $=1.56 \log (B d . w t)-$.

$$
[5<B d . w t .<10 \mathrm{gms} \text {. }]
$$

Brain weight (sexes combined) $=$

$$
0.569 \log (B d . w t .-8.7)+.554
$$

[Bd.wt. $>10 \mathrm{gms}$.

For a given body weight the average brain weight in the male was found to be 1.5 per cent more than in the female, hence the determinations of brain weight on body weight by formulas (6) and (7) give final values which must be increased by 0.75 per cent to represent the male brain and decreased by 0.75 per cent to represent the female brain weight. By using this procedure the data on brain weight given in table 68 were obtained.

Cranial Capacity on Body Wejght. (Hatai, '07 c)

Cranial capacity represented by the weight of the shot contained is given by

Cranial capacity $($ shot wt. $)=0.0072 \times(B d . w t$. male $)+9.349$

To reduce the shot weight to brain weight in the male, the value obtained is to be divided by 5.98 .

The corresponding formula for the female is

Cranial capacity $($ shot $w t)=$.

$$
0.0251 \times(B d . w t . \text { female })+6.168
$$

To reduce the shot weight to brain weight in the female, the value obtained is to be divided by 6.009 . 
For the cranial capacity expressed in cc. Donaldson ('12), the formula for sexes combined is

Cranial capacity in $c c .=$

$$
\begin{gathered}
1.02 \log B d . w t .-0.00027 \text { Bd. wt. }-0.596 \\
{[80<B d . w t .<300]}
\end{gathered}
$$

Spinal Cord Weight on Body Weight (Donaldson, '09)

Spinal cord wt. (sexes combined) $=$

$$
0.585 \log (B d . w t .+21)-0.795
$$

In the female the spinal cord is about 2 per cent heavier than in the male, therefore when using formula (11) the values obtained require to be increased by 1 per cent to represent the weight of the spinal cord in the female and to be diminished by 1 per cent to represent its weight in the male. By using this procedure, the data on the weights of the spinal cord in table 68 have been obtained.

Diameter of Second Cervical Spinal Ganglion Cell Nucleus on Diameter of Cell Body (Hatai, '07b)

Correlation between diameter of cell body and diameter of nucleus in $\mu-$ in spinal ganglion cells of second cervical nerve.

Diameter of nucleus in $\mu=$

$$
12.2939\left\{1.0252+0.3564\left(\frac{x}{1}\right)-0.0758\left(\frac{x}{1}\right)^{2}\right\}
$$

where $\mathrm{x}$ is the diameter of the cell in $\mu$ and $\mathrm{l}$ is a half range of the variates. 
As the value of 1 is 10 , the formula (12) may be transformed by a series of steps here omitted, to read

$$
D n=12.6+4.3\left\{\frac{D c b-29}{20}\right\}-0.9\left\{\frac{D c b-29}{20}\right\}^{2}
$$

Where $\mathrm{D} n=$ Diameter of nucleus in $\mu$ and $\mathrm{D} \mathrm{c} \mathrm{b}=$ Diameter of cell body in $\mu$.

See table 31 .

Weight of Both Eyeballs on Body Weight. (Hatai, '13, p. 112)

Weight of both eyeballs (sexes combined) $=$

$$
0.000428 \text { Bd. wt. }+0.098 \log B d . w t .-0.041
$$

Formula (13) was used for table 68.

Weight of Heart on Body Weight (Hatai, '13)

Weight of heart (sexes combined) $=$

$0.0026(B d . w t .+14)+0.249 \log (B d . w t .+14)-0.336$

Formula (14) was used for table 69.

Weight of Both Kidneys on Body Weight (Hatai, '13)

Weight of both kidneys (sexes combined) $=$

$$
0.00718(B d . w t .-3)+0.132 \log (B d . w t .-3)-0.009
$$

Formula (15) was used for table 69. 
Weight of Liver on Body Weight (Hatai, '13)

Weight of liver (sexes combined) $=$

$$
0.0303(B d . w t .+5)+3.340 \log (B d . w t .+5)-3.896
$$

$[B d . w t .>10]$

Formula (16) was used for obtaining the values given in table 69 for body weights of 10 grams or above. For body weights below 10 grams the weights have been determined by graphic interpolation-using the crude records as a basis.

Weight of Spleen on Body Weight (Hatai, '13)

Weight of spleen (sexes combined $)=$

$$
0.00245 B d . w t .+0.0301 \log (B d . w t .)-0.025
$$

Formula (17) was used for table 69.

Weight of Both Lungs on Body Weight (Hatai, '13)

Weight of both lungs (sexes combined) $=$

$0.00471(B d . w t .+2)+0.122 \log (B d . w t .+2)-0.056$

Formula (18) was used for table 70.

Volume of the Blood on Body Weight (Chisolm, '11) and Hatai (ms '14)

Blood volume (sexes combined $)=\frac{B d . w t ._{0.9}^{0.9}}{10.1}=0.099 B d . w t_{.0 .9}$

$$
[5<B d . w t .<150]
$$

Blood volume $($ males $)=$

$$
\begin{aligned}
& 0.099 \text { Bd.wt. }{ }^{0.9}-.03(.099 B d . w t .)^{0.9} \\
& \quad=0.09603 \text { Bd.wt. }{ }^{0.9} \\
& {[150<\text { Bd.wt. }<350]}
\end{aligned}
$$


Blood volumes $($ females $)=$

$$
\begin{gathered}
0.099 B d . w t_{.0 .9}+.06(.099 B d . w t .)^{0.9} \\
=0.10494 B d . w t^{0.9} \\
{[150<B d . w t .<350]}
\end{gathered}
$$

By using the factor 1.056 for the specific gravity of the blood corresponding formulas for the blood weight on body weight have been obtained as follows: Hatai (MS '14).

Blood weight $($ sexes combined $)=$

$$
\begin{gathered}
0.099 B d . w t^{0.9} \times 1.056 \text { or }=0.1045 B d . w t .0^{0.9} \\
{[5<B d . w t .<150]}
\end{gathered}
$$

Blood weight (males) $=$

$$
\begin{gathered}
0.1045 B d . w t .0 .9-.03(0.1045 B d . w t .)^{0.9} \\
=0.101365 B d . w t .{ }^{0.9} \\
{[150<B d . w t .<350]}
\end{gathered}
$$

Blood weight $($ females $)=$

$$
\begin{aligned}
0.1045 B d . w t^{0.9}+0.06\left(0.1045 B d . w t .^{0.9}\right) \\
\quad=0.11077 \text { Bd.wt. } .^{0.9} \\
(150<B d . w t .<350)
\end{aligned}
$$

These formulas (20), (20 a) and (20 b) for blood weight have been used for table 70 . 
Weight of Alimentary Tract on Body Weight (Hatai, '13)

Weight of alimentary tract (sexes combined) $=$

$$
0.0245 \text { Bd. wt. }+4.720 \log (B d . w t .+7)-5.753
$$

Formula (21) was used for table 70.

Weight of Both Testes on Body Weight (Hatar, '13)

$W t$. of testes $=0.022-0.00992 B d . w t .+0.00127 B d . w t .^{2}$

$$
[4<B d . w t .<10]
$$

$$
\begin{gathered}
=0.043-0.000966 \text { Bd.wt. }+0.000163 \text { Bd.wt. }{ }^{2} \\
{[10<B d . w t .<80]} \\
=2.910 \log B d . w t .-4.520 \\
{[B d . w t .>80]}
\end{gathered}
$$

For the weight of the testes for body weights of 4-10 grams, the values were obtained by formula (22), while formulas (23) and (24) were used for obtaining the values for body weights of 10 grams or over. Formulas (22) (23) and (24) were used for table 70 .

Weight of Both Ovaries on Bodx Weight (Hatai, '13)

Weight of both ovaries $=$

$$
=0.00781 \log . B d . w t .-0.0047
$$

(Phase 1)

$[B d . w t .<65]$

$$
=0.0425-0.00121 B d . w t .+0.0000108 B d . w t .^{2}
$$

(Phase 2)

$[65<B d . w t .<110]$

$$
=0.007 \log .(B d . w t .-105)+0.0352
$$

(Phase 3)

[Bd.wt. $>110]$

Formulas (25) (26) (27) were used for table 70. 
Weight of Hypophysis on Body Weight (Hatai, '13)

In the case of the hypophysis a separate formula for each sex is required.

Weight of hypophysis (male) $=$

$0.0000257(B d . w t .+3)+0.0014 \log (B d . w t .+3)-0.00097$

Formula (28) is also used for the female up to 50 gms. in body weight then

Weight of hypophysis (female) $=$

$$
\begin{gathered}
0.00205+0.000081 \text { Bd.wt. }-0.00196 \log (B d . w t .) \\
{[B d . w t .>50]}
\end{gathered}
$$

Formulas (28) and (29) were used for table 71 in accordance with the restrictions indicated.

Weight of Both Suprarenals on Body Weight (Hatai, '13)

In the case of the suprarenals a separate formula for each sex is required.

Weight of both suprarenals (male) $=$

$$
0.0000855(B d . w t .+3)+0.0113 \log (\dot{B} d . w t .+3)-0.0093(30)
$$

Formula (30) is also used for the female up to 30 gms. in body weight, then

Weight of both suprarenals (female) $=$

$$
0.00023 \text { Bd. wt. }+0.00388 \log (B d . w t .)-0.002
$$

$[B d . w t .>30]$ 
Formulas (30) and (31) were used for table 71 in accordance with the restrictions indicated.

Weight of Thyooid on Body Weight (Hatai, '13)

Weight of thyroid (sexes combined) $=$

$0.0000973(B d . w t .+27)+0.0139 \log (B d . w t .+27)-0.0226(32)$

Formula (32) was used for table 71.

Weight of Nitrogen on Body Weight (Hatat, '05)

To determine the amount of nitrogen eliminated by the rat during twenty-four hours at different body weights. Ration: Uneeda biscuit and water only-Chicago colony.

$N=10^{\frac{233+(3 \times \log B d . w t .)}{4}}$ or $\log N=\frac{233+(3 \times \log B d . w t .)}{4}$

where $\mathrm{N}=$ total nitrogen in milligrams and $\mathrm{Bd}$. wt. = body weight in grams.

Formula 33 is based on the data in table 42 .

\section{GROUP I. ALBINOS}

SECOND DIVISION: FORMULAS BASED ON AGE

Body Weight on Age from 10-365 Days, Hatai (MS '14)

The formulas (34) (35) (36) (37) apply only to the series of data published by Donaldson, Dunn and Watson, ('06.)

Body weight on age in days-males $=$

$$
\begin{gathered}
11.199+0.0475 A g e+0.0184 A g e^{2} \\
{[10<A g e<80]} \\
=448 \log A g e-0.52 A g e-678.2 \\
{[80<A g e<365]}
\end{gathered}
$$


Body weight on age in days-mated females $=$

$$
\begin{gathered}
8.071+0.367 \text { age }+0.0131 \text { Age }^{2} \\
{[10<\text { Age }<80]} \\
=343 \log \text { Age }-0.41 \text { Age }-498.8 \\
{[80<\text { Age }<365]}
\end{gathered}
$$

Formulas (34) (35) (36) (37) were used for table 62.

$$
\text { Weight of Thymus on Age (Hatai, '14) }
$$

Weight of thymus-sexes combined $=$

$$
\begin{gathered}
0.01 \times 10^{1.1\left\{1.1884+0.5865\left(\frac{\text { age }}{55}-1\right)-0.5851\left(\frac{\text { age }}{55}-1\right) 2\right\}} \\
{[A g e<95]}
\end{gathered}
$$

Weight of thymus $=$

$$
\begin{aligned}
0.3903- & 0.00139(\text { age })+0.00000128(\text { age })^{2} \\
\cdot & {[\text { Age }>95] }
\end{aligned}
$$

Formulas (38) (39) were used for table 72.

$$
\text { Percentage of Water in Brain. Hatai (ms '14) }
$$

The formulas do not apply to rats under ten days of age.

Percentage of water in brain-(male $)=$

$$
\begin{gathered}
92.122-0.614 \text { Age }+0.00739 \text { Age }^{2} \text { (Phase 1) } \\
{[10<A g e<40]} \\
=82.756-2.103 \log \text { Age } \quad \text { (Phase 2) } \\
{[40<\text { Age }<160]} \\
\left.=77.671+0.00537 \text { Age }-0.000016 \text { Age }^{2} \text { (Phase } 3\right) \\
{[160<\text { Age }<365]}
\end{gathered}
$$


To transform any determination for the male into that for the female, the value for the male at a given age (see formulas (40) (41), (42)) is modified by a plus correction (Hatai).

$$
\begin{gathered}
\text { Correction }(\text { plus })=0.0555 \log (\text { age }+3)-0.0606 \\
{[10<A g e<365]}
\end{gathered}
$$

The foregoing (40)-(42a) replace the formulas given in the paper by Donaldson ('10).

Formulas (40) (41) (42) (42a) were used for table 74.

Percentage of Water in Spinal Cord-(Hatai MS '14)

The formulas do not apply under 10 days of age. The data for the first ten days are from direct observations.

Percentage of water in spinal cord-male $=$

$$
\begin{gathered}
87.976-0.494 \text { Age }+0.00364 \text { Age }^{2} \text { (Phase 1) } \\
{[10<A g e<40]} \\
=100.3+0.0548 \text { Age }-17.7 \log \text { Age (Phase 2) } \\
{[40<\text { Age }<150]} \\
=62.186-0.0121 \text { Age+4.434log Age (Phase 3) } \\
{[150<\text { Age }<365]}
\end{gathered}
$$

To obtain from the values for the male at different ages the corresponding value for the female, several corrections are required and these differ according to age.

From ten to fifty days the following correction formula (45a) is used:

Correction $($ minus $)=0.0006 A g e^{2}-0.036 A g e+0.3$ 
The values thus obtained are subtracted from the computed values for the male at the corresponding ages.

From fifty to sixty-five days no correction is made.

From sixty-five days to one hundred and thirty-five days, correction is made according to the formula (45b)

Correction $(p l u s)=0.823 \log ($ Age +1$)-0.000542($ Age +1$)-1.4616$

From one hundred and thirty-five to one hundred and sixtyfive days the correction is uniform thus:

Correction $($ plus $)=0.22$

From one hundred and sixty-five to three hundred and sixtyfive days correction is made by the following formula:

Correction $($ plus $)=0.22+0.0005($ Age -165$)$

The foregoing (43)-(45d) replace the formulas given in the paper by Donaldson, ' 10 .

Formulas (43)-(45d) were used for table 74.

GROUP II. NORWAYS

FIRST DIVISION: FORMULAS BASED ON SIZE

Body Length on Body Weight-Norway (Donaldson and Hatai, '11)

Body length (sexes combined $)=159 \log (B d . w t .+18)-165$ (46)

The body length for the male is 0.4 per cent above the value given by formula (46) and that for the female 0.4 per cent below. Formula (46) with above corrections was used for graphs in chart 28. 
Body Wejght on Body Length (Donaldson and Hatai, (11)

By transforming formula (46) and introducing the correction for sex we obtain

(1) For the male

Body weight $=10^{0.0000629(B d . l . \times 100-[(B d . l . \times 100) \times 0.004]+16500)}-18$

$$
=10^{0.0000629(B d . l . \times 99.6+16500)}-18
$$

(2) For the female

Body weight $=10^{0.0000629(B d . l . \times 100+[(B d . l . \times 100) \times 0.004]+16500)}-18$

$$
=10^{0.0000629(B d . l . \times 100.4+16500)}-18
$$

Formulas (47) (48) were used for table 85.

Body Weight of Norway on Body Weight of Albino (Males) (DonaldSON AND HataI, '11, P. 442)

Body weight (Norway) $=$

137.1-0.636 Bd.wl. Albino+0.00643 Bd.wt. Albino ${ }^{2}$

$$
[160<B d \text {. wt. Albino < 300] }
$$

Tail Length on Body Length Norway (Hatai, as '14)

(1) For the male

$$
\text { Tail length }=0.824 \text { Bd. l. }+39.1(\log . B d . l .)-92.6
$$


(2) For the female

$$
\text { Tail length }=0.824 \text { Bd.l. }+43.1 \log (B d . l .)-98.4
$$

Formulas (50) (51) were used for table 85.

Brain Weight on Body Weight, Norway (Donaldson and Hatai, '11)

Brain weight (sexes combined $)=0.825 \log (B d . w t .-4)+0.233(52)$

This formula applies only to rats 5 grams or more in body weight. To obtain the weights for the male the values given by the formula are increased by 1 per cent, and to obtain the weights for the female, they are decreased by 1 per cent.

Formula (52) with corrections mentioned above used for table 85 .

Cranial Capacity on Body Weight, Norway (Donaldon, '12)

Cranial capacity in cc. (sexes combined $)=$

$$
\begin{gathered}
0.00105 \text { Bd.wt. }+0.548 \log B d . w t .+0.476 \\
{[80<B d . w t .<380]}
\end{gathered}
$$

Spinal Cord Weight on Body Weight, Norway (Donaldson and Hatai, '11)

Spinal cord weight (sexes combined) $=$

$$
0.724 \log (B d . w t .+30)-1.082
$$

To obtain the weights for the male the values given by the formula are increased by 0.15 per cent, and to obtain the weights for the female they are decreased by 0.15 per cent.

Formula (54) with corrections mentioned above was used for table 85. 
Spinal Cord Weight on Brain Weight (Sexes Combined) Norway (DonaLDSON AND HataI, '11)

Spinal cord $w t_{.}=0.724 \log \left(10^{\frac{B r . w t .}{0.0 .233}}+34\right)-1.082$

For the Norway we have no extensive data based on agehence there are no formulas based on age.

\section{GROWTH OF PARTS AND ORGANS: REFERENCES}

Chisolm, '11. Donaldson, '06, '08, '09, '11, '11 c, '12. Donaldson and Hatai, '11. Ferry, '13. Hatai, '03 a, '04 a, '07 a, '08, '13, '13 a, '14, '14 a. Jackson and Lowrey, '12. Jackson, '13. Jolly and Stini, '05. Watson, '05.

12. Formulas. Chisolm, '11. Donaldson, '08, '09, '12. Donaldson and Hatai, '11. Hatai, '05, '07 b, '07 c, '09 a, '10, '10 a, '11, '14. 


\section{CHAPTER 8}

\section{GROWTH IN TERMS OF WATER AND SOLIDS}

1. In the body as a whole. 2. In the larger divisions of the body and the organs. 3. In the brain and spinal cord.

Water and solids 1) in the body as a whole and 2) in the larger divisions and the organs. Data on this head have been published by Lowrey ('13) and are here presented.

With the exception of one of the old rats the animals used for the following table 75 were reared at the University of Missouri. They were fed on chopped corn with a daily ration of bread soaked in whole milk and once a week a small quantity of fresh beef was given them. All were sound except some of the older animals which suffered from infected lungs-but not to such a degree as to affect their general nutrition or vigor. Table 75 is based on table 1, Lowrey ('13). The data for the two sexes are combined. In the original the range of the observations is given and also the number of animals used in each instance. In the present table the ranges are omitted and the number of animals is given for the body weight (net) only. The other determinations for the systems and organs were based on about the same number of animals as were used for the body weight, except in the case of the testes where the numbers are about half as large. The oldest animals were somewhat under one year of age. 3) Percentage of water in the brain and spinal cord. Using stock rats from the colony at The Wistar Institute, the percentage of water has been determined for the brain and spinal cord by Donaldson (MS '14). The values obtained by this study replace those previously published. (Donaldson '10.) The methods of removal are given on page 90 . The rats were reared on a scrap diet. The fresh brain or cord was weighed in a closed bottle, then dried at $90^{\circ}-95^{\circ} \mathrm{C}$. until the dried weight was constant-and the difference taken as the amount of water. 
TABLE 75

Percentages of dry substance in the entire body-in several of the systems and in some organs. Observations at seven ages. See chart 24

\begin{tabular}{|c|c|c|c|c|c|c|c|c|c|}
\hline \multirow{2}{*}{$\begin{array}{c}\text { AGE IN } \\
\text { DAYS }\end{array}$} & \multicolumn{3}{|c|}{ BODY (NET) } & \multicolumn{2}{|c|}{ INTEG UMENTS } & \multicolumn{2}{|c|}{$\begin{array}{l}\text { LIGAMENTOUS } \\
\text { SKELETON }\end{array}$} & \multicolumn{2}{|c|}{ MUSCULATURE } \\
\hline & $\begin{array}{l}\text { No. of } \\
\text { animals }\end{array}$ & $\begin{array}{c}\text { Av. fresh } \\
\text { weight }\end{array}$ & $\begin{array}{l}\text { Av. \% of } \\
\text { dry subs. }\end{array}$ & $\begin{array}{c}\text { Av. fresh } \\
\text { weight }\end{array}$ & $\begin{array}{l}\text { Av. } \% \text { of } \\
\text { dry subs. }\end{array}$ & $\begin{array}{c}\text { Av. fresh } \\
\text { weight }\end{array}$ & $\begin{array}{l}\text { Av. } \% \text { of } \\
\text { dry subs. }\end{array}$ & $\begin{array}{c}\text { Av. fresh } \\
\text { weight }\end{array}$ & $\begin{array}{l}\text { Av. \% of } \\
\text { dry subs. }\end{array}$ \\
\hline & & gms. & & gms. & & $g m s$. & & gms. & \\
\hline & 15 & 4.200 & 11.7 & 0.880 & 12.3 & 0.660 & 18.1 & 1.100 & 10.7 \\
\hline $7 \ldots \ldots$ & 10 & 9.100 & 20.1 & 2.180 & 23.4 & 1.710 & 22.1 & 2.020 & 16.2 \\
\hline $20 \ldots \ldots$ & 9 & 24.500 & 29.9 & 5.020 & 41.1 & 4.090 & 33.3 & 6.400 & 22.6 \\
\hline $42 \ldots \ldots$ & 10 & 61.300 & 29.5 & 11.040 & 37.1 & 8.610 & 39.2 & 18.730 & 23.5 \\
\hline $70 \ldots \ldots$ & 7 & 126.700 & 33.0 & 20.020 & 43.0 & 14.840 & 45.9 & 51.500 & 25.2 \\
\hline $150 \ldots \ldots$ & 10 & 182.400 & 32.2 & 32.200 & 44.2 & 20.020 & 50.4 & 76.920 & 24.3 \\
\hline \multirow[t]{2}{*}{365 (?).. } & 2 & 267.500 & 31.5 & 37.780 & 45.5 & 23.180 & 52.6 & 125.000 & 23.8 \\
\hline & & \multicolumn{2}{|c|}{ ALL VISCERA } & \multicolumn{2}{|c|}{ EYEBALLS } & \multicolumn{2}{|c|}{ HEART } & \multicolumn{2}{|c|}{ LUNGS } \\
\hline $0 \ldots \ldots$ & & 0.780 & 15.2 & 0.023 & 7.4 & 0.025 & 13.8 & 0.077 & 15.9 \\
\hline $7 \ldots$ & & 1.760 & 14.2 & 0.066 & 10.4 & 0.061 & 14.4 & 0.169 & 15.8 \\
\hline $20 \ldots \ldots$ & & 5.090 & 19.1 & 0.110 & 14.4 & 0.135 & 18.0 & 0.236 & 18.9 \\
\hline $42 . \therefore$ & & 12.170 & 20.7 & 0.162 & 15.3 & 0.412 & 21.0 & 0.404 & 19.1 \\
\hline $70 \ldots$ & & 20.900 & 24.4 & 0.207 & 17.0 & 0.625 & 21.6 & 0.791 & 19.2 \\
\hline $150 \ldots$. & & 26.570 & 25.6 & 0.279 & 19.0 & 0.714 & 21.2 & 1.354 & 19.0 \\
\hline \multirow[t]{2}{*}{365 (?).. } & & 31.750 & 25.1 & 0.340 & 20.2 & 0.934 & 22.4 & 2.806 & 18.4 \\
\hline & & \multicolumn{2}{|c|}{ LIVER } & \multicolumn{2}{|c|}{ SPLEEN } & \multicolumn{2}{|c|}{ KIDNEYS } & \multicolumn{2}{|c|}{ TESTES } \\
\hline $0 \ldots$. & & 0.234 & 19.4 & & & 0.038 & 13.3 & & \\
\hline $7 \ldots \ldots$ & & 0.307 & 20.6 & 0.041 & 14.3 & 0.123 & 14.5 & & \\
\hline $20 \ldots$ & & 1.200 & 24.3 & 0.076 & 17.2 & 0.322 & 17.2 & 0.106 & 12.9 \\
\hline $42 \ldots \ldots$ & & 3.541 & 24.2 & 0.273 & 19.8 & 0.832 & 20.3 & 0.568 & 13.3 \\
\hline $70 \ldots$ & & 6.617 & 25.5 & 0.588 & 20.1 & 1.320 & 20.8 & 1.653 & 12.4 \\
\hline $150 \ldots \ldots$ & & 9.236 & 25.7 & 0.666 & 20.6 & 1.728 & 21.0 & 2.425 & 12.2 \\
\hline 365 (?).. & & 9.959 & 26.0 & 0.722 & 22.6 & 2.294 & 22.9 & 2.044 & 13.0 \\
\hline
\end{tabular}

By the use of formulas (40)-(42a) for the brain and formulas (43)-(45d) for the spinal cord, the values for table 74 after 10 days of age were obtained and also those for the respective graphs in chart 26 . The data for the first 10 days are from direct observations. The percentage of water in the brain and spinal cord is linked with age and is not readily modified. 


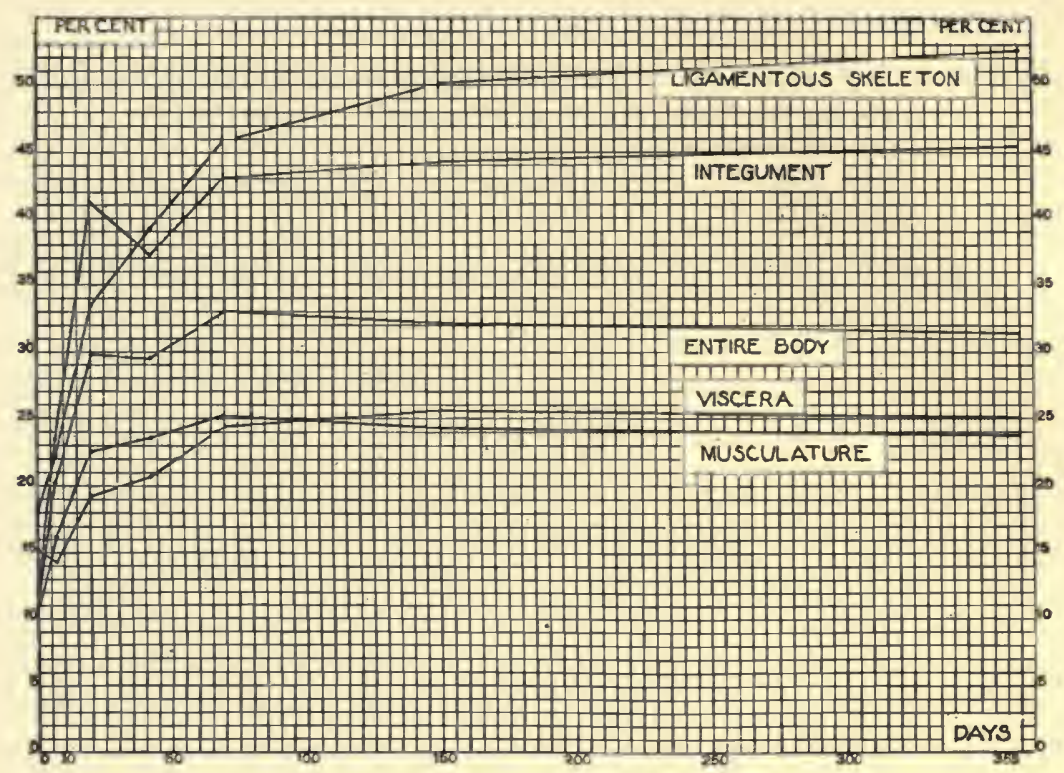

Chart 24 Giving the percentage of dry substance in the body as a whole and in the several systems at different ages. Table 75, Lowrey ('13).

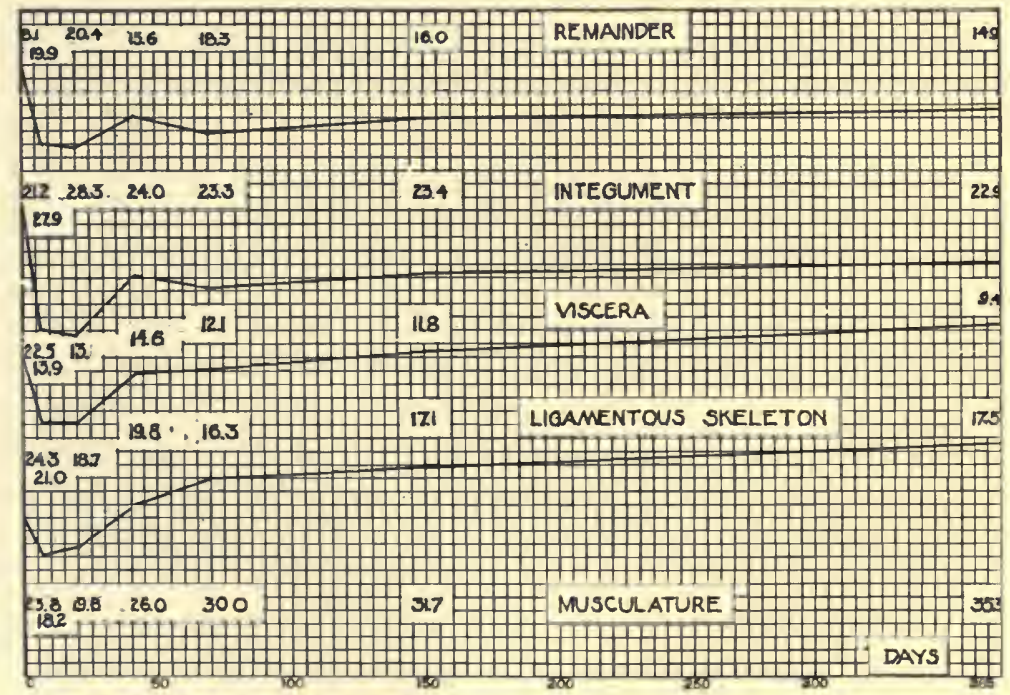

Chart 25 Giving in terms of the dry substance of the entire body the percentage values of the several systems, sexes combined. Plotted on age in days. Table 76, Lowrey ('13). 


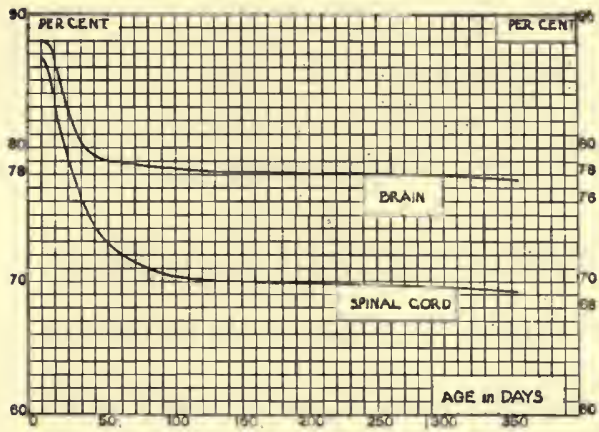

Chart 26 Giving percentage of water in the brain at different ages. Males only. Formulas (40)-(42a), table 74, and percentage of water in the spinal cord. Males only. Formulas (43)-(45d), table 74.

\section{TABLE 76}

Giving the percentage weight of the dry substance in the integument, skeleton (ligamentous), musculature, viscera and remainder in terms of the dry substance of the entire body, Lowrey' 13 . See chart 25

\begin{tabular}{|c|c|c|c|c|c|c|c|}
\hline \multirow{2}{*}{$\begin{array}{c}\text { AGE IN } \\
\text { DAYS }\end{array}$} & \multirow{2}{*}{$\begin{array}{l}\text { NUMBER } \\
\text { OF } \\
\text { ANIMALS }\end{array}$} & \multirow{2}{*}{$\begin{array}{l}\text { ABSOLUTE } \\
\text { WEIGHT OF } \\
\text { DRY BUB- } \\
\text { STANCE ENTIRE } \\
\text { BODY }\end{array}$} & \multicolumn{5}{|c|}{$\begin{array}{l}\text { PERCENTAGE WEIGHT OF DRY SUBSTANCE OF ENTIRE BODY } \\
\text { REPRESENTED BY }\end{array}$} \\
\hline & & & Skin & $\begin{array}{l}\text { Skeleton } \\
\text { (ligamen- } \\
\text { tous) }\end{array}$ & $\begin{array}{l}\text { Museula- } \\
\text { ture }\end{array}$ & Viscera & $\underset{\text { der }}{\text { Remain- }}$ \\
\hline $0 \ldots \ldots$ & $7 \ldots$ & 0.494 & 21.2 & 24.3 & 23.8 & 22.5 & 8.1 \\
\hline $7 \ldots \ldots$ & $10^{\prime}$ & 1.830 & 27.9 & 20.1 & 18.2 & 13.9 & 19.9 \\
\hline $20 \ldots \ldots$ & 9 & 7.320 & 28.3 & 18.7 & 19.6 & 13.0 & 20.4 \\
\hline $42 \ldots \ldots$ & 10 & 17.300 & 24.0 & 19.8 & 26.0 & 14.6 & 15.6 \\
\hline $70 \ldots$ & $7^{1}$ & 42.400 & 23.3 & 16.3 & 30.0 & 12.1 & 18.3 \\
\hline $150 \ldots .$. & 10 & 60.600 & 23.4 & 17.1 & 31.7 & 11.8 & 16.0 \\
\hline $365(?) \ldots$ & 2 & 84.300 & 22.9 & 17.5 & 35.3 & 9.4 & 14.9 \\
\hline
\end{tabular}

' Skeleton and musculature not separately determined in one instance.

GROWTH IN TERMS OF WATER AND SOLIDS: REFERENCES

Cavazani and Muzzioli, '12. Donaldson. '10, '11 a, '11 b. King, '11. Lowrey, '13. Weisbach, 1868. 


\section{CHAPTER 9}

\section{GROWTH OF CHEMICAL CONSTITUENTS}

1. In the body as a whole. 2 . In the nervous system.

1. In the body as a whole. For the body as a whole Hatai (MS '15) has made a determination of its composition in terms of proteins, fat, organic extract and salts, at eight ages. The results are given in table 77 .

TABLE 77.

Giving the chemical composition of albino rat. Hatai (MS '15)

\begin{tabular}{|c|c|c|c|c|c|c|c|c|}
\hline Age, days. & Birth & 7 & 15 & 22 & 28 & 35 & 42 & 294 \\
\hline Body gms. & 4.3 & 10.2 & 13.5 & 24.9 & 47.3 & 52.5 & 65.8 & 277.5 \\
\hline Water, per cent.. & 87.2 & 79.8 & 72.9 & 70.6 & 69.6 & 70.6 & 69.4 & 65.3 \\
\hline Solids, gms........ & 0.6 & 2.1 & 3.7 & 7.3 & 14.4 & 15.5 & 20.1 & 96.4 \\
\hline \multicolumn{9}{|l|}{ Percentages of } \\
\hline Residue. & 56.9 & 42.0 & 39.9 & 38.8 & 38.6 & 44.9 & 44.4 & 44.5 \\
\hline Fat... & 14.2 & 35.4 & 39.2 & 36.6 & 37.7 & 25.9 & 27.1 & 16.5 \\
\hline Organic extr.. & 16.4 & 12.8 & 12.8 & 14.8 & 13.8 & 18.6 & 16.9 & 28.2 \\
\hline Soluble salts.. & 6.6 & 4.6 & 3.0 & 3.2 & 3.3 & 1.5 & 2.7 & 2.5 \\
\hline Fixed salts.. & 5.9 & 5.2 & 5.2 & 6.7 & 6.5 & 9.2 & 8.9 & 8.3 \\
\hline
\end{tabular}

\section{The following paragraphs define the terms used in table 77.}

Residue. The residue is represented by the solids from which all the organic substances soluble in both boiling alcohol and in water, as well as the salts have been removed. Thus the residue as here defined represents practically all the protein substances.

Fat. Fat is represented by the substances soluble in boiling alcohol from which the water soluble organic extractives and salts have been removed.

Organic extractives. All water soluble substances from which the salts were removed are called the organic extractives.

Soluble salts. The salts here designated were obtained from all the extractives with both water and alcohol.

Fixed salts. The solids from which fat, organic extractives and soluble salts had been removed were incinerated and the ash thus obtained is here called the fixed salts. Thus these fixed salts present practically all salts present in the osseous system. 
Using a different plan of analysis McCollum('09) has given data on the composition of the rat. The results appear in table 78 . To obtain the skeleton he boiled the entire animal and then separated the skeleton from the boiled tissues.

TABLE 78

Giving the composition of rats used in experiments with various rations. (McCollum '09)

\begin{tabular}{|c|c|c|c|c|c|c|c|c|}
\hline RATION & $\begin{array}{c}\text { NUMSBER } \\
\text { OF } \\
\text { RAT }\end{array}$ & $\begin{array}{c}\text { BODY } \\
\text { WEIGHT }\end{array}$ & $\begin{array}{l}\text { SKELE- } \\
\text { TON }\end{array}$ & \begin{tabular}{|} 
DRY TIS- \\
SUEE LESS \\
SKELE- \\
TON
\end{tabular} & $\begin{array}{c}\text { ETHER } \\
\text { EXTRACT }\end{array}$ & $\begin{array}{l}\text { ASH OF } \\
\text { SKELE- } \\
\text { TON }\end{array}$ & \begin{tabular}{|c} 
SKELE- \\
TON PER \\
CENT OF \\
LIVE \\
WEIGHT
\end{tabular} & $\begin{array}{c}\text { FAT AND } \\
\text { WATER- } \\
\text { FREE TIS- } \\
\text { SUES PER } \\
\text { CENT OF } \\
\text { LIVE } \\
\text { WEIG HT }\end{array}$ \\
\hline & & grams & grams & grams & grams & grams & & \\
\hline Normal. & 1 & 147 & 6.67 & 38.0 & 8.89 & 3.79 & 4.54 & 19.80 \\
\hline Normal. & 2 & 157 & 6.50 & 45.0 & 10.80 & 3.85 & 4.14 & 21.79 \\
\hline Normal. & 10 & 34 & 1.33 & 9.5 & 3.25 & 0.68 & 3.91 & 18.39 \\
\hline
\end{tabular}

In connection with a study of the phosphorus compounds in the Albino after ovariotomy Heymann ('04) has recorded the $\mathrm{P}_{2} \mathrm{O}_{5}$ distribution in the normal rat (see Keith and Forbes, '14). His data for the normal appear in table 79 .

TABLE 79.

Giving the phosphorus compounds of rats as affected by ovariotomy (Heymann, '04)

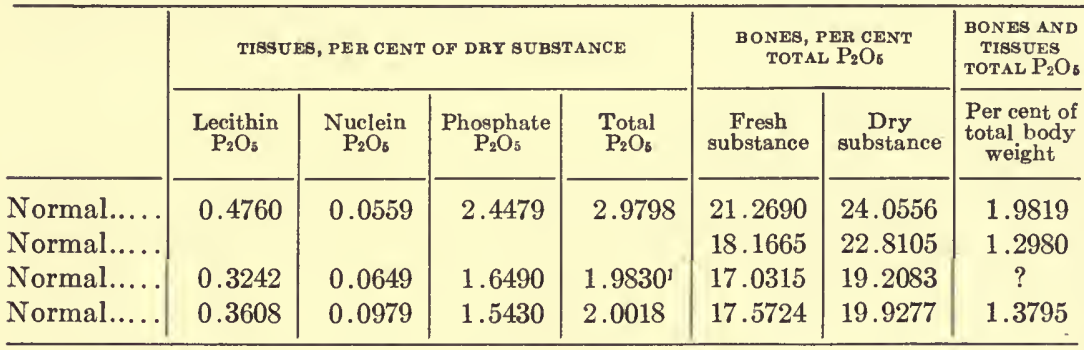

1 Apparently erroneous since the sum of the figures for nuclein, lecithin and phosphate phosphorus is 2.0381 per cent.

2. In the nervous system. . With the purpose of following the changes in the chemical constituents of the brain with advancing age, Koch, W. and M. L. ('13 a) have made a series of observations and to these have been added also observations on one spinal cord at 120 days. The results are given in tables 80 and 81 . 


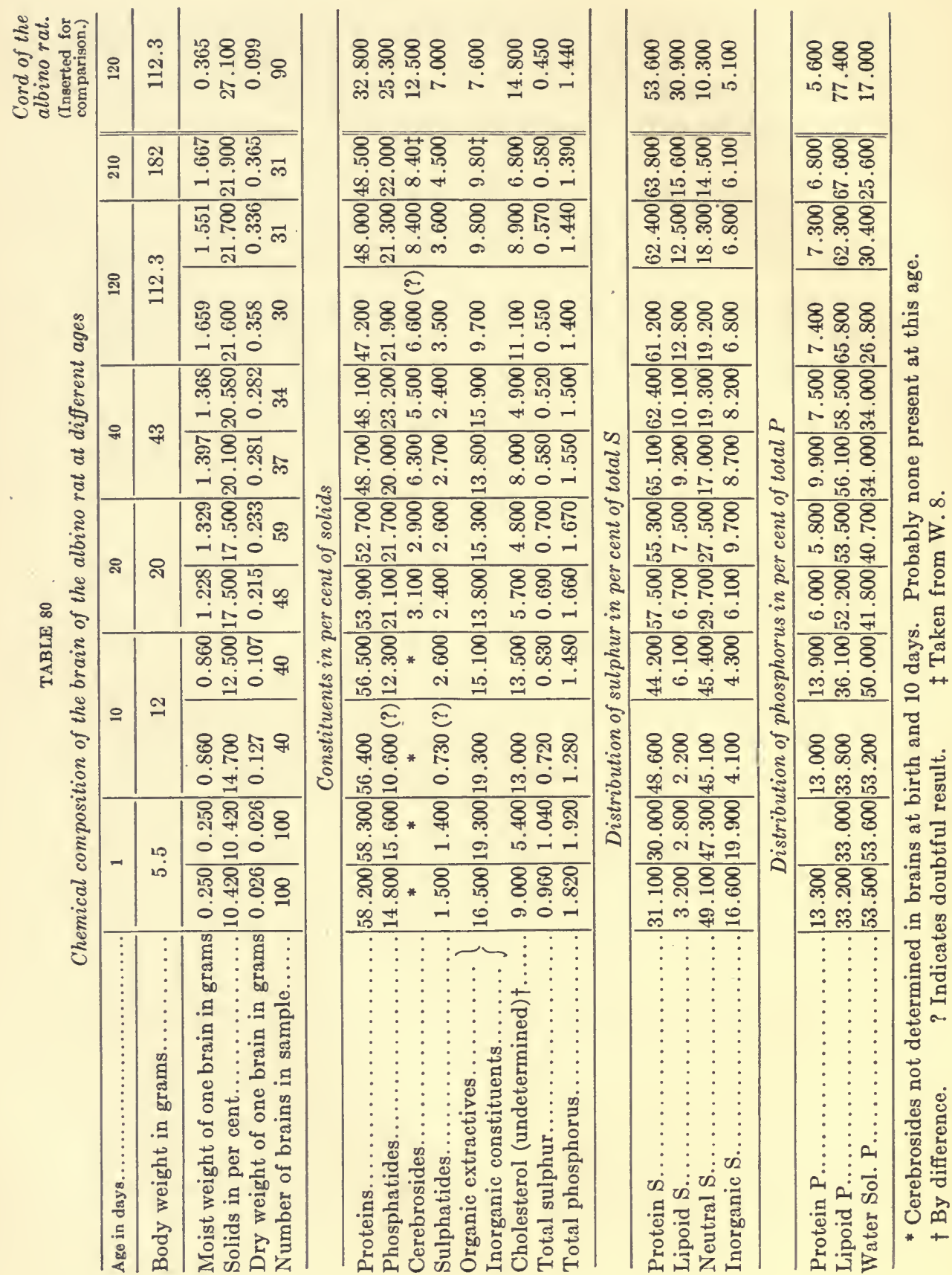


TABLE 81.

Absolute weights, in milligrams, of the constituents of a single brain of the albino rat at different ages (prepared from Table 80)

\begin{tabular}{r|r|r|r|r|r|r}
\hline & \multicolumn{7}{|c|}{ AGE IN DAYS } \\
\cline { 2 - 7 } & \multicolumn{1}{c|}{1} & \multicolumn{1}{c|}{10} & \multicolumn{1}{c|}{20} & \multicolumn{1}{c|}{40} & \multicolumn{1}{c|}{120} & \multicolumn{1}{c}{210} \\
\hline Moist weight of one & & & & & & \\
brain in grams.... & 0.250 & 0.860 & 1.280 & 1.380 & 1.600 & 1.670 \\
Solids in per cent... & 10.420 & 12.500 & 17.500 & 20.340 & 21.650 & 21.900 \\
Dry weight of one & & & & & & \\
brain in grams.... & 0.026 & 0.107 & 0.224 & 0.281 & 0.347 & 0.365 \\
\hline
\end{tabular}

Absolute weights in milligrams

\begin{tabular}{|c|c|c|c|c|c|c|}
\hline Proteins (1) $\ddagger .$. & $15.140^{*}$ & $60.450+$ & $119.400 *$ & $136.000 *$ & $165.200 *$ & $177.000 \dagger$ \\
\hline Phosphatides (2) & 3.950 & 13.160 & 47.900 & 61.300 & 74.950 & 80.300 \\
\hline Cerebrosides (3). & & & 6.700 & 16.600 & 29.150 & 30.660 \\
\hline Sulphatides (4).. & 0.380 & 2.780 & 5.600 & 7.200 & 12.300 & 16.400 \\
\hline $\begin{array}{c}\text { Organic extrac- } \\
\text { tives.......... }\end{array}$ & & & & & & \\
\hline $\begin{array}{c}\text { Inorganic consti- } \\
\text { tuents......... }\end{array}$ & 4.650 & 16.160 & 32.600 & 41.700 & 33.800 & 35.800 \\
\hline $\left.\begin{array}{c}\text { Cholesterol unde- } \\
\text { termined }(5) \ldots . . .\end{array}\right\}$ & 1.870 & $(14.45)$ & 11.700 & 18.200 & 31.600 & 24.800 \\
\hline Total sulphur....... & 0 . & 0 & 1.5700 & 40 & 40 & 2.120 \\
\hline Total phosphorus. . & 0.480 & 1.600 & 3.7200 & 4.300 & 4.930 & 5.070 \\
\hline
\end{tabular}

In absolute weight in milligrams of sulphur

\begin{tabular}{l|l|l|l|l|l|l}
\hline Protein S (1S)§...... & 0.079 & 0.398 & 0.885 & 0.982 & 1.199 & 1.352 \\
Lipoid S (4)......... & 0.008 & 0.054 & 0.111 & 0.149 & 0.246 & 0.330 \\
Neutral S (6)........ & 0.125 & 0.409 & 0.449 & 0.279 & 0.363 & 0.307 \\
Inorganic S (7)....... & 0.047 & 0.039 & 0.122 & 0.130 & 0.132 & 0.129 \\
\hline
\end{tabular}

In absolute weight in milligrams of phosphorus

\begin{tabular}{l|l|l|l|l|l|l}
\hline Protein P (1P)....... & 0.064 & $0.215^{*}$ & 0.220 & 0.374 & 0.360 & 0.345 \\
Lipoid P (2)........ & 0.161 & 0.558 & 1.964 & 2.464 & 3.160 & 3.427 \\
Water sol. P (8)...... & 0.260 & 0.826 & 1.532 & 1.462 & 1.410 & 1.298 \\
\hline
\end{tabular}

* Record from average duplicate analyses.

$\dagger$ Record from one analysis.

$\ddagger$ Figures in parentheses in this section refer to Chart III. See original.

$\S$ Figures in parentheses in this and the following sections refer to Chart IV. See original. 


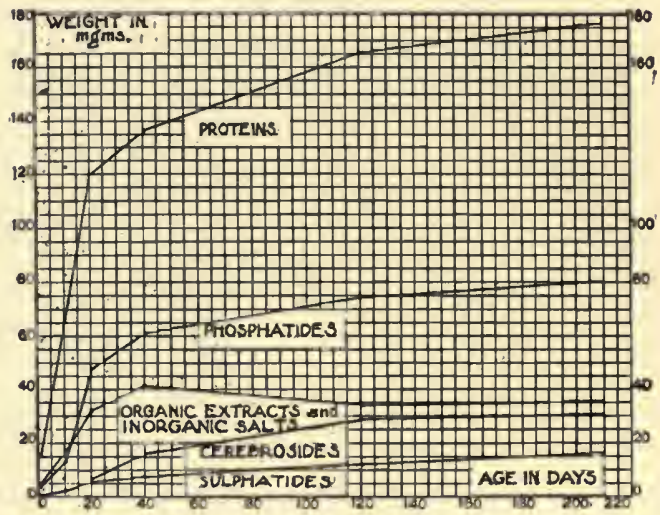

Chart 27. Giving in milligrams the absolute weight of the more important chemical constituents of the brain. Plotted on age. Table 81 .

In chart 27 are given the graphs for the absolute weights of the more important chemical constituents of the brain plotted on age (see table 81 ).

\section{GROWTH IN CHEMICAL CONSTITUENTS: REFERENCES}

1. Entire body. Mendel and Daniels, '12. Pembrey and Spriggs, '04.

2. Nervous system. Bibra, 1854. Hatai, '09, '10. Koch, M., '13. Koch and Mann, '09. Koch and Koch, '13, '13 a. 


\section{CHAPTER 10}

\section{PATHOLOGY}

1. Tumors. 2. Parasites and infections (except leprosy and plague). 3. Leprosy. 4. Plague. 5. Public hygiene. 6. Descriptive and experimental pathology. 7. Economic relations.

In the various studies on the pathology of the rat there are, of course, some data, which might be tabulated or charted. It has been thought best however to adhere to our general plan of treating in detail the data for the normal animal only and the presentation in this chapter is limited therefore to a series of references classified according to the subheads given above.

\section{PATHOLOGY: REFERENCES}

1. Tumors. Bashford and Murray, 1900. Bennett, '14. Bullock, W. E., '13. Cramer and Pringle, '10. Eiselsberg, 1890. Flexner and Jobling, '07. Freund, '11. Gay, '09. Gaylord, '06. Jensen, '08. Joannovics, '12. Lambert, '11. Levin, '08, '10, '10a, '11. Loeb, '01, '02, '02a, '03, '03a, '04, '07. McCoy, '10 a. Moreschi, '09. Ordway and Morris, '13. Robertson and Burnett, '13. Rous, '11, '14 Sweet, Corson-White and Saxon, '13. Taylor, '15. Uhlenhuth and Weidanz, '09. Van Alstyne, '13. Weil, '13.

2. Parasites and infections (except plague and leprosy). Bacot, '14. Bahr, '06. Bancroft, 1893-1894. Bayon, '12 a. Bullock and Rohdenburg, '13. Campana, '11. Chick and Martin, '11. Currie, '10. Dean, '03. Fantham, '06. Giglio-Tos, 1900. Hurler, '12. Jungano, '09. Jurgens, '03. Laveran and Mesnil, 1900, 1900 a, 1900 b. Loghem, '08. Mallory and Ordway, '09. Mitchell, '12. Morpurgo, '01, '02. Ori, '12. Poppe, '13. Pound, '05. Rabinowitsch and Kempner, 1899. Robinson, '13. Rosenau, '01. Sabrazès and Muratet, '05. Shipley, '08. Stiles and Crane, '10. Stiles and Hassall, '10. Terry, '05. Trautmann, A., '12. Trautmann, H., '12. Wasielewski and Senn, 1900. Webel, '13-'14. Wiener, '02, '03.

3. Leprosy. Bayon, '11, '12, '12 b, '12 c, Chapin, '12. Dean, '05. Duval, '10, '11. Duval and Gurd, '11, '11 a. Duval and Wellman, '12. Duval and Harris, '13. Hollmann, '12. Jadassohn, '13. Leboeuf, '12. Marchoux, '10, '11, '11-'12, '12. Marchoux and Sorel, '12, '12 a, '12 b, '12 c. McCoy, '08. Tidswell and Cleland, '12. Wherry, '08. Wolbach and Honeij, '14. Zinsser and Carey, '12.

4. Plague. Advisory Committee, '12 b. Bacot and Martin, '14. Bannerman, '06. Blue, '08,'10. Brinckerhoff,'10. Chick and Martin,'11. Edington,'01. 
'01. Galli-Valerio, '02. Gauthier and Raybaud, '03. Herzog, '05. Hossack, '07 a. India Plague Commission, '08. Liston, '05, '05 a. Loghem and Swellengrebel, '14. Martini, '01. McCoy,'10. Petrie, '10. Reports on Plague Investigations in India, '06. Thompson, '06. Tiraboschi, '02, '04, '04 a.

5. Public hygiene. Advisory Committee, '12 a. Bahr, '09, '09 a, '10. Bergmann, '08. Boelter, '09. Buchanan, '10. Calmette, '10, '11. Converse, '10. Cook, 1885-1886. Creel, '10. DuPuy, and Brewster, '10. Foster, '09. Fox, '12. Foy, '13. Grubbs and Holsendorf, '13. Heiser, '10, '13. Hobdy, '10. Kerr, '10. Konstansoff, '10. Kunhardt and Taylor, '15. Lagarrique, '11. Lantz, '07, '10 a. Lavrinovich, '10. Mandoul, '08-'09. Munson, '10. Neumark, '13. Pottevin, '10. Ramachandrier, '08. Reaney and Malcolmson, '08. Ringeling, '12. Rosenau, '10. Rucker, '10, '12, '13. Schern, '12. Simpson, '13. Suffolk, '10. Symposium, '11. Tailby, '11. Zuschlag, '03.

6. Descriptive and experimental pathology. Ascher, '10. Aumann, '12. Aunett, '08. Bainbridge, '08-'09. Bircher, '11, '11 a. Boinet, 1897, 1897 a. Bullock and Rohdenburg, '15. Cramer, '08. Czerny, 1890. Fibiger, '13, '13 a, '13 b, '14. Flexner and Noguchi, '06. Graham and Hutchison, '14. Horton, '05. Kolmer and Yui and Tyau, '13. Lewin, '12, '12 a. Loeb, '13. Mallory and Ordway, '09. Martin, 1895. Mavrojannis, '03. Mereshkowsky and Sarin, '09. Mereshkowsky, '12, '12 a. Metschnikoff and Roux, 1891. Murphy, '14. Nerking, '09. Olds, '10. Ophüls, '11. Plimmer and Thomson, '08. Remlinger, '04. Rowland, '11. Schern, '09. Schürmann, '08. Sittenfield, '12. Steffenhagen, '10.

7. Economic relations. Bruneau, 1886. Galli-Valerio, '08. Klunzinger, '08. Landois, 1886. Lantz, '10 b. Lersch, 1871. Loir, '03. 


\section{PART II}

NORWAY RAT 



\section{CHAPTER 11}

\section{LIFE HISTORY AND DISTINGUISHING CHARACTERS}

1. Introduction. 2. Life history. a. Span of life. b. Gestation period. c. Number of litters. d. Number in litter. e. Proportion of sexes. f. Opening of eyes. g. Age of sexual maturity. 3. Comparison of Norway with Albino. 4. Similarities of Norways and Albinos in western Europe to those of the United States.

1. Introduction. To obtain more complete information concerning the rat it is important to note differences which may appear between the domesticated Albino and the wild Norway. Since the wild Norway represents the parent stock it might seem proper to use that form as the standard and to record the deviations of the Albino from it. As a matter of fact however our information with regard to the Albino is so much the more complete that the best results will follow from using it as the standard, despite the fact that zoölogically it is but a variety of the Norway.

2. Life history of the Norway rat. As regards behavior, the Norway rat is very responsive to sounds, gnaws its cage, burrows when opportunity offers, is hard to handle and appears fierce because usually in a state of terror, yet after some days in a cage, it often becomes quite docile.

Mus norvegicus when mature weighs $300-500$ grams. (550 grams $=1 \frac{1}{4}$ pounds avd., has been reported but is very unusual). We have recorded one male with a body weight of $523 \mathrm{gms}$. The color above ranges from light gray or orange to brown and dark gray, usually with more or less white or light gray on the ventral surfaces. Melanic sports occasionally occur (see p. 14, note 5). Mus norvegicus is distinguished from Mus rattus, the house rat, by the following superficial characters: larger size; blunter head; smaller ears which are thicker and more covered with hair; tail shorter than body; claws usually relatively dull. Its movements . are less rapid. Commonly the female Norway has twelve, sometimes fourteen nipples, while the house rat has very constantly ten. 
a.) Span of life. The span of life of the Norway rat is not known. It seems probable that it is between three and four years, though here and there individuals may live somewhat longer.

b.) Period of gestation: 21 days Lantz ('09); 23.5-25.5 days Miller ('11). The latter periods are possibly due to the effect of nursing on gestation. See p. 22.

c.) Number of litters. Miller ('11) reports seven litters in seven months from a single pair, and estimates that, in general, five to six litters may be easily reared by a single pair in a year.

d.) Number of young in a litter. Climate and station appear as general modifying influences. Larger litters are reported from northern Europe than from India (Lantz, '09).

Crampe ('84) obtained an average of 10.4 in fourteen litters.

Zuschlag ('03) states that among the rats examined at Copenhagen in 1899, fetuses to the number of 14 were found four times and he himself in 1902 examined one female bearing 16 . Donaldson (MS, '09) also noted in a rat taken in Paris, 16 fetuses.

The India Plague Commission reports ('08) that the average number of fetuses found in females was 8.1 from a total of 12,000 Norway rats.

According to Lantz ('09) the maximum size of litters recorded in England (Field) are 17, 19, 22 and 23; in India however 14.

The maximum numbers just given as recorded in England are not trustworthy as they represent merely the number of young found in a single nest. Since two different litters are sometimes reared in the same nest the inference from the number in the nest to the number in the litter is not convincing. Lantz ('09) assumes the average litter (in north temperate latitude) to be about 10. This is what Miller ('11) (vide infra) and Crampe ('84) (vide supra) found.

Miller ('11) observed in a group of eight litters 7-12 young in a litter, with an average of 10.5 .

e.) Proportion of the sexes. Lantz ('09) and others state that the males are in excess. Donaldson ('12) found the same in trapped series taken in Paris and London. In a small series 
trapped in Vienna however, the females were in excess. There are no observations on the proportions of the sexes at birth in general population, but in a special study of "extracted" Norways made by King (MS., '15) 56 litters from females-themselves taken from litters in which the two sexes were equally or nearly equally represented-gave 212 males and 213 females.

f.) Opening of eyes. Miller ('11) found the eyes to open at 16 or 17 days and also states that the young are weaned during the sixth week.

g.) Age of sexual maturity. Miller ('11) gives one instance of a female conceiving at the age of 120 days.

Owing to the difficulty of keeping $M$. norvegicus happy and contented in captivity, it has not yet been possible to get a trustworthy record for increase in body weight with age in the case of this form. Neither our own data (Donaldson and Hatai, '11) nor those of Miller ('11) show what must be the normal rate of increase in body weight.

3. Comparison of the Norway with the Albino. To determine whether the wild Norway form, as trapped in Philadelphia, differs in any way from the albino rats in the colony at The Wistar Institute, a comparison has been made between the two forms in respect to body length, body weight, brain weight, spinal cord weight and the percentage of water in both the brain andthe spinal cord (Donaldson and Hatai, '11) as well as the weights of several of the parts and viscera. (Jackson and Lowrey, '12; Hatai, '14 a.)

In addition to the familiar facts that the Norway rat is more wild and difficult to handle, more successful in escaping from cages and much more given to gnawing than is the Albino, that it grows bigger, breeds later, has larger litters and a longer sexual life (Crampe, '84) it is now possible to make several further statements.

At birth the Norway is somewhat heavier than the stock Albino (King, '15, table 1) but in their relative body length and the relative weights of the brain and spinal cord, as well as in the percentage of water in these two divisions of the central nervous system, they are approximately alike. 
The marked differences between the two forms appear later, during the period of rapid growth. Grouping together the general differences subsequently found, we may say that the Norway rat is absolutely much heavier, relatively slightly longer, has a relatively heavier brain and a heavier spinal cord, and since for the same body weight as a given Albino it is younger, it has when so compared a higher percentage of water in the central nervous system.

For the same age however, the percentages of water are nearly alike; the percentage in the Norway rat being a trifle higher (Donaldson and Hatai, '11). The relative weights of the ovaries, testes and suprarenals are also greater (C. Watson, 'Q7; Hatai, '14). These plus characters of the Norway tend to disappear when the Norway is subjected to domestication.

The deviations of the Norway may be expressed in another way. When the body weights of Norway and Albino are the same:

The Norway rat has a greater body length; a greater brain weight; a greater spinal cord weight; a higher percentage of water in the central nervous system; heavier ovaries, testes and suprarenals.

When body lengths are the same:

The Norway rat has a smaller body weight; a greater brain weight; a greater spinal cord weight; a higher percentage of water in the central nervous system; heavier ovaries, testes and suprarenals.

When brain weights are the same:

The Norway rat has a smaller body weight; a smaller body length; a smaller spinal cord weight; a higher percentage of water in the central nervous system.

When the spinal cord weights are the same:

The Norway rat has a smaller body weight; a smaller body length; a greater brain weight; a higher percentage of water in the central nervous system.

Speaking generally therefore we may say that when compared with the domesticated Albino, the wild Norway rat weighs more, is longer and possesses a nervous system in which both the brain and spinal cord are relatively larger. 
These differences taken together indicate that the albino rat has grown less well, and it seems most natural to attribute the lack of growth to the whole set of conditions summed up in the word 'domestication.'

The most marked difference in structure thus far described between the two forms is in the relative weight of the central nervous system. That this is due to the effects of domestication seems highly probable, in view of the observations of Darwin ('83) and Lapicque and Girard ('07).

There are still other observations which belong here. In a study on the weight of some of the ductless glands of the Norway and of the albino rat according to sex and variety Hatai, ('14 a) an examination was made of the suprarenals, hypophysis, thyroid and gonads in both forms. The conclusions reached are here given.

In both the Norway and albino rats the suprarenal glands of the males are considerably smaller than those of the females. When, however, these two forms of rats are compared, both sexes of the Norway rats have suprarenals considerably heavier than those of the like sexes of the Albino.

A sex difference is noted in the weight of the hypophysis in both the Norway and albino rats. The male hypophysis is lighter than that of the female. However, when these two forms of rats are compared, the hypophysis of the Norway is found to be smaller than that of the albino rat; the greater difference being in the case of the female.

Neither in the Norway nor the albino rat is a sex difference found in the weight of the thyroid. Moreover, there is no weight difference in the thyroid according to variety in the case of these two forms of rats.

The sex glands (testes and ovaries) of the Norway rats are heavier than those of the albino rats.

Hatai is also of the opinion that the differences noted are again the result of a response to domestication.

4. Similarity of the Norways and Albinos of western Europe to those of the United States. It is to be noted in this connection that so far as tests have been made, the albino rats found in Europe 
are similar to those found in America. For the Albinos from Vienna, Paris and London, the determinations were made by Donaldson ('12) and Chisolm ('11) has reported on the relation of body length to body weight in albino and pied rats in London. Chisolm compares his determinations of length with those by Donaldson ('09) and when correction is made for the slight difference in the methods of measurements, the two sets of results agree nicely.

It is also true that the wild Norways of Europe seem to be similar to those of the United States (Donaldson, '12) so that the differences above noted probably will be found at whatever stations the two forms are compared.

\section{LIFE HISTORY - NORWAY RAT: REFERENCES}

Chisolm, '11. Crampe, 1884. Darwin, 1883. Donaldson, '09, '11, '12. Donaldson and Hatai, '11. Hatai, '14 a. India Plague Commission, '08. Jackson and Lowrey, '12. Lantz, '09. Lapicque and Girard, '07. Miller, '11. Watson, C., '07. Zuschlag, '03. 


\section{CHAPTER 12}

\section{GROWTH IN WEIGHT OF PARTS AND SYSTEMS OF THE BODY}

1. Growth of parts. 2. Growth of systems. 3. Weight of cranium.

1. Growth of parts of the body. For the general conditions under which these observations were made by Jackson and Lowrey ('12), see pp. 73-74.

Five Norways only were examined, these having been trapped in barns at the University of Missouri. They were probably living on grain. As will be seen by reference to table 82 the smallest of these, a male, weighed 65 grams and was therefore probably from three to five weeks old. The percentage relations of the several parts of the body are given in table 82 .

TABLE 82

Norway rat-Percentage weights of head, trunk and extremities. Sexes combined (Jackson and Lowrey, '12)

\begin{tabular}{|c|c|c|c|c|c|}
\hline $\mathrm{sEX}$ & $\begin{array}{l}\text { NET BODY } \\
\text { WEIGHT }\end{array}$ & HEAD & FORE LIMBS & HIND LIMBS & TRUNK \\
\hline & grams & per cent & per cent & per cent & per cent \\
\hline M.. & 65.0 & 14.66 & 5.95 & 13.88 & 65.51 \\
\hline M.. & 95.4 & 12.17 & 5.83 & 15.34 & 66.66 \\
\hline F.. & 107.5 & 10.18 & 5.58 & 15.81 & 68.43 \\
\hline M..... & 164.0 & 9.27 & 5.24 & 14.94 & 70.55 \\
\hline F...... & $254.0^{1}$ & 7.85 & 5.02 & 13.68 & 73.45 \\
\hline
\end{tabular}

${ }^{1}$ Including gravid uterus, which weighed 13.76 grams.

On comparing the relative values here given with those for the albino rat (see p. 74) it appears that for corresponding body weights the average values for the fore limbs and hind limbs are low, while those for the trunk are high - a relation which might be expected in view of the greater body length of the Norwaysee tables 49 and 82 . 
TABLE 83

Norway rat-Percentage of total body weight represented by the weight of integument, ligamentous skeleton, musculature, viscera and remainder. (Jackson and Lowrey, '12)

\begin{tabular}{|c|c|c|c|c|c|c|}
\hline SEX & $\begin{array}{l}\text { NET BODY } \\
\text { WEIGHT }\end{array}$ & INTE GUMENT & $\begin{array}{l}\text { LIGAMENTOUS } \\
\text { SEELETON }\end{array}$ & MUSCOLATURE & VISCERA & REMAINDER \\
\hline & grams & per cent & per cent & per cent & per cent & per cent \\
\hline M... & 65.0 & 18.42 & 13.15 & 35.39 & 23.40 & 9.64 \\
\hline M... & 95.4 & 19.29 & 13.85 & 38.57 & 23.21 & 5.08 \\
\hline F... & 107.5 & 20.37 & 13.86 & 42.14 & 17.51 & 6.12 \\
\hline M... & 164.0 & 17.35 & 13.29 & 41.66 & 20.95 & 6.75 \\
\hline F. & $254.0^{\mathrm{I}}$ & 19.41 & 10.16 & 44.21 & 16.22 & 10.00 \\
\hline
\end{tabular}

1 Including gravid uterus, which weighed 13.76 grams.

2.) Growth of systems. When the values for the five entries in table 83 are compared with the last four in table 50 for the albino rat, it is noted that in the Norway the values for the musculature and viscera are high, while that for the 'remainder' is low. This last difference is due in part to the smaller amount of fat in the Norway. At the same time there is other evidence to show that for the same body weight as the Albino, both the trunk and the viscera of the Norway are heavier, as here found.

3.) Weight of cranium. (Donaldson, '12.) Determinations of the weight of the cranium dried at room temperature have

\section{TABLE 84}

The mean weight in grams of the crania in each body weight group of the four series of wild Norway rats from Paris, London, Philadelphia, Vienna (based on table 1 Donaldson, '12 a.) Each weight group is based on six cases; 3 males and 3 females

\begin{tabular}{|c|c|c|c|c|}
\hline \multirow{2}{*}{$\begin{array}{l}\text { BODY WEIGET } \\
\text { GROUP }\end{array}$} & \multicolumn{4}{|c|}{ WEIGHT OF THE CRANIA IN GRAMS } \\
\hline & LONDON & PARIS & PHILADELPHIA & VIENNA \\
\hline grams & & & & \\
\hline $125 \ldots \ldots \ldots$ & 1.17 & 1.27 & 1.13 & 1.10 \\
\hline $175 \ldots \ldots \ldots$ & 1.58 & 1.58 & 1.34 & 1.37 \\
\hline $225 \ldots \ldots$ & 1.84 & 1.91 & 1.71 & 1.70 \\
\hline $275 \ldots \ldots \ldots$ & 2.25 & 2.17 & 2.14 & 1.90 \\
\hline $325 \ldots \ldots \ldots \ldots$ & 2.69 & 2.60 & 2.40 & 2.27 \\
\hline $375 \ldots \ldots \ldots \ldots$ & 3.13 & 2.98 & 2.86 & 2.48 \\
\hline
\end{tabular}

For the corresponding weights of the albino crania see table 55 . 
been made. By the cranium is meant the skull with upper teeth, minus the mandible with lower teeth and the ear bones. The mean weights are given in table 84 .

GROWTH IN WEIGHT OF PARTS AND SYSTEMS OF THE BODY: REFERENCES

Donaldson, '12 a. Jackson and Lowrey, '12. 


\section{CHAPTER 13}

\section{GROWTH OF ORGANS IN RELATION TO BODY LENGTH-NORWAY}

1. Length of tail and weights of body, brain and spinal cord in relation to body length. 2. Weight-length ratios.

1) Length of tail, body weight, brain weight and spinal cord weight in relation to body length. Before passing to the tables on the Norway rat, it should be pointed out that the observations used for them have been made on the Norway rat as found in Philadelphia. At the same time it has been shown that the Norway rat taken in Vienna, Paris and London is similar in its general form to that found in the United States, so that the determinations in the tables may be applied to the Norway rat in Europe also (Donaldson, '12).

Table 85 contains values for the several characters named above, computed by the formulas devised by Hatai; these formulas being in turn based on series of observations, the number of which is given in each case.

Body length on body weight. From the study of 282 male and 318 female Norway rats, trapped in Philadelphia, measurements have been taken for body weight and body length (Donaldson and Hatai, '11).

The values for body length — sexes combined - on body weight are given by formula (46). In chart 28 the corresponding graph is given and for comparison the graph for the body length of the Albino is also drawn (see formula (1)).

It has been found that for a given body weight, the body length is in the male Norway 0.4 per cent above the mean, and in the female 0.4 per cent below (Donaldson and Hatai, '11, p. 425).

Body weight on body length. When the formula (46) is transformed so as to give the body weight for a given body length and the correction for sex is included, we have for the males formula (47) and for the females formula (48). In chart (29) are given the graphs for both sexes. 


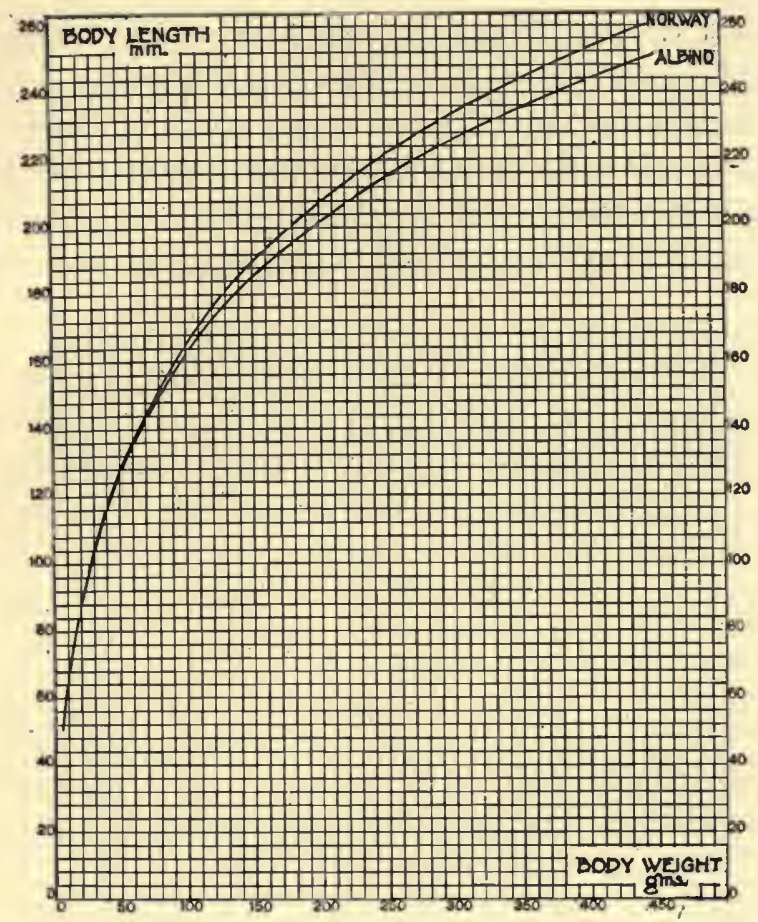

Chart 28 Norway rat-Giving body length on the body weight. Males only. Formula (46), table 85. Inserted for comparison is the corresponding graph for the male Albino (see formula (1).

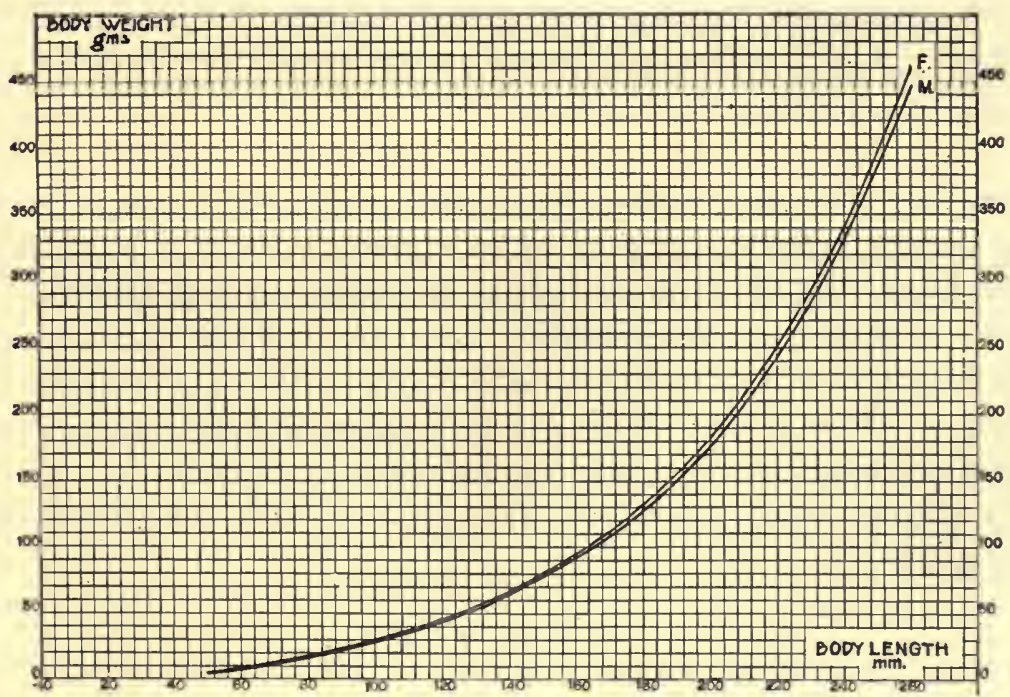

Chart 29 Norway rat-Giving the body weight on the body length. Males, females. Formulas (47), (48), table 85. 
Body weight of the Norway on the body weight of the Albino. Formula (49) gives the body weight of the Norway on the body weight of the Albino for a limited range of Albino body weights.

Tail length on body length. The tail length on the body length has been determined by Hatai (MS '14) and is represented by formulas (50) and (51) for the male and female re-

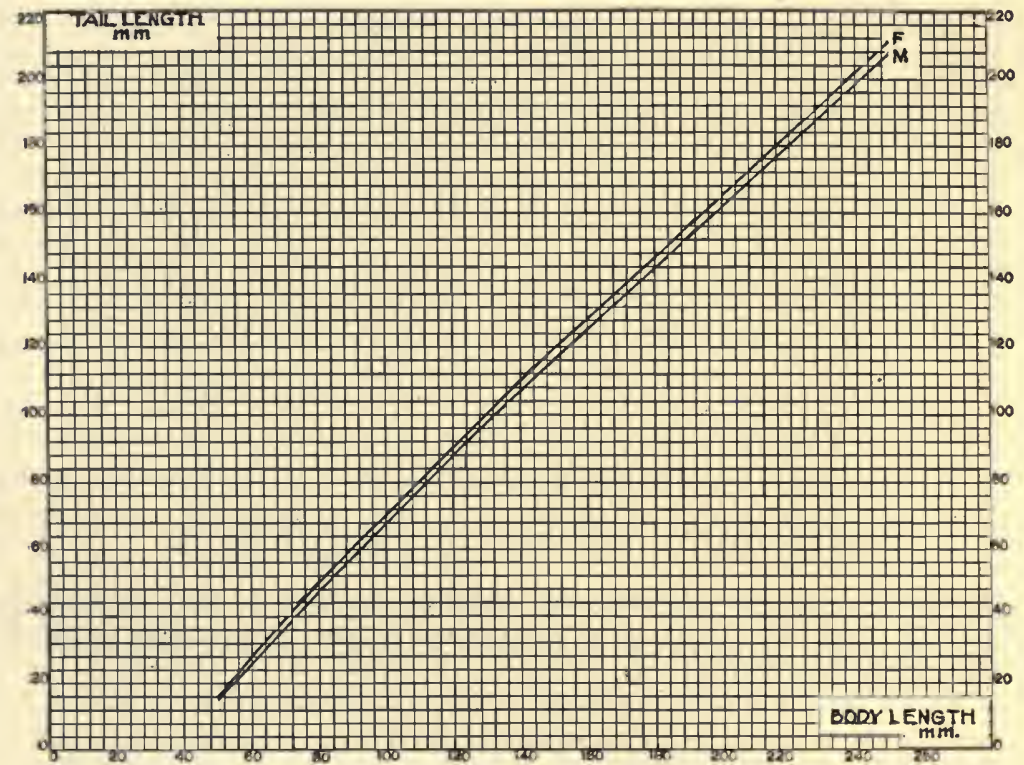

Chart 30 Norway rat-giving the tail length on the body length. Males, females. Formulas (50), (51), table 85 .

spectively. As can be seen by consulting table 85 the males have the shorter tails - a relation which agrees with that found for the Albino. In chart 30 are given the corresponding graphs.

Brain weight on body weight. The direct determinations of the weight of the brain have been made on 232 males and 278 females. The general formula (52) expresses the relation of brain weight on body weight for the sexes combined.

It applies however only to rats with a body weight above five grams. 
Using this formula the brain weights have been computed for each of the series of body weights as determined by formulas (47) and (48).

It has been found however (Donaldson and Hatai, '11, p. 428) that the weight of the male brain is one per cent above the mean for the two sexes, and that of the female, one per cent below.

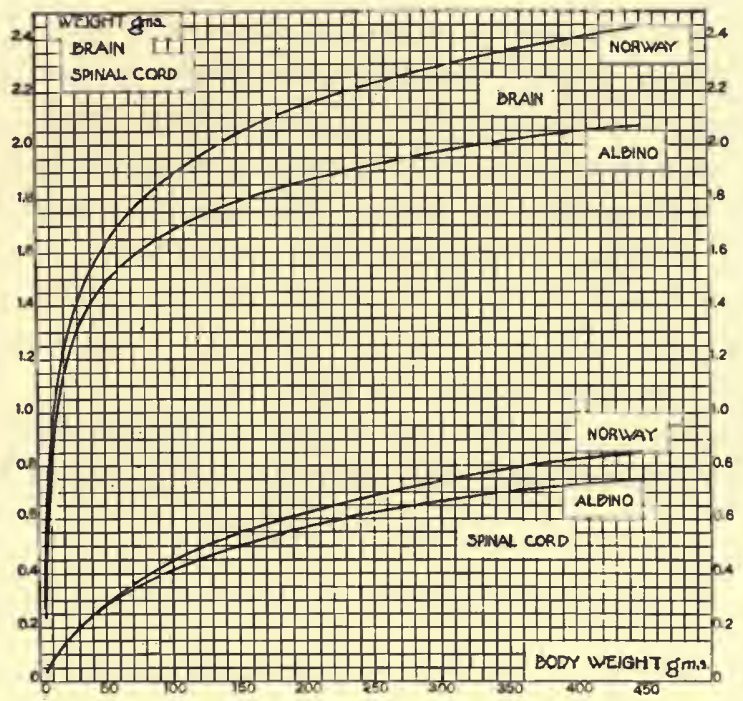

Chart 31 Norway rat, giving brain weight on the body weight. Males only. With the corresponding graph for the Albino inserted for comparison. Formula 52, table 85. Also the spinal cord weight on the body weight. Males only. With the corresponding graph for the Albino inserted for comparison. Formula 54, table 85 .

As a consequence, each value gotten by the foregoing computations has been corrected by adding one per cent to the value found to give the weight for the male brain and by subtracting one per cent to obtain the weight for the female brain.

Chart 31 gives the graph for the male brain weight on the body weight and the corresponding graph (male) for the Albino (see chart 9) is also drawn for comparison. The marked difference in the brain weight of the two forms is clearly shown. 
Formula (53) gives the cranial capacity for the body weighta useful datum in many instances.

Spinal cord weight on body weight. In the case of the spinal cord, the computation was made for the sexes combined by the aid of formula (54). Here again there is a difference according to sex, the male spinal cord exceeding the female by 0.2 per cent, and the value for both sexes combined, by 0.1 per cent. Corrections similar to those applied to the brain have been made in this case also. Chart (31) gives the graph for the male spinal cord on body weight and the corresponding graph (male) for the Albino (see chart 9) is also drawn for comparison.

Formula (55) gives the spinal cord weight (sexes combined) on the brain weight-sexes combined, table 85 .

2. Weight-length ratios. In table 86 are given the values for the Norway obtained by dividing the body weight by the body length, as these appear in table 85 .

The explanation of the use of this table has been given on p. 72 in connection with the corresponding table 48 for the Albino.

GROWTH OF ORGANS IN RELATION TO BODY LENGTH: REFERENCES

Donaldson, '12, '12 a. Donaldson and Hatai, '11. 
TABLE 85

Gives the tail length, body weight, brain weight and spinal cord weight for each millimeter of body length of the male and female Norway rat respectively.

See Charts 28, 29, 30, 31 .

\begin{tabular}{|c|c|c|c|c|c|c|c|c|}
\hline \multicolumn{5}{|c|}{ MALES } & \multicolumn{4}{|c|}{ FEMALES } \\
\hline \multirow{2}{*}{$\underset{\text { length }}{\text { Body }}$} & \multirow{2}{*}{$\begin{array}{c}\text { Tail } \\
\text { length }\end{array}$} & \multirow{2}{*}{$\begin{array}{l}\text { Body } \\
\text { weight }\end{array}$} & \multicolumn{2}{|c|}{ Weight of } & \multirow{2}{*}{ Tail length } & \multirow{2}{*}{$\underset{\text { weight }}{\text { Body }}$} & \multicolumn{2}{|c|}{ Weight of } \\
\hline & & & Brain & $\underset{\text { cord }}{\text { Spinal }}$ & & & Brain & $\underset{\text { Spinal }}{\text { cord }}$ \\
\hline$m m$. & $m m$. & gms. & gms. & gms. & $m m$. & gms. & gms. & oms. \\
\hline 50 & 15.0 & 4.4 & & 0.031 & 16.0 & 4.6 & & 0.032 \\
\hline 51 & 16.2 & 4.8 & & 0.034 & 17.2 & 4.9 & & 0.035 \\
\hline 52 & 17.3 & 5.1 & 0.270 & 0.037 & 18.4 & 5.2 & 0.307 & 0.038 \\
\hline 53 & 18.5 & 5.4 & 0.367 & 0.040 & 19.6 & 5.6 & 0.393 & 0.041 \\
\hline 54 & 19.6 & 5.8 & 0.443 & 0.043 & 20.8 & 5.9 & 0.462 & 0.044 \\
\hline 55 & 20.8 & 6.1 & 0.508 & 0.046 & 21.9 & 6.3 & 0.522 & 0.047 \\
\hline 56 & 21.9 & 6.5 & 0.563 & 0.049 & 23.1 & 6.6 & 0.574 & 0.050 \\
\hline 57 & 23.0 & 6.8 & 0.611 & 0.052 & 24.3 & 7.0 & 0.620 & 0.053 \\
\hline 58 & 24.1 & 7.2 & 0.655 & 0.055 & 25.4 & 7.4 & 0.661 & 0.056 \\
\hline 59 & 25.3 & 7.6 & 0.694 & 0.058 & 26.5 & 7.7 & 0.698 & 0.059 \\
\hline 60 & 26.4 & 7.9 & 0.730 & 0.061 & 27.7 & 8.1 & 0.732 & 0.063 \\
\hline 61 & 27.5 & 8.3 & 0.763 & 0.064 & 28.8 & 8.5 & 0.763 & 0.066 \\
\hline 62 & 28.6 & 8.7 & 0.794 & 0.067 & 29.9 & 8.9 & 0.793 & 0.069 \\
\hline 63 & 29.7 & 9.1 & 0.823 & 0.070 & 31.1 & 9.3 & 0.820 & 0.072 \\
\hline 64 & 30.8 & 9.5 & 0.850 & 0.074 & 32.2 & 9.7 & 0.846 & 0.075 \\
\hline 65 & 31.9 & 9.9 & 0.875 & 0.077 & 33.3 & 10.1 & 0.871 & 0.078 \\
\hline 66 & 32.9 & 10.3 & 0.900 & 0.080 & 34.4 & 10.5 & 0.894 & 0.082 \\
\hline 67 & 34.0 & 10.7 & 0.923 & 0.083 & 35.5 & 10.9 & 0.916 & 0.085 \\
\hline 68 & 35.1 & 11.1 & 0.944 & 0.086 & 36.6 & 11.3 & 0.937 & 0.088 \\
\hline 69 & 36.2 & 11.5 & 0.965 & 0.090 & 37.7 & 11.8 & 0.957 & 0.091 \\
\hline 70 & 37.2 & 11.9 & 0.985 & 0.093 & 38.8 & 12.2 & 0.977 & 0.095 \\
\hline 71 & 38.3 & 12.4 & 1.005 & 0.096 & 39.9 & 12.6 & 0.995 & 0.098 \\
\hline 72 & 39.4 & 12.8 & 1.023 & 0.099 & 41.0 & 13.1 & 1.013 & 0.101 \\
\hline 73 & 40.4 & 13.3 & 1.041 & 0.103 & 42.1 & 13.5 & 1.031 & 0.104 \\
\hline 74 & 41.5 & 13.7 & 1.059 & 0.106 & 43.1 & 14.0 & 1.048 & 0.108 \\
\hline 75 & 42.5 & 14.2 & 1.075 & 0.109 & 44.2 & 14.5 & 1.064 & 0.111 \\
\hline 76 & 43.6 & 14.7 & 1.092 & 0.113 & 45.3 & 14.9 & 1.080 & 0.114 \\
\hline 77 & 44.6 & 15.1 & 1.107 & 0.116 & 46.4 & 15.4 & 1.095 & 0.118 \\
\hline 78 & 45.7 & 15.6 & 1.123 & 0.119 & 47.4 & 15.9 & 1.110 & 0.121 \\
\hline 79 & 46.7 & 16.1 & 1.138 & 0.123 & 48.5 & 16.4 & 1.124 & 0.125 \\
\hline 80 & 47.7 & 16.6 & 1.152 & 0.126 & 49.5 & 16.9 & 1.138 & 0.128 \\
\hline 81 & 48.8 & 17.1 & 1.166 & 0.129 & 50.6 & 17.4 & 1.152 & 0.131 \\
\hline 82 & 49.8 & 17.6 & 1.180 & 0.133 & 51.7 & 17.9 & 1.166 & 0.135 \\
\hline
\end{tabular}


TABLE 85-Continued

\begin{tabular}{|c|c|c|c|c|c|c|c|c|}
\hline \multicolumn{5}{|c|}{ MALES } & \multicolumn{4}{|c|}{ FEMALES } \\
\hline \multirow{2}{*}{$\begin{array}{c}\text { Body } \\
\text { length }\end{array}$} & \multirow{2}{*}{$\begin{array}{c}\text { Tail } \\
\text { length }\end{array}$} & \multirow{2}{*}{$\begin{array}{l}\text { Body } \\
\text { weight }\end{array}$} & \multicolumn{2}{|c|}{ Weight of } & \multirow{2}{*}{ Tail length } & \multirow{2}{*}{$\underset{\text { weight }}{\text { Body }}$} & \multicolumn{2}{|c|}{ Weight of } \\
\hline & & & Brain & $\underset{\text { cord }}{\text { Spinal }}$ & & & Brain & $\begin{array}{c}\text { Spinal } \\
\text { cord }\end{array}$ \\
\hline$m m$. & $m m$. & gms. & gms. & gms. & $m m$. & gms. & gms. & oms. \\
\hline 83 & 50.8 & 18.1 & 1.194 & 0.136 & 52.7 & 18.5 & 1.179 & 0.138 \\
\hline 84 & 51.9 & 18.7 & 1.207 & 0.140 & 53.8 & 19.0 & 1.192 & 0.142 \\
\hline 85 & 52.9 & 19.2 & 1.220 & 0.143 & 54.8 & 19.6 & 1.204 & 0.145 \\
\hline 86 & 53.9 & 19.7 & 1.232 & 0.146 & 55.8 & 20.1 & 1.216 & 0.149 \\
\hline 87 & 54.9 & 20.3 & 1.245 & 0.150 & 56.9 & 20.7 & 1.229 & 0.152 \\
\hline 88 & 55.9 & 20.8 & 1.257 & 0.153 & 57.9 & 21.2 & 1.240 & 0.156 \\
\hline 89 & 57.0 & 21.4 & 1.269 & 0.157 & 59.0 & 21.8 & 1.252 & 0.159 \\
\hline 90 & 58.0 & 22.0 & 1.281 & 0.160 & 60.0 & 22.4 & 1.264 & 0.163 \\
\hline 91 & 59.0 & 22.5 & 1.292 & 0.164 & 61.0 & 23.0 & 1.275 & 0.166 \\
\hline 92 & 60.0 & 23.1 & 1.303 & 0.167 & 62.1 & 23.6 & 1.286 & 0.170 \\
\hline $93_{t}$ & 61.0 & 23.7 & 1.315 & 0.171 & 63.1 & 24.2 & 1.297 & 0.173 \\
\hline 94 & 62.0 & 24.3 & 1.325 & 0.174 & 64.1 & 24.8 & 1.307 & 0.177 \\
\hline 95 & 63.0 & 25.0 & 1.336 & 0.178 & 65.1 & 25.4 & 1.318 & 0.180 \\
\hline 96 & 64.0 & 25.6 & 1.347 & 0.181 & 66.1 & 26.1 & 1.328 & 0.184 \\
\hline 97 & 65.0 & 26.2 & 1.357 & 0.185 & 67.2 & 26.7 & 1.338 & 0.188 \\
\hline 98 & 66.0 & 26.9 & 1.368 & 0.189 & 68.2 & 27.4 & 1.348 & 0.191 \\
\hline 99 & 67.0 & 27.5 & 1.378 & 0.192 & 69.2 & 28.0 & 1.358 & 0.195 \\
\hline 100 & 68.0 & 28.2 & 1.388 & 0.196 & 70.2 & 28.7 & 1.368 & 0.198 \\
\hline 101 & 69.0 & 28.8 & 1.398 & 0.199 & 71.2 & 29.4 & 1.378 & 0.202 \\
\hline 102 & 70.0 & 29.5 & 1.408 & 0.203 & 72.2 & 30.1 & 1.388 & 0.206 \\
\hline 103 & 71.0 & 30.2 & 1.417 & 0.207 & 73.2 & 30.8 & 1.397 & 0.209 \\
\hline 104 & 72.0 & 30.9 & 1.427 & 0.210 & 74.2 & 31.5 & 1.406 & 0.213 \\
\hline 105 & 73.0 & 31.6 & 1.436 & 0.214 & 75.2 & 32.2 & 1.416 & 0.217 \\
\hline 106 & 73.9 & 32.3 & 1.446 & 0.218 & 76.2 & 33.0 & 1.425 & 0.220 \\
\hline 107 & 74.9 & 33.1 & 1.455 & 0.221 & 77.2 & 33.7 & 1.434 & 0.224 \\
\hline 108 & 75.9 & 33.8 & 1.464 & 0.225 & 78.2 & 34.5 & 1.443 & 0.228 \\
\hline 109 & 76.9 & 34.6 & 1.473 & 0.229 & 79.2 & 35.2 & 1.452 & 0.232 \\
\hline 110 & 77.9 & 35.3 & 1.482 & 0.232 & 80.2 & 36.0 & 1.460 & 0.235 \\
\hline 111 & 78.8 & 36.1 & 1.491 & 0.236 & 81.2 & 36.8 & 1.469 & 0.239 \\
\hline 112 & 79.8 & 36.9 & 1.499 & 0.240 & 82.2 & 37.6 & 1.477 & 0.243 \\
\hline 113 & 80.8 & 37.7 & 1.508 & 0.244 & 83.2 & 38.4 & 1.486 & 0.247 \\
\hline 114 & 81.8 & 38.5 & 1.517 & 0.247 & 84.2 & 39.3 & 1.494 & 0.250 \\
\hline 115 & 82.7 & 39.3 & 1.525 & 0.251 & 85.2 & 40.1 & 1.503 & 0.254 \\
\hline 116 & 83.7 & 40.2 & 1.534 & 0.255 & 86.2 & 40.9 & 1.511 & 0.258 \\
\hline 117 & 84.7 & 41.0 & 1.542 & 0.259 & 87.2 & 41.8 & 1.519 & 0.262 \\
\hline 118 & 85.6 & 41.9 & 1.550 & 0.262 & 88.1 & 42.7 & 1.527 & 0.266 \\
\hline
\end{tabular}


TABLE 85-Continued

\begin{tabular}{|c|c|c|c|c|c|c|c|c|}
\hline \multicolumn{5}{|c|}{ MALES } & \multicolumn{4}{|c|}{ FEMALES } \\
\hline \multirow{2}{*}{$\begin{array}{c}\text { Body } \\
\text { length }\end{array}$} & \multirow{2}{*}{$\begin{array}{c}\text { Tail } \\
\text { length }\end{array}$} & \multirow{2}{*}{$\begin{array}{l}\text { Body } \\
\text { weight }\end{array}$} & \multicolumn{2}{|c|}{ Weight of } & \multirow{2}{*}{ Tail length } & \multirow{2}{*}{$\underset{\text { weight }}{\text { Body }}$} & \multicolumn{2}{|c|}{ Weight of } \\
\hline & & & Brain & $\begin{array}{l}\text { Spinal } \\
\text { cord }\end{array}$ & & & Brain & $\begin{array}{l}\text { Spinal } \\
\text { cord }\end{array}$ \\
\hline$m m$. & $m m$ & $g m s$. & gms. & gms. & $m m$. & $g m s$. & $g m s$. & $g m s$. \\
\hline 119 & 86.6 & 42.7 & 1.558 & 0.266 & 89.1 & 43.6 & 1.535 & 0.269 \\
\hline 120 & 87.6 & 43.6 & 1.567 & 0.270 & 90.1 & 44.5 & 1.543 & 0.273 \\
\hline 121 & 88.5 & 44.5 & 1.575 & 0.274 & 91.1 & 45.4 & 1.551 & 0.277 \\
\hline 122 & 89.5 & 45.4 & 1.583 & 0.278 & 92.1 & 46.3 & 1.559 & 0.281 \\
\hline 123 & 90.5 & 46.3 & 1.591 & 0.281 & 93.0 & 47.3 & 1.567 & 0.285 \\
\hline 124 & 91.4 & 47.3 & 1.599 & 0.285 & 94.0 & 48.2 & 1.575 & 0.289 \\
\hline 125 & 92.4 & 48.2 & 1.606 & 0.289 & 95.0 & 49.2 & 1.582 & 0.292 \\
\hline 126 & 93.4 & 49.2 & 1.614 & 0.293 & 96.0 & 50.2 & 1.590 & 0.296 \\
\hline 127 & 94.3 & 50.2 & 1.622 & 0.297 & 96.9 & 51.2 & 1.598 & 0.300 \\
\hline 128 & 95.3 & 51.1 & 1.630 & 0.301 & 97.9 & 52.2 & 1.605 & 0.304 \\
\hline 129 & 96.2 & 52.1 & 1.637 & 0.305 & 98.9 & 53.2 & 1.613 & 0.308 \\
\hline 130 & 97.2 & 53.2 & 1.645 & 0.308 & 99.8 & 54.2 & 1.620 & 0.312 \\
\hline 131 & 98.1 & 54.2 & 1.652 & 0.312 & 100.8 & 55.3 & 1.627 & 0.316 \\
\hline 132 & 99.1 & 55.3 & 1.660 & 0.316 & 101.8 & 56.4 & 1.635 & 0.320 \\
\hline 133 & 100.0 & 56.3 & 1.667 & 0.320 & 102.7 & 57.5 & 1.642 & 0.324 \\
\hline 134 & 101.0 & 57.4 & 1.675 & 0.324 & 103.7 & 58.6 & 1.649 & 0.328 \\
\hline 135 & 101.9 & 58.5 & 1.682 & 0.328 & 104.7 & 59.7 & 1.657 & 0.332 \\
\hline 136 & 102.9 & 59.6 & 1.689 & 0.332 & 105.6 & 60.9 & 1.664 & 0.336 \\
\hline 137 & 103.8 & 60.7 & 1.697 & 0.336 & 106.6 & 62.0 & 1.671 & 0.339 \\
\hline 138 & 104.8 & 61.9 & 1.704 & 0.340 & 107.5 & 63.2 & 1.678 & 0.343 \\
\hline 139 & 105.7 & 63.0 & 1.711 & 0.344 & 108.5 & 64.3 & 1.685 & 0.347 \\
\hline 140 & 106.7 & 64.2 & 1.718 & 0.348 & 109.5 & 65.6 & 1.692 & 0.351 s \\
\hline 141 & 107.6 & 65.4 & 1.725 & 0.352 & 110.4 & 66.8 & 1.699 & 0.355 \\
\hline 142 & 108.6 & 66.6 & 1.732 & 0.356 & 111.4 & 68.0 & 1.706 & 0.359 \\
\hline 143 & 109.5 & 67.8 & 1.739 & 0.360 & 112.3 & 69.3 & 1.713 & 0.363 \\
\hline 144 & 110.5 & 69.1 & 1.746 & 0.363 & 113.3 & 70.6 & 1.720 & 0.368 \\
\hline 145 & 111.4 & 70.4 & 1.753 & 0.367 & 114.2 & 71.9 & 1.727 & 0.372 \\
\hline 146 & 112.3 & 71.6 & 1.760 & 0.371 & 115.2 & 73.2 & 1.733 & 0.376 \\
\hline 147 & 113.3 & 72.9 & 1.767 & 0.375 & 116.1 & 74.5 & 1.740 & 0.380 \\
\hline 148 & 114.2 & 74.3 & 1.774 & 0.379 & 117.1 & 75.9 & 1.747 & 0.384 \\
\hline 149 & 115.2 & 75.6 & 1.781 & 0.384 & 118.0 & 77.2 & 1754 & 0.388 \\
\hline 150 & 116.1 & 77.0 & 1.788 & 0.388 & 119.0 & 78.6 & 1.760 & 0.392 \\
\hline 151 & 117.0 & 78.3 & 1.794 & 0.392 & 119.9 & 80.0 & 1.767 & 0.396 \\
\hline 152 & 118.0 & 79.7 & 1.801 & 0.396 & 120.9 & 81.5 & 1.774 & 0.400 \\
\hline 153 & 118.9 & 81.2 & 1.808 & 0.400 & 121.8 & 82.9 & 1.780 & 0.404 \\
\hline
\end{tabular}


TABLE 85-Coutinued

\begin{tabular}{|c|c|c|c|c|c|c|c|c|}
\hline \multicolumn{5}{|c|}{ MALES } & \multicolumn{4}{|c|}{ FEMALES } \\
\hline \multirow{2}{*}{$\begin{array}{r}\text { Body } \\
\text { length }\end{array}$} & \multirow{2}{*}{$\begin{array}{c}\text { Tail } \\
\text { length }\end{array}$} & \multirow{2}{*}{$\begin{array}{l}\text { Body } \\
\text { weight }\end{array}$} & \multicolumn{2}{|c|}{ Weight of } & \multirow{2}{*}{ Tail length } & \multirow{2}{*}{$\underset{\text { weight }}{\text { Body }}$} & \multicolumn{2}{|c|}{ Weight of } \\
\hline & & & Brain & $\begin{array}{c}\text { Spingl } \\
\text { cord }\end{array}$ & & & Brain & $\begin{array}{c}\text { Spinal } \\
\text { cord }\end{array}$ \\
\hline$m m$. & $m m$. & gms. & gms. & gms. & $m m$. & gms. & gms. & gms. \\
\hline 154 & 119.8 & 82.6 & 1.815 & 0.404 & 122.8 & 84.4 & 1.787 & 0.408 \\
\hline 155 & 120.8 & 84.1 & 1.821 & 0.408 & 123.7 & 85.9 & 1.793 & 0.412 \\
\hline 156 & 121.7 & 85.6 & 1.828 & 0.412 & 124.7 & 87.4 & 1.800 & 0.416 \\
\hline 157 & 122.6 & 87.1 & 1.835 & 0.416 & 125.6 & 89.0 & 1.807 & 0.420 \\
\hline 158 & 123.6 & 88.6 & 1.841 & 0.420 & 126.6 & 90.6 & 1.813 & 0.424 \\
\hline 159 & 124.5 & 90.1 & 1.848 & 0.424 & 127.5 & 92.1 & 1.819 & 0.429 \\
\hline 160 & 125.4 & 91.7 & 1.854 & 0.428 & 128.4 & 93.8 & 1.826 & 0.433 \\
\hline 161 & 126.4 & 93.3 & 1.861 & 0.432 & 129.4 & 95.4 & 1.832 & 0.437 \\
\hline 162 & 127.3 & 94.9 & 1.867 & 0.436 & 130.3 & 97.1 & 1.839 & 0.441 \\
\hline 163 & 128.2 & 96.6 & 1.874 & 0.441 & 131.3 & 98.7 & 1.845 & 0.445 \\
\hline 164 & 129.1 & 98.2 & 1.880 & 0.445 & 132.2 & 100.5 & 1.851 & 0.449 \\
\hline 165 & 130.1 & 99.9 & 1.887 & 0.449 & 133.1 & 102.2 & 1.858 & 0.453 \\
\hline 166 & 131.0 & 101.6 & 1.893 & 0.453 & 134.1 & 104.1 & 1.864 & 0.458 \\
\hline 167 & 131.9 & 103.4 & 1.899 & 0.457 & 135.0 & 105.7 & 1870 & 0.462 \\
\hline 168 & 132.8 & 105.1 & 1.906 & 0.461 & 135.9 & 107.5 & 1877 & 0.466 \\
\hline 169 & 133.8 & 106.9 & 1.912 & 0.465 & 136.9 & 109.4 & 1.883 & 0.470 \\
\hline 170 & 134.7 & 108.7 & 1.918 & 0.469 & 137.8 & 111.3 & 1.889 & 0.474 \\
\hline 171 & 135.6 & 110.6 & 1.925 & 0.474 & 138.8 & 113.1 & 1.895 & 0.478 \\
\hline 172 & 136.5 & 112.4 & 1.931 & 0.478 & 139.7 & 115.1 & 1.901 & 0.483 \\
\hline 173 & 137.5 & 114.3 & 1.937 & 0.482 & 140.6 & 117.0 & 1.908 & 0.487 \\
\hline 174 & 138.4 & 116.3 & 1.944 & 0.486 & 141.5 & 119.0 & 1.914 & 0.491 \\
\hline 175 & 139.3 & 118.2 & 1.950 & 0.490 & 142.5 & 121.0 & 1.920 & 0.495 \\
\hline 176 & 140.2 & 120.2 & 1.956 & 0.494 & 143.4 & 123.0 & 1.926 & 0.499 \\
\hline 177 & 141.1 & 122.2 & 1.962 & 0.499 & 144.3 & 125.1 & 1.932 & 0.504 \\
\hline 178 & 142.1 & 124.2 & 1.968 & 0.503 & 145.3 & 127.2 & 1.938 & 0.508 \\
\hline 179 & 143.0 & 126.3 & 1.975 & 0.507 & 146.2 & 129.3 & $1.9=4$ & 0.512 \\
\hline 180 & 143.9 & 128.4 & 1.981 & 0.511 & 147.1 & 131.5 & 1.949 & 0.516 \\
\hline 181 & 144.8 & 130.5 & 1.987 & 0.515 & 148.1 & 133.7 & 1.955 & 0.520 \\
\hline 182 & 145.7 & 132.7 & 1.993 & 0.520 & 149.0 & 135.9 & 1.962 & 0.525 \\
\hline 183 & 146.7 & 134.9 & 1.999 & 0.524 & 149.9 & 138.1 & 1.968 & 0.529 \\
\hline 184 & 147.6 & 137.1 & 2.005 & 0.528 & 150.8 & 140.4 & 1.974 & 0.533 \\
\hline 185 & 148.5 & 139.3 & 2.011 & 0.532 & 151.8 & 142.8 & 1.980 & 0.537 \\
\hline 186 & 149.4 & 141.6 & 2.017 & 0.536 & 152.7 & 145.1 & 1.986 & 0.542 \\
\hline 187 & 150.3 & 144.0 & 2.023 & 0.541 & 153.6 & 147.5 & 1.992 & 0.546 \\
\hline 188 & 151.2 & 146.3 & 2.029 & 0.545 & 154.5 & 149.9 & 1.998 & 0.550 \\
\hline 189 & 152.2 & 148.7 & 2.035 & 0.549 & 155.5 & 152.4 & 2.004 & 0.554 \\
\hline 190 & 153.1 & 151.1 & 2.042 & 0.553 & 156.4 & 154.9 & 2.010 & 0.559 \\
\hline
\end{tabular}


TABLE 85-Continued

\begin{tabular}{|c|c|c|c|c|c|c|c|c|}
\hline \multicolumn{5}{|c|}{ MALES } & \multicolumn{4}{|c|}{ FEMALẸS } \\
\hline \multirow{2}{*}{$\begin{array}{l}\text { Body } \\
\text { length }\end{array}$} & \multirow{2}{*}{$\begin{array}{c}\text { Tail } \\
\text { length }\end{array}$} & \multirow{2}{*}{$\begin{array}{l}\text { Body } \\
\text { weight }\end{array}$} & \multicolumn{2}{|c|}{ Weight of } & \multirow{2}{*}{ Tail length } & \multirow{2}{*}{$\begin{array}{c}\text { Body } \\
\text { weight }\end{array}$} & \multicolumn{2}{|c|}{ Weight of } \\
\hline & & & Brain & $\begin{array}{l}\text { Spinal } \\
\text { cord }\end{array}$ & & & Brain & $\begin{array}{l}\text { Spinal } \\
\text { cord }\end{array}$ \\
\hline$m m$. & $m m$. & $g m s$. & $g m s$. & gms. & $m m$ & gms. & gms. & gms. \\
\hline 191 & 154.0 & 153.6 & 2.047 & 0.557 & 157.3 & 157.4 & 2.016 & 0.563 \\
\hline 192 & 154.9 & 156.1 & 2.053 & 0.562 & 158.2 & 160.0 & 2.022 & 0.567 \\
\hline 193 & 155.8 & 158.6 & 2.059 & 0.566 & 159.1 & 162.6 & 2.028 & 0.572 \\
\hline 194 & 156.7 & 161.2 & 2.065 & 0.570 & 160.1 & 165.2 & 2.034 & 0.576 \\
\hline 195 & 157.6 & 163.8 & 2.071 & 0.575 & 161.0 & 167.9 & 2.039 & 0.580 \\
\hline 196 & 158.5 & 166.4 & 2.077 & 0.579 & 161.9 & 170.6 & 2.045 & 0.584 \\
\hline 197 & 159.4 & 169.1 & 2.083 & 0.583 & 162.8 & 173.4 & 2.051 & 0.589 \\
\hline 198 & 160.4 & 171.8 & 2.089 & 0.587 & 163.7 & 176.2 & 2.057 & 0.593 \\
\hline 199 & 161.3 & 174.6 & 2.095 & 0.592 & 164.7 & 179.1 & 2.063 & 0.597 \\
\hline 200 & 162.2 & 177.4 & 2.101 & 0.596 & 165.6 & 181.9 & 2.069 & 0.602 \\
\hline 201 & 163.1 & 180.2 & 2.107 & 0.600 & 166.5 & 184.9 & 2.074 & 0.606 \\
\hline 202 & 164.0 & 183.1 & 2.112 & 0.604 & 167.4 & 187.8 & 2.080 & 0.610 \\
\hline 203 & 164.9 & 186.0 & 2.118 & 0.609 & 168.3 & 190.9 & 2.086 & 0.615 \\
\hline 204 & 165.8 & 189.0 & 2.124 & 0.613 & 169.2 & 193.9 & 2.092 & 0.619 \\
\hline 205 & 166.7 & 192.0 & 2.130 & 0.617 & 170.2 & 197.0 & 2.098 & 0.623 \\
\hline 206 & 167.6 & 195.0 & 2.136 & 0.622 & 171.1 & 200.2 & 2.103 & 0.628 \\
\hline 207 & 168.5 & 198.1 & 2.142 & 0.626 & 172.0 & 203.4 & 2.109 & 0.632 \\
\hline 208 & 169.4 & 201.3 & 2.148 & 0.630 & 172.9 & 206.6 & 2.115 & 0.636 \\
\hline 209 & 170.3 & 204.4 & 2.153 & 0.635 & 173.8 & 209.9 & 2.120 & 0.641 \\
\hline 210 & 171.2 & 207.7 & 2.159 & 0.639 & 174.7 & 213.2 & 2.126 & 0.645 \\
\hline 211 & 172.1 & 210.9 & 2.165 & 0.643 & 175.6 & 216.6 & 2.132 & 0.649 \\
\hline 212 & 173.1 & 214.3 & 2.171 & 0.647 & 176.6 & 220.1 & 2.138 & 0.654 \\
\hline 213 & $174.0^{\circ}$ & 217.7 & 2.177 & 0.652 & 177.5 & 223.5 & 2.143 & 0.658 \\
\hline 214 & 174.9 & 221.1 & 2.182 & 0.656 & 178.4 & 227.1 & 2.149 & 0.662 \\
\hline 215 & 175.8 & 224.5 & 2.188 & 0.660 & 179.3 & 230.7 & 2.155 & 0.667 \\
\hline 216 & 176.7 & 228.1 & 2.194 & 0.665 & 180.2 & 234.3 & 2.160 & 0.671 \\
\hline 217 & 177.6 & 231.6 & 2.199 & 0.669 & 181.1 & 238.0 & 2.166 & 0.675 \\
\hline 218 & 178.5 & 235.3 & 2.205 & 0.673 & 182.0 & 241.8 & 2.171 & 0.680 \\
\hline 219 & 179.4 & 239.0 & 2.211 & 0.678 & 182.9 & 245.6 & 2.177 & 0.684 \\
\hline 220 & 180.3 & 242.7 & 2.217 & 0.682 & 183.8 & 249.4 & 2.183 & 0.689 \\
\hline 221 & 181.2 & 246.5 & 2.222 & 0.686 & 184.8 & 253.3 & 2.188 & 0.693 \\
\hline 222 & 182.1 & 250.3 & 2.228 & 0.691 & 185.7 & 257.3 & 2.194 & 0.697 \\
\hline 223 & 183.0 & 254.2 & 2.234 & 0.695 & 186.6 & 261.3 & 2.199 & 0.702 \\
\hline 224 & 183.9 & 258.2 & 2.239 & 0.699 & 187.5 & 265.4 & 2.205 & 0.706 \\
\hline 225 & 184.8 & 262.2 & 2.245 & 0.704 & 188.4 & 269.6 & 2.211 & 0.710 \\
\hline 226 & 185.7 & 266.3 & 2.251 & 0.708 & 189.3 & 273.8 & 2.216 & 0.715 \\
\hline 227 & 186.6 & 270.4 & 2.256 & 0.713 & 190.2 & 278.1 & 2.222 & 0.719 \\
\hline
\end{tabular}


TABLE 85-Concluded

\begin{tabular}{|c|c|c|c|c|c|c|c|c|}
\hline \multicolumn{5}{|c|}{ MALES } & \multicolumn{4}{|c|}{ FEMALES } \\
\hline \multirow{2}{*}{$\underset{\text { length }}{\text { Body }}$} & \multirow{2}{*}{$\begin{array}{c}\text { Tail } \\
\text { length }\end{array}$} & \multirow{2}{*}{$\begin{array}{l}\text { Body } \\
\text { weight }\end{array}$} & \multicolumn{2}{|c|}{ Weight of } & \multirow{2}{*}{ Tail length } & \multirow{2}{*}{$\underset{\text { weight }}{\text { Body }}$} & \multicolumn{2}{|c|}{ Weight of } \\
\hline & & & Brain & $\begin{array}{c}\text { Spinal } \\
\text { cord }\end{array}$ & & & Brain & $\begin{array}{c}\text { Spinal } \\
\text { cord }\end{array}$ \\
\hline $\mathrm{mm}$ & $m m$. & oms. & gms. & gms. & $m m$. & gms. & gms. & oms. \\
\hline 228 & 187.5 & 274.6 & 2.262 & 0.717 & 191.1 & 282.4 & 2.227 & 0.724 \\
\hline 229 & 188.4 & 278.8 & 2.268 & 0.721 & 192.0 & 286.8 & 2.233 & 0.728 \\
\hline 230 & 189.3 & 283.1 & 2.273 & 0.726 & 192.9 & 291.3 & 2.238 & 0.732 \\
\hline 231 & 190.2 & 287.5 & 2.279 & 0.730 & 193.8 & 295.8 & 2.244 & 0.737 \\
\hline 232 & 191.1 & 292.0 & 2.285 & 0.734 & 194.7 & 300.4 & 2.250 & 0.741 \\
\hline 233 & 192.0 & 296.5 & 2.290 & 0.739 & 195.6 & 305.1 & 2.255 & 0.746 \\
\hline 234 & 192.9 & 301.0 & 2.296 & 0.743 & 196.5 & 309.8 & 2.261 & 0.750 \\
\hline 235 & 193.8 & 305.7 & 2.301 & 0.748 & 197.4 & 314.6 & 2.266 & 0.754 \\
\hline 236 & 194.7 & 310.4 & 2.307 & 0.752 & 198.3 & 319.5 & 2.272 & 0.759 \\
\hline 237 & 195.5 & 315.1 & 2.312 & 0.756 & 199.2 & 324.4 & 2.277 & 0.763 \\
\hline 238 & 196.4 & 320.0 & 2.318 & 0.761 & 200.1 & 329.4 & 2.283 & 0.768 \\
\hline 239 & 197.3 & 324.9 & 2.324 & 0.765 & 201.1 & 334.5 & 2.288 & 0.772 \\
\hline 240 & 198.2 & 329.9 & 2.329 & 0.769 & 202.0 & 339.7 & 2.294 & 0.776 \\
\hline 241 & 199.1 & 334.9 & 2.335 & 0.774 & 202.9 & 344.9 & 2.299 & 0.781 \\
\hline 242 & 200.0 & 340.1 & 2.340 & 0.778 & 203.8 & 350.2 & 2.305 & 0.785 \\
\hline 243 & 200.9 & 345.3 & 2.346 & 0.783 & 204.7 & 255.6 & 2.310 & 0.790 \\
\hline 244 & 201.8 & 350.5 & 2.351 & 0.787 & 205.6 & 361.1 & 2.316 & 0.794 \\
\hline 245 & 202.7 & 355.9 & 2.357 & 0.791 & 206.5 & 366.7 & 2.321 & 0.799 \\
\hline 246 & 203.6 & 361.3 & 2.363 & 0.796 & 207.4 & 372.3 & 2.327 & 0.803 \\
\hline 247 & 204.5 & 366.8 & 2.368 & 0.800 & 208.3 & 378.0 & 2.332 & 0.807 \\
\hline 248 & 205.4 & 372.4 & 2.374 & 0.805 & 209.2 & 383.8 & 2.337 & 0.812 \\
\hline 249 & 206.3 & 378.1 & 2.379 & 0.809 & 210.1 & 389.7 & 2.343 & 0.816 \\
\hline 250 & 207.2 & 383.9 & 2.385 & 0.813 & 211.0 & 395.7 & 2.349 & 0.821 \\
\hline 251 & & 389.7 & 2.390 & 0.818 & & 401.7 & 2.354 & 0.825 \\
\hline 252 & & 395.6 & 2.396 & 0.822 & & 407.9 & 2.359 & 0.830 \\
\hline 253 & & 401.6 & 2.401 & 0.827 & & 414.1 & 2.365 & 0.834 \\
\hline 254 & & 407.7 & 2.407 & 0.831 & & 420.4 & 2.370 & 0.838 \\
\hline 255 & & 413.9 & 2.412 & 0.835 & & 426.9 & 2.376 & 0.843 \\
\hline 256 & & 420.2 & 2.418 & 0.840 & & 433.4 & 2.381 & 0.847 \\
\hline 257 & & 426.5 & 2.423 & 0.844 & & 440.0 & 2.386 & 0.852 \\
\hline 258 & & 433.0 & 2.429 & 0.849 & & 446.7 & 2.392 & 0.856 \\
\hline 259 & & 439.6 & 2.434 & 0.853 & & 453.5 & 2.397 & 0.861 \\
\hline 260 & & 446.2 & 2.440 & 0.858 & & 460.4 & 2.403 & 0.865 \\
\hline
\end{tabular}


TABLE 86

Giving in grams the values obtained by dividing the body weight by the body length in millimeters. Based on data in table 85

\begin{tabular}{|c|c|c|c|c|c|c|c|c|}
\hline \multirow{2}{*}{$\begin{array}{c}\text { BODY } \\
\text { LENGTH }\end{array}$} & \multicolumn{2}{|c|}{ RATIO } & \multirow{2}{*}{$\begin{array}{c}\text { BODY } \\
\text { LENGTH }\end{array}$} & \multicolumn{2}{|c|}{ RATIO } & \multirow{2}{*}{$\underset{\text { LENGT }}{\text { BODY }}$} & \multicolumn{2}{|c|}{ RATIO } \\
\hline & Male & Female & & Male & Female & & Male & Female \\
\hline 50 & 0.09 & 0.09 & 87 & 0.23 & 0.24 & 124 & 0.38 & 0.39 \\
\hline 51 & 0.09 & 0.10 & 88 & 0.24 & 0.24 & 125 & 0.39 & 0.39 \\
\hline 52 & 0.10 & 0.10 & 89 & 0.24 & 0.24 & 126 & 0.39 & 0.40 \\
\hline 53 & 0.10 & 0.11 & 90 & 0.24 & 0.25 & 127 & 0.40 & 0.40 \\
\hline 54 & 0.11 & 0.11 & & & & 128 & 0.40 & 0.41 \\
\hline 55 & 0.11 & 0.11 & 91 & 0.25 & 0.25 & 129 & 0.40 & 0.41 \\
\hline 56 & 0.12 & 0.12 & 92 & 0.25 & 0.26 & 130 & 0.41 & 0.42 \\
\hline 57 & 0.12 & 0.12 & 93 & 0.25 & 0.26 & & & \\
\hline 58 & 0.12 & 0.13 & 94 & 0.26 & 0.26 & 131 & 0.41 & 0.42 \\
\hline 59 & 0.13 & 0.13 & 95 & 0.26 & 0.27 & 132 & 0.42 & 0.43 \\
\hline 60 & 0.13 & 0.14 & 96 & 0.27 & 0.27 & 133 & 0.42 & 0.43 \\
\hline & & & 97 & 0.27 & 0.28 & 134 & 0.43 & 0.44 \\
\hline 61 & 0.14 & 0.14 & 98 & 0.27 & 0.28 & 135 & 0.43 & 0.44 \\
\hline 62 & 0.14 & 0.14 & 99 & 0.28 & 0.28 & 136 & 0.44 & 0.45 \\
\hline 63 & 0.14 & 0.15 & 100 & 0.28 & 0.29 & 137 & 0.44 & 0.45 \\
\hline 64 & 0.15 & 0.15 & & & & 138 & 0.45 & 0.46 \\
\hline 65 & 0.15 & 0.16 & 101 & 0.29 & 0.29 & 139 & 0.45 & 0.46 \\
\hline 66 & 0.16 & 0.16 & 102 & 0.29 & 0.30 & 140 & 0.46 & 0.47 \\
\hline 67 & 0.16 & 0.16 & 103 & 0.29 & 0.30 & & & \\
\hline 68 & 0.16 & 0.17 & 104 & 0.30 & 0.30 & 141 & 0.46 & 0.47 \\
\hline 69 & 0.17 & 0.17 & 105 & 0.30 & 0.31 & 142 & 0.47 & 0.48 \\
\hline 70 & 0.17 & 0.17 & 106 & 0.30 & 0.31 & 143 & 0.47 & 0.48 \\
\hline & & & 107 & 0.31 & 0.31 & 144 & 0.48 & 0.49 \\
\hline 71 & 0.17 & 0.18 & 108 & 0.31 & 0.32 & 145 & 0.49 & 0.50 \\
\hline 72 & 0.18 & 0.18 & 109 & 0.32 & 0.32 & 146 & 0.49 & 0.50 \\
\hline 73 & 0.18 & 0.18 & 110 & 0.32 & 0.33 & 147 & 0.50 & 0.51 \\
\hline 74 & 0.19 & 0.19 & 111 & 0.33 & 0.33 & 148 & 0.50 & 0.51 \\
\hline 75 & 0.19 & 0.19 & 112 & 0.33 & 0.34 & 149 & 0.51 & 0.52 \\
\hline 76 & 0.19 & 0.20 & 113 & 0.33 & 0.34 & 150 & 0.51 & 0.52 \\
\hline 77 & 0.20 & 0.20 & 114 & 0.34 & 0.34 & & & \\
\hline 78 & 0.20 & 0.20 & 115 & 0.34 & 0.35 & 151 & 0.52 & 0.53 \\
\hline 79 & 0.20 & 0.21 & 116 & 0.35 & 0.35 & 152 & 0.52 & 0.54 \\
\hline 80 & 0.21 & 0.21 & 117 & 0.35 & 0.36 & 153 & 0.53 & 0.54 \\
\hline & & & 118 & 0.36 & 0.36 & 154 & 0.54 & 0.55 \\
\hline 81 & 0.21 & 0.21 & 119 & 0.36 & 0.37 & 155 & 0.54 & 0.55 \\
\hline 82 & 0.21 & 0.22 & 120 & 0.36 & 0.37 & 156 & 0.55 & 0.56 \\
\hline 83 & 0.22 & 0.22 & 120 & 0.00 & 0.08 & 157 & 0.55 & 0.57 \\
\hline 84 & 0.22 & 0.23 & 121 & 0.37 & 0.38 & 158 & 0.56 & 0.57 \\
\hline 85 & 0.23 & 0.23 & 122 & 0.37 & 0.38 & 159 & 0.57 & 0.58 \\
\hline 86 & 0.23 & 0.23 & 123 & 0.38 & 0.38 & 160 & 0.57 & 0.59 \\
\hline
\end{tabular}


TABLE 86-Concluded

\begin{tabular}{|c|c|c|c|c|c|c|c|c|}
\hline \multirow{2}{*}{$\begin{array}{c}\text { BODY } \\
\text { LENGTH }\end{array}$} & \multicolumn{2}{|c|}{ RATIO } & \multirow{2}{*}{$\begin{array}{c}\text { BODY } \\
\text { LENGTH }\end{array}$} & \multicolumn{2}{|c|}{ RATIO } & \multirow{2}{*}{$\begin{array}{c}\text { BODY } \\
\text { LENGTH }\end{array}$} & \multicolumn{2}{|c|}{ RATio } \\
\hline & Male & Female & & Male & Female & & Male & Female \\
\hline 161 & 0.58 & 0.59 & 195 & 0.84 & 0.86 & 228 & 1.20 & 1.24 \\
\hline 162 & 0.59 & 0.60 & 196 & 0.85 & 0.87 & 229 & 1.22 & 1.25 \\
\hline 163 & 0.59 & 0.61 & 197 & 0.86 & 0.88 & 230 & 1.23 & 1.27 \\
\hline 164 & 0.60 & 0.61 & 198 & 0.87 & 0.89 & & & \\
\hline 165 & 0.61 & 0.62 & 199 & 0.88 & 0.90 & 231 & 1.24 & 1.28 \\
\hline 166 & 0.61 & 0.63 & 200 & 0.89 & 0.91 & 232 & 1.26 & 1.29 \\
\hline 167 & 0.62 & 0.63 & & & & 233 & 1.27 & 1.31 \\
\hline 168 & 0.63 & 0.64 & 201 & 0.90 & 0.92 & 234 & 1.29 & 1.32 \\
\hline .. 169 & 0.63 & 0.65 & 202 & 0.91 & 0.93 & 235 & 1.30 & 1.34 \\
\hline 170 & 0.64 & 0.65 & 203 & 0.92 & 0.94 & 236 & 1.32 & 1.35 \\
\hline & & & 204 & 0.93 & 0.95 & 237 & 1.33 & 1.37 \\
\hline 171 & 0.65 & 0.66 & 205 & 0.94 & 0.96 & 238 & 1.34 & 1.38 \\
\hline 172 & 0.65 & 0.67 & 206 & 0.95 & 0.97 & 239 & 1.36 & 1.40 \\
\hline 173 & 0.66 & 0.68 & 207 & 0.96 & 0.98 & 240 & 1.37 & 1.41 \\
\hline 174 & 0.67 & 0.68 & 208 & 0.97 & 0.99 & & & \\
\hline 175 & 0.68 & 0.69 & 209 & 0.98 & 1.00 & 241 & 1.39 & 1.43 \\
\hline 176 & 0.68 & 0.70 & 210 & 0.99 & 1.02 & 242 & 1.41 & 1.45 \\
\hline 177 & 0.69 & 0.71 & & & & 243 & 1.42 & 1.46 \\
\hline 178 & 0.70 & 0.71 & 211 & 1.00 & 1.03 & 244 & 1.44 & 1.48 \\
\hline 179 & 0.71 & 0.72 & 212 & 1.01 & 1.04 & 245 & 1.45 & 1.50 \\
\hline 180 & 0.71 & 0.73 & 213 & 1.02 & 1.05 & 246 & 1.47 & 1.51 \\
\hline 181 & 0.72 & 0.74 & 214 & 1.03 & 1.06 & 247 & 1.49 & 1.53 \\
\hline 182 & 0.73 & 0.75 & 215 & 1.04 & 1.07 & 248 & 1.50 & 1.55 \\
\hline 183 & 0.74 & 0.75 & 216 & 1.06 & 1.08 & 249 & 1.52 & 1.57 \\
\hline 184 & 0.75 & 0.76 & 217 & 1.07 & 1.10 & 250 & 1.54 & 1.58 \\
\hline 185 & 0.75 & 0.77 & 218 & 1.08 & 1.11 & & & \\
\hline 186 & 0.76 & 0.78 & 219 & 1.09 & 1.12 & 251 & 1.55 & 1.60 \\
\hline 187 & 0.77 & 0.79 & 220 & 1.10 & 1.13 & 252 & 1.57 & 1.62 \\
\hline 188 & 0.78 & 0.80 & & & & 253 & 1.59 & 1.64 \\
\hline 189 & 0.79 & 0.81 & 221 & 1.12 & 1.15 & 254 & 1.61 & 1.66 \\
\hline 190 & 0.80 & 0.82 & 222 & 1.13 & 1.16 & 255 & 1.62 & 1.67 \\
\hline & & & 223 & 1.14 & 1.17 & 256 & 1.64 & 1.69 \\
\hline 191 & 0.80 & 0.82 & 224 & 1.15 & 1.18 & 257 & 1.66 & 1.71 \\
\hline 192 & 0.81 & 0.83 & 225 & 1.17 & 1.20 & 258 & 1.68 & 1.73 \\
\hline 193 & 0.82 & 0.84 & 226 & 1.18 & 1.21 & 259 & 1.70 & 1.75 \\
\hline 194 & 0.83 & 0.85 & 227 & 1.19 & 1.23 & 260 & 1.72 & 1.77 \\
\hline
\end{tabular}




\section{CHAPTER 14}

\section{GROWTH IN TERMS OF WATER AND SOLIDS}

1. Percentage of water in blood. 2. Percentage of water in brain and spinal cord.

(1) Percentage of water in the blood. Hatai (MS '15) has determined the percentage of water in the blood of a small series of Norways.

The Norways were recently caught and examined before the day's feeding. The rat was chloroformed, but before the heart ceased beating it was exposed in situ, the tip clipped away and the blood from it caught in a small glass weighing bottle. The fresh weight was immediately taken and after drying at $95^{\circ} \mathrm{C}$. for a week the weight of the residue was obtained. The results are given in table 87 .

TABLE 87

Giving the percentage of water in the blood of the Norway rat, Hatai (MS., '15)

\begin{tabular}{|c|c|c|c|c|c|}
\hline \multirow{2}{*}{$\operatorname{sex}$} & \multirow{2}{*}{$\begin{array}{l}\text { NUMBER OF } \\
\text { CASES }\end{array}$} & \multicolumn{2}{|c|}{ BODYWEIGHT, GRAMS } & \multicolumn{2}{|c|}{ PERCENTAGE OF WATER IN BLOOD } \\
\hline & & Range & Mean & Range & Mean \\
\hline M. & 5 & $114-169$ & 144 & $79.02-82.05$ & 80.34 \\
\hline M.. & 6 & $173-440$ & 243 & $79.92-81.53$ & 80.52 \\
\hline F.. & 4 & $103-190$ & 148 & $79.82-80.35$ & 80.05 \\
\hline F.. & 5 & 199-304 & 271 & $79.52-81.77$ & 80.82 \\
\hline
\end{tabular}

(2) Percentage of water in the brain and spinal cord. Since the percentage of water in the nervous system is most closely linked with age, a precise determination in the case of the Norway rat is wanting, by reason of the difficulty of rearing the Norway in captivity. A few data are however at hand.

From Norways born in captivity from trapped females we obtain the percentages according to age, given in table 88 . It 
TABLE 88.

Showing the percentage of water in the brain and spinal cord of the Norway rat at different ages (sexes combined), (Donaldson and Hatai, '11)

\begin{tabular}{|c|c|c|c|c|}
\hline \multirow{2}{*}{ NUMBER OF CABES } & \multirow{2}{*}{ AGE IN DAYS } & \multirow{2}{*}{ BODY WEIGHT } & \multicolumn{2}{|c|}{ PERCENTAGE OF WATER } \\
\hline & & & Brain & Spinal cord \\
\hline & & grams & & \\
\hline $5 \ldots \ldots \ldots \ldots$ & 1 & 5.1 & 88.2 & 87.0 \\
\hline $3 \ldots \ldots \ldots \ldots$ & 10 & 12.2 & 86.9 & 83.3 \\
\hline $8 \ldots \ldots \ldots$ & 13 & 18.1 & 85.3 & 82.5 \\
\hline $6 \ldots \ldots \ldots$ & 15 & 17.7 & 84.5 & 81.0 \\
\hline $11 \ldots \ldots \ldots \ldots$ & 16 & 26.1 & 82.8 & 79.4 \\
\hline $10 \ldots \ldots \ldots \ldots$ & 19 & 25.5 & 81.5 & 77.8 \\
\hline $7 \ldots \ldots \ldots \ldots$ & 25 & 32.6 & 80.9 & 76.7 \\
\hline $4 \ldots \ldots$ & 40 & 35.8 & 79.2 & 74.3 \\
\hline $5 \ldots \ldots$ & 47 & 38.5 & 79.3 & 74.0 \\
\hline
\end{tabular}

is to be noted that for the most part the rats grew poorly, as shown by the body weights. (Donaldson and Hatai, '11.)

For Norways trapped in Philadelphia and killed shortly after capture, we obtain, according to body weight, sexes combined, the percentage values of water in brain and spinal cord which are given in table 89 .

A comparison of the values for the Norways and Albinos shows that the percentage of water in the Norways tends to run above that in the Albinos-being +0.37 per cent for the brain and + 0.73 per cent for the spinal cord. 
TABLE 89

Giving the percentage of water in the brain and spinal cord of the Norway rat according to body weight (sexes conbined). Based on Donaldson and Hatai, '11, tables 11 and 14

\begin{tabular}{|c|c|c|c|}
\hline \multirow{2}{*}{ BODY WEIGHT IN GRAMS } & \multirow{2}{*}{$\begin{array}{l}\text { NUMBER OF CASES } \\
\text { (SEXES COMBINED) }\end{array}$} & \multicolumn{2}{|c|}{ PERCENTAGE OF WATER (SEXES COMBINED) } \\
\hline & & Brain & Spinal cord \\
\hline $195 \ldots \ldots \ldots \ldots \ldots$ & 7 & 78.4 & 71.3 \\
\hline $205 \ldots \ldots \ldots \ldots \ldots$ & 8 & 78.4 & 71.7 \\
\hline $215 \ldots \ldots \ldots \ldots \ldots \ldots$ & 14 & 78.6 & 71.7 \\
\hline $225 \ldots \ldots \ldots \ldots \ldots \ldots$ & 13 & 78.6 & 70.8 \\
\hline $235 \ldots \ldots \ldots \ldots \ldots \ldots$ & 16 & 78.5 & 71.4 \\
\hline $245 \ldots \ldots \ldots \ldots \ldots \ldots$ & 14 & 78.7 & 71.5 \\
\hline $255 \ldots \ldots \ldots \ldots \ldots \ldots$ & 12 & 78.5 & 71.5 \\
\hline $265 \ldots \ldots \ldots \ldots \ldots \ldots$ & 14 & 78.3 & 70.1 \\
\hline $275 \ldots \ldots \ldots \ldots \ldots \ldots$ & 11 & 78.3 & 70.3 \\
\hline $285 \ldots \ldots \ldots \ldots \ldots \ldots$ & 15 & 78.3 & 70.4 \\
\hline $295 \ldots \ldots \ldots \ldots \ldots$ & 9 & 78.6 & 71.0 \\
\hline $305 \ldots \ldots \ldots \ldots \ldots \ldots$ & 11 & 78.6 & 70.1 \\
\hline $315 \ldots \ldots \ldots \ldots \ldots \ldots$ & 11 & 78.4 & 70.0 \\
\hline $325 \ldots \ldots \ldots \ldots \ldots \ldots$ & 12 & 78.0 & 69.3 \\
\hline $335 \ldots \ldots \ldots \ldots \ldots \ldots$ & 10 & 78.2 & 70.3 \\
\hline $345 \ldots \ldots \ldots \ldots \ldots \ldots$ & 9 & 78.2 & 69.7 \\
\hline $355 \ldots \ldots \ldots \ldots \ldots \ldots$ & 3 & 78.3 & 70.7 \\
\hline $365 \ldots \ldots \ldots \ldots \ldots \ldots$ & 8 & 78.1 & 68.0 \\
\hline $375 \ldots \ldots \ldots \ldots \ldots \ldots$ & 7 & 78.3 & 71.2 \\
\hline $385 \ldots \ldots \ldots \ldots \ldots \ldots$ & 5 & 78.0 & 69.6 \\
\hline $395 \ldots \ldots \ldots \ldots \ldots \ldots$ & 3 & 78.3 & 69.8 \\
\hline $405 \ldots \ldots \ldots \ldots \ldots \ldots$ & 2 & 78.0 & 69.0 \\
\hline $415 \ldots \ldots \ldots \ldots \ldots$ & 5 & 78.4 & 70.2 \\
\hline $425 \ldots \ldots \ldots \ldots \ldots$ & 2 & 78.0 & 69.0 \\
\hline $435 \ldots \ldots \ldots \ldots \ldots \ldots$ & & & \\
\hline $445 \ldots \ldots \ldots \ldots \ldots \ldots$ & 6 & 78.5 & 69.6 \\
\hline $455 \ldots \ldots \ldots \ldots \ldots \ldots$ & 1 & 78.0 & 69.0 \\
\hline $465 \ldots \ldots \ldots \ldots \ldots \ldots$ & 1 & 78.0 & 67.0 \\
\hline
\end{tabular}

Growth in terms of WATER and Solids: References Donaldson and Hatai '11. 


\section{CHAPTER 15}

\section{REFERENCES TO THE LITERATURE}

Introduction. The list of references which follows does not claim to be complete and in several directions is intentionally selective. For example, many bacteriological investigations in which the rat has been used are omitted, as are also a large number of descriptive papers belonging to the earlier zoölogical literature. To this list of omissions belong about a dozen titles which do not appear to be accessible in any of the larger libraries of the United States; the printing of such titles was therefore regarded as superfluous.

On the other hand, it has been my intention to include the titles of all the papers which record anatomical investigations and physiological studies, so far as these were generally available.

At the outset of such a plan one meets with the difficulty that the rat has been used in many cases where the fact is not stated in the title of the paper, and moreover in other instances it is only one of several animals which have been examined or tested.

In the selection of the titles of this class the plan has been to include everything which gave information-no matter how restricted-that applied to the rat. Of course it is inevitable under these circumstances that some papers should have been overlooked.

In accordance with the general plan of the book we have included papers not only on the wild Norway and the domesticated Albino, but also on both forms of the house rat, Mus rattus rattus and Mus rattus alexandrinus.

The specific names and designations as given by the authors are quoted without comment but can be revised by reference to the foregoing section on nomenclature. Now and then I have permitted myself an annotation when this was pertinent. 
Thus far the statements apply to the literature which follows and which is arranged alphabetically by authors' names and under authors by date.

It was desirable at the same time to get some sort of a subject classification, and this has been done in the following manner.

At the end of each chapter, references to the literature bearing on the subject of the chapter are given by author's name and date. The full reference appears in the list of the end of the volume. The chapter lists contain not only the citations in the text, but also other references which have not been cited there. The presentation is not uniform but dictated by the arrangement of the chapter. Where possible the references are given in alphabetical order without subdivisions, but where it will be of advantage to have the references grouped according to the sub-headings, this is done, although under this plan the same reference often appears under more than one sub-heading.

\section{REFERENCES TO THE LITERATURE}

AddendA : PP. 265-266

Ackroyd, H. 1914, 1915 On the purine metabolism of rats. Biochem. J., vol. 8, pp. 434-437.

Adams, Henry F. 1913 A set of blind white rats which could not learn the maze. J. Animal Behavior, vol. 3, pp. 300-302.

Addison, W. H. F. 1911 The development of the Purkinje cells and of the cortical layers in the cerebellum of the albino rat. J. Comp. Neurol., . vol. 21 , pp. 459-481.

Addison, W. H. F. And Appleton, J. L. 1915 The structure and growth of the incisor teeth of the albino rat. J. of Morphol., vol. 26, pp. 43-96.

Adloff, PaUL 1898 Zur Entwickelungsgeschichte des Nagetiergebisses. Inaug.-Diss. Universität Rostock, Gustav Fischer, Jena. Figs. 77-81 inclusive.

Advisory Committee see (Reports on Plague Investigations)

Advisory Cоммiтtes 1912 Observations on the breeding of Mus rattus in. captivity. J. Hyg., Plague Suppl. 1, pp. 193-206.

1912 a The immunity of the wild rat in India. J. Hyg., Plague Suppl. II, 7th Report on Plague Investigations in India, pp. 229-265.

1912 b Experimental plague epidemics among rats. J. Hyg., Plague Suppl. II, 7th Report on Plague Invest. in India, pp. 292-299.

Ahrend 1903 Beitrag zur Geschichte des sog. "Rattenkönigs." Natur. u. Haus., vol. 11, pp. 371-373.

Akamatsu, Kunitaro 1905 On the brown rat. Zool. Mag. (In Japanese) Tokio, vol. 17, no. 203. 
Alaertus, Magnus 1206-1280 B. Alberti Magni, Opera Omnia, edited by August Borgnet-38 vols., 1890-1899, Paris. See vol.12,1891, p. 420. Mus "quod nos ratum vocamus," in Lib. xxii De Animalibus, Tract II, n. 78.

ALDRICH, T. B. 1912 On feeding young white rats the posterior and the anterior parts of the pituitary gland. Am. J. Physiol., vol. 31, pp. 94-101.

Allen, Ezra 1912 The cessation of mitosis in the central nervous system of the albino rat. J. Comp. Neurol., vol. 22, pp. 547-568.

Alston, Edward R. 1879-1882 Biologia Centrali Americana. Mammals, p. 141.

Apolant, Hugo 1896 Ueber die sympathischen Ganglienzellen der Nager. Arch. f. mikr. Anat., vol. 47, pp. 461-471, p. 466, rats mentionedmostly rabbits.

Arnstein, C. 1877 Zur Kenntnis der quergestreiften Muskulatur in den Lungenvenen. Med. Centralbl., 15 Jahrg., pp. 692-694. Extended to veins of small caliber in the rat.

Aron, Hans 1912 Weitere Untersuchungen über die Beeinflussung des Wachstums durch die Ernährung. Verhandl. der 29th Versamml. der Gesellsch. f. Kinderheilk. in der Abt. für Kinderheilkunde der 84 Versamml. der Gesellsch. deut. Naturforcher und Aerzte in Münster. Bergmann. Wiesbaden.

Aron, Hans 1913 Biochemie des Wachstums des Menschen und der höheren Tiere: (In Oppenheimer, Carl, Handbuch der Biochemie des Menschen und der Tiere-Engänzungsband, pp. 610-674. Fischer, Jena.)

Asar, K. 1908 Die Blutgefässe des häutigen Labyrinthes der Ratte. Beiträge zur vergleichenden Anatomie des inneren Ohres. Anat. Hefte, vol. 36, pp. 711-728.

Ascher, L. 1910 Beitrag zur Kenntnis der Rattenkrätze. Arch. f. Dermat. u. Syph., Wien u. Leipz., vol. 101, pp. 211-220. 2 pl.

Asfier, Leon ANd Erdely, A. 1903 Ueber die Beziehung zwischen Bau und Function des lymphatischen Apparates des Darmes. Centralbl. f. Physiol., vol. 16, pp. 705-709.

Asher, Leon 1908 Des Verhalten des Darmepithels bei verschiedenen funktionellen Zuständen. Ztschr. f. Biol., vol. 51, pp. 115-126.

Askanazy, M. 1908 Die Teratome nach ihrem Bau, ihrem Verlauf, ihrer Genese und im Vergleich zum experimentellen Teratoid. Verh. deutsch. path. Ges., vol. 11, pp. 39-82.

Asp, Georg A. 1873 Bidrag till spottkörtlarnes mikroskopiska anatomi. pp. 128, 1 pl. J. C. Frenckell \& Son, Helsingfors.

1873 a Om nervernas ändingsätt i spottkörtlana. (Ueber die Endigungsweise der Nerven in den Speicheldrüsen.) Nord. med. Ark., vol. 5, no. 5, pp. 1-9.

Astaschewsky, P. 1877 Ueber die diastatische Wirkung des Speichels bei verschiedenen Tieren. Centralbl. f. d. med. Wiss., pp. 531-534. p. 533, saliva of rat remarkably active.

Admann 1912 Vergleichende Untersuchungen über die Wirksamkeit bakterieller und chemischer Rattenvertilgungsmittel. Centralbl. f. Bakteriol., 1 Abt., vol. 63, pp. 212-221. 
Aunett, H. E. 1908 Virus for the destruction of rats and mice. Brit. M. J., Lond., vol. 2, p. 1524.

BACOT, A. 1914 A study of the bionomics of the common rat fleas and other species associated with human habitations, with special reference to the influence of temperature and humidity at various periods of the life history of the insect. J. Hyg., Plague Suppl. III, pp. 447-654.

Bacot, A. W. And Martin, C. J. 1914 Observations on the mechanism of the transmission of plague by fleas. J. Hyg., Plague Suppl. III, 8th Report on Plague Invest. in India, pp. 423-440.

BAHr, L. 1906 Ueber das Vorkommen von Trichinen bei der Ratte. Zeitschr. Infektionskr. parasit. Krankh. Hyg. Haustiere, vol. 2, pp. 62-65.

1909 Die Resultate der Versuche zur rationellen Rattenvertilgung vermittelst Präparate des Laboratoriums. Centralbl. f. Bakteriol., 1 Abt. vol. 52, pp. 441-455.

1909 a The rational extirpation of rats by means of ratin preparations. Hälsovännen, Stockholm, vol. 24, pp. 329-333.

1910 Zur rationellen Vertilgung von Ratten mit Hilfe von Präparaten des Laboratoriums unter besonderer Berücksichtigung des Ratinsystems. Ztschr. f. Fleisch. u. Milchhyg., Berl., vol. 20, pp. 389-393.

BaINBridge, F. A. 1909 On the bacterial nature and efficiency of certain rat viruses. J. Path. and Bacteriol., vol. 13, pp. 457-466.

BANCRoft, T. L. 1894 On the whip-worm of the rat's liver. J. and Proc. Roy. Soc. N. South Wales, 1893, Sydney, 1894, xxvii, 86-90, 2 pl.

Bannerman, W. B. 1906 The spread of plague in India. J. Hyg., vol. 6, pp. 179-211.

Bardeleben, Karl von 1899 Handbuch der Anatomie, vol. 4, Centralnervensystem, I Teil, von Prof. Dr. Th. Ziehen., p. 12. Spinal cord weight; rat (Ranke).

Barnabo, VALEntino 1913 Ulteriori richerce sperimentali sulla secrezione interna testicolare. Policlin., vol. 20, pp. 165-192.

Barrett-Hamilton, G. E. H. 1892 Mus alexandrinus in Ireland. The Zoölogist, vol. 16, p. 75 .

BartenefF, L. 1891 On the distribution of the nerves in the plexus of the small intestine. Inaug.-Diss. 32 pp. 1 pl. (in Russian).

Basch, S. von 1870 Die ersten Chyluswege und die Fettresorption. Sitz. d. k. Akad. d. Wiss. math.-naturw. Cl. Wien, vol. 62, Abt. 2, pp. 617-634. $1 \mathrm{pl}$.

Bashford, E. T. ANd Murray, J. A., ETC. 1900 General results of propagation of malignant new growths. The Imp. Cancer Research Fund, 3rd Scien. Report, pp. 262-283.

BASLer, A. 1909 Beiträge zur Kenntnis der Bewegungsvorgänge des Blinddarminhaltes. Arch. f. d. ges. Physiol., vol. 128, pp. 251-276, 9 text figures.

BAsset, Gardner C. 1914 Habit formation in a strain of albino rats of less than normal brain weight. Behavior monographs, vol 2, no. 4, serial number 9 .

Bate, Dorothea M. A. 1912 On a new species of mouse and other rodent remains from Crete. Geol. Mag. Déc., V. vol. ix, no. 571, pp. 4-6. Epimys (Mus) rattus from the pleistocene cave deposits of Crete. 
Bateson, W. 1903 The present state of knowledge of color heredity in mice and rats. Proc. Zoöl. Soc., London, vol. 2, p. 71.

Baumgart, Martin 1904 Vergleichende Untersuchungen über Mus rattus und Mus decumanus und über die Ursachen der Verdrängung der Hausratte durch die Wanderratte. Inaug.-Diss. Philos. Fak. Zürich.

BAyoN, H. 1911 Demonstration of specimens relating to the culture of the leprosy bacillus. Brit. M. J. part 2, pp. 1269-1272.

1912 Demonstration of acid-fast germs cultivated from cases of leprosy. Tr. Soc. Trop. M. and Hyg., vol. 5, pp. 103-105. Authors mentioned in text; no tables-rats.

1912 a The experimental transmission of the spirochaete of European relapsing fever to rats and mice. Parasitology (Suppl. to the J. Hyg.) vol. 5, pp. 135-149 3 figs.; experiments on white rats, pp. 142145; results summarized, not tabulated.

$1912 \mathrm{~b}$ The culture and identification of the germ of leprosy and the relationship of the human disease to rat leprosy. Tr. Soc. Trop.M. and Hyg., vol. 5, pp. 158-167.

$1912 \mathrm{c}$ On the transmission of leprosy to animals by direct inoculation. Brit. M. J., part 1, pp. 424-426.

Bechstein, J. M. 1801 Gemeinnützige Naturgeschichte Deutschlands nach allen drey Reichen. Zweite Ausgabe, vol 1, Säugethiere, pp. 931-952. Leipzig.

Bechterew, W. von 1890 Ueber die verschiedenen Lagen und Dimensionen der Pyramidenbahnen beim Menschen und den Thieren und über das Vorkommen von Fasern in denselben welche sich durch eine frühere Entwickelung auszeichnen. Neurol. Centralbl., pp. 738-741.

Beck, Wilhelm 1896 Utber den Austritt des N. Hypoglossus und N. Cervicalis Primus aus dem Centralorgan beim Menschen und in der Reihe der Säugetiere unter besonderer Berücksichtigung der dorsalen Wurzeln. Anat Hefte, vol. 6, pp. 251-344. Mus rattus, p. 312.

BeIllNG, Karl 1906 Beiträge zur makroskopischen und mikroskopischen Anatomie der Vagina und des Uterus der Säugetiere. Archiv. f. mikr. Anat., vol. 67, pp. 573-637. Mus decumanus, p. 588.

BELL, E. T. 1911 The interstitial granules of striated muscle and their relation to nutrition. Internat. Monat. f. Anat. u. Physiol., vol. 28, pp. 297347.

Bell, Thomas 1837-1874 British quadrupeds including the cetacea. John van Voorst, London; 2nd ed., pp. 310-320. Both rattus and decumanus: excellent pictures of each.

Bellonci, G. 1885 Del fuso direzionale e della formazione di un globulo polare nell'ovulo ovarico di alcuni mammiferi. Atti della R. Accad. dei Lincei, Ser 4. Rendiconti, pp. 285-286.

Belloy, G. 1899 Recherches sur l'origine des corps jaunes de l'ovaire chez le rat et le cochon d'Inde. Compt. rend. de l'Asś. d. Anat. Première session, Paris, pp. 47-52.

Benda, Carl 1887 Untersuchungen über den Bau des funktionirenden Samenkanälchens einiger Säugethiere und Folgerungen für die Spermatogenese dieser Wirbelthierklasse. Archiv f. mikr. Anat., vol. 30, pp. 49110. Rat, pp. 58 and 66. 
Benedicenti, A. 1892 Recherches sur les terminaisons nerveuses dans la muqueuse de la trachée. Résumé de l'Auteur. Arch. ital. de biol., vol. 17 , pp. $46-48$.

Bennett, Charles B. 1914 The cholesterol content of cancers in rats. J. Biol.. Chem., vol. 17. pp. 13-14.

Beretta, Artur 1913 La normala dentatura dei Roditori in rapporto alle anomalie dentali in questi osservate. Stomatol., vol. 10, no. 2 and 3.

Bergmann, A. M. 1908 Two methods for the extermination of rats, by the culture of Danysz' rat bacillus and ratin. Svensk Veterinärtidskr., Stockholm, vol. 13, pp. 377-387.

Berkley, H. J. 1893 The intrinsic pulmonary nerves by the silver method. J. Comp. Neur., vol. 3, pp. 10̣7-111, 1 pl. Mus decumanus.

1895 The intrinsic pulmonary nerves in mammalia. Johns Hopkins Hosp. Rep. (Baltimore), vol. 4, pp. 72-78 (240-246), 1 pl.

Berry, C. S. 1906 The imitative tendency of white rats. J. Comp. Neur. and Psychol., vol. 16, pp. 333-361.

Bert, Paul 1878 La pression barométrique; rescherches de physiologie expérimentale. G. Masson, Paris. Some observations on rats.

Bibra, Ernst von 1854 Vergleichende Untersuchungen über das Gehirn des Menschen und der Wirbelthiere. Basssermann and Mathy, Mannheim. Hausratte-Mus rattus, p. 22.

Biedl, Artur 1913 Innere Sekretion. 2 vols. Urban and Schwarzenberg, Berlin.

Bignotri, G. 1900 Sul tarso del Mus decumanus. Monit. zoöl. ital., vol. 11, suppl. pp. 17-19.

Bircher, Eugen 1911 Die kretinische Degeneration (Kropf, endemischer Kretinismus und Taubstummheit) in ihrer Beziehung zu anderen Wissensgebieten. Fortschr. d. Naturwissen. Forschung, vol. 2, pp. 273338 , p. 289 , figures of the normal and abnormal thyroid of the rat. All references by name only.

1911 a Weitere Beiträge zur experimentellen Erzeugung des Kropfes. Die Kropfätiologie ein colloid-chemisches Problem. Ztschr. f. exper. Path. u. Therap., vol. 9.

Bischoff, T. L. W. 1832 Nervii accessorii Willisii anatomia et physiologia. 104 pp., 6 pl. $4^{\circ}$. Heidelbergae, typ. Reichardianis.

Blanc, Louis 1892 Sur un ovule à deux noyaux observé dans l'ovaire de Mus decumanus. Ann. de la société Linneenne de Lyon Nouv. Sér., vol. 39 , pp. $73-80$.

Blasius, J. H. 1857 Fauna der Wirbelthiere Deutschlands und der angrenzenden Länder von Mitteleuropa. Vol. 1, Säugethiere. Braunschweig. Viehweg. Descriptions of the several species of rats.

Blue, RUPERT 1908 The underlying principles of anti-plague measures. Calif. State J. Med., vol. 6, pp. 271-277.

1910 Rodents in relation to the transmission of bubonic plague. Found in "The rat and its relation to the public health," pp. 145-152. Treasury Dept. Pub. Health and Mar. Hosp. Service of U. S. Government Printing Office, Wash., D. C.

Boelter, W. R. 1909 The rat problem. John Bale, Sons and Danielsson, London, pp. 165 . 
Bogardus, E. S. and Henke, F. G. 1911 Experiments on tactual sensations in the white rat. J. Animal Behavior, vol. 1, pp. 125-137.

BонLen, F. 1894 Ueber die elektromotorischen Wirkungen der Magenschleimhaut. Arch. f. d. ges. Physiol., vol. 57, pp. 97-122.

BorNet, Ed. 1895 Résistance à la fatigue de 11 rats décapsulés depuis cinq et six mois. Compt. rend. Soc. de biol., Paris, vol. 47, pp. 273-274.

1895 a Ablation des capsules vraies et accessoires chez le rat d'égout. Compt. Rend. Soc. de Biol., vol. 47, pp. 498-500.

1897 Diminution de résistance des rats doublement décapsulés à l'action toxique de diverses substances. C. R. Soc. de Biol., p. 466.

1897 a Dix nouveaux cas de maladie d'Addison expérimentale chez le rat d'égout. C. R. Soc. de Biol., 8th and 15th of May, pp. 439 and 473.

Borcherding, Fr. 1889 Utber das Vorkommen dér Hausratte, Mus rattus L., im nordwestlichen Deutschland. Zoölog. Garten, 30 Jahrg., pp. 9293.

Borgnet, August See Albertus Magnus.

Boughton, T. H. 1906 The increase in the number and size of the medullated fibers in the oculomotor nerve of the white rat and of the cat at different ages. J. comp. Neur. and Psychol., vol. 16, pp. 153-165.

Boycott, A. E. ANd Damant, G. C. C. 1908 Experiments on the influence of fatness on susceptibility to caisson disease. J. Hyg. Cambr., vol. 8, pp. 445-456. Pp. 447-450, tables and notes on experiments with rats giving sex, body weight and fatty acids.

1908 a A note on the total fat of rats, guinea-pigs and mice. J. Physiol., vol. 37, pp. 25-26.

Boycott, A. E., Damant, G. C. C. And Haldane, J. S. 1908 The prevention of compressed air illness. J. Hyg. Cambr., vol. 8, pp. 342-443.

Bradley, O. Charnock 1903 On the development and homology of the mammalian cerebellar fissures. J. Anat. and Physiol., vol. 37, pp. 112-130. Cerebellum: Mus decumanus figs. 38, 39, 40 and 41.

BraUn, M. 1882 Entwicklungsvorgänge am Schwanzende bei einigenSäugethieren mit Berücksichtigung beim Menschen. Arch. f. Anat. u. Physiol., Anat. Abt., pp. 207-241. Taf. XII, XIII. Rat among animals used.

Brinckerhoff, Walter R. 1910 Rat leprosy. Found in "The rat and its relation to the public health." Pp. 49-53. Treasury Dept. Pub. Health and Mar. Hospt. Service of the U. S. Government Printing Office, Wash., D. C.

Brisson, A. D. 1756 Le régne animal divisé en IX classes, etc. $4^{\circ}$ Paris. P. 168, description of Mus rattus-many references.

Brown, Herbert H. 1885 On spermatogenesis in the rat. Quart. J. Micr. Sc., London, vol. 25, pp. 343-369.

Brown-SEquard, E. 1856 Recherches expérimentales sur la physiologie et la pathologie des capsules surrénales. Arch. gén. de méd. vol. 2 (ser. 5, vol. 8) pp. 385-401; 572-598 (Oct. and Nov). Experiments chiefly on rabbits; but mentions another physiologist's observations on rats, p. 595. 
BrüMmer, ЈонANNES 1876 Anatomische und histologische Untersuchungen über den zusammengesetzten Magen verschiedener Saugethiere. Tafeln I-V. Deutsche Ztschr. f. Thiermed., vol. 2, pp. 158-298 and 299-319.

Bruneau 1886 Un tuyau à gaz en plomb coupé par les rats. Ann. d'hyg., Par., 3s., xv, 530.

Brüning, Hermans 1914 Experimentelle Studien über die Entwicklung neugeborener Tiere bei langerdauernder Trennung von der Säugenden Mutter und nachheriger verschiedenartiger künstlicher Ernährung (Rats). Jahrb.f. Kinderheilk., vol. 80, pp. 65-85. 6 fig. in text (tables and graphs important).

1914 a Untersuchungen über das Wachstum von Tieren jenseits der Säuglingsperiode bei verschiedenartiger künstlicher Ernährung (Rat). Jahrb. Kinderheilk., vol. 79, pp. 305-319. 2 text figs., tables (important).

BrunN, A. von 1880 Notiz über unvollkommene Schmelzentwicklung auf den Mahlzähnen der Ratte-M. decumanus. Arch. f. mikr. Anat., vol. 17, pp. 241-242.

1887 Ueber die Ausdehnung des Schmelzorganes und seine Bedeutung für die Zahnbildung Arch. f. mikr. Anat., vol. 29, pp. 367-383.

Buchanan, A. 1910 The destruction of rats. Brit. M. J., Lond., vol. 2, p. 1388.

Buckland, Francis T. 1859 Curiosities of natural history. Rudd and Carleton, N. Y. Rats, pp. 87-205.

Buffon, George Louis le Clerc, Comte de 1749-1789 Histoire naturelle, générale et particuliére. Paris, vol. 7, 1758, pp. 278-308; vol. 8, 1760, pp. 206-218.

Bujard, Eug. 1905 Sur les villosités intestinales. Bibl. anat., vol. 14, p. 236. 1909 Etude des types appendiciels de la muqueuse intestinale, en rapport avec les régimes alimentaires. Morphologie comparée. Sitiomorphoses naturelles et expérimentales. Internat. Monatschr. f. Anat. u. Physiol., vol. 26, pp. 101-192. Plates VI-X, Rats, pp. 123124.

Bulle, Hermans 1887 Beiträge zur Anatomie des Ohres. Archiv f. mikr. Anat., vol. 29. pp. 237-264. Rat, p. 245.

Bullock, F. D. ANd Rohdenburg, G. L. 1913 Primary sarcoma of the liver of the rat originating in the wall of a parasitic cyst. J. Med. Research, vol. 28 (n. s. vol. 23 ) pp. $477-481$.

1915 Tumor-like growths in the rat stomach following irritation. Proc. of the Soc. for Exper. Biol. and Med., vol. 12, pp. 161-162.

Bullock, W. E 1913 Contributions to the biochemistry of growth. On the lipoids of transplantable tumors of the mouse and the rat. Proc. $R$. Soc., London, vol. 87 B, pp. 236-239.

Cabibbe, Giacomo 1904 Histologische Untersuchungen über die Nervenendigungen in den Sehnen und im Perimysium der Ratte und des Meerschweinchens. Monatschr. f. Psychiat. u. Neurol., vol. 15, pp. 81-89. 3 figs.

CaJal, S. Ramon 1889 Neuvas aplicaziones de metodo de colaración de Golgi. Gac. med. Catal., vol. 12, pp. 6-8. 
Cajal, S. Ramon 1893 Sur les ganglions et plexus nerveux de l'intestin. Compt. rend. soc. de biol., ser. 9, vol. 5, pp. 217-223, Paris. 3 figs. 1897 Leyes de la morfologia y dinamismo de las células nerviosas. Rev. trimestr. Microgr., vol. 2, pp. 1-28.

1903 Un sencillo método de coloración del reticulo protoplasmico y sus efectos en los diversos centros nerviosos de vertebrados é invertebrados. Rev. trimestr Microgr., vol. 7, pp. 129-221, fig. 33.

1909, 1911 Histologie du système nerveux de l'homme et des vertébrés. 2 vols. A. Maloine. Paris For rat (vol. 1) figs. 19, 113, 123, 189, 190; (vol. 2) figs. 20, 21, 46, 246.

Calef, A. 1900 Studio istologico e morfologico di un'appendice epiteliale del pelo nella pelle del Mus decumanus var. albino e del Sus scrofa. Anat. Anz., vol. 17, pp. 509-517.

Calmette, A. 1910 La lutte internationale contre les rats. L'Hygiène, Par., no. $9,5-7$. .

1911 La lutte internationale contre les rats. J. de méd. de Par., 2s. vol. 23 , pp. $588-591$.

Campana, Roberto 1911 I bacilli acidi nei topi in Mancuiria; ed altri studi. Clin. dermosifilopat d. r. Univ. di Roma, vol. 29, pp. 47-50.

Campbell, J. MACNaught 1892 On the appearance of the brown rat (Mus decumanus Pallas) on Ailsa Craig. Ann. of Scott. Nat. Hist. I. no. 2, pp. 132-134.

Cannied, André 1893 Récherches sur le nerf auditif, ses rameaux et ses ganglions. Revue biol. du Nord de la France, Année VI, pp.87-153. Rat among animals used.

Carmichael, E. S. and Marshall, F. H. A. 1907 The correlation of the ovarian and uterine functions. Proc. Roy. Soc. S. B. vol.79, pp.387-394. Rats -4 experiments.

Carpenter, F. W. and Coned, J. L. 1914 A study of ganglion cells in the sympathetic nervous system, with special reference to intrinsic sensory neurones. J. Comp. Neur., vol. 24, pp. 269-281.

Carr, Harvey and Watson, J. B. 1908 Orientation in the white rat. J. Comp. Neur. and Psychol., vol. 18, pp. 27-44.

Castle, W. E. 1911 Heredity. Chapter 6. D. Appleton \& Co., N. Y.

1912 Some biological principles of animal breeding. Am. Breeders Mag., vol. 3, pp. 270-282.

1912 a The inconstancy of unit characters. Am. Naturalist, vol. 46, pp. 352-362.

Castle, W. E. And Phillips, J. C. 1914 Piebald rats and selection. An experimental test of the effectiveness of selection and of the theory of gametic purity in Mendelian crosses. Carnegie Inst. Wash., no. 195.

Castle, W. E. 1914 Some new varieties of rats and guinea pigs and their relation to problems of color inheritance. Am, Naturalist, vol. 48, pp. 65-73.

1914 a Yellow varieties of rats. Am. Naturalist, vol. 48, p. 254.

Cavazzani, E. And Muzzioli, M. 1912 Contribution à l'étude de l'eau dans les organismes. Arch. ital. Biol., vol. 57, pp. 473-480. 
Cesana, G. 1910 Lo sviluppo ontogenico degli atti riflesi (Rat) Arch. di Fisiol., vol. 9, pp. 1-120, 43 figs.-full tables.

Chapin, C. W. 1912 An acid-fast organism resembling the bacillus of human leprosy cultivated from the tissues of a leprous rat. Pub. health rep. U. S. Mar. Hosp. Serv., vol. 27, part 1, p. 161.

Chick, Harriette and Martin, C. J. 1911 The fleas common on rats in different parts of the world and the readiness with which they bite man. J. Hyg., vol. 11, pp. 122-136.

Chidester, F. E. 1912 Experiments with desiccated thyroid, thymus and suprarenals. Science, vol. 36 , no. 932 , November 8 th.

Chievirz, J. H. 1885 Beiträge zur Entwicklungsgeschichte der Speicheldrüsen. Arch. f. Anat. u. Entwcklngsgesch., pp. 401-436, 1 pl.

Chisolm, R. A. 1911 On the size and growth of the blood in tame rats. Quart. J. Exper. Physiol., vol. 4, pp. 207-229.

Clarke, W. E. 1891 Black and Alexandrine rats at Leith (M. rattus and alexandrinus) Ann. of Scott. Nat. Hist., vol. 3, p. 36.

Cos, W. R. 1908 The maturation of the egg of the rat. Science, vol.27, no. 690, March 20th, p. 444.

Congdon, E. D. 1912 The surroundings of the germ plasm. III. The internal temperature of warm-blooded animals (Mus decumanus, M. musculus, Myoxus glis) in artificial climates. Archiv f. Entwcklngsmechn. d. Organ., vol. 33, pp. 703-715.

Converse, G. M. 1910 Rat suppression in San Francisco, California. Pub. Health Rep., U. S. Mar. Hosp. Serv. Wash., vol. 25, pp. 1003-1005.

Сook, C. 1886 Poisoning from a rat bite. Indiana M. J., vol. 9, p. 77.

Соoк, F. C. 1913 The importance of food accessories as shown by rat-feeding experiments. Science, p. 675. November 7.

Cornalia, Emile 1858-1871 Mammifères fossiles de Lombardie, Milan-being 2nd Series in Paléonotologie Lombarde par l'Abbie Antoine Stoppani. $4^{\circ}$. pp. 38-40. Mus rattus.

Cornish, Tном. 1890 Black rat in Cornwall. Zoölogist, vol. 13, p. 450.

Cramer, W. 1908 The gaseous metabolism in rats inoculated with malignant new growths. Third Scien. Report Imp. Cancer Research Fund, pp. 427433.

Cramer, W. and Pringle, Harold 1910 Contributions to the biochemistry of growth. The total nitrogen metabolism of rats bearing malignant new growths. Proc. R. Soc., London, vol. 82 B, pp. 307-315.

Crampe, Hugo 1877 Kreuzungen zwischen Wanderatten verschiedener Farbe. Landwirths. Jahrb., vol. 6, p. 384.

1883 Zucht-Versuche mit zahmen Wanderratten. I. Resultate der Zucht in Verwandtschaft. Landwirths. Jahrb., vol. 12.

1884 Zucht-Versuche mit zahmen Wanderratten. II. Resultate der Kreuzung der zahmen Ratten mit wilden. Landwirths. Jahrb., vol. 13.

Creel, Richard H. 1910 Rat proofing as an antiplague measure. Found in "The rat and its relation to the public health," pp. 171-178. Treasury Dept. Pub. Health and Mar. Hosp. Service of the U. S. Government Printing Office, Wash., D. C. 
Cristiani, H. 1892 L'inversion des feuillets blastodermiques chez le rat albinos. Arch. de Phys. norm. et pathol., vol. 24 (S. 5, T. 4).

1893 De la thyroïdectomie chez le rat pour servir à la physiologie de la glande thyroïde. Arch. de physiol. norm. et path., 5th series, vol. 5 , pp. 39-46.

1893 a Remarques sur l'anatomie et la physiologie des glandes et glandules thyroïdiennes chez le rat. Arch. de physiol. norm. et path., 5th series, vol. 5, pp. 164-168.

$1893 \mathrm{~b}$ Des glandules thyroidiennes accessoires chez la souris e le campagnol. Arch. de physiol. norm. et path., 5th series, vol. 5, pp. 279-283.

1895 De la greffe thyroïdienne in général et de son évolution histologique en particulier. Arch. de physiol. norm. et path., 5th series, vol. 7 (vol. 27), pp. 65-76.

1900 Développement des greffes thyroïdienne; analogie avec le développement embryonnaire du corps thyroïde et avec la formation du goitre hyperplasique. Compt. rend. Soc. de Biol., Paris, vol. 52, pp. $967-969$.

Cristiani, H. And Cristiani, A. 1902 Recherches sur les capsules surrénales (Planche I.) J. de physiol. et de path. gen., vol. 4, pp. 837-844.

1902 a De la greffe des capsules surrénales (Planche II). J. de physiol., vol. 4, pp. 982-997.

1902 b Rôle prépondérant de la substance médullaire des capsules surrénales dans la fonction de ces glandes. Compt. rend. Soc. de Biol., vol. 54, pp. 710-711.

1902 c Histologie pathologique des greffes de capsules surrénales. Compt. rend. Soc. de Biol., vol. 54, pp. 811-814.

1902 d De l'insuffisance fonctionelle des greffes de capsules surrénales. Compt. rend. Soc. de Biol., vol. 54, pp. 1124-1126.

Сбелот, L. 1899 Sur la determination du sexe chez les animaux. Bull. sci. de la France et de la Belgique, vol. 32.

Currie, Donald H. 1910 Bacterial diseases of the rat other than plague. Found in "The rat and its relation to the public health," pp. 55-57. Treasury Dept. Pub. Health and Mar. Hosp. Service of the U. S. Government Printing Office, Wash., D. C.

Custor, J. 1873 Ueber die relative Grösse des Darmcanals und der hauptsächlichsten Körpersysteme beim Menschen und bei Wirbelthieren. Diss. Berlin.

Cuvier, G. 1805 Lécons d'Anatomie comparée. Paris. T. iii, p. 383. In the rat family the stomach presents two divisions.

Czermak, Nicolay 1895 Ernährungswege einer epithelialen Zelle. Anat. Anz., vol. 11 , pp. 547-550, $1 \mathrm{Abb}$.

Czerny, Adalbert 1890 Ueber Rückbildungsvorgänge an der Leber. Archiv f. mikr. Anat., vol. 35, pp. 87-103. Rat, p. 88 and 101.

Darwin, Charles 1883 Animals and plants under domestication. Vol. 2, p. 65. Varieties of cross-bred rats.

Dean, George 1903 A disease of the rat caused by an acid-fast bacillus. Centralbl. f. Bakteriol. u. Parasitenk., vol. 34, part 1, pp. 222-224. 
Dean, George 1905 Further observations on a leprosy-like disease of the rat. J. Hyg., vol. 5, pp. 99-112.

Dehne, A. 1855 Mus decumanus, Pallas: Die Wanderratte u. ihre Varietäten. Allg. deutsche Naturhist. Zeit. n. f., vol. 1, pp. 169-174.

Demaison, L. 1906 Sur les rois de rats. Feuille jeun. Natural (4) Ann. 37, p. 38.

Demjanenko, K. 1909 Das Verhalten des Darmepithels bei verschiedenen funktionellen Zuständen. Ztschr. f. Biol., vol. 52, pp. 153-188. (Zweite Mitt. nebst Bemerkung von Leon Asher.)

Drmock, James F. See Giraldus Cambrensis.

Disselhorst, Rudolf 1897 Die accessorischen Geschlechtsdrüsen der Wirbeltiere. Eine vergleichend-anatomische Untersuchung. Arch. f. wissensch. u. prakt. Thierh., vol. 23.

1897 a Die accessorischen Geschlechtsdrüsen der Wirbeltiere, mit besonderer Berücksichtigung des Menschen. viii, pp. 279, 16 pl. $8^{\circ}$. J. F. Bergmann, Wiesbaden.

1904 Ausführapparat und Anhangsdrüsen der Männlichen Geschlechtsorgane. In Oppel, A, "Lehrbuch der Vergleichenden Mikroskopischen Anatomie der Wirbeltiere." Vierter Teil. Gustav Fischer. Jena. Rodentia-Mus decumanus, pp. 263-282.

Dollfus, Adrien 1906 Les rois de rats. Feuille jeun. Natural (4) Ann. 36, pp. 174-175, 185-188.

Donaldson, H. H. 1900 The functional significance of the size and shape of the neurone. J. Nerv. and Ment. Dis., vol. 27, no. 10.

Donaldson, H. H. ANd Hoke, G. W. 1905 On the areas of the axis cylinder and medullary sheath as seen in cross sections of the spinal nerves of vertebrates. J. Comp. Neur. and Psychol., vol. 15, pp. 1-16.

Donaldson, H. H. 1906 A comparison of the white rat with man in respect to the growth of the entire body. Boas Anniversary Volume, pp. 5-26. G. E. Stechert \& Co., N. Y.

1908 A comparison of the albino rat with man in respect to the growth of the brain and of the spinal cord. J. Comp. Neur. and Psychol., vol. 18, pp. 345-392.

1909 On the relation of the body length to the body weight and to the weight of the brain and of the spinal cord in the albino rat (Mus norvegicus var. albus). J. Comp. Neur. and Psychol., vol. 19, pp. 155-167. 1910 On the percentage of water in the brain and in the spinal cord of the albino rat. J. Comp. Neur. and Psychol., vol. 20, pp. 119-144.

1911 On the influence of exercise on the weight of the central nervous system of the albino rat. J. Comp. Neur., vol. 21, pp. 129-137.

1911 a The effect of underfeeding on the percentage of water, on the ether-alcohol extract, and on medullation in the central nervous system of the albino rat. J. Comp. Neur., vol. 21, pp. 139-145.

$1911 \mathrm{~b}$ An interpretation of some differences in the percentage of water found in the central nervous system of the albino rat and due to conditions other than age. J. Comp. Neur., vol. 21, pp. 161-176.

1911 c Studies on the growth of the mammalian nervous system. J. Nerv. and Ment. Dis., vol. 38, pp. 257-266. 
Donaldson, H. H. And Hatai, S 1911 A comparison of the Norway rat with the albino rat in respect to body length, brain weight, spinal cord weight and the percentage of water in both the brain and the spinal cord. J. Comp. Neur. vol. 21, pp. 417-458.

1911 a Note on the influence of castration on the weight of the brain and spinal cord in the albino rat and on the percentage of water in them. J. Comp. Neur., vol. 21, pp. 155-160.

Donaldson, H. H. 1912 A comparison of the European Norway and albino rats (Mus norvegicus and Mus norvegicus albinus) with those of North America in respect to the weight of the central nervous system and to cranial capacity. J. Comp. Neur., vol. 22, pp. 71-97.

1912 a On the weight of the crania of Norway and albino rats from three stations in western Europe and one station in the United States. Anat. Record, vol. 6, pp. 53-63.

$1912 \mathrm{~b}$ The history and zoölogical position of the albino rat. J. Acad. Nat. Sc. Phila., vol. 15, 2nd series, pp. 365-369.

$1912 \mathrm{c}$ An anatomical analysis of growth. Trans. 15th Internat. Cong. Hyg. and Demography, Wash., D. C., Sept. 23-28.

Doncaster, L. 1906 On the inheritance of coat color in rats. Proc. Cambridge Philos. Soc., vol. 13, pp. 215-228.

Donndorff, J. A. 1792 Zoölogische Beiträge zur XIII Ausgabe des Linneschen Natursystem. 2 vols. Leipzig. Vol. 1, Die Säugethiere, p. 427.

Dostoiewsky, A. 1886 Ueber den Bau der Vorderlappen des Hirnanhanges. Arch. f. mikr. Anat., vol. 26, pp. 592-598.

1886 a Ein Beitrag zur mikroskopischen Anatomie der Nebennieren bei Sảugethieren. Archiv f. mikr. Anat., vol. 27, pp. 272-296. Rat, p. 279 and 287.

Drasch, O. 1886 Zur Frage der Regeneration und der Aus-und Rückbildung der Epithelzellen. Sitz. d. k. Akad. d. Wiss. math.-naturw. Cl. Wien. Vol. 93, Abt III, pp. 200-213, 1 pl.

Duesberg, J. 1907 Die Mitochondrial-Apparat in den Zellen der Wirbeltiere und Wirbellosen. Arch. f. mikr. Anat., vol. 71, pp. 284-296.

1908 Les divisions des spermatocytes chez le rat (Mus decumanus Pall., variété albinos). Arch. f. Zellforsch., vol. 1.

1908 a La Spermatogénèse chez le rat (Mus decumanus Pall., Variété albinos) Mémoire présenté pour l'obtention du titre de docteur spécial en sciences anatomiques, Université de Liège. Wilhelm Engelmann. Leipzig. Also (b) Arch. f. Zellforsch., vol. 2, pp. 137-180. 1909 Note complémentaire sur la spermatogenèse du rat. Arch. f. Zellforsch., vol. 3, pp. 553-562.

Dunn, Flizabeth H. 1908 A study in the gain in weight for the light and heavy individuals of a single group of albino rats. Proc. Assoc. Am. Anat. in Anat. Record, vol. 2, pp. 109-110.

1912 The influence of age, sex, weight and relationship upon the number of medullated nerve fibers and on the size of the largest fibers in the ventral root of the second cervical nerve of the albino rat. J. Comp. Neur., vol. 22, pp. 131-157. 
DuPuy, W. A. And Brewster, E. T. 1910 Our duel with the rat. McClure's Mag., vol. 35, pp. 69-79.

Durham, Florence M. 1904 On the presence of tyrosinases in the skins of some pigmented vertebrates. Proc. Roy. Soc., vol. 74, pp. 310-313.

Duval, C. W. 1910 The cultivation of the leprosy bacillus and the experimental production of leprosy in the Japanese dancing mouse. J. Exper. M., vol. 12 , pp. $649-665$.

1911 Notes on the biology of B. leprae. N. Orl. M. and S. J., vol. 63, pp. 549-559.

Duval, C. W. AND GuRd, F. B. 1911 Experimental immunity with reference to the bacillus of leprosy. Part 1. A study of the factors determining infection in animals. J. Exper. Med., vol. 14, pp. 181-195.

1911 a Studies on the biology of and immunity against the bacillus of leprosy: with a consideration of the possibility of specific treatment and prophylaxis. Arch. Int. Med., vol. 7, pp. 230-245.

Duval, C. W. and Wellman, Creighton 1912 A new and efficient method of cultivating bacillus leprae from the tissues; with observations on the different strains of acid-fast bacilli found in leprous lesions. J. Am. M. Ass., vol. 58, p. 1427.

Duval, C. W. ANd Harris, W. H. 1913 Further studies upon the leprosy bacillus: its cultivation and differentiation from other acid-fast species. J. Med. Research, vol. 26 (n.s. 21), pp. 165-198.

Ebner, V. voN 1873 Die acinösen Drüsen der Zunge und ihre Beziehungen zu den Geschmacksorganen. Leuschner und Lubensky, Graz., 66 pp., 2 pl. 1888 ZurSpermatogenese bei den Säugethieren. Archivf.mikr. Anat., vol. 31, pp. 236-292. Tafel XV, XVI, XVII (Rat).

EdelmanN, Richard 1889 Vergleichend anatomische und physiologische Untersuchungen über eine besondere Region der Magenschleimhaut (Cardiadrüsen-region) bei den Säugethieren. Deutsche Ztschr. f. Thiermed., vol. 15, pp. 165-214.

Edington, A 1901 Rattenpest. Centralbl. f. Bacter., vol. 29, p. 889.

Edwards, A. Milne 1871 Melanism in Mus decumanus. Ann. Soc. Nat. Hist., vol. 15 , art. 7 .

1872 Note sur la variété mélanienne du surmulot (Mus decumanus). Ann. des. Sc. Nat. Zool., 5th ser., vol. 15.

Eimer, G. H. Тн. 1869 Die Wege des Fettes in der Darmschleimhaut bei seiner Resorption. Arch. f. pathol. Anat., vol. 48, pp. 119-177, pl. 4 and 5.

Eiselsberg, voN 1890 Ueber einen Fall von erfolgreicher Transplantation eines Fibrosarkoms bei Ratten. Wiener klin. Wochenschr., no. 48.

Ellenberger, W. 1906 Zum Mechanismus der Magenverdauung. Arch. f. d. ges. Physiol., vol. 114, pp. 93-107. Critique of A. Scheunert, ibid., p. 64.

Ellenberger, Wilhelm and Guenther, G. 1908 Grundriss der vergleichenden Histologie der Haussäugetiere. Berl. Parey., 3rd ed. rev. and enlarged.

Elliott, T. R. ANd Barclay-Smith, E. 1904 Antiperistalsis and other muscular activities of the colon. J. Physiol., vol. 31, pp. 272-304. Rat: pp. 283-287. Fig. 3. 
Elliott, T. R. ANd Tuckets, J. 1906 Cortex and medulla in the suprarenal glands. J. Physiol., vol. 34, pp. 332-369.

Engelmann, Th. W. 1877 Vergleichende Untersuchungen zur Lehre von der Muskel- und Nervenelektrizität. Arch. f. d. ges. Physiol., vol. 15, pp. 116-148.

ERdEly, A. 1905 Untersuchungen über die Eigenschaften und die Entstehung der Lymphe. Fünfte Mitt. UUber die Beziehungen zwischen Bau und Funktion des lymphatischen Apparates des Darmes. Taf. III. Ztschr. f. Biol., vol. 46, pp. 119-152. Tabulation of numbers of lymphocytes.

Erdheim, JakoB 1906 Zur Anatomie der Kiemenderivate bei Ratte, Kaninchen und Igel. Anat. Anz., vol. 29, pp. 609-623. Rats, pp.610-616, Fig., p. 621.

1906 a Tetania parathyreopriva. Mitt. a. d. Grenzgeb. d. Med. u. Chir., vol. 16, pp. 632-744.

1907 Tetania parathyreopriva. Med. Press and Circ., vol. 83, pp. 91-93.

1911 Ueber den Kalkgehalt des wachsenden Knochens und des Callus nach der Epithelkörperchenexstirpation. Frankfurt. Ztschr. f. Path., vol. 7, pp. 175-230.

1911 a Zur Kenntnis der parathyreopriven Dentinveränderung. Frankfurt Ztschr. f. Path., vol. 7, pp. 238-248. Figs. Rats. No tables.

$1911 \mathrm{~b}$ Ueber die Dentinverkalkung im Nagezahn bei der Epithelkörperchentransplantation. Frankfurt. Ztschr. f. Path., vol. 7, pp. 295-342.

Erxleben, Jo. Christ P. 1777 Systema regni animalis. Classis I. Mammalia. Lipsiae. p. 381. Mus norvegicus: original description.

Falcone, Cesare 1898 Contribution a l'histogénèse et à la structure des glandes salivaires. Monitore zool. ital., vol. 9, pp. 11-27. 1 plate.

Falta, W. and Noeggerath, C. T. 1905 Fütterungsversuche mit künstlicher Nahrung. Beiträge z. chem. Physiol. u. Pathol., vol. 7, pp. 313-322.

Fantham, H. B. 1906 Piroplasma muris Fant., from the blood of the white rat, with remarks on the genus Piroplasma. Quart. J. micr. Sc., vol. 50, pp. 493-516.

Ferrier, David 1886 The functions of the brain. 2nd ed. Smith, Elder \& Co., London. Rat, pp. 261-262.

Ferry, Edna L. 1913 The rate of growth of the albino rat. Anat. Record, vol. 7 , pp. $433-441$.

Fibiger, J. 1913 Ueber eine durch Nematoden (Spiroptera sp.n.) hervorgerufene papillomatöse und carcinomatöse Geschwulstbildung im Magen der Ratte. Berl. Klin. Wochenschr., L, pp. 289-298.

1913 a The nematode (Spiroptera sp. n.) and its capacity to develop papillomatous and carcinomatous tumors in the ventricle of the rat. Hosp.-Tid. Kobenh., 5 R., 6, 417; 449, 6 pl., 473. Discussion, pp. 441-448.

1913 b Untersuchung über eine Nematode (Spiroptera sp.n.) und deren Fähigkeit, papillomatöse und carcinamatöse Geschwulstbildungen im Magen der Ratte hervorzurufen. Zeitschr. f. Krebsforsch., Berl., vol. $13, \mathrm{pp} .217-280,14 \mathrm{pl}$. 
Frbiger, J. 1914 Further investigations on Spiroptera cancer in rats. Hosp.Tid., Kobenh., 5 R., 7, 1049; 1081, 3 pl.

Fischer, Alfred 1914 Zur normalen Anatomie und Physiologie der weiblichen Geschlechtsorgane von Mus decumanus sowie über die experimentelle Erzeugung von Hydro- und Pyosalpinx. Arch. f. Entwcklngsmechn. d. Organ., vol. 39, pp. 578-616.

Fischer, F. von 1872 Calculation of possible progeny of one pair of rats in ten years. Zool. Garten, pp. 125-126. (48, 319, 698, 843, 030, 344, 720.)

Fischer, J. von 1869 Die Säugethiere des St. Petersburg Governments. Zool. Garten, vol. 10 .

1874 Beobachtungen über Kreuzungen verschiedener Farbenspielartan innerhalb einer Species. Zool. Garten, vol. 15.

Flexner, Simon and Noguchi, H. 1906 The effect of eosin upon tetanus toxin and upon tetanus in rats and guinea-pigs. J. Exp. Med., vol. 8, pp. 1-7.

Flexner, Simon and Jobling, J. W. 1907 Metaplasia and metastasis of a rat tumor. Proc. Soc. Exp. Biol. and Med., vol. 5, pp. 52-53.

Flower, W. H. 1872 Lectures on the comparative anatomy of the Mammalia. Med. Times and Gaz., vol. 1 and vol. 2. For rat, see vol. 2, p. 115.

Folin, Otto And Morris, J. Lucien 1913 The normal protein metabolism of the rat. J. Biol. Chem., vol. 14, pp. 509-515. Metabolism like that of man.

Forbes, E. B. And Keith, M. Helen 1914 A review of the literature of phosphorous compounds in animal metabolism. Ohio Agr. Exp. Station, Technical series, bull. no. 5. See p. 332 and p. 506-valuable bibliography with abstracts.

Forturn, A. B. Droogleever 1914 Cortical cell-lamination of the hemispheres of some rodents. Arch. Neurol., Path. Lab. London County Asyl., vol. 6, pp. 221-354. Mus decumanus (Pall), p. 260, figures 18-22.

Foster, N. K. 1909 The rat as a factor in disease (Abstr.) Am. J. Pub. Hyg., vol. 19 , pp. 58-61.

Fox, C. 1912 The rat guard used in the Philippine Islands. Pub. Health Rep. U. S. Mar. Hosp. Serv., Wash., xxvii, 907.

Fox, F. A. 1913 Destruction of rats in the port of Rangoon. Brit. M. J., Lond., vol. 2, pp. 439-441.

Frank, Franz and Schittenheim, A. 1912 Ueber die Brauchbarkeit tief abgebauter Eiweisspräparate für die Ernährung. Therap. Monatsh., vol. 26 , pp. 112-117.

Frankenhaeuser, Constantin 1879 Untersuchungen über den Bau der Tracheo-bronchialschleimhaut. Diss. von Dorpat, 120 pp., 1 plate. St. Petersburg.

Fraser, A. 1883 On the inversion of the blastodermic layers in the rat and mouse. Proc. Roy. Soc., no. 223.

Frédéric, J. 1907 Beiträge zur Frage des Albinismus. Ztschr. f. Morphol. u. Anthrop., vol. 10, no. 2.

Frenkel, MoÏse 1892 Du tissu conjontif dans le lobule hépatique de certains mammifères. Compt. rend. soc. de biol. Année 44 (ser. 9, v.4), pp. 38-39. 
Freund, Paula 1892 Beiträge zur Entwicklungsgeschichte der Zahnanlagen bei Nagethieren. Arch. f. mikr. Anat., vol. 39, pp.,525-556.

1911 Über experimentelle Erzeugung teratoider Tumoren bei der weissen Ratte. Inaug.-Diss. Munchen.

Fuchs-Wolfring, Sornie 1898 Ueber den feineren Bau der Drüsen des Kehlkopfes und der Luftröhre. Arch. f. mikr. Anat., vol. 52, pp. 735-762. Rat, pp. 755-756, 1 plate.

Fusari, R. ANd Panasci, A. 1891 Les terminasions des nerfs dans la muqueuse et dans les glandes sereuses de la langue des mammifères. Résumé originel des auteurs. Arch. ital. de biol., vol. 14, pp. 240-246, pl. 1.

Fusari, Romeo 1894 Terminaisons nerveuses dans divers épithéliums. (Note lué à l'Académie des sciences naturelles et médicales de Ferrare dans la séance du 28 Mai 1893). Arch. ital. de biol., vol. 20, pp. 279-287. Observations mainly on the white rat.

Galli-Valerio, Bruno 1902 The part played by the fleas of rats and mice in the transmission of bubonic plague. Journ. trop. Med., vol. 5, pp. 33-36.

1908 Dangers et destruction des rats noirs (Mus rattus) et gris (Mus decumanus). Chronique Agric. Vaud Ann. 21, pp. 142-147.

Gamgee, Arthur 1898 Article "Haemoglobin" in E. A. Schäfer s Textbook of Physiology, vol. I, pp. 193-194. Small haemoglobin content and rapid crystalization in rat's blood, p. 206. Oxyhaemoglobin in rat's blood highly insoluble.

Garnier, Charles 1897 Les filaments basaux des cellules glandulaires. Note préliminaire. Bibliog. Anat., vol. 5, pp. 278-289, 13 fig.

Gauthier, J. C. And Raybaud, A. 1903 Sur le rôle des parasites du rat dans la transmission de la peste. C. R. Soc. de Biol., vol. 54, p. 1497.

GAY, F. P. 1909 A transmissible cancer of the rat considered from the standpoint of immunity. J. Med. Research, vol. 20, p. 175.

GAYloRd, H. R. 1906 Endemisches Vorkommen von Sarkomen in Ratten. Zeitschr. f. Krebsforschung, vol. 4, p. 679.

Gegenbaur, Carl 1892 Die epiglottis. Vergleichend anatomische Studie. fol. 69 pp., 2 plates and 15 cuts in text. In Festschr. Albert von Koelliker. W. Engelmann, Leipzig.

Geisenheymer, L. 1892 Zum Vorkommen der Hausratte, Mus rattus L. Naturwiss. Wochenschr., vol. 7, pp. 96-97.

Gemelli, Edoardo 1903 Nuove richerche sull'anatomia e sull'embriologia dell' ipofisi. Boll. della soc. medico-chir. di Pavia. Anno 1903, pp. $177-222,5 \mathrm{pl}$.

Gemelli, Edoardo after 1904 = Gemelli, (Fra) Agostino

Gemelli, Agostino 1905 Nuovo contributo alla conoscenza della struttura dell'ipofisi dei mammiferi. Rivista di Fisicae Matematica, vol. 12, pp. 136-145; pp. 235-247; pp. 338-346; pp. 419-431.

1906 Contributo alla fisiologia dell'ipofisi. Arch. di fisiol., vol. 3, pp. 108-112.

1906 a Ulteriori osservazioni sulla struttura dell'ipofisi. Anat. Anz., vol. 28 , pp. 613-628, 14 figures. 
Gentes, L. 1903 Note sur la structure du lobe nerveux de l'hypophyse. Compt. rend. Soc. de Biol., vol. 55, pp. 1559-1561. Rat among other animals.

Geofrroy Saint-Hilaire, Étienne 1812 Mus alexandrinus. Descr. Egypt. II, p. 733, 1812 (1829). Atlas, p. V, fig. 1, 1809.

Gesner, C. von 1551 Conradi Gesneri medici Tigurini Historiae Animalium Lib l de Quadrupedibus Viviparis. Tiduri Christ Froschoverum Anno 1551, p. 829. De majore domestico mure quem vulgo rattum vocant.

Gevaerts, Jacques 1901 Diète sous phosphore. La Cellule, vol. 18, pp. 7-33.

Giglio-Tos, E. 1900 Un parasite intranucléaire dans les reins du rat des égouts. Arch. ital. de Biol., vol. 34, p. 36.

Gillette 1872 Description et structure de la tunique musculaire de l'oesophage chez l'homme et chez les animaux. J. de l'anat. et physiol., vol. 8 , pp. $617-644$.

Giraldus Cambrensis (1146?-1220) 1861-1891 Opera (8 vols.) Vol. 5, 1867, vol. 6, 1868, edited by James F. Dimmock, M.A. Published under the direction of the Master of the Rolls. Longmans, Green, London.

Glas, Emil 1904 Utber die Entwickelung und Morphologie der inneren Nase der Ratte. Anat. Hefte, vol. 25, pp. 275-341.

Gmelin 1892 Zur Morphologie der Papilla vallata und foliata. Archiv f. mikr. Anat., vol. 40, pp. 1-28.

Godman, John D. 1826-1828 American natural history. 3 v., $8^{\circ}$. H. C. Carey and I. Lea, Phila. Pt. 1. Mastology.

Goetsch, Emil and Cushing, Harvey 1913 The pars anterior and its relation to the reproductive glands. Proc. Soc. Exper. Biol. and Med., vol. 11 , pp. 26-27.

Goldmann, E. E. 1909 Die äussere und innere Secretion des gesunden und kranken Organismus im Lichte der vitalen Färbung. Beitr. z. klin. Chir., vol. 64, p. 192.

1912 Die äussere und innere Sekretion des gesunden und kranken Organismus im Lichte der vitalen Färbung. Beitr. z. klin. Chir., vol. 78, pp. 1-108.

Goldstein, K. 1904 Zur vergleichenden Anatomie der Pyramidenbahn. Anat. Anz., vol. 24, p. 451.

Goto, Seitaro 1906 A laboratory guide of zoölogy (In Japanese). 2 vols. Kinkodo, Japan. See vol. 2, pp. 297-373-white rat (Mus rattus, $\times$ Mus decumanus).

Gоттsснат, M. 1883 Structure und embryonale Entwickelung der Nebennieren bei Säugethieren. Arch. f. Anat. u. Physiol., Anat. Abthlg., fig. 12 .

Gourlay, C. A. 1907 Notes on the rats of Dacca,-Eastern Bengal. Records of the Indian Museum, Calcutta, vol. 1, pp. 263-266. Relative numbers of Mus rattus and Nesokia bengalensis. Measurements on both good.

Graham, L. W. and Hutchison, R. H. 1914 The influence of experimental trypanosomiasis upon the body temperature of white rats. Am. J. of Trop. Dis and Prev. Med., vol. 1, pp. 760-775. 
Greenman, M. J. 1913 Studies on the regeneration of the peroneal nerve of the albino rat: number and sectional areas of fibers: area relation of axis to sheath. J. Comp. Neur., vol. 23, pp. 479-513.

Gregersen, J. P. 1911 Untersuchungen über den Phosphorstoffwechsel. Zeit. physiol. Chem., vol. 71, pp. 49-99.

Grubbs, S. B. and Holsendorf, B. E. 1913 Fumigation of vessels for the destruction of rats. Pub. Health Rep., Wash., vol. 28, pp. 1166-1274.

GrÜtzner, P. 1875 Neue Untersuchungen über die Bildung u. Ausscheidung des Pepsins. Breslau.

1878 Ueber Bildung und Ausscheidung von Fermenten. Arch. f. d. ges. Physiol., vol. 16, pp. 105-123.

1894 Zur Physiologie der Darmbewegung. Deutsche med. Wchnschr., vol. 20 , pp. $897-898$.

1898 Ueber die Bewegung des Darminhaltes. Arch. f. d. ges. Physiol., vol. 71, pp. $492-522$.

1905 Ein Beitrag zum Mechanismus der Magenverdauung. Arch. f. d. ges. Physiol., vol. 106, pp. 463-522. (13 text figures.)

Gudernatsch, J. F. 1915 Feeding experiments on rats. Anat. Record, vol. 9, pp. 78-80. In full in Am. J. Physiol., vol. 36, pp. 370-379.

Goieysse, A. 1898 Sur quelques points d'anatomie des muscles des appareil respiratoire. J.de l'anat. et physiol., vol. 34, pp.419-432. 5 figs. Rat p. 423.

Gulliver, George 1839 Observations on the muscular fibers of the oesophagus and heart in some of the Mammalia. Part 1. Proc. Zool. Soc., vol. 7, pp. 124-129. Mus decumanus, p. 126.

1842 Observations on the muscular fibers of the oesophagus and heart in some of the Mammalia. Part 2. Proc. Zool. Soc., vol. 10, pp. 6372. Mus decumanus, p. 70.

1875 Observations on the sizes and shapes of the red corpuscles of the blood of vertebrates, with drawings of them to a uniform scale, and extended and revised tables of measurements. Proc. Zool. Soc., London, pp. 474-494.

HaAcke, V. W. 1895 Ueber Wesen, Ursachen, und Vererbung von Albinismus, etc. Biol. Centralbl., vol. 15.

HAGEDOORN, A. L. 1911 The interrelation of genetic and non-genetic factors in development. Verh. d. naturf. Verein Brünn, vol. 49, pp. 1-18.

1914 Studies on variation and selection. Ztschr. f. indukt. Abstammungs u. Vererbungsl., vol. 11, pp. 145-183.

Haller, B. 1910 Zur Ontogenie der Grosshirnrinde der Säugetiere. Anat. Anz., vol. 37, pp. 282-293. 4 figures. Rat, p. 285.

Halliburton, W. D. 1888 On the haemoglobin crystals of rodents' blood. Quart. J. Microscop. Science, vol. 28, pp. 181-199. Rat, pp. 192, 193, 194.

Hamilton, Alice 1901 The division of differentiated cells in the central nervous system of the white rat. J. Comp. Neur, vol. 11, pp. 297-320.

Hamp, E. T. 1906 Sur la variété nègre du Mus decumanus observée au Muséum de Paris. Bull. du Mus. d'hist. nat., vol. 12, pp. 87-89. 
Hansemann, David 1895 Ueber die Poren der normalen Lungenalveolen. Sitz. d. Preuss. Akad. d. Wiss., pp. 999-1001 1 plate. Also Math. u. naturw. Mitt. d. k. Preuss. Akad. d. Wiss., vol. 9, pp. 451-454.

Hansemann, von 1904 Ueber abnorme Rattenschädel. Arch. Anat. Physiol. physiol. Abt.

Harlan, Richard 1825 Fauna Americana. Being a description of the mammiferous animals inhabiting North America-Philadelphia. p. 148-M. Rattus-description.

Harley, George 1857 Report on meeting of the Pathological Society, November 28,1857 , giving report of Dr. Harley on "Rats from which the suprarenal capsules had been removed." Med. Times and Gaz., N. S., vol. 15 (O. S., vol. 36), pp. 564-565.

1858 Living specimen of a rat from which both the suprarenal capsules and the spleen had been removed. Tr. Path. Soc. Lond., vol. 9, p. 401 .

1858 a An experimental inquiry into the function of the suprarenal capsules, and their supposed connection with bronzed skin (in 2 parts). Brit. and For. M.-Chir. Rev., vol. 21, pp. 204-221; 498-510.

1858 b Diseased suprarenal capsule, removal by operation from an apparently healthy animal. Tr. Path. Soc., Lond., vol. 9, pp. 401-402. (This volume is a report of the season of 1857-58.)

Hart, E. B. and McCollum, E. V. 1913 The influence of restricted rations on growth. Proc. Soc. Biol. Chemists, vol. 3, pp. 38-39.

Hartley, Perctval 1907 On the nature of the fat contained in the liver, kidney and heart. J. of Physiol., vol. 36, pp. 17-26.

Harz, W. 1883 Beiträge zur Histologie des Ovariums der Säugetiere. Arch.f. mikr. Anat., vol. 22, pp. 374-407.

HataI, S. 1901 The finer structure of the spinal ganglion cells in the white rat. J. Comp. Neur., vol. 11, pp. 1-24.

1901 a On the presence of the centrosome in certain nerve cells of the white rat. J. Comp. Neur., vol. 11, pp. 25-39.

1902 Number and size of the spinal ganglion cells and dorsal root fibers in the white rat at different ages. J. Comp. Neur., vol. 12, pp. 107-124. 1902 a Preliminary note on the presence of a new group of neurones in the dorsal roots of the spinal nerves of the white rat. Biol. Bull., vol. 3 , pp. 140-142.

$1902 \mathrm{~b}$ On the origin of neuroglia tissue from the mesoblast. J. Comp. Neur., val. 12, pp. 291-296.

1903 The finer structure of the neurones in the nervous system of the white rat. Decennial Pub., Univ. of Chicago, vol. 10, pp. 3-14.

1903 a The effect of lecithin on the growth of the white rat. Am. J. Physiol., vol. 10, pp. 57-66.

$1903 \mathrm{~b}$ On the increase in the number of medullated nerve fiben in the ventral roots of the spinal nerves of the growing white rat. J. Comp. Neur., vol. 13, pp. 177-183.

$1903 \mathrm{c}$ On the nature of the pericellular network of nerve cells. J. Comp. Neurol., vol. 13, pp. 139-147. 
HATAI, S. $1903 \mathrm{~d}$ The neurokeratin in the medullary sheaths of the peripheral nerves of mammals. J. Comp. Neurol., vol. 13, pp. 149-156.

1904 A note on the significance of the form and contents of the nucleus in the spinal ganglion cells of the foetal rat. J. Comp. Neur. and Psychol., vol. 14, pp. 27-48.

1904 a The effect of partial starvation on the brain of the white rat. Am. J. Physiol., vol. 12, pp. 116-127.

1905 The excretion of nitrogen by the white rat as affected by age and body weight. Am. J. Physiol., vol. 14, pp. 120-132.

1907 On the zoölogical position of the albino rat. Biol. Bull., vol. 12, pp. 266-273.

1907 a Effect of partial starvation followed by a return to normal diet, on the growth of the body and central nervous system of albino rats. Am. J. Physiol., vol. 18, pp. 309-320.

$1907 \mathrm{~b}$ A study of the diameters of the cells and nuclei in the second cervical spinal ganglion of the adult albino rat. J. Comp. Neur. and Psychol., vol. 17, pp. 469-491.

$1907 \mathrm{c}$ Studies on the variation and correlation of skull measurements in both sexes of mature albino rats (Mus norvegicus var. albus). Am. J. Anat., vol. 7, pp. 423-441.

1908 Preliminary note on the size and condition of the central nervous system in albino rats experimentally stunted. J. Comp. Neur. and Psychol., vol. 18, pp. 151-155.

1909 A comparison of the albino with the gray rats in respect to the weight of the brain and spinal cord. Proc. of Assoc. of Am. Anat. in Anat. Record, vol. 3, p. 245.

1909 a Note on the formulas used for calculating the weight of the brain in the albino rats. J. Comp. Neur. and Psychol., vol. 19, pp. 169-173.

1910 A mathematical treatment of some biological problems. Biol. Bull., vol. 18, pp. 126-130.

1910 a DeForest's formula for "An unsymmetrical probability curve." Anat. Record, vol. 4, pp. 281-290.

1911 An interpretation of growth curves from a dynamical standpoint. Anat. Record, vol. 5, pp. 373-382.

1911 a The Mendelian ratio and blended inheritance. Am. Naturalist, vol. 45, pp. 99-106.

1912 On the appearance of albino mutants in litters of the common Norway rat, Mus norvegicus. .Science, n.s. vol. 35, no. 909 , pp. $875-$ 876, May 31.

1913 On the weights of the abdominal and the thoracic viscera, the sex glands, ductless glands and the eyeballs of the albino rat (Mus norvegicus albinus) according to body weight. Am. J. Anat., vol. 15, pp. 87-119.

1913 a. The effect of castration, spaying or semi-spaying on the weight of the central nervous system and of the hypophysis of the albino rat; also the effect of semi-spaying on the remaining ovary. J. Exper. Zool., vol. 15, pp. 297-314. 
HATAI, S. 1914 On the weight of the thymus gland of the albino rat (Mus norvegicus albinus) according to age. Am. J. Anat., vol. 16, pp. 251-257. 1914 a On the weight of some of the ductless glands of the Norway and of the albino rat according to sex and variety. Anat. Record, vol. 8, pp. 511-523.

1915 The growth of organs in the albino rat as affected by gonadectomy. J. Exper. Zoöl., vol. 18, pp. 1-67.

1915 a Growth of the body and organs in albino rats fed with a lipoidfree ration. Anat. Record, vol. 9, pp. 1-20.

Hens, Vikтоr 1911 Kulturpflanzen und Hausthiere in ihrem Uebergang aus Asien nach Griechenland und Italien sowie in das übrige Europa. Achte auflage. Historisch-linguistische Skizzen, Berlin, Gebrüder Borntraeger.

Heiser, Victor G. 1910 Plague eradication in cities by sectional extermination of rats and general rat proofing. Found in "The rat and its relation to public health," pp. 205-206. Treasury Dept. Pub. Health and Mar.-Hosp. Service of the U. S. Government Printing Office, Wash., D. C.

1913 The rats of our cities; what becomes of the carcasses of rats dying natural deaths? Pub. Health Rep., Wash., vol. 28, p. 1553.

Henneberg, B. 1899 Die erste Entwickelung der Mammarorgane bei der Ratte. Anat. Hefte, Wiesb., vol. 13, pp. 1-68.

1900 Verhalten der Umbilicalarterien bei den Embryonen von Ratte und Maus. Anat. Anz., vol. 17, pp. 321-324.

Herzog, Maxmilian 1905 Zur Frage der Pestverbreitung durch Insecten. Eine neue Species von Rattenfloh. Zeitschr. Hyg. Infektionskrankh., vol. 51, pp. 268-282.

Heuser, Chester H. 1914 The form of the stomach in mammalian embryos. Proc. Am. Assoc. of Anatomists in Anat. Record, vol. 8, no. 2.

Hewer, Evelyn E. 1914 The effect of thymus feeding on the activity of the reproductive organs in the rat. J. Physiol., vol. 47, pp. 479-490.

Hewetr, G. M. A. 1904 The rat. Adam and Charles Black. London.

Heymann, Felix 1904 Zur Einwirkung der Castration auf den Phosphorgehalt des weiblichen Organismus. Arch. Gynäkol., vol. 73, pp. 366-405. Also Zeit. physiol. Chem., vol. 41, pp. 246-258.

HILl, A. M. 1913 The effects of high external temperatures on the metabolism of rats. J. Physiol., vol. 46, pp. xxxi-xxxii.

Hili, Leonard and Macleod, J. J. R. 1903 The influence of compressed air on the respiratory exchange. J. Physiol., vol. 29, pp. 492-510.

Hовdy, William C. 1910 The rat in relation to shipping. Found in "The rat and its relation to the public health," pp. 207-213. Treasury Dept. Pub. Health and Mar.-Hospt. Service of the U.S. Government Printing Office, Wash., D. C.

Höber, Rudolf 1911 Physikalische Chemie der Zelle und der Gewebe. Wilhelm Engelmann. Leipzig. 3rd Ed., p. 254. Analysen der Plasmahautstruktur bei den Blutkörperchen.

Hohlbaum, Jos. 1912 Beiträge zur Kenntnis der Epithelkörperchenfunktionen. Beitr. z. path. Anat. u. z. allg. Path., vol. 53, pp. 91-104. 
Hohmeier, F. 1901 Ueber Aenderungen der Fermentmengen im Mageninhalt. Inaug.-Diss. Tübingen.

HollmanN, Harry T. 1912 The cultivation of an acid-fast bacillus from a rat suffering with rat leprosy (a preliminary report) Pub. health rep. U. S. Mar. Hosp. Serv., vol. 27, part 1, pp. 69-70.

Home, Sir Evered 1807 Observations on the structure of the stomach of different animals. Phil. Trans. Roy. Soc., part 1, Plates V-XIII, p. 150. The common rat.

HöNigSCHMIED, JoH. 1873 Beiträge zur mikroskopischen Anatomie über die Geschmacksorgane der Säugethiere. Zeitschr. f. wissen. Zool., vol. 23, pp. 414-434.

Hopkins, F, G. 1912 Feeding experiments illustrating the importance of accessory factors in normal dietaries. J. Physiol., vol. 44, pp. 425-460.

Hopkins, F. G. and Neville, Allen 1912 A note concerning the influence of diets upon growth. Biochem. J., vol. 7, pp. 97-99.

Horton, Jessie M. 1905 The anthracidal substance in the serum of white rats. J. of Infect. Dis., vol. 3, pp. 110-115.

Hossack, W. C. 1906 Preliminary note on the rats of Calcutta. Journ. Proc. Asiat. Soc., Bengal, vol. 2, pp. 183-186.

1907 An account of the rats of Calcutta. Mem. Ind. Museum, vol. 1, no. 1. Pl. I-VIII. Elaborate tables of measurements-very complete. Several colored plates.

1907 a Aids to the identification of rats connected with plague in India. Allahabad, Pioneer Press, $10 \mathrm{pp}$.

$1907 \mathrm{~b}$ The original home of Mus decumanus. Records of the Indian Museum, Calcutta, vol. 1, pp. 275-276. Discussion of wild coloration.

Hoyer, H. 1890 Ueber den Nachweis des Mucins in Geweben mittelst der Färbemethode. Arch. f. mikr. Anat., vol. 36, pp. 310-374. Rat included among mammals examined.

Hubbert, Helen B. 1914 Time versus distance in learning. J. Animal Behavior, vol. 4, pp. 60-69.

1915 Elimination of errors in the maze. J. Animal Behavior, vol. 5, pp. 66-72.

Huber, G. Carl 1915 The development of the albino rat from the end of the first to the tenth day after insemination. Anat. Record, vol. 9, pp. 84-88.

1915 a The development of the albino rat (Mus norvegicus albinus). Part 1. From the pronuclear stage to the stage of mesoderm anlage; end of the first to the end of the ninth day. J. of Morphology, vol. 26 , pp. 247-358.

$1915 \mathrm{~b}$ The development of the albino rat (Mus norvegicus albinus). Part II. Abnormal ova. End of the first to the end of the ninth day. J. of Morphology, vol. 26, pp.359-386.

Hunt, Reid, and Seidell, A. 1909 Studies on thyroid. I. The relation of iodine to the physiological activity of thyroid preparations. Bull. no. 47 Hyg. Lab. U. S. Pub. Health and Mar. Hosp. Serv., Wash. 
Hunt, ReId 1910 The effects of a restricted diet and of various diets upon the resistance of animals to certain poisons. Bull. no. 69, Hyg. Lab. U. S. Pub. Health and Mar. Hosp. Serv., Wash., pp. 3-93.

Hunter, A., Givens, M. H. And Guion, C. M. 1914 Studies in the comparative biochemistry of purine metabolism. I. The excretion of purine catabolites in the urine of marsupials, rodents and carnivora. J. Biol. Chem., vol. 18, p. 387.

Hunter, Walter S. 1912 A note on the behavior of the white rat. J. Animal Behavior, vol. 2, pp. 137-141.

1913 The delayed reaction in animals and children. Behavior Monographs, vol. 2, no. 1, serial number 6, pp. 1-86.

1914 The auditory sensitivity of the white rat. J. Animal Behavior, vol. 4, pp. 215-222.

Horler, K. 1912 Vergleichende Untersuchungen über den Bacillus paratyphosus B, den Bacillus enteritidis Gärtner und die Rattenbacillen: Ratinbacillus, Bacillus ratti Danysz, Bacillus ratti Dunbar und Bacillus ratti Issatschenko. Centralbl. f. Bakteriol., 1 Abt., Jena, vol. 63, pp. 341-372.

Hyrtr, JoSEPH 1845 Vergleichend-anatomische Untersuchungen über das innere Gehörorgan des Menschen und der Säugethiere. Pp. 1-139, 9 plates. Friedrich Ehrlich. Prag. Diameters of the several semi-circular canals with their greatest distance from the vestibule for M. decumanus.

India Plague Commission 1908 Etiology and epidemiology of plague, p. 9. Calcutta.

Iselin, HaNs 1908 Wachstumshemmung infolge von Parathyreoidektomie bei Ratten: ein Beitrag zur Kenntnis der Epithelkörperchen-Funktion bei jungen Ratten. Deutsche Ztschr. f. Chir., vol. 93, pp: 494-500.

L'Isle, A. DE, 1865 De l'existence d'une race nègre chez le Rat ou de l'identite spécifique du Mus rattus et du Mus alexandrinus. Ann. d. sc. nat. Zoöl., 5th series, vol. 4, pp. 173-222.

JACkson, C. M. AND Lowrey, L. G. 1912 On the relative growth of the component parts (head, trunk and extremities) and systems (skin, skeleton, musculature and viscera) of the albino rat. Anat. Record, vol. 6, pp. 449-474.

JACKson, C. M. 1912 On the recognition of sex through external characters in the young rat. Biol. Bull., vol. 23, pp. 171-174.

1913 Postnatal growth and variability of the body and of the various organs in the albino rat. Am. J. Anat., vol. 15, pp. 1-68.

1915 Effects of acute and chronic inanition upon the relative weights of the various organs and systems of adult albino rats. Anat. Record, vol. 9, pp. 90-91. Full paper: Am. J. Anatomy, vol. 18, pp. 75-116.

1915 a Changes in young albino rats held at constant body weight by underfeeding for various periods. Anat. Record, vol. 9, pp. 91-92.

$1915 \mathrm{~b}$ Changes in the relative weights of the various parts, systems and organs of young albino rats held at constant body weight by underfeeding for various periods. J. Exper. Zoöl., vol. 19, pp. 99-156. 
JACOB, Lodwig 1906 Fütterungsversuche mit einer aus den einfachen Nahrungsstoffen zusammengesetzten Nahrung an Tauben und Ratten. Zeit. Biol., vol. 48 (N. F. 30) pp. 19-62.

JADASSOHN, J. 1913. Lepra. in (Kolle, Wilhelm und Wassermann, A. von, (eds.) Handbuch der pathogenen Mikroorganismen. vol. 5, part 2, pp. 791930). Page 821, Rattenleprabacillus.

Jensen, C. O. 1908 Uebertragbare Rattensarkome. Ztschr. f. Krebsforschung, vol. 7, p. 45 .

Jensen, O. S. 1887 Untersuchungen über die Samenkörper der Säugethiere, Vögel und Amphibien. Arch. f. mikr. Anat., vol. 30.

JoANnovics, Georg 1912 Ueber das Verhalten transplantierter Karzinome in künstlich anämischen Mäusen. Wiener Klin. Wochenschr., vol. 25, pp. 37-39.

Jов, Thesle T. 1915 The adult anatomy of the lymphatic system in the common rat (Epimys norvegicus). Anat. Record, vol. 9, pp. 447-458.

Jolly, J. ет Stini, J. 1905 Masse totale du sang chez le rat blanc. Compt. rend. Soc. de biol., Paris, vol. 58, pp. 835-837.

Jolyet et Chaker 1875 De l'acte de ronger étudie chez les rats. C. R. et Mem. Soc. Biol., Paris, Ann. 1875, pp. 73-74. Lateral motion of inferior incisors.

Jungano 1909 Sur la flore anaérobie du rat. Comp. rend. Soc. de biol., vol. 66, p. 112.

JứRgens, G. 1903 Beitrag zur Biologie der Rattentrypanosomen. Arch. f. Hyg., vol. 42, p. 265.

Kanthack, A. A. And HARDY, W. B. 1894 The morphology and distribution of the wandering cells of mammalia. J. Physiol., vol. 17, pp. 81-119.

Katzenstein, J. 1903 Ueber die elastischen Fasern im Kehlkopfe mit besonderer Berücksichtigung der funktionellen Struktur und der Function der wahren und falschen Stimmlippe. Arch. f. Laryngol. u. Rhinol., vol. 13, pp. 329-352, pl. XVIII-XIX.

Keller, Otтo 1909 Die Antike Tierwelt. I. Säugetiere. pp. 203-205. Engelmann, Leipzig.

Keller-Zschokкe, J. 1892 Mus rattus noch in der Schweiz. Zool. Garten, 33 Jhg. no. 2, p. 60 .

KERR, JoHN W. 1910 The rat in relation to international sanitation. Fcund in "The rat and its relation to the public health," pp.227-254. Treasury Dept. Pub. Health and Mar.-Hospt. Service of the U. S. Government Printing Office, Wash., D. C.

King, Helen D. 1910 The effects of various fixatives on the brain of the albino rat, with an account of a method of preparing this material for a study of the cells in the cortex. Anat. Record, vol. 4, pp. 214-244.

1911 The effects of pneumonia and of post-mortem changes on the percentage of water in the brain of the albino rat. J. Comp. Neur., vol. 21, pp. 147-154.

1911 a The effects of semi-spaying and of semi-castration on the sex ratio of the albino rat (Mus norvegicus albinus). J. Exper. Zoöl., vol. 10, pp. 381-392. 
King, Helen D. 1911 b The sex ratio in hybrid rats. Biol. Bull., vol. 21, pp. 104-112.

1913 Some anomalies in the gestation of the albino rat (Mus norvegicus albinus). Biol. Bull., vol. 24, pp. 377-391.

1913 a The effects of formaldehyde on the brain of the albino rat. J. Comp. Neur., vol. 23, pp. 283-314.

1915 On the weight of the albino rat at birth and the factors that influence it. Anatomical Record, vol.9, pp. 213-231.

King, Helen D. And Stotsenburg, J. M. 1915 On the normal sex ratio and the size of the litter in the albino rat (Mus norvegicus albinus). Anatomical Record, vol. 9, pp. 403-420.

KING, Jessie L. 1910 The cortico-spinal tract of the rat. Anat. Rec., vol.4, pp. 245-252.

Kirkham, William B. 1910 Ovulation in mammals, with special reference to the mouse and rat. Biol. Bull., vol. 18, pp. 245-251.

Kirkham, William B. AND BuRr, H. S. 1913 The breeding habits, maturation of eggs and ovulation of the albino rat. Am. J. Anat., vol. 15, pp. 291317. Six excellent plates illustrating the egg in various phases.

Klebs, E. 1891 Zur vergleichenden Anatomie der Placenta. Archiv. f. mikr. Anat., vol. 37, pp. 335-356.

Klein, Edward und Verson, E. 1871 Der Darmkanal. In Stricker's Handbuch der Lehre von den Geweben des Menschen und der Tiere. See "Magen," p. 395.

KLeIN, E. 1875 The anatomy of the lymphatic system. II. The lung. Smith, EIder \& Co., London, 88 pages, 6 plates. Observations mainly on guinea pig. Rat among other animals used.

KLunzinger, C. B. 1908 Ueber unsere Ratten und Mäuse, deren Schaden und Bekämpfung. Jahresh. Ver. vaterl. Naturk. Württemberg Jahrg., 64 p. xxxi-xxxviii.

KNAPP, PAUL 1908 Experimenteller Beitrag zur Ernährung von Ratten mit künstlicher Nahrung und zum Zusammenhang von Ernährungsstörungen mit Erkrankungen der Conjunctiva. Zeit. exp. Path. u. Ther., vol. 5, pp. 147-169.

Koch, MAthilde L. 1913 Contributions to the chemical differentiation of the central nervous system. I. A comparison of the brain of the albino rat at birth with that of the fetal pig. J. Biol. Chem., vol. 14, pp. 267-279.

Koch, W. AND ManN, S. A. 1909 A chemical study of the brain in healthy and diseased conditions, with especial reference to dementia praecox. Archives of Neurol. and Psychiatry (Mott), vol. 4, pp. 201-204.

Koch, Waldemar and Koch, Mathilde L. 1913 Contributions to the chemical differentiation of the central nervous system. II. A comparison of two methods of preserving nerve tissue for subsequent chemical examination. J. Biol. Chem., vol. 14, pp. 281-282.

1913 a Contributions to the chemical differentiation of the central nervous system. III. The chemical differentiation of the brain of the albino rat during growth. J. Biol. Chem., vol. 15, pp.423-448.

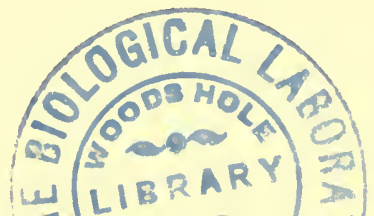


Koepert, Otтo 1904 Nochmals der Rattenkönig. Natur u. Haus., vol.12, pp. 118-119.

KoganeI, J. 1885 Untersuchungen über den Bau der Iris des Menschen und der Wirbelthiere. Archiv. f. mikr. Anat., vol. 25, pp. 1-48. Rat, p. 16

Konlmeyer, O. 1906 Topographie des elastischen Gewebes in der Gaumenschleimhaut der Wanderratte, Mus decumanus. Zeitschr. wiss. Zool., vol. 81 , pp. 145-190.

Kolazy, Josef 1871 Ueber die Lebensweise von Mus rattus, varietas, alba. Verhandl. Zool. Bot. Gesellsch. Wien, pp. 731-734. Unusually good account.

Kolmer, J. A. ANd YUi, C. V. And Trad, E. S. 1913 Concerning the activity and fixability of the complement in rat serum. J. Med. Research, vol. 28 (n.s. vol. 23), pp. 483-495.

Kolster, RUD. 1901 Vergleichend anatomische Studien über den M. pronator teres der Säugetiere. Anat. Hefte, vol. 17, pp.673-834. Mus. rattus, p. 714 .

KonstansofF, S. V. 1910 Organized extermination of rats in general and on the territory of the port of Feodossiyz in particular. Vestnik obsh. hig., sudeb. i prakt. med., St. Petersb., vol. 46, pp. 777-783.

Korolkow, P. 1892 Die Nervenendigungen in den Speicheldrüsen. Rev. d. sc. nat. de St. Petersbourg, Ann. 3, pp. 109-112 (Russian). In German in Anat. Anz., vol. 7, pp. 580-582, 1 fig., white rat.

Krause, Wilhelm 1870 Die Nervenendigung in der Zunge des Menschen, Göttinger Nachr., pp. 423-426.

1876 Allgemeine und mikroskopische Anatomie. Handbuch der menschlichen Anatomie, Bd. 1. Hannover, 1876. (Vol. 1 of Krause, Carl F. T. Handbuch der menschlichen Anatomie, 3 Aufl.).

Kreidl, A. Und Neumans, A. 1908 Zur Frage der Labgerinnung im Säuglingsmagen. Zentralbl. f. Physiol., vol. 22, pp. 133-136. (See p. 136).

Kunhardt, J. C., TAYlor, J. and Others 1915 Epidemiological observations in Madras Presidency. VI. Rat and flea prevalence, p. 725. J. of Hyg., Plague Suppl. IV, 9th Report on Plague Investigations in India.

KUPfFer, C. W. vow 1876 Ueber Sternzellen in der Leber. Arch. f. mikr. Anat., vol. 12, part 2, pp. 352-358. Results verified on rat.

Lagarrique, Maurice 1911 La lutte contre le rat. Paris, Jouve \& Cie. 102 pp. $8^{\circ}$.

Lambert, R. A. 1910 A note on parabiosis between mice and rats. Proc. Soc. Exper. Biol. and Med., 38th meeting, April 20.

1911 The influence of mouse-rat parabiosis on the growth in rats of a transplantable mouse sarcoma. J. Exp. Med., vol. 13, pp. 257-262.

LANDoIs, H. 1886 Uber Bleirohre von Ratten zernagt. 15 Jahresber. Westfäl. Prov.-Ver., pp. 12-13.

Lane-Claypon, Janet E. 1909 Observations on the influence of heating upon the nutrient value of milk as an exclusive diet for young animals. J. Hyg., vol. 9, pp. 233-238.

LANGLEY, J. N. 1879 On the structure of serous glands in rest and activity. Proc. Roy. Soc., London, vol. 29, pp. 377-382. 
Langley, J. N. ANd Sewall, H. 1879 On the changes in pepsin-forming glands during secretion. J. Physiol., vol. 2, pp. 281-301; Proc. Roy. Soc., London, vol. 29, p. 383.

LANGLEY, J. N. 1882 On the histology of the mammalian gastric glands, and the relation of pepsin to the granules of the chief cells. J. Physiol., vol. 3 , pp. 269-291.

Langlois, J. P. ANd Loir, A. 1902 La résistance des rats et des insectes à l'acide carbonique et à l'acide sulfureux. Compt. rend. Soc. de biol., vol. $54, \mathrm{pp} .414-415$.

Lantz, David E. 1907 Methods of destroying rats. U. S. Dept. of Agr. Farmers' Bull.no.297. Government Printing Office, Washington, D.C. 1909 The brown rat in the United States. U. S. Dept. of Agr., Biol. survey, Bull. no. 33, Washington, D. C., pp. 12-13.

1910 Natural history of the rat. Found in "The rat and its relation to the public health," pp. 15-27. Treasury Dept. Pub. Health and Mar.-Hospt. Service of the U. S., Washington, D. C. Government Printing Office.

1910 a Natural enemies of the rat. Found in "The rat and its relation to the public health," pp. 163-169. Treasury Dept. Pub. Health and Mar.-Hospt. Service of the U.S. Government Printing Office.

Washington, D. C.

$1910 \mathrm{~b}$ The rat as an economic factor. Found in "The rat and its relation to the public health," pp. 215-226. Treasury Dept. Pub. Health and Mar.-Hospt. Service of the U. S. Government Printing Office, Washington, D. C.

LAPicQUe, Louis 1907 Différence sexuelle dans le poids de l'encéphale chez les animaux. Rat et moineau. C. R. Soc. Biol., Paris, vol. 63, pp. 746-748.

Lapicque, Louis and Girard, P. 1907 Sur le poids de l'encéphale chez les animaux domestiques. Societé de Biol., vol., 62, p. 1015.

Lapicque, Lodis and Legendre, R. 1911 Sur les rats noirs du Jardin des Plantes. Bull. du Muséum d'histoire naturelle, no. 6, pp. 1-5.

LASHLEY, K. S. 1912 Visual discrimination of size and form in the albino rat. J. Animal Behavior, vol. 2, pp. 310-331.

LAUBer, HaNS 1901 Beiträge zur Anatomie des vorderen Augenabschnittes der Wirbeltiere. Anat. Hefte, vol. 18, pp.371-453. Mus rattus, p. 427.

Laveran, A. and Mesnil, F. 1900 Sur l'agglutination des trypanosomes du rat par divers sérums. C. R. Soc. de Biol., Nov. 10, p. 939.

1900 a De la longue conservation à la glacière des trypanosomes du rat et de l'agglomération de ces parasites. C. R. Soc. de Biol., Oct. 6, p. 816 .

1900 b Sur le mode de multiplication du trypanosome du rat. C. R. Soc. de Biol., Nov. 17, p. 976.

Lavrinovich, M. O. 1910 Extermination of rats in St. Petersburg by cultures of Danich's bacilli. Vestnik. Obsh. vet., St. Petersb., vol. 22, p. 885. (Russian.)

I.eboeuf, A. 1912 Existence de lepra murium (lèpre des rats) en Nouvelle Calédonie. Bull. Soc. path. exot., vol. 5, pp. 463-465. 
Lee, Frederic S. 1910 The nature of fatigue. Popular Science Monthly, February, pp. 182-195. See fig. 4.

Lenuwenhoeck, ANt. 1693 On the testicles of a rat and the animalcules therein contained; with some observations of small animals found in oysters and in the sap of vines. Phil. Trans., vol. 17, pp. 593-594.

Lefroy, Sir John Henry 1882 The Historye of the Bermudaes or Summer Islands, 1609- By Capt. John Smith (?) Pub. of the Hakluyt Soc., London.

Leischner, H. 1907 Ueber Epithelkörperchen-Transplantationen und deren praktische Bedeutung in der Chirurgie. Arch. f. klin. Chir., vol. 84, pp. 208-222.

Leischner, H. AND KöHLer, R. 1911 Ueber homioplastische Epithelkörperchen und Schilddrüsenverpflanzung. Arch. f. klin. Chir., vol. 94, pp. 169-185.

Lenhossék, M. von 1889 Ueber die Pyramidenbahnen im Rückenmarke einiger Säugetiere. Anat. Anz., vol. 4, pp. 208-219.

1898 Untersuchungen über Spermatogenese. Arch. f. mikr. Anat., vol. $51, \mathrm{pp} .215-318$.

Leopold, Jerome S. ANd Reuss, A. von 1908 Ueber die Beziehungen der Epithelkörperchen zum Kalkebestand des Organismus. Wien klin. Wchnschr., pp. 1243-1246.

Lensch, B. M. 1871 Zur Geschichte der Rattophagie. Deutsche Klinik, Berl., vol. 23, p. 42 .

Levin, IsAaC 1908 The reactive power of the white rat to tissue implantation (Second communication.) Proc. Soc. Exper. Biol. and Med., vol. 5. pp. 41-43.

1910 Immunity to the growth of cancer induced in rats by treatment with mouse tissue. Proc. Soc. Exper. Biol. and Med., 38th meeting, April 20.

1910 a Resistance to the growth of cancer induced in rats by injection of autolyzed rat tissue. Proc. Soc. Exper. Biol. and Med., February 16 .

1911 The relation of the reactive stroma formation to the transplantability of the cancers of the white rat. J. Exp. Med., vol. 13, pp. 604615.

LEwin, C. 1912 Ueber Immunisierung mit Blutserum von spontan geheilten Tumorratten. Zeitschr. f. Krebsforsch., vol. 11, p. 334.

1912 a Immunisierungs und Heilversuche mit Autolysaten bei Rattentumoren. Zeitschr.f. Krebsforsch., vol. 11, p. 317.

Lewis, Frederic T. 1915 The comparative embryology of the mammalian stomach. Proc. of Am. Assoc. of Anatomists in Anat. Record, vol. 9, pp. 102-103.

LEWIS, W. BEvan 1881 On the comparative structure of the brain in rodents. Phil. Trans., 1882, pp. 699-749.

Leydig, F. 1850 Zur Anatomie der männlichen Geschlechtsorgane und Analdrüsen der Säugetiere. Ztschr. f. wiss. Zool., vol. 2, pp. 1-57, Taf. I-IV. 
LEYDIG, F. 1854 Kleinere Mitteilungen zur tierischen Gewebelehre. Arch.f. Anat. u. Entwcklngsgesch., pp. 296-348, pl. XII and XIII. Mus decumanus, pp. 341-345.

1857 Lehrbuch der Histologie des Menschen und der Tiere. Frankfurt a.M. $551 \mathrm{pp.}$ See p. 374 .

Liebe, K. Th. 1891 Zu dem Vorkommen der Hausratte (Mus rattus). Zoolog. Garten, 31 Jhg., pp. 156-157.

Lindner, Fr. 1891 Notiz über das Vorkommen der Hausratte (Mus rattus). Zoolog. Garten 31 Jhg., pp. 155-156.

Linnaeus, C. 1746 Fauna Suecica. Stockholm.

1758 Systema naturae, etc. Tome 1, Editio 10. p. 61, M. rattus-5 references.

1766 Systema naturae, etc. Tome 1, Editio 12 (Mus rattus only).

Linser, PAUL 1900 Ueber den Bau und die Entwicklung des elastischen Gewebes in der Lunge. Anat. Hefte, H. 42/43 (Bd. 13, H. 2/3) pp. 307335.

Liston, W. G. 1905 Plague, rats and fleas. J. Bombay Nat. Hist. Soc., vol. 16, p. 253.

1905 a The rats of India. Indian M. Gaz., Calcutta, vol. 40, pp. 130132.

Livini, Ferd. 1896 Intorno alla struttura della trachea. Monitore zool. ital. Anno 7. Mus decumanus, p. 103.

LLOYD, R.E. 1908 Remarkable cases of variation, I. Records Indian Museum, vol. 2, p. 29 .

1909 The races of Indian rats. Records of Indian Museum, vol. 3, pp. 1-100.

1909 a The relation between fertility and normality in rats. Records Indian Museum, vol. 3, pp. 261-265.

1910 Further observations on the races of Indian rats. Records of the Indian Museum, Calcutta, vol. 5, pt. II, pp. 105-115. Peculiar large groups.

1911 The inheritance of fertility. Biometrika, vol. 8, pp. 244-247.

1912 The growth of groups in the animal kingdom. London. 1 colored plate of three color varieties of Mus rattus.

Loeb, LeO 1901 On transplantation of tumors. J. Med. Research, vol. 6 (n.s. vol. 1-continuation of the Journ. of the Boston Soc. of Med. Sciences, pp. 28-38.

1902 Further investigations in transplantations of tumors. J. Med. Research, n.s. vol. 3, pp. 44-73.

1902 a Ueber Transplantationen eines Sarcoms der Thyreoidea bei einer weissen Ratte. Arch. f. path. Anat., vol. 167, pp. 175-191.

1903 Mixed tumors of the thyroid gland. Am. J. Med. Sc., vol. 125, pp. 243-256.

1903 a Über Transplantation von Tumoren. Arch. f. path. Anat., vol. 172 , pp. $345-368$.

1904 Ueber das endemische Vorkommen des Krebses beim Tiere Centralbl. f. Bakteriol. u. Parasitenk., vol. 37, pp. 235-245. 
Lоeв, Leo. 1907 Observations on the inoculability of tumors and on the endemic occurrence of cancer. Internat. Clin., vol. 3 , series 17, pp. 114-130.

1913 Venom of heloderma. Carnegie Inst., Wash., D. C. Pub. no. 177, pp. 250.

Loewenthal, N. 1894 Zur Kenntnis der Glandula infraorbitalis einiger Säugetiere. Anat. Anz., vol. 10, pp. 123-130.

1894 a Zur Kenntnis der Glandula submaxillaris einiger Säugetiere. Anat. Anz., vol. 9, pp. 223-229. White rat, pp. 224-225.

1897 Note sur le structure fine des glandes de Cowper du rat blanc. Bibliogr. Anat., vol. 4, pp.168-170. (1 text fig.)

1900 Drüsenstudien. II. Die Gl. infraorbitalis und eine besondere der Parotis anliegende Drüse bei der weissen Ratte. Arch. f. mikr. Anat., vol. 56, p. 535 .

1908 Drüsenstudien. III. Die Unterkieferdrüse des Igels und der weissen Ratte. Arch. mikr. Anat., vol. 71, pp. 588-666.

LogHeM, J. J. VAN 1908 Some notes on the morphology of Spirochaeta duttoni in the organs of rats. Ann. trop. Med. Parasit., vol. 1, pp. 521525 .

Loghem, J. J. van and Swellengrebel, N. H. 1914 Kontinuierliche und metostatische Pest verbreitung. Ztschr. f. Hyg. u. Infectionskrankh., vol. 77, p. 460 .

Loir, I. M. 1903 Dégâts causés par les rats. Caducée Par., vol. 3, p. 89.

LöNs, H. 1908 Mus rattus in Celle. Jahresber. nat. Ges., Hannover, pp.41-42.

Loves, C. 1868 Bidrag, till kännedomen om tungans smakpapiller. Med. Arch. Stockholm, vol. 3, 1866-1867. Trans. Beiträge zur Kenntnis vom Bau der Geschmackswärzchen der Zunge. Arch. f. mikr. Anat., vol. 4, pp. $96-110$.

Lowrey, LAwSON G. 1913 The growth of the dry substance in the albino rat. Anat. Record, vol. 7, pp. 143-168.

McCorudm, E. V. 1909 Nuclein synthesis in the animal body. Am. J. Physiol., vol. 25, pp. 120-141. Also in Research Bull. no. 8, Univ. of Wis. Agr. Exper. Station, May, 1910.

McCollum, E. V. and Davis, Margderite 1913 The influence of the composition and amount of the mineral content of the ration on growth. J. Biol. Chem., vol. 14, no. 2.

1913 a The necessity of certain lipins in the diet during growth. J. Biol. Chem., vol. 15, pp. 167-175.

1914 Further observations on the physiological properties of the lipins of the egg yolk. Proc. Soc. Exper. Biol. and Med., vol. 11, p. 101.

McCoy, George W. 1908 Distribution of the leprosy-like disease of rats in San Francisco, Cal. Pub. Health Rep. U. S. Mar. Hosp. Serv., Wash., vol. $23, \mathrm{p} .1601$.

1909 The keeping and handling of rats for laboratory purposes. ' N. Y. Med. J., vol. 89, p. 275.

1910 Plague infection in rats. Found in "The rat and its relation to the public health," pp. 29-48. Treasury Dept. Pub. Health and Mar. Hospt. Service of the U. S. Government Printing Office, Wash., D. C. 
McCoy, George W. 1910 a Organic diseases of the rat, including tumors. Found in "The rat and its relation to the public health," pp. 59-68. Treasury Dept. Pub. Health and Mar. Hospt. Service of the U. S., Government Printing Office, Wash., D. C.

McMunn, Charles A. 1884 On myohaematin, an intrinsic muscle-pigment of vertebrates and invertebrates, on histohaematin and on the spectrum of the suprarenal bodies. Proc. of Physiol. Soc. in J. of Physiol., vol. 5, pp. xxiv-xxvi.

MacCurdy, Hansford and Castle, W. E. 1907 Selection and cross-breeding in relation to the inheritance of coat pigments and coat-patterns in rats and guinea-pigs. Carnegie Inst., Wash., Pub. no. 70.

MacGillavry, T. H. 1875 Les dents incisives du Mus decumanus. Arch. Néerl. Sc. exact. et nat., Haarlem., vol. 10, 1 pl. Same as paper in Dutch, 1876.

1876 De snitjanden von M. decumanus. Vers. en mededed. der Kon. Akad. v. Wetensch., II. R. 9. Amsterdam. 1 pl.

MACLEOD, J. J.R. 1907 Observations on the excretion of carbon dioxide gas and the rectal temperature of rats kept in a warm atmosphere which was either very moist or very dry. Am. J. Physiol., vol. 18, pp. 1-13.

MAJor, C. J. Fonsyth Mus rattus remains at Molina di Anosa-near Pisa. Quoted at length by Baumgart, 1904, p. 8.

Mallory, F. B. AND ORDWAy, Thomas 1909 Lesions produced in the rat by a typhoid-like organism-Danysz virus. J. Am. Med. Assoc., vol. 52, p. 145.

Mandodz, H. 1909 Rats et pétrole. Arch. de parasitol., vol. 12, pp. 451-455.

Manodvrier, L. 1905 Un rapt de progéniture entre femelles de rat blanc. Bull. de l'Inst. gén. psychol., vol. 5, pp. 165-169.

MArchoux, E. 1910 Les migrations du bacille de la lèpre. Lepra, vol. 11, pp57-60. (II. Internationale wissenschaftliche Lepra-Konferenz abgehalten vom 16 bis 19 August, 1909, in Bergen. III. Band. Leipzig.) 1911 Culture d'un bacille acido-résistant provenant du mucus nasal des lépreux. (Note préliminaire.) Bull. Soc. path. exot., vol. 4, pp. 89-91.

1911 and 1912 Human leprosy and rat leprosy; a discussion of their respective problems. Tr. Soc. Trop. M. and Hyg., vol. 5, pp. 184-189. 1912 Rôle des infections secondaires dans le développement de la lèpre du rat. Bull. Soc. path. exot., vol. 5, pp. 466-468.

Marchodx, E. AND Sorel, F. 1912 Lepra murium; infection et maladie ne son t pas synonymes. Compt. rend. Soc. de Biol., vol. 72, pp. 169-171.

1912 a Lèpre des rats; comparaison avec la lèpre humaine. Compt. rend. Soc. de biol., vol. 72, pp. 214-217.

1912 b Lèpre des rats; inoculation expérimentale. Compt. rend. Soc. de biol., vol. 72, pp. 269-272.

$1912 \mathrm{c}$ Recherches sur la lèpre. $1^{\mathrm{er}}$ memoire: La lèpre des rats (lepra murium). Ann. de l'Inst. Pasteur, vol. 26, pp. 675-700.

MARK, E. L. AND LoNG, J. A. 1912 Studies on early stages of development in rats and mice. No. 3. The living eggs of rats and mice with a description of apparatus for obtaining and observing them. Univ. Cal. Pub. Zool., vol. 9, pp. 105-136. 
Marshall, F. H. A. AND Jolly, W. A. 1907 Results of removal and transplantation of ovaries. Tr. Roy. Soc. Edinb., vol. 45, pp. 589-597.

1908 On the results of heteroplastic ovarian transplantation as compared with those produced by transplantation in the same individual. Quart. J. Exper. Physiol., vol. 1, pp. 115-120.

Martin, Charles J. 1895 On the physiological action of the venom of the Australian black snake (Pseudechis porphysiacus). J. and Proc. Roy. Soc. of New South Wales, Sydney, vol. 29, pp. 146-277. Rat among test animals.

Martin, H. N. and Moale, W. A. 1884 Handbook of vertebrate dissection. Part III. How to dissect a rodent. Macmillan \& Co., N. Y. Mus decumanus the rodent used.

Martini, E. 1901 Ueber Inhalationspest der Ratten. Ztschr. f. Hyg., vol. 38, p. 332 .

Martinotti, Giovanni 1889 Le reti nervose del fegato e della milza scoperte dal Prof. G. Rattone. Gior. d. r. Accad. di med. di Torino, Anno 52, vol. 37, pp. 15-30.

Matthes, M. and Marquardsen, E. 1898 Uber die Reaktion des Dünndarminhaltes. Verhaldl. des Congresses für innere Med. XVI. Wiesbaden, pp. 358-365.

Mavrojannis 1903 L'action cataleptique de la morphine chez les rats. Contribution à la théorie toxique de la catalepsie. Compt. rend. Soc. de Biol., vol. 55, p. 1092.

MAYer, F. J. C. 1843 Ueber die Zunge als Geschmacksorgan. Nov.Act.Acad. C. L.-C. nat. cur., vol. 20, pp. 721-748. 4 pl. Mentions Mus rattus among other forms.

Maxer, S. 1894 Adenologische Mitteilungen. Anat. Anz., vol. 10, pp.177191. Rat, p. 179.

Mazzarelli, G. F. 1890 Sulla structura dello stomaco del Mus decumanus Pall, var. alba, e del Mus musculus L. Internat. Monatsschr. Anat. Phys., vol. 7, pp.91-96, T.8 (1) pl. VIII, figs. 1, 3 and 4. M. decumanus var. alba.

Meer, Alexander 1899 On the post-embryonal history of voluntary muscles in mammals. J. Anat. and Physiol., vol. 33, p. 601.

Meek, Walter J. 1907 A study of the choroid plexus. J. Comp. Neur. and Psychol., vol. 17, no. 3, pp. 286-306.

Melissinos, Konst. 1907 Die Entwicklung des Eies der Mäuse (Mus musculus var. alba u. Mus rattus albus) von den ersten Furchungs-Phänomenen bis zur Festsetzung der Allantois an der Ectoplacentarplatte. Arch. f. mikr. Anat., vol. 70, pp. 577-628.

Mellanby, Edward 1908 Creatin and creatinin. J. Physiol., vol. 36, pp. 447-487. Rat, p. 472 .

Mendel, L. B. And Daniels, Amy L. 1912 The behavior of fat-soluble dyes and stained fat in the animal organism. J. Biol. Chem., vol. 13, p. 71.

Mendel, L. B. 1913 The role of proteins in growth. Trans. XV Internat. Congress on Hyg. and Demography.

Mereshrowsky, S. S. AND Sarin, E. 1909 Ueber das Ratin II. Centralbl. f. Bakteriol., 1 Abt., Jena, vol. 51, pp. 6-10. 
Mereshiowsky, S. S. 1912 Der Einfluss der Passagen durch graue Ratten (Mus decumanus) auf die Virulenz des Bacillus Danysz. Centralbl. f. Bakteriol., vol. 62 , pp. 3-68.

1912 a Die Wirkung der 186.-515. in 10 proz.Hühnereiweissdekokt erwachsenen Generationen des Bacillus Danysz auf graue Ratten (Mus decumanus). Centralbl. f. Bakteriol., 1 Abt., vol. 65, pp. 482-488.

Messer 1889 Das Vorkommen der Hausratte, Mus rattus, in Bremen. Zoolog: Garten, 30 Jahrg., pp. 26-27.

Metschnikoff and Roux 1891 Sur la propriété bactéricide du sang de rat. Ann. de l'Inst. Pasteur, no. 8, p. 479. Also Centralbl. f. Bacteriol., vol. 10 , p. 756 .

Meves, F. 1898 Ueber das Verhalten der Centralkörper bei der Histogenese der Samenfäden von Mensch und Ratte. Verhandl.d.anat. Gesellsch. 12 Vers., pp. 91-98. Diss. p. 98-100.

Meyer, Nicholaus 1800 Prodromus Anatomiae Murium. Inaug.-Diss. Jena, 40 pp., 2 pl. (50 figs.). Copper plates based on mouse-figures enlarged by 3. Gives teeth and ear bones. Dedicated to Goethe.

Meyerheim, Martin 1898 Beiträge zur Kenntnis der Entwicklung der Schneidezähne bei Mus decumanus. Inaug.-Diss. Universität Leipzig, Pöschel \& Trepte, Leipzig.

MiddendorfF, A.v. 1875 Reise in den äussersten Norden und Osten Sibiriens. Bd. 4 Uebersicht der Natur Nord und Ost-sibiriens. Teil 2. St. Petêrsburg, Kommission d. Akademie.

Mrluars, J. G. 1904 Mammals of Great Britain and Ireland. 4 . Pp. 203-232. Excellent colored plates for Mus norvegicus and Mus rattus.

1905 The true position of Mus rattus and its allies. $1 \mathrm{pl}, 2$ figs. The Zoologist, ser. 4, vol. 9, pp. 201-207. Figures of Mus rattus ater.

Mrller, Gerrit S. JR. 1910 The generic name of the house rat. Proc. Biol. Soc. Wash., vol. 23, pp. 57-60.

Miller, Newton 1911 Reproduction in the brown rat (Mus norvegicus). Am. Naturalist, vol. 45, pp. 623-635.

Miller, W. S. 1893 The structure of the lung. J. Morphol., vol. 8, pp. 165188. 3 plates and other illustrations in text. Rat used with other mammals.

Mrlls, Wesley 1897 The functional development of the cerebral cortex in different groups of animals. Trans. R. Soc. Canada, vol. 2, Sect. IV, pp. 3-18.

Milne-Edwards See Edwards, Milne.

Minot, C. S. 1900 On a hitherto unrecognized form of blood circulation without capillaries in the organs of vertebrata. Proc. of Boston Soc. of Nat. Hist., vol. 29, pp. 185-215. p. 207, Suprarenal capsule-rat.

Mitchell, O. W. H. 1912 Bacillus muris as the etiological agent of pneumonitis in white rats and its pathogenicity for laboratory animals. J. Infect. Dis., vol. 10, pp. 17-23.

Mrtchell, P. C. 1911 Longevity. (Rat, 5-6 years.) Encyc.Britannica, 11th ed., vol. 16, p. 976 (middle of first column).

Mojsisovics, von Mossvár 1897 Das Tierleben der österr.-ungar. Tiefebenen. Wien, Hölder, 1897. 
Montane, M. 1889 De la cytodierèse dans le testicule du rat. Compt. rend. Soc. de biol., Paris, vol. 1, 9 th series.

Moreschi, C. 1909 Beziehungen zwischen Ernährung und Tumorwachstum. Zeitschr. f. Immunitätsforschung, vol. 2, pp. 651-685.

Morgan, T. H. 1909 Breeding experiments with rats. Am. Naturalist, vol. 43, pp. 182-185.

Morgulis, Sergius 1911 Studies of inanition in its bearing upon the problem of growth. I. Arch. f. Ent. d. Organ., vol. 32, pp. 169-268.

Morpurgo, B. 1898 Uber die postembryonale entwickelung der quergestreiften Muskeln von weissen ratten. Anat. Anz., vol. 15, pp. 200-206.

1899 Ueber die Verhältnisse der Kernwucherung zum Längenwachstum an den quergestreiften Muskelfasern der weissen Ratten. Anat. Anz., vol. 16, pp. 88-91.

1899 a Ueber die Regeneration des quergestreiften Muskelgewebes bei neugeborenen weissen Ratten. Anat. Anz., vol. 16, pp. 152-156. 1901 Ueber eine infectiöse Form von Knochenerweichung bei weissen Ratten. Verhandl. d. Versamml. d. Gesellsch. f. Kinderh. deutsch. Naturf. u. Aerzte, vol. 72.

1902 Durch Infection hervorgerufene malacische und rachitische Skelet-veränderungen an jungen weissen Ratten. Centralbl. f. allg. Path. u. path. Anat., vol. 13, pp. 113-119.

Morrell, G. Herbert 1872 Supplement to the anatomy of the mammalia, containing dissections of the sheep's heart and brain, rat, sheep's head and ox's eye. Longman \& Co., London, pp. 153-269.

Moss, Samuel 1836 Notes on the habits of a domesticated white rat and a terrier dog (Flora) that lived in harmony together. London Mag. Nat. Hist., vol. 9.

Modret, J. 1895 Contribution à l'étude des cellules glandulaires (pancréas). J. de l'anat. et physiol. Ann. 31, pp. 221-236, 1 pl. Mainly on frog and salamander. Rat among the mammals examined.

MUDGE, G. P. 1908 On some features in the hereditary transmission of the self black and the Irish coat characters in rats. Proc. R. Soc. London, vol. $80 \mathrm{~B}$, pp. 97-121.

1908 a On some features in the hereditary transmission of the albino character and the black piebald coat in rats. Proc. R. Soc. London, vol. $80 \mathrm{~B}$, pp. 388-393.

1909 Note on the chemical nature of albinism. J. Physiol., vol. 38, p. Ixvii.

1910 Article "Albino." Encyc. Brit., vol 1, p. 510 at the bottom, 11 th ed. Recognizes 13 gametic types of the albino rat.

Mueller, Claus 1902 Utber die Tyson'schen Drüsen beim Menschen und einigen Säugetieren. Inaug.-Diss. Friedrichs-Universität,Halle-Wittenberg.

MÜller, Johannes 1830 De glandularum secernentium structura penitiori earumque prima formatione in homine atque animalibus. Leipzig, 131 pp., $17 \mathrm{pl}$.

MÜnch, Francis 1896 Die Topographie der Papillen der Zunge des Menschen und der Säugethiere. Morphol. Arb., vol. 6, pp. 605-690, 2 pl., 53 text figs. Rat, pp. $615,616$. 
Munson, T. M. 1910 An efficient rat killing device for use on board ship. U. S. Nav. M. Bull., Wash., vol. 4, p. 514.

MURPhy, James B. 1914 Heteroplastic tissue grafting effected through Roentgen-ray lymphoid destruction. Journ. Am. Med. Assoc., vol. 62, p. 1459 .

Murray, ANDrew 1866 Geographical distribution of mammals. London, Day and Son. $4^{\circ}$.

Nerking, Joseph 1909 Narkose und Lezithin. Münch. med. Wochenschr. 56, II, pp. 1475-1478.

NeUmark, E. 1913 Ueber die Bedeutung von Bakterienpräparaten als Rattenvertilgungsmittel. Gesundh.-Ingenieur, München, vol.36, pp.589 -591 .

Nicolas, A. 1890 Sur les cellules à grains du fond des glandes de Lieberkühn. Bull. des séances de la Soc. des Sciences de Nancy, An. 2, pp. 45-49.

Ohlmacher, A. P. 1897 A modified fixing fluid for general histological and. neuro-histological purposes. J. Exper. Med., vol. 11.

OLDs, W. H. 1910 The effects of thyroidectomy on the resistance of rats to morphine poisoning. Am. J. Physiol., vol. 26, pp. 354-360.

Ophưls, W. 1911 Spontaneous nephritis in wild rats. Proc. Soc. Exper. Biol. and Med., 42nd meeting, February 15.

Ordway, Thomas and Morris, J. Lucien 1913 The protein metabolism in certain tumor-bearing rats. J. Med. Research, vol. 28, (N.S. vol. 23), pp. 301-308.

OrI, A. 1912 Pseudotubercolosi nei topi (M.decumanus) catturati nel porto di Venezia. Igiene mod., Genova, v. pp. 233-242.

Osborne, T. B. and Mendel, L. B. 1911 Feeding experiments with mixtures of isolated food substances. Am. J. Physiol., vol. 27, p. xxvi.

1911 a Feeding experiments with isolated food substances. Carnegie Inst. Wash., Pub. 156, parts I and II.

$1911 \mathrm{~b}$ The rôle of different proteins in nutrition and growth. Science vol. 34, pp. 722-732.

1912 The rôle of proteins in growth. Proc. Am. Soc. Biol. Chem. J. Biol. Chem., vol. 11, p. xxii.

1912 a Maintenance and growth. Proc. Am. Soc. Biol. Chem., J. Biol. Chem., vol. 11, p. xxxvii.

1912 b Feeding experiments with fat-free food mixtures. Proc. Soc. Exper. Biol. and Med., vol. 9, p. 73. Also J. Biol. Chem., vol. 12, pp. 81-89.

1912 c Growth and maintenance on purely artificial diets. Proc. Soc. Exper. Biol. and Med., vol. 9, p. 72.

1912 d Ein Stoffwechselkäfig und Fütterungsvorrichtungen für Ratten. Ztschr. biol. Techn. u. Methodik, vol. 2, pp. 313-318.

1912 e Beobachtungen über Wachstum bei Fütterungsversuchen mit isolierten Nahrungs-substanzen. Ztschr. f. physiol. Chem., vol. 80, pp. 307-370.

$1912 \mathrm{f}$ The rôle of gliadin in nutrition. J. Biol Chem., vol. 12, pp. 473-510.

$1912 \mathrm{~g}$ Maintenance experiments with isolated proteins. J. Biol. Chem., vol. 13, pp. 233-276. 
Osborne, T. B. 1913 The nutritive value of the proteins of maize. Science, N. S., vol. 37, pp. 185-191.

Osborne, T. B. And Mendel, L. B. 1913 Feeding experiments relating to the nutritive value of the proteins of maize. Proc. Am. Soc. Biol. Chem. in J. Biol. Chem., vol. 14, p. xxxi.

1913 a The relation of growth to the chemical constituents of the diet. J. Biol. Chem., vol. 15, pp. 311-326.

$1913 \mathrm{~b}$ The influence of butter-fat on growth. J. Biol. Chem., vol. 16, pp. 423-437. Also in Proc. Soc. Exper. Biol. and Med., vol. 11, pp. 14-15.

1914 Some problems of growth. Am. J. Physiol. vol. 33, p. xxviii.

1914 a Amino acids in nutrition and growth. J. Biol. Chem., vol. 17, p. 325 .

$1914 \mathrm{~b}$ Influence of cod liver oil and some other fats on growth. J. Biol. Chem., vol. 17, p. 401.

1914 c Nutritive properties of proteins of the maize kernel. J. Biol. Chem., vol. 18, pp. 1-16.

$1914 \mathrm{~d}$ The suppression of growth and the capacity to grow. J. Biol. Chem., vol. 18, pp. 95-106.

$1914 \mathrm{e}$ The contribution of bacteria to the feces after feeding diets free from indigestible components. J. Biol. Chem., vol. 18, pp. 177182.

1915 The influence of beef-fat on growth. Given at Soc. for Exper. Biol. and Med., 64th Meeting, Jan. 20, 1915.

Oudemans, J. Th. 1892 Die accessorischen Geschlechtsdrüsen der Säugetiere. Haarlem, 96 pp. 16 pl. $4^{\circ}$.

Ovalle, Alonso de 1646 An historical relation of the Kingdom of Chili, 1646. Translated from Spanish into English, London, 1703, in A. \& J. Churchill's "A collection of voyages and travels." vol.3, London, 1704. p. 44 rat or pericote.

OWEN, RICHARD 1840-1845 Odontography; or a treatise on the comparative anatomy of the teeth; their physiological relations, mode of development, and microscopic structure in the vertebrate animals. 2 v., xix, $74,655 \mathrm{pp}$; atlas, $37 \mathrm{pp} .150 \mathrm{pl}$. roy. $8^{\circ}$. London, H. Baillière.

1868 On the anatomy of vertebrates. London, 1866-1868. Vol. 3, Mammals, 1868. Mus decumanus, alimentary canal, p.421 and fig. 317; No gall bladder, p. 485; Low type of pancreas, p. 493 and fig. 380 (Hyde Salter).

Pallas, Pietro 1778 Novae species Quadrupedum e Glirium mordine. Erlangen. 1831 Zoographica Rosso-Asiatica. Sistens omnium animalium in extenso imperio rossico et adjacentibus maribus observatorium recensionem domicilia, mores et descriptiones, anatomen atque icones plurimorum. Petropoli, vol. 1, p. 164.

Paneth, J. 1888 Ueber die secernierenden Zellen des Dünndarm-Epithels. Arch. f. mikr. Anat., vol. 31, pp. 113-191., 3 pl. Mainly Triton and mouse. Rat: see figs. $30,31, \mathrm{pl}$. X.

1888 a Ein Beitrag zur Kenntniss der Lieberkühn'schen Krypten. Centralbl. f. Physiol., vol. 1, pp. 255-256. 
PAUL, C. B. 1906 On the influence of an excessive meat diet on the male reproductive organs. J. Physiol, vol. 34, pp. xiv-xv.

Pearson, Karl 1910 Darwinism, biometry and some recent Biology I. Biometrika, vol.:7, part 3, pp. 368-385.

1911 Remarks on Professor Lloyd's note on inheritance of fertility. Biometrika, vol. 8, pp. 247-249.

Pembrey, M. S. 1895 The effect of variations in external temperature upon the output of carbonic acid and the temperature of young animals. J. Physiol., vol. 18. pp. 363-379.

Pembrey, M. S. and Spriggs, E. I. 1904 The influence of fasting and feeding upon the respiratory and nitrogenous exchange. J. Physiol., vol. 31, pp. 320-345.

Pennant, Thos. 1781 History of quadrupeds. 2 vols. London. Vol. II. Rats. M.rattus introduced into South America in 1544-time of Viceroy Blasco Minez. (Minez-a misprint for Núñez.)

Peters, Albert 1890 Beitrag zur Kenntniss der Harder'schen Drüse. Arch.f. mikr. Anat., vol. 36, pp. 192-203.

Petrie, G. F. 1910 Rats and plague. Nature, vol. 85, pp. 15-16. Historical: Late association circa 1800 of rat with plague.

Prtrs 1898 Article "Animal heat" in Schäfer's Text Book of Physiol., vol. 1, p. 790 .

Plimmer, H. G. and Thomson, J. D. 1908 Further results of the experimental treatment of trypanosomiasis in rats; being a progress report of a Committee of the Royal Society. Proc. R. Soc. London, vol. 80 B, pp.1-12.

Ploschko, Adam and v. Arnstein 1897 Die Nervenendigungen und Ganglien der Respirationsorgane. Anat. Anz., vol. 13, pp. 12-22. 1 fig. Rat.

Podwisotzky, Valerian 1878 Anatomische Untersuchungen über die Zungendrüsen des Menschen und der Säugethiere (bothM. decumanus and M. rattus). Inaug.-Diss. Dorpat., 144 pp., 2 pl.

Podwyssotzki, W. 1882 Beiträge zur Kenntnis des feineren Baues der Bauchspeicheldrüse. Arch. f. mikr. Anat., vol. 21, pp. 765-768. Rat exam-

ined. Results apply especially to the dog.

Poljakoff, P. 1888 Ueber eine neue Art von fettbildenden Organen im lockern Bindegewebe. Arch. f. mikr. Anat., vol. 32, pp. 123-182.

Poll, Heinrich 1898 Ueber das Schicksal der verpflanzten Nebenniere. Centralbl. f. Physiol., yol. 12, pp. 321-326.

1899 Veränderungen der Nebenniere bei Transplantation. Arch. f. mikr. Anat., vol. 54, pp. 440-481.

Pontier and Gérard, G. 1900 De l'entre-croisement des pyramides chez le rat. Leur passage dans le faisceau de Burdach (note préliminaire). Bibliogr. anat. Nancy, vol. 8, pp. 186-190, Ten figures-sections of the bulb.

Poppe, K. 1913 Pseudotuberkulose. in (Kolle, Willemlu and Wassermann, A. v (eds). Handbuch der pathogenen Mikro-organismen, 2nd ed.enl. vol. 5, part 2, pp. 779-781.

Pottevin, H. 1910 La dératisation rapport sur l'état actuel des méthodes applicables a la déstruction des rongeurs et de leurs parasites. Bull. de l'Office internat. d'hyg. pub. Par., vol. 2, pp. 542-613. 
Pound, C. J. 1905 On trypanosoma and their presence in the blood of Brisbane rats. Proc. R. Soc. Queensland, vol. 19, pp. 33-38.

PreYer, W. 1866 Quantitative Bestimmung des Farbstoffs im Blute durch das Spectrum. Annalen der Chemie u. Pharmacie, vol. 140, pp. 187200. Rat, p. 198.

1871 Die Blutkrystalle. Mauke's Verlag, Jena. Rat: pp. 3, 13, 16, $38,127$.

Prodromus, Theodorus See Keller, Otto '09.

Przibram, Hans 1907 Demonstrationen über Vererbung bei Säugetieren. Zentralbl. f. Physiol., vol. 21, p. 257.

1910 Uebertragungen erworbenerEigenschaften bei Säugetieren. Versuche mit Hitze-Ratten. Verh. Ges. deutsch. Nat. Aertze Vers. 81, Tl, 2, Hälf te 1, pp. 179-180.

1911 Albinismus bei Inzucht. Verhandl. d. naturf. Ver. in Brünn, vol. 49 (Festband für Mendel).

1912 Ueber das Vorkommen der Hausratte (Mus rattus L.) in Oesterreich. Wochenschr. Das österreichische Sanitätswesen, no. 16, pp. 297-299.

QUINQUAOD 1873 Sur les variations de l'hemoglobine dans la serie zoölogique. Compt. rend. de l'Acad. de Science, Paris, vol. 77, pp. 487-489.

Rabinowitsch, L. AND Kempner, W. 1899 Beitrag zur Kenntnis der Blutparasiten, speciell der Ratten-trypanosomen. Zeitschr. f. Hyg., vol. 30 , p. 251.

Ramachandrier, P. S. 1908 Rat destruction in India (Abstr.). Med. Times, Lond., vol. 36, p. 319.

Ramón y Cajal, S. See Cajal, S. Ramón.

RAMStröM, M. 1905 Untersuchungen und Studien über die Innervation des Peritoneum der vorderen Bauchwand. Anat. Hefte, vol. 29, pp. 351443. Mus decumanus, p. 372.

RaNson, S. W. 1903 On the medullated fibers crossing the site of lesions in the brain of the white rat. J. Comp. Neur., vol. 13, pp. 185-207.

1904 Retrograde degeneration in the corpus callosum of the white rat. J. Comp. Neur. and Psychol., vol. 14, pp. 381-389.

1906 Retrograde degeneration in the spinal nerves. J. Comp. Neur. and Psychol., vol. 16, pp. 3-31.

1913 The fasciculus cerebrospinalis in the albino rat. Am. J. Anat., vol. 14, p. 411.

1914 A note on the degeneration of the fasciculus cerebro-spinalis in the albino rat. J. Comp. Neur., vol. 24, pp. 503-507.

1914 a The tract of Lissauer and the substantia gelatinosa rolandi. Am. J. Anat., vol. 16, pp. 97-126.

Ranvier, L. A. 1883 De l'éxistence et de la distribution de l'éléidine dans la muquese bucco-oesophagienne des Mammifères. C. R. de l'Acad. des Sc. Paris, vol. 97, pp. 1377-1379.

1884 Les membranes muqueuses et le système glandulaire. J. de microg., vol. 8, pp. 29-38; 77-86; 142-150; 194-200; 310-317; 419-422.

1885 Les membranes muqueuses et le système glandulaire. Le foie (Rat). J. de microg., vol. 9, pp. 6-14;55-63;103-109;155-163; 194-201 ; $240-247$; 287-295; 334-343; 389-396; 438-445; 480-482. 
Ranvier, L. A. 1886 Les membranes muqueuses et le système glandulaire. Le foie. J. de microg., vol.10, pp. 5-10; 55-58;160-166;211-214;355-362; 443-447.

1886 a Etude anatomique des glandes connues sous les noms de sousmaxillaire et sublinguale, chez, les mammifères. Arch. de physiol. norm. et path., ser.3, vol.8, pp.223-256. M. decumanus, p. 224, fig.1. 1887 Le mécanisme de la sécrétion. M. decumanus, see p. 530. J. de microg., vol. 11, pp. 527-534.

1888 Le mécanisme de la sécrétion. J. de microg., vol.12,pp.3-11;33 $-41 ; 65-73 ; 104-111 ; 165-173 ; 212-218 ; 243-250 ; 298-303 ; 329-335 ; 364-$ $368 ; 389-393$.

1894 Des chyliferes du rat et de l'absorption intestinale. Compt. rend. acad. d. sc. Paris, vol. 118, pp. 621-626.

RAPP, W.v. 1839 Ueber die Tonsillen. Arch.f.Anat., Physiol., u. wiss. Med., pp. 189-199. Pl. VII and VIII. Absence of tonsils.

Rattone, G. ANd Mondino, C. 1888 Sulla circolazione del sangue nel fegato. Giorn. di sc. nat. ed econ., vol. 19, pp. 125-136., 2 pl.

1888 a Sur la circulation du sang dans le foie. Arch. ital. de biol., vol. 9 , fasc. 1 , pp. 13-15.

1889 Sur la circulation du sang dans le foie. Arch. ital. de biol., vol. 12, pp. 156-177, $2 \mathrm{pl}$. (Abrégé d'un travail duquel la $1^{\circ}$ partie a été publiée à Palerme, la $2^{\circ}$ dans l'Arch. per le sc. med., Torino, vol. 13, no. 3.) Rat among animals used.

1889 a Sulla circolazione del sangue nel fegato, pt. 2. Arch. per le sc. med., vol. 13, pp. 45-72, 1 pl.

Rauther, MAx 1903 Ueber den Genitalapparat einiger Nager u. Insektivoren, insbesondere die accessorischen Genitaldrüsen derselben. Jenaische Ztschr. f. Naturw., vol. 38, pp. 377-472. 3 pl.

Reaney, M. F. and Malcolmison, G. E. 1908 Rat destruction in Kamptree. Indian M. Gaz., Calcutta, vol. 43, p. 338.

Regaud, CL. 1900 - Note sur le tissu conjonctif du testicule chez le rat. Compt. rend Soc. de Biol., vol. 52, pp. 26-27.

1900 a Dégénérescence des cellules séminales chez les mammifères en l'absence de tout état pathologique. Compt. rend. Soc. deBiol., Paris, vol. 52 , pp. 268-270.

$1900 \mathrm{~b}$ Note sur certaines différenciations chromatique observées dans le noyau des spermatocytes du rat. Compt. rend. Soc. de biol., Paris, vol.52, pp. 698-700.

1900 c La sécrétion liquide de l'epithélium séminal; son processus histologique. Compt. rend. Soc. de Biol., vol. 52, pp. 912-914.

$1900 \mathrm{~d}$ Les phases et les stades de l'onde spermatogénetique chez les mammifères (rat). Classification rationnelle des figures de la spermatogenèse. Compt. rend. Soc. de biol., Paris, vol. 52, pp. 1039-1042.

1900 e Diréction hélicoïdale du mouvement spermatogénétique dans les tubes séminifères du rat. Compt. rend. Soc. de biol., Paris, vol. 52, pp. 1042-1044.

$1900 \mathrm{f}$ Les phénomènes sécrétoires du testicule et la nutrition de l'epithélium séminal. Compt. rend. Soc. de viol., Paris, vol. 52, pp. 11021104. 
Regaud, Cl. 1901 Pluralité des karyokinèses des spermatogonies chez les mammifères (rat). Compt. rend. Soc. de biol., Paris, vol. 53, pp. $56-58$.

1901 a Division directe ou bourgeonnement du noyau des spermatogonies, chez le rat. Compt. rend. Soc. de biol., Paris, vol. 53, pp. 74-76.

1901 b Variations de la chromatine nucléaire au cours de la spermatogenèse. Compt. rend. Soc. de biol., Paris, vol. 53, pp. 224-226.

1901 c Sur le mode de formation des chromosomes pendant les karyokinèses des spermatogonies, chez le rat. Compt. rend. Soc. de biol., Paris, vol. 53, pp. 406-407.

1901 d Note sur les cellules glandulaires de l'épididyme du rat. Compt. rend. Soc. de biol., Paris, vol. 53, pp. 616-618.

1902 Sur l'existence de cellules séminales dans le tissu conjonctif du testicule, et sur la signification de ce fait. Compt. rend. Soc. de biol., Paris, vol. 54, pp. 745-747.

1902 a Note histologique sur la sécrétion séminale du moineau domestique. Compt. rend. Soc. de biol., Paris, vol. 54, pp. 583-585.

1903 Quelques faits nouveaux relatifs aux phénomènes de sécrétion de l'épithélium séminal du rat. Compt. rend. de l'Ass. d. anat. Nancy, vol. 5, pp. 179-186. Bibliographie anatomique Suppl. 1903.

1904 Variations histochimiques du filament axile pendant le développement des spermies, chez le rat. C. R. Ass. Anat. Sess. 6, p. 202.

Rehn, James A. G. 1900 An older name for the Norway rat. Proc. Biol. Soc. Wash., vol. 13, p. 167. Mus decumanus (Pall) to Mus (Epimys) norvegicus (Erxleben). Merely a three line note.

Reichardt, Martin 1906 Ueber die Untersuchung des gesunden und kranken Gehirnes mittels der Wage. Arb. a. d. psychiat. Klin. zu Würzburg, part 1.

Rerchert, E. T. And Brown, A. P. 1909 The differentiation and specificity of corresponding proteins and other vital substances in relation to biological classification and organic evolution: The crystallography of hemoglobins. Carnegie Inst. of Wash., Wash., D. C., pp. 229-237. The blood of the rat.

Remlinger, P. 1904 Rage expérimentale de la souris et du rat. Compt. rend. Soc. de biol., vol. 56, p. 42.

Renaut, J. 1904 Les cellules fixes des tendons de la queue du jeune rat sont toutes des cellules connectives rhagiocrines. C. R. Soc. Biol. Paris, vol. 56, pp. 1067-1069.

Renson, Geo. 1882 De la spermatogenèse chez les mammifères. Arch. de biol., vol. 3, pp. 291-334.

Reports on Plague Investigations in India 1906 Issued by the Advisory Committee appointed by the Secretary of State for India, the Royal Society and the Lister Institute. J. Hyg., vol. 6, pp. 421-536; vol. 7, pp. 324-476; pp. 694-986.

Retterer, Ev. 1905 Des ménisques interarticulaires du genou du Cobaye et du Rat. C. R. Soc. Biol. Paris, vol. 58, pp. 44-47. 
Retzius, A. 1841 Ueber den Bau des Magens bei den in Schweden vorkommenden Wühlmäusen (Lemmus Nilss., Hypudaeus Jllig.) (A. d.Schwed. von F. C. H. Creplin.) Taf. XIV. fig. 2-9. Archiv. für Anat. u. Physiol., pp. 403-420. Comparisons with Mus decumanus.

Retzids, Gustaf 1893 Biologische Untersuchungen, Neue Folge V. 2. Studien über Ependym und Neuroglia, pp. 9-15. Samson \& Wallin. Stockholm.

1894 Biologische Untersuchungen. Neue Folge VI, 1. Die Neuroglia der Neurohypophyse der Säugetiere, pp.1-28. Samson \& Wallin, Stockholm.

1909 Biologische Untersuchungen, 14. Die Spermien der Nagetiere. Taf. XI-XLVIII, Taf. XLIX, fig. 13-20, pp. 133-162. p. 160, Mus norvegicus Erxl. (Mus decumanus Pall) Neue Folge, XIV. Gustav Fischer, Jena.

Richardson, Florence 1909 A study of sensory control in the rat. Psych. Monographs, vol. 12, no. 1, pp. 1-124.

Ringeling, H. G. 1912 Naar aanleiding van een opvallende sterfte onder de ratten aan boord van een stoomschips te Amsterdam. Tijdschr. v. sociale hyg. Zwolle, xiv, 29-53.

Ritzema-Bos, J. 1894 Untersuchungen über die Folgen der Zucht in engster Blutverwandtschaft. Biol. Centralbl., vol. 14, pp. 75-81.

Robertson, T. B. 1908 On the normal rate of growth of an individual and its biochemical significance. Arch. f. Entwcklngs-mechn. d. Organ., vol. 25, pp. 571-614.

1912 Studies in the blood relationship of animals as displayed in the composition of the serum proteins. I. A comparison of the serum of the horse, rabbit, rat and ox with respect to their content of various proteins in the normal and in the fasting condition. J.Biol. Chem., vol. 13, p. 325 .

Robertson, T. B. And Burnett, T. C. 1913 The influence of lecithin and cholesterin upon the growth of tumors. J. exper. Med., vol. 17, pp. 344 352.

Robinson, Arthur 1889 Observations on the early stages in the development of the lungs of rats and mice. J. of Anat. $u$ Physiol., vol. 23, pp. 224241.

1892 Some points in the early development of Mus musculus and Mus decumanus; the relation of the yolk-sac to the decidua and the placenta. Rep. Brit. Assoc. Adv. Sc., 61st Meeting, Cardiff, pp. 690691.

1892 a Observations upon the development of the spinal cord in Mus musculus and Mus decumanus. Rep. Brit. Assoc. Adv. Sc.,61st meeting, Cardiff, pp. 691-692.

1896 On the formation and structure of the optic nerve, and its relation to the optic stalk. J. Anat. and Physiol., vol. 30, pp. 319-333.

1904 Lectures on the early stages in the development of mammalian ova and on the differentia tion of the placenta in different groups of mammals. J. Anat. and Physiol., vol. 38, pp. 186-204. 
Roвinson, G. H. 1913 The rats of Providence and their parasites. Am. J. Pub. Health, vol. 3, pp. 773-776.

Rodwell, James 1858 The rat: Its history and destructive character. G. Routledge \& Co., London.

Rohde, Alice and Jones, Walter 1909 The purine ferments of the rat. J. Biol. Chem., vol. 7, p. 237.

Römer, F. 1896 Studien über das Integument der Säugethiere. I. Entwickel. d. Schuppen u. Haare am Schwanze u. an d. Füssen v. Mus decumanus und einigen anderen Muriden. Jenaische Zeitschr. f. naturw., vol. 30, pp. 603-622. Two plates mainly from M. n. albinus.

Rosenat, M. J. 1901 An investigation of a pathogenic microbe (B. typhi murium Danyz) applied to the destruction of rats. Bull. no. 5, Hyg. Lab., U. S. Mar. Hosp. Serv. Wash.

1910 The in efficiency of bacterial viruses in the extermination of rats. Found in "The rat and its relation to the public health," pp. 179-204. Treasury Dept. Pub. Health and Mar. Hospt. Service of the U. S. Government Printing Office, Wash., D. C.

Rosenfeld, Carl 1899 Zur vergleichenden Anatomie des Musculus tibialis posticus. Anat. Hefte, vol. 11, pp. 361-388. Mus rattus, p. 364 .

Rотн, A. H. 1905 The relation between the occurrence of white rami fibers and the spinal accessory nerve. J. Comp. Neur. and Psychol., vol. 15, pp. 482-493.

Rous, Peyton 1911 The rate of tumor growth in underfed hosts. Proc.of Soc. for Exper. Biol. and Med., vol. 8, pp. 128-130.

1914 The influence of diet on transplantable and spontaneous mouse tumors. J. Exp. Med., vol. 20, p. 433.

Rowland, SydNey 1911 Preliminary observations on the protective and curative value for rats of the serum of a horse immunised with a toxic nucleo-protein extracted from the plague bacillus. J. of Hyg., Plague Suppl. 1, 6th Report of Plague Investigations in India, pp. 11-19.

Rubeli, O. 1890 Ueber den Oesophagus des Menschen und der Hausthiere. Ztschr. f. wissensch. Mikr., vol. 7, pp. 224-225.

Rucker, William C. 1910 Rodent extermination. Found in "The rat and its relation to the public health," pp. 153-162. Treasury Dept. Pub. Health and Mar. Hospt. Service of the U. S. Government Printing Office, Washington, D. C.

1912 How to poison rats. Pub. Health Rep., U. S. Mar. Hosp. Serv., Wash., vol. 27, p. 1267.

1913 Deratization of rat-proof buildings. Pub. Health Rep. Wash., vol. 28, p. 254 .

RYDER, J A. 1888 A theory of the origin of placental types, and on certain vestigiary structures in the placentae of the mouse, rat and field mouse. Am. Naturalist, vol. 21, pp. 780-784.

Rrwosch, D. 1907 Vergleichende Untersuchungen über die Resistenz der Erythrocyten einiger Säugethiere gegen hämolytische Agentien. Arch. f. d. ges. Physiol., vol. 116, pp. 229-251. 
Sabrazès, J. ANd Muratet 1905 Fréquence des Trypanosomes chex Mus rattus. Rareté chez Mus decumanus et chez Mus musculus. Résistance du decumanus et du rat blanc à l'infestation naturelle. C. R. Soc. Biol. Paris, vol. 59, pp. 441-443.

Salter, H. H. 1859 Pancreas. (Article in R. B. Todd's "The Cyclopaedia of anatomy and physiology.") Vol. 5 (suppl. vol.), pp. 81-114, London. Several text figures for the rat.

SANDrI, O. 1908 Contribution à l'anatomie et à la physiologie de l'hypophyse. Résumé de l'auteur. Riv. di pat. nerv. e ment., vol. 13, pp. 518-550. Arch. ital. de Biol., vol. 51, pp. 337-348. Growth of rats fed with hypophysis.

Savioti, Giovanni 1869 Untersuchungen über den feineren Bau des Pancreas. Arch. f. mikr. Anat., vol.5, pp. 404-414, pl. XXIII and XXIV.

Schäfer, E. A. 1898 (see GAMgee, A.) Rat, haemoglobin of. Text-book of Physiol., vol. 1, pp. 193, 194 and 206.

1900 Rat, motor area of. Text-book of Physiol., vol. 2, p. 732.

1900 a Rat, muscle spindles of. Text-book of Physiol., vol. 2, p. 1008 .

1908 Present condition of our knowledge regarding the functions of the suprarenal capsules. Brit. M. J., May 30 and June 6, pp. 1-10.

1912 The effects upon growth and metabolism of the addition of small amounts of ovarian tissue, pituitary, and thyroid to the normal dietary of white rats. Quart. J. Exper. Physiol., vol. 5, pp. 203-228.

SchÄFf, E. 1891 Schwärzliche Varietät von Mus decumanus. Sitzgsber. Ges. Naturf. fr. Berlın, no. 4, p. 61.

Schern, K. 1909 Ueber eine durch den Bazillus enteritidis Gärtner hervorgerufene Rattenseuche. Arb. a. d. k. Gsndhtsamte, Berl., vol. 30, pp. pp. 575-583.

1912 Ueber das Rattenvertilgungsmittel Virus sanitar A. Centralbl. f. Bakteriol., 1 Abt., vol. 62, pp. 468-471.

Schiff, J. Moritz 1859 Untersuchungen über die Zuckerbildung in der Leber und den Einfluss des Nervensystems auf die Erzeugung des Diabetes. Würzburg.

1884 Bericht über eine Versuchsreihe betreffend die Wirkungen der Exstirpation der Schilddrüse. Arch. f. exper. Path. u. Pharmakol., vol. 18, pp. $25-34$.

1884 a Résumé d'une série d'expériences sur les effets de l'ablation des corps thyroïdes. Rev. méd. de la Suisse-Rom., vol. 4, pp. 65-75.

Schміdт, F. Тн. 1863 Das folliculäre Drüsengewebe der Schleimhaut der Mundhöhle und des Schlundes bei dem Menschen und den Säugetieren. Ztschr. f. wiss. Zool., vol. 13, pp. 221-302, pl. XIV-XVI.

Scholze, F. E. 1871 Die Lungen. In Stricker's Handbuch der Lehre von den Geweben des Menschen und der Tiere. Leipzig. Pp.464-477. P.465, diameter of alveolar passages, $0.1 \mathrm{~mm}$. in rat.

SchÜrmanN, W. 1908 Ueber eine durch Milben hervorgerufene Erkrankung von Ratten. Centralbl. Bakt. Parasit. Abt 1, Orig., vol.48, pp. 167172. 
Schwalbe, G. 1872 Beiträge zur Kenntniss der Drüsen in den Darmwandungen in's Besondere der Brunner'schen Drüsen. Arch. f. mikr. Anat., vol. 8, pp. $92-140$, pl. V.

Selenka, Emil 1883 Studien über Entwickelungsgeschichte der Thiere,, I. Keimblätter und Primitivorgane der Maus. C. W. Kreidel, Wiesbaden.

1884 Studien über Entwickelungsgeschichte der Thiere., 3. Die Blätterumkehrung im Ei der Nagethiere. C. W. Kreidel, Wiesbaden.

Severin, Friedrich 1885 Untersuchungen über das Mundepithel bei Säugetieren mit Bezug auf Verhornung, Regeneration und Art der Nervenendigung. Arch. f. mikr. Anat., vol. 26, pp. 81-88, 1 pl. Rat included among mammals examined.

Sherborn, C. Davies 1897 On the dates of the natural history portion of Savigny's "Description de l'Égypte." Proc. Zoöl. Soc. of London, 1897, pp. 285-288.

Sherrington, C. S. And Copeman, S. M. 1893 Variations experimentally produced in the specific gravity of the blood. J. Physiol., vol. 14, p. 54 .

Shipley, A. E. 1908 Rats and their animal parasites. J. Economic Biol., vol. 3, pp. 61-83.

Simpson, F. 1913 Rat proofing; its practical application in the construction or repair of dwellings or other buildings. Pub. Health Rep., Wash., vol. 28, pp. $679-687,10 \mathrm{pl}$.

Sittenfield, M. J. 1912 Influence of anemia and hyperemia on the growth of sarcoma in the white rat. Proc. Soc. Exper. Biol. and Med., vol. 9, pp. 56-57.

Slonaker, J. R. 1907 The normal activity of the white rat at different ages. J. Comp. Neur. and Psychol., vol. 17, pp. 342-359.

1912 The normal activity of the albino rat from birth to natural death, its rate of growth and the duration of life. J. Animal Behavior, vol. 2, pp. 20-42.

1912 a The effect of a strictly vegetable diet on the spontaneous activity, the rate of growth, and the longevity of the albino rat. Leland Stanford Jr. Univ. Pub., Univ. Series.

Small, W. S. 1899 Notes on the psychic development of the young white rat. Am. J. Psychol., vol. 11, pp. 80-100.

1900 An experimental study of the mental processes of the rat. Am. J. Psychol., vol. 11, pp. 133-164.

1901 Experimental study of the mental processes of the rat, II. Am. J. Psychol., vol. 12, pp. 206-239.

Soвотta, J. AND Burckhard, G. 1910 Reifung und Befruchtung des Eies der weissen Ratte. Anat. Hefte, I Abt., 127 heft (42 band, heft 2), pp. $433-492$.

Solaer, B. 1889 Säugethier-Mitosen im histologischen Kursus. Archiv f. mikr. Anat., vol. 33, pp. 517-518.

Soulit, A.H. 1903 Recherches sur le développement des capsules surrénales chez les vertébrés supérieurs. J. de l'Anat. et Physiol., vol. 39, pp. $197-293 ; 390-525 ; 492-533 ; 634-664$. 
Spitzka, E. C. 1886 The comparative anatomy of the pyramid tract. J.Comp. M. and S., vol. 7, p. 46.

Stahr, Hermann 1903 Ueber die Ausdehnung der Papilla foliata und die Frage einer einseitigen "kompensatorischen Hypertrophie" im Bereiche des Geschmacksorgans. Arch. f. Entwcklngsmechn. d. Organ., vol. 16, pp. 179-199.

STEFFEnHAGEN, K. 1910 Untersuchungen über das Rattenvertilgungsmittel Liverpoolvirus. Arb. a. d. k. Gsndhtsamte Berl., vol. 36, pp. 198-220.

Steinach, E. 1894 Untersuchungen zur vergleichenden Physiologie der männlichen Geschlechtsorgane, insbesondere der accessorischen Geschlechtsdrüsen. Arch. f. d. ges. Physiol., vol. 56, pp. 304-338.

1910 Geschlechsttrieb und echt sekundare Geschlechtsmerkmale als Folge der innersekretorischen Funktion der Keimdrüsen.

I. Präexistente und echt sekundäre Geschlechtsmerkmale.

II. Ưber die Entstehung des Umklammerungsreflexes bei Fröschen.

III. Entwicklung der vollen Männlichkeit in funktioneller und somatischer Beziehung bei Säugern als Sonderwirkung des inneren Hodensekretes. Zentralbl. f. Physiol., vol. 24, pp. 551-566.

1911 Umstimmung des Geschlechtscharakter bei Säugetieren durch Austausch der Pubertätsdrüsen. Zentralbl. f. Physiol., vol. 25, pp. 723-725.

1912 Willkürliche Umwandlung von Säugetier-Männchen in Tiere mit ausgeprägt weiblichen Geschlechtscharakteren und weiblicher Psyche. Arch. f. d. ges. Physiol., vol. 144, pp. 71-108.

1913 Feminierung von Männchen und Maskulierung von Weibchen. Zentralbl. f. Physiol., vol. 27, pp. 717-723.

Stendell, W. 1913 Zur vergleichenden Anatomie und Histologie der Hypophysis cerebri. Arch. f. mikr. Anat., vol. 82, pp. 289-332.

Sterzi, Gidseppe 1904 Die Blutgefasse des Rückenmarks. Anat. Hefte, vol. 24, pp. 5-364. Mus decumanus, p. 169.

Stewart, Colin C. 1898 Variations in daily activity produced by alcohol and by changes in barometric pressure and diet, with a description of recording methods. Am. J. Physiol., vol. 1, pp. 40-56.

Stieda, L. 1869 Studien über das centrale Nervensystem der Vögel und Säugetheire. Ztschr.f. wissensch. Zoöl., vol. 19, p. 68.

Stiles, Ch. W. and Crane, C. G. 1910 The internal parasites of rats and mice in their relation to diseases of man. Found in "The rat and its relation to the public health," pp. 87-110. Treasury Dept. Pub. Health and Mar.-Hospt. Service of the U. S. Government Printing Office, Wash., D. C.

Stiles, Ch. W. and Hassall, Albert 1910 Compendium of animal parasites reported for rats and mice (Genus Mus). Found in "The rat and its relation to the public health," pp. 111-122. Treasury Dept. Pub. Health and Mar.-Hospt. Service of the U.S. Government Printing Office, Wash., D. C.

Stirling, W. 1883 A simple method of demonstrating the nerves of the epiglottis. J.Anat. and Physiol., vol. 17, p. 203. Rats included in mammals observed. 
Stirling, W. 1883 a The trachealis muscle of man and animals. J. Anat. and Physiol., vol. 17, pp. 204-206.

Stotsenburg, J. M. 1909 On the growth of the albino rat (Mus norvegicus var. albus) after castration. Proc. Assoc. Am. Anat. in Anat. Record, vol. 3 , pp. 233-244.

1913 The effect of spaying and semi-spaying young albino rats (Mus norvegicus albinus) on the growth in body weight and body length. Anat. Record, vol. 7, pp. 183-194.

Strehl, Hans and Weiss, Otтo 1901 Beiträge zur Physiologie der Nebenniere. Archiv f. d. ges. Physiol., vol. 86, pp. 107-121.

Stutzmann, J. 1898 Die accessorischen Geschlechtsdrüsen von Mus decumanus und ihre Entwicklung. Diss. Leipzig.

SufFolk 1910 The epizoötic of rat plague. Lancet, Lond., vol. 2, p. 1497.

Sweet, J. E., Corson-White, E. P. and Saxon, G. J. 1913 The relation of diets and of castration to the transmissible tumors of rats and mice. J. Biol. Chem., vol. 15, p. 181.

Symposium 1911 Ueber die Vertilgung der Ratten. Im Sinne einer Abwehrmassregel gegen die Pest. Das österreichische Sanitätswesen, no. 17 and 18, 1911.

Szymanski, J. S. 1914 Lernversuche bei weissen Ratten. Arch. f. d. ges. Physiol., vol. 185, pp: 386-418.

TAFAni, A. 1889 La fécondation et la segmentation. Etudieés dans les oeufs des rats. Arch. Ital. de Biol., vol. 11.

1889 a I primi momenti dello sviluppo dei mammiferi. Studi di morfologia normale ef patologica eseguiti sulle uova dei topi. Atti d. T. Accad. d. Lincei, Roma. Ser. 4, Rendiconti, vol. 5, semestre 1, pp. 119-125.

TAILby, T. M. J. 1911 A plea for the owl (the best of all rat killers). J. Roy. Inst. Pub. Health, Lond., pp. 108-113.

TAndler, J. 1899 Zur vergl. Anat. der Kopfarterien bei den Mammalia. (1898.) Denkschr. der kais. Akad. der Wissensch. in Wien, vol. 67, p. 729; Mus rattus-albino among those examined.

1902 Zur Entwickelungsgeschichte der Kopfarterien bei den Mammalia. Morphol. Jahrb., vol. 30, pp. 275-373.

TAYLOR, KenNeth 1915 Observations upon a rat sarcoma treated with emulsions of embryonic tissues. Proc. of Soc. for Exper. Biol. and Med., vol. 12 , pp. 216-218.

Tello, Francisco 1906 Terminaciones sensitivas en los pelos y otros organos. Rev. trimestr. Microgr., vol. 9, pp. 49-77, fig. 1.

Terra, PaUl DE 1911 Vergleichende Anatomie des menschlichen Gebisses und der Zähne der Vertebraten. Jena. Fischer, p.301, fig.125. Teeth of M. norvegicus.

Terry, Benjamin T. 1905 An epidemic of trypanosmiasis among white rats. Trans. Chicago Path. Soc., pp. 1-4.

Thompson, J. A. 1906 On the epidemiology of plague. J. Hyg., vol. 6, pp. 537-569.

Tidswell, F. And Cleland, J. B. 1912 Leprosy-like disease in rats. Rep. Gov. Bur. Microbiol., Syndey, vol. 2, pp. 49-51. 
Tilney, Frederick 1911 Contribution to the study of the hypophysis cerebri with especial reference to its comparative histology. Memoirs of The Wistar Institute of Anatomy and Biology, no. 2, p. 47. Mus decumanus (figs. 34 and 35 ).

1913 An analysis of the juxta-neural epithelial portion of the hypophysis cerebri, with an embryological and histological account of a hitherto undescribed part of the organ. Internat. Monatschr. f. Anat. u. Physiol., vol. 30, pp. 258-293, Pl. V-XIX and 3 fig. Rat among other animals studied.

Tiraboschi, Carlo 1902 Gli animali propagatori della peste bubbonica. 3 Nota. Caratteri distintivi del Mus decumanus Pall. e Mus rattus L. Diffusione del Mus rattus in Italia. Boll. Soc. zool. ital. Ann. 11, pp. 173-177.

1904 Gli animali propagatori della peste bubbonica. 4a Nota. I ratti e i loro ectoparassiti. Boll. Soc. zool. ital. Ann. 13, pp. 88-97.

1904 a Les rats, les souris et leurs parasites cutanés dans leurs rapports avec la propagation de la peste bubonique. Arch. Parasitol., vol. 8 , pp. 161-349.

Toepfer, Karl and Fleischmann, A. 1891 Die Morphologie des Magens der Rodentia. Morphol. Jahrb., vol. 17, pp.380-416.

Topsell, Edward 1658 History of four-footed beasts. No place. No publisher. Rat, p. 403.

Tournade, A. 1913 Sur les délais de régénération du vague chez le rat blanc. C. R. Soc. Biol., Paris, vol. 74, pp. 956-957.

TоYоFUKU, TAMAKI 1911 Ueber die parathyreoprive Veränderung des Rattenzahnes. Frankfurt. Ztschr. f. Path., vol. 7, pp. 249-294.

Tradtmann, A. 1912 Ueber Massenausstreuung von Bacillus enteritidis Gärtner. Arch. f. Hyg., vol. 76, pp. 206-209.

Tradtmann, H. 1912 Zurückweisung der Versuche Mereschowsky's: Ueber die Anwendung des Trautmannschen Verfahrens zur Virulenzsteigerung des Bacillus Danysz. Centralbl. f. Bakteriol., 1 Abt., vol. 65, pp. 58-60.

Trommsdorf, R. 1909 Ueber biologische Eiweissdifferenzierung bei Ratten und Mäusen. Arb. a. d. k. Gsndhtsamte, Berl., vol. 32, pp. 560$-567$.

Trouessart, E. L. 1881 Epimys-subgenus-including Rattus and Norvegicus. Bull. Soc. d'Etudes Sci. d'Angers, vol. 10, p. 117.

1897 Catalogus mammalium tam viventium quam fossillum. Nova Editio (Prima completa) Berolini. See Fasciculus III. Rodentia II, p. 471 et seq.

1910 Faune des mammifères d'Europe. Berlin. Friedländer.

Tuckerman, Frederick 1892 Further observations on the gustatory organs of the Mammalia. J. Morphol., vol. 7, pp. 69-94. Mus decumanus, pp. 73-75.

Tullbera, Tycho 1900 Ueber das System der Nagethiere. Nova Acta Reg. Soc. Sc. Upsaliensis Ser. 3, vol. 18, pp. 1-514. Mus decumanus, pp. 254-257. 
TURNer, JOHN 1904 On the primary staining of the rat's brain by methylene blue. Brain, vol. 27, pp. 64-83.

Uhlenhuth, Paul and Weidanz, O. 1909 Mitteilungen über einige experimentelle Krebsforschungen. Arb. a. d. k. Gsndhtsamte, vol. 30, pp. 434-444.

ULRICH, JohN L. 1913 The number and distribution of trials in learning in the white rat. Behavior Monographs, vol. 2, no. 5, serial number 10, pp. 1-51.

Usкоw, N. 1883 Ueber die Entwickelung des Zwerchfells, des Pericardiums und des Coeloms. Archiv. f. mikr. Anat., vol. 22, pp. 143-219. Rat, pp. 191 and 192.

Van Alstyne, Eleanor and BeEbe, S. P. 1913 Diet studies in transplantable tumors. I. The effect of non-carbohydrate diet upon the growth of transplantable sarcoma in rats. J. Med. Research, vol. 29 (n.s. vol. 24), pp. 217-232. White rats, 10 tables.

VAN Der Vloet 1906 Ueber den Verlauf der Pyramidenbahn bei niederen Säugetieren. Anat. Anz., vol.29, p.113.

Vega, Garcilaso de LA (1535-1616) 1688 The royal commentaries of Peru, 1609-1617. Rendered into English by Sir Paul Rycaut. Portrait of Rycaut and 10 plates. London.

ViNCENT, S. B. 1912 The function of the vibrissae in the behavior of the white rat. Behavior Monographs, vol. 1, no. 5, Johns Hopkins University.

Vincent, S. B. 1913 The tactile hair of the white rat. J. Comp. Neurol., vol. 23, pp. 1-27.

1915 The white rat and the maze problem. I. The introduction of a visual control. J. of Animal Behavior, vol. 5, pp. 1-24.

1915 a The white rat and the maze problem. II. The introduction of an olfactory control. J. of Animal Behavior, vol. 5, pp. 140-157.

$1915 \mathrm{~b}$ The white rat and the maze problem. III. The introduction of a tactual control. J. of Animal Behavior, vol 5, pp. 175-184.

VINCENT, SWALE 1897 The effects of subcutaneous injections of extracts of suprarenal capsules. J. Physiol., vol. 21, Proc. of Physiol. Soc., p. xxv.

1897 a On the general physiological effects of extracts of the suprarenal capsules. J. Physiol., vol. 22, pp. 111-120.

Vincent, Swale AND Jolly, W. A. 1905 Some observations upon the function of the thyroid and parathyroid glands. J. Physiol., vol. 32, pp. 65-86. 1906 Further observations upon the functions of the thyroid and parathyroid glands. J. Physiol., vol. 34, pp. 295-305.

Vincent, Swale 1910 The chromaphil tissues and the adrenal medulla. Proc. Roy. Soc., Lond., S. B., vol. 82, pp. 502-515.

1912 Internal secretion and the ductless glands. Edward Arnold, London.

WAGNeR, RUDOLPH 1841 Icones zootomicae. Handatlas zur vergleichenden Anatomie nach fremden und eigenen Untersuchungen, xvi, 44 pp., 35 pl., fol. L. Voss, Leipzig. Achte Tafel, p. 9, fig.XI. Brain of M. decumanus. 
WALLER, R. 1693 Some observations in the dissection of a rat (with illustrations). Phil. Trans., vol. 17, pp. 594-596.

WARD, HeNry L. 1906 Observation on a pied rat. Bull. Wis.Nat. Hist. Soc., n. s. vol. 4, pp. 37-38.

Wasielewski, v. ANd Senn, G. 1900 Beiträge zur Kenntnis der Flagellaten des Rattenblutes. Zeitschr. f. Hyg., vol. 33, p. 444.

Watney, H. 1874 Note on the minute anatomy of the alimentary canal. Proc. Royal Soc., London, vol. 22, pp. 293-294. Rat included among animals studied.

Watson, B. P. 1907 The effect of a meat diet on fertility and lactation. Proc. Roy. Soc. Edinb., vol. 27, part 1, pp. 6-10.

Watson, Chalmers 1904 Stimulation of the thyroid and parathyroid glands by a proteid dietary (raw meat). J. Physiol., vol. 31, Proc. of the Physiol. Soc., p. v.

1906 The influence of a meat diet on the thyroid gland in the second generation of meat fed rats. J. Physiol., vol. 34, Proc. of the Physiol. Soc., p. xxix.

1906 a The influence of diet on growth and nutrition. J. Physiol., vol. 34, pp. 111-132.

1906 b Preliminary note regarding an experimental investigation into the effects of varying diets upon growth and nutrition. Proc. Roy. Soc., Edinb., vol. 26, part 1, pp. 87-94.

Watson, Chammers, and Campbell, M. 1906 The minute structure of the uterus of the rat with a note on the influence of a meat diet on it. J. Physiol., vol. 34, Proc. of Physiol. Soc., p. xvi.

Watson, Chalmers, and Lyon, G. 1906 A preliminary note on the influence of a meat diet on the kidneys. J. Physiol., vol. 34, Proc. of the Physiol. Soc., p. xix-xxi.

Watson, Chalmers 1907 . A note on the adrenal gland in the rat. J. Physiol., vol. 35, pp. 230-232.

1907 a The influence of a meat diet on the kidneys. Internat. Monatschr. f. Anat. u. Physiol., vol. 24, pp. 197-208.

$1907 \mathrm{~b}$ The effects of captivity on the adrenal glands in wild rats. J. Physiol., vol. 35, Proc. of Physiol. Soc., pp. xlix-1.

$1907 \mathrm{c}$ The influence of an excessive meat diet on the osseous system. Proc. Roy. Soc. Edinb., vol. 27, part 1 (no. 1).

$1907 \mathrm{~d}$ The influence of diet on the liver. Lancet, October 12. Weight of liver in Norway rat reduced by diet poor in nitrogen.

1909 A note on the minute structures of the thyroid gland in the rat. Quart. J. Exper. Physiol., vol. 2, pp. 383-387.

1910 The influence of diet on the structure of the tissues. Reprint of the Appendix from the new work on "Food and Feeding in Health and Disease" (Chalmers Watson, November, 1910). Oliver and Boyd, London.

1912 The influence of diet on the thyroid gland. Quart. J. Exper. Physiol., vol. 5, pp. 229-232.

Watson, G. W. AND Gibss, J. H. 1906 The influence of an excessive meat diet on the development and structure of the teeth. J. Physiol., vol. 34, Proc. of Physiol. Soc., pp. xvii-xviii. 
Watson, John B. 1903 Animal education. Con. from the Psychol. Lab. Univ. of Chicago, vol. 4, no. 2, pp.5-122. Plates showing medullation of the nervous system at various ages.

1905 The effect of the bearing of young upon the body weight and the weight of the central nervous system of the female white rat. J.Comp. Neur. and Psychol., vol. 15, pp. 514-524.

1907 Kinaesthetic and organic sensations; their rôle in the reactions of the white rat to the maze. Monograph Suppl., Psychol. Review, vol. 8, pp. 1-100.

Watson, John B. AND Watson, Mary I. 1913 A study of the responses of rodents to monochromatic light. J. Animal Behavior, vol. 3, pp. 1-14.

Watson, JoHN B. 1914 Behavior. An introduction to comparative psychology. Henry Holt \& Co., N. Y. Rat, pp. 129-131, 198, 210-219, 235, 237-238, 292, 348, 384-385, 423-425.

Webel, H. von 1914 A bacteriological study of a rat epidemic. Proc. N. Y. Pathol. Soc., vol. 13, pp. 97-103.

Webster, J. G. 1892 Melanic variety of the rat (Mus decumanus, Pallas). Ann. of Scott. Nat. Hist., vol. 1, p. 134.

Weil, Richard 1913 The intravascular implantation of rat tumors. J. Med. Research, vol. 28 (n.s. vol. 23), pp. 497-508. 2 plates.

Weisbach, A. 1868 Der Wassergehalt des Gehirns nach Alter, Geschlecht und Krankheiten. Med. Jahrbücher, vol. 16, nos. 4 and 5, pp. 1-76.

WeIss, ARmin 1900 Ein postoccipitaler Wirbelkörper bei Rattenembryonen. Centralbl.f. Physiol., vol. 14, pp.93-96.

1901 Die Entwicklung der Wirbelsäule der weissen Ratte, besonders der vordersten Halswirbel. Ztschr. f. wissensch. Zool., vol.69, pp. 492-532.

Wherry, W. B. 1908 Further notes on rat leprosy and on the fate of human and rat lepra bacilli in flies. J. Infec. Dis., Chicago, vol.5, pp. 507-518.

White, Moses C. 1901 Article "Blood stains" in reference Handbook of the Medical Sciences. Wm. Wood \& Co., N. Y., vol. 2, pp. 84 and 86.

WIDAKowich, Victor 1909 Ueber die erste Bildung der Körperform bei Entypie des Keimes. Beiträge zur Entwicklungsgeschichte der Ratte. Ztschr. f. wissensch. Zool., vol. 94, pp. 240-298.

Wredersherm, R. 1903 Ueber ein abnormes Rattengebiss. Anat. Anz., vol. 22, pp. 569-573.

Wiedersperg, Gustav von 1885 Beiträge zur Entwickelungsgeschichte der Samenkörper. Archiv f. mikr. Anat., vol. 25, pp. 113-136. Rat, pp. $117,118,119$.

Wiener, E. 1902 Ueber den Bazillus Danyz. München. med. Wchnschr., vol. $49, \mathrm{pp} .401-402$.

1903 Weitere Bemerkungen zur Enstehung von Rattenepizoötieen. Centralbl. f. Bakteriol., vol. 34, part 1, pp. 406-411.

Wresel, Josef 1899 Ueber accessorische Nebennieren am Nebenhoden beim Menschen und über Kompensations-hypertrophie dieser Organe bei der Ratte. Sitz.-Ber. d. Akad. d. Wissen. in Wien. Math.-naturw. Kl., Bd. 108, Abt. 3, pp. 257-280. 1 plate. 
Wiesel, Josef 1899 a Ueber Compensations-Hypertrophie der accessorischen Nebennieren bei der Ratte. Centrabl. f. Physiol., vol.12, pp. 780-783.

Willach, PaUl 1888 Beiträge zur Entwicklung der Lunge bei Säugethieren. $23 \mathrm{pp}, 8^{\circ}$. Osterwieck, Harz; A. W. Zickfeldt.

Williams, J. Leon 1896 On the formation and structure of dental enamel. The Dental Cosmos, vol. 38, pp. 101-127.

Wolbach, S. B. ANd Honeis, James A. 1914 A critical review of the bacteriology of human and rat leprosy. J. Med. Research, vol. 29 (n.s. vol. 24), pp. 367-423.

WoLdřich, ЈоH. 1880-1884 Diluviale Fauna von Zudslawitz bei Winterberg in Böhmerwalde. Sitzber. d. k. Akad. d. Wiss. 3 parts, 1880-18811884.

Wormley, T.G. 1888 Microchemistry of poisons. 2d ed. Phila.

Wyss, Hans von 1870 Die becherförmigen Organe der Zunge. Arch. f. mikr. Anat., vol. 6, pp. 237-260. Rat, pp. 255-256.

YeRKES, RoBert M. 1913 The heredity of savageness and wildness in rats. J. Animal Behavior, vol. 3, pp. 286-296.

ZawarYkin, Th. 1883 Ueber die Fettresorption im Dünndarm. Arch. f. d. ges. Physiol., vol. 31, pp. 231-240.

Zillinberg-PaUL, Ottilie 1909 Fortgesetzte Untersuchungen über das Verhalten des Darmepithels. III. Mitteil. (Rat.) Ztschr. f. Biol., vol. 52, pp. 327-354, pl. VI.

Zinsser, Hans and Carey, Edward G. 1912 A contribution to the study of rat leprosy. J. Am. M. Ass., vol. 58, pp. 692-695.

Zuckerkande, E. 1903 Die Entwickelung der Schilddrüse und der Thymus bei der Ratte. Anat. Hefte, vol. 21, pp. 3-28.

Zumstein, J. J. 1890 Ueber den Bronchialbaum des Menschen und einiger Säugetiere. Sitzungsb. d. Gesellsch. z. Beförd. d. ges. Natur. zu Marburg. Jahrg., 1889, pp. 25-29. (Sitz. vom 26 Marz, 1889.) Rat among mammals used.

1891 Ueber die Unterkieferdrüse einiger Säuger. 1 Anat. Teil. Habilitationsschrift, Marburg, $32 \mathrm{pp}$.

ZoschlaG, EmIL 1903 Le rat migratoire et sa destruction rationnelle. Copenhagen.

\section{ADDENDA}

Titles of papers which appeared while this volume was in press or which had been overlooked.

Barber, Alda Grace 1915 The localization of sound in the white rat. J. Animal Behavior, vol. 5, pp. 292-311.

Brompr, E. 1907 Phénomènes de la parturition chez le rat blanc. Bull. Soc. Zool., France, vol. 32 , pp. 50-52.

Conrow, SARA B. 1915 Taillessness in the rat. Anat. Record, vol. 9, pp. 777783. 
DAELs, F. 1908 On the relations between the ovaries and the uterus. Sury. Gynec. and Obst:, vol. 6, pp. 153-159.

Hatal, S. $1915 \mathrm{~b}$ On the influence of exercise on the growth of organs in the albino rat. Anat. Record, vol. 9, pp. 647-665.

Heape, Walter 1900 The "sexual season" of mammals and the relation of the "pro-oestrum" to menstruation. Quart. J. Micr. Science, vol. 44, pp. 1-70.

Henneberg, B. 1905 Beitrag zur Kenntnis der lateralen Schilddrüsenanlage. Anat. Hefte, vol. 28, pp. 287-302.

1909 Ǔber die Bedeutung der Ohrmuschel. Anat. Hefte, vol. 40, pp. 95-147.

1914 Beitrag zur Entwickelung der äusseren genitalorgane beim Säuger. Erster Teil. Anat. Hefte, vol. 50, pp. 425-498.

Honter, Walter S. 1915 The auditory sensitivity of the white rat. J.Animal Behavior, vol. 5, pp. 312-329.

Ivanoff, Elie 1900 La fonction des vésicules séminales et de la glande prostatique dans l'acte de la fécondation. J. de Phys. et de Path. gen., vol. 2, pp. 95-100.

1907 De la fécondation artificielle chez les mammifèrès. Arch. des Sc. Biol., vol. 12, pp. 377-511.

KING, HELEN D. 1915 a Growth and variability in the body weight of the rat. Anat. Record, vol. 9, pp. 751-776.

Косн, R. 1898 Reise-Berichte über Rinderpest, Bubonenpest in Indien und Afrika, Tsetse oder Surrakrankheit Texasfieber, tropische malaria u. Schwarzwasserfieber. J. Springer. Berlin. 136 pp. $8^{\circ}$. Trypanosomes-rat.

Königstein, H. 1907 Die Veränderungen der Genitalschleimhaut während der Gravidität und Brunst bei einigen Nagern. Arch. f. d. ges. Physiol., vol. 119, pp. 553-570.

LANe-Claypon, JANet E. 1907 On ovogenesis and the formation of the interstitial cells of the ovary. J. Obst. and Gynaec., vol. 11, pp. 205-214.

Laveran, A., and Mesnil, F. 1901 Recherches morphologique et expérimentales sur le trypanosome des rats. Ann. de l'Institut Pasteur, vol.15, pp. 673-713.

Meinardus, Отto 1882 Der historische Kern der Hameler Rattenfängersage. Separat Abdruck aus der Ztschr. des Historischen Vereins für Niedersachsen, Jahrg. 1882, Hannover. Hahn'sche Buchhandlung.

Osborne, Thomas B. and Mendel, L. B. 1915 a The comparative nutritive value of certain proteins in growth, and the problem of the protein minimum. J. Biol. Chemistry, vol. 20, pp. 351-378.

$1915 \mathrm{~b}$ Further observations of the influence of natural fats upon growth. J. Biol. Chemistry, vol. 20, pp. 379-390.

1915 c Protein minima for maintenance. J. Biol. Chemistry, vol. 22, pp. 241-258.

Osborne, Thomas B. and Wakeman, Alfred J. 1915 Does butter-fat contain nitrogen and phosphorus? J. Biol. Chemistry, vol. 21, pp. 91-94.

Robinson, Arthor $1892 \mathrm{~b}$ The nutritive importance of the yolk-sac. J. of Anat. and Phys., vol. 26, pp. 308-323. 
Stotsenburg, J. M. 1915 The growth of the fetus of the albino rat from the thirteenth to the twenty-second day of gestation. Anat. Record, vol. 9, pp. 667-682.

Vincent, Stella B. 1915 the white rat and the maze problem. IV. The number and distribution of errors-a comparative study. J. Animal Behavior, vol. 5, pp. 367-374.

WARREN, JOHN 1915 On th eearly development of the inguinal region in mammalia. Anat. Record, vol.9, pp. 131-133.

Wiedersheim, Robert 1897 Comparative anatomy of vertebrates. Parker's translation, $2 \mathrm{~d}$ ed., London. 



\section{INDEX}

Page numbers preceded by $N$ refer to the Norway rat.

\section{Activity}

Miles run, 20.

\section{Age}

Characters which are functions of, 3 . of opening eyes, 19, N 191.

of independence, 19.

of sexual maturity, 21, N 191.

Span of life, 6, 20, 21, N 190.

Body weight on, 31-33, 63-72, 105-113.

Thymus on, 102.

Percentage of water on, 114.

\section{Albino Rat (See Rat)}

Anatomy, 30-57.

General, 30.

Embryology, 30.

Bones, joints and connective tissues, 33 .

Muscles, 38.

Vessels and lymphatics, 39 .

Nervous system, 41.

Sense organs, 55 .

Integument, $\mathbf{5 5}$.

Gastro-pulmonary systems, 55 .

Uro-genital, 56.

Endocrine, 56.

Axis-of Nerve Fiber (See Nerves)

\section{Behavior}

under natural conditions, 28.

under experimental conditions, 28.

Biology, 19-28, N 189-194.

\section{Blood}

Cell elements (number), 40-41.

Erythrocytes (diameter), 39.

Growth of, 83.

Hemoglobin, percentage of, 84 .
Blood (continued)

Oxygen capacity, 84.

Percentage of water in, 40, N 211.

Specific gravity, 39, 83.

Volume, 83.

Wandering cells in, 41 .

Weight of, 83.

\section{Body Weight (See Growth)}

on age, 31-33, 63-72, 105-113.

on body length, 88, N 198.

at maturity-according to sex, 27.

Modified by external conditions, 69. 71.

Net, 74.

Variations in weight at birth, 103.

Bones (See Skeleton)

Brain (See Organs)

Composition, chemical, 180-184.

Growth, 90, N 200-201.

Methods for fixation, 49-55.

Water-percentage of, 6, 176-179, $N$ 211-213.

Mitoses in, 41. 42.

Specific gravity, 41 .

Cell Division (See Mitosis)

Cells

Erythrocytes (diameter), 39.

Erythrocytes (number), 40.

Leucocytes, 40.

Wandering cells, 41.

of peritoneal fluid, 41.

of liver (diameters), 56 .

of pancreas (diameters), 56 .

of nervous sytem:

Purkinje cells (diameters), 43.

in ganglia (numbers and diameters), 44, 45,46 . 


\section{Charts 1-31}

1. The growth of the fetus from the 13 th to the $22 \mathrm{~d}$ day of gestation $\ldots \ldots \ldots \ldots \ldots \ldots . \ldots 4$

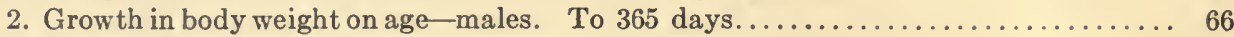

3. Growth in body weight on age-females. To 365 days.................. 67

4. Growth in body weight on age - males and females. To 485 days.............. 69

5. Percentage weights of systems on age. Muscalature, ligamentous skeleton, viscera

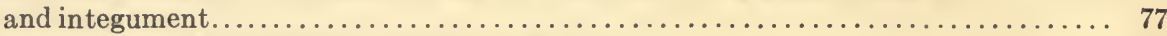

6. Body length on body weight - males and females. . . . . . . . . . . . . . . . . 88

7. Body weight on body length-males and females.................... 89

8. Tail length on body length - males and females...................... 89

9. Brain weight on body weight-males only. Spinal cord weight on body weight-

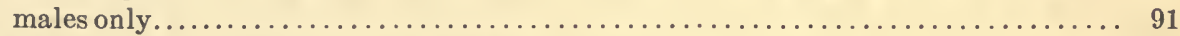

10. Weight of both eyeballs on body weight - males...................... 92

11. Weight of heart on body weight - males.......................... 93

12. Weight of both kidneys on body weight - males..................... 93

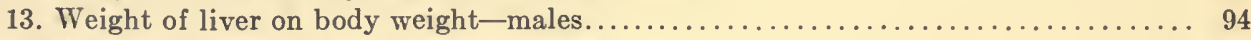

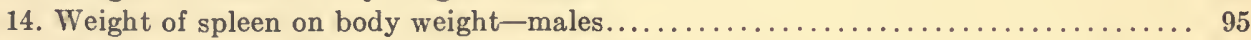

15. Weight of both lungs on body weight - males....................... 96

16. Weight of blood on body weight-males and females.................. 96

17. Weight of alimentary tract on body weight-males................... 97

18. Weight of thyroid on body weight-males and females.................. 98

19. Weight of hypophysis on body weight-males and females................ 99

20 . Weight of both suprarenals on body weight-males and females............ 100

21. Weight of both ovaries on body weight........................... 101

22. Weight of both testes on body weight.............................. 101

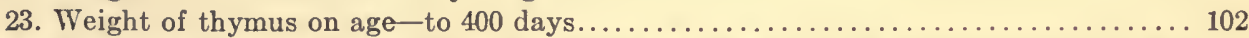

24. Percentage of dry substance in the body as a whole and in the several systems-ligamentous skeleton, integument, viscera and musculature-on age.......... 178

25. In terms of the dry substance of the entire body the percentage weight of the dry substance of the integument, viscera, ligamentous skeleton and musculature-on

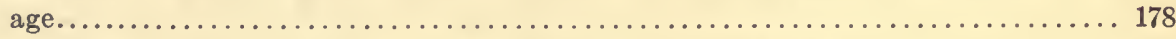

26. Percentage of water in brain-on age-males. Percentage of water in spinal cord-

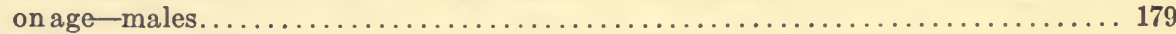

27. Absolute weight of the more important chemical constituents of the brain-on age.... 184

28. Norway rat Body length on body weight-males. (Graph for the Albino inserted

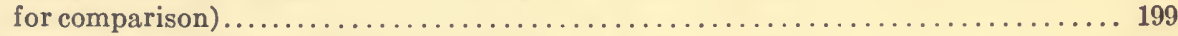

29. Norway rat Body weight on body length. Males and females ................ 199

30. Norway rat Tail length on body length. Males and females................ 200

31. Norway rat Brain weight on body weight-males. (Graph for Albino inserted for

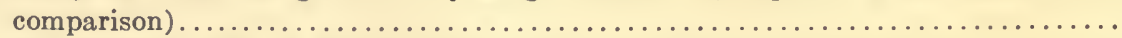
Spinal cord weight on body weight-males. (Graph for Albino inserted for comparison).

Chromosomes, Number of, 31 .

Classification and Nomenclature, 7-10.

Composition, Chemical (See Water, percentage of)

of entire body, 180-181. of bones, 181.

of brain, 181-182.

of spinal cord, 182.

Correlation, Coefficients of, 103. 
Distribution (See Early Records and Migrations), 10-15.

Dry Substance (See Water, percentage of)

Early Records and Migrations, 10-15.

Embryology, 30-33.

Early stages, 31-33.

Later stages, 33.

Volumes of ova and embryos, 32 .

Eyes

Age of opening, 19, N 191.

Fat

Fatty acids, 84. according to size, 85 . according to sex, 85 .

Total fat, 83 .

\section{Feces}

Weight of, 59.

\section{Fecundity, 22.}

Influence of weight of mother, 23.

Influence of food conditions, 23.

\section{Fetus}

Crown-rump length, 64-65.

Weight from 13th day of gestation, 64-65.

\section{Fibers-Nerve}

Number, 44-49.

Diameter and area, 44, 45, 47, 48, 49.

\section{Formulas}

Catalogue of, 158-159.

Use of, 3.

\section{Fossil Remains}

Mus rattus, 10.

\section{Functions (See Physiology)}

Circulation, 61.

Digestion, 61.

Endocrine glands, 61, 62 .

Muscle, nerve, 61.

Nervous system, 61 .

Nutrition, 58, 59, 60.

\section{Functions (continued)}

Body temperature, 60, 61 .

Reproduction, 61.

Respiration, 61.

Secretion, 61.

Special senses, 61 .

Ganglia (See Cells)

\section{Gestation}

Period of, 21, N 190.

Lengthening of, 22.

\section{Growth}

of entire body in weight on length:

Birth to maturity, 65-69, N 198.

Weight-length ratio, 72, N 202.

Body length on body weight, 87, N 198.

Body weight (Norway) on body weight (Albino), N 200.

of entire body in weight on age:

before birth, 31-33, 63-64.

Birth to maturity, 65-72.

Body weight, net, 74 .

under various external conditions, 63, 69.

of parts on body weight:

Head, trunk, limbs, 73-75, N 195.

Method of dissection, 73-74.

Tail length on body length, 88, N 200.

of systems on body weight:

Integument, 75, 76, N 196.

Musculature, 75, 76, N 196.

Skeleton (ligamentous), 75, 76, N 196.

Skeleton (cartilaginous), 78 .

Viscera, 75, 76, N 196.

Teeth, 37-39.

of organs on body length and weight:

Methods of examination and graphs, 87102.

Alimentary tract, 97.

Blood (weight), 96.

Brain, 90, N.200-201.

Eyeballs, 91-92.

Heart, 92-93.

Hypophysis, 98-99.

Kidneys. 92-93.

Liver, 94. 


\section{Growth-Continued}

Lungs, 95-96.

Ovaries, 100-101.

Spinal cord, 90-91, N 202.

Spleen, 95.

Suprarenals, 99-100.

Testes, 101-102.

Thymus (on age), 102.

Thymus (on body weight), 114.

Thyroid, 97-98.

Viscera combined, 114.

Variations in organ weight, 103-104.

\section{Heredity}

in general, 29.

Coat color, 29.

\section{Independence}

Attainment of, 19.

\section{Impregnation}

Time of, 21.

\section{Length}

of body, 87, N 198 .

of limb bones, 81-82.

of tail, 88-89, N 200.

Life History, 19, N 189-191.

\section{Litter}

Average number in, 26, N 190.

Second the best, 26.

Unit for experimental work, 3.

\section{Litters}

Usual number of, 26, N 190.

\section{Liver}

Cells and nuclei-diameters, 55-56.

Menopause, 21.

\section{Metabolism}

Protein, 58-60.

\section{Methods}

Statistical, 2.

for fixation of brain

Various figuratives, 49-51.

Formaldehyde, 51-55.
Migrations, 11-13.

Mitosis

in brain, 41, 42 .

in spinal cord, 41-43.

Modification of Body Growth

Experimental, 69, 71.

Method of measuring, 5 .

\section{Muscles}

Number of fibers and nuclei, 39.

Myeline Sheath (See Nerves)

Nerve Fibers (See Nerves)

\section{Nerves}

Cerebral

Number of fibers:

N. cochlearis, 43 .

N. oculomotorius, 44.

Spinal nerves and ganglia:

Number and size of fibers, 45-47.

Number of ganglion cells, 43-49.

Diameter of ganglion cells, 44,48 .

Peripheral, 48, 49.

Number of fibers

N. peronealis, 48 .

Autonomic

Fibers less than $4 \mu, 49$.

Nervous System, 41-49.

Fixation methods, 49-55.

Physiology of, 61.

Nitrogen

Weight of, excreted, 58, 60 .

Norway Rat (See Rat)

\section{Number}

of mitoses (nervous system), 41, 42 .

of erythrocytes, 40 .

of leucocytes, 40 .

of nerve cells, 41-49.

of nerve fibers, 41-49.

of muscle fibers and nuclei, 39 .

Nutrition (See Functions) 
Organs (See Growth of)

Alimentary tract, 97.

Blood (weight and volume), 96 .

Brain, 90, N 200-201.

Eyeballs, 91-92.

Heart, 92-93.

Hypophysis, 98-99.

Kidneys, 92-93.

Liver, 94.

Lungs, 95-96.

Ovaries, 100-101.

Pancreas, 56.

Sense organs, 55.

Spinal cord, 90-91, N 202.

Spleen, 95.

Suprarenals, 99-100.

Testes, 101-102.

Thymus, 102, 114.

Thyroid, 97-98.

Ovulation, 21, 31 .

Ova-distance from fimbria, 31 .

Ova-diameter, 31 .

Ova-volume, 32.

Ovum (See Ovulation)

\section{Pancreas}

Size of cells and nuclei, 56 .

\section{Parts (Larger Divisions of Body)}

Fore-limbs, hind-limbs, head and trunk 7375, N 195.

\section{Peritoneal Fluid}

Cells of, 41.

Physiology (See Functions) 58-62.

Puberty, 21.

\section{Rat}

Norway, 1.

$=$ Mus norvegicus, $1,7,8$.

$=$ Mus decumanus, 7,8 .

$=$ Epimys norvegicus, 7 .

gray, brown, or sewer rat-Wanderratte (G.).

Surmulot, rat d'égout, (Fr.). compared with Albino, N 191-193. similar to European form, N 193, 194. melanic variety, 14 .
Rat (continued)

Norway-Albino $=$ white rat

$=$ Mus norvegicus albinus, 14 .

$=$ Mus norvegicus albino, 7 .

$=$ Mus norvegicus var. albino, 7 .

$=$ Mus norvegicus var. albus, 7 .

coat color, 9, 29. compared with Norway, N 191-193.

extracted, 9.

Gametic purity, 9, 10.

Inbred, 9.

Laboratory animal, 1.

Observations mainly for the first year, 2 .

Origin of variety, 14.

similar to European form, 14.

strains-local, 3.

House rat-black

Mus rattus rattus (old English black rat), 7,8 .

Ship rat (gray)

Mus rattus alexandrinus, 8 .

Albino of M. rattus, 8, 9.

M. n. albinus wrongly identified with Albino of M. rattus, 14 .

Mus rattus $\times$ Mus norvegicus mutually infertile, 14 .

\section{Rattenkönig, 15.}

Records, Early, and Migrations, 10-15.

Mus norvegicus, 12, 13.

Mus rattus, 11.

\section{Reference Tables, 2, 3.}

References to Literature-By Subject

Classification, 10.

Fossil remains, 10.

Melanic variety, 14 .

Early records and migrations, 15.

Rattenkönig, 15.

Albino:

Biology, 28.

Heredity, 29.

Anatomy, 56-57.

Physiology, 61-62.

Growth:

in total body weight, 72 .

of parts and systems, 85 . 


\section{References to Literature-By Subject- Continued}

of parts and organs, 175.

in terms of water and solids, 179 .

of chemical constituents, 184 .

Pathology, 185-186.

Norway:

Life history and characters, N 194.

Growth:

of parts and systems, N 197.

of organs, N 202.

in terms of water and solids, N 213.

\section{References to Literature-By Authors}

Introduction to literature cited, 214.

Titles by authors, 215-265.

Addenda, 265-267.

\section{Sense Organs}

Cochlea, 55.

\section{Sex}

Body weight according to, 27.

Sexual maturity, 21, N 191.

Proportion of sexes, N 190-191.

Sex ratio, 26-27.

in first litters, 27.

according to season, 27.

Recognition of, in young, 26-27.

Ano-genital distance, 27.

\section{Skeleton}

List of bones, 34 .

Cartilaginous skeleton, 76-78.

Weight of moist skeleton, 79 .

Weight of dry skeleton, 79-80.

Ligamentous skeleton, 76-78.

Growth of skeleton, 33, 76-81.
Skeleton (continued)

Phosphorus content, skeleton, 181.

Ash, 181.

Percentage of water, 79 .

Transformation of weights, 77.

Cranium (skull), 82.

definition of, 82-83.

Measurements of, 33-36.

Weight of, 83, N 196.

Long bones

lengths, absolute and relative, 81-82.

shrinkage on drying, 82 .

Skull (See Skeleton; Cranium)

Span of Life, 6, 20-21, N 190.

\section{Specific Gravity}

Blood, 39, 83.

Brain, 41.

Spermatỏgenesis, 30,31 .

\section{Spinal Cord}

Composition, chemical, 182.

Growth, 90-91, N 202.

Water, percentage of, 176-179, N 211-213.

Mitosis in, 41-43.

\section{Superfecundation, 22.}

Superfetation, 22.

Systems (weighed) (See Anatomy)

Integumentary, muscular, skeletal, visceral, 75,76 .

Weight-absolute, 76.

Weight-proportional, 75.

Adult proportions, 78 .

\section{Tables}

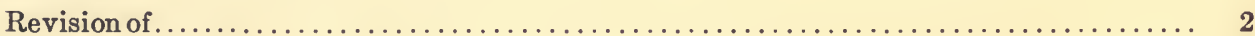

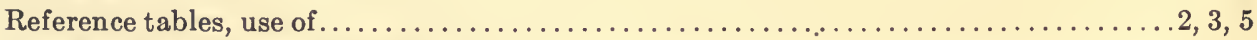

List of tables 1-89 in serial order.

1. Percentage of water in encephalon of rat compared with that in man at correspond-

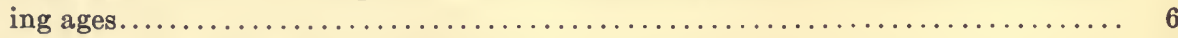

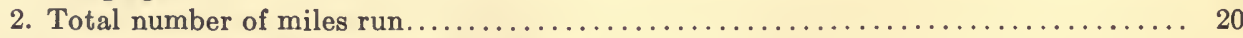

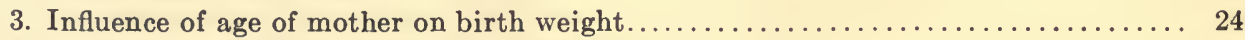

4. Influence of weight of mother on birth weight. ..................... 24 


\section{Tables-Continued}

5. Influence of size of litter on the individual birth weight $\ldots \ldots \ldots \ldots \ldots \ldots \ldots \ldots 25$

6. Individual birth weight in relation to body weight of mother............. 25

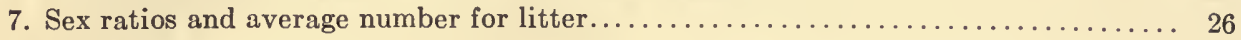

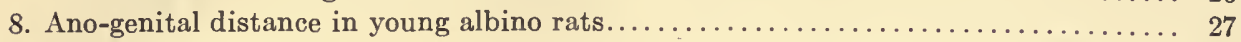

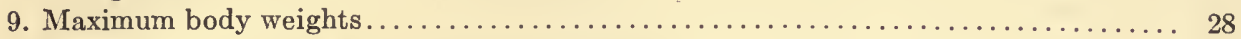

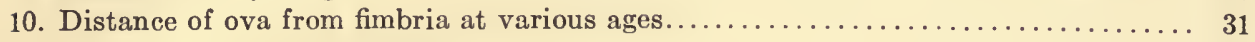

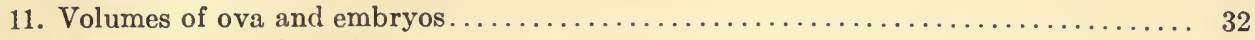

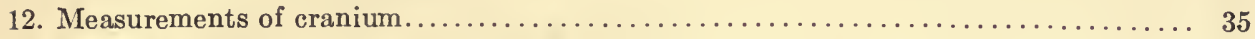

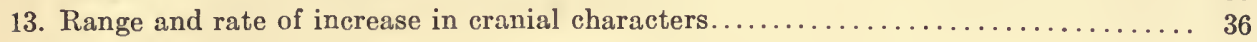

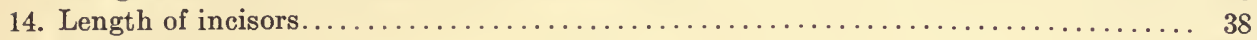

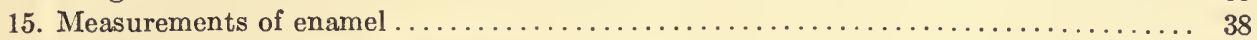

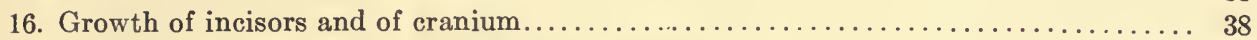

17. Number of fibers and of nuclei in Musc. radialis .................... 39

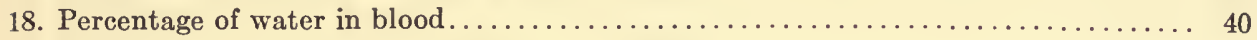

19. Number of erythrocytes, leucocytes, etc., in blood................... 40

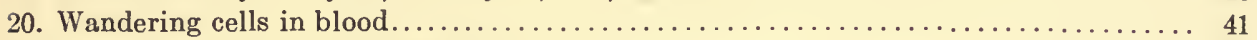

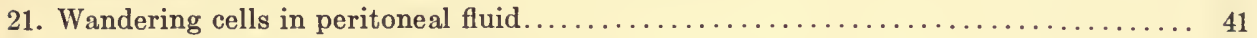

22. Mitoses in brain and cord. Hamilton ('01) ...................... 42

23. Mitoses in brain and cord-special observations on cerebellum $\ldots \ldots \ldots \ldots \ldots \ldots \ldots 42$

24. Diameters of Purkinje cells and their nuclei........................ 43

25. Number of myelinated fibers in the oculomotor nerve................ 44

26. Range of diameter in cells of cervical ganglion...................... 44

27. Number of spinal ganglion cells and number and size of myelinated root fibers of spinal nerves from three levels and at five ages (body weights) $\ldots \ldots \ldots \ldots \ldots \ldots \ldots \ldots \ldots$

28. Number of ganglion cells and of root fibers in the second cervical nerve....... 46

29. Number of myelinated fibers in the ventral and dorsal roots of the second cervical nerve - together with the distal excess of fibers in the nerve............. 46

30. Number of ventral root fibers in the second cervical nerve at different ages--together with the areas of the fibers and of their axes.......................... 47

31. Diameters of cell body and of nucleus in second cervical spinal ganglion together

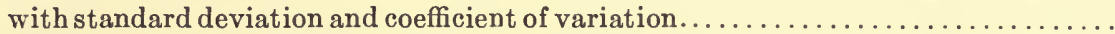

32. Number of myelinated fibers in the peroneal nerve . . . . . . . . . . . . . . . . 48

33. Sectional areas of largest fibers and of their axes -in peroneal nerve ........... 49

34. Myelinated fibers less than $4 \mu$ in diameter in the ventral roots of the second to the

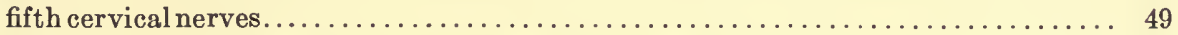

35. Effects of various fixing solutions on the weight of the brain . . . . . . . . . . . . 50-51

36. Increase in the weight of rats' brains in a neutralized 4 per cent formaldehyde solution, made five months before using. . . . . . . . . . . . . . . . . . . . . . .

37. Increase in the weight of rats' brains in a neutralized 4 per cent formaldehyde solu-

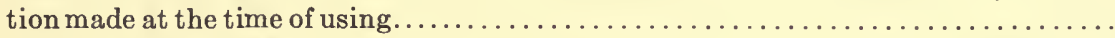

38. Increase in the weight of rats' brains in a neutralized 4 per cent formaldehyde

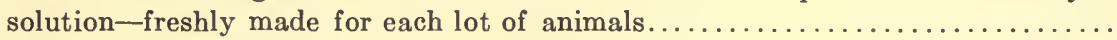

39. Increase in the weight of rats' brains in a non-neutralized solution of 4 per cent for-

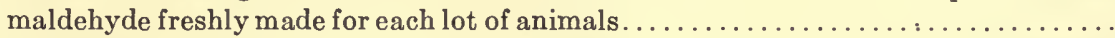

40. Percentage of solids in rats' brains after fixation in various 4 per cent formaldehyde

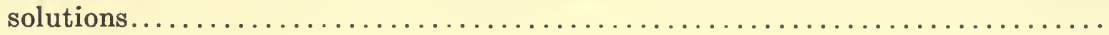




\section{Tables-Continued}

41. Volumes of cell body and of nucleus: liver cells; volumes of cell body and of nucleus:

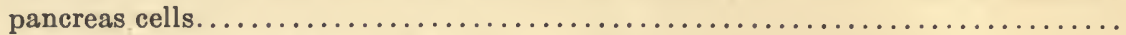

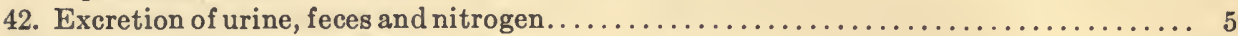

43. Protein metabolism -nitrogen distribution-female.................... 60

44. Protein metabolism - nitrogen distribution - male....................... 60

45. Body temperature under different external temperatures.................. 61

46. Mean weights of fetuses at daily intervals from the 13 th day of gestation......... 65

47. Crown-rump lengths of fetuses at daily intervals from the 14th day of gestation..... 65

48. Ratios obtained by dividing the body weight in grams by the body length in millimeters-for both males and females.............................. 70.71

49. Percentages of the entire body weight represented by the weights of head; trunk,

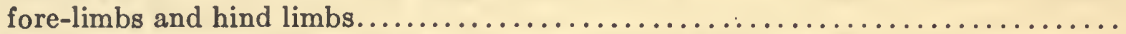

50. Percentages of the entire body weight represented by the weights of the integument,

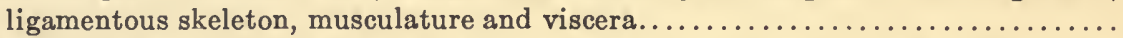

51. Absolute weights of integument, ligamentous skeleton, musculature and viscera in

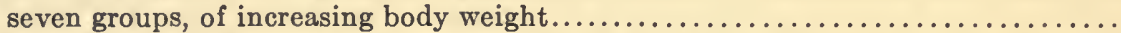

52. The percentage values for the weight of the cartilaginous skeleton-and by difference the percentage values for the periosteum, ligaments, etc., combined...........

53. Cartilaginous skeleton-moist weight and percentage value-also percentage value

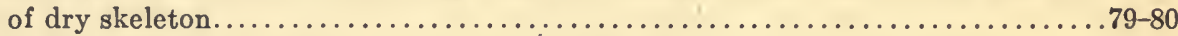

54. Lengths of long bones-femur, tibia, humerus and ulna-absolute and relative...... 81-82

55. Weights of crania -in series from London, Paris, Philadelphia and Vienna......... 83

56. Growth of blood in volume and oxygen capacity with increasing age (body weight)... 84

57. Proportion of fat with increasing age (body weight) $\ldots \ldots \ldots \ldots \ldots \ldots \ldots \ldots \ldots \ldots$

58. Coefficients of variation in body weights............................ 103

59. Coefficients of variation in organ weights........................... 104

60. Coefficients of correlation of organ weights with body weight............... 104

61. Mean weights of fetuses at daily intervals from the 13th day of gestation and also at

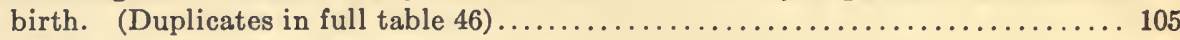

62. Growth in body weight on age-based on the records of Donaldson, Dunn and

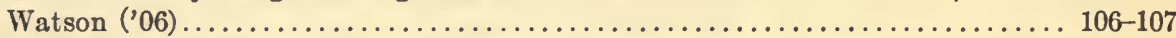

63. Growth in body weight on age-males. Observations of Donaldson, Dunn and

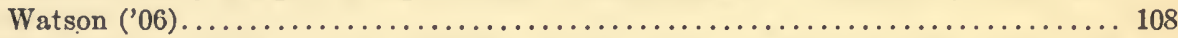

64. Growth in body weight on age-females. Observations of Donaldson, Dunn and

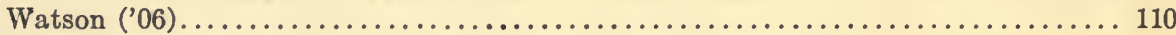

65. Growth in body weight on age. New Haven Colony-Ferry ('13)............ 112

66. The numbers of animals used in computing the values in the growth table $65 . . . . . .113$

67. Growth in body weight on age-King (MS '15). Mean of two series, with coefficients

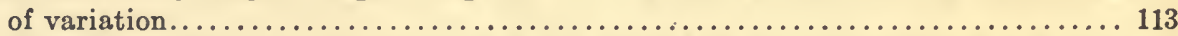

68. Increase in the length of the tail, and in the weights of the body, brain, spinal cord and both eyeballs, on body length............................. 115-120

68. Increase in the weights of the body and of the heart, both kidneys, liver and spleen

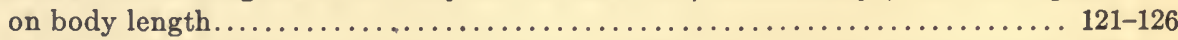

70. Increase in the weights of the body and of the lungs, blood, alimentary tract, testes

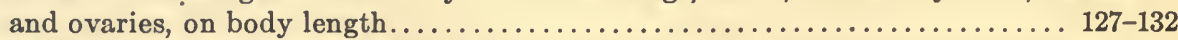

71. Increase in the weights of the body and of the hypophysis, suprarenals and thyroid on body length. 


\section{Tables-Continued}

72. Weight of the thymus on age in days............................. 139-141

73. Increase in the weight of all the viscera-including the thymus-which is entered

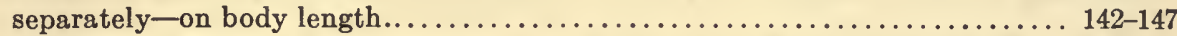

74. Percentage of water in the brain and in the spinal cord-with increasing age-up to

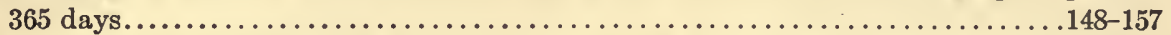

75. Percentage of dry substances in the entire body, in the several systems and in some organs. Observations at seven ages.................................. 177

76. Giving in terms of the dry substance of the entire body the percentage represented by the weights of the dry substance of the skin, ligamentous skeleton, musculature

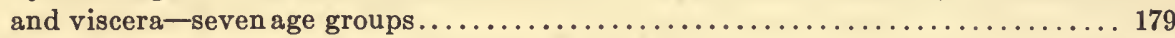

77. Chemical composition of the entire rat, Hatai (MS '15) .................. 180

78. Chemical composition of the entire rat McCollum ('09) $\ldots \ldots \ldots \ldots \ldots \ldots \ldots \ldots \ldots 18 \ldots \ldots$

79. The phosphorus compounds of the rat as affected by ovariotomy $\ldots \ldots \ldots \ldots \ldots \ldots 181$

80. Chemical composition of the brain at different ages.................... 182

81. Absolute weights of constituents of one brain at different ages............. 183

82. Norway rat Percentages of the entire body weight represented by the weights of

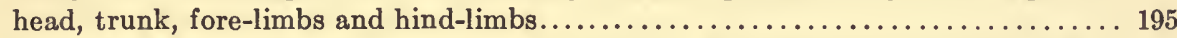

83. Norway rat Percentage of the entire body weight represented by the weights of the integument, ligamentous skeleton, musculature and viscera........... 196

84. Norway rat Weights of crania in series from London, Paris, Philadelphia and

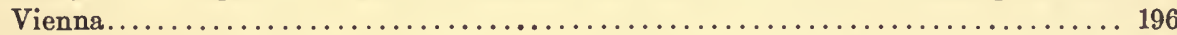

85. Norway rat Increase in the length of the tail and in the weights of the body, brain and spinal cord, on body length............................. 203-208

86. Norway rat Giving the ratios obtained by dividing the body weight in grams, by the body length in millimeters............................. 209-210

87. Norway rat The percentage of water in the blood ......................... 211

88. Norway rat Percentage of water in the brain and in the spinal cord. Ages known 212

89. Norway rat Percentage of water in the brain and in the spinal cord of rats of increasing body weights. Ages not known................................. 213

\section{Technic}

Body, length, 87 .

Body, weight, 88 .

Tail, length, 87.

Brain, weight, 90.

Spinal cord, weight, 90.

Eyeballs, weight, 91 .

Heart, weight, 92 .

Kidneys, weight, 92.

Liver, weight, 94.

Spleen, weight, 95.

Lungs, weight, 95.

Blood, weight, 96 .

Alimentary tract, weight, 97.

Thyroid, weight, 97.

Hypophysis, weight, 98.

Suprarenals, weight, 99.
Ovaries, weight, 100.

Testes, weight, 102.

Thymus, weight, 102.

\section{Teeth}

Eruption of, 37.

Formula for, 37 .

Incisors

Development-time relations, 37 .

Growth of, 37-39, 83.

Measurement in skull, 38.

Enamel, 38.

Rate of growth before attrition, 38 .

Rate of growth after attrition, 38.

Temperature of Body, 60, 61 .

Testes, descent of, 27. 


\section{Urine}

Volume, 59.

Weight of nitrogen in, 59, 60 . similar to that of man, 60 .

\section{Variations-Coefficients of} in body weight $103,113$.

Cranial measurements, 33-35.

\section{Water, Percentage of}

in entire body (dry substance), $176-179,180$. in systems, 177, 179 . in organs, 176, 177. in blood, 40, N 211.

in brain of rat and of man, 6 .

in brain and spinal cord, 176, 179, N 211-213.

in skeleton, 78-81.

Weight at Birth, 22, 24-26.

According to size of litter, 25.

According to characters of mothers:

Age, 24.

Weight, 24, 25.

Undergrowth, 26.

Disease, 26.

Weight-length Ratio, 72, N 202. 







\section{a.}

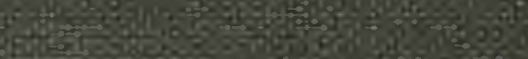

590 a

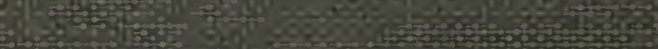
ive

Q.

1

Fin

Fio

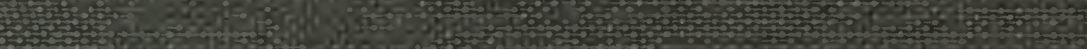

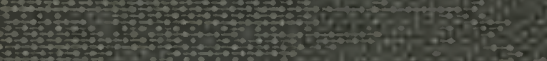

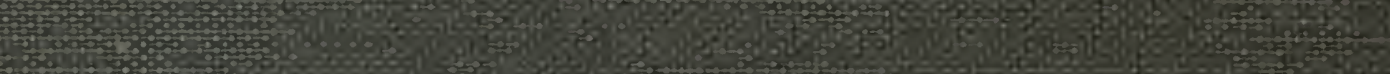

(5)

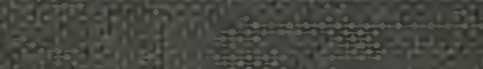

H.

2.

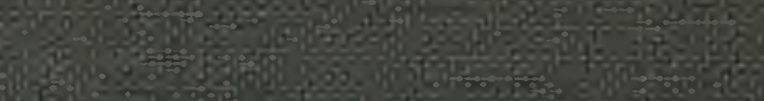

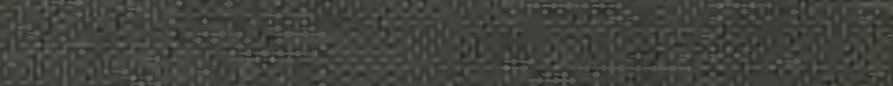

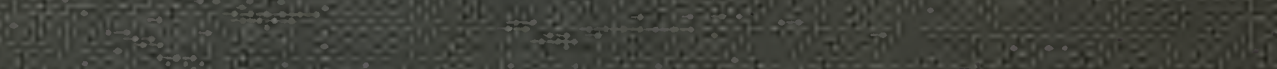

$$
\text { (1) }
$$

98

Q

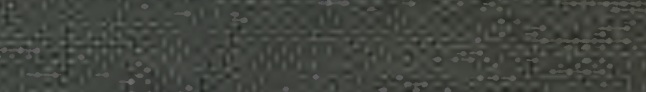

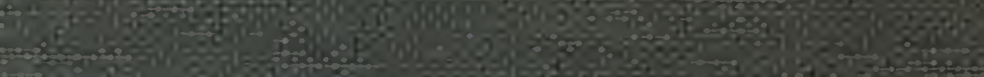

an

(1)

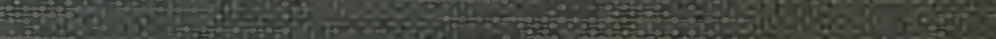

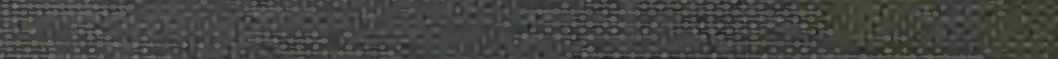

